Laura Mendes Amando de Barros

\title{
O fomento e o Conselho Municipal \\ dos Direitos da Criança e do Adolescente de São Paulo
}

\author{
Dissertação de Mestrado \\ Orientador: Professor Doutor Gustavo Justino de Oliveira
}

Faculdade de Direito da Universidade de São Paulo 
Laura Mendes Amando de Barros

\section{O fomento e o Conselho Municipal dos Direitos da Criança e do Adolescente de São Paulo}

Dissertação apresentada à Banca Examinadora da Faculdade de Direito da Universidade de São Paulo como requisito parcial para a obtenção do título do título de Mestre em Direito.

Área de Concentração: Direito do Estado

Orientador: Professor Doutor Gustavo Justino de Oliveira 
Serviço de Processos Técnicos da Biblioteca da Faculdade de Direito da Universidade de São Paulo

Amando de Barros, Laura Mendes
A499f O fomento e o Conselho Municipal dos Direitos da Criança e do Adolescente de São Paulo / Laura Mendes Amando de Barros. -- São Paulo : L. M. Amando de Barros, 2012.

336 f. ; $30 \mathrm{~cm}$.

Dissertação (Mestrado) - Universidade de São Paulo, 2012.

Orientador: Prof. Dr. Gustavo Justino de Oliveira.

Inclui referências bibliográficas.

1. Direitos da criança e do adolescente - Fomento - São Paulo (SP). 3. Políticas públicas - São Paulo (SP). 4. Convênio - São Paulo (SP). I. Conselho Municipal dos Direitos da Criança e do Adolescente de São Paulo. II. Oliveira, Gustavo Justino de. III. Título. 
Nome: AMANDO DE BARROS, Laura Mendes.

Título: O fomento e o Conselho Municipal dos Direitos da Criança e do Adolescente de São Paulo.

Dissertação apresentada à Banca Examinadora da Faculdade de Direito da Universidade de São Paulo como requisito parcial para a obtenção do título do título de Mestre em Direito.

Aprovado em:

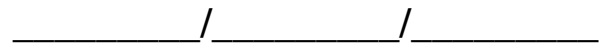

Banca Examinadora:

Prof. Dr. Instituição:

Julgamento: Assinatura:

Prof. Dr. Instituição:

Julgamento: Assinatura:

Prof. Dr. Instituição:

Julgamento: Assinatura: 
Dedico este trabalho ao Vô Mando, meu mestre maior. 


\section{AGRADECIMENTOS}

A elaboração de um trabalho acadêmico é tida corriqueiramente como tarefa árdua e solitária. Não havia como fugir à regra. Contei com a sorte, porém, de ter ao meu lado pessoas maravilhosas que atuaram decisivamente para torná-la mais leve e, definitivamente, menos solitária.

Minha imprescritível gratidão:

Ao meu orientador, Professor Doutor Gustavo Justino de Oliveira, pela impressionante generosidade intelectual;

Aos meus pais, Carmem Silvia e Antonio Carlos, verdadeiros responsáveis por tudo de bom e de belo em minha vida;

Ao meu marido, Marcelo, pelo inabalável entusiasmo pela vida;

Às minhas irmãs, Elisa e Luísa, queridas companheiras, por toda a leveza e cor... 
"Não será através de miraculosos preceitos técnicos elevados ao Direito Constitucional e ao Direito Administrativo que segurança jurídica e justiça serão garantidos pelo Estado, pois no Direito não se contém a arte de governar, mas, seguramente, o seu limite civilizado".

(MOREIRA NETO, 2007, p. 36) 


\section{RESUMO}

AMANDO DE BARROS, Laura Mendes. O fomento e o Conselho Municipal dos Direitos da Criança e do Adolescente de São Paulo. 2012. 336 f. Dissertação (Mestrado) - Faculdade de Direito, Universidade de São Paulo, São Paulo, 2012.

O presente trabalho tem por escopo analisar, de forma crítica e problematizada, o fomento enquanto atividade administrativa, portanto desbordante dos estritos limites do Estado. A obra tem início com o seu exame, conceituação e delineamento, de forma a criar para o leitor suporte seguro para o que adiante virá: seu exercício por meio de uma arena de participação popular, no caso, o Conselho Municipal dos Direitos da Criança e Adolescente de São Paulo. Este, ente despersonalizado apenas burocráticoadministrativamente ligado à estrutura estatal tradicional, desponta como um novo lócus de exercício da discricionariedade administrativa, sendo responsável pelo próprio exercício do poder político, pela definição e desenvolvimento de políticas públicas de forma vinculante - neste particular, do próprio Executivo. Colocamos o leitor, então, diante de interessante sistemática em que interagem mecanismos de ponta do Direito Administrativo e da lógica constitucional: participação democrática, descentralização e subsidiariedade, horizontalização entre as relações Administração-cidadão, contratualização do agir administrativo, ação pública concertada e sistematizada, com ênfase no planejamento. Delineada a interação objeto do estudo, são analisadas peculiaridades, polêmicas e situações ainda não assentes no Direito pátrio, como a parceirização com entidades do Terceiro Setor e a sua forma de estabelecimento; as possíveis roupagens da concessão de incentivo a essas entidades; o perfil das atividades a serem ofertadas diretamente à população, no caso crianças e adolescentes; a responsabilidade por eventuais desvios ocorridos durante o imbricado processo de construção, desenvolvimento e exaurimento do fomento outorgado por intermédio do Conselho. Buscamos, assim, chamar a atenção para a importância dos mecanismos de mobilização popular e de incentivo à inciativa privada de interesse público como alternativa para a sustentabilidade social e estatal e para a satisfação de interesses e demandas públicas inerentes ao Estado Pós-Social típico deste século XXI.

Palavras-chave: Fomento. Participação democrática. Conselho. Deliberação. Parceirização. 


\begin{abstract}
AMANDO DE BARROS, Laura Mendes. Incentives and the Municipal Children and Adolescents Rights Council. 2012. 336 f. Dissertação (Mestrado) - Faculdade de Direito, Universidade de São Paulo, São Paulo, 2012.

This paper aims to analyze, in a critic and problematized way, the incentives as an Administrative activity - so overflowing the strict limits of the State. The study begins with its exam, conceptualization and definition, in order to create for the reader a secure support for what is to come: its exercise by an arena of participation - in case, the Municipal Children and Adolescents Rights Council. This one, depersonalized being only burocratic-administratively related to the State traditional structure, emerges as a new locus for administrative discretion - so responsible for the exercise of the political power itself, for the definition and development of public policies in a mandatory way of the Executive. The reader is then placed before an interesting system in which interact cutting edge mechanisms of Administrative Law and constitutional logics: democratic participation, decentralization and subsidiarity, horizontalization of the relations Administration-citizens, contratualization of the administrative action, concerted and systematic public action with emphasis on the planning. Once delineated the interaction object of study, peculiarities, controversies and situations further unsettled in national Law are analyzed, such as parcerization with Third Sector organizations and their form of establishment; possible forms of incentive concession to those organizations; profile of activities to be offered directly to the population (children and adolescents); responsibility for any deviations during the imbricate process of construction, development and depletion of incentives awarded through the Council. The aim is thus to draw attention to the importance of popular mobilization and mechanisms to encourage private initiative of public interest as an alternative for social and the State sustainability, and for the satisfaction of interests and public demands inherent in state post-social.
\end{abstract}

Keywords: Incentives. Democratic participation. Council. Deliberation. Parcerization. 


\section{LISTA DE ABREVIATURAS E SIGLAS}

CC Código Civil

CF Constituição Federal

CLT Consolidação das Leis Trabalhistas

CMDCA Conselho Municipal dos Direitos da Criança e do Adolescente

ECA Estatuto da Criança e do Adolescente

Fumcad Fundo Municipal dos Direitos da Criança e do Adolescente

IN Instrução Normativa

INRF Instrução Normativa da Receita Federal

IR Imposto de Renda

LGS Ley General de Subvenciones

MARE Ministério da Administração Federal e Reforma do Estado

OCDE Organização para Cooperação e Desenvolvimento Econômico

PGM Procuradoria Geral do Município de São Paulo

SMPP Secretaria Municipal de Participação e Parceria de São Paulo

TRF Tribunal Regional Federal 


\section{SUMÁRIO}

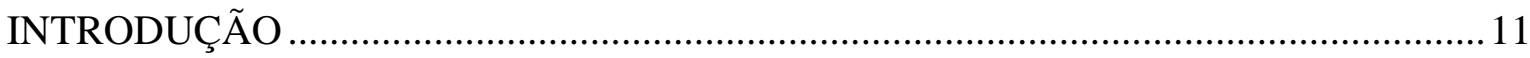

1 A ATIVIDADE ADMINISTRATIVA DE FOMENTO ……………………………..... 14

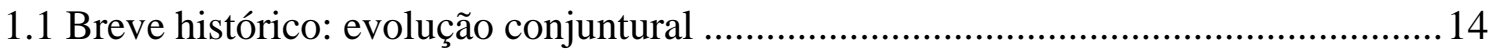

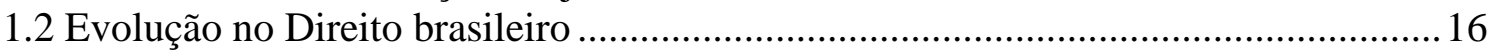

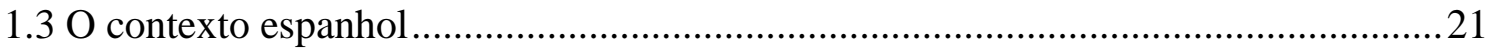

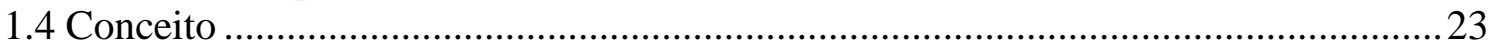

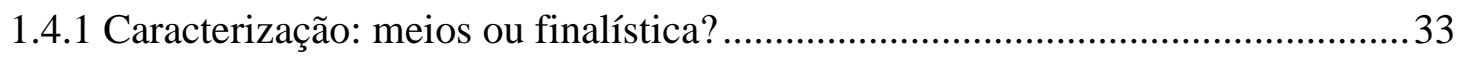

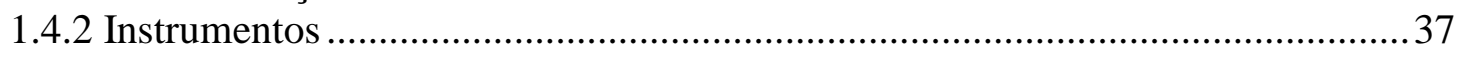

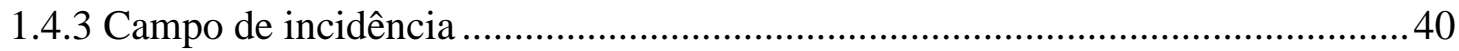

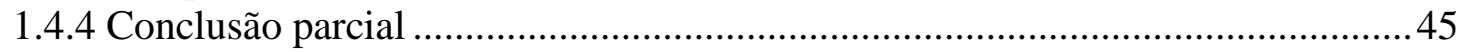

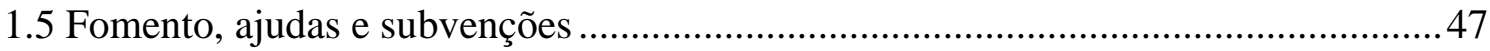

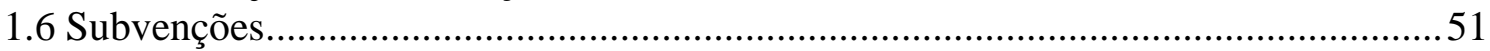

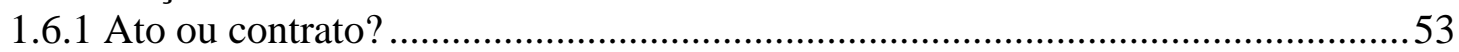

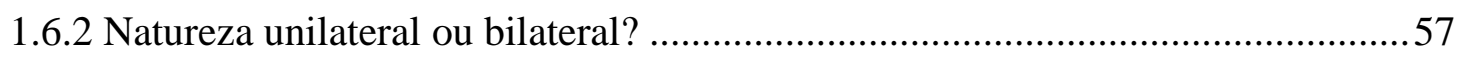

1.6.3 Tratamento das subvenções no ordenamento pátrio ............................................5

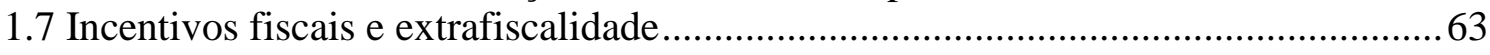

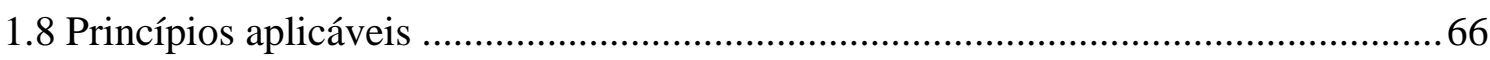

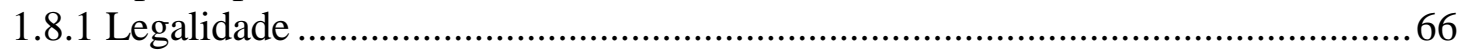

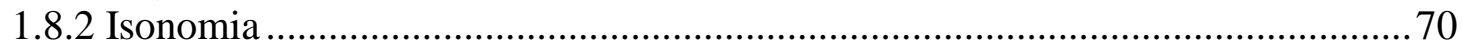

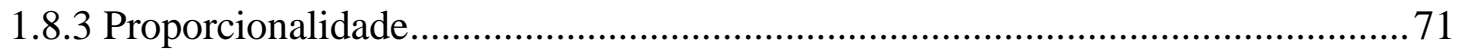

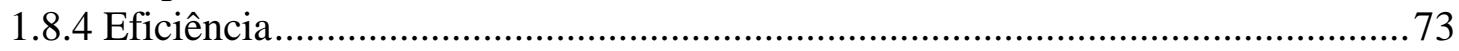

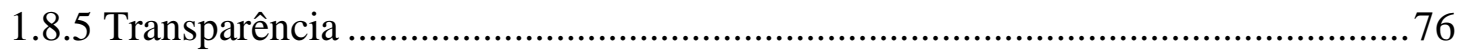

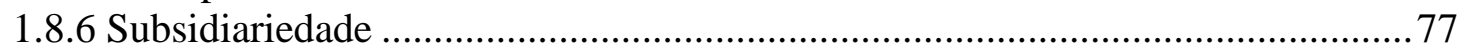

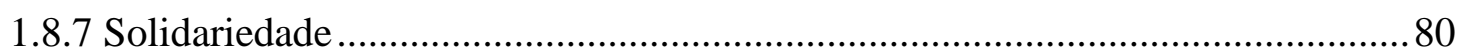

1.8.8 Princípios da livre concorrência, do preço de custo e da intercambialidade das

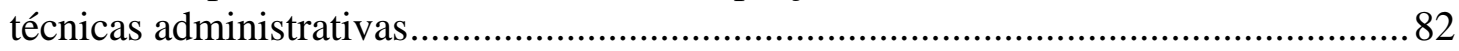

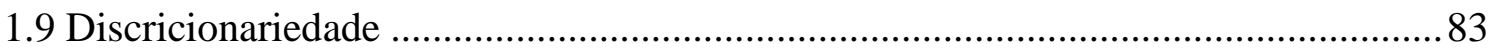

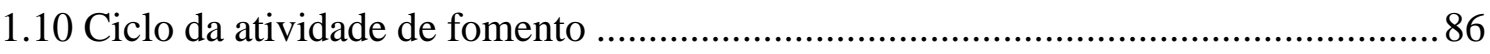

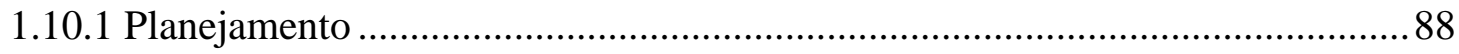

1.10.2 Incidência propriamente dita: a efetivação da relação de fomento com o

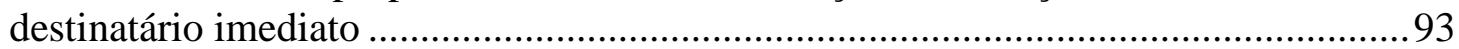

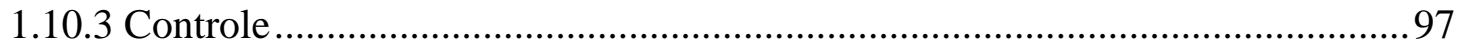

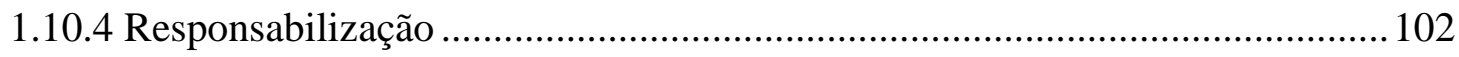

2. O CONSELHO DOS DIREITOS DA CRIANÇA E DO ADOLESCENTE DO

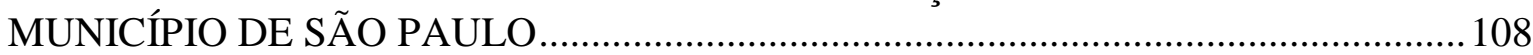

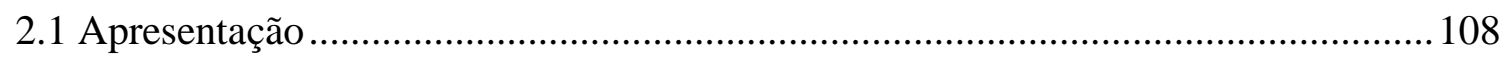

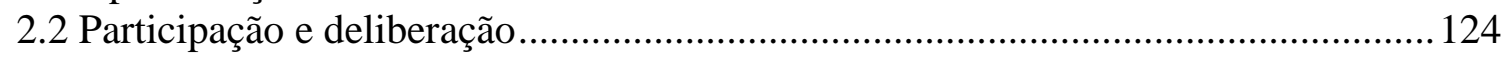

$2.3 \mathrm{O}$ destaque das esferas locais de decisão e poder ..................................................132

2.4 Arcabouço normativo aplicável ............................................................................139

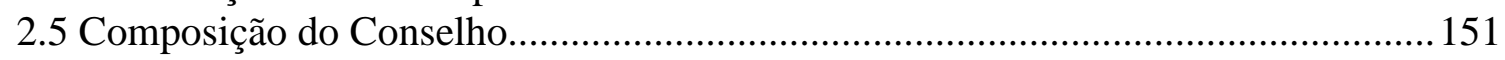

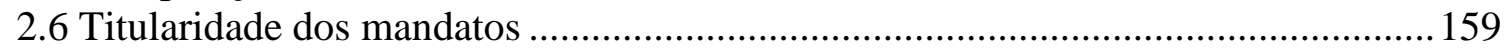

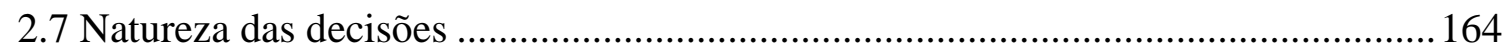

2.8 As atividades/projetos passíveis de custeio pelo Fundo Municipal dos Direitos da Criança e do Adolescente - Fumcad: complementaridade .............................................. 171

2.9 O regime financeiro do Fundo Municipal dos Direitos da Criança e do Adolescente: sujeição às regras gerais orçamentárias?..................................................................... 177

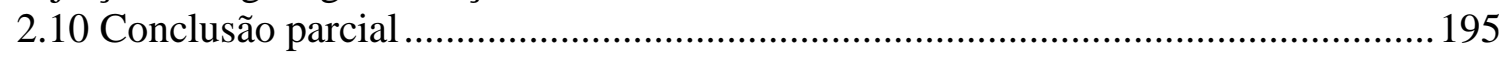


3 A ATIVIDADE DE FOMENTO EXERCIDA POR INTERMÉDIO DO CMDCA.......197

3.1 Incentivo fiscal ao setor econômico e subvenções às entidades do Terceiro Setor: delimitação do objeto de investigação ......................................................................... 197

3.2 A nova contratualização administrativa: administração por contratos ...................205

3.3 Instrumental utilizado: convênios .................................................................... 210

3.4 A escolha das entidade/projetos a serem fomentados e os limites e grau de

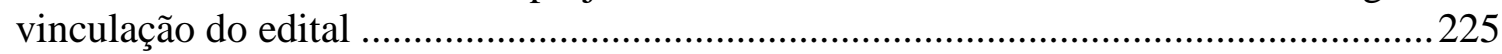

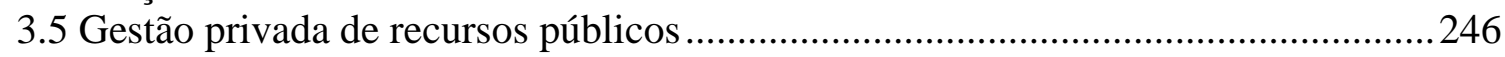

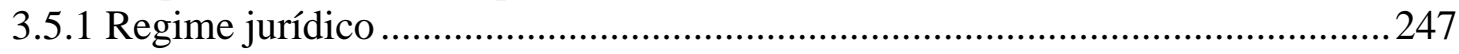

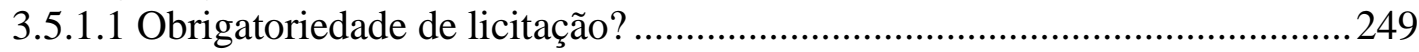

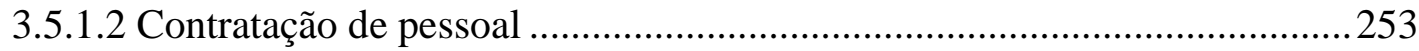

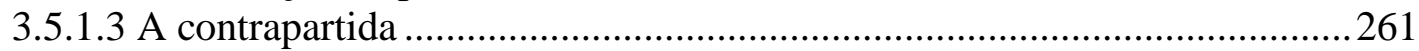

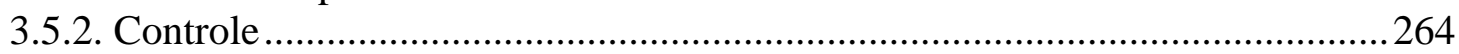

3.5.2.1 O momento de incidência .................................................................2267

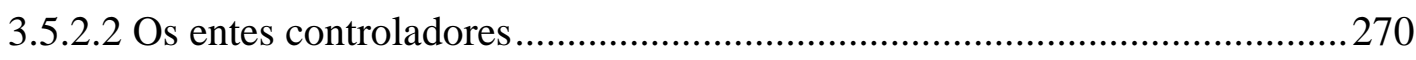

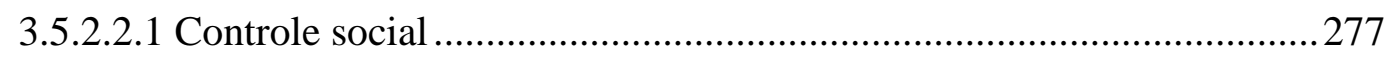

3.5.2.3 O controle da eficiência/resultados versus controle burocrático .................228

3.6 Os quatro momentos do ciclo do fomento na esfera do Conselho Municipal dos Direitos da Criança e do Adolescente de São Paulo ....................................................293

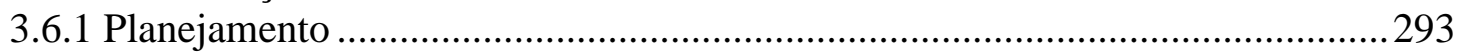

3.6.2 Incidência propriamente dita: a efetivação da relação de fomento com o

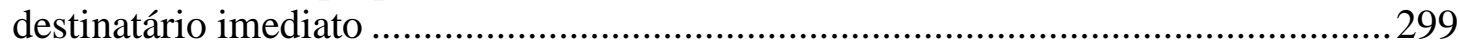

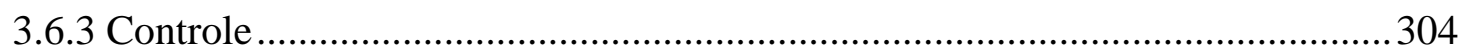

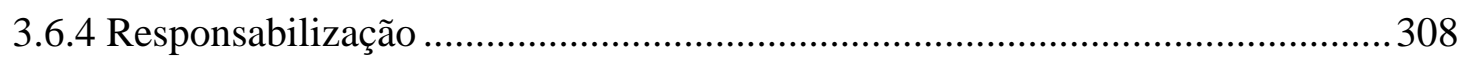

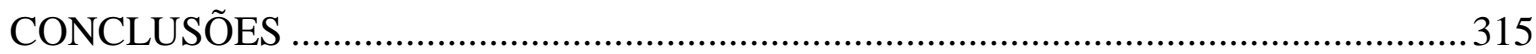

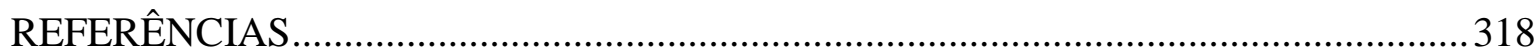




\section{INTRODUÇÃO}

O objeto do presente trabalho é o estudo da atividade administrativa de fomento exercida com a intervenção do Conselho Municipal dos Direitos da Criança e Adolescente de São Paulo, a qual ocupa, no contexto do Estado Pós-Social em que vivemos, posição de grande destaque.

Tal proeminência decorre da visão e compreensão das atribuições estatais e administrativas, e do papel da própria sociedade nesse processo.

Enquanto o Estado do século XIX traduzia-se como liberal e limitado à garantia das liberdades individuais, sem grandes ingerências sobre a forma de agir privada e sobre os sistemas econômico e social, o modelo do século XX (Estado Social), foi marcado pelo recrudescimento da ingerência estatal nas mais diversas áreas, com intensa interferência nas formas organizacionais da sociedade e na atividade econômica.

O século XXI trouxe novas demandas, novas necessidades, determinantes de uma alteração do foco da Administração, do desenho até então marcadamente estadocêntrico para uma aproximação, interlocução, interação e mobilização conjunta entre público e privado.

Essa dicotomia assume contornos cada vez menos nítidos. Ganha força a ideia de corresponsabilidade entre ambos, assim encarregados da promoção, proteção e atendimento dos interesses públicos. ${ }^{1}$

Institutos denotativos de uma Administração Pública mais aberta, mais parceira, consensual e marcadamente democrática passam a dar o tom da atuação estatal.

As funções administrativas perdem a titularidade exclusiva do Estado. Tornam-se passíveis de efetivação, inclusive com destaque, por atores outros, quer privados, quer públicos, mas não necessariamente estatais.

O estímulo à atividade privada de interesse público — manifesto em qualquer das suas fórmulas - , assume posição basilar, em razão, inclusive, do próprio desgaste e ineficiência dos modelos anteriores, em que se outorgava destaque polarizado ou ao império estatal ou à liberdade da iniciativa privada.

\footnotetext{
1 "O termo corresponsabilidade comporta, em primeiro lugar, tomar consciência de objetivos comuns e identificá-los adequadamente; em segundo lugar, a assunção de responsabilidades concretas em sua consecução; e, em terceiro lugar, a articulação efetiva das responsabilidades assumidas por cada uma das partes. Incrementar a relação entre Estado e sociedade em termos de corresponsabilidade significa, pois, abandonar a desconfiança própria do Estado do bem estar e substituí-la por uma atitude decidida de diálogo e cooperação." (MENDONZA; VERNIS, 2008, p. 52).
} 
O fomento não pode ser considerado de forma dissociada da atividade de planejamento, da qual é, em um regime de privilégio à livre iniciativa, e nas palavras de Marcos Juruena Villela Souto (2003, p. 39), consequência natural: não podemos falar em estímulo sério - e eficiente - sem um planejamento prévio que lhe dê substância e fundamento.

Mais que uma visão estática do agir administrativo, imprescindível se faz uma consideração dinâmica dessa atividade, em que se lhe toma de forma contextual, causal e determinante de resultados orientadores de seu próprio aperfeiçoamento.

Daí o enfoque adotado, segundo a qual o fomento não é tido como um ato administrativo isolado, uma mobilização instantânea que se exaure de plano: defendemos essa atividade administrativa como um ciclo, um processo composto por quatro momentos fundamentais: a) planejamento; b) incidência propriamente dita, com a vinculação efetiva dos agentes fomentador e fomentado; c) controle; e d) responsabilização por eventuais irregularidades.

Tal abordagem se coaduna com o contemporâneo entendimento de que a atividade administrativa deve ser compreendida a partir do paradigma do processo administrativo. $^{2}$

O processo de fomento, escolhido como tema de nossa pesquisa, ganha contornos especiais, sujeitando-se a um regime específico, quando levado a termo por meio de uma arena de participação, como é o Conselho Municipal dos Direitos da Criança e Adolescente de São Paulo.

Temos aí a congregação de competências e interesses tanto da iniciativa privada com finalidade lucrativa quanto das entidades do Terceiro Setor e do próprio Estado - em uma atuação administrativa que, tendo em vista a sua composição paritária entre representantes do governo e da sociedade civil, não pode ser tida como meramente estatal.

Desse contexto decorre o nosso interesse pela interação e pela dinâmica do fomento com a mobilização da iniciativa privada de interesse público e os mecanismos de participação democrática — tais como o Conselho.

Ganham destaque questões como os limites e autonomia dessa atividade, e o delineamento do papel a ser exercido pela arena de participação popular na qual nos

\footnotetext{
2 "O processo administrativo despontou sob o contexto da democracia administrativa, da melhoria das relações Administração/administrado, da atuação dos administrados na tomada de decisões, entre outros fatores. E tornou-se um dos grandes tópicos do Direito Administrativo moderno, suscitando, no presente, mais estudos que o ato administrativo." (MEDAUAR, 2008, p. 419).
} 
concentramos, qual seja, o Conselho Municipal dos Direitos da Criança e Adolescente de São Paulo.

Debruçamo-nos sobre a posição fundamental assumida pela atividade administrativa de fomento nesse início de século, a qual pode vir a ser o mais valioso recurso para a satisfação do interesse público e para o atendimento às necessidades coletivas.

Fixados os parâmetros fáticos, dogmáticos e normativos de pesquisa, inauguramos o trabalho com o detido delineamento do fomento, a definição dos seus elementos fundamentais, o estabelecimento das suas circunstâncias e destinatários e, ao final, sua conceituação, a ser considerada como basilar das ponderações que se seguirão.

O foco adotado parte da umbilical conexão entre essa atividade e a própria noção do Estado, sua organização e funções.

O segundo capítulo trata de apresentar o Conselho Municipal dos Direitos da Criança e do Adolescente de São Paulo, com a sua disciplina normativa, suas atividades, grau de autonomia e discricionariedade, e legitimidade democrática.

No derradeiro capítulo, os parâmetros dogmáticos explicitados ao longo do trabalho serão conciliados, de forma a analisarmos especificamente o exercício da atividade administrativa de fomento por intermédio do CMDCA-SP.

Para tanto, serão consideradas cada uma das quatro fases envolvidas, com a explicitação de outros parâmetros referenciais que se fazem necessários, como o controle social da atividade administrativa e o seu controle por resultados.

Como adiante se verá, importante referência adotada, no que toca ao fomento, é o contexto espanhol, em razão do considerável grau de desenvolvimento e sistematização que historicamente alcançou esse tema naquele país.

Todas as citações e referências originariamente redigidas e consultadas em língua estrangeira foram livremente por nós traduzidas, com vista a facilitar a leitura e proporcionar o maior acesso possível ao trabalho. 


\section{A ATIVIDADE ADMINISTRATIVA DE FOMENTO}

\subsection{Breve histórico: evolução conjuntural}

A atividade administrativa de fomento vem ganhando grande repercussão nos tempos atuais, em razão, principalmente, da evolução das funções e modelo estatais. ${ }^{3}$

Diferentemente do que hoje se vê, enquanto vigia a concepção liberal de Estado o destaque era concentrado quase que integralmente, em um primeiro momento, na função de polícia - a qual evoluiu para se desdobrar também na atividade incentivadora.

Ao Estado cabia então uma postura negativa, passiva, de simples manutenção e garantia da ordem, sem grandes interferências na vida dos cidadãos e na seara econômica.

Ao modelo social se vinculou basicamente a função de prestação de serviços, ficando o fomento, não obstante presente, relegado a um segundo plano. ${ }^{4}$

Nesse sentido, inclusive, as lições de Jordana de Pozas ${ }^{5}$ e Garrido Falla. ${ }^{6}$

Com a evolução do modelo estatal até o atual século XXI, em que toma corpo a concepção pós-social, ${ }^{7}$ marcada fundamentalmente pela aproximação entre Estado e

\footnotetext{
3 “A organização, formas e ação administrativas estão intimamente ligadas com a organização, formas e ação dos poderes políticos. São, portanto, ainda que vivam e se movam separadamente, inseparáveis e dependentes dos princípios em que se baseia a organização política." (URUGUAI, 2002, p. 89).

4 " [...] existe uma evidente correlação entre a preferência por uma ou outra dessas técnicas e a concepção mesma do Estado que as aplica; e, assim, enquanto o Estado abstencionista, que restringe seus próprios fins à elementar atenção de garantir a ordem pública, limita suas atividades às de polícia, o Estado social dos nossos dias se preocupa em montar um sistema de serviços públicos capaz de satisfazer com suas prestações as necessidades que atualmente se sentem como públicas. Por sua parte, a ação de fomento representa uma correção ao inicial abstencionismo do Estado liberal.” (GARRIDO FALLA, 1992, p. 300, traduzimos).

5 "Na segunda metade do século XIX não somente se restabelecem alguns serviços do antigo regime suprimidos durante o predomínio das crenças liberais, senão que surgem e se desenvolvem espantosamente os grandes serviços públicos de comunicações, assistência, saúde e ensino. Em seu final, e no que já vai do século XXI, o intervencionismo econômico, as circunstâncias nascidas das grandes guerras e as novas doutrinas sociais e financeiras, produzem um abundante florescer de novos serviços em todas as esferas administrativas e nos mais diversos campos da atividade. [...] A polícia é a modalidade administrativa mais própria do antigo regime; o fomento é mais adequada ao Estado liberal, e o serviço público é o modo predileto do Estado intervencionista. Mas se trata do predomínio de um ou outro sistema, sem exclusão dos demais." (JORDANA DE POZAS, 1949, p. 45- 49, traduzimos).

6 "No momento somente nos interessa assinalar como ao longo de sua evolução o moderno Estado de Direito, em sua relativamente curta história, tem utilizado com uma intensidade variável as diversas formas de atividade administrativa. Assim, na sua etapa inicial, o Estado abstencionista realizava sua quase exclusiva missão - a manutenção da ordem pública - mediante medidas de polícia administrativa, é dizer, mandatos e proibições semelhantes aos já conhecidos na etapa anterior do Estado-polícia. Posteriormente, uma vez que o sistema dos serviços públicos havia se expandido suficientemente, o aspecto autoritário da intervenção estatal veio a quase obscurecer-se diante da realidade de uma Administração que em grande medida se caracterizava por oferecer prestações aos administrados. Finalmente, o Estado assistencial dos nossos dias não se limita ao tipo de prestação que constitui o conteúdo tradicional do conceito de serviço público, senão irrompe, quase sem limites, como sujeito da atividade econômica, industrial e mercantil, inclusive submetendo-se às formas jurídicas do Direito privado (Estado empresário)." (GARRIDO FALLA, 1992, p. 115 , traduzimos).
} 
sociedade, pela horizontalização e consensualidade ${ }^{8}$ de suas relações, o fomento passa a se mostrar cada vez mais essencial.

Tal cenário decorre, inclusive, do fato de os modelos anteriores, em que predominavam ora o absenteísmo ora a marcante intervenção estatal, já não se mostrarem suficientes ao satisfatório atendimento ao interesse público e às demandas sociais. ${ }^{9}$

A consolidação da atividade de fomento de deu no século XIX, quando a necessidade de cooperação entre Estado e sociedade passou a ser absolutamente importante:

\begin{abstract}
A Administração de fomento e as reformas administrativas foram, no despertar do liberalismo espanhol, a grande esperança daqueles que as viam como algo neutro às tensões políticas e a possibilidade de lhe dar o Estado uma estrutura e uma atuação que tinham como imprescindível. Juridicamente, sua importância se revela em dois aspectos: o organizativo, com a criação do Ministério do Fomento, e na atuação do Estado, ao constituir um título genérico de intervenção na vida econômica que constituía um fim, um direito e uma obrigação para o Monarca. Dessa forma, a ideia de fomento se apresenta à primeira vista como a de uma necessidade generalizada de crescimento das artes e indústrias e, juridicamente, como um dever do Estado, como uma missão ou fim justificado e como um título de atuação com efetividade concreta. Na divisão de tarefas entre o Estado e a sociedade, no momento de transição ao Estado de Direito, a ideia de fomento serve na Espanha para buscar uma tarefa comum, em que o Estado dirija e regule o movimento das melhoras sociais e a sociedade "promova indiretamente a riqueza geral com os particulares esforços". (Circular 9 jan. 1816). ${ }^{10}$
\end{abstract}

\footnotetext{
${ }^{7}$ Conforme distinção tecida por Campilongo, “o Estado liberal formula uma teoria da norma jurídica; o Estado social constrói uma teoria do ordenamento jurídico; e o Estado pós-social enfrenta o desafio de construção de uma teoria de pluralismo político." (CAMPILONGO, 2005, p. 32). Veja-se, ainda: “[...] Ao combinar as hermenêuticas de bloqueio e legitimação com uma interpretação reflexiva - isto é, que espelhe a correlação de forças sociais, o momento econômico e a capacidade circunstancial de resposta do sistema político - , as práticas do Estado pós-social nada mais fazem que calibrar, em função da escassez de recursos, as expectativas e pretensões jurídicas. Começam a ganhar corpo, no discurso jurídico, teses como a da 'impossibilidade material' de aplicação do direito, da 'ineficácia absoluta das decisões', do direito supra legal'.” (CAMPILONGO, 1994, p. 124-125).

8 “[...] Pode-se estabelecer uma tipologia da consensualidade em referência às funções fundamentais do Estado. Primo, a consensualidade na produção das normas, com o reaparecimento de fontes alternativas, fontes consensuais e de fontes extraestatais: a regulática. Secundo, a consensualidade na administração dos interesses públicos, com o emprego das formas alternativas consensuais de coordenação de ações, por cooperação e por colaboração. Tertio, a consensualidade na solução de conflitos, com a adoção de formas alternativas de composição. A consensualidade, pela via da participação política, vem modificando a atuação do Estado na legislação, na administração e na jurisdição, mas é a Administração Pública o campo mais aberto e mais diversificado para medrar o consenso, tanto como método de decisão como de operação." (MOREIRA NETO, 2007, p. 41-42).

9 “[...] Cabe advertir-se desde já que cada uma das etapas que acabam referidas são determinadas pela sucessiva superposição em mãos do Estado de competências relativas a cada uma delas. As competências típicas da etapa anterior não somente não são substituídas, senão que, antes, inclusive restam reforçadas." (GARRIDO FALLA, 1992, p. 115-116 traduzimos)

${ }^{10}$ Citado por CUÉTARA, 1983, p. 288, traduzimos.
} 
Nas palavras de Garrido Falla, "a relação das técnicas de fomento com o Estado de Direito não se produz, obviamente, senão no século XIX.” (GARRIDO FALLA, 1992, p. 302, traduzimos).

Operou-se, então, a sistematização legislativa do assunto, sob o princípio da centralização financeira (iniciada com a criação dos impostos).

\subsection{Evolução no Direito brasileiro}

No ordenamento pátrio, a primeira notícia que se tem de mecanismos de fomento remonta ao Brasil colônia, mais especificamente às Ordenações Filipinas que, em seu Livro II, previam "a isenção de pagamento de dízimo e outros direitos a El-Rei, para a Igreja, Mosteiros e Pessoas Eclesiásticas (título XI)” (DI PIETRO, 2002, p. 8).

No século XIX, eram “acanhadas as incursões do Estado no meio social. Consistiam nas regras sobre a proteção e socorro dos infelizes, os estabelecimentos de beneficência [...]." (OLIVEIRA, 1975, p. 16).

Durante a República Velha, insta-nos referir a edição, em 18 de janeiro de 1922, do Decreto n. 4.492, que determinava ao "Poder Executivo a assegurar, de modo permanente, ao Insituto Historico e Geographico Brasileiro, uma subvenção annual de 40:00\$, entregue em duas prestações de 20:00\$ cada uma, em janeiro e julho, a concederlhe outros favores e a organizar um museu historico em edificio apropriado."

Veja-se, também, o Decreto n. 726, de 8 de dezembro de 1900, dispensador de incentivo à Academia Brasileira de Letras.

Da mesma forma o Decreto n. 2.380, de 31 de dezembro de 1910, em especial seus artigos $1^{\circ}, \S \S 4^{\circ}$ e $7^{\circ}$, veiculadores de benefícios como isenção de taxa postal e não sujeição de associações especificadas a contribuições em geral. ${ }^{11}$

Chama a atenção, por fim, o disposto no parágrafo único do seu artigo $1^{\circ}$, que veiculava, já àquela época, exigência de espécie de "prestação de contas":

Paragrapho unico. Do termo de accôrdo, que deverá ser lavrado, deverá constar que nenhuma dessas prestações se effectuará sem que seja

\footnotetext{
11 "§ $4^{\circ}$ As associacoes organizadas de accôrdo com a citada Lei 173 e officialmente reconhecidas gozarão de isensão de taxa postal para o serviço de sua correspondencia e nao estarão sujeitas a contribuição de especie alguma, quer quanto aos respectivos escriptorios. quer quanto ao material, que terá entrada, livre de direitos fiscaes, nos portos da Republica e transporte gratuito nas estradas de ferro e companhias de navegação, officiaes ou subvencionadas. [...] $\S 7^{\circ}$ As multas provenientes da applicação da presente lei serão arrecadadas e entregues á directoria da Associasdo da Cruz Vermelha, existente na circumscripção judiciaria em que so tiver dado a violacão, on na falta dessa, á directoria da associação mais proxima."
} 
préviamente demonstrada perante o Ministério da Justiça e Negócios Interiores, e pelo respectivo titular approvada, a applicação da anteriormente recebída mediante documentos e contas que comprovem ter sido empregada em pagamento do pessoal ou acquisição de material necessario aos serviços do referido insituto.

Com a Constituição Federal de 1934, o Estado assumiu uma postura mais ativa quanto à promoção dos direitos sociais, com o consequente aumento da máquina estatal e de seu quadro de funcionários.

Os serviços públicos - cujo rol cresceu consideravelmente nesse momento ganharam protagonismo em detrimento da atividade de fomento.

A pujança daquela atividade era então tamanha que se chegava a identificá-la com a própria Administração em sentido objetivo, como o objeto único do Direito Administrativo, entendido então como "o conjunto de princípios e normas jurídicas que presidem a organização e o funcionamento dos serviços públicos.” (CAVALCANTI, 1936, p. 79).

Tal entendimento, porém, não foi consagrado de forma absoluta, na Carta de 1934, cujo artigo 117 tinha a seguinte redação: “a lei promoverá o fomento da economia popular, o desenvolvimento do crédito e a nacionalização progressiva dos bancos de depósito [...]."

Digno de registro, ainda, seu artigo 121 (“a lei promoverá o amparo da produção e estabelecerá as condições do trabalho, na cidade e nos campos, tendo em vista a proteção social do trabalhador e os interesses econômicos do País”).

Notamos que, à época, a função de fomento era direcionada fundamentalmente ao domínio econômico, ficando a questão social, conforme asseverado, a cargo do Estado prestador, e não da sociedade civil estimulada.

Do referido texto constava somente uma recomendação quanto a este segundo campo, no artigo 138 do dito diploma: "Incumbe à União, aos Estados e aos Municípios, nos termos das leis respectivas: [...] g) cuidar da higiene mental e incentivar a luta contra os venenos sociais."

A Carta de 1937, outorgada pelo governo de Getúlio Vargas, estabelecia que a intervenção do Estado no domínio econômico só se legitimaria para suprir as deficiências da iniciativa individual e coordenar os fatores da produção, de maneira a evitar ou resolver conflitos e introduzir no jogo das competições particulares "o pensamento dos interesses da Nação" (SOUTO, 2003, p. 12-13). 
Figuravam em seu artigo 141 os dizeres de que "a lei fomentará a economia popular, assegurando-lhe garantias especiais [...]”.

Tem-se aí, porém, um avanço da noção de fomento sobre o campo social, conforme se depreende do seu artigo 128: “Art. 128. A arte, a ciência e o ensino são livres à iniciativa individual e a de associações ou pessoas coletivas públicas e particulares. É dever do Estado contribuir, direta e indiretamente, para o estímulo e desenvolvimento de umas e de outro, favorecendo ou fundando instituições artísticas, científicas e de ensino."

O diploma de 1946 introduziu os princípios - mantidos em todas as ordens subsequentes e hoje consagrados como fundamentos da República brasileira - da justiça social, livre iniciativa, valorização do trabalho humano, que então guardavam relação específica com a ordem econômica e a intervenção estatal nessa seara. ${ }^{12}$

Isso decorre do fato de que, nos correlatos contextos jurídicos, sociais e organizacionais, somente se vislumbravam dois setores: o primeiro, correspondente ao Estado, e o segundo, relacionado à atividade econômica.

O domínio social, ${ }^{13}$ tal qual hoje compreendido, não gozava de qualquer destaque, não sendo sequer diagnosticado e, portanto, considerado.

A função incentivadora era aventada nos artigos 150 (“a lei criará estabelecimentos de crédito especializado de amparo à lavoura e à pecuária”) e 174 (“o amparo à cultura é dever do Estado").

Conforme daí se vê, o protagonismo do serviço público foi sendo superado, ao longo dos tempos, com o reconhecimento de que a atividade administrativa o transcendeu para abarcar também, e além da função de polícia, o fomento.

Tal tendência já pode ser sentida na Carta de 1967, em seus artigos 171, parágrafo único, ${ }^{14}$ referente aos estímulos à pesquisa científica e tecnológica; $168, \S 2^{\mathrm{o}}{ }^{15}$ voltado à educação; e $172,{ }^{16}$ direcionado à cultura.

\footnotetext{
${ }^{12}$ Nas palavras de Villela Souto, trata-se da denominada Constituição econômica. (SOUTO, 2003, p. 11).

${ }^{13}$ Correspondente à área de atuação típica das entidades do Terceiro Setor, as quais desenvolvem atividades complementares às posturas estatais: "[...] na seara social, observa-se que o Estado, por ter adotado um modelo de Estado Social e Democrático de Direito, deve, como regra, assegurar a prestação dos serviços públicos sociais, tais como saúde, educação, previdência e assistência social. Segue-se também que a atividade de fomento nessa área somente poderá se efetivar de modo complementar, subsidiário mediante o incentivo, a promoção, o auxílio dos particulares que desenvolvam, ao lado da Administração Pública, atividades consideradas de interesse público.” (HIGA, 2010, p. 125).

14 "Parágrafo único. O Poder Público incentivará a pesquisa científica e tecnológica."

15 " $\S 2^{\circ}$ Respeitadas as disposições legais, o ensino é livre à Iniciativa particular, a qual merecerá o amparo técnico e financeiro dos Poderes Públicos, inclusive bolsas de estudo."

16 "Art. 172. O amparo à cultura é dever do Estado."
} 
Era trazido à baila, então, e uma vez mais, o incentivo à atividade econômica, nos artigos 19, $\S 8^{\text {o }}{ }^{17}$ e $163^{18}$ da Carta Maior.

A Emenda Constitucional de 1969 dedicava ao fomento seus artigos 170 (“Às emprêsas privadas compete, preferencialmente, com o estímulo e o apoio do Estado, organizar e explorar as atividades econômicas”); 172 (“[...] O mau uso da terra impedirá o proprietário de receber incentivos e auxílios do Govêrno"); 176, § $2^{\circ}$ ("respeitadas as disposições legais, o ensino é livre à iniciativa particular, a qual merecerá o amparo técnico e financeiro dos Podêres Públicos, inclusive mediante bôlsas de estudos"); 179, parágrafo único (“o Poder Público incentivará a pesquisa e o ensino científico e tecnológico"), e 180 (“o amparo à cultura é dever do Estado").

Essa breve retrospectiva do tratamento do fomento em nosso país permite-nos constatar a sua evolução, e cada vez mais expressiva incorporação ao agir público.

Em importante artigo datado de 1975, Oliveira (1975, p. 20) asseverava que “[...] a atividade administrativa do Estado não se exaure na organização e no funcionamento dos serviços públicos. No seu âmbito estão incluídos outros setores, tecnicamente bem diferenciados e especificados, como os concernentes ao fomento às realizações privadas e à polícia administrativa."

Assinalava o autor, àquela altura, que a atividade de fomento abarcava: a) os auxílios financeiros e subvenções; b) os financiamentos para a construção de hotéis e obras voltadas ao desenvolvimento do turismo, ao aperfeiçoamento de indústrias de construção civil e à edificação de residências populares, com vista ao seu barateamento; c) favores fiscais voltados a ações tidas como benéficas ao desenvolvimento do país (OLIVEIRA, 1975).

Além dessas quatro possibilidades, corriqueiras sob a atual exegese do fomento, inseria nessa categoria as desapropriações em prol de entidades sem fins lucrativos e úteis às coletividades - em clara adesão à visão finalística e teleológica dessa atividade.

Da sua obra, portanto, depreende-se que ele não considerava a não-coerção, os meios facultativos e voluntários como essenciais ao fomento: admitia o emprego de mecanismos autoritários, expressivos do poder de mando estatal, para o incentivo de ações de interesse público com vista a corporificar atividades dessa natureza.

\footnotetext{
17 “乌 $8^{\circ}$ A União, os Estados e os Municípios criarão incentivos fiscais à industrialização dos produtos de solo e do subsolo, realizada no imóvel de origem."

18 “Art. 163. Às empresas privadas compete preferencialmente, com o estímulo e apoio do Estado, organizar e explorar as atividades econômicas."
} 
A CF de 1988, ao consagrar princípios como a participação popular e a subsidiariedade, colocou a atividade de fomento em posição de grande destaque:

\begin{abstract}
A tudo isso pode ser acrescentado, sob inspiração da globalização e da chamada Reforma do Estado, a ideia de Estado Subsidiário, baseado no princípio da subsidiariedade, formulado pela doutrina social da Igreja a partir de fins do século XIX, e que agora assume papel fundamental na definição do papel do Estado. De acordo com esse princípio, duas ideias são fundamentais: de um lado, a de que o Estado deve respeitar os direitos individuais, pelo reconhecimento de que a iniciativa privada, seja através dos indivíduos, seja através das associações, tem primazia sobre a iniciativa estatal; em consonância com essa ideia, o Estado deve abster-se de exercer atividades que o particular tem condições de exercer por sua própria iniciativa e com seus próprios recursos; em consequência, o princípio implica uma limitação à intervenção estatal. De outro lado, a ideia de que o Estado deve fomentar, coordenar, fiscalizar a iniciativa privada, de tal modo a permitir aos particulares, sempre que possível, o sucesso na condução de seus empreendimentos. Em consonância com esse princípio, várias medidas vêm sendo adotadas, como [...] a ampliação da atividade de fomento a entidades particulares que desempenhem atividades de interesse público. (DI PIETRO, 2002, p. 21).
\end{abstract}

Trouxe diversos dispositivos potencialmente ensejadores da aproximação entre Estado e sociedade civil, dentre os quais merece registro o artigo $6^{\circ},{ }^{19}$ consagrador, como direitos sociais, da saúde, da educação, do trabalho, moradia, lazer, segurança, previdência social, proteção à maternidade e à infância e da assistência aos desamparados.

Ao contemplar esses valores fundamentais, o Texto Maior trouxe, também e como decorrência natural e automática, o dever estatal de fomentar, de incentivar as atividades particulares voltadas à sua consecução.

Referidos valores deverão ser alcançados a partir da mobilização e interferência estatal - seja direta, por meio da disponibilização de serviços públicos, seja indireta, pelos mecanismos de estímulos e incentivos.

Nesses termos, independentemente das previsões expressas específicas distribuídas ao longo da Constituição, ${ }^{20}$ esse dever existe e tem hierarquia supralegal -

\footnotetext{
19 “Art. 6º São direitos sociais a educação, a saúde, a alimentação, o trabalho, a moradia, o lazer, a segurança, a previdência social, a proteção à maternidade e à infância, a assistência aos desamparados, na forma desta Constituição."

${ }^{20}$ Artigos 197, 205, 213, 150, VI, “c”, 195, §7 215 a 218, 225, 230 e 227. Nesse sentido, decisão do STF, no sentido de que "mais que uma possibilidade, é dever do Estado fomentar práticas desportivas formais e não formais, como direito de cada um, nos termos do artigo 217 da Constituição Federal." (MC em ADIN 4.259/PB, rel. Min. Ricardo Lewandowski).
} 
até porque a atividade de fomento depende, diferentemente do que se dá com os serviços públicos, de previsão constitucional meramente exemplificativa e genérica. ${ }^{21}$

\subsection{0 contexto espanhol}

Conforme asseverado, a atividade de fomento não é criação dos tempos correntes. $^{22}$

Suas bases dogmáticas mais sólidas, estruturadas e sistematizadas, ganharam relevância na Espanha do século XVIII.

Tal escolha encontra justificativa, ainda, na Lei Geral de Subvenções ibérica, editada em 2003, cuja estrutura retrata uma visão contemporânea avançada sobre o tema.

Esse diploma conceitua as subvenções como sendo toda disposição de dinheiro realizada pela Administração Geral do Estado, pelas entidades administrativas locais ou pela Administração das comunidades autônomas, em favor de pessoas públicas e privadas, observados os seguintes requisitos: a) independer de contraprestação aos beneficiários; b) estar condicionada ao cumprimento de um determinado objetivo, à execução de um projeto, à realização de uma atividade, à adoção de um comportamento singular realizados ou por realizar, devendo o destinatário cumprir as obrigações exatamente como assumidas; c) traduzir o projeto, a ação, conduta ou situação financiada atividade de utilidade pública ou interesse social ou promoção de uma finalidade pública (artigos 2.1 c/c 3.1).

Seu artigo 2.2 traz restrição reveladora da área de incidência do fomento, especificamente no que tange à sua defesa quanto às competências públicas inerentes, aspecto sobre o qual discorreremos mais adiante.

Dispõe expressamente sobre a possibilidade de criação de um regime específico a partir do instrumento subvencional, no caso, convênios (artigo 5.2), destacando a importância do planejamento quanto ao desempenho do fomento (artigo 8.1), da eficiência e eficácia — além dos princípios da publicidade, transparência, concorrência, objetividade, igualdade e não-discriminação (artigo 8.3).

21 "Na Constituição, as funções de prestação são definidas de modo taxativo, e, nelas, os direitos fundamentais operam como limites das ações públicas, enquanto que as funções de propulsão são apenas exemplificadas, e os direitos fundamentais atuam como orientações mandatórias para as ações públicas." (MOREIRA NETO, 2007, p. 159).

${ }^{22}$ Como bem lembra Jordana de Pozas, "a ação persuasiva e estimulante exercida a partir do poder sobre o ânimo dos governados para lhes persuadir, sem usar a força, a fazer o que julga o governante ser considerado bom, a encontramos em todas as épocas. Ainda que mal estudada, constitui um dos principais capítulos da política." (POZAS, 1949, p. 47, traduzimos). 
Admite a hipótese de concessão de benefício a entes despersonalizados (artigo 11.3) e, no que tange ao controle, veicula traços atualmente já superados, de mecanismos mais formais, burocráticos, focados no resultado (artigo 30).

Retornando nosso olhar ao passado, aos pilares conceituais ora adotados, na Espanha se encontra, realmente, o nascedouro da atividade de fomento - ou ao menos de sua sistematização e abordagem técnico-doutrinária -, assim como os aspectos mais significativos de sua evolução.

Ator fundamental desse processo foi Jordana de Jordana de Pozas, que importantíssimas contribuições deu à evolução e aprofundamento do estudo da matéria.

Como bem salienta Baena de Alcázar,

[...] E se isso se dá com a doutrina espanhola, na estrangeira se desconhece o conceito ou se lhe atribui muito pouco valor, como demonstra a consideração dessa ideia como algo original do nosso Direito administrativo. Uma passada pelas obras gerais, sem sair da bibliografia mais comum, foi bastante para nos mostrar que se lhe desconhece na Itália, Alemanha e França, o que não significa que se ignorem, por exemplo, a subvenção e as diversas ajudas em particular. Mas sempre se desconhece a ideia de fomento em si. Isso é especialmente importante, porque mostra a absoluta originalidade da postura de Jordana de Pozas quanto ao conceito de fomento. Não se trata nem de uma tradição recolhida e sistematizada, nem de uma construção estrangeira. Jordana desenvolve o novo conceito antes descrito e o designa com o termo fomento. (BAENA DEL ALCÁZAR, 1967, p. 58-59, traduzimos).

De se lembrar, juntamente com Villar Palasí (1954, p. 16-19), que já na Espanha da Idade Média era possível diagnosticar a presença de mecanismos de fomento, traduzidos na criação e manutenção de impostos e taxas destinados, por exemplo, à construção de obras de interesse público atribuídas aos Conselhos Municipais.

Foi o que se verificou com relação à construção da Ponte de Zaragoza, em 1336, de cujo memorial consta súplica ao Rei para a concessão de subvenção, sob o argumento de que seus predecessores haviam reiteradamente adotado essa prática.

Aí, porém, o estímulo, o incentivo estatal ganhava a feição - em decorrência da própria ausência da noção de Estado de Direito - muito mais de favor do que de instrumento voltado à consecução do interesse público: "em todos esses casos o Rei atuava como particular, sem interposição de império administrativo, como um 'emprestador' ou banqueiro - a frase, aplicada justamente na Espanha, é de Montesquieu." (PALLASÍ, 1954, p. 21, traduzimos). 
No século XVIII, a atividade de fomento era inserida no âmbito do poder de polícia, abrangente do exercício da integralidade das atividades e competências do governante.

Podia-se distinguir, então, e com base na doutrina alemã, entre uma polícia de ordem e uma polícia do bem-estar ou da prosperidade, correspondente exatamente à atividade promocional do Estado. ${ }^{23,} 24$

Voltavam-se as subvenções, em especial, somente à promoção de construções militares, havendo sido, em 1788, praticamente substituídas pelas isenções tributárias.

Nessa época, e segundo assevera Villar Ezcurra, o fomento se revelava como meio típico de auxílio da Coroa à realização de obras públicas (que corriam a cargo de Conselhos Municipais e Corporações). No século XIX, passou a se identificar com as construções levadas a cabo pelo Ministério do Fomento (1833), da mesma forma que com ideias de estímulo ao progresso e a atividades particulares, tendo em vista a então reinante resistência à intervenção estatal no domínio econômico. Foi então paulatinamente se divorciando da noção de obras públicas, aproximando-se mais e mais das atividades econômicas privadas (VILLAR EZCURRA, 1999, p. 98).

Nos dias atuais, a atividade de fomento na Espanha se encontra em notável grau de desenvolvimento e aplicação, razão pela qual consideraremos, ao longo do nosso estudo, as importantes contribuições originárias de suas construções dogmáticas e legislativas.

\subsection{Conceito}

O presente estudo tem por foco a atividade administrativa de fomento - a qual pode ser exercida tanto por entes estatais quanto não-estatais.

\footnotetext{
23 "No século XVIII a toda a atividade que receberia depois o nome de fomento, se lhe chama polícia (em razão do que o Estado dessa época recebe precisamente sua denominação), e o direito que as regia (jus politiae) compreendia toda a atividade administrativa que se inseria na competência do príncipe. [...] Pois bem, já esta mesma distinção nos demonstra que junto à polícia de ordem existe uma policia do bem estar ou da prosperidade, e é precisamente essa ideia a que se identifica com o fomento na acepção a que nos referimos agora, pelo que se pode afirmar com Villar Palasí que já no século XVIII aparece como fim a função de fomento.” (BAENA DEL ALCÁZAR, 1967, p. 54-55, traduzimos).

24 “Na Alemanha, nesse mesmo período (século XVIII), a doutrina juspublicista já traçava distinções entre uma atividade de polícia da segurança e outra atividade de polícia dirigida ao bem estar. A primeira se manterá ligada ao conceito de ordem pública (ou 'tranquilidade') enquanto que da segunda surgirá a atividade de fomento. Nessa expressão se englobam, inicialmente, todas as atuações do poder público voltadas a facilitar ou estimular a atividade dos particulares (especialmente as de caráter econômico)." (VILLAR EZCURRA, 1999, p. 27, traduzimos).
} 
Cumpre-nos, portanto, delinear perfeitamente o que se entende por atividade administrativa, noção indissociável do conceito de função administrativa.

Traduz-se esse último no poder-dever de promoção de interesses determinados, nas palavras de Justen Filho, em um "conjunto de poderes jurídicos destinados a promover a satisfação de interesses essenciais, relacionados com a promoção de direitos fundamentais, cujo desempenho exige uma organização estável e permanente e que se faz sob regime jurídico infralegal e subjetivo a controle jurisdicional." (JUSTEN FILHO, 2012, p. 94).

Trata-se, portanto, de um conjunto de poderes, de um feixe de competências - a serem exercidas e concretizadas justamente por meio das atividades administrativas: "A função administrativa é um conjunto de competências, e a atividade administrativa é a seqüência conjugada de ações e omissões por meio das quais se exercita a função e se persegue a realização dos fins que norteiam e justificam sua existência. A função administrativa se traduz concretamente na atividade administrativa." (JUSTEN FILHO, 2010, p. 101).

Conforme se depreende do exposto no item anterior, o conceito jurídico de fomento surgiu pioneiramente na Espanha, pela doutrina de Jordana de Pozas, ${ }^{25}$ que cunhou, no ano de 1949, a seguinte definição:

\begin{abstract}
A noção de fomento é uma via média entre a inibição e o intervencionismo do Estado que pretende conciliar a liberdade com o bem comum mediante a influência direta sobre a vontade do indivíduo para que queira o que convém para a satisfação da necessidade geral, sem usar a coação nem criar serviços públicos. Poderíamos defini-la como a ação da Administração voltada a proteger ou promover aquelas atividades, estabelecimentos ou riquezas devidos aos particulares e que satisfazem necessidades públicas ou se estimam de utilidade geral, sem usar da coação nem criar serviços públicos. (JORDANA DE POZAS, 1949 , p. 46, traduzimos)
\end{abstract}

Sua divisão tripartite, consagrada como clássica, parte do entendimento de que as atividades administrativas necessariamente se desdobram em polícia, serviço público ou fomento. $^{26}$

\footnotetext{
${ }^{25}$ De se lembrar a edição, em 1955, do Reglamento de Servicios de las Corporaciones Locales (Decreto de 17 de junho), veiculador de mecanismos de fomento compreendidos a partir da doutrina do referido autor, e que segue em vigor até os dias atuais.

${ }^{26}$ Lembre-se, por oportuno, que o autor vislumbrava ainda uma quarta forma de satisfação das necessidades gerais, qual seja, a atividade legislativa, que, por não se inserir no âmbito de atuação da Administração pública, não integrará nossas ponderações.
} 
À primeira, corresponderia a limitação das iniciativas privadas por meio de instrumentos de coação sustentados, inclusive, pelo potencial uso da força, caso necessário, e com vista à manutenção da ordem pública.

Para a sua perfeita delimitação, Jordana de Pozas invoca Santi Romano, para quem "denomina-se polícia a atividade administrativa que, por meio de limitações eventualmente coativas da atividade privada, se dirige a prevenir os danos sociais de que desta última podem derivar-se.” (JORDANA DE POZAS, 1949, p. 44, traduzimos).

Sob a ótica do autor em questão, o serviço público, se traduz na atividade administrativa vocacionada a "satisfazer a necessidade pública de que se trate de uma maneira direta, pelos órgãos da própria Administração criados com essa finalidade e com exclusão ou em concorrência com particulares.” (JORDANA DE POZAS, 1949, p. 44, traduzimos).

Ao fomento restaria uma caracterização subsidiária: as atividades que não se inserissem em nenhuma das duas outras categorias estariam em seu âmbito de incidência.

Os elementos distintivos dessas três categorias seriam: a) existência ou ausência de coação; b) prevenção-repressão ou proteção-promoção; c) atuação direta ${ }^{27}$ ou indireta da Administração.

Essa classificação foi objeto de diversas críticas, as quais, não obstante, não tiveram o condão de invalidar, até os tempos correntes, as bases teóricas fundadas pelo autor ibérico, as quais seguem como o principal apoio dogmático para os estudiosos do assunto.

Tanto é assim que a conceituação de Jordana de Pozas, como as de todos os seus críticos e seguidores, partem das noções de fomento, polícia e serviço público, motivo pelo qual nos deteremos um momento, também, na sua abordagem.

O ponto inicial para a caracterização do fomento é o entendimento relativo ao conjunto e às espécies de atividades estatais, do tratamento que lhes outorga o ordenamento jurídico.

Muitos discordam da classificação defendida por Pozas, quer no sentido de enxergarem outros indispensáveis desdobramentos e subdivisões, quer para simplesmente rearranjá-la.

Garrido Falla se manifesta sobre a questão nos seguintes termos:

\footnotetext{
${ }^{27}$ Ainda que por intermédio de terceiros.
} 
A abundante literatura, geralmente de origem francesa, dedicada a colocar relevo na chamada "crise da noção de serviço público", como consequência da nova e enorme atividade estatal no campo da economia, tem sido utilizada entre nós para submeter à revisão o sistema triparticional antes referido, concluindo que às atividades de polícia, fomento e serviço público deve somar-se à gestão econômica, cuja característica não é a de prestar serviços, mas de dar bens ao mercado. (GARRIDO FALLA, 1992, p. 121, traduzimos).

Salientemos, ainda, a inclusão, pelo autor, de uma mais espécie, dentro da atividade de coação da Administração, correspondente às prestações obrigatórias dos particulares. $^{28}$

Para Ariño Ortiz, as modalidades de atuação administrativa se distinguem em: a) polícia e regulação econômica; b) fomento; c) serviço público; d) gestão econômica; d) planejamento; e e) atuação arbitral (ARIÑO-ORTIZ, 2004, p. 295).

Villar Ezcurra elenca as atividades de: a) manutenção da ordem pública; b) estímulo à atividade de particulares; c) prestação direta de serviços ou bens; e d) garantia de prestação de serviços (assim retratada em razão da desnecessidade de prestação direta pelo Estado) (VILLAR EZCURRA, 1989, p. 25).

Villar Palasí, por sua vez, defende a inclusão da atividade de fomento no quadro geral da administração indireta do Estado, especificamente como colaboração privada nos fins administrativos (VILLAR PALASÍ, 1950, p. 60).

Para ele, há que se admitir a existência de uma quarta categoria, correspondente à gestão econômica administrativa, além das três já assentes (VILLAR PALASÍ, 1950, p. 53-129).

\footnotetext{
28 " [...] nos interessa, pois, enumerar a seguinte tipologia da atividade administrativa: 1. Atividade de coação — é a que realiza a Administração pública para conseguir que os particulares ajustem obrigatoriamente sua conduta ou seu patrimônio ao interesse público. A satisfação de uma necessidade pública existente se atinge aqui com uma determinada conduta dos particulares; a atividade da Administração se volta a que tal conduta se realize obrigatoriamente, inclusive sob ameaça de coação. O exame dessa atividade inclui o estudo de dois capítulos do Direito administrativo tradicional: a) a polícia administrativa, e b) as prestações obrigatórias dos particulares à Administração. 2. Atividade de estímulo ou persuasão - também aqui é a atividade dos particulares que vem a satisfazer diretamente as necessidades públicas do momento. Mas por tal razão a Administração exerce sua própria atividade para lhes persuadir e estimular. É a atividade administrativa que se conhece na doutrina espanhola com o nome de fomento. 3. Atividade de prestação - As prestações necessárias para satisfazer as necessidades públicas são aqui oferecidas pela própria Administração (ou por pessoa que atua por sua delegação). Essa atividade inclui tanto prestações que pressupõem a montagem de uma empresa econômica (por exemplo, exploração de trens pelo Estado), como prestações de tipo gratuito assistencial (beneficência), tanto a atividade monopolista como atividade em concorrência com a dos particulares, tanto atividade submetida às regras de Direito público como prestações que se produzem segundo um regime privado. Em suma, aqui incluímos a teoria do serviço público, as prestações da Administração aos administrados e o que uma parte da doutrina denomina atividade de 'gestão econômica'." (GARRIDO FALLA, 1992, p. 123, traduzimos).
} 
No Brasil, não obstante historicamente praticado (conforme breve panorama histórico anteriormente traçado), o fomento tradicionalmente não ocupava local de destaque, permanecendo ofuscado pelas funções de polícia, serviços públicos e ordenação econômico-social (HIGA, 2010, p. 66-67).

Realmente, dos estudos do Visconde de Uruguai extrai-se a visão extremamente centralizadora que se tinha à época (primeira metade do século XIX), incompatível com o compartilhamento de atribuições e competências, quer entre os diversos níveis políticos e geográficos, quer entre Estado e cidadãos (URUGUAI, 2002).

Os exercícios e dinâmicas democráticos eram tidos como inviáveis e inaplicáveis ao contexto brasileiro, na medida em que nossa sociedade se apresentava então desprovida da homogeneidade e maturidade imprescindíveis ao exercício da democracia popular. ${ }^{29}$

O século XIX foi marcado, no Brasil, pela raríssima ingerência estatal no domínio social (OLIVEIRA, 1975, p. 16).

Essa Administração de polícia evoluiu para a prestadora de serviços, atividade cuja posição protagônica somente começa a se desvanecer na segunda metade de século XX, quando a ideia de fomento estatal começa a raiar (OLIVEIRA, 1975, p. 20).

A Constituição Federal de 1988, responsável pela redemocratização do país, prestigiou os mecanismos de participação popular e aproximação entre as esferas pública e privada, em um processo que resultou no fundamental papel atribuído ao fomento da iniciativa privada de interesse público nos tempos que correm.

Segundo pontua Sílvio Luís Ferreira da Rocha, a efetiva consagração da atividade de fomento se deu na década de 1990, com a Reforma Administrativa levada a termo pelo Ministério da Administração Federal e Reforma do Estado - MARE.

Refere-se a essa função administrativa como teleológica, voltada à satisfação das necessidades coletivas, sem o uso da coação e sem prestar serviços públicos, promovendo ou protegendo as atividades dos particulares (ROCHA, 2003).

\footnotetext{
29 “Assim é e deve ser, ao menos a certos respeitos, naqueles afortunados países, onde o povo for homogêneo, geralmente ilustrado e moralizado, e onde a sua educação e hábitos o habilitem para se governar bem a si mesmo. Quais e quantas são as nações entre as quais se tem podido estabelecer o self government? Ide estabelecê-lo em certos lugares da Itália, entre os Lazzaroni, no México, e nas Repúblicas da América Meridional! O pobre Soberano, o povo, deixar-se-á iludir, e será vítima do primeiro ambicioso esperto [...]. Nos países nos quais ainda não estão difundidos em todas as classes da sociedade aqueles hábitos de ordem e legalidade, que únicos podem colocar as liberdades públicas fora do alcance das invasões do Poder, dos caprichos da multidão, e dos botes dos ambiciosos, e que não estão portanto devidamente habilitados para o self government, é preciso começar a introduzi-lo pouco a pouco, e sujeitas esses ensaios a uma certa cautela, e a certos corretivos. Não convém proscreve-lo, porque, em termos hábeis, tem grandes vantagens, e nem o Governo central, principalmente em países extensos e pouco povoados, pode administrar tudo. É preciso ir educando o povo, habituando-o pouco a pouco, a gerir os seus negócios." (URUGUAI, 2002, p. 491).
} 
Não compartilhamos, conforme adiante se verá, dessa última ressalva trazida pelo autor, pois não detectamos nenhum óbice a que o fomento se destine também a entes públicos, estatais ou não.

Maria Sylvia Zanella Di Pietro (2012, p. 35) relaciona fomento à subsidiariedade, em análise acolhida no presente estudo.

Adotamos como referência a lição de Moreira Neto, segundo a qual:

No Brasil, Diogo de Figueiredo Moreira Neto elabora classificação das atividades administrativas, distinguindo as seguintes: poder de polícia a Administração "limita e condiciona o exercício das liberdades e direitos individuais, visando a assegurar um nível aceitável de convivência social"; serviços públicos - a Administração, "por si ou por seus delegados, satisfaz não só as necessidades essenciais como certas necessidades secundárias da comunidade"; ordenamento econômico "função de caráter disciplinativo ou substitutivo das atividades privadas no campo da economia, isto é, nos processos de produção, circulação e consumo das riquezas"; ordenamento social - execução de imposições legais de uma disciplina pública ou substitutiva da ação da sociedade no campo social, ou seja, na saúde, na educação, no trabalho, na previdência"; fomento público, também denominada atividade propulsora - "a Administração procura, por todos os meios a seu alcance, por à disposição do maior número possível de indivíduos os instrumentos do desenvolvimento econômico e do progresso sociocultural, pela adoção de medidas capazes de incentivas a iniciativa de interesse coletivo nesses campos". (MOREIRA NETO, 2009, p. 134-135). ${ }^{30}$

Celso Antonio Bandeira de Mello fala em serviço público, obra pública, gestão de bens, polícia e intervenção do Estado no domínio econômico (BANDEIRA DE MELLO, 2012, p. 683-685).

O que ressalta dessa questão é que a classificação adotada seja compatível com o momento histórico a que se pretenda aplicar, e que produza resultados úteis e funcionais, no sentido de viabilizar o diagnóstico e implementação do correto regime jurídico incidente, até porque a atividade administrativa se desenvolve, nas palavras de Villar Ezcurra, em:

[...] uma zona atormentada de disposições e quase órfã de categorias que conduz a uma espécie de Direito difuso na medida em que a enorme quantidade de regulações concretas apenas permite desenhar os perfis de uma estrutura que possibilita seu enquadramento sob um esquema preconcebido. As categorias, aqui, serão puramente tendenciais na

${ }^{30}$ MOREIRA NETO, Diogo de Figueiredo. Curso de Direito Administrativo, 2009, p. 134-135, apud MEDAUAR, 2012, p. 116-117. 
medida em que não responderão a critérios que possam ser formulados de forma clara. (VILLAR EZCURRA, 1999, p. 21, traduzimos).

A análise voltada a sua definição encontra-se "intimamente relacionado com a forma de entender a relação entre o Estado (ou, mais genericamente, os poderes públicos) e a sociedade civil." (VILLAR EZCURRA, 1989, p. 23, traduzimos).

A celeuma reinante retratada, tradutora da instabilidade, provisoriedade e contornos inexatos das atividades administrativas, demonstra claramente a absoluta insuficiência - e inviabilidade - da adoção do critério residual para a definição técnica do fomento, que ficaria sujeita aos alvedrios e alterações doutrinárias quanto à compreensão das referidas funções.

Indispensável o perfeito delineamento dessa atividade a partir de seus próprios traços característicos, determinantes do regime jurídico correspondente, e não em virtude de uma relação de suposto equilíbrio e mútua exclusão quanto às demais atividades administrativas - sob pena de se desenvolver um ambiente de total instabilidade e imprevisibilidade, decorrente até mesmo do dissenso dogmático e do frágil entendimento daí resultante quanto à definição de fomento.

Tecidas essas ponderações, passemos às soluções doutrinariamente apresentadas para a definição independente e propriamente dita do fomento, considerado o paradigma da lição originária e basilar de Jordana de Pozas, porém com o afastamento da caracterização residual.

Para Baena de Alcázar (1967), a divisão tripartite e residual de Jordana Pozas apresenta-se insuficiente em razão, principalmente, da profusão de conceitos de fomento, ou da ausência de uma sua acepção unívoca.

Ressalta o autor a existência de três concepções jurídicas diferentes de fomento: a) a desenvolvida na primeira metade do século XIX, correspondente a uma releitura do que no século XVIII era tido como polícia do bem-estar, voltada à promoção do desenvolvimento nacional espanhol e tida como fim universal da atividade administrativa; b) a decorrente da formulação de Jordana de Pozas, que passa a enxergá-la não como um fim, mas como um meio da atividade administrativa; e c) a resultante da postura de Guaita, que merece maior destaque, conforme termos a seguir desenvolvidos.

Temos, primeiramente, que Guaita não se satisfaz com o caráter residual da classificação de Jordanas de Pozas, tendo em vista o papel central desenvolvido pelo fomento dentre as funções estatais. 
Agrega ao conceito originário um aspecto teleológico específico, finalístico, segundo o qual seria absolutamente essencial ao fomento a busca do aperfeiçoamento e a melhora do nível econômico ou social.

A partir desse raciocínio, estariam atraídas para o seu âmbito de incidência atividades até então unanimemente relacionáveis ao poder de polícia, já que, ao se outorgar mais destaque à finalidade da atuação que aos seus mecanismos, passar-se-ia a admitir uma pluralidade de meios para o alcance da meta colocada.

A essa questão, correspondente ao predomínio dos meios ou dos fins, voltaremos com vagar mais adiante.

Retornemos, pois, a Baena del Alcázar, para quem o fomento é composto por três elementos fundamentais: a) objeto, segundo o qual pode recair tanto sobre atuações particulares quanto de entes públicos; b) fim, traduzido na satisfação indireta de necessidades de ordem pública pela via não coativa (sendo este o fator diferencial elementar com relação à atividade de polícia e que, isoladamente, não é suficiente para qualificar o fomento como tal); somam-se a esse a finalidade de intervenção na ordem econômica - a qual, em última análise, se apresenta como um desdobramento daquele primeiro - , e a cooperação entre entes públicos e privados; c) noção de técnica, traduzida nos mais diversos mecanismos, conforme adiante se verá, necessariamente veiculadores de meios indiretos e não coercitivos de atingimento do fim preconizado; neste particular, há, ainda, um outra acepção, correspondente justamente ao método persuasivo.

Posiciona-se de forma a priorizar — se divorciando da postura de Guaita — uma perspectiva instrumental, baseada na natureza da técnica empregada em detrimento do elemento teleológico.

Villar Ezcurra trata do fomento a partir do elemento do benefício a ser alcançado, nos seguintes termos:

A atividade administrativa de estímulo se define, basicamente, por oposição à de limitação ou polícia, dentro das duas formas essenciais que tem a Administração Pública para controlar a atividade dos particulares (e que já revelou doutrina alemã do século XIX ao distinguir entre uma polícia de segurança e outra de bem estar). Sob essa primeira perspectiva se poderia incluir na atividade de estímulo todas aquelas formas de intervenção não enquadráveis na polícia, com o que não se haveria avançado muito, já que se envolveria em um conceito meramente residual em que ficariam incluídas coisas muito diferentes. De seu a própria expressão de estímulo aponta para a existência de outro elemento de caráter positivo já que alude à necessidade de produzir algum tipo de benefício. Nisso precisamente radica a essência do que na Espanha, de 
forma absolutamente original (ainda que pareça incrível) se denomina como atividade de fomento e que já desde sua gênese nas Partidas onde aparece a expressão "femência" — faz referência a uma atuação dos poderes públicos que tende a favorecer ou facilitar a atividade dos particulares. (VILLAR EZCURRA, 1999, p. 97, traduzimos)

\title{
Para Ariño-Ortiz:
}

\begin{abstract}
A atuação fiscal e/ou financeira de fomento ou dissuasão está integrada por aquelas medidas de ingresso e/ou gastos públicos que orientam ou incentivam (ou dissuadem) a ação econômica privada, encaminhando a ação dos agentes para a produção de determinados bens e serviços necessários para a coletividade. No direito público espanhol se chamou a essa modalidade de "ação de fomento". (ARINO-ORTIZ, 2004, p. 303, traduzimos).
\end{abstract}

Notemos que o autor limita - indevidamente, conforme veremos adiante - a atividade de fomento àquelas direcionadas ao exercício particular de natureza econômica.

Garrido Falla define fomento como "aquela atividade administrativa que se dirige a satisfazer certas necessidades consideradas de caráter público protegendo ou promovendo, sem empregar a coação, as atividades dos particulares ou de outros entes públicos que diretamente as satisfazem" (GARRIDO FALLA, 1992, p. 301, traduzimos).

Há, aí, em acréscimo à postura paradigma de Jordana de Pozas, a admissibilidade de figurarem entes públicos como destinatários.

No mesmo sentido de posiciona Entrena Cuesta, ${ }^{31}$ para quem o fomento corresponde à "atividade administrativa encaminhada a proteger ou promover aquelas atividades, estabelecimentos ou riquezas dos particulares ou de outros entes públicos que satisfazem necessidades públicas ou se estimam de utilidade geral, sem usar a coação nem criar serviços públicos." (Traduzimos).

Lopez-Muniz, a seu termo, apresenta o seguinte conceito:

[...] podemos definir essa atividade dispensadora de ajudas e recompensas como aquela atividade administrativa consistente na outorga direta ou indireta de bens ou direitos a determinados administrados — privados ou públicos - , com caráter não devolutivo e por razão de certas atividades que lhes são próprias, já realizadas ou ainda por desenvolver, ficando neste último caso afetados à sua realização. (LOPES-MUNIZ, 1989, p. 758 , traduzimos).

${ }^{31}$ ENTRENA CUESTA, Apuntes de Derecho Administrativo. Curso 1958-1959, p. 139-140, apud BAENA DEL ALCÁZAR, 1967. 
Vemos que, aos critérios tradicionais e da destinação tanto a particulares quanto a entes públicos, somou este último autor o caráter não devolutivo, a titularidade típica do ente fomentado no que tange à atividade a ser desenvolvida e a abrangência tanto de atividades desenvolvidas quanto a desenvolver.

Em sentido contrário, nesse particular, a doutrina de Santamaría Pastor (2000, p. 350-356), segundo o qual somente poderiam ser objeto de fomento as atividades futuras, a serem desenvolvidas.

Isso porque, no que tange àquelas já efetivadas (com relação às quais se falaria em recompensa), não existiria nexo de causalidade — ou de incentivo, de estímulo entre a postura estatal e a conduta do agente, fato esse suficiente para excluí-la do âmbito de incidência em foco.

De la Riva posiciona-se pela plena viabilidade de a atividade de fomento se direcionar a atividades ex post, já que o fato teria o condão de estimular terceiros à adoção de postura relevante nos mesmos moldes. ${ }^{32}$

No mesmo sentido, Lopez-Muniz:

A diferença entre ajudas e recompensas reside em que as primeiras se referem a atividades por desenvolver ou em vias de ser desenvolvidas, enquanto as segundas, a atividades ou condutas já executadas, muitas vezes, inclusive, sem uma consciente expectativa de prêmio. Tanto as ajudas como as recompensas poderão se traduzir em medidas honoríficas ou econômicas ou financeiras, não obstante aquelas serem mais comuns nas recompensas e estas nas ajudas. (LOPEZ-MUNIZ, 1989, p. 758, traduzimos).

Nesse aspecto, temos que o fomento, o estímulo propriamente dito, somente pode se direcionar a atividades futuras, a se realizarem, sob o risco de comprometimento da isonomia.

Realmente, as regras, inclusive benéficas, devem estar bem claras e expressas para toda a sociedade. Não se pode admitir que o administrador eleja livremente, em momento que julgue conveniente, as condutas e posturas — já realizadas — dignas de premiação.

Tal cenário subtrairia aos demais potenciais interessados a possibilidade de assim atuar e garantir o mesmo tratamento diferenciado, trazendo o risco de admissão de

\footnotetext{
32 “[...] inclusive naqueles casos em que a condecoração foi criada a posteriori de sua ação, é inegável que ao menos aquela terá por efeito incentivar a outros para que imitem o exemplo de quem foi reconhecido." (DE LA RIVA, 2004, p. 112, traduzimos).
} 
critérios subjetivos a orientar a consagração administrativa de condutas como de interesse público e, portanto, merecedoras de incentivo ou recompensa.

A ciência de todos os mecanismos atrativos é indispensável para que se possa falar em igualdade de oportunidades a todos os integrantes do corpo social - ou público, em hipóteses específicas, conforme adiante se verá.

Quanto à titularidade típica do destinatário no que tange às atividades a serem fomentadas, teceremos maiores comentários adiante.

Entre os autores pátrios, lembra Célia Cunha de Mello (2003, p. 33) que o fomento desponta no século XXI como um poderoso instrumento de intervenção estatal nos domínios público e social vocacionado à proteção e/ou promoção de necessidades pública, operacionalizando-se por meios não compulsórios.

Marcos Juruena Villela Souto (2007, p. 17) assevera que, não obstante a adesão às medidas de fomento serem facultativas - em decorrência da livre iniciativa, fundamento da República —, uma vez formalizada a relação o aderente estará sujeito aos seus termos e a regime jurídico específico.

Alberto Shinji Higa (2010, p. 124-125) ressalta a complementaridade das atividades particulares fomentadas.

Sílvio Luís Ferreira da Rocha (2006, p. 33), a seu turno, pondera que a atividade em questão deve ser orientada pelo princípio da repartição de riscos, ou do risco compartido - entre fomentador e fomentado.

Quanto à relação entre planejamento e fomento, excluem o primeiro do âmbito do segundo, colocando-o como um seu pressuposto, Célia Cunha Mello (2003, p. 76-81), Marcos Juruena Villela Souto (2003, p. 39), Maria Tereza Fonseca Dias (2008, 266).

A essa discussão também voltaremos adiante.

Carolina Caiado Lima conceitua fomento como a atividade administrativa “voltada à proteção ou ao estímulo de atividades de interesse público e coletivo desenvolvida por particulares, que se concretiza por atuação indireta e não coercitiva do Estado, distinta de serviços públicos e pressupondo adesão voluntária dos agentes fomentados" (LIMA, 2010, 69).

\subsubsection{Caracterização: meios ou finalística?}

A adoção do critério teleológico ou de meio para a caracterização da atividade de fomento foi alvo, ao longo dos tempos, de intensas discussões doutrinárias. 
Estaria ela configurada em todas as hipóteses em que a Administração buscasse, por quaisquer meios, mobilizar a iniciativa privada em prol do bem comum, ou somente naquelas situações em que essa perseguição do interesse coletivo ${ }^{33}$ se desse a partir de ferramentas não coativas?

A adoção da primeira posição, conforme a qual prepondera o diferenciador finalístico, levaria à possibilidade de utilização de técnicas típicas de polícia ou mesmo dos serviços públicos para a consecução da atividade fomentadora.

Nesse cenário, poderia se vislumbrar um entrelaçamento entre aspectos das três categorias clássicas de atuação estatal, admitindo-se, por exemplo, a proibição de determinada atividade em certos locais com vista a melhorar a segurança, e, consequentemente, o desempenho do comércio do entorno, como atividade de fomento.

Essa concepção foi defendida por Garrido Falla, para quem:

[...] na prática, os diferentes tipos de atividade administrativa se interpenetram até parecer confundir-se, por vezes. Assim, para estabelecer um serviço público, a Administração pode utilizar métodos coativos; inclusive a própria regulamentação do serviço tem uma natureza coativa semelhante a que oferece a polícia. A seu turno, há medidas de fomento que unicamente se podem provocar mediante o emprego prévio da polícia ou medida coativa: por exemplo, para estimular determinado setor da indústria nacional (finalidade de fomento) se impõe a aquisição obrigatória de seus produtos a determinado setor de consumidores (medida coativa de fomento). (GARRIDO FALLA, 1992, p. 123, traduzimos).

Os partidários da corrente finalística ou teleológica da definição de fomento adotam o princípio da intercambialidade das formas, ${ }^{34}$ autorizativo da utilização dos mais diversos meios para a consecução do estímulo, incentivo ou promoção.

Em contraposição a esse entendimento a doutrina de Baena de Alcázar e de Lopez-Muñiz:

Em resumo, nos deparamos com que o fomento considerado como um fim foi entendido e ainda se entende como atividade de política em sentido amplo. Por outra parte, admitindo a ideia de fim em concorrência

\footnotetext{
${ }^{33} \mathrm{Na}$ lição de Luis Roberto Barroso, “[...] na linha de fronteira entre o público e o privado, situa-se uma categoria jurídica desenvolvida nas últimas décadas: a dos interesses coletivos. Sob esse rótulo genérico desvelam-se os bens materiais e imateriais compartilhados por toda a sociedade ou por amplas parcelas nela integradas, como os bens de valor histórico, artístico e paisagístico; o meio ambiente; a segurança dos produtos de consumo de massa; a preservação da cultura nacional, em meio a muitos outros. As relações sociais e os interesses coletivos situam-se no espaço entre a vida exclusivamente privada e a vida pública." (BARROSO, 2010, p. 62).

${ }^{34}$ A ser tratado com mais vagar adiante.
} 
com a coação ou persuasão, comprovou-se que existia uma confusão possível entre a atividade de polícia e a de fomento. Permanece, pois, unicamente a diferença em razão da técnica coativa ou persuasiva na medida em que essas podem se considerar verdadeiras técnicas. (BAENA DEL ALCÁZAR, 1967, p. 63, traduzimos).

As ideias de persuasão, ou de estímulo ou incentivo que, com frequência, se propõem como distintivas do fomento, e que, sem dúvida, traduzem sua semântica própria, não podem furtar-se tampouco a uma significação principalmente finalística muito semelhante, motivo pelo qual as sugestões de substituir a denominação de atividade de fomento pela de atividades de persuasão ou de incentivo etc., não resolvem nada. No final, esses fins de persuadir, estimular ou promover, etc., podem ser atingidos através de diferentes meios, com modos diversos de atuação administrativa e não só com os que se quer aludir quando se fala da atividade de fomento, a qual, por outra parte, como já se disse, nem sempre se propõe a esses fins. $\mathrm{O}$ importante para distinguir os modos de ação administrativa é seu componente estrutural e não sua orientação teleológica. Os fins poderão ter, sem dúvida, sua relevância com relação a outros efeitos, mas não a estes. [...] Ocorre simplesmente que o elemento teleológico não intervém na diferenciação conceitual da atividade dispensadora de ajudas e recompensas a respeito dos demais modos de ação administrativa. (LOPEZ-MUNIZ, 1989, p. 756-758, traduzimos).

Segundo esses autores, o aspecto diferencial das atividades estatais estaria justamente na natureza dos mecanismos empregados, e não na sua finalidade, a qual, em última análise, acabará sempre se confundindo com a própria noção de interesse — ou interesses públicos. ${ }^{35}$

Villar Palasí aponta outra questão, a seu ver predominante com relação aos meios ou fins perseguidos: a ampliação da esfera jurídica do particular. ${ }^{36}$

De la Riva também traz um elemento a mais, asseverando que o ponto diferenciador fundamental do fomento é a coincidência entre os interesses público e particular envolvidos, os quais devem necessariamente se orientar no mesmo sentido. ${ }^{37}$

\footnotetext{
35 “[...] a lei atribui à Administração pública fins e interesses contraditórios entre si, reconhecendo à própria Administração o poder de ponderar tais interesses e fazer as escolhas. Assim, alguns avanços eram feitos reconhecia-se que nem toda atividade pública era planejada de acordo com um resultado que, ao contrário, é produto do conflito de interesses públicos, quando vários interesses são canonizados sem que sejam estabelecidas ordem e prioridade; admitia-se que poderia haver um conflito que não fosse o público/privado; constatava-se que decisões administrativas implicam ponderações e, portanto, comparações de interesses." (CASSESE, 2010, p. 87).

36 "Seguindo esse critério, a policia atua técnicas de atribuição de um minus na situação jurídica do particular, frente às técnicas de fomento que implicam em todo caso na atribuição de um plus. Desse modo, é o resultado da atuação administrativa em um ou outro caso — polícia e fomento —, o que importa primariamente para delimitar ambas as técnicas, segundo se amplie ou restrinja a esfera própria do súdito." (PALASÍ, 1955, p. 44, traduzimos).

37 "A meu ver, o que se destaca na área da atividade administrativa estudada e funciona como pressuposto para a identificação do elemento configurador que estamos buscando é a coincidência, ao menos parcial, que se constata no fomento entre os interesses públicos e privados envolvidos, já que ambos se orientam ao mesmo sentido. É isso, precisamente, o que permite a Administração persuadir os particulares para que atuem
} 
Realmente, considerada a voluntariedade das atividades particulares desencadeadas a partir dos estímulos públicos, temos que referida coincidência apresentase até mesmo como intuitiva, não se podendo imaginar que o particular se mobilize em determinado sentido, por iniciativa própria, de modo a sacrificar ou a ir contra seus próprios interesses.

Ressaltemos, porém, a possibilidade, cada vez mais comum, de mobilização da iniciativa privada em prol de terceiros, por vezes inclusive com redução de sua esfera jurídica.

Tais hipóteses se fundamentam no princípio da solidariedade, absolutamente atual e determinante da assunção, por todos os integrantes de uma dada sociedade, da responsabilidade pelo seu desenvolvimento e aprimoramento.

A consciência dos inevitáveis efeitos das relações dos diversos grupos com o todo descortina situações em que o agente fomentado não tem ganho direto algum com sua conduta - e, ainda assim, opta por adotá-la, com vista a fazer valer a denominada reciprocidade social. ${ }^{38}$

Não obstante a inviabilidade de refutarmos a necessária coincidência de pretensões em todas as atividades e posturas resultantes do fomento, não cremos ser possível inseri-la no seu âmbito estrutural fundamental, como elemento essencial dessa atividade. Isso porque incide essa coincidência apenas em um segundo momento, em que o fomento já se aperfeiçoou, e em um outro âmbito, estranho à esfera administrativa.

Temos mesmo que seria inadmissível pretender que o fomento existisse somente a partir do momento em que o particular a ele aderisse, na medida em que a Administração age por si, autonomamente e independentemente de qualquer postura condicionante de sujeitos que lhes sejam estranhos.

Não podemos confundir a atividade administrativa de fomento com os seus resultados, potenciais ou efetivos.

A ausência de coação já desempenha suficientemente a função de explicitar a faceta não autoritária da Administração fomentadora.

Temos, pois, que os parâmetros mais adequados à exata definição da atividade de fomento são aqueles correspondentes aos meios não coercitivos empregados, em cujo foco se deve concentrar o intérprete.

voluntariamente em uma direção determinada, porque desse modo, perseguindo seu próprio interesse beneficiarão, sem querer, a sociedade em geral." (DE LA RIVA, 2004, p. 116, traduzimos).

${ }^{38}$ Para mais detalhes, confira-se item 1.8.7, infra. 
É claro que essa postura não afasta a necessidade de a atividade se voltar à satisfação e promoção do interesse público - o que se verifica, porém, com relação a toda e qualquer atuação administrativa, motivo pelo qual não pode este ser tido como aspecto diferenciador ou como o elemento essencial da definição.

\subsubsection{Instrumentos}

Conforme bem adverte Jordana de Pozas, é absolutamente impossível o elenco completo e conclusivo de todas as formas de que pode se revestir a ação de fomento. (JORDANA DE POZAS, 1959, p. 50-51).

Apresenta o autor, porém, algumas possíveis classificações, segundo as quais seus instrumentos viabilizadores poderiam ser divididos, inicialmente, em: a) positivos, que outorgam prestações, bens ou vantagens; e b) negativos, "que significam obstáculos ou encargos criados para dificultar por meios indiretos aquelas atividades ou estabelecimentos contrários aos que o governante quer fomentar" (JORDANA DE POZAS, 1959, p. 51, traduzimos).

Sua classificação mais repercussiva, no entanto, vislumbra a existência de meios: a) honoríficos, compreensivos das distinções e recompensas outorgadas em reconhecimento público a um ato ou conduta exemplar; b) econômicos, determinantes da percepção de valores ou da dispensa de onerações obrigatórias, e divididos em reais ou financeiros, consistindo os primeiros no uso ou aproveitamento privilegiado de bens de domínio público, ou na utilização gratuita de serviços, e c) jurídicos, desencadeadores da outorga de uma condição privilegiada que, indiretamente, pode acarretar vantagens econômicas.

Ambas são também aceitas por Garrido Falla (1992, p. 304-317), Ariño Ortiz (2004, p. 346-347) e Baena del Alcazár (1967, p. 69-74).

Este último lembra a lição de Pellisé, para quem, ao lado dos meios honoríficos, estariam também os psicológicos, "que consistem fundamentalmente na propaganda" (BAENA DEL ALCÁZAR, 1967, p. 70).

A grande discussão relacionada a essas classificações vincula-se: a) à possibilidade de haver mecanismos negativos de fomento; e b) à existência dos denominados estímulos psicológicos.

Esses dois pontos apresentam-se intimamente ligados, conforme se depreenderá das ponderações desenvolvidas a seguir. 
Os mecanismos negativos se caracterizariam essencialmente pela ausência de vantagem ou de ajuda ao indivíduo engajado na atividade fomentada, o que seria para muitos inconcebível, vez que os instrumentais a serem utilizados nas atividades promocionais deviam assumir conotação sempre positiva, ampliativa de direitos e franqueadora de "vantagens".

Não se poderia vislumbrar, segundo essa linha, que o cidadão se sujeitasse, voluntariamente, a partir de mecanismos não coercitivos, a situações determinantes de restrições ou prejuízos em sua esfera jurídica. A neutralidade até poderia ser admitida, mas a limitação seria tida como incompatível com a noção de fomento.

A celeuma fica ainda mais complexa e distante de um deslinde tecnicamente satisfatório na medida em que a doutrina finda por traçar exemplos infelizes com vista a ilustrar a possibilidade dos mecanismos negativos.

É o que se observa, demonstrativamente, com o suposto exemplo de mecanismo negativo de fomento articulado por Garrido Falla, o qual defendeu que "um exemplo de meio negativo de fomento seria o imposto sobre o estado de solteiro (para fomentar o aumento da população do país) ou o imposto sobre as bebidas alcóolicas (para combater o alcoolismo)". (GARRIDO FALLA, 1992).

Ora, é claro que a medida invocada não apresenta, de forma alguma, qualquer voluntariedade, sendo absolutamente obrigatória, vinculante e inevitável.

Não se trata de mecanismo de incentivo ou estímulo, mas da mais típica tradução da atuação imperativa e autoritária da Administração - a qual, em decorrência de distorção determinada pela adoção da postura teleológica de identificação do fomento, e não obstante suas características marcadamente de polícia, é indevidamente alocada na seara do estímulo estatal.

Afastada essa linha de argumentação, e retomando a viabilidade dos mecanismos negativos de fomento, cumpre-nos lembrar que os destinatários, o polo passivo, na relação de fomento, se desdobra - ou pode se desdobrar — em sujeitos distintos.

Realmente, conforme adiante se verá, tem-se por vezes o destinatário imediato, que se sujeita às condições estabelecidas pelo ente fomentador, e o indireto, traduzido naqueles que são final e efetivamente beneficiados pela mobilização dos primeiros provocados pelo Estado.

Plenamente plausível, nesse cenário, que o sujeito passivo intermediário atue com lastro em valores cívicos ou morais que lhe conduzam a fazê-lo, independentemente da existência de qualquer proveito direto para si. 
São hipóteses em que o agente fomentado age solidariamente em benefício de um terceiro - acarretando, por vezes, uma restrição na sua esfera jurídica, seja abrindo mão de direitos, seja de valores economicamente traduzíveis. Essa atuação deve apresentar indispensável nexo de causalidade com o estímulo, com o incentivo estatal.

Nesse ponto, a questão ora tratada se entrelaça com a segunda discussão indicada, relacionada à admissão — ou não — de métodos psicológicos, ou melhor, da sua aceitação, como mecanismos de fomento.

Baena del Alcázar manifesta-se contrário a essa possibilidade, ao asseverar que é "muito discutível que a propaganda seja uma atividade interessante para o Direito Administrativo porque é, quando menos, duvidoso que a Administração atue nesses casos como poder público" (BAENA DEL ALCÁZAR, 1967, p. 71, traduzimos).

Outras linhas argumentativas, porém, existem, no sentido defendido por Villar Ezcurra: "A respeito dos estímulos puramente psicológicos a doutrina geralmente cita como exemplo as campanhas institucionais de publicidade [...] através das quais a Administração pretende influir no comportamento dos particulares" (VILLAR EZCURRA, 1999, p. 113, traduzimos).

Na doutrina pátria, compartilha desse posicionamento Célia Cunha Mello:

\begin{abstract}
A finalidade perseguida pela atividade de fomento pode ser atingida empregando-se meios psicológicos, capazes de persuadir, sugestionar e induzir opiniões, atitudes e valores. Indubitavelmente, entre nós, os meios de comunicação em massa mostram-se cada vez mais eficazes nesse propósito. A propaganda veiculada por televisão, rádio ou Internet evidencia-se como poderoso instrumento condicionador de opiniões e do comportamento de pessoas. (MELLO, 2003, p. 90-91).
\end{abstract}

Não só seriam admissíveis os incentivos dessa natureza, como teriam eles uma forma de expressão basilar, traduzida nos mecanismos de propaganda. ${ }^{39}$

De fato, as campanhas levadas a cabo pela Administração representam meios não coercitivos de mobilização privada, pelos quais se pretende a promoção de finalidades de interesse público, em clara interação entre as duas esferas, motivo pelo qual não vemos como não incluí-las na classe das atividades objeto do presente estudo.

\footnotetext{
${ }^{39}$ Necessário, nesse ponto, lembrar da definição técnica de propaganda, a qual não se confunde com a noção de publicidade: "[...] os termos publicidade e propaganda não são sinônimos, embora, habitualmente sejam utilizados um pelo outro até entre operadores do direito. Publicidade tem objetivo comercial, próprio para anunciar produtos e serviços possíveis de negociação. Propaganda, por sua vez, visa a um fim ideológico, próprio para a propagação de princípios, idéias, teorias, com objetivo religioso, político ou cívico." (CAVALIERI FILHO, 2011, p. 132).
} 
Seria o caso, por exemplo, daquelas pessoas beneficiadas com a doação de bens e alimentos após tragédias naturais: os doadores, cuja ação foi estimulada a partir de uma política governamental, não apresentam ampliação alguma em sua esfera de direitos, diferentemente do que se vê com relação aos destinatários finais, que são socorridos e veem ampliados os seus bens/direitos.

Tem-se, portanto, que à Administração é dada, sim, a realização de propaganda, com vistas à promoção do interesse público - e que se traduz como mecanismos não coercitivos e indiretos de satisfação dos interesses e necessidades coletivas, podendo haver, nesse processo, a limitação voluntária da esfera de direitos de determinados entes/pessoas em detrimento do auxílio/promoção de outros.

\subsubsection{Campo de incidência}

Levando em conta o fato de os autores espanhóis inicialmente terem considerado como destinatária da atividade de fomento a esfera de atuação dos particulares, tradicionalmente se desenvolveu e sedimentou a crença de que ela se direcionaria exclusivamente ao domínio econômico.

Referida leitura se apresenta, nos dias atuais, não só insuficiente como também deficiente.

Isso porque não mais perdura o contexto do século XIX, em que o Estado se contrapunha à sociedade, o público ao privado, como duas esferas dicotômicas, independentes e, sob muitos aspectos, contrapostas.

A sociedade civil passou a ser vista para muito além dos conglomerados econômicos, das atividades negociais, assumindo também, e definitivamente, a condição de arena de participação (CASSESE, 2010, p. 90) que age rotineiramente e de maneira simbiótica com a esfera estatal.

A consagração dos valores levada a termo a partir do advento do Estado social, com a posterior falência desse modelo, conduziu a uma mudança conjuntural completa que resultou, entre outros, no surgimento do denominado "Terceiro Setor". 40, 41

\footnotetext{
${ }^{40}$ Considerado o ordenamento brasileiro, e invocada a lição de Gustavo Justino de Oliveira, podem as entidades do terceiro setor assumir a natureza de associações ou fundações. Tem-se, pois, por terceiro setor, “o conjunto de atividades voluntárias, desenvolvidas por organizações privadas não governamentais e sem ânimo de lucro (associações ou fundações), realizadas em prol da sociedade, independentemente dos demais setores (Estado e mercado), embora com eles possa firmar parcerias e deles possa receber investimentos (públicos e privados)." (OLIVEIRA, 2007, p. 217). Conforme esclarece Salinas, "é comum confundir a forma jurídica das entidades sem fins lucrativos com os títulos que estar podem adquirir. $\mathrm{O}$ formato jurídico
} 
Não há mais espaço para a idealização de um modelo estatal garantidor e promotor de todas as necessidades coletivas, ${ }^{42}$ de todos os aspectos do interesse público ou dos interesses públicos.

A imprescindibilidade da atuação da sociedade civil para o atendimento das demandas coletivas - e a própria manutenção do modelo estatal — trouxe a necessidade de políticas públicas voltadas também, e principalmente, ao incentivo à sua atuação.

Não encontramos justificativa plausível, pois - e considerando todos esses aspectos - , para a restrição de toda a sociedade, de todo o domínio não estatal, às entidades de cunho e envolvidas na prática econômica.

A esfera privada vai muito além desse aspecto, motivo pelo qual insta-nos considerar todas as suas facetas, as quais devem ser conjunta e indistintamente tomadas ao menos em um primeiro momento - quando se trata de formulação de políticas públicas, ordenação e equilíbrio sociais.

Nesse sentido a lição de Cassagne, segundo a qual imprescindível se faz o desenvolvimento de uma "noção funcional compreensiva de toda ajuda que outorguem os Estados com fundos estatais a empresas ou setores produtivos, [...] mas também inclua aquelas vantagens que sem falsear a competência se orientam ao campo da saúde, a educação ou a investigação [...].” (CASSAGNE, 2003, p. 607, traduzimos).

Como bem lembra Lopez Muñiz (1989, p. 755), o conteúdo originariamente atribuído ao fomento "[...] ficou, por um lado, estreito para denominar a ação administrativa a que Jordana quis reduzir a sua significação técnica, quando o Poder Público a emprega como instrumento de direção e conformação das realidades econômicas

dessas entidades, sob a égide do vigente Código Civil, pode revestir-se de apenas duas figuras: as associações e as fundações. Já os títulos que as entidades poderão adquirir são variados: utilidade pública federal ('UPF'), registro no Conselho Nacional de Assistência Social (CNAS), Certificado de Entidade Beneficente de Assistência Social ('CEBAS'), registro no Cadastro Nacional de Entidades Ambientalistas ('CNEA'), bem como OSCIP.” (SALINAS, 2008, 113-114).

${ }^{41}$ Nesse sentido, também, a lição de Sabo Paes: "Por isso, antes de procurar conceituar, faz-se mister esclarecer que, junto com o Estado (Primeiro Setor) e como Mercado (Segundo Setor), identifica-se a existência de um Terceiro Setor, mobilizador de um grande volume de recursos humanos e materiais para impulsionar iniciativa voltadas para o desenvolvimento social, setor no qual se inserem as sociedades civis sem fins lucrativos, as associações civis e as fundações de direito privado, todas entidades de interesse social". E, ainda: "Importante salientar que o denominado Terceiro Setor compõe-se de entes coletivos, pessoas jurídicas de direito privado, configurados, de acordo com o Código Civil brasileiro, em associações e fundações de direito privado.” (SABO PAES, 2006, p. 121-122; p. 131).

${ }^{42}$ Conforme assevera Ariño Ortiz "ninguém acredita na possibilidade de que o Estado se encarregue das necessidades dos cidadãos e se ocupe deles, como diziam os primeiros profetas do Welfare State, 'desde o berço até a sepultura'. O Estado do bem estar deve ser substituído pela 'sociedade do bem-estar'. E assim, o repensar dos fins do Estado e, sobretudo, dos meios que este tem que por em jogo para resolver os problemas da vida coletiva é hoje geral em todo o mundo." (ARIÑO-ORTIZ, 2004, p. 312, traduzimos). 
e sociais ou em garantia de direitos fundamentais e não só da promoção de seu exercício em condições de maior igualdade." (Traduzimos).

Villela Souto faz o diagnóstico de dois tipos de fomento: o social e o econômico, voltado às atividades empresariais (SOUTO, 2007, p. 17).

Superado esse aspecto, existe outro, cuja solução traz repercussões ainda mais sérias — posto que não assente na práxis administrativa.

Trata-se da admissão — ou não — do desenvolvimento da atividade de fomento voltada a entes públicos.

Conforme já restou assentado, Jordana de Pozas (1954, p. 46) não entrevia essa possibilidade, da mesma forma que Villar Ezcurra (1999, p. 97).

De la Riva, por outro lado, juntamente com Baena Del Alcázar, não vê qualquer empecilho ou limitador decorrente dessa natureza dos potenciais destinatários dos incentivos:

[...] Basta assinalar, por um momento, que as ajudas podem ser conferidas também a favor de entes públicos, em cujo caso estaremos ante as chamadas ajudas públicas interadministrativas. (DE LA RIVA, 2004 , p. 125, traduzimos).

[...] o objeto sobre o qual recai o fomento são as atividades dos particulares e outros entes públicos, e, por outra, que o fim de fomento é a satisfação indireta de necessidades de ordem pública. É dizer, existe uma atividade administrativa que recai sobre as atuações dos particulares e de outros entes públicos e tende a satisfazer necessidades de ordem pública, se bem que o elemento fundamental é que a satisfação das necessidades se realiza de modo indireto (através da atividade dos particulares) e sem empregar coação. (BAENA DEL ALCÁZAR, 1967, p. 66, traduzimos).

Ponderemos, de plano, que, juntamente com a doutrina supratranscrita, não vislumbramos qualquer limitação à admissão do fomento a entes públicos. Isso porque também eles podem se engajar em políticas não coativas traduzidas em estímulos ao desenvolvimento de atividades de relevância pública, a partir, inclusive, da disponibilização de receitas originariamente vinculadas a outros entes ou órgãos.

Cumpre-nos aqui tecer breve digressão com vista a afastar preliminarmente qualquer alegação ou crítica que se pretenda levantar contra a viabilidade de negócios, relações ou contratos - consideradas as três expressões, aqui, em sentido genérico, não técnico - entre diferentes órgãos da mesma pessoa jurídica de Direito Público. 
Invocamos, para tanto, e analogicamente, o disposto no artigo $37, \S 8^{\circ}$, da Constituição Federal, ${ }^{43}$ assim como a lição de Maria Sylvia Zanella Di Pietro, ao tratar dos contratos de gestão:

\begin{abstract}
Embora o dispositivo constitucional não mencione a expressão contrato de gestão, é a esse tipo de contrato que quis referir-se com a peculiaridade de que o mesmo poderá ser celebrado não apenas com entidades da administração indireta, como também com órgãos (sem personalidade jurídica) da própria administração direta. Isto significa que poderá ocorrer que dois órgãos sem personalidade jurídica própria celebrem acordo de vontade. [...]. (DI PIETRO, 2012, p. 345, grifamos).
\end{abstract}

Note-se que a interpretação que pretendemos outorgar toma por base a analogia, cuja incidência nas circunstâncias ora consideradas se justifica como decorrência do princípio da eficiência.

Realmente, uma vez reconhecida a possibilidade pela própria Carta Magna, com a subversão das noções tradicionais de hierárquica visão unitária da Administração, ou dos órgãos públicos, a possibilidade pode - e deve - ser estendida a todas as situações em que virtualmente funcione como promotora do interesse público e da funcionalidade administrativa.

A partir do momento em que se reconhece, com Cassese, ${ }^{44}$ Schimidt-Assmann ${ }^{45} \mathrm{e}$ Moreira Neto, ${ }^{46}$ que a Administração não é una e que a sua hierarquização não é absoluta,

\footnotetext{
43 " $\$ 8^{\circ} \mathrm{A}$ autonomia gerencial, orçamentária e financeira dos órgãos e entidades da administração direta e indireta poderá ser ampliada mediante contrato, a ser firmado entre seus administradores e o poder público, que tenha por objeto a fixação de metas de desempenho para o órgão ou entidade [...]".

${ }_{44}$ "A fragmentação dos poderes públicos é um dos principais problemas dos ordenamentos modernos. Nos ordenamentos unitários, a instituição e posterior multiplicação das entidades públicas nacionais e o surgimento de figuras híbridas, constituídas de organismos semipúblicos, tiraram o sono dos Cultores do Estado. [...] Portanto, podemos dizer que o policentrismo dos ordenamentos gerais traz hoje alguns problemas comuns, embora com intensidades diferentes. O primeiro deles é o das definições. Inicialmente procurou-se definir o ente público, depois, a figura deste entrou em crise, e, por fim, percebeu-se que as noções são tão numerosas quanto os entes - ou categorias de entes - existentes. [...] Primeiramente, o princípio da unitariedade organizacional ou de ações dos poderes públicos. Com as autoridades independentes são estabelecidos novos procedimentos de criação do direito e, portanto, diversificados os produtores de normas. Além disso, reafirma-se o princípio de que nem todos os órgãos públicos se reportam a uma pessoa jurídica e que a entidade subjetiva Estado, no direito interno, exprime apenas parte da organização pública." (CASSESE, 2010, p. 32-35).

${ }^{45}$ "No que respeita às divisões características ou sistematizadoras, o mais importante é a distinção entre Administrações (Verwaltungstrages) e órgãos ou unidades administrativas (Vrwaltungsstellen). As Administrações tem normalmente capacidade jurídica e, portanto, a esta distinção subjaz o conceito de pessoa jurídica. Sua função primária consiste em estabelecer um centro de imputação unitário para os direitos e obrigações na relação entre o cidadão e o Estado. $\mathrm{O}$ atual Direito da organização não dá demasiada importância às demais repercussões dessa figura jurídica, que, sem embargo, são muito relevantes. A ideia do caráter unitário da capacidade jurídica deriva das exigências e condicionantes do Direito privado. Pelo contrário, não responde de maneira suficientemente adequada às questões de caráter claramente jurídicoadministrativas a respeito de outras. O conhecimento em numerosas suposições da chamada capacidade
} 
desenvolvendo-se em um complexo modelo de rede, insustentável o afastamento de tal possibilidade, para cuja defesa se invocariam argumentos que tomam por base noções superadas e atualmente insuficientes.

Nenhum empecilho há de se admitir, portanto, contra esse tipo de relação jurídica entre órgãos. $^{47}$

Retomando o foco da discussão, e reafirmando a plena possibilidade de figurar a esfera pública como polo fomentado, havemos de tecer algumas ressalvas.

A primeira delas respeita à exigência de as atividades a serem desenvolvidas a partir desse fomento estarem, lembrada a lição de Lopez-Muniz, ${ }^{48}$ na esfera de competências, ou ao menos na esfera de competências afins do órgão/ente fomentado.

Não se poderia cogitar, assim, e exemplificativamente, da outorga de estímulos econômicos a órgão tematicamente incumbido da promoção de políticas relacionadas ao verde e meio ambiente para que este concretizasse políticas relacionadas especificamente aos esportes.

Outro impeditivo corresponde à impossibilidade de outorga de transferências dessa natureza para a cobertura de despesas de custeio de órgão ou ente.

Inviável, nesses termos, a destinação de receitas com vistas, por exemplo, à superação de déficit relativo à folha de pagamento, que não venha sendo efetivamente remunerada - ao menos não na seara do fomento. Isso porque a manutenção da estrutura

jurídica parcial indica a necessidade de estabelecer distinções mais matizadas do que permite o conceito de pessoa jurídica." (SCHIMIDT-ASSMANN, 2003, p. 253, traduzimos).

46 "A profunda repercussão da nova morfologia social sobre as tradicionais construções cratológicas atingiu em cheio o Estado contemporâneo, abalando-se a 'estrutura organizativa unitária, de vontade unitária e de ação unitária', a ponto de Massimo Severo Giannini, um dos mais emitentes pensadores do Direito Publico do século vinte, haver observado, ainda na década e oitenta, que essa concepção não é mais exata [...]. Esse admirável prenúncio do processo, que o grande mestre peninsular denominou de desagregação da organização do Estado, logo se robusteceria com sua iminente aceleração. Efetivamente, em menos de duas décadas de publicada essa impressionante afirmação, haviam proliferado, além de todas as expectativas, inúmeras entidades e órgãos constitucionalmente independentes, administrativamente independentes e até dotados de atividades normativas independentes, confirmando a prenunciada transformação do Estado contemporâneo, em todas as latitudes e quadrantes, de uma tradicional, definida e limitada partição de 'poderes' funcionais, típica de uma organização uniclasse ou biclasse, voltada ao atendimento de estamentos dominantes, para tornar-se um inovador, variado e ilimitado do mosaico de funções, próprias de uma organização nitidamente pluriclasse e, por isso, vocacionada ao atendimento de uma sociedade pluralista." (MOREIRA NETO, 2008, p. 54-55).

${ }^{47}$ Nesse sentido, inclusive, expresso o artigo $6^{\circ}$, IV, do Decreto municipal n. 43.135/03: "Art. $6^{\circ}$. A gestão administrativa dos recursos do Fumcad abrange: IV - a transferência de recursos destinados à execução de convênios celebrados com outros órgãos da Administração Municipal, utilizando-se de recursos do Fundo.”

48 "O bem que se faz ao ajudar, dando a alguém, comporta necessariamente sempre - para que seja de fato ajuda - uma certa cooperação, um sentido de auxílio ou de socorro, de complemento, que vem a somar-se a certa atividade ou capacidade de atuar ou de realizar algo concreto do sujeito ajudado, a efeito de que se possa realizar ou exercer na prática ou de que se desenvolva com mais facilidade. Toda ajuda se revela assim certamente como uma co-operação a respeito a alguém e para algo; um algo que pertence à esfera de atuação, de capacidade potencial de atuação do ajudado." (LOPES-MUÑIZ, 1989, p. 760, traduzimos). 
administrativa não pode, em hipótese alguma, ser considerada medida, ou postura, objeto de estímulo, promoção ou incentivo.

Trata-se de dever legal, de medida impositiva, que conta com previsão perfeitamente delineada nas leis orçamentárias, conforme lição de Matias-Pereira. ${ }^{49}$

Ainda uma ressalva mais: a função afim ou de competência do órgão/ente deve se revestir da qualidade de atipicidade, não ser rotineira e essencialmente inserida na sua esfera de atribuições.

Objetivamente, não deve constar nominalmente da rubrica orçamentária que lhe seja correspondente.

Tal assertiva é decorrência natural e inderrogável do princípio da legalidade, segundo o qual o desempenho das funções nominal e orçamentariamente atribuídas ao órgão/ente não se qualificam como faculdade, como opção passível de ser atendida ou não — e, portanto, de estímulo.

Trata-se de dever legal, do qual o ente/órgão tem de inarredavelmente se desincumbir. E, por óbvio, onde há dever de agir, não há que se falar em fomento.

Praticamente, portanto, assevera-se que a atividade de fomento pode se direcionar tanto à iniciativa privada - seja ela de natureza econômica, social ou individual — quanto à pública, desde que, nesta última hipótese, pretenda condutas/posturas correlatas à esfera de atuação do órgão/ente destinatário não referidas nominalmente nas normas orçamentárias como um seu dever.

\subsubsection{Conclusão parcial}

Do exposto até o momento, temos que tanto o critério residual quanto o teleológico não se mostram satisfatórios para o perfeito delineamento da atividade de fomento.

Imprescindível, para uma caracterização técnica, o diagnóstico de seus contornos, que, para Villar Ezcurra, seriam: a) ausência de coação e limitação de direitos; b) incidência sobre a atividade particular; c) adesão voluntária por parte dos destinatários; d)

\footnotetext{
49 "“...] a Constituição Federal, com base em critério político, atribui ao orçamento as funções essenciais de reduzir as desigualdades regionais e sociais. Dessa forma, o orçamento afirma-se como instrumento de interação do Estado no domínio econômico, orientado para a realização o bem comum da sociedade. Tendo sido aprovado o orçamento, conforme determina a Constituição Federal, deve ser cumprido fielmente. Sua elaboração, de acordo com os dispositivos que tratam das estimativas das receitas e fixação das despesas, está inserida na Constituição Federal, bem como nas normas infraconstitucionais." (MATIAS-PEREIRA, 2009, p. 282).
} 
relação da atividade fomentada com o interesse público (VILLAR EZCURRA, 1999, p. 99-100).

Conforme expresso no item anterior, discordamos da posição do autor no que toca especificamente à limitação voluntária de direitos dos destinatários do fomento.

Quanto à busca da promoção do interesse público, consideramos traço não distintivo da atividade, na medida em que deve ser a finalidade inarredavelmente perseguida por toda e qualquer atuação administrativa.

Redundante, portanto, o seu elenco como um dos aspectos indispensáveis e definidores.

Baena Del Alcazár elenca como elementos do fomento: a) objeto e fim, quais sejam, as atividades públicas ou particulares sobre as quais recai e a satisfação indireta de necessidades de ordem pública, respectivamente, e b) as técnicas de promoção, traduzidas nos instrumentais e métodos descritos no item 1.2.3 supra (BAENA DEL ALCÁZAR, 1967, p. 66-67).

De la Riva, ao tratar especificamente das ajudas, afirma que a sua essência estaria no nexo entre a disponibilização de "bens" ${ }^{50}$ e a realização das atividades em que se lhes deve aplicar o seu destinatário (DE LA RIVA, 2004, p. 123).

Para o autor, a atuação incentivada seria parte constitutiva da atividade estatal, diferentemente do resultado de interesse público por ela perseguida.

No nosso entender, os elementos constitutivos essenciais são: a) sujeitos: agente fomentador, destinatário(s), mediato e imediato; b) objeto; c) meios.

No que tange aos sujeitos, admitimos figure no polo ativo da relação de fomento quaisquer entes ou órgãos públicos, sejam eles integrantes da estrutura estatal — administração direta ou indireta — ou não.

Os destinatários, por sua vez, podem incidentalmente se desdobrar em diretos, ou simplesmente destinatários, e indiretos ou beneficiários, sendo os primeiros os sujeitos efetivamente mobilizados, envolvidos na atividade de fomento, e os segundos aqueles que venham a usufruir de seus resultados positivos.

O objeto do fomento será, sempre, a mobilização do destinatário direto com vistas à consecução do interesse público.

\footnotetext{
${ }^{50}$ Considerada, aqui, a sua concepção mais ampla, abarcadora de quaisquer direitos, vantagens ou condição mais benéfica.
} 
Os meios utilizados para tanto, finalmente, correspondem aos instrumentos de estímulo, incentivo, mobilização etc., marcados pela facultatividade, pela não coercitividade.

Importante registrar, ainda, o nexo de causalidade que se estabelece entre a atividade de fomento e a do particular que a ela adere. É claro que esta última não se insere no âmbito da atividade estatal propriamente dita, não integra elemento interno do fomento, mas sim um seu desdobramento necessário e insuperável.

Trata-se de efeito indissociável dessa modalidade de atuar pública - o que automaticamente afasta de seu espectro de incidência as doações simples eventualmente operadas em favor da iniciativa privada - a qual, no momento mesmo da transferência dos bens ou valores, os vê incorporados ao seu patrimônio, que assume, portanto, natureza também privada, ${ }^{51}$ sendo a sua destinação, assim, indiferente à opinião ou direção administrativa.

À parte as discussões colocadas, e consideradas as ponderações tecidas até o momento, chegamos a que o fomento pode ser traduzido como a atividade administrativa incidentalmente contratualizada exercida por entes públicos, estatais ou não, voltada à mobilização voluntária de particulares ou órgãos/entes públicos a partir de mecanismos negativos ou positivos, psicológicos, econômicos, jurídicos ou honoríficos, em uma relação causal, com vistas à realização de condutas/atos de interesse coletivo inseridos, ainda que indiretamente e sem exclusividade, em seu campo de atuação.

\subsection{Fomento, ajudas e subvenções}

A celeuma envolvendo a referência da doutrina - e da própria legislação — aos três vocábulos em epígrafe traduz disputa terminológica que, segundo alguns, repercutiria, também, na qualificação técnica das diferentes práticas administrativas.

\footnotetext{
${ }^{51}$ Nesse sentido, veja-se lição de Maria Sylvia Zanella Di Pietro que, não obstante referente especificamente aos convênios, pode ser estendida a todos os meios econômicos diretos de fomento: "[...] no contrato, a Administração paga uma remuneração em troca de uma obra, um serviço, um projeto, um bem, de que necessita; essa obra, serviço, projeto ou bem entra para o patrimônio público e o valor pago pela Administração entra para o patrimônio do contratado; a forma como este vai utilizar esse valor deixa de interessar ao Poder Público; aquele valor deixou de ser dinheiro público no momento em que entrou para o patrimônio privado; vale dizer que o interesse do Poder Público se exaure com a entrega definitiva do objeto do contrato nas condições estipuladas. Já no convênio, se o conveniado recebe determinado valor, este fica vinculado ao objeto do convenio durante toda a sua execução, razão pela qual o executor deverá demonstrar o resultado final obtido; é necessário demonstrar que todo o valor repassado foi utilizado na consecução daquele resultado. Vale dizer que o dinheiro assim repassado não muda sua natureza por força do convênio; ele é transferido e utilizado pelo executor do convenio, mantida sua natureza de dinheiro público (no sentido de que está destinado a fim público).” (DI PIETRO, 2011, p. 236).
} 
Segundo essa vertente, implicaria, mais que isso, posicionamentos distintos a resultarem na adoção — ou negação — de regimes jurídicos específicos.

Lopez-Muniz defende a substituição do termo "fomento" pela expressão "atividade dispensadora de ajudas e recompensas", em um processo que batiza de depuração terminológica e conceitual. ${ }^{52}$ Outros advogam a manutenção da designação e do modelo classificatório tradicional, em que se considera o fomento gênero, cuja espécie mais consagrada seria a subvenção. É o caso de Baena Del Alcázar, ${ }^{53}$ Ariño Ortiz ${ }^{54}$ e Villar Ezcurra, que a têm como a "técnica arquetípica" (VILLAR EZCURRA, 1999, p. 112) da atividade de fomento. 55

Ariño Ortiz lembra que "em nível da Comunidade Europeia, a legislação e a jurisprudência utilizam um conceito mais amplo de 'ajuda pública', incluindo a subvenção em sentido estrito, vantagens fiscais e creditícias, e vantagens econômicas de todo tipo." (ORTIZ, 2004, p. 357-358, traduzimos).

Para Villar Palasí, “a ajuda administrativa pode servir não só a fins de fomento em cujo caso é voluntária por parte do destinatário —, mas também a fins de política, em cujo caso se transforma em obrigatória.” (VILLAR PALASÍ, 1954, p. 64, traduzimos).

\footnotetext{
52 "Esse termo do nosso Direito Administrativo ficou, por uma parte, estreito para denominar a ação administrativa a que Jordana quis reduzir seu significado técnico, quando o Poder Público a emprega como instrumento de direção e conformação das realidades econômicas e sociais ou em garantia de direitos fundamentais e não só de promoção do seu exercício em condições de maior igualdade. [...] A referência aos objetivos de promoção - aos que se somaria a proteção - certamente inerentes à noção tradicional de fomento, tendeu sempre a dominar sua significação conceitual técnica, devendo acudir os autores a elementos de delimitação negativa como a ausência de coação, para alcançar uma especificidade técnico-jurídica do conceito na classificação dos modos ou formas da atividade administrativa. As ideias de persuasão, ou de estímulo e incentivo que, com frequência, se propõem como distintivas do fomento, e que, sem duvida, traduzem sua semântica própria, não podem furtar-se tampouco a uma significação principalmente finalística muito semelhante, pelo que as sugestões de substituir a denominação de atividade de fomento pela de atividades de persuasão ou incentivo, etecétera, não resolvem nada. [...] Nossa proposta é concreta na conveniência de substituir a categoria atividade de fomento pela de ação — ou atividade — dispensadora de ajudas ou recompensas, que entendo pode compreender dois elementos de significados precisos para abarcar e explicar as técnicas de atuação administrativa que usualmente se quiseram englobadas no fomento. Outras expressões como a de atividade de favorecimento não nos parece que reúnam suficiente especificidade, pondendo-se aplicar também a supostos determinados de atuação administrativa que corretamente se situam em outros modos de ação. [...].” (MUNIZ, 1989, p. 755-757, traduzimos).

53 " "...] Tampouco se trata de estudar a subvenção, por mais que esta seja a mais importante das manifestações do fomento.” (BAENA DEL ALCÁZAR, 1967, p. 44, traduzimos)

54 "Entre as medidas de fomento, a subvenção é a que tem ganhado maior atenção da doutrina, a legislação e a jurisprudência." (ORTIZ, 2004, p. 355, traduzimos).

55 "A advertência vem em razão da tendência generalizada de identificar a atividade de fomento com subvenção, tomando assim a espécie pelo gênero ou confundindo as formas de intervenção com as técnicas que lhe servem de suporte [...]. A subvenção é uma técnica de fomento, de conteúdo econômico, em virtude da qual a Administração entrega a um particular uma quantidade de dinheiro a fundo perdido (é dizer, sem impor sua devolução, o que seria sua nota distintiva [...]. A subvenção não engloba pois todas as técnicas de conteúdo econômico já que se excluem as de caráter negativo (extensões, bonificações etc.) que não implicam transferência de dinheiro, assim como aquelas outras em que o particular tem obrigação de devolver seu valor (empréstimos, antecipações etc.). (VILLAR EZCURRA, 1999, p. 100-120, traduzimos).
} 
Gimeno Feliu afirma que a subvenção deve ser entendida como "mais uma das diversas medidas de fomento de caráter econômico, com um regime peculiar que as diferencia notavelmente de outras ajudas econômicas, de tal maneira que uma coisa será a subvenção e outra muito distinta a ajuda, que apresenta, por demais, outras modalidades." (GIMENO FELIU, 1995, p. 170-171, traduzimos).

Cassagne, ao traçar interessante panorama sobre a questão, lembra que na Argentina praticamente já não se fala em fomento, mas em "atividades de promoção ou proteção de indústrias ou atividade econômicas". Na Espanha, a referência dominante seria a "ajudas públicas” (CASSAGNE, 2003, p. 604).

Ainda na lição do autor:

\begin{abstract}
A eliminação paulatina dos conceitos tradicionais geralmente obedece ou a razões ideológicas, ou ao o império das modas dos tempos. Tal é o caso do conceito de ajuda, que soa a algo mais social que o fomento ou subvenção, com um sentido mais psicológico que jurídico-econômico, que é o plano onde se movem essas instituições. É mais próximo à ideia de auxílio, socorro e cooperação. O risco que se corre radica em privar o conceito de seu conteúdo essencial e deixar outras manifestações da intervenção administrativa fora de uma teoria geral que as agrupe sobre a base das coincidências de seu regime jurídico. Sem embargo, e à vista do uso generalizado que fazem os ordenamentos europeus, por obra do direito comunitário, creio que se pode acudir a um novo conceito de ajuda pública sobre a base de um critério funcional, o qual se amolda aos diferentes tipos de vantagens que, de forma direta ou indireta, concede o Estado ao particular. (CASSAGNE, 2003, p. 601, traduzimos).
\end{abstract}

De la Riva chama atenção para o fato de a noção de fomento, tal como originariamente tratada pela doutrina, carregar uma inapropriada carga teleológica, o que justificaria a sua substituição, indicativa da nova noção que hoje defendemos, segundo a qual essa atividade deve ser tomada a partir de seus elementos técnicos e instrumentais. ${ }^{56}$

Utiliza uma terminologia com contornos mais amplos e menos exatos, esclarecendo que o "adjetivo subvencional [...] deve ser interpretado com sentido amplo — é dizer, compreensivo de todas as técnicas de fomento - e, não limitado ao caso estrito da figura da subvenção" (DE LA RIVA, 2004, p. 111, traduzimos).

Mais adiante, ao abordar a questão terminológica, pontua que bastaria a referência a ajudas públicas, em paralelo à omissão que se faz aos vocábulos "prestação",

\footnotetext{
56 “Já se adiantou no final do capítulo anterior a necessidade de substituir a castiça denominação de fomento por outra que esteja livre da carga finalista que ela traz dada a sua inevitável referência à vontade de persuadir." (DE LA RIVA, 2004, p. 118, traduzimos).
} 
quanto aos serviços públicos, e "exercício do poder", em se tratado de polícia (DE LA RIVA, 2004, p. 120, traduzimos).

Ora, não nos parece razoável que o entendimento inicial — e não pacífico — de determinado termo (fomento) tenha o condão de condená-lo à abolição, na medida em que a evolução, com eventual sucessão de significados e entendimentos, não é processo estranho ao mundo da ciência, seja ela jurídica ou não.

O próprio autor argentino reconhece que a expressão "ajudas públicas", que vem sendo amplamente empregada no Direito Comparado, "não substitui a clássica noção de fomento, que nasceu como englobante da totalidade da atividade subvencional (entendida esta em sentido lato)”. (DE LA RIVA, 2004, p. 118-119, traduzimos).

De nossa parte, portanto, e respeitadas as opiniões divergentes supracolacionadas, não vemos utilidade - ou motivação plausível — para a substituição terminológica, com abandono do vocábulo fomento.

Realmente, quer-nos parecer, junto com Villar Ezcurra, que essa designação se mantém firme e insuperada no desígnio de abarcar todas as espécies de atividades de estímulo, cooperação, promoção, proteção e ajuda, independentemente dos instrumentos de que se lance mão ${ }^{57}$ :

Atividades de estímulo (fomento): aqui estariam incluídas todas as técnicas de ajuda aos particulares cuja figura mais relevante é a subvenção [...]. Igualmente haveria que incluir outros tipos de ajudas econômicas (como empréstimos, as antecipações, as isenções e as bonificações) e de estímulo não econômico (honrarias, prêmios, títulos etc.). [...] A advertência vem em razão da tendência generalizada a identificar a atividade de fomento com a de subvenção, tomando assim a espécie pelo gênero e confundindo as formas de intervenção com as técnicas que lhe servem de suporte. (VILLAR EZCURRA, 1999, p. 39101, traduzimos).

A natureza e regime jurídico basilares se mantêm, respeitadas, por óbvio, as peculiaridades e exigências próprias de cada uma das modalidades de fomento.

\footnotetext{
${ }^{57}$ As posturas adotadas são diversas, lançando mão os autores consultados das diversas expressões relatadas. Notar-se-á, ao longo do trabalho, a utilização equívoca dos termos colacionados, como reflexo do que cada autor defende ser a designação mais correta. Registre-se, desde já, porém, que, independentemente da terminologia que se empregue, o tema abordado será sempre o fomento, genericamente considerado, e excepcionadas aquelas situações em que a delimitação conceitual for expressa.
} 


\subsection{Subvenções}

Tendo em vista o destaque e recorrência com que se operacionaliza a atividade subvencional da Administração, assim como as peculiaridades e celeumas envolvendo seu regime jurídico, julgamos por bem tratá-la, ainda que em linhas gerais, de uma forma isolada e específica.

Registremos que a doutrina, por diversas vezes, conforme assentado no item anterior, lança mão do vocábulo em situações bastante equívocas, invocando "ajudas" em substituição às “subvenções”, ou vice-versa, ou, ainda, simplesmente "fomento".

De se traçar, assim, um conceito técnico e exato do que venha a ser a atividade subvencional.

Vale lembrar que se trata de meio de concretização da atividade de fomento, responsável, assim como outros, por trazer a iniciativa privada para dentro do seu âmbito, com o estabelecimento de relação jurídica própria fundada na faceta mobilizadora e estimulante da Administração.

Não se confundem, portanto, os conceitos de fomento e subvenção, sendo esta uma das formas de concretização, um dos mecanismos de efetivação daquele.

Villar Palasí (1954, p. 59-60) insere no âmbito das subvenções tanto as transferências em dinheiro como as indiretas, traduzidas na dispensa ou decréscimo de determinada despesa em princípio obrigatória (empréstimos com encargos reduzidos, bonificações, isenções fiscais).

Para ele, "a subvenção administrativa implica uma técnica geral de atuação administrativa ou, como se disse também, um modo de atuação administrativa — um 'procedé d'administration'.' (VILLAR PALASÍ, 954, p. 61, traduzimos).

Villar Ezcurra, por sua vez, refere-se à subvenção como:

Uma técnica de fomento, de conteúdo econômico, em virtude da qual a Administração entrega a um particular uma quantidade de dinheiro a fundo perdido (é dizer, sem impor sua devolução, o que seria a nota distintiva mas relevante quanto ao resto das técnicas econômicas [...]. A subvenção não engloba pois todas as técnicas de conteúdo econômico já que se excluem as de caráter negativo (isenções, bonificações etc.) que não implicam transferência de dinheiro assim como aquelas em que o particular tem obrigação de devolver sua importância (empréstimos, antecipações etc.). (VILLAR EZCURRA, 1999, p. 120, traduzimos). 
Para Ariño-Ortiz, é toda "entrega gratuita de fundos públicos, procedentes dos impostos pagos pelos contribuintes, em troca de determinadas atividades que se consideram de interesse público ou interesse social" (ORTIZ, 2004, p. 355, traduzimos).

Traça o autor uma diferença entre subvenções de fomento, ou em sentido estrito, e outras subvenções lato sensu, que não se inserem nesse conceito, como, por exemplo, as denominadas subvenções-dotações de serviços públicos e subvenções-consignações para entidades públicas.

Explicita, invocando a lição de Guétara, que:

Quanto aos serviços públicos, a subvenção tende a cobrir um déficit originado fundamentalmente pela política tarifária seguida e permite que o serviço responda ao princípio da continuidade, ao equilibrar, ano após ano, seu balanço. A subvenção-consignação é uma figura mais complexa. Por um lado, ao centralizar os fundos econômicos no Estado, se permite um certo dirigismo das administrações menores através da política de subvenções; por outro lado, o fato de um organismo autônomo receber ou não subvenções do Estado é decisivo na hora de sua classificação segundo a L.E.E.A; finalmente, existem subvenções-consignações que são resultado da supressão de determinados fundos próprios de que gozavam os organismos a que afetam. (GUÉTARA, 2004, p. 358, traduzimos).

Santamaría Pastor elenca como características básicas comuns a todas as espécies de subvenção: a) a necessidade de previsão orçamentária; b) o caráter não lucrativo; c) a incidência dos princípios da publicidade, concorrência e impessoalidade (SANTAMARÍA PASTOR, 2000, p. 359-363).

Notamos que esses últimos não poderiam, a nosso ver, ser tidos como elementos diferenciais da atividade subvencional, vez que necessariamente orientadores de toda e qualquer atuação da Administração.

Quanto ao seu caráter não lucrativo, traduz-se no denominado princípio de preço de custo, mais adiante abordado no item 1.8.8.

As definições apresentadas por Hartmut Maurer e Roberto Dromi traduzem as subvenções, respectivamente, nas palavras de Silvio Luis da Rocha (2006, p. 41), como: "Doações de valor patrimonial do Estado ou de outra corporação administrativa a pessoas privadas, sem contraprestação conforme o mercado, para o fomento de uma finalidade situada na área do interesse público.” E, ainda: “O subsídio que se outorga às pessoas públicas subordinadas ou a instituições privadas, eventualmente pessoas físicas, para a execução de atividades necessárias ao interesse público. Na subvenção há transferência 
direta de recursos monetários com o propósito de incentivar a atividade considerada de interesse público." (ROCHA, 2000, p. 42).

No ordenamento pátrio, Villela Souto defende que a classificação se opera entre dois tipos de subvenção: subvenção imprópria, em cujo âmbito se inserem dotação para os serviços públicos e as consignações para custeio de serviços executados pelos entes locais e custeados pelo Poder Central; e subvenção estímulo, noção mais ampla, "que se confunde com a própria noção de fomento" (SOUTO, 2007, p. 23).

Os grandes desafios, de acordo com os posicionamentos trazidos à baila, gravitam em torno de duas questões centrais: a) as subvenções se traduzem, necessariamente, na transferência direta de bens/valores, ou abarcam também os mecanismos econômicos indiretos de estímulo estatal? b) a transferência de bens/valores por seu intermédio acarretada implica em outorga de que grau de liberdade aos destinatários? Em outras palavras, qual o nível de vinculação dos valores/bens referidos às finalidades inicialmente fixadas?

Para o esclarecimento desses questionamentos, imprescindível algum aprofundamento da matéria, nos termos propostos nos itens seguintes.

\subsubsection{Ato ou contrato?}

Muito se discute acerca da natureza jurídica das subvenções, se assumiriam a condição de contratos ou se seriam "meros" atos administrativos.

Questiona-se, ainda, se estariam inseridas no campo das doações e, nessa hipótese, se simples ou modais, tendo em vista a recorrente utilização da expressão " $a$ fundo perdido" quando da sua conceituação. ${ }^{58}$

Nesse particular, Villar Ezcurra assinala a tendência da doutrina espanhola em considerar as subvenções como doações modais, em que se estabelecem condições para o seu aperfeiçoamento (VILLAR EZCURRA, 1999, p. 120).

Para Rego Blanco:

A jurisprudência que enfrentou esses problemas construiu a solução do caso sobre a base da natureza condicionada da subvenção. Afirma-se que uma subvenção, mais que responder à tipicidade de um ato puro declarativo de direitos, constitui uma "doação modal" ou um benefício "condicionado ao cumprimento, pelo seu beneficiário, dos requisitos e

\footnotetext{
${ }^{58}$ Nesse sentido, FELIU, 1995, p. 171, nota 71, e PALASÍ, 1967, p. 64.
} 
fins previstos na norma [...] que a estabeleceu". (REGO BLANCO, 1996, p. 181, traduzimos).

Temos, diferentemente do exposto, que de doação não se pode tratar, vez que a relação subvencional não altera a natureza, ou a titularidade dos valores/bens disponibilizados, os quais mantêm a característica pública.

Realmente, a sua simples entrega a entes diversos para que se lhes apliquem em finalidade de interesse público previamente estipulada não é suficiente para que se lhes faça incorporar ao patrimônio privado ou dos entes públicos beneficiários diretos.

O beneficiário não tem livre disposição dos bens/valores, que ficam vinculados à causa subvencional. É o que defendem Justino de Oliveira ${ }^{59}$ e Lopez-Muñiz. ${ }^{60}$

Este último advoga a natureza de ato jurídico declarativo e a aplicação, analógica, do regime das doações modais (LOPEZ-MUNIZ, 1989, 761-763).

Para Santamaría Pastor (2000, p. 358-360), Baena del Alcázar (1967, p. 76) e Garrido Falla, podem assumir a natureza tanto de ato como de contrato, ficando a critério da Administração a adoção de um ou outro modelo:

Existe, assim, uma primeira série de subvenções, que se concedem unilateralmente pela Administração. O caráter unilateral está, desde logo, claro naquelas que, na expressão de Zwahlen, constituem "um fim em si mesma", posto que tendem simplesmente a ajudar o subvencionado, sem exigir de sua parte uma conduta determinada. Pode-se incluir aí as subvenções que discricionariamente são outorgadas a entidades privadas de caráter benéfico, centros de docentes, agrupações culturais ou artísticas, etc. Agora, o caráter unilateral não desaparece naqueles casos em que a subvenção tem por sua causa jurídica um certo comportamento — ativo ou passivo - do subvencionado. Nesses casos, a subvenção geralmente é uma das consequências jurídicas de um ato administrativo anterior que coloca o sujeito afetado em uma situação complexa de direitos e deveres anteriormente prevista em lei ou regulamento. Há outros casos, ao contrário, em que a subvenção tem igualmente por causa o comportamento do subvencionado, sua concessão se realiza mediante um procedimento contratual. (GARRIDO FALLA, 1992, p. 311-312, traduzimos).

\footnotetext{
59 "Parece-nos estreme de dúvidas a afirmação segundo a qual o repasse de verbas públicas para uma entidade privada sem fins lucrativos, efetivada pela via do convênio, termo de parceria, contrato de gestão, contrato de repasse ou qualquer outro instrumento jurídico, não tem o condão de transformar a natureza do repasse financeiro, de público para privado." (OLIVEIRA, 2007, p. 231).

60 "A afetação ou vinculação desse direito implica na obrigação do beneficiário de ater-se a ela, exercendo-o somente para a realização da atividade a que afetado. Se lhe foi concedido somente para isso ou na medida em que se aplique a essa atividade: nos demais aspectos, o bem ou direito de que se trate, por assim dizer, não lhe pertencem, não lhe foi transferido. Daí que o Poder público dispensador, que tem o dever de velar pela legalidade e que ademais retém as dimensões do bem ou direito dispensado, poderá exigir que se respeite e cumpra a afetação e revogar, em sendo o caso, a ajuda." (LOPEZ-MUÑIZ, 1989, 761, traduzimos).
} 
Discordamos do autor citado no que toca à possibilidade, retratada no início do excerto, de outorga desse tipo de mecanismo de fomento independentemente da assunção de qualquer postura pelo beneficiário.

O princípio da isonomia não admitiria a outorga de estímulos nessas condições, sem que por seu intermédio se promovesse, indiretamente, uma postura coletivamente relevante, denotante de interesse público.

Villar Palasí defende a natureza de ato administrativo sujeito a condição resolutória, na medida em que:

A forma de outorga é um ato administrativo de direito público, a postura da Administração frente ao beneficiário é a de potentior persona, com faculdades exorbitantes das correspondentes a uma doação civil. O beneficiário não exerce influência alguma na formação do vínculo subvencional, vez que se limita à sua solicitação e aceitação. $\mathrm{O}$ fim da subvenção é sempre um fim público ou de interesse público. (VILLAR PALASÍ, 1954, p. 65, traduzimos).

No mesmo sentido, Gimeno Feliu. ${ }^{61}$

Para De la Riva, a hipótese seria de estabelecimento de uma "relação especial de sujeição":

É sabido que as relações de especial sujeição, categoria forjada no âmbito do Direito alemão, caracterizam-se por comportar uma dependência particularmente acentuada a respeito da Administração, que se traduz na prática de um estado de liberdade restrita dos súditos que as alcança. A presença desse regime mais intenso foi atribuída à maior proximidade entre administrado e Administração causada pela inserção daquele na esfera organizativa desta última, a ponto de o particular passar a fazer parte de seus quadros e desenvolver em benefício daquela uma concreta atividade manual ou intelectual. No caso específico das ajudas públicas nasce, sim, uma relação jurídica entre Administração outorgante e

\footnotetext{
61 “A concessão de uma ajuda ou subvenção é um ato declarativo de direitos, pelo que sua eventual revisão de ofício fica submetida aos procedimentos previstos nos artigos 102 e 103 da Lei 30/1992, reguladora do Regime Jurídico das Administrações Publicas e do Procedimento Comum. Sem embargo, esse procedimento não será necessário quando não se cumpra o encargo que impõe a Administração, que nesse caso procederá à reintegração da ajuda ou subvenção, tal e como expressamente dispõe a legislação específica vigente: a pessoa, pública ou privada, que seja beneficiária da ajuda ou subvenção não tem livre disposição, dado que, pelo caráter finalista dessas medidas, está comprometida a certas obrigações [...]. Dado esse caráter finalista, se não satisfeitos efetivamente esses encargos (vez que se configuram como um direito-dever) proceder-se-á à devolução da subvenção, como dispõe o artigo 81.9 LGP, por descumprimento da obrigação ou a finalidade. Nessas situações a exigência de devolução (não revogação) é correta, pois existe na concessão da ajuda um encargo (que se comporta como uma espécie de 'resolução resolutória') que, se descumprido, determina a extinção da mesma, sem que isso pressuponha uma revogação.” (FELIU, 1995, p. 177, traduzimos).
} 
beneficiário aceitante (aquela, precisamente, que denominei relação subvencional), em razão da qual se cria um vínculo de sujeição que habilita a primeira a exercer poderes de controle e fiscalização da atividade subvencionada. (DE LA RIVA, 2004, p. 186, traduzimos).

Respeitadas todas as convicções supratranscritas, consideramos inegável a presença, nas subvenções, de obrigações recíprocas, não necessariamente sinalagmáticas, mas que findam por vincular as partes envolvidas, a ponto de se justificar o controle mútuo quanto ao atendimento aos compromissos originariamente assumidos.

Há, ainda, a concorrência de duas vontades, independentes, para a criação de referidas obrigações e prestações, e que são compatibilizadas por meio do processo subvencional.

Existe quem defenda até mesmo a própria incidência, nesta seara, da cláusula exceptio inadimplendi contratus, inerente, como sói de ser, às diversas categorias contratuais: “[...] Na verdade, o procedimento de reintegração se justifica pela exceptio inadimplendi prevista no Código Civil para as obrigações recíprocas que, a seu ver, constituem o apoio sobre o qual se sustentam as relações de caráter contratual.” (VILLAR EZCURRA, 1999, p. 128, ${ }^{62}$ traduzimos).

E nem se articule, conforme lição de De la Riva (2004, p. 176-179), que não haveria a possibilidade de a Administração exigir o cumprimento da obrigação/prestação assumida pelo beneficiário.

Os próprios princípios da moralidade, eficiência, economicidade e isonomia são incompatíveis com esse entendimento, na medida em que não se pode ter por compatível com o atual estágio evolutivo das ciências jurídicas no que toca à atuação administrativa a outorga de bens a particulares individualizados, em detrimento dos demais, sem que tal ato seja justificado - efetivamente - pela implementação real das medidas de interesse público buscadas.

Subtrair da Administração a possibilidade de exigência de atendimento às condições inicialmente fixadas seria compactuar com a malversação de verba pública em benefício de alguns poucos, sem qualquer motivo que lhe desse sustentação (OLIVEIRA, 2010, p. 225).

Registremos, também, que outros mecanismos de fomento há em que a mobilização da Administração fomentadora se restringe à criação e publicação das

\footnotetext{
${ }^{62}$ Vale registrar, nesse contexto, postura um tanto paradoxal adotada pelo autor, na medida em que, não obstante defenda a incidência da referida exceção de contrato não cumprido, não considera as subvenções inseridas na categoria dos contratos.
} 
condições a serem seguidas, sem qualquer necessidade de formalização posterior de acerto em que se prevejam as circunstancias e moldes do exercício por ambos os envolvidos.

Nesses casos, ressaltada a indevassável exigência de atendimento ao interesse público, não consideramos a estipulação unilateral das condições a serem observadas indicativo suficiente do afastamento da natureza contratual da relação que se estabelece. Até porque a autonomia da vontade, a ilimitada e absoluta liberdade negocial, não é tida, em muitos casos, e desde há muito, como elemento essencial dos contratos, nem mesmo em sua acepção mais estreita.

Veja-se, nesse sentido, as figuras dos contratos de adesão e os próprios contratos administrativos, em que incide regime peculiar e específico, derrogatório de grande parte das normas - e da liberdade — de Direito Privado.

\subsubsection{Natureza unilateral ou bilateral?}

Outro aspecto de fundamental importância no que tange às subvenções guarda relação com a sua natureza unilateral ou bilateral, no que, uma vez mais, a doutrina se encontra bastante dissonante.

Não necessariamente os que defendem a natureza jurídica da subvenção como ato concluem pela sua natureza unilateral.

Lopez-Muñiz, por exemplo, constata a existência de obrigações bilaterais, porém não sinalagmáticas, as quais não se caracterizam como elemento essencial do ato administrativo subvencional.

Na sua visão, estaria presente a reciprocidade obrigacional, mas não prestacional, adstrita à esfera pública, em convicção segundo a qual seria possível a existência de relações recíprocas sem prestações recíprocas. ${ }^{63}$

\footnotetext{
63 "Existe, portanto, como efeito do conteúdo das ajudas, obrigações recíprocas — se se outorgam por ato jurídico declarativo — e, em todo caso, ao menos direitos recíprocos — inclusive quando se dispensam mediante atos jurídicos reais, o que não é normal em Direito Público —, no sentido de que Poder dispensador e beneficiário ficam vinculados por uma relação jurídica bilateral que, por um lado, reconhece nesse o direito à aplicação do benefício ou vantagem à atividade própria a que afetado e à obrigação conseguinte de não desbordar em seu exercício, abusando, desviando ou usando mal o direito recebido, gozando de suas vantagens para outras atividades, assim como de não deixar de aplicar o benefício recebido na atividade de que se trate, e, de outra parte, implica para o Poder dispensador a obrigação de fazer efetivo o direito constituído em favor do beneficiário, e o direito a exigir que o beneficiário se aplique à atividade a que se tenha afetado." (MUNIZ, 1989, p. 762, nota 18, traduzimos).
} 
Para Villar Palasí, “a subvenção não se pactua. Solicita-se e se outorga pela Administração" (VILLAR PALASÍ, 1954, p. 69), assumindo a natureza, portanto, de ato administrativo condicionado à aceitação.

Na Argentina, conforme bem salienta De la Riva (2004, p. 174), parcela expressiva da doutrina, liderada por Cassagne, se inclina à consideração de que se trata de atos bilaterais, não necessariamente traduzidos na categoria de contratos.

Para ele, porém:

\begin{abstract}
A sujeição do particular que recebe a ajuda a dar-lhe o destino prefixado não constitui, estritamente, nem uma obrigação nem um encargo. À primeira se opõe a ausência de um destinatário preciso a quem favoreça o cumprimento do dever inerente à vantagem outorgada, e que possa, portanto, ser considerado titular de um direito correlativo. Está claro que a Administração, dotada de poderes para exigir que se respeite a afetação do benefício concedido, não ocupa referido lugar, o que fica evidenciado por sua incapacidade de reclamar o ressarcimento em caso de descumprimento. [...] em consequência, e seguindo a postura assumida na doutrina italiana por Pericu, considero que a categoria que melhor se ajusta à situação em que se encontra o beneficiário, de ter que investir a vantagem recebida em uma determinada atividade, é a de dever, tomado em seu sentido estrito. A tal conclusão me leva a inexistência de uma relação obrigacional particularizada (como assinalei, não há sujeito ativo capaz de reclamar para si de forma coativa o cumprimento do comportamento ao qual se vincula a ajuda), verificando-se, melhor, um gravame genérico a cargo do beneficiário da ajuda, que vê limitada a vantagem que se lhe foi concedida, a qual somente poderá ser aplicada ao destino previsto no ato de sua concessão. (DE LA RIVA, 2004, p. 176177, traduzimos).
\end{abstract}

Defende, pois, a natureza unilateral da relação, da qual decorrem direitos subjetivos somente aos beneficiários, que poderão cobrar da Administração o compromisso assumido. A esta, contrariamente, não seria dado compelir o beneficiário a cumprir as exigências de interesse público determinantes da concessão da subvenção - ao menos não com base no ato subvencional.

A obrigatoriedade de atendimento ao interesse público se traduziria, segundo o autor, em dever, decorrente, portanto, do próprio ordenamento jurídico, e não de qualquer espécie de contrato.

Temos que discordar desse posicionamento, na medida em que a Administração tem à sua disposição, sim, meios coercitivos voltados ao efetivo atendimento dos fins perseguidos pelo mecanismo de fomento, os quais decorrem diretamente do ato de outorga subvencional. 
O estabelecimento de dita relação desencadeia o surgimento de obrigações para ambos os envolvidos, que, muito embora não possam ser compelidos a permanecer vinculados, não podem da mesma forma simplesmente desconsiderar as condições inicialmente propostas e aceitas.

Uma vez que se fala em proposta e aceitação vinculantes dos envolvidos, resta inquestionável o surgimento de obrigações - e prestações — bilaterais (ainda que não necessariamente marcadas, como bem salienta Lopez-Muñiz, pelo sinalagma). ${ }^{64}$

Concluímos, assim, e juntamente com Garrido Falla, Santamaría Pastor e Baena de Alcázar (citados no item anterior), que as subvenções se inserem na classe dos atos jurídicos bilaterais, de igual forma que no fenômeno da contratualização lato sensu, nos termos referidos por Justino de Oliveira:

[...] o reconhecimento cumulativo dos critérios assinalados em técnicas, medidas ou experiências negociais permite demonstrar que estar-se-ia perante modelos correspondentes a nova contratualização administrativa, ou seja, de espécies do gênero módulo convencional da Administração Pública. Eis a acepção do termo contrato quando o mesmo é empregado para retratar a base consensual dessas novas relações, as quais desenvolvem-se no cenário ora apresentado. (OLIVEIRA, 2010, p. 225).

O mesmo se dá, se bem que incidental e não necessariamente, com os demais mecanismos de fomento.

\subsubsection{Tratamento das subvenções no ordenamento pátrio}

O Direito brasileiro trata das subvenções na Lei federal n. 4.320, de 17 de março de 1964 , cujo artigo 12 , § $3^{\circ}$, I, faz remissão às subvenções sociais como "transferências correntes destinadas a cobrir despesas de custeio de instituições públicas ou privadas de caráter assistencial ou cultural, sem finalidade lucrativa", observada sua necessária previsão na Lei orçamentária.

As subvenções econômicas, por sua vez, e nos termos do inciso II daquele mesmo dispositivo, seriam as "transferências correntes que se destinam a empresas públicas ou

\footnotetext{
${ }^{64}$ Nas palavras de Orlando Gomes, "não é pacífica a noção de contrato bilateral. Para alguns, todo contrato que produz obrigações para as duas partes, enquanto para outra a sua característica é o sinalagma, isto é, dependência recíproca das obrigações, razão porque preferem chamá-las contratos sinalagmáticos ou de prestações correlatas. Realmente, nesses contratos, uma obrigação é a causa, a razão de ser, o pressuposto da outra, verificando-se interdependência essencial entre as prestações. A dependência pode ser genética ou funcional. Genética, se existe desde a formação do contrato. Funcional, se surge em sua execução o cumprimento da obrigação por uma parte acarretando o da outra.” (GOMES, 1998, p. 71).
} 
privadas de caráter industrial, comercial, agrícola ou pastoril, sempre decorrentes de expressa autorização de lei especial".

Pois bem, as referidas transferências correntes são definidas como "as dotações para despesas as quais não corresponda contraprestação direta em bens ou serviços, inclusive para contribuições e subvenções destinadas a atender à manifestação de outras entidades de direito público ou privado.” (art. 12, § $2^{\circ}$, da Lei n. 4.320/67).

Quanto às despesas de custeio, são aquelas “dotações para manutenção de serviços anteriormente criados, inclusive as destinadas a atender a obras de conservação e adaptação de bens imóveis" (art. 12, § $1^{\circ}$, da Lei n. 4.320/67).

Notamos, de plano, algumas incongruências e inexatidões na disciplina legal da matéria, haja vista as ponderações supracolacionadas, inclusive e principalmente no que toca à indispensabilidade de a atividade de fomento, ocasionar a adoção de determinada postura/prática de interesse público por parte do seu destinatário.

Tem-se que o referido conceito legal de subvenção - excludente das atividades denotadoras da união de esforços, da mobilização do ente fomentado em prol do bem comum - não se coaduna com o espírito, com a própria natureza da atividade de fomento.

As subvenções aí referidas não se inserem, portanto, na categoria de estímulos ou incentivos, assumindo natureza jurídica diversa e não se sujeitando, assim, às posturas objeto do presente estudo. ${ }^{65}$

Não fosse isso, no que toca especificamente às subvenções sociais, a Lei federal n. 4.320/67 estabelece, em seu artigo 16, que constituem medidas excepcionais, tendo prioridade, em qualquer hipótese, o desenvolvimento das atividades pelo próprio Estado, diretamente.

Referido dispositivo, frontalmente ofensivo e incompatível com o princípio da subsidiariedade (a ser especificamente abordado, no item 1.8.6), não pode ser tido como recepcionado pela ordem constitucional de 1988, posto que incompatível com toda a lógica da Carta Maior, mormente após a Reforma Gerencial de $1995 .{ }^{66}$

\footnotetext{
${ }^{65}$ Registre-se, nesse ponto, posicionamento de Silvio Luiz Ferreira da Rocha, para quem "referido diploma se ocupa tão somente da atividade de fomento econômica direta." (ROCHA, 2000, p. 46).

${ }^{66}$ Levada a termo pelo Ministério da Administração e Reforma o Estado - MARE, chefiado pelo então Ministro Bresser Pereira, tinha por finalidade adaptar à Constituição de 1988 os princípios e ideais relativos ao modelo gerencial, em que ganham destaque a eficiência, o controle por resultados, a descentralização, a parceirização, a aproximação e horizontalização entre as esferas pública e privada. Nas palavras de Di Pietro, "em substituição parcial à tradicional Administração Pública Burocrática, introduz-se, em determinados setores, a Administração Pública Gerencial, na qual as ideias de hierarquia, imperatividade e executoriedade de decisões unilaterais são substituídas pela idéia de consensualidade. Em conseqüência, surgem novas formas de parceria entre o Estado e o particular e mesmo entre o Estado e órgãos públicos ou entidades da Administração Indireta, de que constituem exemplos os acordos-programa ou, na linguagem adotada no
} 
Tecidas essas primeiras considerações, cumpre-nos repisar a insuficiência e inefetividade da disciplina normativa do instituto no ordenamento pátrio, motivo pelo qual, muitas vezes, atividades subvencionais típicas findam por sequer ser identificadas como tais, ficando sob a égide das regras especificamente traçadas quando de sua concessão.

No atual estágio, com a assunção de cada vez maior protagonismo pelo Terceiro Setor, ${ }^{67}$ a atividade subvencional de fomento — seja ela identificada como tal ou não vem se ampliando de maneira bastante considerável.

As limitações constantes dos supratranscritos excertos legais não afastam a possibilidade de outorga de subvenções em hipóteses mais amplas que aquelas ali referidas.

A questão é que nosso ordenamento não detalha nem disciplina satisfatoriamente o instituto - motivo pelo que o seu regramento findava por se mostrar cada vez mais casuístico.

Findava porque, talvez realizando a inescusável lacuna, o legislador pátrio, tanto federal como estadual e municipal, vem expedindo normas disciplinadoras da transferência de receitas públicas a outros entes públicos ou privados, sem fins lucrativos, com vista a trazer uma maior segurança jurídica, homogeneidade e uniformidade de tratamento às situações ora consideradas.

É o se depreende da edição de instrumentais como o artigo 116 da Lei federal n. 8.666, de 21 de junho de 1993; o Decreto n. 6.170, de 25 de julho de 2007; a Instrução Normativa SRF n. 1, de 05 de janeiro de $1997 ;^{68}$ a Portaria Interministerial

direito brasileiro, os contratos de gestão." (DI PIETRO, 2007, p. 56-57). Veja-se, ainda, a lição de Gabardo: "O modelo burocrático é essencialmente metapragmático, propugnando pela adoção da impessoalidade como princípio fundamental, pela separação do patrimônio público do privado e pela dissociação entre esfera política e administrativa. Para o atingimento de tais pressupostos, caracteriza-se pela centralização das decisões, pela manutenção da hierarquia e unidade de comento, além de certa rigidez nas rotinas e procedimentos (cujo controle seria extensivo). Por estes motivos, foi taxado de um 'regime de desconfiança' por Bresser pereira, que passou a defender uma nova sistemática, fundada na confiança e no controle $a$ posteriori — de resultados. Neste modelo alternativo, fundado no princípio da subsidiariedade, o Estado passa a ser um ente responsável prioritariamente pela atuação por via do fomento o dentro de limites de razoabilidade e excepcionalidade. Para tanto, deve desregulamentar e conceder incentivos fiscais e isenções." (GABARDO, 2009, p. 114).

${ }^{67}$ Nas ilustrativas palavras de Salamon, Sokolowski e Haddock, estima-se que "a 'voluntarilândia', se fosse um país, teria a segunda maior população adulta de todos o mundo, e seria a sétima economia mundial. [...] Quase um bilhão de pessoas ao redor do mundo disponibilizam seu tempo voluntariamente por meio de organizações públicas, com ou sem finalidade lucrativa, ou diretamente para amigos ou vizinhos, em um ano típico, fazendo da 'voluntarilândia', se um país fosse, o segundo mais populoso do mundo, atrás somente da China.” (SALAMON; SOKOLOWSKI; HADDOCK, 2011, p. 218-219, traduzimos).

68 “Art. $1^{\circ}, \S 1^{\circ}$. Para fins desta Instrução Normativa, considera-se: [...] VIII - subvenção social - transferência que independe de lei específica, a instituições públicas ou privadas de caráter assistencial ou cultural, sem 
MPOG/MF/CGU n. 507, de 24 de novembro de 2011; e do Decreto municipal de São Paulo n. 49.539, de 29 de maio de 2008 . $^{69}$

As subvenções sociais são operacionalizadas no contexto brasileiro, portanto, por meio de mecanismos como o convênio, o termo de parceria, o contrato de gestão, dentre outros. $^{70,71}$

O Tribunal de Contas do Município do Rio de Janeiro também já se manifestou conforme esse entendimento:

É de se entender que, a princípio, o "convênio" é, apenas, uma modalidade formal, um dos veículos formais de avença pública. Não se pode confundir o veículo com a avença em si. Dessa maneira entende-se, por exemplo, que os convênios são a modalidade formal apropriada à subvenção, não se confundindo com essa. Subvenção, a rigor da lei, circunscreve-se ao suporte de custeio de atividades/entidades existentes. (MARTINS, 2008, p. 15).

Temos, finalmente, que as subvenções implicam necessariamente a transferência de bens ou valores do ente fomentador ao fomentado, os quais ficam, porém, absolutamente vinculados à consecução do objetivo de interesse público, orientador e direcionador de todo o atuar do destinatário do estímulo ou incentivo.

\footnotetext{
finalidade lucrativa, com o objetivo de cobrir despesas de custeio; note-se que aí já não há referência a 'transferências correntes', que independem de um agir do destinatário do estímulo."

${ }^{69} \mathrm{O}$ qual, registre-se desde já, não se aplica aos convênios formalizados a partir das receitas do Fumcad, como expressamente dispõe seu artigo $1^{\circ}$, parágrafo único, VI: "Art. $1^{\circ}$. Este decreto regulamenta a celebração, a liberação de recursos, a execução e seu acompanhamento, a fiscalização e a prestação de contas de convênios celebrados pelos órgãos e entidades da administração pública municipal direta e indireta com órgãos ou entidades públicas ou privadas, para a execução de programas, projetos, atividades e eventos de interesse recíproco, que envolvam a transferência de recursos oriundos do orçamento municipal. Parágrafo único. As normas deste decreto não se aplicam aos convênios: VI - que envolvam verbas advindas do Fundo Municipal dos Direitos da Criança e do Adolescente - Fumcad.”

${ }^{70}$ Nesse sentido teve oportunidade de reconhecer o senhor Desembargador do Tribunal de Justiça de Minas Gerais Jarbas Ladeira: "O Apelante alega a inexistência de qualquer irregularidade no repasse de verbas públicas a um hospital particular, vez que tal ato foi motivado pela precariedade do serviço de atendimento médico-hospitalar do Município de Conselheiro Lafaiete, sendo que, por meio de subvenção pública, um hospital particular passaria a atender à população. Assim, afirmando que não se aplicam às subvenções as regras da Lei 8.666/93, pede a reforma da sentença primeva. Ao contrário dos argumentos do recorrente, entendo que as subvenções, por versarem sobre o erário, não estão sujeitas ao arbítrio e boa vontade subjetiva do Administrador. Para que um ente público subvencione outro ente público ou entidade particular, deve necessariamente obedecer aos ditames da lei, especialmente as orientações dispostas no art. 116 da Lei 8.666/93[...].” (Ap. 1.0183.04.066951-1/001, 2. ${ }^{a}$ Câm. Cív., j. 04.12.2007).

${ }^{71}$ No mesmo sentido, vale citar o Decreto municipal de Foz do Iguaçu n. 19.178, de 28 de setembro de 2009, cujo artigo $2^{\circ}$ assim dispõe: "A transferência, execução e prestação de contas de recursos repassados pela Administração Pública direta e indireta do Município de Foz do Iguaçu às entidades da Administração Pública e às entidades privadas sem fins lucrativos a título de contribuições, auxílios e subvenções sociais, a partir da celebração de convênios, acordos, termos de cooperação ou outro instrumento similar, deverão atender às normas deste Regulamento [...]."
} 
É, assim, por meio desse instrumental, dentre outros, que se efetiva a confluência entre Direito Financeiro e Direito Administrativo, entre as esferas pública e privada, na medida em que a atividade subvencional da Administração - que goza da natureza jurídica de contratos lato sensu, reafirme-se — vem sendo efetivada por meio de instrumentais que já contam, para tranquilidade do intérprete, dos administradores e dos próprios entes beneficiários, com uma disciplina mais cuidadosamente elaborada.

\subsection{Incentivos fiscais e extrafiscalidade}

A evolução do modelo estatal, com a expansão de funções deflagrada pelo advento do Estado Social, criou um cenário em que a regulação da vida econômica e social, a direção de sua organização e impacto na sociedade passaram a integrar a paleta de missões estatais. ${ }^{72}$

Justificada, assim, a sua abordagem mais detida, paralelamente às subvenções ainda que despretensiosa de se mostrar conclusiva ou completa.

Temos o despontar da possibilidade - que, aliás, vem dando excelentes resultados - de manipulação dos valores arrecadados a título de tributos com finalidades outras, que vão além do mero abastecimento dos cofres públicos.

Trata-se, em oposição à fiscalidade, da faceta da extrafiscalidade, cujos contornos foram definidos por Matias-Pereira:

Essa atividade fiscal deve ser entendida como a desempenhada pelos poderes públicos com o objetivo de obter e aplicar recursos para a manutenção da rede de serviços públicos. E, à medida que o Estado utiliza o instrumental financeiro para alcançar determinados resultados econômicos e políticos, a ciência das finanças atua como orientadora da política, para fins extrafiscais. Nesse sentido, a atividade financeira do Estado deixou de refletir o Estado-gendarme para converter-se em um instrumento da política econômica e social dos governos, reorientando-se de finanças públicas neutras para finanças públicas funcionais, ou seja, passou a utilizar a política extrafiscal para alcançar os propósitos do Estado. Essa política extrafiscal utilizada pelo Estado realiza-se de duas maneiras: pela tributação, por meio dos efeitos da política tributária sobre o meio econômico e social, ou por meio da despesa, por ser essa uma

\footnotetext{
72 "Na concepção do Estado liberal, do qual se demandava reduzir ao mínimo sua intervenção na economia, o poder tributário deveria ser exercido de forma neutra, causando os menores efeitos de distorção do mercado possíveis. Com o advento do Estado social, esse enfoque sofreu profundas mudanças, e passou-se a exigir do Poder público uma maior ingerência com vistas a conjurar as deficiências do mercado. Começou-se então a vislumbrar a enorme potencialidade da potestade impositiva como ordenadora do processo econômico, à margem de sua tradicional função reguladora. Aparece, assim, a atividade tributária com fins parafiscais ou extrafiscais." (DE LA RIVA, 2004, p. 136, traduzimos).
} 
parcela significativa da economia nacional. (MATIAS-PEREIRA, 2009, p. 133).

Na lição de Ruy Barbosa Nogueira (1976, p. 158), “O imposto deixa de ser conceituado como exclusivamente destinado a cobrir as necessidades financeiras do Estado. É, também, conforme o caso [...], utilizado como instrumento de intervenção e regulador de atividades. É o fenômeno que hoje se agiganta da natureza extrafiscal do imposto."

Nesse contexto é dado à Administração incentivar as atividades mais necessárias e de que a sociedade se encontre mais carente, da mesma forma que desestimular aquelas potencialmente danosas ou mesmo irrelevantes, sob o ponto de vista coletivo.

A admissão e incorporação da extrafiscalidade não foram, porém, processo pacífico, havendo aqueles que se posicionassem frontalmente contrários a ela, sob o argumento de potencial ofensa à isonomia e capacidade contributiva. ${ }^{73}$

Essa corrente não prosperou. ${ }^{74}$

Na Espanha, há previsão expressa, constante do art. $4^{\circ}$ da Ley General Tributaria de 28 de dezembro de 1963, de que "os tributos, além de serem meios para arrecadar ingressos públicos, hão de servir como instrumentos da política econômica geral, atender às exigências de estabilidade e progresso sociais e procurar uma melhor distribuição da renda nacional" (traduzimos).

Ainda nesse país, o Tribunal Constitucional já teve oportunidade de indicar explicitamente o fundamento constitucional da função extrafiscal dos tributos. ${ }^{75}$

Outra discussão é a relativa à subsunção dos incentivos fiscais — dentre os quais se destaca a isenção - à atividade de fomento do Estado, em razão, principalmente, de sua natureza eminentemente tributária.

Realmente, poder-se-ia imaginar que, considerado o regime jurídico básico e a esfera de produção das normas incentivadoras, não se lhes poderia inserir na atividade administrativa de que ora nos ocupamos.

\footnotetext{
${ }^{73}$ Nesse sentido, GONZALEZ, 1983.

74 “À margem da controvérsia mencionada, é opinião geral que em toda medida fiscal confluem, inevitavelmente, em algum grau, fins arrecadatórios e extrafiscais, sem que se possa apartá-los de forma absoluta. Daí que do que se trata é de estabelecer, em dado caso, qual desses objetivos assume preponderância sobre o outro.” (DE LA RIVA, 2004, p. 137, traduzimos).

75 Sentença n. 37/87 (BOE 14 abr. 1987, FJ 13, Pt. Jusís Leguina Villa), segundo a qual os artigos $40.1 \mathrm{e}$ 130.1 da Constituição espanhola consagraram os princípios da política social e econômica, privilegiando uma distribuição de renda regional e pessoal mais equitativa, assim como o incentivo ao desenvolvimento e modernização dos setores econômicos com vistas à equiparação do nível de vida de todos os cidadãos espanhóis.
} 
Os argumentos lançados nesse sentido são, em suma, e à parte da origem tributária de tais medidas, os seguintes: a) diferença, ainda que parcial, dos regimes jurídicos administrativo e tributário. Lembremo-nos, nesse ponto, que, em última análise, a atividade fiscal do Estado nada mais é que uma das facetas da sua atuação administrativa. Além disso, cada um dos mecanismos de fomento conta, naturalmente, com um regime jurídico específico marcado por peculiaridades, não sendo estas, portanto, exclusividade das isenções; b) as isenções tributárias são concedidas em prol de um número indefinido de pessoas - o que também ocorre, registre-se, nas atividades de fomento; c) as isenções não implicam a transferência, aos beneficiários, de quaisquer bens. Nesse ponto, e conforme já assente, a ampliação da esfera de direitos do destinatário não é exigência inarredável da atividade de fomento. Além disso, os efeitos finais, tanto no caso de outorga de bens quanto no de desobrigação de pagamentos, se mostram, na prática, absolutamente semelhantes.

Temos, assim, e considerada a definição anteriormente assentada, que as medidas de incentivo fiscal traduzidas em mecanismos para/extrafiscais se inserem, sem quaisquer problemas, na seara da atividade fomentadora da Administração.

Nesse sentido, decisão do Supremo Tribunal espanhol:

Os tributos com fins não fiscais são, por uma parte, instrumentos da atividade administrativa de fomento, com um conteúdo econômico ou sinal negativo, para evitar ou pelo menos obstaculizar indiretamente ou tendenciosamente, sem o uso da coação, determinadas condutas ou situações não convenientes ou inadequadas a respeito do interesse geral, e em tal sentido, atuam como fatores de dissuasão. Agora bem, estrutural e funcionalmente são, por outra parte, autênticos tributos, submetidos no todo ao regime desses. (STS, 19.09.1988, Ar. 7196 , FJ 1, Pte. Rafael de Mendizábal Allende, traduzimos).

Registre-se, ainda, a lição de Cassagne, segundo a qual, "dentro dessa noção ampla de ajuda pública cabe incluir as distintas medidas tributárias que os Estados ditam com finalidades extrafiscais, que vieram alterando, em muitos países, o princípio da neutralidade fiscal" (CASSAGNE, 2003, p. 607, traduzimos).

A doutrina brasileira tem, da uma maneira geral, se manifestado no mesmo sentido:

As formas de exoneração tributária, tais como redução de alíquota, remissão, anistia, diferimentos e fixação de prazos excepcionais de 
recolhimento de tributo, isenção e imunidade são exemplos clássicos de auxílio indireto de natureza econômica [...]

[...] com a passagem do Estado Liberal para o Estado Democrático de Direito, reconheceu-se que interesses sociais, políticos ou econômicos, considerados relevantes para promover o bem comum, poderiam justificar uma interferência no manejo do produto da arrecadação fiscal. Nessa porfia o Estado utiliza o tributo com fins extrafiscais. A fiscalidade ocorre sempre que a arrecadação tributária tiver por finalidade o financiamento da atividade estatal. A extrafiscalidade por sua vez, não persegue os objetivos meramente arrecadatórios, mas busca incentivar ou restringir o desenvolvimento de determinada região ou atividade. [...] Os incentivos fiscais constituem, se utilizados com essa finalidade, formas estimulantes capazes de persuadir as pessoas que preenchem determinadas condições a praticarem atos ou executarem atividades que gerem o retorno socioeconômico almejado pelo Estado incentivador. (MELLO, 2003, p. 107-108).

\subsection{Princípios aplicáveis}

A atividade de fomento está sujeita, da mesma forma que quaisquer outras titularizadas pela Administração, aos princípios gerais do regime administrativo, que, no Direito brasileiro, vêm consagrados no artigo 37 da Constituição Federal. ${ }^{76}$

Cabe registrar, rapidamente, as especificidades que assume no âmbito da atuação do fomento cada um deles, da mesma forma que aqueles dispersos no nosso sistema constitucional.

\subsubsection{Legalidade}

Esse princípio experimentou, desde a sua originária concepção contextualizada junto ao modelo do Estado Liberal, sensíveis alterações, havendo evoluído de uma noção marcadamente formal de compatibilidade com as disposições legais expressas para a adequação aos valores e vetores consagrados em um dado ordenamento. ${ }^{77}$

\footnotetext{
76 “Art. 37. A administração pública direta e indireta de qualquer dos Poderes da União, dos Estados, do Distrito Federal e dos Municípios obedecerá aos princípios da legalidade, impessoalidade, moralidade, publicidade e eficiência [...]."

${ }_{77}$ Conforme salienta De la Riva, "[...] o principio da legalidade se foi flexibilizando e enriquecendo, até adquirir na atualidade uma configuração que desborda sua originária formulação como sujeição do poder público à lei. Hoje o princípio da legalidade se traduz, substancialmente, na ideia de que o Estado está vinculado ao Direito (e não só à lei) de uma maneira positiva, no sentido de que aquele só pode atuar mediante autorização do ordenamento jurídico. Não obstante, a raiz da crescente amplitude reconhecida à Administração como foco criador de normas, a evolução sofrida pelo princípio de legalidade, desembocou na enunciação de uma série de postulados ou técnicas, compreendidos naquele princípio, que procuram garantir sua vigência e sua coerência com o novo status quo [...].” (DE LA RIVA, 2004, p. 218-219, traduzimos).
} 
Ganhou a dimensão, ainda, de legitimidade, na medida em que passou a abarcar, além da compatibilidade do ato com as normas e valores jurídicos em geral, a análise quanto à sua base de sustentação política, se dotada de escopo e suporte decorrentes da soberania popular.

Nesse sentido a esclarecedora lição de Diogo de Figueiredo Moreira Neto, segundo a qual o fenômeno da aplicação do Direito é muito mais rico do que o da aplicação da lei, tal como compreendida no positivismo jurídico, em que o aplicador do Direito era tão somente a "boca da lei". (2008, p. 16)

Quanto ao pós-positivismo, assinala que:

[...] o intérprete-aplicador, qualquer que seja, e não apenas o magistrado, é também um conformador da norma aplicada pois lhe cabe retirar do teto inicial, que é a lei, o comando a ser efetivado, que é o direito, mas não ficar apenas na exegese, pois que também deve integrá-lo com seus próprios subsídios para afeiçoá-lo adequadamente á hipótese sob decisão $\mathrm{e}$, necessariamente, enunciar os valores e as razões por que o faz, na interpretação e na integração. [...] Tem-se, desse modo, uma interessante visão pós-moderna da ordem jurídica, de certo modo axiologicamente aberta, integrada e equilibrada, pois que duplamente submetida - à legalidade e à legitimidade - e não mais aprioristicamente definida como um sistema fechado, absolutamente reverente a uma legalidade pura, fundada em míticas razões de Estado e na perigosa supremacia do interesse público ou, ainda, em uma exacerbada valorização do formalismo procedimental. [...] a afirmação do constitucionalismo não apenas como foi classicamente concebido, restrito a declarar liberdades, direitos e garantias, organizar poderes estatais e estabelecer metas programáticas, instituidor de um Estado de Direito, mas um constitucionalismo expandido, desenvolvido para instalar valores e processos legitimatórios e prestigiar o homem e a cidadania em todas as suas manifestações e sob todos os seus aspectos, inclusive entronizar a licitude do comportamento público como valor constitucional, para instituir também, nesse novo processo, um Estado Democrático. (MOREIRA NETO, 2008, p. 16- 24-41).

Com relação especificamente à atividade de fomento, o ponto fulcral da legalidade traduz-se na celeuma quanto à obrigatória - ou não - autorização legal expressa: haveria a necessidade de norma autorizadora explícita daquela atividade mobilizadora em especial? 
Há os que defendem a não sujeição da atividade de fomento ao princípio da legalidade, vez que suas consequências não são de limitação, mas de ampliação da esfera de direitos dos particulares. ${ }^{78}$

Tal premissa, porém, não pode ser tomada por válida, posto que denotante de uma visão parcial sobre o tema.

Realmente, na medida em que amplia a esfera de direitos — o que, conforme já definido anteriormente, não é essencial —, a atividade fomentadora restringe o patrimônio jurídico de outros, ainda que indireta e potencialmente.

Isso porque a outorga de estímulo a um pode implicar sua negativa a outro, ou, de forma mais remota, o comprometimento a essa finalidade de uma parte do orçamento. Não fosse isso, poderia vir a beneficiar uma outra parcela da população.

Temos por inquestionável, portanto, a obrigatoriedade de previsão autorizativa e a incidência do princípio em questão. Resta saber, porém, em que medida, e com que contornos essa incidência deve se dar, se por meio de uma legalidade estrita, formal, ou, ainda, se de forma expressa, a partir de rol nominal taxativo.

Comungamos da opinião de Villar Ezcurra, segundo a qual a previsão do fomento pode se dar genericamente, em linhas gerais. ${ }^{79}$

Para o autor, as atividades dessa natureza se desenvolvem na seara das “potestades públicas”, são inerentes à competência explicitamente atribuída por uma norma, de forma que "se a Administração tem competência reconhecida para intervir ou regular um determinado setor, poderá utilizar as técnicas de fomento, ainda que não se encontrem expressamente previstas na Constituição e [...] não colida com outros princípios constitucionais" (VILLAR EZCURRA, 1999, p. 120-121, traduzimos).

Villar Ezcurra invoca o artigo 40.1 da Constituição espanhola, o qual, juntamente com a doutrina das potestades inerentes ou implícitas, daria guarida a toda e qualquer

\footnotetext{
${ }^{78}$ Nesse sentido, GARCIA DE ENTERRIA; FERNANDEZ, 2000, p. 566-567 e SANTAMARÍA PASTOR, 1988 , p. 783.

79 "A atuação administrativa por via de fomento poderia encontrar cobertura na declaração genérica do artigo 40.1 da CE: 'os poderes públicos promoverão as condições favoráveis para o progresso social e econômico e para uma distribuição da renda regional e pessoal mais equitativa no marco de uma política de estabilidade econômica'. O certo é que as expressões utilizadas nesse preceito não são exclusivamente referíveis ao fomento, já que a Administração também promove as condições favoráveis ao progresso social e econômico utilizando qualquer das restantes formas de intervenção (polícia, serviços públicos ou empresa pública), mas com isso não fica invalidada a cobertura para uma atividade estrita de fomento. [...] Ademais, e nisso residirá uma das peculiaridades da atividade de fomento, a intervenção administrativa por esta via não terá que se cingir unicamente aos aspectos especificamente previstos pela Constituição, podendo se expressar em quaisquer outros sob a cobertura genérica do artigo $40 \mathrm{da} \mathrm{CE}$. A alusão nesse preceito ao 'progresso social e econômico' permite sustentar essa conclusão já que se trata de uma expressão que forma parte da noção mesma de fomento desde que esta expressão começa a ser utilizada pelos escritores do século XVIII." (VILLAR EZCURRA, 1999, p. 117-118, traduzimos).
} 
atividade promocional da Administração, respeitada a pertinência temática com os valores consagrados.

Não obstante nossa Carta Maior não contar com dispositivo idêntico, esses mesmos valores são genericamente consagrados pelo artigo seu $3^{\circ}-$ do qual não se pode fazer letra morta - e, em decorrência da eficácia otimizadora ${ }^{80}$ dos valores constitucionais, já seriam suficientes a embasar toda atuação estatal de fomento com vista à promoção dos valores consagrados. ${ }^{81}$

\section{Dessa convicção compartilha Diogo de Figueiredo Moreira Neto:}

[...] É o que os franceses costumam apontar como característica de um État propulseur, que nada mais é que aquele dedicado a um exercício afincado do dever de fomento, que, entre nós, já se define constitucionalmente como um macro objetivo governamental, uma vez que vem reiteradamente contido em todos os enunciados dos objetivos fundamentais da República, nos quatro incisos do artigo $3^{\circ}$ da Carta Federal.

Desponta, assim, desse alto cometimento constitucional, que a responsabilidade dos governos em lograr o atingimento daqueles objetivos através de políticas públicas eficientes, não mais deve ser entendida como mera responsabilidade política, pois se vai tornando, paulatinamente, também uma responsabilidade jurídica, tal como hoje pacificamente se reconhece no reiterado referendo da prática constitucional européia, já acatada em decisões de nosso Supremo Pretório e tida até como uma das características diferenciais do constitucionalismo pós-moderno - que é o seu valor normativo direto [...]. (MOREIRA NETO, 2008, p. 129).

Não há que se falar portanto em uma lei específica para cada medida de fomento que se pretenda adotar — observada, repise-se, a sua indispensável compatibilidade com as leis orçamentárias e as restrições delas constantes.

Registremos, por fim, que esse posicionamento não é assente, advogando conclusão contrária Sílvio Luis Ferreira da Rocha, segundo quem "a atividade de fomento deve ser prevista em lei, não se admitindo, como válida, atividade de fomento não estipulada por lei, mas tão-somente por regulamento ou ato administrativo". (ROCHA, 2006, p. 30-31).

\footnotetext{
80 "A eficácia otimizadora consiste em orientar a interpretação dos preceitos e dos atos concretos que conformam uma ordem jurídica no sentido de dar a mais ampla, profunda e completa aplicação possível a seu conteúdo e valor." (MOREIRA NETO, 2008, p. 88).

${ }^{81}$ O mesmo se pode dizer com relação ao conteúdo do artigo $6^{\circ}$, nos termos do posicionamento já explicitado.
} 


\subsubsection{Isonomia}

Esse preceito assume, conforme lição de Vilar Ezcurra, a função de limitante da discricionariedade administrativa (VILLAR EZCURRA, 1999, p. 123).

Para Jordana de Pozas, os meios positivos de fomento constituiriam exceção ao princípio da isonomia, na medida em que implicariam a necessária concessão de privilégios: "Todos os meios de fomento de caráter positivo significam verdadeiros privilégios, enquanto supõem uma exceção vantajosa da norma geral a favor de pessoas ou classes determinadas" (JORDANA DE POZAS, 1949, p. 51-52, traduzimos).

Diferentemente do que articulava o autor ibérico, traduz-se, em verdade, em uma igualdade de oportunidades, segundo a qual todo e qualquer cidadão/entidade deve se encontrar indistintamente na posição de potencial agente fomentado - ao qual se chegará a partir de critérios legitimantes objetivos, universais e prévios.

Conforme bem pontua De la Riva:

[...] a outorga de uma ajuda pública importa necessariamente beneficiar a quem a recebe com exclusão do resto dos particulares, o que significa que sua concessão leva formalmente uma disposição em si mesma discriminatória de parte do Poder concedente. Essa circunstância, que faz da análise do princípio da igualdade um aspecto medular dentro do estudo dessa forma de intervenção administrativa, é consequência direta do caráter seletivo das ajudas. A constatação dessa tendência ao trato desigual ínsita aos atos subvencionais exige a presença de uma razão legitimante, justificativa que anda, precisamente, da mãos dadas com o alargamento da noção de igualdade a que se aludiu anteriormente. É dizer, parte-se, sim, do reconhecimento das diferenças inatas que existem entre os indivíduos, diferenças que reclamam de parte dos Poderes públicos uma consideração legal correlativa à situação particular de cada um (igualdade formal), mas se assume em seguida a necessidade iniludível de facilitar em certos casos os meios para que quem se encontre pior posicionado possa ascender a condições de vida dignas ou desenvolver adequadamente certas tarefas que se estimam particularmente valiosas para o bem do todo (igualdade material), o que de modo algum importa cair em um corte igualitarista orientado pela utopia de uma equiparação absoluta de todos os cidadãos. (DE LA RIVA, 2004, p. 200-202, traduzimos).

O Supremo Tribunal Federal já teve oportunidade de se manifestar sobre a matéria, entendendo que a isonomia teria sido ofendida, no caso, na sua faceta impessoalidade. $^{82,83}$

${ }^{82}$ Voto do relator ministro Lewandoswki na MC em ADI n. 4259 /PB: "Ocorre que a lei combatida singulariza de tal modo os beneficiários que apenas uma pessoa se beneficiaria com mais de $75 \%$ dos valores 


\subsubsection{Proporcionalidade}

A atividade de fomento traz como efeito reflexo insuperável a criação de situações menos benéficas aos terceiros não beneficiários, quando comparada com aqueles que efetivamente ingressaram na relação mobilizadora na condição de destinatários — ainda que indiretos — dessas medidas.

Imprescindível que esse desnivelamento, o qual será determinado pelos instrumentais de que a Administração lançar mão com vista a concretizar o fomento, se dê da forma socialmente menos gravosa possível, e alcance os melhores resultados viáveis.

Nas palavras de De la Riva, o principio da proporcionalidade “[...] aponta, precisamente, a destacar a necessidade de que o gravame causado pela intervenção se veja compensado pela envergadura dos fins alcançados ou por alcançar através da medida pública adotada, e exige, ao mesmo tempo, que ditos fins não se possam lograr por meios menos gravosos." (DE LA RIVA, 2004, p. 206-207, traduzimos).

Trata-se de valor que sempre orientou a atividade administrativa, ao menos após o advento do Estado de Direito.

Nesse sentido, recuperamos assertiva prolatada por Jordana de Pozas, em 1949, e que já traduzia a essência desse desiderato: “A intervenção deve ser proporcional ou ajustada ao motivo que a justifica, o que determina uma suave gradação dos meios

destinados ao programa, o que afronta o princípio da impessoalidade. Nas lições de Celso Antonio Bandeira de Mello, referido princípio 'traduz a ideia de que a Administração tem que tratar a todos os administrados sem discriminações, benéficas ou detrimentosas. Nem favoritismos nem perseguições são toleráveis. Simpatias ou animosidades pessoais, políticas ou ideológicas não podem interferir na atuação administrativa e muito menos interesses sectários, de facções ou grupos de qualquer espécie. O princípio em causa não é senão o próprio princípio da igualdade ou isonomia.' E a norma jurídica atende o princípio da igualdade quando é geral, abstrata, ou seja, não é editada com vistas a beneficiar um indivíduo. Nesse sentido assevera o mestre Celso Antonio não poder a lei 'erigir em critério diferencial um traço tão específico que singularize no presente e definitivamente, de modo absoluto, o sujeito a ser colhido pelo regime peculiar'. E continua o professor: se a norma é enunciado em termos que prefigura situação atual única, logicamente insuscetível de se reproduzir ou materialmente inviável (pelo que singulariza agora e para sempre o destinatário), denunciase a sua função individualizadora, incorrendo, pois, no vício indigitado. A inviabilidade de reprodução na hipótese, pois, tanto pode ser lógica quanto material. Haverá inviabilidade lógica se a norma singularizadora figurar situação atual irreproduzível por força da própria abrangência racional do enunciado. Seria o caso, exemplificandi gratia, de lei que declarasse conceder o benefício tal aos que houvessem praticado determinado ato, no ano anterior, sendo certo e conhecido que um único indivíduo desempenhara o comportamento previsto."

${ }^{83}$ ADI 4.259-MC "Lei 8.736/2009 do Estado da Paraíba que institui programa de incentivo aos pilotos de automobilismo. Violação do princípio da impessoalidade. Medida cautelar deferida. I - A Lei estadual 8.736/2009 singulariza de tal modo os beneficiários que apenas uma única pessoa se beneficiaria com mais de $75 \%$ dos valores destinados ao programa de incentivo fiscal, o que afronta, em tese, o princípio da impessoalidade. II - Medida cautelar concedida para suspender, com efeito ex nunc até julgamento final da ação a Lei 8.736, de 24 de março de 2009, do Estado da Paraíba." 
empregados, que devem ser, em boa doutrina, aqueles que consigam o fim perseguido no momento adequado, mas com o grau mínimo de coação." (JORDANA DE POZAS, 1949, p. 42, traduzimos).

Historicamente, estava relacionado ao poder de polícia, somente após se transformando em limite geral à intervenção do Executivo, mais adiante se estendendo também à atividade legislativa, conforme bem assinala Freitas, invocando Peter Badura (FREITAS, 2007, p. 65, nota 13, e p. 67).

O Tribunal Constitucional espanhol ${ }^{84}$ aponta três requisitos elementares para a apreciação de respeito — ou não — à proporcionalidade.

Necessária seria, nesses termos, a consideração, primeiramente, da idoneidade dos meios empregados para a consecução do fim proposto; na sequência, a análise da inexistência de outra via igualmente eficaz e menos gravosa aos particulares; e, por fim, do equilíbrio entre as vantagens perseguidas em prol do interesse público e o sacrifício de outros bens ou valores em conflito.

A adequação entre meios e fins, a ótima equação entre promoção e sacrifício de direitos, é elemento basilar do desiderato em questão.

Para Freitas:

[...] o princípio da proporcionalidade não estatui simples adequação meio-fim. Para ser preciso, a ofensa à proporcionalidade ocorre, não raro, quando, na presença de valores legítimos a sopesar, o agente dá prioridade indevida a um deles, em detrimento imotivado de outro. Não por mera coincidência, o princípio da proporcionalidade avulta no cotejo dos direito fundamentais. (FREITAS, 2007, p. 63).

Lembra o autor, ainda, e com bastante pertinência, que a evolução da proporcionalidade ainda não se completou, uma vez que não se encontra, até o momento, perfeitamente compatibilizado com as hipóteses de omissão da atuação estatal, as quais da mesma forma comprometem o direito fundamental à boa administração. (FREITAS, 2007, p. 67).

Registremos, por fim, posição daqueles segundo os quais seria a proporcionalidade "uma das dimensões do princípio da subsidiariedade, entendido nesse caso como subsidiariedade nos meios de intervenção" (LAGUNA DE PAZ, 1991, p. 136, traduzimos).

${ }^{84}$ STC n. 66/1995; STC n. 55/1996; STC n. 207/1996. 


\subsubsection{Eficiência}

Originariamente vinculado à seara econômica, trata-se de critério absolutamente incorporado, nos dias que correm, à ciência do Direito.

Não se limita aos parâmetros financeiros, aos preços da atividade estatal, abarcando, para muito além disso, os seus custos sociais e o resultado para a coletividade, que deve ser o melhor possível, com o menor custo viável.

Na lição de Odete Medauar:

O vocábulo eficiência liga-se à idéia de ação que leve à ocorrência de resultados de modo rápido e preciso; significa obter o máximo de resultado de um programa a ser realizado, como expressão de produtividade no exercício das atribuições. Eficiência opõe-se a lentidão, a descaso, a negligência, a omissão. Como princípio da Administração Pública, determina que esta deve agir de modo ágil e preciso, para produzir resultados que atendam às necessidades da população. (MEDAUAR, 2003, p. 242)

Ainda que sejam muitas as formas de atuação admissíveis, somente será considerada compatível com o ordenamento jurídico aquela ótima, que preconize, da maneira mais perfeita, o equilíbrio entre meios e fins, entre custos (econômicos, sociais, conjunturais) e resultados.

Não obstante a sua previsão expressa somente tenha se aperfeiçoado, no ordenamento pátrio, com o advento da EC n. 19/98, a sua preexistência é indiscutível, na condição de princípio implícito. ${ }^{85}$

Há quem defenda — sem razão — um embate, uma incompatibilidade entre eficiência e legalidade, tendo em vista que o proceder administrativo mais satisfatório possível seria potencialmente afrontoso a alguma(s) da(s) formalidade(s) e critério(s) decorrente(s) da legalidade.

Nesse particular, lembramos que a relação estabelecida entre os princípios não é de exclusão, de sobreposição, como se dá com as regras, mas sim de ponderação, de conciliação, tendo em vista a própria lógica do ordenamento. ${ }^{86,87}$

\footnotetext{
${ }^{85}$ Nesse sentido: “A Administração Pública é regida por vários princípios: legalidade, impessoalidade, moralidade e publicidade (Constit. art. 37). Outros também evidenciam-se na Carta Política. Dentre eles, o princípio da eficiência. A atividade administrativa deve orientar-se para alcançar resultado do interesse público.” (STJ, RMS 5.590/95/DF, 6a T., rel. Min. Luiz Cernicchiaro, DJ 10 jun. 1996, p. 20.395).

86 "A ponderação não constitui na dogmática jurídico-administrativa uma instituição unitária. Entre os conceitos já assentados de ponderação 'na execução' e 'na planificação' há um amplo elenco de possíveis atuações e tarefas para concretizar as normas legais, de modo diferente. Não obstante, todos esses tipos e
} 
Não cogitamos do afastamento da eficiência em prol da legalidade ou vice-versa - qualquer um desses cenários conduzia à comprometedora inconstitucionalidade, à antijuridicidade dos atos praticados.

A conciliação entre os dois basilares valores é não apenas possível como absolutamente desejável.

Nesse sentido, trazemos à baila as considerações de De la Riva, que, invocando Parejo Alfonso, assim se posiciona:

Parejo Alfonso aduz que não existe tal contradição entre legalidade e eficácia, senão que unicamente pode produzir-se em algumas ocasiões uma certa tensão entre ambos os valores (cfr. Parejo Alfonso, Eficácia e administração (três estudos), Instituto Nacional de Administração Pública e Boletim Oficial do Estado, Madrid, 1995, p. 108-109). O mencionado autor deixou claro nessa oportunidade que a pretendida antinomia é falsa, vez que a eficácia no atuar administrativo só pode se dar quando a Administração atua dentro de seu marco próprio de atuação (cfr. Parejo Alfonso, Estado social e administração, p. 145) [...] Deve-se coligir, então, que a legalidade constitui um pressuposto necessário, ainda que não suficiente, da eficácia no atuar administrativo, do que se segue que não qualquer política pública exitosa a curso prazo resulta admissível. Se ela não se atém aos postulados do ordenamento jurídico, não deverá nos surpreender que cedo ou tarde venham á luz suas consequências nocivas para os direitos dos cidadãos, pondo assim em evidência que a ilegalidade e a eficácia do agir público são incompatíveis. Sem ir mais longe, um proceder antijurídico da Administração trará aparelhado, quanto menos, um déficit de segurança jurídica. Compartilho, portanto, da posição de Parejo de que o problema não reside em escolher um dos dois polos da disjuntiva - eficácia ou Direito - a expensas do outro, senão melhor determinar as condições em que a atuação da Administração, sendo conforme ao Direito, seja também efetiva, é dizer, idônea para a satisfação dos interesses gerais. (DE LA RIVA, 2004, p. 210-211).

Notamos que a doutrina citada lança mão do termo "eficácia", em substituição da "eficiência".

subtipos de ponderação tem em comum o fato de considerar as margens de apreciação resultantes como competências próprias das instâncias administrativas encarregadas da aplicação das leis, e de tentar dotar-lhes de uma organização decisória adequada à índole das funções. Dessa forma, o mandato ou dever de ponderação foi adquirindo progressivamente uma estrutura diferenciada: cada vez mais resta claro que para levar a cabo uma ponderação integral em toda sua extensão, tal como se desenvolveu no âmbito do planejamento urbanístico, é necessário levar a cabo primeiro ponderações parciais em campos específicos, vez que, do contrário, em uma ponderação geral os interesses debilmente representados resultam facilmente preteridos." (ASSAMANN, 2003, p. 139, traduzimos).

87 "Para aplicar o método da ponderação, são necessárias três fases sucessivas: primeiramente, a fase da identificação, visando à definição de qual ou de quais os princípios incidentes sobre a hipótese considerada; em segundo lugar, a fase de valoração, pela qual se vai definir qual a prevalência em tese, e em que grau, de um princípio sobre o outro; e, em terceiro lugar, a fase de avaliação do menor prejuízo, pela qual se vai decidir pela prevalência, na hipótese considerada, do princípio que, em tese, seria o mais sacrificado." (MOREIRA NETO, 2008, p. 92). 
Afora as questões culturais e de distanciamento dogmático, cumpre-nos lembrar que a noção de eficiência veio justamente como desdobramento da eficácia, conforme bem esclarece Diogo Figueiredo Moreira Neto. ${ }^{88}$

No que toca especificamente à atividade de fomento, a eficiência incide igualmente quanto aos resultados perseguidos.

Não se trata, porém, da melhor ou pior avaliação que alcance o destinatário direto — análise essa a ser desenvolvida na seara da atividade de controle —, mas sim da compatibilidade e da satisfação dos meios escolhidos: "a eficácia da Administração na consecução dos fins ou objetivos de interesse geral a que se orienta sua atividade quando ela se instrumenta através da dispensa de favores." (DE LA RIVA, 2004, p. 214-215, traduzimos).

A grande dificuldade, aí, está na fixação de parâmetros válidos e satisfatórios de apreciação dessa eficiência, os quais não podem ser simplesmente importados da seara econômica.

Necessário o estabelecimento de estândares mínimos, a serem compatibilizados e direcionados a uma avaliação de resultados, nos termos sugeridos por Moreira Neto:

\begin{abstract}
Assim, sem mais insistir nem acrescentar, à guisa de orientação para lastrear uma experiência brasileira em busca de uma disciplina legal de resultados constitucionalmente devidos e, por isso, da ação constitucionalmente legítima dos agentes encarregados de promove-los, pende-se da iniciativa de algumas ações em curto e médio prazo. Em curto prazo, desde logo, impende continuar a definir e a aperfeiçoar os parâmetros para a aferição objetiva da eficiência administrativa: uma tarefa que parte de seu explicito fundamento constitucional, para que difunda o seu regular emprego por todas as entidades e órgãos administrativos. [...] Em médio prazo, é necessário pensar afincadamente em produzir legislação que se volte à aplicação do controle de resultados em todos os entes públicos da Federação - definindo, para tanto, os elementos legitimatórios essenciais, com a abertura de controles na tramitação de processos administrativos e a correlativa disposição de onímodas formas de participação controladora pela sociedade; tudo, enfim, para que um almejado futuro controle de qualidade de resultado na Administração pública esteja cada vez mais próximo do nosso presente. (MOREIRA NETO, 2007, p. 194).
\end{abstract}

\footnotetext{
88 "Não basta, hoje, ao Direito, que a ação administrativa do Estado exista, seja válida e eficaz. A simples busca da produção de efeitos, ou seja, pretender-se apenas a eficácia da ação, já era insuficiente para a Sociologia do Direito. Agora passou a sê-lo também para o Direito Administrativo. Acrescentou-se, aos quatro princípios constitucionais da administração pública, um quinto, o da eficiência, que, doutrinariamente, no plano do Direito Público, poderá ir até mais além, para nortear acolá da ação administrativa, também a produção legislativa e a interpretação judiciária tema de grande interesse e atualidade." (MOREIRA NETO, 2007, p. 32).
} 


\subsubsection{Transparência}

Segundo defende parte da doutrina, o princípio da transparência seria uma versão da publicidade, ${ }^{89}$ uma sua evolução com vista a adaptá-lo às novas demandas do século XXI e ao contexto pós-moderno.

Conforme afirma Gustavo Binenbjom:

A publicidade é, assim, instrumental necessário ao regime democrático, a fim de que o povo possa acompanhar pari passu o desenvolvimento das atividades administrativas, seja para a defesa de interesses individuais (uti singuli), seja para a promoção de interesses públicos (uti universi). A publicidade constitui, ainda, pressuposto necessário da transparência administrativa, visto que o trato da coisa pública não pode ser secreto, reservado, acessível apenas a determinados grupos hegemônicos. (BINENBJOM, 2009, p. 5).

Traduzir-se-ia na obrigatoriedade de a Administração dar a conhecer, de maneira geral e difusa, as suas condutas.

A peculiaridade ora agregada consiste na necessidade de efetiva comunicação, da criação de condições viabilizadoras da real compreensão dos dados disponibilizados, pela população. $^{90}$

Não se esgotaria, portanto, e exemplificativamente, na mera afixação do relatório de despesas e receitas públicas nos quadros das respectivas repartições; mais que isso, somente se considerará respeitado com a circulação de ditas informações via Internet, ${ }^{91}$ ou outros meios de comunicação de grande penetração, e, ainda, com a redação e exposição das questões de maneira simples, clara e inteligível por aqueles que não detêm conhecimento técnico no assunto.

\footnotetext{
89 “[...] o conceito vai se transmudando, de publicidade para transparência, onde se pode com maior propriedade insertar a idéia de dar a conhecer mais do que o conteúdo da ação, mas cada passo que em relação a ela se adota - pelo menos, cada passo que compreenda uma parcela de opção, de valoração, de alternativas que possa ser socialmente relevante." (VALLE, 2002, p. 88).

90 “A prática antes incensada por vetustos profissionais da Administração Pública, que se jactavam mesmo de sua capacidade de redigir expedientes a serem submetidos à publicação, que supostamente atendessem — do ponto de vista formal - à exigência de publicidade, sem todavia descerrar o verdadeiro conteúdo daquela decisão, não mais se coaduna com a sociedade participativa, nem tampouco com a gestão pública por cooperação.” (VALLE, 2002, p. 108).

91 "Nestes tempos extraordinários em que nos toca viver, quiçá um dos aspectos mais promissores do progresso do Conhecimento humano e de como bem dispô-lo a serviço desta e das gerações futuras é a sua explosiva difusão pelos meios eletrônicos, um fenômeno que vem mudando a face da cultura ocidental dominante. O computador democratiza o Conhecimento, tornando-se a nossa universalidade e a nossa biblioteca - sem fronteiras geográficas, políticas e linguísticas e, auspiciosamente, aberto, multidisciplinar, sem se encerrar em especialidades estanques.” (MOREIRA NETO, 2007, p. 106).
} 
Na didática organização externada por Jacob Soderman, em Mallorca, em maio de 2001, como Defensor do Povo Europeu, a transferência implica em:

\begin{abstract}
a) que os processos de tomadas de decisões sejam compreensíveis; b) que as próprias decisões estejam motivadas; c) que, na medida do possível a informação em que se baseiam os motivos seja acessível ao público; e d) que as reuniões dos órgãos públicos que tomam decisões sobre assuntos de repercussão direta para os cidadãos sejam abertas e públicas, de forma tal que esses possam as possam seguir e escutar os argumentos. (SODERMAN, 2001, traduzimos).
\end{abstract}

Incide em todo o ciclo do fomento, desde o planejamento até seu controle e eventual responsabilização.

Instrumentaliza o controle, a garantia de isonomia, de objetividade da escolha e de impessoalidade.

\title{
1.8.6 Subsidiariedade
}

O princípio da subsidiariedade desponta como um dos vetores do Estado do século XXI, em que a função de mediadora, mobilizadora da Administração ganha também destaque.

Nas palavras de Schimidt-Assmann, que trata pela designação de Estado Social nosso conceito de Estado Pós-Social ${ }^{92}$ :

A dialética do princípio do Estado social se materializa, desde a perspectiva organizativa-instrumental, através da idéia da subsidiariedade. A intervenção do Estado social somente deve ocorrer quando a autorregulação da sociedade não satisfaz as exigências da justiça social. [...] A subsidiariedade não põe em questão a responsabilidade dos poderes públicos sobre os assuntos sociais, mas reparte tal responsabilidade e a converte em um sistema em que, dentro de um marco geral de responsabilidade pública, se equilibram as esferas de auto-regulação com atuações próprias dos poderes públicos de distinta intensidade. [...] há que se ter em conta que a divisão de funções entre o Estado e a sociedade não se encontra estabelecido normativamente em todos os campos sociais, mas por vezes vem determinado pela tradição. Mas inclusive naqueles casos em que se vislumbrem novas necessidades que se mostrem de urgente atendimento, um exato entendimento do princípio da subsidiariedade fará com que a administração pública se abstenha de reclamar imediatamente para si toda a responsabilidade de sua satisfação. (SCHIMIDT-ASSAMANN, 2003, p. 146, traduzimos).

\footnotetext{
${ }^{92}$ Conceito que, como visto, toma por base a lição de Campilongo (2005, p. 32).
} 
É considerado por Moreira Neto como um dos quatro pilares do novo constitucionalismo, ladeado pelos direitos fundamentais, pela participação e pelo conceito de constituição como ordem de valores. ${ }^{93}$

Desdobra-se em duas acepções, uma horizontal, relacionada à interface entre Estado e sociedade, outra vertical, quanto aos entes administrativos gerais, regionais ou locais.

Implica preferência de atuação descentralizada, seja quanto à estrutura administrativa (interna e internacional, no caso da relação União Europeia-Estadosmembros), seja quanto à mobilização dos entes privados.

Passa-se a reservar a atuação estatal, assim, somente e de maneira residual, àquelas hipóteses em que a sociedade civil efetivamente não tem condições de fazê-lo, da mesma forma que os entes locais.

Conforme Odete Medauar, “[...] o princípio da subsidiariedade horizontal é aventado como critério nas relações entre a esfera de atuação estatal e a iniciativa privada, para conferir primazia a esta e caráter residual àquela; seria, pois, um critério para fixar a distribuição entre a atuação púbica e a atuação privada no âmbito interno de um Estado.” (MEDAUAR, 2003, p. 245).

Registremos, porém, que a supracitada autora não aceita essa noção de subsidiariedade horizontal, defendendo que não se poderia explicar a relação Estadosociedade civil em termos de alternatividade/fungibilidade, vez que ausentes estariam os supostos quesitos da homogeneidade e possibilidade de intercâmbio entre as atuações pública e privada (MEDAUAR, 2003, p. 245-246).

Discordamos desse ponto de vista, já que, ainda que o agir público e o agir privado se desenvolvam de formas absolutamente distintas, com a incidência de regimes próprios e peculiaridades insuperáveis, a finalidade de interesse público estará sempre presente, e poderá ser alcançada pelos mais diversos meios, sejam de origem pública ou privada.

\footnotetext{
93 “A subsidiariedade, como um segundo pilar, dos quatro destacados, atua como fator reorganizador não apenas das relações aqui tratadas, entre sociedade e estado, como uma referência para todas as relações internas entre entidades e órgãos públicos, que dele se vão desdobrando em um processo contínuo de desmonopolização do poder. Assim, com a subsidiariedade está ocorrendo uma novíssima e dinâmica aplicação do luminoso princípio da separação dos poderes, hoje mais apropriadamente relido como separação de funções autônomas. Assim, nas atuais sociedades humanas, que deixaram de ser uniclasse e monolíticas ou apenas divididas em duas ou poucas classes sociais, como quase nenhuma mobilidade interna, como no passado recente, para se tornarem sociedades pluriclasse e de alta mobilidade, somente a aplicação desse princípio pode proporcionar as condições para um atendimento diversificado e, por isso mesmo, adequado, das plúrimas necessidades que demandam satisfação coletiva pelos meios atribuídos ao estado." (MOREIRA NETO, 2008, p. 6-7).
} 
Denota a subsidiariedade importante aproximação entre o Estado e a sociedade civil, igualmente responsável pela promoção, proteção e desenvolvimento dos interesses coletivos, conforme explicitam Di Pietro ${ }^{94}$ e Valle. $^{95}$

Funciona como um dos grandes fundamentos da atividade de fomento, visto que determina a mobilização privada de maneira preferencial e predominante, sendo relegada a atuação estatal direta apenas àquelas situações em que inviável seja diferente.

Como bem explicita Cassagne:

O fundamento da ajuda pública não é outro que o princípio da subsidiariedade. Como se nota há tempos, esse primeiro joga em sentido negativo (por exemplo, não falsear a competência ou não dar ajuda a quem não necessita) como um mandato positivo que obriga ao Estado a suprir certas falências do mercado ou que não possam cobrir as organizações intermédias ou a própria sociedade. (CASSAGNE, 2003, p. 606 , traduzimos).

Asseveremos, por fim, que o princípio da subsidiariedade vem assumindo, ainda, uma terceira faceta, que floresceu no ambiente da Comunidade Europeia, em que a preferência de atuação é reservada aos diversos Estados-membros em detrimento da Comissão centralizada ${ }^{96}$ - ressalvadas as dificuldades dessa sua aplicação, traduzidas

94 “[...] o Estado deve abster-se de exercer atividades que o particular tem condições de exercer por sua própria iniciativa e com seus próprios recursos; sob esse aspecto, o Estado deve fomentar, coordenar, fiscalizar a iniciativa privada, de tal modo a permitir aos particulares, sempre que possível, o sucesso na condução de seus empreendimentos. A aplicação desse princípio faz com que o Estado perca a feição assumida no período do Estado Social ou Estado do Bem-Estar ou Estado Providência. Ele libera-se da prestação de inúmeras atividades, deixando-as nas mãos da iniciativa privada. Em conseqüência, ele diminui o tamanho de seu aparelhamento administrativo. Ele assume a posição de planejamento, regulação, controle. Além disso, ele ajuda, subsidia, incentiva a iniciativa privada de interesse público. Pela nova concepção do Estado, os direitos fundamentais do homem já não constituem apenas uma barreira à atuação do Estado. Cabe a este promover, estimular, criar condições para que o indivíduo se desenvolva livremente e igualmente dentro da sociedade; para isso é necessário que se criem condições para a participação do cidadão no processo político e no controle das atividades governamentais." (DI PIETRO, 2007, p. 52-53).

95 "Sabe-se que uma das ideias hoje prevalecentes em relação perfil a se conferir ao Estado é de estruturação segundo um parâmetro de subsidiariedade. Assim, ao Estado se reconhece, num contrafluxo, a necessidade de dimensionar-se segundo aquilo que lhe seja essencial realizar concretamente no mais, contando com as técnicas inerentes à chamada administração por cooperação (descentralização, privatização, parcerias e outros institutos), para o desenvolvimento de suas atividades. De outro lado, o incremento da ideia de Estado subsidiário - até porque encontra como um dos seus suportes técnicos, justamente a ideia [...] de cooperação — pressupõe o incremento da participação popular [...]. Caminham, portanto, lado a lado, subsidiariedade e participação, como instrumentos de realização do interesse público, agora com mais atores envolvidos do que na concepção antiga, em que se preconizava exclusividade de tutela desse valor em favor do Estado. [...] Como se vê, a ideia de subsidiariedade contém na sua essência, uma recuperação da importância do papel ativo do grupo social na organização de seus próprios interesses, e na regulação de suas próprias relações." (VALLE, 2002, p. 112-114).

96 "O peso fundamental da Administração nos assuntos da Comunidade Europeia recai sobre os Estados membros. Isso é consequência necessária, de plano, das competências limitadas à Administração da Comunidade Europeia em que, em essência, nada se verá alterado, apesar da progressiva complexidade das estruturas organizativas. Juridicamente, a preferência pela execução em nível nacional deriva do princípio da 
principalmente na imperiosa, ou desejável, incidência homogênea e uniforme das regras comunitárias, a qual resta não raramente desatendida.

Trata-se de evolução do axioma, de sua compatibilização com as novas demandas decorrentes das alterações contextuais e sociais.

\title{
1.8.7 Solidariedade
}

O princípio da solidariedade, tal como atualmente compreendido, já não guarda consonância com o ideal de caridade, de auxílio pontual ao próximo em que se podia diagnosticar o estabelecimento de uma relação vertical, em que o beneficiário era colocado em condição de dependência, de inferioridade.

Com a evolução da noção, chegamos a que todos são solidariamente responsáveis pela definição dos rumos da sociedade, de modo que a atribuição de seu progresso e sustentabilidade não recai sobre os governantes, ou sobre a Administração Pública, exclusivamente.

Desponta, pois, um dever de mobilização, de cooperação, difuso e irradiante por todos os componentes do corpo social, fundado na ideia de reciprocidade dos encargos sociais:

\begin{abstract}
A própria responsabilidade e a solidariedade se articulam e desenvolvem através do princípio da cooperação. $\mathrm{O}$ direito administrativo social se apresenta como o ordenamento jurídico da cooperação solidária. A esse respeito cabe distinguir, ao menos, três manifestações ou esferas em que expressa influência dita cooperação. Em primeiro lugar, há cooperação quando as prestações não são levadas a cabo pela própria Administração, senão por terceiros que atuam como intermediários, como ocorre na maior parte dos casos de prestações sociais que consistem em serviços e aportações não monetárias, como, por exemplo, no seguro-doença. Em segundo lugar, a idéia de cooperação preside também, de modo singular, a relação que existe entre a esfera de responsabilidade pública e a atividade que desenvolvem as entidades de voluntariado social. Finalmente, a cooperação se faz também presente na relação individual com os destinatários das prestações sociais, pois inclusive naqueles casos em que, à primeira vista, parecem dominar as formas de decisão unilaterais e imperativas, um exame mais detido permite descobrir muitas possibilidades de participação dos particulares. (SCHIMIDTASSMANN, 2003, p. 145-146, traduzimos).
\end{abstract}

competência limitada (o principio atributivo de competências, ou melhor, de competências de atribuição) estabelecido no artigo 5 (parágrafo 1) TCE.” (SCHIMIDT-ASSMANN, 2003, p. 388-389, traduzimos). 
Conforme bem explicita Casalta Nabais, a noção de solidariedade não é novidade dos dias atuais - mas tem sofrido considerável mudança de enfoque compatível com a nova dimensão da cidadania hoje reinante: "a cidadania solitária ou a cidadania responsivamente solidária. Uma cidadania que acresce assim à cidadania passiva do estado liberal, à cidadania política (activa) do estado democrático e à cidadania social do estado social" (NABAIS, 1999, p. 172).

O autor se refere a um dever de solidariedade dos indivíduos, que são investidos, pelo simples fato de integrarem - ainda que precariamente — uma sociedade, em uma situação de corresponsabilidade social da qual depende a própria dignidade da pessoa humana abstratamente considerada:

Solidariedade e direito não são, portanto, separadas. Pode-se até mesmo defender a hipótese de que a solidariedade democrática declina-se ao mesmo tempo como auto-organização igualitária no seio da sociedade civil e como conquista de direitos. A solidariedade democrática aparece sob duas faces, uma que designa o laço social voluntário entre cidadãos livres e iguais, e outra que designa as normas jurídicas e as prestações redistributivas estabelecidas pelo Estado para reforçar a coesão social e corrigir as desigualdades. (LAVILLE, 2010, p. 43, traduzimos).

Temos, assim, o estabelecimento de relações que, no campo específico do fomento, levam à mobilização da sociedade civil em prol do interesse coletivo, sem que, para tanto, a Administração tenha que se investir na faceta autoritária e imperativa.

O grande fundamento é a cooperação, ${ }^{97}$ baseada em deveres lastreados no ideal cívico, e não na subordinação ao Estado-polícia. ${ }^{98}$

\footnotetext{
97 “'A ideia de fomento e, em concreto, a de subvenção, nos levou assim à colaboração dos administrados com a Administração e às atividades privadas de interesse público. Boulouis enunciou corretamente isso ao dizer que se produziu uma evolução na natureza e na existência jurídica do particular. Atualmente as necessidades públicas se satisfazem também pelos particulares, que, através da via da colaboração que levam consigo as subvenções, ou de outras distintas, se inserem nas estruturas administrativas, tendo lugar um processo de intercomunicação entre as pessoas privadas e públicas.” (BAENA DEL ALCÁZAR, 1967, p. 83-84, traduzimos).

98 "O conceito consensual convencional, distintamente do conceito consensual contratual, parte, assim, da idéia de que a segurança obtida convencionalmente resulta da presunção de que todos se comportarão de acordo com a expectativa de que pelo menos uma expressiva maioria adotará esse mesmo previsível comportamento. É sob essa presunção que pode germinar no meio social a confiança, essa virtuosa situação que a doutrina contemporânea precisamente caracteriza como uma 'expectativa de reciprocidade'." (MOREIRA NETO, 2008, p. 38).
} 


\title{
1.8.8 Princípios da livre concorrência, do preço de custo e da intercambialidade das técnicas administrativas
}

Há, ainda, alguns outros princípios, específicos, que sujeitam igual e diretamente a atuação fomentadora.

Tem-se, assim, segundo Ariño Ortiz, o princípio da livre concorrência, que incide sobre as atividades de estímulo direcionadas ao domínio econômico e se relaciona preponderantemente com o regime da Comunidade Europeia, no qual a regra - claro que acompanhada de exceções — é a inadmissão de ajudas ou incentivos (ARIÑO-ORTIZ, 2004, p. 351-354).

Como bem lembra Cassagne:

\begin{abstract}
A reação aos extremos gerados pelas ideias intervencionistas veio pelo lado do direito comunitário, erigido precisamente para promover a livre concorrência, princípio esse que, como não poderia deixar de ser, parte da interdição de qualquer tipo de ajuda outorgada pelos Estados membros ou mediante fundos estatais que falseiem ou ameacem falsear a competência, favorecendo a determinadas empresas ou produções, na medida em que afetem aos intercâmbios comerciais entre os Estados membros (ap. 1 del art. 92, Tratado Constitutivo da Comunidade Europeia - TCE). (CASSAGNE, 2003, p. 602)
\end{abstract}

Villar Palasí fala do denominado "princípio do preço de custo", segundo o qual "a soma das quantidades que o particular prestador de serviço percebe em razão do mesmo, mais a subvenção que a Administração lhe outorgue, deve ser igual ao custo financeiro do serviço”. (VILLAR PALASÍ, 1954, p. 63, traduzimos).

Nesse particular, consignamos nossa visão segundo a qual referido princípio incidiria em todas as modalidades de fomento operacionalizadas por meios econômicos diretos em que houvesse transferência de bens ou valores estatais para a iniciativa pública ou privada.

Nessas hipóteses, não se poderia admitir essas transferências tomassem por base valores originários relacionados à finalidade mediata do fomento acrescida de qualquer margem de lucro, qualquer superávit a reverter em benefício do agente fomentado.

Os próprios princípios da eficiência, da moralidade e da isonomia afastariam essa possibilidade.

É o que defende, também, Villela Souto, invocando J. A. Manzanedo, J. Hernando e E. Gomez Reino, ao explicitar que "a subvenção tem por fim cobrir 
insuficiências da atividade econômica dos particulares (daí o sentido finalista de indenização ou compensação), não se confundindo com a garantia de lucratividade, que é instituto afim". (SOUTO, 2007, p. 23).

Há, ainda, o princípio da intercambialidade das técnicas administrativas, somente passível de defesa por aqueles que adotam o critério finalístico, teleológico, para a definição da natureza da atuação de fomento.

Nesse sentido, os posicionamentos de Villar Ezcurra (1999, p. 40) e Garrido Falla (1992, p. 123).

Sob o nosso ponto de vista, já claramente exposto, não há que se falar em referida intercambialidade, vez que consideramos como elemento diferenciador fundamental das diversas modalidades de atuação administrativa justamente os meios empregados, se coativos ou não, diretos ou indiretos — e não o fim alcançado.

Tal postulado, ressaltamos, não se confunde com o princípio da equivalência das técnicas de fomento, originariamente defendido por Jordana de Pozas: "A finalidade perseguida e sempre a mesma: convencer para que se faça ou omita algo [...]. A seleção dos meios não é uma questão de técnica jurídica, [...] a eleição dos que se devem se utilizar é propriamente política" (JORDANA DE POZAS, 1959, p. 50-51, traduzimos).

No mesmo sentido, afirma Villar Palasí que "todas as técnicas de fomento são entre si conversíveis. Em definitivo, implicam na única finalidade que se pode conseguir mediante a aplicação de uma série de meios distintos" (VILLAR PALASÍ, 1954, p. 58, traduzimos).

\subsection{Discricionariedade}

A atividade de fomento foi, historicamente, marcada pelo alto grau de liberdade do Administrador. ${ }^{99}$

Villar Palasí afirmou que "uma vez afirmada a potestade administrativa nessa matéria, tal atribuição se qualifica de potestade discricionária, sendo, portanto, indiscutível jurisdicionalmente as disposições e resoluções administrativas sobre o tema" (VILLAR PALASÍ, 1954, p. 13, traduzimos).

\footnotetext{
99 "Estudando-se a evolução da Administração Pública a partir do Estado de polícia, verifica-se a partir da idéia de discricionariedade ampla - sinônimo de arbítrio próprio das monarquias absolutas, em que os atos de Administração não eram subordinados à lei nem passíveis de apreciação pelo Poder Judiciário - para passar-se a uma fase, já no Estado do Direito, em que a discricionariedade, assim entendida, fica reduzida a certos tipos de atos; e chega-se a uma terceira fase em que praticamente desapareceu essa idéia de discricionariedade e esta surgiu como poder jurídico, ou seja, limitado pela lei." (DI PIETRO, 2012, p. 2).
} 
Chegou ao extremo de lançar mão da expressão "faculdades libérrimas y discrecionales" (VILLAR PALASÍ, 1954, p. 82.), ao se referir à natureza da outorga de subvenções.

De la Riva lembra que "[...] O certo é que a atividade subvencional foi desde sempre esquiva às exigências derivadas do princípio da reserva de lei, e isso também provavelmente se devia ao caráter, em princípio, não restritivo dessa atividade.” (DE LA RIVA, 2004, p. 91, traduzimos).

Referida noção, com os seus inerentes desdobramentos, já não se mostra compatível com a atual concepção de Estado, de sociedade - e a correlação entre ambos.

Conforme salienta Juarez de Freitas, “o Estado Constitucional, numa de suas mais expressivas dimensões, pode ser traduzido como o Estado das escolhas administrativas legítimas" (2007, p. 7), motivo pelo que já não se vislumbra espaço para o reconhecimento de competências exclusivamente discricionárias, concedentes de plena liberdade ao Administrador. ${ }^{100}$

Um dos aspectos determinantes desse novo cenário é o reconhecimento da subordinação da discricionariedade administrativa aos direitos fundamentais em geral e, em especial, ao direito fundamental à boa Administração, incompatível com decisões tomadas ao talante de uma pessoa - ou grupo de pessoas - sem o escopo de garantir e promover o bem geral:

A discricionariedade administrativa, no Estado Democrático, encontra-se vinculada ao direito fundamental à boa administração pública, sob pena de serem solapados os limites indispensáveis à liberdade de conformação. Toda discricionariedade administrativa precisa guardar referência ao sistema: a liberdade é dada para facultar a melhor conformação possível, não para obstá-la. Nesse sentido, não se admite a mera faculdade. A liberdade, se e quando exercida como negação dos princípios fundamentais, torna-se viciada por excesso ou por deficiência - e, como tal, negadora da discricionariedade legítima. Em outras palavras, faz-se arbitrária e não-universalizável racionalmente. É que o estado da discricionariedade legítima, na perspectiva adotada, consagra e concretiza o direito fundamental à boa administração púbica, que pode ser assim compreendido: trata-se do direito fundamental à administração pública eficiente e eficaz, proporcional cumpridora de seus deveres, com transparência motivação, imparcialidade e respeito à moralidade, à participação social e à plena responsabilidade por suas condutas omissivas e comissivas. A tal direito corresponde o dever de a

\footnotetext{
100 “'Ora, bem examinados de perto tais e outros casos de discricionariedade administrativa, verificar-se-á que, à diferença do que supõem os menos avisados, a autoridade jamais desfruta, legitimamente, de liberdade pura para escolher (ou deixar de escolher), ainda que a atuação guarde, aqui e acolá, menor subordinação à legalidade estrita que na concretização dos atos vinculados.” (FREITAS, 2007, p. 32).
} 
Administração pública observar, nas relações administrativas, a cogência da totalidade dos princípios constitucionais que a regem. (FREITAS, 2007, p. 125)

Tratar-se-á, portanto, mais que de mera análise de legalidade, de uma apreciação quanto à legitimidade, ${ }^{101}$ a partir da qual se poderá chegar não a várias soluções cabíveis e igualmente aceitáveis, mas a uma mais apropriada, mais bem preparada à eficiente e eficaz conquista do interesse público. "Com efeito, existe somente a melhor escolha administrativa (não 'a' única resposta correta)” (FREITAS, 2007, p. 38).

O âmbito de incidência das competências discricionárias, assim, não apenas se reduziu consideravelmente como também passou a contar com novos parâmetros - e limitadores.

No que toca especificamente à atividade de fomento, notamos, primeiramente, sua estreita relação com o protagonismo social, vez que somente alcançarão a legitimidade, e portanto a juridicidade, as decisões discricionárias consentâneas com os anseios e demandas sociais.

A responsividade ${ }^{102}$ é, pois, alçada, e ainda com mais força na seara discricionária, à condição de validade, de sustentabilidade e prevalência das decisões - o que torna cada vez mais exigível que o Estado mobilize, incentive e promova a atuação da sociedade civil. ${ }^{103}$

Registremos, ainda, que durante o processo, ou o ciclo do fomento, a liberdade para decidir não incide de maneira homogênea e invariável: muda consideravelmente, tanto no que toca à sua abrangência quanto à intensidade. ${ }^{104}$

\footnotetext{
${ }^{101}$ Conforme salienta Moreira Neto, "ainda que o Estado Democrático de Direito tenha resolvido tão bem a antinomia entre legitimidade e legalidade, esses dois padrões continuam a existir, com funções muito claras, no novo continuum jus-político: o interesse público, antes ou depois de legislado, é sempre padrão de legitimidade, mas só o interesse público legislado alça-se a padrão de legalidade.” (MOREIRA NETO, 1991, p. 8).

${ }_{102}$ Conforme bem define Gustavo Justino de Oliveira, "cumpre aprioristicamente à organização administrativa estatal conferir respostas à demandas sociais. A principal função do aparato administrativo estatal é a de receber os influxos e estímulos da sociedade, rapidamente decodificá-los e prontamente oferecer respostas à satisfação das necessidades que se apresentam no cenário social." (OLIVEIRA, 2010, p. 160).

103 "O Estado da discricionariedade legítima requer (ao mesmo tempo, suscita) o protagonismo da sociedade amadurecida e do agente público que defende a dignidade de todos. É o Estado da continuidade planejada dos serviços essenciais, do intangível equilíbrio econômico-financeiro dos ajustes e da superação da lógica antagonizadora, precária e adversarial nas relações da administração.” (FREITAS, 2007, p. 19).

104 “[...] a intensidade da regra em questão não pode ser a mesma na primeira fase do exercício da atividade subvencional, é dizer, quando se cria a medida de fomento e se limitam seus potenciais destinatários - e, ao fazê-lo, se exclui a outros setores —, que no momento da adjudicação da ajuda a um determinado sujeito, que é quando o princípio da igualdade adquire seu máximo rigor. Esta distinção [...] tem muito a ver com a desigual margem de discricionariedade de que goza a Administração (ou, em seu caso, o legislador) em uma ou outra etapa." (DE LA RIVA, 2004, p. 203-204, traduzimos).
} 
Assim, o planejamento das medidas de estímulo não é marcado por igual discricionariedade que as decisões de outorga de subvenções, por exemplo.

Em outras palavras, a análise do grau de vinculação do agente público deve ser feita a partir consideração da específica do momento da atividade fomentadora que se leve em conta, tomado, sempre, o seu ciclo dinâmico de implementação.

O cenário descrito gera, ou pode gerar, certa insegurança, vez que o ciclo em questão se desenvolve sobre bases pouco definidas, preceitos pouco delineados.

Daí defendermos a importância da edição de uma lei geral de fomento, capaz de parametrizar, orientar e criar rotinas seguras públicas e prévias a orientar o exercício dessa atividade.

A nossa Lei federal n. 4.320/64, pretensamente reguladora das subvenções em geral, já não se mostra suficiente nem compatível com as demandas e expectativas atuais, nem com o próprio agir do Estado — e da Administração — nesse início de século.

Conforme ponderado anteriormente, ela não se presta sequer a abarcar todas as possíveis modalidades de subvenções, e já não se mostra consentânea com diretrizes de grande destaque no nosso ordenamento, como são a subsidiariedade da atuação estatal e a eficiência.

Nesse particular, e tomado mais uma vez o exemplo espanhol, ${ }^{105}$ defendemos a necessidade de edição de um diploma que transcenda a noção de subvenção, que trate, ainda que em linhas gerais, da ação de fomento lato sensu, com seus princípios orientadores, as suas nuances específicas e o reconhecimento da indispensável mobilização responsável e responsiva da sociedade civil como um todo.

Assim se conquistará maior segurança jurídica, com a potencial maior adesão dos destinatários das normas de estímulos — que serão atraídos então para terreno seguro, previamente disciplinado e regulamentado.

Não mais se esperará a adesão a relações pouco disciplinadas, pouco conhecidas, e de consequências quiçá não pretendidas ou imaginadas.

\subsection{Ciclo da atividade de fomento}

Tecidas todas as considerações prévias relativas ao arcabouço técnico conceitual do fomento, cabe-nos ir um pouco além no estudo de sua efetivação propriamente dita, a

${ }^{105}$ Ley General de Subvenciones - Ley n. 38, de 17 de novembro de 2003. 
partir de uma visão dinâmica do fenômeno.

Referida atividade não se aperfeiçoa em um único estágio, irradiando efeitos importantíssimos e interdependentes para momentos anteriores e posteriores à sua incidência, de modo a criar um verdadeiro ciclo, tradutor dessa prática desde seus atos preparatórios até os seus efeitos e decorrências práticas.

Trata-se de um processo, de um conjunto de atos e providências concatenados e conectados entre si com vista a chegar - e em razão dos quais se chega - a um desfecho satisfatório: o efetivo atendimento e promoção do interesse público, da forma mais eficiente, legítima e "responsiva" possível.

Rego Blanco, identificando esse fenômeno processual que se desdobra no tempo, enumera: a) a criação e derrogação da norma subvencional/de fomento; b) a resolução quanto à sua concessão ou negativa; c) a quantificação da subvenção; d) seu controle (REGO BLANCO, 1996, p. 173).

Para De la Riva, pode-se distinguir entre três etapas: a) estabelecimento dos requisitos para a outorga da ajuda; b) seleção do beneficiário; c) efetiva atribuição patrimonial.

Referidos momentos poderiam tanto ser implementados por uma mesma pessoa jurídica, como por pessoas distintas (hipótese em que vislumbra confusão quanto a qual seria, verdadeiramente, a outorgante da ajuda). (DE LA RIVA, 2004, p. 144-145).

Villar Ezcurra, a seu lado, fala em:

Aprovação do plano, que, necessariamente, e por tratar-se de uma regulação geral, deve se fazer mediante uma norma de estatura suficiente. O mais frequente é que uma norma com natureza de lei formal autorize a elaboração do Plano, assim como a designação de recursos financeiros ao mesmo e que seu conteúdo se desenvolva, posteriormente, por outra norma de hierarquia regulamentar, o que permitirá substituir o Plano por outro ou modificá-lo sem necessidade de voltar a utilizar uma norma com estatura de lei. [...]

Oferta da Administração: as empresas ou particulares que estejam interessados em obter os benefícios previstos em no Plano, mediante a subscrição de um convênio estandarizado ou, em alguns casos, negociado entre ambas as partes dentro das possibilidades admitidas a respeito desse Plano.

Subscrição do convênio entre a Administração e o particular em virtude do qual este adquire o direito à obtenção dos benefícios incluídos no Plano (empréstimos oficiais, subvenções, desagravações ou bonificações fiscais) e, em contrapartida, fica submetido ao cumprimento de uma série de obrigações, assim como ao controle da Administração. (VILLAR EZCURRA, 1999, p. 116-117, traduzimos). 
Lembrando que, conforme ponto de vista exaustivamente exposto ao longo do presente, não consideramos admissível a restrição da atividade de fomento às subvenções, julgamos ser tal análise merecedora de alguns reparos.

Realmente, considerado o gênero fomento, emergem, invariavelmente, quatro distintos momentos de irradiação de efeitos variáveis: a) previsão normativa, correspondente ao planejamento dos estímulos e, portanto, dos rumos a serem assumidos pelas ordens econômica e social; b) efetivação da relação de fomento propriamente dita, com a vinculação entre agente fomentador e destinatário imediato; c) controle, voltado a garantir a eficiência e eficácia da relação estabelecida, assim como dos resultados perseguidos; d) responsabilização, voltada à promoção de medidas direcionadas à garantia do fim de interesse público eventualmente negligenciado ou comprometido e a eventual fixação de culpas.

\subsubsection{Planejamento}

O planejamento estatal nada mais é do que a pilotagem do processo de desenvolvimento nacional, e, portanto, ele extrapola o setor meramente econômico e desdobra o processo de desenvolvimento em três grandes dimensões: a dimensão econômica, a dimensão social, ou seja, a luta contra a desigualdade de condição social e a luta contra esta oposição cultural entre país atrasado e país moderno, e, finalmente, a dimensão política, que nada mais é do que a democracia. (COMPARATO, 2001).

Como salientado no excerto supratranscrito, o planejamento encontra-se, nos dias que correm, alçado à condição de indispensável ao desenvolvimento do Estado e da sociedade em geral.

Não podemos admitir uma atuação administrativa dissociada da organização consistente, da conciliação e compatibilização entre os diversos objetivos a serem perseguidos e os interesses públicos a serem contabilizados — sob pena de naufrágio da organização social e risco de comprometimento dos direitos fundamentais.

Tanto é assim que o autor suprainvocado defende mesmo o reconhecimento - ou estruturação — de um poder estatal de planejamento. ${ }^{106}$

\footnotetext{
106 “....] A segunda proposta de superação dessa dicotomia Estado/sociedade civil é recriar um poder planejador, mas um poder planejador com participação popular. Em nenhuma Constituição atual existe a previsão do poder de planejamento, e, no entanto, até o advento do neoliberalismo isso já foi amplamente praticado, no Estado japonês por exemplo. É preciso criar um poder planejador que não seja apenas burocrático, e que conte com a participação do povo. Nesse sentido, a nossa modestíssima Constituição de 88 já dá algumas diretrizes, que obviamente até agora não foram implementadas, mas são importantes. O plano
} 
Seria, nas palavras de Moreira Neto, "uma nova visão acerca do devido processo constitucional de formulação de políticas públicas, integrado, além do planejamento, pela programação e orçamentação" (MOREIRA NETO, 2008, p. 123-126).

Conforme salienta, a formulação de políticas públicas traduz-se em um “complexo de processos juspolíticos destinado à efetivação dos direitos fundamentais" (MOREIRA NETO, 2008, p. 124), o qual é composto pelos seguintes momentos: a) fixação de objetivos e elaboração de planejamento; b) etapa financeiro-orçamentária; c) processo administrativo de execução.

Trata-se de etapa "prévia ao ato de dispensa da ajuda [...]. Trata-se, a rigor, de uma atividade de natureza normativa que condicionará a ulterior decisão de outorga. Serve de marco à relação subvencional a entabular-se, mas está claro que quem a desenvolve não toma parte da relação subvencional singular” (DE LA RIVA, 2004, p. 145, traduzimos).

Referida organização prévia da atuação administrativa não constitui, atualmente, mera faculdade, ou vetor ético a ser perseguido pelos governantes:

A racionalização das atividades dos governos não mais deve se considerar apenas como mera aspiração ético-política das sociedades contemporâneas, uma vez que já se a tem constitucionalmente erigida como um direito difuso - e, por isso, exigível por toda cidadania, em todos os níveis políticos e, de modo especial, ainda que não exclusivo, posto sob vigilância do Ministério Público, entre os elevados cometimentos que lhe são outorgados pelos artigos 127, caput, e 129, da Constituição (MOREIRA NETO, 2008, p. 132-133).

E a esfera de atuação em que alcança o ápice da proximidade com a sociedade civil é justamente no fomento.

Isso porque implica ele uma descentralização da atuação administrativa, ${ }^{107} \mathrm{em} \mathrm{um}$ “convite" e incentivo a que a sociedade civil assuma responsabilidades pelo atingimento e satisfação dos interesses coletivos.

nacional de educação e o plano nacional de saúde deveriam contar com a participação dos setores do povo que têm ligação direta com essas atividades e com a organização de políticas públicas. É muito pouco, reconheço, mas é apenas uma indicação do rumo que deveríamos seguir." (COMPARATO, 2001).

107 "Numa visão moderna das estruturas de fomento, é possível afirmar que a gestão de fundos públicos de fomento pode ser descentralizada a particulares. [...] Dentre as técnicas de descentralização para particulares, a que mais simplesmente se aperfeiçoa é a celebração de convênio com entidade civil [...]." (SOUTO, 2007, p. 37). Note-se, porém, e conforme pertinente advertência de Maria Sylvia Zanella Di Pietro, que a referência à descentralização em questão não se confunde com a noção técnica de transferência de serviços públicos a entidades privadas, em que se verifica a modalidade da denominada descentralização por cooperação: "É importante lembrar que nem todas as formas de parceria implicam descentralização de serviço público. É o caso, por exemplo, dos termos d parceria com as organizações da sociedade civil de interesse público, que prestam atividade privada e, exatamente por atuarem no campo dos serviços sociais não exclusivos do Estado, recebem ajuda do poder público, dentro de sua atividade de fomento. Na mesma categoria entram os 
Essa atuação necessariamente se desenrolará nos moldes previamente planejados — de cuja discussão deverão participar os responsáveis pela implementação das medidas: em última análise, os representantes da coletividade. ${ }^{108}$

Não se pode cogitar de uma atividade incentivadora da Administração que, por desorganização, finde por ofender os desideratos constitucionais da eficiência, economicidade, moralidade.

Nesse sentido, reafirmamos a imprescindibilidade da interação constante e efetiva entre órgãos públicos e sociedade civil, com a criação de um fluxo ininterrupto de informações e diagnóstico de demandas.

É, na expressão utilizada por Schimidt-Assmann (2003, p. 288), a "sociedade da informação", na sua vertente relacionada com a própria conquista e garantia da responsividade, do estabelecimento de íntima relação de causa e consequência, de demanda e respostas entre as necessidades coletivas e a forma de atuar/incentivos disponibilizados. ${ }^{109}$

Nas palavras de Moreira Neto:

[...] o mundo vai se encolhendo e os indivíduos, os grupos, as sociedade e os Estado ficando cada vez mais próximos e interagentes, integrados pelo desenvolvimento científico e tecnológico que, notadamente os últimos cem anos, disseminou ecumenicamente o conhecimento e possibilitou a eclosão dessa nova etapa civilizatória de que desfrutamos, por isso denominada pelo brilhante sociólogo espanhol Manuel Castells: a Era da informação. Os desdobramentos sociais deste fenômeno explodem, complexos e vertiginosos: as populações passam, sucessivamente, a ter

convênios com entidades do terceiro setor (a declaradas de utilidade pública, as filantrópicas e outras), que prestam atividade privada de interesse público e também tem parceria como o poder público para fins de fomento. [...] é essencial ao conceito de descentralização a idéia de transferência da gestão de serviço público, o que não ocorre na atividade de fomento à atividade privada, ainda que este seja de interesse público. Nem toda atividade de interesse público constitui serviço público de titularidade do Estado." (DI PIETRO, 2011, p. 47). Mantemo-nos, portanto, na esfera do fomento, absolutamente distinta daquela reservada aos serviços públicos e ao poder de polícia.

${ }^{108}$ Daí a lição de Luciano Fedozzi: "Devido ao caráter nuclear que ocupa na gestão sócio-estatal, a discussão dos orçamentos públicos com os atores da sociedade civil (em especial, com os segmentos excluídos do desenvolvimento social) adquire importância capital para o avanço da democracia e da inclusão social como uma de suas fontes de legitimação." (FEDOZZI, 2005, p. 145).

109 “O Direito Administrativo não pode prescindir do papel central que joga a informação como objeto de prestação ou procura estatal. [...] O Direito administrativo tem que garantir tanto o controle como a eficácia da ação administrativa. [...] uma ordenação da informação tem transcendência em sua totalidade para a formação dos sistemas jurídico-administrativos desde duas perspectivas: de um lado, a informação e a comunicação são elementos e processos que são pressuposto dos dogmas básicos do Direito administrativo e, consequentemente devem ser tomados em consideração na configuração da relação cidadão-Estado e na fixação do marco da organização. Ao construir o sistema, não se deve partir unicamente das decisões que adota o executivo em fases procedimentais avançadas, senão também, e antes, dos processos de obtenção e uso da informação. A outra perspectiva se refere à elaboração das exigências específicas de proteção e de eficácia que derivam das novas técnicas de informação.” (SCHIMIDT-ASSMANN, 2003, p. 289-290, traduzimos). 
amplo acesso ao conhecimento, e, porque o conhecimento as muda irreversivelmente, a tomar consciência de seus interesse, a reivindicar participação e, como decorrência, a se organizar cada vez mais e a exigir, no final desta cadeia causal, eficiência dos governos no atendimento de suas necessidades. (MOREIRA NETO, 2008, p. 100).

Temos, pois, que o planejamento já não resulta unicamente da vontade do legislador ou do administrador, sendo fundamental a participação e consideração da sociedade civil como atores da mesma forma protagônicos nesse processo. ${ }^{110}$

Ganham destaque as ditas "arenas de participação", ou "arenas públicas", 111 a partir das quais o planejamento é efetivamente levado a cabo, e sem cuja consulta a programação estará sujeita a sérias ameaças de inefetividade, insuficiência e ineficácia.

Como assinala Gimeno Feliu, a efetiva consecução dos objetivos socioeconômicos é condicionada pela coordenação entre as diversas medidas de fomento (entre a própria Administração, ou entre Administrações), voltadas a evitar duplicidades e distorções indesejáveis (GIMENO FELIU, 1995, p. 160).

Villar Ezcurra desenvolve raciocínio que, não obstante originariamente voltado à intervenção do Estado no domínio econômico, se aplica à perfeição à sua interferência e orientação na seara social:

O planejamento econômico (como meio para canalizar medidas de fomento) implica, pois, um reconhecimento prévio por parte dos particulares das condições sob as quais a Administração se compromete a atuar sobre um determinado setor da economia. Este conhecimento prévio permite ao particular sopesar as vantagens e inconvenientes que possa sofrer ao submeter-se ao planejamento, já que, como indicado, as medidas de fomento geralmente vêm acompanhadas de outras típicas de polícia. [...] o planejamento não é, portanto, uma técnica (nem de fomento nem de polícia) senão um sistema de ordenação de técnicas de muitas diversas procedências cuja finalidade - isso sim - consiste em dirigir ou controlar um determinado setor econômico. Com isso resta claramente

\footnotetext{
${ }^{110}$ Como se dá, a título de exemplo, com as audiências públicas, o orçamento participativo e os conselhos de participação popular, de que mais adiante se tratará.

111 "Deu-se ao novo paradigma (talvez seja melhor dizer aos novos paradigmas) o nome provisório de 'arena pública'. Essa expressão é utilizada em um sentido genérico, advindo da ciência política anglo-saxã, segundo a qual 'arena pública' é o espaço em que se desenvolvem atividade pública e o intercambio entre Estado e sociedade. Por outro lado, trata-se de uma expressão muito próxima à de esfera pública, de origem habermasiana, que indica o espaço social onde se desenvolvem diálogos e conflitos e que serve para transferir a demanda social para o corpo político. 'Arena pública', no sentido de 'espaço', não prejudica as posições dos sujeitos que nela atuam — segundo o paradigma tradicional, o Estado no alto, os cidadãos embaixo —, não estabelece definitivamente as relações que ali se estabelecem — de oposição, segundo o paradigma tradicional —, não vincula a ação dos sujeitos a um tipo — como o da discricionariedade, válido para a administração pública, e o da liberdade, aplicável ao sujeito privado, segundo o paradigma tradicional. Permite, ao contrário, intercambialidade dos papeis, modificação das relações, comércio das regras e dos princípios ordenatórios.” (CASSESE, 2010, p. 90).
} 
manifesta o móvel que subjaz a toda atividade de fomento, já que, em verdade, os poderes públicos não perseguem com isso simplesmente ajudar ou estimular uma determinada atividade dos particulares (se assim fosse resultaria injustificada a repercussão nos gastos e ingressos públicos) se não controlá-la devido ao interesse geral ou utilidade social que esta atividade pode reportar (VILLAR EZCURRA, 1999, p. 116, traduzimos).

Nesse sentido, imprescindível que as medidas de fomento estejam incluídas na esfera de prioridades e de alguma forma guardem consonância com as leis orçamentárias ${ }^{112}$ e o plano de metas do governo.

Assinala Villela Souto que a intervenção é função administrativa e, como tal, deve ser orientada pelo princípio da legalidade; o planejamento, a seu turno, deve ser elaborado conforme as diretrizes legais e definir os limites e objetivos daquela, de forma a se constituir um conjunto de ações interligadas, sistematizadas e coordenadas pelo planejamento, o qual influirá não somente em questões orçamentárias ou tributárias, mas na própria composição da Administração (SOUTO, 2003, p. 16).

A escala de fundamento, de legitimidade, seria, pois, a seguinte: os atos interventivos deverão tomar por base o planejamento, o qual deve ser reflexo fidedigno da vontade popular sufragada nas eleições a partir do plano de governo (arts. $14, \S 3^{\circ}$, V, c/c 84, VI e XI, da CF) que lhe dará origem. "O planejamento visa, pois, a dar organicidade à intervenção, tomada esta atividade vinculada" (SOUTO, 2003, p. 16).

O plano de governo apresenta a natureza de ato jurídico criador de vinculações para o Administrador, conforme esclarece o mesmo autor:

No Brasil, tendo em vista que o plano estabelece obrigações para o setor público, tendo caráter imperativo, e, se aceita a orientação pelo setor privado, a promessa feita vale como direito [...], forçoso é reconhecer ao plano uma eficácia jurídica, como consequiência lógica do princípio da legalidade que rege a Administração Pública (CF, art. 37), traduzido no seu poder-dever de agir na ocorrência do interesse público (consubstanciado no plano identificador dessas áreas de interesse). Ora, se o Presidente deve remeter mensagem e plano de governo ao Congresso Nacional, expondo a situação do país e solicitando as providências necessárias (CF, art. 84, XI), não parece razoável que, aprovado o plano (CF, art. 48, IV) e contabilizadas as ações nas leis orçamentárias (CF, art. $\left.165, \S 4^{\circ}\right)$, não decorra daí nenhum direito em ver atendidos os anseios da sociedade; tanto mais que, materializadas as diretrizes do plano em uma

\footnotetext{
${ }^{112}$ Como salienta Furtado, "uma das missões primordiais da Lei Complementar 101/00 (LRF) é banir do País a idéia de que o orçamento público não passe de uma peça de ficção ou documento de faz de conta. Para tanto, várias providências foram tomadas no sentido de dar maior rigidez ao orçamento, de modo a forçar o seu cumprimento, impondo o planejamento na elaboração das peças orçamentárias." (FURTADO, 2009, p. 130).
} 
lei (CF, art. 174), o seu descumprimento caracteriza crime de responsabilidade (CF, art. 85, VII). (SOUTO, 2003, p. 29-30).

Caberá ao administrador, assim, lançar mão da medida que julgar mais conveniente para alcançar as finalidades orçamentariamente consagradas, em uma análise marcadamente discricionária - trata-se de momento do ciclo de fomento em que as competências discricionárias despontam com mais intensidade, em que as margens de "liberdade" para decidir são mais distendidas. ${ }^{113,114}$

Hipóteses há, porém, em que essa discricionariedade quanto à adoção de técnicas de fomento, serviço público ou polícia é afastada em razão de uma destinação específica a ser outorgada a determinada receita, a qual se vincula, por disposição normativa, diretamente à atividade de fomento.

É o que se dá com os ingressos no Fundo Municipal dos Direitos da Criança e do Adolescente a partir da destinação de imposto de renda, conforme veremos adiante.

\subsubsection{Incidência propriamente dita: a efetivação da relação de fomento com o destinatário imediato}

A implementação das medidas de fomento varia sensivelmente conforme sua natureza, os meios empregados e objetivos perseguidos.

Tem-se, assim, situações em que basta ao destinatário a assunção de determinada postura, ou a prática de certas atividades, para que a medida estimulante seja atraída para a sua esfera jurídica.

É o que se vê, exemplificativamente, nos casos de incentivos fiscais, em que, a partir da efetivação do planejamento do fomento, a captação de sua incidência ficará a

\footnotetext{
113 “É evidente que a discricionariedade de que goza a Administração na etapa prévia à da efetiva dispensa da ajuda, isto é, a liberdade de eleição que possui no momento de ditar as normas regulamentares à que deverá se sujeitar a outorga dos benefícios é muito mais ampla que a que ostenta ao decidir a concessão de favores. Deixando a salvo as exigências do princípio de reserva de lei, poderia se dizer que a discricionariedade da Administração naquela etapa preliminar é amplíssima, contando os particulares com uma margem muito estreita para discutir juridicamente os resultados do seu exercício. Nessa etapa, enquanto não contrariem os princípios constitucionais em matéria econômica e social e não vulnerem direitos fundamentais dos cidadãos, primeiro o legislador e então a autoridade administrativa competente gozam de plena liberdade para estabelecer os critérios a seguir." (DE LA RIVA, 2004, 141-142, traduzimos).

114 "Afirmar que a criação da normativa subvencionada responda a uma potestade discricionária não é obstáculo para sustentar que as Bases vinculam pró-futuro a atuação a Administração, de maneira, (e isso não é mais que mera aplicação da inderrogabilidade singular do regulamento), que a Administração, por exemplo, não está facultada a, discricionariamente, adicionar ex novo requisitos no momento de decidir se subvencionar ou não uma atividade." (BLANDO, 1996, p, 174, traduzimos).
} 
cargo exclusivamente de seu destinatário imediato, incumbido de se mobilizar nos termos exigidos pela lei instituidora.

Outras situações existem, porém, em que a mobilização pública também se faz necessária, como no exemplo clássico e paradigmático da subvenção e em todas as outras circunstâncias em que o estímulo se opera a partir de instrumentos de contratualização, ou parceirização com entidades do Terceiro Setor. ${ }^{115}$

Há, aí, como em todas as situações em que a atividade fomentadora se traduz em transferência direta de patrimônio público para a esfera de terceiros - o que não implica, conforme já visto, alteração da natureza pública dessas receitas/bens - o estabelecimento de uma relação contratual lato sensu.

Referida relação somente poderá ser formalizada posteriormente à adoção de determinadas providências indispensáveis ao respeito à isonomia, eficiência, moralidade, publicidade, impessoalidade.

Trata-se de uma série de atos voltados a possibilitar a todos os interessados, em iguais condições, participar do processo tendente a escolher quais serão os destinatários merecedores dos estímulos.

São medidas a nosso ver imprescindíveis, ainda que não expressa e nominalmente exigidas pela legislação específica que disciplina as medidas estimulantes.

Essa a única interpretação consentânea com a lógica do nosso ordenamento jurídico-constitucional, que não admite quaisquer tipos de privilégios, discriminações ou escolhas arbitrárias ou não fundadas em critérios universais e objetivos. ${ }^{116,117}$

Não vislumbramos a possibilidade, portanto, de escolha discricionária do destinatário imediato das medidas de fomento.

É o que defendem Rego Blanco, Justen Filho e Rothenburg:

115 Conforme bem lembra Higa, “[...] consideram-se [...] agentes fomentados do domínio social as associações e fundações sem fins lucrativos com finalidades públicas (que visam atender o interesse social e bem comum, em contraposição àquelas de interesse mútuo), os serviços sociais autônomos e as cooperações sociais." (HIGA, 2010, p. 223).

116 "A influência dos direitos fundamentais nas relações com o Estado não permite que se afaste completamente o regime de Direito Público. Então nos relacionamentos conveniais ou contratuais com o Estado, mesmo que sob modalidades 'de última geração' como os termos de parceria, deve haver algum tipo eficiente de concorrência, que assegure aos diversos interessados a oportunidade de se oferecerem e à coletividade a melhor oferta de serviços ou bens, mesmo que essa concorrência não seja a licitação disciplinada pela Lei 8.666/93." (ROTHENBURG, 2007, p. 89).

117 “As exigências da impessoalidade e moralidade reclamam um procedimento objetivo de escolha do parceiro do Estado, para verificar-se se existem interessados em concorrer. Afinal, a perspectiva para o Terceiro Setor é abrir espaço e estimular a maior participação possível de sujeitos organizados da sociedade em atividades de interesse público. Essa almejada concorrência é reconhecida por Luiz Carlos Bresser Pereira e Nuria Cunill Grau [...], quando afirmam que a reforma do Estado deve induzir 'as entidades públicas não estatais a competir entre si para prestar serviços à comunidade com financiamento parcial do Estado."” (ROTHENBURG, 2007, p. 102). 
O pressuposto de fato da subvenção é um elemento que a Jurisprudência unanimemente qualifica de regrado, tendo que separá-lo, em muitas ocasiões, dos aspectos discricionários que possam concorrer. Assim, vez por outra vez deve-se recordar que os requisitos estabelecidos para poder optar por uma subvenção ou ajuda não outorgam faculdades discricionárias administrativas para selecionar os candidatos, senão que, pelo contrário, constituem elementos regrados vinculantes para a Administração. (REGO BLANCO, 1996, p. 176, traduzimos).

[...] Então, a Administração não pode privilegiar certa instituição, de modo injustificado. Se diversas instituições desempenham atividades equivalentes [...], é imperioso justificar o motivo de preferência por uma delas especificamente. Se não for possível encontrar um fundamento compatível com o princípio da isonomia, a solução será produzir um processo seletivo que assegure tratamento igualitário a todas as possíveis interessadas. (JUSTEN FILHO, 2012, p. 372).

As exigências de impessoalidade e moralidade reclamam um procedimento objetivo de escolha do parceiro do Estado, para verificar-se se existem interessados em concorrer. Afinal, a perspectiva para o Terceiro Setor é abrir espaço e estimular a maior participação possível de sujeitos organizados da sociedade em atividades de interesse público. Essa almejada concorrência é reconhecida por Luiz Carlos Bresser Pereira e Nuria Cunill Grau - citados por Fernando Borges Mânica quanto afirmam que a reforma do Estado deve induzir "as entidades públicas não estatais a competir entre si para prestar serviços à comunidade com financiamento parcial do Estado". Não é lícito ao Poder Público escolher arbitrariamente uma dentre as Organizações da Sociedade Civil de Interesse Público porventura interessadas, por exemplo. (ROTHENBURG, 2007, p. 102).

Referida postura foi consagrada em nosso ordenamento por meio de diversas normas, dentre as quais merecem destaque, a titulo meramente exemplificativo: art. 23 do Decreto n. 3.100, de 30 de junho 1999, ${ }^{118}$ que trata da formalização de termos de parceira com organizações da sociedade civil de interesse público; art. $4^{\circ}$ do Decreto n. 6.170, de 25 de julho de $2007 ;{ }^{119}$ Lei municipal de São Paulo n. 13.153, de 21 de junho de $2001 .^{120}$

\footnotetext{
118 “Art. 23. A escolha da Organização da Sociedade Civil de Interesse Público, para a celebração do Termo de Parceria, deverá ser feita por meio de publicação de edital de concursos de projetos pelo órgão estatal parceiro para obtenção de bens e serviços e para a realização de atividades, eventos, consultoria, cooperação técnica e assessoria."

119 "Art. $4^{\circ}$. A celebração de convênio ou contrato de repasse com entidades privadas sem fins lucrativos será precedida de chamamento público a ser realizado pelo órgão ou entidade concedente, visando à seleção de projetos ou entidades que tornem mais eficaz o objeto do ajuste." (Redação outorgada pelo Decreto n. $7.568 / 2011)$.

120 "Art. $3^{\circ}$. A política que rege a prestação de atenções de assistência social através de convênios entre a Prefeitura e associações civis sem fins lucrativos deve observar os seguintes princípios, emanados do art. $4^{\circ}$ da Lei federal 8742/93 (LOAS): [...] VI - a defesa da igualdade de oportunidades e da democratização da relação através de processo público desde a proposição, chamamento até a homologação dos convênios de assistência social."
} 
O ordenamento espanhol adota essa mesma leitura, ao dispor, no artigo 22.1 da LGS $^{121}$ que "o procedimento ordinário de concessão de subvenções tramitará em regime de concorrência competitiva, a qual se efetivará por meio de comparação das solicitações apresentadas, a fim de estabelecer uma preleção entre as mesmas de acordo com os critérios e valoração previamente fixados nas bases reguladoras e na convocatória". ${ }^{22}$

Consignemos, por fim, que o concurso de projetos, ou a utilização de mecanismos concorrenciais somente terão lugar quando necessários, quando viáveis.

$\mathrm{Na}$ hipótese, por exemplo, de existência de recursos suficientes para o atendimento de todos os potenciais interessados, ou caso somente um deles se apresente, inviabilizada restará a promoção da "concorrência". ${ }^{123}$

Ultrapassada a etapa da definição dos beneficiários diretos do fomento, partir-seá, quando o caso, à formalização das medidas voltadas à criação do liame jurídico entre agente fomentador e fomentado, em uma fórmula a ser inserida no conceito lato de contrato, de parceirização.

Estabelecem-se, assim, compromissos mútuos, os quais deverão ser obrigatoriamente observados, sob pena de desfazimento do ajuste, com dever de devolução dos valores repassados e não destinados às atividades de interesse público, nos termos previamente estabelecidos.

Devemos notar, nesse particular, que, uma vez sendo os interesses envolvidos coincidentes, não haveria que se falar em obrigatoriedade de manutenção do vínculo, ou

\footnotetext{
“Art. $7^{\circ}$. O poder público municipal editará no Diário Oficial do Município e na grande imprensa a necessidade de implantação de atenções de assistência social através de convênio indicando a modalidade do serviço, a região em que se localizará, a forma e os prazos de apresentação da proposta pelos interessados." “Art. $8^{\circ}$. A análise do órgão competente sobre as propostas de convênio apresentadas deverá ser submetida a audiência pública convocada através do Diário Oficial do Município: [...] II - o órgão competente deverá publicar no Diário Oficial do Município a homologação do convênio, especificando seu valor, sua quantificação, prazo e padrões de qualidade a serem assegurados; III - caso se apresentem duas associações civis sem fins lucrativos habilitadas para celebrar o mesmo convênio, caberá à Prefeitura Municipal de São Paulo definir critérios de qualidade para proferir a decisão."

${ }^{121}$ Ley General de Subvenciones - Ley n. 38/2003.

122 Vale registrar, nesse ponto, notícia veiculada pelo jornal El País em 08 ago. 2012, por meio da qual se qual se dava conta que "apesar de a lei deixar claro que a forma 'ordinária' de adjudicá-las seja o concurso público, na prática mais de oitenta por cento das ajudas distribuídas pela 'Administração' de Barcelona chegam às entidades por concessão direta, ou seja, sem concurso" (traduzimos). Afirmava a reportagem que, dos trezentos e dezenove milhões e oitocentos mil euros outorgados a título de ajudas, duzentos e sessenta e um milhões o foram diretamente, asseverando, em tom crítico, que o governo em questão fazia da exceção a regra.

${ }^{123}$ Conforme esclarece Diaz Lema, invocado por De La Riva, “o concurso como sistema de seleção de solicitações para concessão de benefícios é uma conseqüência de um fato jurídico-financeiro, a saber: a limitação de recursos. É por esse motivo que, ao me referir a essa exigência, deixei claro que ela somente será aplicada quando se mostre necessária.” (DE LA RIVA, 2004, p. 228, traduzimos).
} 
de cláusula de permanência obrigatória (conforme veremos adiante), sendo facultado a qualquer dos envolvidos renunciar a essa sua condição, a qualquer momento.

Imprescindível, porém, que quaisquer prejuízos experimentados pelas partes em razão da assunção de determinada postura pela outra devam ser integral e prontamente ressarcidos.

Não obstante não exista exigibilidade cogente em favor do beneficiário, contra a Administração, no que toca ao estabelecimento efetivo do vínculo de fomento, uma vez criado esse liame ambos estarão relacionados em razão dessas circunstâncias, que farão incidir limites e obrigações em sua esfera jurídica de atuação.

Temos, pois, que a formalização da relação de fomento viabilizada por meio de instrumento de parceirização apresenta, quanto à sua natureza discricionária ou vinculada, três momentos distintos: a) quanto à escolha do agente fomentado, a competência é vinculada ao melhor e mais eficiente atendimento às condições estabelecidas e resultados buscados; b) quando da formalização do vínculo, com a fixação de suas condições e regime, prevalecerá a esfera de "liberdade" do Administrador; b) uma vez superado esse momento, com o estabelecimento da relação colaborativa, nasce a vinculação no que tange à transferência dos valores e atendimento às condições fixadas.

Tal cenário discrepa, uma vez mais, daquele relativo aos mecanismos de fomento não condicionados à mobilização administrativa, conforme se tratou no início deste item; naquele contexto, de se falar, naturalmente, e uma vez preenchidas as condições inicial e unilateralmente ${ }^{124}$ apresentadas pela Administração, no surgimento de direito subjetivo à percepção do estímulo, conforme salienta Gimeno Feliu. ${ }^{125}$

\subsubsection{Controle}

$\mathrm{O}$ controle da relação de fomento traz à tona, mais uma vez, questões bastante polêmicas.

Nesse sentido, vale lembrar o posicionamento defendido por Villar Ezcurra, para quem o controle da atividade fomentada se insere no âmbito do poder de polícia, vez que

\footnotetext{
${ }^{124}$ Circunstância essa que não tem o condão de afastar, conforme já exposto, a natureza contratual das relações em fomento em geral - até porque a autonomia da vontade tem uma acepção, e um espectro de incidência, bastante peculiares e modificados neste âmbito de atuação estatal.

125 “[...] aqui o que realmente importa é o regime jurídico aplicável, e não o nome que se dá à medida, de tal maneira que se essa tem um caráter regrado, ainda que se denomine subvenção, de se cumprir os requisitos nascerá um autêntico direito subjetivo que deverá satisfazer a Administração.” (FELIU, 1995, p. 172).
} 
implica controle coercitivo e obrigatória sujeição do particular às condições e exigências colocadas pela Administração:

[...] Interesse público da atividade fomentada: ainda que a legislação específica em matéria de subvenções geralmente não explicite, esse requisito, deve se entender implícito no conceito de subvenção. ${ }^{126} \mathrm{Na}$ medida em que as subvenções afetam o gasto público, é iniludível que sua aplicação obedeça a motivos de interesse geral, já que, de outra forma, careceriam de justificativa. Esse elemento alude, ademais, à "contraprestação" que a Administração exige do particular, a qual pode adotar diversas modalidades (contratação de mão de obra, localização de empresas em uma determinada zona, construção de habitações com as características de "VPO" etc.). Em princípio, a satisfação do particular pode tanto se realizar antes ou depois de percebida a subvenção. $\mathrm{O}$ importante é que, como consequência da "contraprestação obrigada", o particular se submete a um controle da Administração próprio da atividade de polícia (ainda que com um fundamento especial que se apoia na submissão prévia e voluntária do particular), fazendo patente o mútuo apoio e a intercambialidade das técnicas de fomento e polícia. (VILLAR EZCURRA, 1999, p. 123, traduzimos).

Sob o nosso ponto de vista, a atividade estatal nesses moldes desenvolvida não poderia ser incluída nessa seara.

Isso porque o poder de polícia tem como pressuposto básico e elementar a relação de autoridade, a postura de império do órgão governamental, as quais funcionam como fundamento para a coerção aos particulares.

Diferentemente dessa situação, o controle e eventual responsabilização por atividade de fomento toma por base relação contratual lato sensu, ${ }^{127}$ em que as partes envolvidas se encontram em situação senão de total igualdade, de marcada horizontalidade. $^{128}$

\footnotetext{
${ }^{126}$ Nota-se, aqui, clara manifestação do referido no item 1.5 , supra, na medida em que toda a atividade estatal de fomento viria traduzida, na opinião de alguns autores, por meio de sua forma mais representativa, qual seja, a subvenção. Trata-se de inexatidão terminológica em que se toma a espécie pelo gênero.

${ }^{127}$ Adota-se, aqui, o conceito amplo de contratualização traduzido por Justino de Oliveira nos termos referidos no item 1.4.3, supra.

${ }^{128}$ Conforme bem traduz Moreira Neto, "o refluxo da imperatividade e a tendência reequilibradora da afirmação imemorial da coerção, são as características de um Estado que se vai conformando ao influxo dos princípios mencionados, produzindo conceitos afins, como os de desestatização, de despolitização e de deslegalização. [...] A participação e a consensualidade tornaram-se decisivas para as democracias contemporâneas, pois contribuem para aprimorar a governabilidade (eficiência); propiciam mais freios contra o abuso (legalidade); garantem a atenção a todos os interesses (justiça); proporcionam decisão mais sábia e prudente (legitimidade); desenvolvem a responsabilidade das pessoas (civismo); e tornam os comandos estatais mais aceitáveis e facilmente obedecidos (ordem). Em suma, a consensualidade, posta como alternativa preferível à imperatividade, sempre que possível, ou em outros termos, sempre que não seja necessário aplicar o poder coercitivo [...]". (MOREIRA NETO, 2007, p 40-41). E: "[...] agita-se uma dramática mutação do próprio conceito de administração pública, que vai aos poucos perdendo suas características imperativas, que a postavam, tradicionalmente, como expressão de um poder do Estado, para
} 
Trata-se de vinculação baseada no consenso, na liberdade dos envolvidos para se mobilizarem e, mais que isso, se unirem em prol do interesse público.

A Administração não figura, nesse cenário, sob a sua faceta autoritária, controladora e impositiva, condição essencial ao exercício do poder de polícia.

Daí defendermos tratar-se o controle, de consequência natural, de insuperável desenrolar da relação de fomento originária, que se desenvolve em seu próprio seio e que, portanto, leva consigo essa mesma natureza.

Nesse mesmo sentido:

Uma parte da atividade devida aos particulares se explica com a teoria da polícia administrativa, posto que, frente às potestades que a polícia supõe em mãos da Administração, o particular se encontra em uma situação jurídica de submissão. Mas o Direito Administrativo impõe ao particular uma série de prestações forçosas (pessoais ou reais) que não encontram sua explicação nos esquemas de polícia, nem sequer ampliando esta até suas últimas possibilidades. (GARRIDO FALLA, 1992, p. 121, traduzimos).

Abrange tanto os entes públicos como os privados eventualmente destinatários do fomento, ${ }^{129}$ sendo caracterizado como um verdadeiro princípio por De La Riva. ${ }^{130}$

Cumpre-nos registrar que referido dever de controle não está adstrito aos órgãos externos, ou aos momentos posteriores à prática do ato, quando de seus resultados.

Pode assumir diversas facetas, traduzidas basicamente nos controles: a) interno (por órgãos da própria Administração/órgão fomentador); b) externo (exercido tanto pelo

entendê-la como nada mais que uma função constitucionalmente vinculada a ser desempenhada pelo Estado e a ser o mais amplamente possível compartilhada com a sociedade, compreendendo todo o seu desenvolvimento, desde o seu planejamento ate o seu controle [...].” (MOREIRA NETO, 2008, p. 134).

129 Art. 70, parágrafo único, da CF. No mesmo sentido: “como ocorre com a fiscalização da atividade desenvolvida pela Administração subvencionante, os controles sobre os beneficiários das ajudas provêm de órgãos pertencentes aos três Poderes do Estado. Para começar, enquanto as vantagens outorgadas conduzem necessariamente uma operação de gasto público, a atividade a cargo do destinatário da ajuda ficará sujeita aos mecanismos de controle orçamentário. Daí que se justifique que no ordenamento argentino as normas relativas ao sistema de controle do setor público nacional sejam aplicáveis à prestação de contas das organizações privadas que ajam acordado subsídios ou aporte, assim como também que o Congresso da Nação estenda sua competência de controle externo às entidades públicas não estatais e às de direito privado a que se houver outorgado esse mesmo tipo de vantagens." (DE LA RIVA, 2004, p. 247, traduzimos).

${ }^{130}$ Este "[...] principio surge como corolário inescusável da afetação da ajuda à realização de uma atividade que contribui a uma finalidade específica e concreta de interesse geral. É evidente que a única forma de garantir que isso se cumpra é através do controle sobre a aplicação da ajuda ao objetivo estabelecido. Sem embargo, é igualmente certo que tal controle também há de se estender à etapa que precede ao desenvolvimento da atividade subvencionada por parte do beneficiário, é dizer, ao que sucede no âmbito da própria Administração. Adverte-se, então, que o controle das ajudas públicas se desdobra em duas direções: de um lado, está o controle que se exerce sobre a atividade administrativa dispensadora dos benefícios, e, de outro, aquela que se orienta a verificar a efetiva e regular observância, por parte do beneficiário, da atividade a que a ajuda está atrelada (2004, p. 231-232, traduzimos). 
Legislativo, com auxílio dos Tribunais de Contas, ${ }^{131}$ como pelo Judiciário); c) social ${ }^{132}$ (levado a cabo pela própria sociedade civil, seja por intermédio de entidades representativas, seja individualmente, com a provocação dos órgãos competentes).

Todas essas três modalidades têm a sua efetividade - e viabilidade condicionadas à plena individualização, ao prévio esclarecimento, seja pelo Legislador, seja pela Administração, em momento anterior ao exercício do controle, de qual é a finalidade pública a ser objetivamente perseguida:

\begin{abstract}
Nieves Borrego destaca a importância de a finalidade de interesse público implicada na subvenção ser especificada pelo legislador ou pela Administração, posto que, de outro modo, não será possível exercer um adequado controle sobre a aplicação da ajuda pública ao objeto previsto para ela por parte do beneficiário. É que, sendo a noção de interesse público um conceito tão estreitamente vinculado às circunstâncias histórico-políticas de cada momento, resulta em si mesmo um parâmetro incerto e variável, o qual explica que não seja suficiente somente a sua alegação para fixar a finalidade de uma medida subvencional, se ao mesmo tempo não se precisa em que consiste tal interesse para esse caso particular. (DE LA RIVA, 2004, p. 191, traduzimos).
\end{abstract}

Havendo as duas primeiras categorias - controle interno e externo - sido exaustivamente tratadas pela doutrina pátria, ${ }^{133}$ cumpre-nos repisar a importância do controle social, instrumento indispensável à evolução de uma democracia tão somente formal para o modelo material, dependente do fortalecimento da fiscalização participativa e determinante da sincronia entre as prioridades públicas e o cumprimento das promessas democrática (FREITAS, 2007, p. 45).

Consiste em instrumento fundamental de legitimidade e sustentação das posturas administrativas, as quais, uma vez contraditórias às demandas sociais, ou dissonantes do planejamento difusamente traçado com a participação dos diversos representantes da sociedade, maculam irremediavelmente o referido atuar, que, mais que insustentável ética e politicamente, será também antijurídico.

Lembra Moreira Neto que essa espécie de controle é essencial ao Estado Democrático de Direito, qualificando-se como imprescindível a uma gestão pública democrática, posto que "as regras democráticas, como o diálogo, o debate, a consulta, o

\footnotetext{
${ }^{131}$ Nos termos do art. $71 \mathrm{da}$ CF.

132 "A Lei Maior de 1988, ao lado de aperfeiçoar o sistema de controle do Executivo pelo Legislativo, passou a submeter a Administração a uma nova modalidade de controle — o controle social — incorporado aos institutos de participação popular na Administração Pública." (PEREZ, 2009, p. 152).

${ }^{133}$ Nesse particular, veja-se CASTRO, 2008.
} 
processo, a justificação, o sufrágio, a regra da maioria e outras, são meios para chegar a consensos praticáveis para a condução dos negócios de uma coletividade" (KLIKSBERG, 2005, p. 77).

No que tange à análise da finalidade a ser levada a cabo, o controle não deve, em hipótese alguma, tomar por base aspectos meramente formais, instrumentais ou burocráticos: deve ir muito além, com a efetiva análise, inclusive, dos resultados alcançados.

Trata-se de condição da eficácia do ato, a partir de parâmetros de legitimidade e juridicidade, os quais, como visto, permeiam todo o ciclo de atuação administrativa e promoção do interesse público.

Na lição de Diogo Figueiredo Moreira Neto:

[...] os resultados também devem estar conformados aos princípios de legitimidade e eficiência. A expressão resultado, embora oriunda das ciências administrativas, não deve ser tomada como mera transposição de um conceito de sentido econômico, mas, com muito maior amplitude, ser coerentemente adaptada em referencia aos imperativos de efetiva realização das diretrizes constitucionais que orientam e balizam os Poderes Públicos. Assim é que, não obstante legítimo o planejamento e legítima a execução de uma política pública, deve ser também legítimo o resultado, o que vale dizer: o bem ou o serviço entregue à sociedade deve necessariamente garantir uma utilização eficiente por parte de seus destinatários [...] Eis uma visão finalística de resultado e não de intenções, tanto da legitimidade como da eficiência, indispensável para a compreensão da incidência desses fundamentos que vai além da juridicidade da orientação teleológica de uma política pública, seja na sua formulação, seja na sua execução. A referência aqui, portanto, é a um resultado administrativo legítimo e eficiente e não apenas a processos administrativos legítimos e eficientes e, muito menos e ainda mais remotamente, a atos administrativos singulares legítimos e eficientes. (MOREIRA NETO, 2008, p. 135).

Repisemos, por fim, que o controle deve ser efetivado tendo em vista, de igual modo, e paralelamente às formas e resultados pretendidos, a compatibilidade das medidas adotadas com o planejamento aprovado, de forma que o ciclo do fomento se implemente, na prática, de forma dinâmica e interativa, devendo todas as suas fases guardar consonância, compatibilidade e continuidade entre si. ${ }^{134}$

\footnotetext{
134 "Ora, sendo [...] a lei do plano um pressuposto essencial de compreensão e plena realização da ordem jurídica que a Constituição pretende, e, portanto, lei material, não pode ser afastada ou modificada pelo orçamento, ato formalmente legislativo, mas materialmente administrativo (logo, a hierarquia inferior na pirâmide jurídica); entender de modo diverso implicaria negar vigência ao art. 174, $\mathrm{CF}$, sem falar no desrespeito ao conteúdo ideológico do plano, sobre o qual repousa uma preferência eleitoral ('estelionato' político que se enquadra como violação à moralidade administrativa).” (SOUTO, 2003, p. 30-31).
} 


\subsubsection{Responsabilização}

Exercido regularmente o controle dos atos decorrentes da atividade de fomento, considerada a hipótese de inadimplemento, ou de não atendimento integral e satisfatório ao convencionado - ou compromissado - tem lugar a mobilização da Administração com vista a proteger, a garantir a efetiva promoção do interesse público objetivado.

Essa a primeira faceta da responsabilização vinculada ao fomento, em que caberá à Administração incentivadora - considerada a inexistência de coação, de poder de império típica dessa atividade - agir.

Não haverá que se falar, conforme assentado, no exercício do poder de polícia, mas no desenrolar natural das consequências do desatendimento às condições — ou compromissos — assumidos.

Inviável, nesse contexto, em razão da voluntariedade na adesão à relação de fomento, a estipulação de cláusula — seja contratual lato sensu, seja normativa — de permanência obrigatória. ${ }^{135,136,137,138}$

${ }^{135}$ Decreto n. 6.170, de 25.07.07, artigo 12: “O convênio poderá ser denunciado a qualquer tempo, ficando os partícipes responsáveis somente pelas obrigações e auferindo as vantagens do tempo em que participaram voluntariamente do acordo, não sendo admissível cláusula obrigatória de permanência ou sancionadora dos denunciantes." O artigo 27 do Decreto municipal de São Paulo n. 49.539/08 traz idêntica redação, da mesma forma que a Instrução Normativa n. 01/97, ao estabelecer, em seu artigo $7^{\circ}$, que o termo de convênio deve trazer, expressa e obrigatoriamente, dispositivo que estabeleça a faculdade aos partícipes para denunciá-lo ou rescindi-lo, a qualquer tempo, imputando-se-lhes as responsabilidades das obrigações decorrentes do prazo em que tenham vigido e creditando-se-lhes, igualmente os benefícios adquiridos no mesmo período.

${ }^{136}$ Nesse sentido: "Embora perfeito, o ato administrativo complexo que é o convênio, só isso não gera direito a ser mantido intacto tal qual se aperfeiçoou, pois, repete-se, a liberdade de ingresso e retirada dos partícipes do convênio é traço característico dessa cooperação associativa a impedir obrigatoriedade de permanência ou sancionadora de quem o denuncie ou queira de modo diverso do acordado, para conformá-lo, como é o caso dos autos, à nova sistemática legal. Em outras palavras, quando o Instituto de Previdência do Estado de São Paulo exigiu o cumprimento a lei nova ele, em absoluto, não afrontou ato perfeito e/ou direito adquirido, pois é da natureza do convênio a sua precariedade e, ao certo ele não gera direito adquirido para seus partícipes, em razão de sua própria natureza jurídica." (STF, RE n. 119.256-9/SP, rel. Min. Moreira Alves, DJU 29.05.1992).

137 Veja-se, ainda, acórdão do STJ prolatado no RMS n. 30.634/SP e ementado nos seguintes termos: “Administrativo. Convênio. Distinção. Contratos. Denúncia unilateral. Possibilidade. Ampla defesa e contraditório. Prescindibilidade. Prejuízos materiais. Possibilidade de aplicação de sanções estabelecidas no instrumento de colaboração. Recurso não provido. 1. A ação mandamental foi impetrada contra ato do Prefeito do Município de São Paulo e do Secretário Municipal do Trabalho que rescindiram unilateralmente a participação do Município de São Paulo na qualidade de interveniente, em convênio firmado com o impetrante para a capacitação de jovens em situação de risco social e a inserção desses no mercado de trabalho. 2. Os convênios administrativos são ajustes firmados entre pessoas administrativas, ou entre essas e particulares, cujo objetivo é a obtenção de determinados interesses em comum. Diferem dos contratos administrativos, basicamente, pela ausência de interesses contrapostos, já que o elemento principal da união entre os convenentes é a cooperação e não o lucro geralmente visado nos contratos. 3. O vínculo jurídico existente nos convênios não possui a mesma rigidez inerente às relações contratuais, daí porque o art. 116, caput, da Lei 8.666/93 estabelece que suas normas se aplicam aos convênios apenas 'no que couber'. Diante 
Como bem esclarece Edmir Netto de Araújo, invocado por Maria Sylvia Zanella

Di Pietro:

[...] em decorrência disso, há uma outra distinção feita por Edmir Netto de Araújo: "a ausência de vinculação contratual, a inadmissibilidade de cláusula de permanência obrigatória (os convenentes podem denunciá-lo antes do término do prazo de vigência, promovendo o respectivo encontro de contas) e de sanções pela inadimplência (exceto eventuais responsabilidades funcionais que, entretanto, são medidas que ocorrem fora da avença)." (DI PIETRO, 2011, p. 232-233).

Permeia toda a relação a faculdade, ou o direito dos envolvidos se retirarem do vínculo estabelecido, a qualquer momento.

Nesse ponto, cumpre-nos lembrar o princípio da boa-fé objetiva, ${ }^{139}$ norteador de toda e qualquer atitude com impacto sobre terceiros, seja ela oriunda de particulares ou de entes públicos. ${ }^{140}$

Temos, assim, caso a retirada inesperada e desmotivada de algum dos envolvidos venha a ocasionar qualquer espécie de prejuízo ao interesse público, que deverá tal dano

disso, tem-se como regra a possibilidade de cada pactuante denunciar livremente o convênio, retirando-se do pacto. Entretanto, se essa atitude causar prejuízos materiais aos outros convenentes, é cabível a aplicação de sanções, a serem estabelecidas, via de regra, no próprio instrumento de colaboração. 4 . No caso, a despeito da possibilidade de denúncia unilateral, deu-se efetiva oportunidade para a impetrante manifestar-se no processo administrativo e comprovar o cumprimento das prestações contempladas no pacto firmado. No entanto, da análise dos documentos anexados aos autos, não se demonstrou a impertinência das constatações realizadas pelo ente público. 5. Recurso ordinário em mandado de segurança não provido."

${ }^{138}$ Em sentido contrário, cumpre mencionar posicionamento defendido por Oliveira, nos seguintes termos: “[...] é comum a doutrina mencionar que as relações formalizadas pela via do convênio são dotadas de relativa instabilidade, e em regra não gerariam efeitos vinculantes para as partes. Discorda-se desse entendimento. Embora se tratam, com efeito, de espécie de acordo administrativo — e não de contrato administrativo — os convênios podem sim instituir obrigações recíprocas, e não unicamente estabelecer obrigações unilaterais para o convenente e o conveniado. Ademais disso, de que adiantaria firmar um acordo se a qualquer momento o vínculo pode ser rompido ou, como ocorre cotidianamente, o Estado se compromete sem respeitar suas obrigações? Um outro argumento ainda. Atualmente, é bastante comum que convênios e outros acordos congêneres sejam firmados para conferir efetividade ao Plano Plurianual e à Lei de Diretrizes Orçamentárias, sendo absolutamente necessário — porque metas e objetivos devem ser alcançados - que os mesmos atinjam seus resultados, sob pena de frustrar-se a programação originária do Pode Público, tornando a gestão pública ineficiente." (OLIVEIRA, 2007, p. 247-248).

${ }^{139} \mathrm{O}$ aspecto prático da boa-fé objetiva está muito bem retratado nesta precisa lição de Karl Larenz: "O devedor deve cumprir a sua obrigação atendendo-se não apenas à letra, mas também, ao espírito da relação obrigatória correspondente, em especial, de acordo com o sentido e a ideia fundamental do contrato. O credor deve exercitar o direito que lhe corresponde atuando segundo a confiança depositada pela outra parte e a consideração altruística que esta possa pretender, segundo a classe de vinculação especial existente. Todos os participantes da relação jurídica devem se conduzir em correspondência ao sentido geral e à finalidade da vinculação especial e a uma consciência honrada." (CAVALIERI FILHO, 2011, p. 39).

140 "Uma das funções que me parece mais relevante atribuir-se à boa-fé como princípio veiculado pela moralidade do art. 37 da Constituição Federal de 1988 é justamente o mandamento de proteção à confiança enquanto elemento componente do Estado de Direito Social. A confiança, que adquirira no âmbito privado especial relevância, tem-na, na órbita pública, redobrada." (GIACOMUZZI, 2001, p. 266). 
ser suportado por aquele que não honrou o comportamento ou postura objetiva e concretamente compromissada.

Tratar-se-á de responsabilidade decorrente da inobservância do dever geral e universal de cumprimento do referido desiderato da boa-fé, incompatível com a criação, consciente, de falsas e descumpridas expectativas em prol da coletividade.

Na lição de Marçal Justen Filho:

A imposição de um dever jurídico significa constranger um sujeito à realização de uma certa conduta, consistente numa ação ou omissão. No direito privado, costuma-se utilizar a expressão latina debitum para indicar essa faceta da obrigação. Mas o dever jurídico também abrange a submissão do sujeito e de seu patrimônio a recompor os interesses do credor em caso de violação ao conteúdo primário do dever. Essa vinculação complementar é indicada pelo vocábulo obligatio. A responsabilidade consiste, então, num aspecto complementar e inerente ao dever jurídico, relacionando-se com a infração à conduta imposta diretamente como obrigatória. A responsabilidade é inerente à existência de um dever jurídico. Consiste num aspecto ou consequência da existência desse dever e seu conteúdo envolve a submissão do sujeito a arcar com os efeitos decorrentes da ausência de cumprimento espontâneo da conduta diretamente imposta a ele (ou a terceiro) como obrigatória. (JUSTEN FILHO, 2012, p. 1.215).

Outra possibilidade que vislumbramos, no que toca à relação de fomento, é o desatendimento, puro e simples, dos compromissos assumidos, por qualquer dos envolvidos.

Nessa hipótese, em se tratando de relação de fomento de natureza contratual lato $s e n s u$, incidirá a indispensável devolução dos valores eventualmente disponibilizados ${ }^{141}$ ou cassação do incentivo concedido, independentemente de sua natureza, além do restabelecimento das partes ao status quo ante.

Quanto à possibilidade de imposição de sanções, a análise deverá ser feita caso a caso, e dependerá, necessariamente, da sua previsão nas fases de planejamento e aperfeiçoamento da relação de fomento.

Isso decorre da relevância dos valores coletivos envolvidos e da "liberdade" marcante da atuação administrativa nas fases preparatória e executória do estímulo.

\footnotetext{
${ }^{141}$ Defende Ezcurra que "A aplicação do procedimento de reintegração implica não só na obrigação de devolver o importe da subvenção, senão também os juros de demora desde o momento em que se fez efetiva sua entrega." (VILLAR EZCURRA, 1999, p. 128, traduzimos).
} 
Realmente, o ente fomentador goza da capacidade de condicionar a concessão e manutenção - dos incentivos ao atendimento dos requisitos que julgar necessários para a garantia da consecução do resultado de interesse público almejado.

Nesse sentido, e considerado o ordenamento espanhol, explicita Villar Ezcurra ${ }^{142}$ :

O caráter sinalagmático com que se concebem as subvenções [...] resulta ainda mais patente desde o momento em que se prevê a possibilidade de utilizar a potestade sancionatória [...]. O cometimento de qualquer das infrações dá lugar à incidência do correspondente expediente sancionador [...], como consequência da obrigação de reintegração antes exposta: multa até o triplo da quantidade indevidamente obtida, aplicada ou não justificada; perda, durante o prazo de até cinco anos, da possibilidade de obter subvenções públicas; proibição, durante um prazo de até cinco anos, para celebrar contratos com o Estado e outros entes públicos. Ademais, deve ter-se em conta que se a conduta puder configurar o delito contra a Fazenda Pública tipificado no artigo 350 do Código Penal, a Administração deve passar a aferição da culpa à jurisdição competente, abstendo-se de seguir o procedimento sancionador enquanto a autoridade judicial decide; na hipótese de ser condenatória, a decisão exclui a imposição de sanção administrativa, em decorrência do princípio no bis in idem. (VILLAR EZCURRA, 1999, p. 128-129, traduzimos).

A terceira possibilidade guarda relação com a responsabilidade por eventuais danos ocasionados a terceiros em razão da relação de fomento.

Surge, aí, uma série de questões, que gravitam em torno da inter-relação entre agente fomentador e fomentado e o seu posicionamento face à parte lesada.

Registramos, de plano, que os entes fomentados, enquanto nessa condição, não atuam por delegação do Estado, vez que transitam em domínio que lhes é comum, em cuja seara seu agir é também franqueado, não havendo que se falar em transferência, ou delegação, de funções.

Não existe a substituição do Estado, ou a prestação de serviços indireta, mas sim a mobilização privada, decorrente de estímulos públicos, em prol do coletivo, em um fenômeno tradutor de união de esforços, de cooperação, de parceria.

Anotemos, também, a inaplicabilidade, em casos que tais, e tendo em vista que a relação base não se traduz em serviço público, mas justamente na atividade de fomento, do artigo 37, § $6^{\circ}$, da Constituição Federal.

Efetivamente, a partir do momento em que não se fala em serviço público, e inexistindo delegação, resta afastada a responsabilidade objetiva, expressamente vinculada

\footnotetext{
${ }^{142}$ Vale registrar, em sentido contrário, pela inviabilidade de fixação de sanções em caso de inadimplemento, posição de Maria Sylvia Zanella Di Pietro e Edmir Neto (DI PIETRO, 2011, p. 232-233).
} 
pelo supracitado dispositivo constitucional às situações em que presentes esses dois requisitos.

Imprescindível, assim, a demonstração ao menos de culpa - contratual ou extracontratual, dependendo da técnica de fomento empregada - para que se possa falar em obrigatoriedade de ressarcimento por parte das entidades beneficiárias do fomento.

Essa a regra geral, a qual não impede, por óbvio, a incidência de normas especiais decorrentes de peculiaridades relacionadas aos mecanismos de estímulo empregados e às especificidades dos entes envolvidos na relação promocional. ${ }^{143}$

Como bem lembra Higa, existem duas exceções à incidência da referida responsabilidade, nos moldes indicados: a) casos de responsabilidade objetiva expressamente previstos em lei, como no caso do Código de Defesa do Consumidor; b) organizações sociais constituídas com vistas à substituição estatal na atividade prestacional de serviços públicos, de forma a burlar, na prática, a incidência do regime jurídico-administrativo. (HIGA, 2010, p. 232).

No que toca à responsabilidade do agente fomentador, quanto aos prejuízos causados a terceiros, de se lembrar que a atividade de fomento pressupõe uma atuação conjunta, de cooperação e parceria, entre este e o ente fomentado.

Figuram ambos no vínculo, portanto, de forma intrincada, indissociável e conjunta, o que levaria a propugnar por uma proporcionalidade ou equivalência na "distribuição" dos ônus decorrentes, comunicando-se a natureza subjetiva da responsabilidade do polo fomentado para o fomentador.

Ainda que assim não fosse, vale lembrar que não se pode falar em responsabilidade estatal objetiva sem expressa previsão legal. ${ }^{144}$

E as hipóteses de responsabilização ora consideradas, decorrentes da atuação do agente fomentado, não se enquadram, como visto, na hipótese - adstrita aos serviços públicos — constante do art. $37, \S 6^{\circ}$.

\footnotetext{
143 “Cumpre, inicialmente, anotar que não se aplica aos referidos entes a regra inserta no art. 37 , $\S 6^{\circ}$, da Constituição Federal de 1988, que atribui responsabilidade objetiva às pessoas jurídicas de direito público e às pessoas jurídicas de direito privado prestadoras de serviços públicos (concessionárias e permissionárias). Isso porque essas organizações sem fins lucrativos não integram a Administração Pública direta ou indireta e também não prestam serviços públicos por delegação do Estado.” (HIGA, 2010, p. 232).

${ }^{144}$ A responsabilidade objetiva não substitui a subjetiva, mas fica circunscrita aos seus justos limites. A propósito, adverte Caio Mário da Silva Pereira: “[...] a regra geral, que deve presidir a responsabilidade civil, é a sua fundamentação na idéia de culpa; mas, sendo insuficiente esta para atender às imposições do progresso, cumpre ao legislador fixar especialmente os casos em que deverá ocorrer a obrigação de reparar, independentemente daquela noção. Não será sempre que a reparação do dano se abstrairá do conceito de culpa, porém quando o autorizar a ordem jurídica positiva.” (PEREIRA, Caio Mário da Silva. Responsabilidade civil. 9 ed., Forense: 1998, p. 507, apud GONÇALVES, 2012, p. 61).
} 
Uma vez incabível, portanto, a incidência da responsabilidade objetiva, remanesce apenas aquela decorrente de culpa.

Relembramos, nesse ponto, o dever irrenunciável da Administração de fiscalizar e zelar pela qualidade e regularidade da atuação dos destinatários dos estímulos; ${ }^{145} \mathrm{em}$ havendo omissão ou negligência nesse aspecto, inevitável e incidência da responsabilidade estatal, por omissão e também na modalidade, portanto, subjetiva. ${ }^{146}$

Quanto a esse aspecto cumpre-nos registrar a existência de divergência doutrinária, na medida em que alguns autores defendem que, em havendo descumprimento de um dever, de uma obrigação específica, a qual era desde sempre do conhecimento do órgão/ente omisso, a responsabilidade será equiparada àquelas hipóteses comissivas, ou seja, independerá da demonstração de culpa:

Os casos de ilícito omissivo próprio são equiparáveis aos atos comissivos, para efeito de responsabilidade civil do Estado. Assim, se uma norma estabelecer que é obrigatório o agente público praticar certa ação, a omissão configura atuação ilícita e gera a presunção de formação defeituosa da vontade. $\mathrm{O}$ agente omitiu a conduta obrigatória ou por atuar intencionalmente ou por formar defeituosamente sua própria vontade - a não ser que a omissão tenha sido o resultado intencional da vontade orientada a produzir uma solução conforme ao direito e por ele autorizada. (JUSTEN FILHO, 2012, p. 1.234).

Referida ressalva nos parece bastante ponderada, motivo pelo qual compartilhamos dessa visão, admitindo, portanto, e ocasionalmente, a incidência de responsabilidade independentemente de culpa, quando o prejuízo se insere no contexto da atividade de fomento e decorre de ofensa ao dever de fiscalização da Administração.

Estabelecidas as bases, contorno e regime atinentes à atividade administrativa de fomento, cumpre-nos voltar o olhar para a segunda premissa sobre a qual se assenta o nosso objeto de estudo.

Passemos, pois, à apresentação, compreensão e discussão dos principais pontos atinentes ao Conselho Municipal dos Direitos da Criança e Adolescente.

\footnotetext{
${ }^{145}$ Veja-se, nesse aspecto, decisão proferida pelo STJ no Agravo Regimental em Agravo de Instrumento n. 973.577/SP, 2. T., rel. Min. Paulo Campbell Marques.

${ }^{146}$ Nos termos estabelecidos pelo STJ no julgamento do Recurso Especial n. 1.133.257/RJ, 1. ${ }^{\mathrm{a}}$ T. e no Agravo de Instrumento n. 1.192.340, ambos relatados pelo Ministro Luiz Fux.
} 


\section{O CONSELHO DOS DIREITOS DA CRIANÇA E DO ADOLESCENTE DO MUNICÍPIO DE SÃO PAULO}

\subsection{Apresentação}

A primeira notícia histórica relativa ao Conselho Municipal dos Direitos da Criança e do Adolescente de São Paulo remonta ao ano de 1974, em que, por meio da edição do Decreto n. 11.141, o então prefeito Miguel Calasuonno instituiu o órgão.

Àquela época não se revestia o Conselho, em última análise, das características de arena de participação popular, de real instrumento viabilizador da aproximação e interação entre as esferas pública e privada.

Vigia o regime ditatorial, em que a participação popular era tida, quando muito, como um discurso, uma ferramenta a mais a ser utilizada em favor dos interesses dominantes, como forma de manipulação popular ou legitimação artificial de intenções estritamente governistas. ${ }^{147}$

Nesse diapasão, cumpre-nos registrar que o percurso evolutivo dos conselhos paulistanos se divide em três momentos básicos, assim definidos: a) aqueles instituídos durante o período ditatorial, em que desempenhavam papel meramente decorativo; b) os concomitantes ao processo de abertura política, em que a pressão popular passa a repercutir de forma mais direta na sua formatação e atuação; c) os inseridos no cenário de estabilização — ou assimilação — da cultura democrática, tidos como centros de implementação dos princípios de participação e descentralização.

Na lição de Luciana Tatagiba:

Como vários estudos têm demonstrado, os conselhos municipais em São Paulo têm uma longa história. Uma história que em seu movimento irregular e descontínuo evidencia tanto as profundas rupturas políticas no plano local, no suceder de administrações orientadas por princípios éticopolíticos profundamente distintos, como a ação dos movimentos societários e sua tensa e ambígua relação com a institucionalidade política. No final dos anos 80 , a questão dos conselhos se insere na agenda política da capital, suscitando muita controvérsia quanto aos riscos e possibilidades de institucionalização da participação. [...]

\footnotetext{
${ }^{147}$ Conforme lembra Tatagiba, invocando Gohn: "Na prática, esses conselhos seriam utilizados como forma de cooptação das lideranças e manipulação das demandas populares, como explica Gohn: 'a prefeitura catalogou tudo de forma burocratizada, despolitizando qualquer conteúdo das reivindicações, e continuou a administrar segundo as prioridades definidas nos gabinetes, objetivando mais o atendimento dos interesses econômicos organizados'." (TATAGIBA, 2004, p. 327).
} 
Recuperando registros legais de criação e/ou regulamentação dos conselhos e dispondo-os em ordem cronológica, foi possível identificar três fases ou momentos distintos, na história da participação conselhista em São Paulo. A primeira, no período ditatorial, na qual os conselhos cumpriam uma função meramente decorativa, em razão do cerceamento da arena decisória. A segunda, no contexto de abertura política, em que a pressão da sociedade pela democratização do Estado gerava novos formatos participativos que, mesmo em todas as suas limitações, já evidenciavam a complexificação da arena de produção das políticas pela incorporação de novos temas e atores. E, por fim, uma terceira fase, na qual os conselhos apresentam-se como peças centrais no processo de reestruturação das políticas, legitimados pelos novos princípios constitucionais da participação semidireta e da descentralização políticoadministrativa. (TATAGIBA, 2004, p. 325-326).

No que toca ao momento correspondente a essa terceira fase, vale registrar que:

No final dos anos 80, o PT assume o governo da cidade e as perspectivas da democratização da gestão pública ganham forma num intenso movimento de criação de novos canais de interlocução governosociedade, entre os quais se destacam os conselhos. Esse é o ponto de partida do que estou aqui considerando a terceira fase da criação dos conselhos municipais em São Paulo. (TATAGIBA, 2004, 231).

Nos seus dias iniciais, portanto, o CMDCA/SP ${ }^{148}$ funcionava muito mais como mero legitimador - exclusivamente superficial e formal - das pretensões e intenções governamentais que como uma arena de participação propriamente dita.

A possibilidade de mobilização e atuação efetiva da sociedade civil se desenvolvia a partir de critérios formais absolutamente divorciados de qualquer substrato verdadeiramente democrático ou participativo.

O amadurecimento democrático, conjugado com o surgimento e a incorporação de ferramentas de participação efetiva, de direito da sociedade civil não apenas à manifestação, mas também a ser ouvida - e levada em consideração —, determinaram o aprimoramento desses mecanismos.

Tal processo todavia não se acha ainda completo, ou finalizado, visto operacionalizar-se de forma constante e ininterrupta com vista à compatibilização dos mecanismos juridicamente concebidos com as novas demandas, necessidades e dinâmica sociais.

A Constituição Federal de 1988 desempenhou papel fundamental nesse processo evolutivo, como bem pontuam Santos Junior, Azevedo e Ribeiro:

\footnotetext{
${ }^{148}$ Conselho Municipal dos Direitos da Criança e do Adolescente de São Paulo, o qual será doravante assim designado.
} 
[...] a participação da sociedade na formulação e gestão das políticas públicas começa a ser legitimada institucionalmente já na Constituição Federal de 1988, quando são estabelecidas como fundamentos do sistema de governo do país a soberania e a cidadania, nas quais o poder pode ser exercido tanto por meio de representantes eleitos - na forma do sufrágio universal com o voto direito e secreto - como por meio da participação direta - principalmente mediante três institutos aprovados, o plebiscito, o referendo e a iniciativa popular de lei (art. $1^{\circ}$ ). Nesse sentido, pode-se dizer que a Constituição institui mecanismos que consubstanciam os princípios da democracia semidireta, caracterizada pela combinação dos procedimentos de democracia representativa com os de democracia direta. No momento marcado pelo ambiente participacionista da Constituição de 1988, a década de 90 vai ser caracterizada pela regulamentação nacional de diversas políticas sociais, com a incorporação da participação da sociedade na sua gestão e controle através dos conselhos. Os conselhos se transformam, assim, no formato institucional que materializa os artigos da Constituição Federal que estabelecem essa participação, presentes em diversos capítulos: na saúde, como "participação da comunidade" (inciso III, art. 198); na assistência social, como "participação da população, por meio de organizações representativas, na formulação das políticas e controle das ações em todos os níveis" de governo (inciso II, art., 204); e na educação, como 'gestão democrática do ensino público' (inciso VI, art. 206). [...] Assim, os conselhos - federais, estatuais e municipais - proliferaram no país, na forma de canais institucionais de participação da sociedade [...]. (SANTOS JUNIOR; AZEVEDO; RIBEIRO, 2004, p. 21-22).

Referido cenário não se manteve estático desde a edição do Texto Maior, tendo as diversas alterações contextuais determinado o aparecimento de novas necessidades, de novos conceitos e diretrizes vinculantes da atividade administrativa - e pública, de uma forma geral.

Realmente, o final do século XX e o início do XXI foram marcados, conforme já pontuado no presente estudo, pelo despontar de noções como legitimidade, eficiência, responsividade, pluralismo, consensualismo e governança democrática - esta última decorrente justamente da noção de otimização das relações Estado-sociedade, e da constante incidência de vetores de incremento de qualidade sobre ela. ${ }^{149}$

\footnotetext{
149 “[...] denominamos governança democrática os padrões de interação entre as instituições governamentais, agentes do mercado e atores sociais que realizem a coordenação e, simultaneamente promovam ações de inclusão social e assegurem e ampliem a mais ampla participação social nos processos decisórios em matéria de políticas públicas. Tal padrão de interação entre governo e sociedade se expressa em canais ou arenas, institucionalizados ou não, de intermediação entre instituições governamentais e atores sociais. [...] a institucionalização de práticas de governança democrática, bem como o sucesso de experiências locais de governo no contexto da produção de políticas públicas responsivas em relação aos seus cidadãos, estão relacionadas à maneira como se organizam esses arranjos, no sentido de (i) bloquear ou minimizar as práticas clientelistas vigentes e a captura das esferas públicas por interesses coorporativos e particularistas, através de procedimentos institucionais, como também pela disseminação de uma cultura democrática que se incorpore às práticas dos atores e que possa sobrepor-se hegemonicamente à cultura política não democrática presente
} 
Como adiante com mais vagar se verá, os conselhos, especialmente em âmbito municipal, apresentam-se como mecanismos ideais à efetivação desses valores.

Em panorama traçado por Barbosa:

\begin{abstract}
A percepção dos membros da sociedade como portadores de direitos inclusive o de participar diretamente na formulação e controle de uma política pública - traz como consequência a emergência da construção de espaços públicos, seja para introdução de novos temas no debate público, seja para constituição de espaços de ampliação e democratização da gestão estatal (DANIGNO, 2002). Cabe à legislação infraconstitucional regular a forma dessa participação. Um dos caminhos encontrados na legislação foi a criação de "Conselhos" [...]. Trata-se de uma inovação. Tradicionalmente, a escolha de opções políticas, mediante um juízo de oportunidade e conveniência, coube ao Poder Executivo. Mas, a partir do momento em que se reconhece a participação do povo na gestão do poder político, está-se admitindo um outro foro de decisão, quebrando a tradição de escolha única pelo Poder Executivo, na forma clássica (LIBERATI; CYRINO, 1993). Tem-se, pois, que, em certas matérias, o ordenamento jurídico abriu um novo canal para a escolha de opções políticas: os Conselhos. Sua criação viabiliza um canal de participação popular em decisões que afetam o cotidiano da sociedade, na formulação e no controle de determinadas políticas públicas. Trata-se de uma forma de participação na gestão do poder político. A proposta conselhista oferece assim um novo "locus" de discricionariedade, permitindo a participação da sociedade civil nos espaços institucionais de decisão. [...] A participação popular nos conselhos das áreas sociais, intervindo na discussão, elaboração, fiscalização e controle das políticas, tende a potencializar "a criatividade da sociedade civil na elaboração de políticas públicas", uma vez que é ela quem percebe no cotidiano dos serviços prestados a efetividade ou não de suas políticas e, principalmente, as lacunas deixadas pelos serviços públicos (SOUZA, 2006, p. 182). (BARBOSA, 2009, p. 11-13). ${ }^{150}$
\end{abstract}

Pontuados esses aspectos antecedentes da atual sistemática, temos que o CMDCA paulistano resulta da edição da Lei municipal n. 11.123, de 22 de novembro de $1991,{ }^{151}$

no sistema político brasileiro; (ii) gerar práticas e estruturas horizontais de participação, capazes de produzir 'capital social'; (iii) 'empoderar' grupos sociais em situação de vulnerabilidade e exclusão de forma a reduzir o impacto das relações assimétricas de poder; (iv) reforçar vínculos associativos dos grupos locais, suas mobilizações e suas organizações representativas, de forma a incentivar e fortalecer as relações de interação entre os diferentes atores com presença na esfera pública. [...] Nesse sentido, entendemos que os conselhos municipais são a maior expressão da instituição, pelo menos no plano legal, do modelo de governança democrática no âmbito local.” (SANTOS JUNIOR; AZEVEDO; RIBEIRO, 2004, p. 19-21).

${ }^{150}$ Maria Nazaré Lins Barbosa faz referência aos seguintes autores: DANIGNO, Evelina (Org.). Sociedade civil e espaços públicos no Brasil. São Paulo: Paz e Terra, 2002. LIBERATI, Wilson Donizeti; CYRINO, Públio Caio Bessa. Conselhos e Fundos no Estatuto da Criança e do Adolescente. 2. ed., São Paulo: Malheiros, 1997. SOUZA, Rodriane de Oliveira. Participação e Controle Social. In: SALES, Mione Apolinário; MATOS, Maurílio Castro de; LEAL, Maria Cristina (Orgs.). Política social, família e juventude: uma questão de direitos. 2. ed., São Paulo: Cortez, 2006.

151 “Art. 5”. Fica criado, vinculado ao Gabinete do Prefeito, o Conselho Municipal dos Direitos da Criança e do Adolescente, órgão deliberativo e controlador da política de atendimento, observada a composição 
consubstanciadora, em nível local, do disposto no artigo 88, II, do Estatuto da Criança e do Adolescente. ${ }^{152}$

Esta última norma, por sua vez, outorga eficácia específica e direta ao artigo 227, $\S \S 1^{\circ}$ e $7^{\circ}$, da $C F$, os quais, a partir da adoção da lógica participativa e, portanto, da integração da sociedade junto à esfera estatal voltada à promoção do interesse geral, estabelecem que "o Estado promoverá programas de assistência integral à saúde da criança e do adolescente, admitida a participação de entidades não governamentais [...] e que no atendimento dos direitos da criança e adolescente levar-se-á em consideração o disposto no artigo 204."

Este último, por sua vez, fixa as seguintes diretrizes:

I - descentralização jurídico-administrativa, cabendo a coordenação e as normas gerais à esfera federal e a coordenação e a execução dos respectivos programas às esferas municipal e estadual, bem como a entidades beneficentes e de assistência social;

II - participação da população, por meio de organizações representativas, na formulação das políticas e no controle das ações em todos os níveis.

A Lei municipal supracitada disciplina a política de atendimento aos direitos da criança e do adolescente e dispõe, em linhas gerais, sobre os Conselhos Tutelares e de Direitos, consagrados em seu artigo $3^{\circ}$ como órgãos da política de atendimento aos direitos desses seres em condição peculiar de desenvolvimento. ${ }^{153}$

Detalha, assim, todo o arcabouço institucional do CMDCA, o qual, de acordo com as diretrizes constantes do Estatuto da Criança e Adolescente, ${ }^{154}$ deve necessariamente assumir as características de órgão deliberativo e controlador das ações em todos os níveis, em que seja assegurada a popular paritária por meio de organizações representativas.

paritária de seus membros, nos termos do artigo 88 , inciso II, da Lei federal $\mathrm{n}^{\circ} 8.069$, de 13 de julho de 1990."

152 “Art. 88. São diretrizes da política de atendimento: [...] II - criação de conselhos municipais, estaduais e nacional dos direitos da criança e do adolescente, órgãos deliberativos e controladores das ações em todos os níveis, assegurada a participação popular paritária por meio de organizações representativas, segundo leis federal, estaduais e municipais; [...]".

${ }^{153}$ Conforme expressão adotada pela Constituição Federal, em seu artigo 227, § $3^{\circ}$, V. Nas palavras de Denise Auad, "o paradigma da 'condição peculiar de pessoa em desenvolvimento reconhece que a criança e o adolescente estão em fase de formação, tanto física quanto emocional, a exigir, de fato, uma atenção especial dos atores que são responsáveis por sua educação, o que implica uma atuação interligada da família, da comunidade, da sociedade e do Poder Público para que, durante esta fase, não lhes sejam negadas as oportunidades para seu desenvolvimento completo. Por esse motivo, justifica-se plenamente a necessidade de ofertar à infância e à juventude uma atenção diferenciada, conforme preconiza a doutrina da proteção integral." (AUAD, 2007, p. 11).

${ }^{154}$ Lei n. 8.069, de 13 de julho de 1990, art. 88, II. 
Incontornável, ainda, e nos termos da Lei nacional, sua natureza autônoma.

A liberdade municipal - ou estadual - nessa matéria não é portanto absoluta, devendo ser observada aquela norma nacional (não meramente federal) veiculada pelo artigo 88, II, do Estatuto da Criança e Adolescente.

Estabelecida, assim, e de antemão, a sua natureza deliberativa, ${ }^{155}$ em razão da qual as decisões do Conselho não podem ser tidas por meras recomendações ao poder público: a marca fundamental da função deliberativa é justamente criar uma vinculação quanto às suas posições a partir dela procedimentalizadas e cristalizadas.

Imperioso apartarmos o efeito e o grau de vinculação das decisões exaradas pelos conselhos deliberativos daquelas provenientes de órgãos meramente consultivos, conforme lições de Tatagiba ${ }^{156}$ e Santos Junior, Azevedo e Ribeiro. ${ }^{157}$

No que tange especificamente aos Conselhos Municipais dos Direitos da Criança e do Adolescente, esclarecem Liberati e Cyrino que eles "têm o poder de deliberar. E deliberar significa decidir sobre a matéria que lhes for afeta. Não se trata de órgãos meramente consultivos do Poder Executivo. [...] os Conselhos têm a missão de deliberar

\footnotetext{
${ }^{155}$ Conforme distinção proposta na pesquisa "Conselhos Municipais e Políticas Sociais", desenvolvido pela Comunidade Solidária no ano de 1997 e citada por Tatagiba, seriam três as espécies de conselhos deliberativos: os Conselhos de programas, os temáticos e os de políticas. Nesta última classe estariam incluídos os Conselhos da Criança e Adolescente, vez que se caracterizam por "serem ligados às políticas públicas mais estruturadas ou concretizadas em sistemas nacionais [...]. São, em geral, previstos em legislação nacional, tendo ou não caráter obrigatório, e são considerados parte integrante do sistema nacional, com atribuições legalmente estabelecidas no plano da formulação e implementação das políticas na respectiva esfera governamental, compondo as práticas de planejamento e fiscalização das ações. São também concebidos como fóruns públicos de captação de demandas e negociação de interesses específicos dos diversos grupos sociais e como uma forma de ampliar a participação dos segmentos com menos acesso ao aparelho de Estado." (TATAGIBA, 2002, p. 49).

156 "Quanto à natureza de suas funções, os conselhos podem ser deliberativos, consultivos, normativos ou fiscalizadores, assim como podem ter suas atribuições definidas por combinação de algumas dessas funções. Em certos casos, essa definição já está presente na legislação federal, como no caso dos conselhos de Saúde, Assistência Social e Criança e Adolescente. Um conselho bem-sucedido pode não ter sua ação diretamente relacionada à deliberação ('induzir o Estado à ação'), mas ao controle social do Estado (no sentido fiscalizatório que visa 'impedir o Estado de transgredir'), ou a uma eficiente vocalização das demandas, ou a uma junção feliz dessas características. Conselhos com baixa capacidade deliberativa podem ser fortes no controle da aplicação dos recursos orçamentários, ou na execução dos programas e projetos. Esse reconhecimento, contudo, não pode nos levar [...] a subestimar a importância da deliberação como um preceito legal profundamente impactante no sentido da radicalização da partilha do poder. É essa prerrogativa que torna os conselhos arranjos institucionais profundamente promissores no sentido da reforma democrática do Estado." (TATAGIBA, 2004, p. 360-361).

157 "Em geral, são deliberativos, abrangentes e permanentes. As atribuições dos conselhos não se restringem à formulação de sugestões ou ao encaminhamento de demandas, mas abrangem a deliberação sobre as diretrizes das políticas temáticas, a aprovação da normatização e da regulação das ações do governo, e a aprovação da proposta orçamentária, e incidem, portanto, na definição de macro prioridades e na formulação de políticas públicas regulatórias. Em síntese, nas temáticas aos quais estão vinculados, os conselhos incidem sobre todo o circuito de gestão de uma política pública, desde a formulação até a sua implementação." (SANTOS JUNIOR; AZEVEDO; RIBEIRO, 2004, p. 23).
} 
sobre as políticas relacionadas à infância e juventude.” (LIBERATI; CYRINO, 1997, p. 94).

A condição deliberativa leva a uma maior e mais efetiva participação democrática, assim como a uma elevação da responsividade ${ }^{158}$ entre as políticas públicas e as demandas sociais, vez que, por meio da restrição da discricionariedade governamental, ${ }^{159}$ torna obrigatórias as decisões adotadas a partir da manifestação efetiva da sociedade, via Conselho.

Limita-se, assim, a discricionariedade da Administração, que passa ao próprio Conselho - um dos mais marcantes aspectos da atuação dos Conselhos Municipais dos Direitos da Criança e do Adolescente.

Competências historicamente concentradas nas mãos do chefe do Executivo e seus assessores passam a ser partilhadas com a sociedade, em um processo que depende da manifestação e da conjugação das intenções e ponderações de ambas as esferas governamental e privada - para a formação da vontade pública final.

Conforme bem explicitam Liberati e Cyrino:

[...] a margem de discricionariedade do Governo - Chefe do Executivo - fica reduzida diante de dois imperativos constitucionais: a prioridade absoluta e a necessidade de formulação e deliberação de certas matérias por outra instância mais democrática, onde conjugarão forças e vontades a sociedade civil e o Governo, resultando em manifestação de caráter administrativo público estatal. [...] Portanto, além de a discricionariedade sofrer a restrição constitucional quanto ao seu apreciador, pois compete ao Chefe do Executivo repartir essa tarefa, antes exclusivamente sua, com os Conselhos — , o mérito administrativo, antes intangível, é agora, também, resultado de manifestação complexa. (LIBERATI; CYRINO, 1997, p. 89).

Essa característica determina um ganho em qualidade democrática e, consequentemente, no grau de legitimidade ${ }^{160}$ das políticas públicas, ${ }^{161}$ determinando o

\footnotetext{
${ }^{158} \mathrm{Na}$ lição de Justino de Oliveira, a participação administrativa "possibilita às autoridades decididoras maior informação sobre as questões que envolvem a satisfação das necessidades coletivas. Confere maior grau de eficácia e efetividade dessas decisões, por refletirem os anseios da coletividade em virtude da intervenção prévia dos cidadãos ou organizações representativas. Isso ensejaria uma maior adesão dos destinatários das decisões administrativas [...].” (OLIVEIRA, 2005, p. 13-14).

${ }^{159}$ À qual se voltará adiante.

${ }^{160}$ Conforme bem pontua Perez, “[...] a adesão da sociedade, quando não a atuação ativa desta, é fundamental para a eficiência da administração pública. Daí a necessidade de se utilizar instrumentos que procurem o consentimento da coletividade, que procurem, enfim, a aproximação da sociedade e do Estado, do burocrata e do cidadão, do governante e do governado. Criam-se, desse modo, as bases para o nascimento de uma legitimidade fruto da adesão racional da sociedade a um conjunto de medidas concretas, políticas, ou programas que esta ajudou a formular, decidir e muitas vezes executar. Fala-se, pois, de uma legitimidade que ao mesmo tempo em que decorre da aproximação entre a Administração e a sociedade, reforça os
} 
surgimento de uma sistemática de cogestão, ${ }^{162}$ em que sociedade civil e governo decidem conjuntamente os rumos e políticas a serem adotados em prol da infância e adolescência.

Outros traços inerentes aos Conselhos da Criança e Adolescente são a já referida autonomia e a carência de personalidade jurídica, a qual não impede o seu relacionamento com os demais entes governamentais ou integrantes da sociedade civil, conforme já explicitado.

Da sua autonomia — também expressa no artigo 88 da Lei n. 8.069/90 —, resulta a inexistência de qualquer relação de subordinação, de qualquer vínculo ou controle hierárquico entre o Conselho e o Executivo ${ }^{163}$ :

[...] esta característica especial, sui generis, dos Conselhos dos Direitos inova o Direito administrativo, no sentido de caracterizá-lo como órgão independente e autônomo, mesmo sem personalidade jurídica própria.

vínculos entre elas. Legitimidade é essencial para o êxito de políticas públicas e é incrementada por meio deste resultado. Legitimidade e eficiência são, portanto, finalidades que se alimentam reciprocamente, isto é, mais legitimidade importa em maior eficiência da atuação da administração pública e mais eficiência implica em maior legitimidade." (PEREZ, 2006, p. 167-168).

161 "Vínhamos de uma participação em conselhos consultivos e verificamos que esses serviram aos interesses do Executivo. Eventualmente respaldavam algumas das suas ações, mas o Executivo não estava obrigado a acatar nenhuma posição. Agora, se você coloca o conselho como deliberativo e controlador, você coloca a idéia de que ele efetivamente exerce poder público." (GARRIDO, Paulo. Entrevista concedida a Satancini, 1997, p. 111, apud STANCINI, 1997, p. 111).

162 "Os dois artigos da Constituição acima mencionados [204 e 227] contêm as premissas basilares que fundamentam a possibilidade de aplicação da democracia participativa no Brasil por meio de Conselhos Gestores de Políticas Públicas, já que estes órgãos impactam uma mudança na perspectiva da participação política e a ampliação de um locus para sociedade civil participar diretamente das decisões de governo. Criase, portanto, uma nova relação entre a sociedade civil e o Estado, a qual decorre da ruptura da centralidade das deliberações políticas nas mãos do Poder Executivo. Assim, os artigos 204 e 227, § 7º da Constituição Federal institucionalizam um espaço de cogestão para a formulação e para a fiscalização de políticas na área da assistência social e dos direitos da criança e do adolescente." (AUAD, 2007, p. 8). Compartilham dessa posição Zeni e Gonçalvez: "No caso dos conselhos municipais, vê-se que grande é o êxito encontrado, porque é um meio simples de organização social. Trata-se de uma prática de gestão pública compartida que se prolifera no país, sendo tal proliferação resultado de uma mudança ainda tímida, tanto no perfil da administração pública como da sociedade, que vem deixando de lado uma postura de mera espectadora das decisões administrativas, tornando-se detentora de uma cidadania ativa, participativa." (ZENI; GONÇALVEZ, 2010, p. 7.292).

163 Esse entendimento, porém, não é aceito de forma unânime na doutrina, cumprindo-nos registrar posicionamentos como o de Perez, para quem haveria uma subordinação hierárquica autorizativa do controle do Executivo: "[...] diante à sua integração à estrutura orgânica da Administração, os conselhos não possuem personalidade jurídica e, dessa forma, não gozam em regra de autonomia gerencial, administrativa ou financeira, não podem contrair obrigações, não respondem judicialmente pelos atos e, somente em casos excepcionais, que envolvam o exercício de suas prerrogativas decisórias, possuem capacidade postulatória judicial. Decorre, ainda, dessa posição institucional dos conselhos deliberativos o fato de subordinarem-se à estrutura hierárquica da Administração Pública. Sendo assim, em regra, caberá recurso hierárquico das decisões tomadas pelos conselhos deliberativos, pois a desconcentração da competência decisória não elimina o sistema de controles hierárquicos inerentes à organização político-administrativa. Portanto, a decisão ilegal tomada por um conselho deliberativo pode ser anulada pela autoridade administrativa a que se subordina organicamente (Ministro de Estado, Presidente da República, por exemplo. Também é possível, pela mesma razão, a revogação, pela autoridade hierarquicamente superior, das decisões de caráter discricionário tomadas pelo conselho deliberativo, mediante juízo de conveniência, o que, certamente, dependerá de motivação técnica, jurídica e política.” (PEREZ, 1999, p. 122) 
[...] No caso dos Conselhos dos Direitos da Criança e do Adolescente, verifica-se a inexistência de subordinação hierárquica destes em relação ao governo. O controle, pelo governo, sobre as ações do Conselho não se dá no mérito (embora mesmo os órgãos autônomos "clássicos" sofram esse tipo de controle), mas apenas de forma finalística, de legalidade. (LIBERATI; CYRINO, 2003, p. 96).

\section{Partilham dessa opinião Santos Junior, Azevedo e Ribeiro e Justen Filho. ${ }^{164}$ \\ O fundamento para não sujeição do Conselho à ao Executivo decorre da própria} lógica do princípio da participação e dos desideratos da soberania popular e da democracia, que inviabilizam ao Executivo, composto em decorrência de uma lógica democrática unicamente representativa, ceifar as competências e se sobrepor ao Conselho - o qual assume a condição, em última instância, de interlocutor do povo, de seu canal legítimo de manifestação e atuação.

Esse entendimento não implica obrigatória implementação, pelos demais órgãos administrativos, de eventuais medidas ilegais deliberadas e decididas pelo Conselho; não se pode admitir a atuação administrativa contraria à lei, com base unicamente no apelo democrático.

Mas não se pode aceitar, da mesma forma, a interferência subordinante de uma esfera sobre a outra.

Em hipóteses tais, poderá o Executivo - ou qualquer órgão outro que figure como destinatário, como parte interessada ou relacionada ao ato/medida ilegal porventura deliberada - se negar a implementá-lo, ou a assumir a postura em questão - mas nunca

\footnotetext{
164 “[...] Apesar de estarem vinculados aos órgãos do poder público, os conselhos têm autonomia em suas atribuições para definirem suas regras e dinâmica de funcionamento, o que deve ser estabelecido com a participação de todos os segmentos sociais representados no seu âmbito, incluindo, portanto, o próprio poder público. É exatamente o fato de serem espaços vinculados ao poder público e ao mesmo tempo constituídos de representantes da sociedade que torna os conselhos órgãos públicos de natureza ambivalente ou uma forma particular de controle público não-estatal. [...]. A participação autônoma da sociedade diz respeito às condições necessárias para que as organizações sociais possam se fazer representar na esfera pública e tomar decisões no diálogo com os demais atores. Segundo Santos, 'já não se trata de autonomia dos anos 70/80, quando o espaço da política se restringia ao aspecto da pressão sobre o Estado, e a negociação significava cooptação e enfraquecimento da luta. A autonomia dos anos 90 [...] diz respeito à possibilidade de constituição de um espaço que, apesar de estar vinculado à estrutura do Estado, é construído de forma colegiada, onde as próprias regras de seu funcionamento têm que ser decididas no seu âmbito, incorporando além da racionalidade administrativa inerente à ação do Estado, a dimensão política dos grupos de interesse. Nesse sentido, o Estado seria, ao mesmo tempo, um dos participantes dessa arena e lócus de interação da sociedade." (SANTOS JUNIOR; AZEVEDO; RIBEIRO, 2004, p. 44). "O controle interno envolve apenas a atuação administrativa do próprio ente. Isso significa, primeiramente, que não caberá essa espécie de controle quando não se configurar uma atividade de natureza administrativa. A ressalva é especialmente importante relativamente ao controle interno fora do âmbito do Poder Executivo. [...] a questão pode apresentar alguma complexidade no caso de atribuição normativa de autonomia a uma entidade integrante de um mesmo e único Poder. [...] Em termos práticos, isso significa a ausência de validade de um ato administrativo pelo Chefe do Poder Executivo desconstituindo um ato praticado no âmbito de uma autarquia. Nem mesmo caberia uma ordem nesse sentido." (JUSTEN FILHO, 2012, p. 1117).
} 
interferir, positivamente, na anulação ou extirpação dos atos do mundo jurídico. Não, ao menos, na esfera administrativa, com base no poder hierárquico — vez que de hierarquia ou subordinação definitivamente não se trata.

Temos que de autotutela, na hipótese de interferência do Executivo sobre o Conselho, da mesma forma não se pode falar: referida prerrogativa pressupõe a movimentação dentro de uma mesma esfera, de uma mesma natureza - na qual não se inclui a figura sui generis do Conselho, que, não obstante ligado à estrutura administrativa, não pode ser tido como um órgão exclusivamente estatal:

Mais recentemente, aguçou-se a percepção de que o público não se
confunde com o estatal. Tal constatação se manifesta em planos diversos.
No domínio público, a democracia contemporânea assumiu uma feição
deliberativa, em que as decisões dos órgãos estatais são frequentemente
produzidas em um ambiente de audiências e debates públicos, que
incluem manifestações de diferentes segmentos sociais e ampla utilização
dos meios de comunicação de massa. O jogo democrático já não é jogado
apenas em uma data fixa - a dos pleitos eleitorais -, nem se limita à
formação de uma vontade majoritária que reinará absoluta por prazo
certo. Ao contrário, a legitimidade do poder depende da participação
social permanente, produzindo uma esfera pública informal, na qual
governantes e governados estabelecem um diálogo permanente acerca da
condição dos negócios públicos. Assim, à organização dicotômica
clássica "público-privado", agrega-se um novo e importante elemento: a
esfera pública não estatal. (BARROSO, 2010, p. 62-63).

Acrescenta Tatagiba que “[...] uma das características que respondem pela natureza pública e democrática desses novos arranjos deliberativos diz respeito à pluralidade de sua composição. Os conselhos não são espaços do governo, tampouco da sociedade civil.” (TATAGIBA, 2004, p. 348).

No mesmo sentido a lição de Cassese, que se refere a "organismos públicos não submetidos ao governo central", ao "policentrismo dos ordenamentos gerais", a uma "fragmentação dos ordenamentos estatais" e, especificamente, a "setor público não estatal".

Ao tratar da submissão deste último ao governo, afirma que "estes fogem, pela própria natureza, de sua ordenação e controle”. (CASSESE, 2010, p. 32).

E detecta, como consequência desse cenário, uma "mudança no ordenamento tradicional, que via a administração inserida no aparelho executivo. Dessa forma, uma parte da administração pública foge ao governo, não está ligada a uma estrutura 'hierárquica'.'(CASSESE, 2012, p. 34) 
Ainda com relação à autotutela, pressupõe, ainda, a existência de uma estrutura hierarquicamente organizada, em que à autoridade superior caberá a revisão, manutenção ou eventual anulação dos atos praticados por seus subordinados. ${ }^{165}$

Somente o próprio Conselho - autônomo, repise-se, - poderia lançar mão dos poderes-deveres dela resultantes, dentro de sua esfera de atuação e competências.

Quanto ao Judiciário, a sua atuação será sempre franqueada, como órgão controlador externo, desde que provocado. Trata-se de mera aplicação da garantia fundamental consagrada no artigo $5^{\circ}, \mathrm{XXXV}$, da Constituição Federal.

Essa análise é compartilhada integralmente por Denise Auad. ${ }^{166}$

A derradeira característica compulsória dos Conselhos é a sua composição paritária ${ }^{167}$ : os representantes do governo e da sociedade civil devem observar rigorosamente a mesma proporção, contando com idêntico número de assentos.

Nesse sentido, trazemos à baila as palavras de Tatagiba:

165 “O dever de regularidade dos atos administrativos produz o surgimento de um dever genérico de controle interno à própria Administração Pública. O dever-poder genérico de controle interno alcança toda e qualquer autoridade administrativa, relativamente a todo e qualquer ato administrativo praticado por ela própria ou por seus subordinados. Isso significa que qualquer agente administrativo, verificando a irregularidade de algum ato, deve adotar as providências necessárias a impedir que produza seus efeitos. Isso não equivale a reconhecer a competência genérica para desfazimento de atos alheios, a não ser quando exista uma competência jurídica específica para tanto. Assim se passa nos casos em que exista um vínculo hierárquico de subordinação. A autoridade administrativa superior é investida na competência para revisão dos atos administrativos dos órgãos hierarquicamente inferiores. Essa competência costuma ser denominada poder de autotutela, o qual se pode exteriorizar inclusive para afins de desfazimento de atos. Nesse caso, a autoridade superior pode ser investida da competência para sustar a eficácia dos atos da autoridade subordinada." (JUSTEN FILHO, 2010, p. 1.107).

166 “Caso haja indícios de que uma resolução seja ilegal consideramos haver dois caminhos para que seus efeitos sejam anulados. O primeiro deles decorre do princípio administrativo da autotutela, o qual permite aos órgãos da Administração Pública, independentemente da tutela do Poder Judiciário, rever seus próprios atos para anular os ilegais e revogar aqueles que, embora legais, não sejam nem convenientes e nem oportunos politicamente. O segundo caminho permite ao cidadão ou órgão que possui legítimo interesse processual, ingressar com uma ação no Poder Judiciário para pleitear a anulação da resolução. Em relação ao princípio da autotutela, algumas questões precisam ser esclarecidas. Coloca-se a seguinte divergência: pode algum órgão da Administração Direta Municipal, como, por exemplo, a Secretaria Especial de Participação e Parceria, à qual o CMDCA/SP está ligado, revogar ou anular uma resolução deste ou apenas o Conselho teria este poder? [...] Permitir que haja controle hierárquico do Conselho de Direitos subverte sua qualidade de órgão autônomo, o que atinge, inclusive, a própria lógica de seu papel deliberativo e seu reconhecimento como espaço institucional para a prática da democracia participativa. Por esse motivo, entendemos que somente o Conselho pode revogar suas resoluções por questões de discricionariedade política. No caso de ser constatada alguma ilegalidade em tais atos normativos, a anulação poderá ser feita pelo Conselho também com base no princípio da autotutela, ou, então, pelo Poder Judiciário, com lastro em sua função típica de apreciar lesão ou ameaça de lesão a Direito.” (AUAD, 2007, p. 51-52).

167 "Em relação à divisão dos assentos entre governo e sociedade civil, os conselhos podem ser definidos como paritários, de super-representação societária, ou super-representação governamental. Os conselhos paritários são os que apresentam igual número de representantes da sociedade civil e do governo. Os ouros dois casos são conselhos não paritários, nos quais se observa um número maior de representantes da sociedade civil (conselho com super-representação societária) ou um maior numero de representantes do governo (conselho de super-representação governamental)." (TATAGIBA, 2004, p. 350). 
No que se refere à sua composição, a legislação impõe o respeito ao princípio da paridade entre Estado e sociedade, como mecanismo de equilíbrio nas decisões. A representação governamental nos conselhos é feita, em geral, por agentes públicos titulares de cargos de direção na Administração direta ou indireta, por responsáveis pelas áreas das políticas sociais, e por outros que atuem nas áreas afins, por indicação do chefe do Poder Executivo. A sociedade civil é representada por conselheiros escolhidos por seus pares, em fórum próprio, dentre as entidades e organizações não governamentais prestadoras de serviço, de defesa de direitos, movimentos, associações de usuários, devendo essa composição ser prevista por lei específica, de acordo com as particularidades de cada contexto. (TATABIGA, 2002, p. 50-51).

Tal distribuição visa justamente garantir e viabilizar o princípio da participação democrática, assim como o perfeito equilíbrio entre a atuação governista e da sociedade.

A mera garantia de paridade/equilíbrio numérico - e portanto formal —, porém, apresenta importantes limitações.

Muitas das esferas ou facetas da atual sociedade (marcada expressivamente pelo pluralismo) findam por se verem excluídas do processo decisório levado a termo a partir dos mecanismos de participação, o que determina um déficit de representatividade dos conselhos.

Dessa opinião compartilham Tatagiba ${ }^{168}$ e Auad. ${ }^{169}$

Os traços fundamentais referidos, todos inafastáveis pelas instâncias estaduais e municipais - caráter deliberativo, autonomia, e composição paritária - marcam, portanto, o Conselho Municipal dos Direitos da Criança e Adolescente de São Paulo, havendo sido consagrados e assimilados pela sistemática inaugurada pela Lei $\mathrm{n}$. 11.123/91.

Sobre esse pano de fundo, foram inseridos, em linhas gerais, as seguintes diretrizes:

\footnotetext{
168 “A busca pelo equilíbrio na representação dos interesses governamentais e não governamentais nos conselhos não se exaure nas garantias procedimentais da paridade numérica; antes, deve ser construída no cotidiano das práticas e articulações no interior dos conselhos. Isto porque a diversidade interna dos referidos campos abre a possibilidade de múltiplas clivagens e articulações no desenrolar dos processos deliberativos." (TATAGIBA, 2002, p. 57)

169 “[...] a opção do legislador, ao estabelecer a paridade nos três níveis da Federação, foi pela igualdade numérica, ou seja, garantir que os membros do Conselho dos Direitos sejam divididos, em igual número, entre representantes do governo, geralmente nomeados pelo chefe do Poder Executivo, e representantes da sociedade civil, escolhidos, por meio de eleições, dentre pessoas ligadas a movimentos e entidades de proteção dos direitos infanto-juvenis. A paridade numérica, todavia, é alvo de severas críticas. Em primeiro lugar, aponta-se para o fato de que ela garante tão somente uma igualdade formal e não substantiva [...]. Para que a igualdade numérica de fato garanta um poder paritário de decisão entre o governo e a sociedade civil, questões como capacitação dos conselheiros, cooptação de interesses, dimensão e natureza da representatividade, remuneração e tempo de mandato precisam ser debatidas." (AUAD, 2007, p. 63-64).
} 
1. Vinculação, originariamente, ao Gabinete do Prefeito, e posteriormente transferida à Secretaria Municipal de Participação e Parceria, por meio do Decreto n. 45.683, de $1^{\mathrm{o}}$ de janeiro de 2005 (art. $7^{\mathrm{o}}$, II).

Essa vinculação não implica, conforme exposto, qualquer grau de subordinação hierárquica, traduzindo mero vínculo administrativo-organizacional:

Sendo órgãos do Poder Público, os Conselhos precisam estar administrativamente vinculados a algum setor, departamento, secretaria etc. da Administração municipal. Contudo, também fica claro que esta vinculação não significa subordinação, pois é da natureza deste órgão a independência e autonomia para deliberar sobre o mérito de suas matérias. Por isso, não há necessidade de estrutura administrativa própria. O conselho deve contar com o apoio do órgão, setor ou secretaria a que esteja vinculado.

$[\ldots]$

O município, por força da Constituição Federal, tem competência privativa para organizar sua estrutura administrativa. O conselho de Direitos, resultante de previsão implícita na Constituição Federal e explícita na Lei 8.069/90, é órgão de natureza pública, descentralizado.

Isto bastava por si, pois órgão descentralizado é sempre autônomo. Mas, para eliminar dúvidas, afirmamos que não se pode confundir vinculação administrativa com subordinação hierárquica.

Pode-se vincular o Conselho a uma das Secretarias de Governo ou Departamento, e situá-lo na organização administrativa, para os fins, inclusive, de facilitar o apoio infra-estrutural. Somente. A vinculação administrativa não lhe retira sua independência, que faz parte de sua natureza jurídica. (LIBERATI; CYRINO, 2003, p. 113-115).

2. Composição por 16 conselheiros, a exercerem mandatos de dois anos, da seguinte forma distribuídos: a) oito representantes do poder público municipal das áreas de políticas sociais, de orçamento e finanças e outras a serem definidas pelo Executivo; ${ }^{170} \mathrm{~b}$ ) oito representantes da sociedade civil, de movimentos e entidades.

Os conselheiros representantes da sociedade civil são eleitos em assembleia geral convocada pelo poder público municipal para esse fim, enquanto os relacionados ao Executivo dependerão de indicação do Prefeito, exarada após apresentação de lista tríplice pelos titulares de cada um dos órgãos municipais com assento no Conselho.

Conforme determina o artigo $6^{\circ}$ do Decreto n. 31.319, de 17 de março, de 1992, ${ }^{171}$ estes últimos são: a) Secretaria Municipal de Assistência e Desenvolvimento Social; b) Secretaria Municipal de Saúde; c) Secretaria Municipal de Educação; d) Secretaria Municipal de Finanças; e) Secretaria Municipal de Participação e Parceria; f)

\footnotetext{
${ }^{170}$ Referido dispositivo encontra-se hoje disciplinado pelo Decreto n. 45.744/05.

${ }^{171}$ Com redação outorgada pelo Decreto n. 45.744, de 03 de março de 2005.
} 
Secretaria de Negócios Jurídicos; g) Secretaria Municipal de Esportes, Lazer e Recreação; h) Secretaria Municipal de Cultura.

Deverão aqueles, por sua vez, estar vinculados, necessariamente, a entidades ou movimentos ${ }^{172}$ atuantes nas seguintes searas ${ }^{173}$ : a) atendimento à criança e adolescente, para a qual estão reservados dois assentos no colegiado; b) defesa dos direitos, brindada também com dois assentos; c) defesa da melhora das condições de vida da população, com dois assentos; d) defesa dos trabalhadores relacionados à questão, que titularizará um assento; e) estudos, pesquisas e formação, com intervenção política na área, também com uma vaga. $^{174}$

Caso não existam candidatos suficientes ao preenchimento de cada uma dessas vagas, assumirão os mais votados remanescentes, independentemente do segmento a que se filiem. É o que determina o inciso II daquele mesmo artigo $6^{\circ}$.

Os candidatos deverão, no caso das entidades, estar necessariamente registrados junto ao CMDCA/SP e, se movimentos: a) comprovar, mediante manifestações públicas de seus representantes, declarações de autoridades públicas, registros comprobatórios ou reportagens que atuam em defesa da causa há pelo menos seis meses; b) apresentar lista nominal, com assinatura e número do documento de identidade, de pelo menos 20 integrantes, da qual conste, ainda, o nome de seus líderes, com os respectivos endereços e a indicação de seu representante. ${ }^{175}$

Referida opção legislativa não permanece isenta de críticas, das quais compartilhamos:

\footnotetext{
${ }^{172}$ No âmbito municipal, referidos movimentos são delineados pelo $\S 1^{\circ}$ do artigo $6^{\circ}$ do Decreto, com redação outorgada pelo Decreto n. 44.728/2004: “§ $1^{\circ}$. Para efeitos deste decreto, entende-se por Movimento todas as organizações não constituídas juridicamente, que comprovem sua atuação no Município por um período mínimo de 6(seis) meses de funcionamento."

${ }^{173}$ Conforme artigo $7^{\circ}$ da Lei municipal n. 11.123/91.

${ }^{174}$ A "explicitação" do conteúdo dessas classes é efetivada por meio do artigo $6^{\circ}$, $\S 2^{\circ}$ do Decreto $n$. 31.319/92, com redação definida pelo Decreto n. 44.728/04: "§ $2^{\circ}$. Para efeitos do disposto no inciso II do 'caput' deste artigo, entende-se por: I - atendimento social à criança e ao adolescente: a prestação de serviços diretos à criança e ao adolescente, cujos programas e projeto encontram-se registrados no CMDCA; II defesa de direitos: a defesa dos direitos fundamentais e especiais das crianças e adolescentes por meio de proteção jurídico-social, atividades organizativas e de mobilização da sociedade; III - defesa da melhoria das condições de vida: a defesa dos direitos sociais, difusos e coletivos dos habitantes do município de São Paulo, inclusive através do fomento e do financiamento de ações voltados à criança e adolescente; IV estudos, pesquisas e formação com intervenção política na área: desenvolvimento d ações de pesquisa, capacitação e consultoria, voltada à área da infância e adolescência, realizadas por universidades, centros de pesquisa, institutos, fundações e grupos de pesquisadores vinculados a uma instituição reconhecida; V defesa dos trabalhadores vinculados à questão: a representação dos trabalhadores e profissionais de áreas afins, desempenhada por organizações como sindicatos, associações profissionais e conselhos profissionais." ${ }^{175}$ Conforme artigo $9^{\circ}, \S 4^{\circ}$, do Decreto municipal n. 31.319/92, com redação outorgada pelo Decreto $n$. $44.728 / 2004$.
} 
Tais requisitos têm o objetivo de garantir que apenas organizações com trabalhos mais consistentes na área infanto-juvenil possam fazer parte do Conselho, a fim de evitar uma representação "vazia" dos anseios da sociedade civil. No entanto, vemos como um pouco exagerado o requisito contido na alínea "b" supracitada, na medida em que exige o nome e o endereço dos "líderes" do movimento, condição que, de certo modo, até implica um caráter "conspiratório" aos movimentos. Atualmente, tais organizações pulverizam a liderança entre várias pessoas, além de desenvolver seus trabalhos com base na idéia de co-responsabilidade de ações entre todos os integrantes, os quais atuam como facilitadores e não como "líderes". Neste sentido, melhor seria que a redação da alínea "b" fosse modificada e passasse a exigir, por exemplo, a identificação e o endereço de um membro do movimento, responsável por responder administrativamente por ele. Além disso, seria importante que constasse do art. $9^{\circ}, \S 4^{\circ}$, do Decreto municipal paulista 44.728/04, bem como em outras legislações pertinentes ao tema, que movimentos fomentadores de violência, discriminação, bem como ações antidemocráticas teriam acesso negado ao Conselho de Direitos. (AUAD, 2007, p. 32).

3. Dispõe o artigo $7^{\circ}, \S 4^{\circ}$, da Lei n. 11.123/91 que "os membros do Conselho e respectivos suplentes exercerão mandato de 2 (dois) anos, admitindo-se a reeleição apenas uma vez e por igual período".

Tal norma não especifica se a vedação de mais de uma recondução se direciona também às pessoas físicas indicadas pelas entidades/movimentos, ou se apenas a estes propriamente ditas.

A discussão gira em torno da titularidade dos assentos no Conselho, questão que será oportunamente aprofundada.

4. O artigo $8^{\circ}$ da Lei municipal elenca as funções do Conselho: a) estabelecer políticas públicas municipais que garantam os direitos da criança e do adolescente previstos em lei; b) acompanhar e avaliar as ações governamentais e não governamentais dirigidas ao atendimento dos direitos da criança e do adolescente, no âmbito do município; c) participar da elaboração da proposta orçamentária destinada à execução das políticas públicas voltadas à criança e ao adolescente, inclusive no que se refere aos conselhos tutelares; d) fiscalizar e controlar o cumprimento das prioridades estabelecidas na formulação das políticas previstas no orçamento; e) gerir o Fundo Municipal dos Direitos da Criança e do Adolescente, a que se refere o art. 88, inciso IV da Lei federal n. 8.069/90, definindo o percentual de utilização de seus recursos, alocando-os nas respectivas áreas, de acordo com as prioridades definidas no planejamento anual; f) controlar e fiscalizar o emprego e utilização dos recursos destinados a esse Fundo; g) elaborar seu regimento interno; h) solicitar as indicações para o preenchimento de cargo de conselheiro, nos casos 
de vacância; i) nomear e dar posse aos membros do Conselho; ${ }^{176}$ j) manifestar-se sobre a conveniência e oportunidade de implementação de programas e serviços, bem como sobre a criação de entidades governamentais ou realização de consórcio intermunicipal; k) inscrever programas, com especificação dos regimes de atendimento, das entidades governamentais e não governamentais de atendimento, mantendo registro das inscrições, do que fará comunicação aos conselhos tutelares e à autoridade judiciária; 1) proceder ao registro das entidades não governamentais de atendimento e autorizar $\mathrm{o}$ seu funcionamento, observado o parágrafo único do artigo 91 da Lei n. 8.069/90, comunicando os conselhos tutelares e a autoridade judiciária da localidade, constituindo-se no único órgão de concessão de registro; m) divulgar a Lei federal n. 8.069, de 13 de julho de 1990 - Estatuto da Criança e Adolescente - dentro do âmbito do município, prestando à comunidade orientação permanente sobre os direitos da criança e adolescente; n) informar e motivar a comunidade, por meio dos diferentes órgãos de comunicação e outros meios, sobre a situação social, econômica, política e cultural da criança e adolescente na sociedade brasileira; o) garantir a reprodução e afixação, em local visível nas instituições públicas e privadas, dos direitos da criança e adolescente, e proceder ao esclarecimento e orientação desses direitos, no que se refere à utilização dos serviços prestados; p) receber, analisar e encaminhar denúncias ou propostas para melhor desenvolvimento da defesa da criança e do adolescente; q) receber, analisar e encaminhar denúncias ou propostas para melhor encaminhamento da defesa da criança e do adolescente; r) levar ao conhecimento dos órgãos competentes, mediante representação, os crimes, as contravenções e as informações que violem interesses coletivos e/ou individuais da criança e do adolescente; s) promover conferências, estudos, debates e campanhas visando a formação de pessoas, grupos e entidades dedicadas à solução de questões referentes à criança e ao adolescente; t) deliberar quanto à fixação da remuneração dos membros do conselho tutelar; u) realizar assembleia anual aberta à população com a finalidade de prestar contas.

Essas atribuições foram reproduzidas pelo Regimento Interno do CMDCA/SP, veiculado pela Resolução n. 79/2005, com o acréscimo da obrigatoriedade de comunicação, nas hipóteses contempladas no item “k”, também ao Ministério Público.

\footnotetext{
${ }^{176}$ Em sentido contrário, vale registrar o disposto no artigo 23 do Decreto municipal n. 31.319/92: "Os membros indicados pelo Poder Público e os membros eleitos serão nomeados Conselheiros, por ato da Prefeita."
} 
O Regimento inseriu uma outra determinação, constante de seu artigo $2^{\circ}$, XXI, segundo a qual cabe ao Conselho "consolidar, atualizar e manter os dados enviados pelos conselhos tutelares prioritariamente através do SIPIA ${ }^{177}$ ou outros relatórios mensais".

A esse órgão é dada, ainda, a missão de controlar e coordenar a atuação de toda e qualquer entidade voltada ao atendimento, promoção ou proteção da criança/adolescente na cidade de São Paulo.

Tal medida destina-se, entre outros aspectos, a garantir a coerência das políticas públicas a serem desenvolvidas, da mesma forma que a sua responsividade, observadas as condições geográficas, o campo de atuação e as necessidades populacionais correlatas.

Isso sem dizer da fiscalização constante com vista a garantir locais seguros, em boas condições de higiene e habitação, conforme se depreende do disposto na Resolução CMDCA/SP n. 47/99 (posteriormente alterada pelas de número 59 e 88).

Daí todas elas terem de obrigatoriamente se registrar junto ao Conselho registro sem o qual não poderão desempenhar qualquer de suas atividades no âmbito municipal. $^{178}$

Temos, por fim, o grande impacto da competência relacionada à gestão dos valores integrantes do Fundo Municipal dos Direitos da Criança e do Adolescente, cuja receita, a título de ilustração, contou, neste ano de 2012, com a estimativa de $\mathrm{R} \$$ 120.643.543,00 (cento e vinte milhões, seiscentos e quarenta e três mil e quinhentos e quarenta e três reais), conforme Lei municipal n. 15.520, de 5 de janeiro de 2012.

\subsection{Participação e deliberação}

O âmbito de exercício da democracia direta, ou participativa, não se limita aos Conselhos, traduzindo-se em técnica de atuação social e interação entre a sociedade civil e o aparato Estatal de incontáveis aplicações e possibilidades.

Nas palavras de Robbe, pode ser definida como "o conjunto dos procedimentos pelos quais o cidadão se envolve diretamente no exercício do poder político, antes, durante ou depois da adoção da norma jurídica” (ROBBE, 2007, p. 15, traduzimos).

Segundo concepção de Parés:

\footnotetext{
177 Sistema de Informação para a infância e Adolescência. Conforme informações constantes do sítio do Ministério da Justiça, "o SIPIA é um sistema nacional de registro e tratamento de informação criado para subsidiar a adoção de decisões governamentais sobre políticas para crianças e adolescentes, garantindo-lhes acesso à cidadania. (BRASIL. Ministério da Justiça, 2010).

${ }^{178}$ Conforme Resoluções CMDCA/SP n. 47 (alterada pelas de n. 59 e n. 88) e n. 79, itens XI e XII.
} 
[...] podemos entender a participação cidadã como todas aquelas práticas políticas e sociais pelas quais a cidadania pretende incidir sobre alguma dimensão daquilo que é público. Debaixo desse guarda-chuva, podemos englobar uma grande quantidade de formas de participação: desde o voto nas eleições representativas até quaisquer formas de ação coletiva de proposta ou reivindicação. [...] podemos falar de práticas de participação cidadã quando essas se situem na lógica da consulta, a deliberação ou a decisão. (PARÉS, 2009, p. 17, traduzimos).

Vejamos ainda:

Somente os processos da democracia deliberativa e pós-decisional apresentam uma característica realmente nova no início do século XX. Os processos de democracia semidireta, ao seu lado, existem desde muitos séculos nos países democraticamente avançados. E o desenvolvimento dos novos processos de democracia deliberativa e pós-decisional, ao lado das técnicas tradicionais de democracia semidireta, que criaram a necessidade de uma expressão nova englobante de todas as formas de participação cidadão dissociadas do processo eletivo. Essa é provavelmente a origem da expressão "democracia participativa". (ROBBE, 2007, p. 16, traduzimos).

A participação cidadã tem a importantíssima função de "transformar um modelo de democracia fraca, cuja prática é restrita aos representantes, especialistas ou profissionais da política, em uma democracia forte, exercida e usufruída por cidadãos ativos, que possam participar da vida política em momentos para além das eleições" (MENDES, 2004, p. 79).

Em outras palavras, a sua razão de ser maior, a sua missão essencial, é emprestar mais legitimidade às decisões políticas, sedimentar a soberania popular, em grau mais extenso e profundo do que se dá com o modelo unicamente representativo. ${ }^{179}$ Toma por base as noções de soberania popular e autodeterminação. ${ }^{180}$

\footnotetext{
${ }^{179}$ Nas palavras de Robbe, “A crítica do sistema representativa não é nova. Ela é tão antiga quanto o próprio sistema representativa, na medida que se pode falar em um estado de crise permanente. [...] a democracia participativa é voltada a suprir as insuficiências da representação." (ROBBE, 2007, p. 18, traduzimos).

180 "Nesse modelo se define que o eixo central da democracia não deve ser somente a legitimidade das decisões do Governo, senão a soberania popular (intransferível) e o direito à autodeterminação (inalienável). Busca-se que a implicação dos cidadãos seja mais frequente e direta, evitando substituir suas capacidades de decisão pelas de seus representantes. Entende-se que os cidadãos são os melhores conhecedores de seus problemas e, portanto, quando podem tomar parte nas decisões públicas que lhes afeta, o farão com mais eficácia que os técnicos do Governo. [...] O modelo participativo [...] surge como uma resposta ao que se considera ineficácia da democracia representativa em atender às aspirações da sociedade e representar os interesses de setores minoritários ou de menor influência no poder institucional. [...] Assim, nos modelos categorizados como 'democracias participativas', os cidadãos são chamados a participar de forma constante na formulação, planificação e/ou gestão de determinadas políticas públicas." (VIEJO et al., 2009, p. 43-44, traduzimos).
} 
Sua concepção gravita em torno da centralidade da prática política, da pretensão de ampliação da cidadania ativa da população a quem, por seu intermédio, será dado interferir determinantemente nos rumos adotados para o atendimento ao interesse coletivo.

Na visão de Mendes, o modo participativo pode ser visto como:

[...] um processo contínuo e autolegislativo, marcado pela criação de uma comunidade política capaz de transformar indivíduos dependentes e privados em cidadãos livres, e interesses parciais em bens públicos. A idéia e ampliação da cidadania justificam a participação a partir da necessidade de maior valorização dos desejos e argumentos de cada indivíduo na construção do espaço coletivo. Cada cidadão tem muito mais a contribuir para a formação da vontade coletiva, e a ganhar com ela, do que o sistema representativo possibilita. A distância entre o potencial latente de participação e a ausência de espaços institucionais capazes de canalizar deliberações públicas mais amplas constitui, para os participativistas, a principal razão" do déficit de legitimidade [...]. (MENDES, 2004, p. 78).

Ainda conforme a autora, seus fundamentos se traduzem em um fortalecimento do espaço público e do processo de tomada de decisões coletivas, que se operacionaliza a partir de: a) aprofundamento democrático, fundado na cidadania e na necessidade e ampliação do exercício político para além do sistema representativo; b) relação direta entre maior participação e redução das desigualdades sociais e democracia material; c) potencial educativo da participação política, capaz de desenvolver as capacidades sociais e políticas individuais. (MENDES, 2004, p. 77).

Constatamos, nesse particular, situação aparentemente paradoxal, vez que a prática da democracia participativa, voltada ao incremento do amadurecimento político da população, depende justamente desse amadurecimento, da existência de uma consciência política social para se fazer viável. ${ }^{181}$

Trata-se, porém, de processo em constante mutação, por meio do qual os dois polos da questão se influenciam e alimentam mutuamente, e que somente pode evoluir com a criação de mecanismos voltados à sua incorporação no modo de pensar, agir e sentir social.

A idealização de referidas ferramentas deve ocorrer, da mesma forma, em ambos os sentidos: tanto pela estrutura estatal — que deve cumprir sua missão maior de melhor

\footnotetext{
${ }^{181}$ Como expõe Robbe, “com efeito, o conteúdo da opinião pouco importa. O que conta, antes de tudo, é a inovação procedimental que consiste em associar os cidadãos a um processo decisório, na medida em que ele é a base de um diálogo entre o eleitor e o eleito. A democracia não pode perdurar sem um envolvimento mínimo dos cidadãos. Mas, em senso inverso, a democracia participativa, não pode perdurar sem o concurso dos eleitos." (ROBBE, 2007, p. 26, traduzimos).
} 
atendimento ao interesse público possível e, portanto, persecução dos ideais de legitimidade e responsividade de sua atuação —, quanto pela iniciativa da própria sociedade mobilizada, cujo amadurecimento político viabilizará, cada vez mais, a clara apresentação e exigência de satisfação de demandas coletivas. ${ }^{182}$

Consiste em fenômeno observado em diversos países ocidentais, dentre os quais a própria França, ${ }^{183}$ tradicionalmente centralizadora e unitária, a qual diagnosticou, nos idos de 2005, influência brasileira nessa área:

\begin{abstract}
A democracia participativa já não invade apenas o discurso e práticas dos "presidentes de região": ela bem poderia situar-se no coração da próxima campanha eleitoral presidencial. Ségoléne Royal, candidato à candidatura pelo partido socialista, escolheu se colocar esse tema no centro de sua pré-campanha. Tudo se passa finalmente como se a esquerda francesa quisesse seguir o caminho traçado pela esquerda brasileira. $\mathrm{O}$ orçamento participativo praticado em Porto Alegre desde os anos 1990 por uma prefeitura do Partido dos Trabalhadores representou um ponto de apoio importante para Lula no caminho à presidência. Certos presidenciáveis franceses, à esquerda do tabuleiro político, quiseram se inspirar nesse modelo. Mas a democracia participativa não sensibilizou as lideranças da direita parlamentar: nos "departamentos" de "Haute de Seine" que preside, Nicolas Sarkozy, cujas ambições eleitorais não são nenhum mistério, organizou duas assembléias gerais para consultar a população. (ROBBE, 2007, p. 11-12).
\end{abstract}

Lembremos que a noção de democracia participativa em hipótese alguma exclui a sua modalidade representativa, ${ }^{184}$ podendo as duas formas conviver tranquilamente (o que corriqueiramente se mostra bastante desejável):

\footnotetext{
182 "De qualquer forma, o interesse contido hoje na 'democracia participativa' está intimamente ligado a uma vontade de superar o déficit democrático que marca o sistema representativo. As novas técnicas de participação realmente libertaram a democracia da lógica binária em que está o momento se encontrava limitada. No processo eletivo e mesmo no referendum, a gama de opções abertas ao cidadão é de toda forma restrita: votar pelo sim, pelo não, preferir um candidato a outro ou, em desespero de causa, abster-se [...]. A cédula eleitoral, instrumento de manifestação democrática limitada, jamais poderá traduzir toda a complexidade da opinião de um cidadão. As novas técnicas democráticas deixam entrever uma democracia mais madura, em que o cidadão poderá exprimir de maneira quase contínua uma opinião suscetível de evolução e múltiplas nuances, indevassáveis na democracia clássica. Essa última sofre certamente da característica da instantaneidade do voto e da classificação efetivada em escalas partidárias limitadas e pré definidas. [...] o desenvolvimento da democracia participativa pode ser percebido como um remédio milagroso que curará as velhas democracias da apatia em que parecem ter caído. As novas técnicas de participação cidadã formarão a base de um novo pacto entre governantes e governados e reduzirá — apesar da dificuldade - a distância que os separa." (ROBBE, 2007, p. 17, traduzimos).

${ }^{183}$ Vale registrar, nesse ponto, a edição da Lei de 27 de fevereiro de 2002, que tornou obrigatória, nas "comunas" com mais de oitenta mil habitantes, a criação de "conseils de quartier", com vista ao estabelecimento de diálogo constante e direto com os cidadãos. Merecem registro, ainda, a lei de 6 de fevereiro de 1992 - pela qual as autoridades locais podem solicitar a manifestação dos cidadãos acerca de quaisquer questões correlatas à sua esfera de competências —, e a Lei Constitucional de 28 de março de 2003, que cria a possibilidade de convocação de referendos acerca de todos os projetos de deliberação e atos relevantes.
} 
A ideia não é a substituição do sistema indireto pelo direto, mas a criação de novos espaços de discussão e deliberação política que eliminem, ou ao menos diminuam, os problemas de legitimidade abertos pelo mecanismo representativo, como a distância entre representantes e representados, a falta de transparência, publicidade e accountability. [...] Trata-se de um sistema de democracia integral, que combina espaços de participação e deliberação direta com os mecanismos da democracia representativa (sistema de partidos políticos, Parlamento e Poder Executivo), entendendo-os não como sistemas antagônicos, mas compatíveis e complementares. (MENDES, 2004, p. 80-82)

Especificamente no que toca aos Conselhos da Criança e Adolescente, ainda mais evidente essa combinação entre representação e participação. ${ }^{185,186}$

\begin{abstract}
Atores coletivos podem participar, de diversas maneiras, de cada um desses três tipos de arranjos institucionais (ou variáveis dependentes). As novas instituições de participação foram intencionalmente criadas para incluir organizações civis, e, em alguns casos, os cidadãos individuais, nos diferentes momentos públicos de tomada de decisão e ação - no desenho e regulação das políticas públicas, na supervisão ou monitoramento da sua implementação e mesmo na sua implementação ou no gerenciamento de programas. Nos conselhos, por exemplo, pode-se ser um membro com assento no conselho, um gestor do fundo de recursos do conselho, ou um participante das audiências públicas convocadas pelo conselho. (HOUTZAGER, LAVALLE; ACHARYA, 2004, p. 274).
\end{abstract}

\footnotetext{
184 Na lição de Viejo, Martí-Costa, Parés, Resende e Vilaregut, "bebendo do pensamento liberal, a democracia representativa se fundamenta na proteção individual dos cidadãos frente ao Estado, e pretende garantir a não intromissão do Estado na vida privada. Esse modelo democrático tem como princípio básico o reconhecimento da soberania popular, expressado pela necessidade de legitimar o Governo e limitar o poder dos governantes. É dizer, os governantes necessitam do consentimento dos governados para administrar as instituições públicas, e, como efeito, os cidadãos têm algum grau de controle sobre as atuações de seus representantes. Através de eleições periódicas e competitivas, os indivíduos podem aceitar ou recusar seus dirigentes, baseados em informações provenientes das associações em que participem ou pela fiscalização do Governo efetuada pela imprensa livre e independente." (VIEJO et al., 2009, p. 40, traduzimos).

${ }^{185} \mathrm{Na}$ lição de Houtzager, Lavalle e Acharya, "[...] enquanto a maior parte da literatura tem pensado a participação nos novos espaços como uma inovação nas modalidades da democracia direta, ou seja, como participação de cidadão ou de indivíduos comuns, atenta-se aqui para a centralidade da participação das organizações civis - fenômeno que desloca a problemática teórica do plano da participação para o terreno espinhoso da representação. [...] as organizações civis têm diferentes capacidades de ação e, portanto, de alcançar e aproveitar as oportunidades criadas pelas novas instituições de participação. [...] indivíduos ou participação de cidadãos, de um lado, e atores coletivos ou participação de organizações civis, de outro, obedecem a diferentes lógicas particulares que não deveriam ser combinadas. Há claros sinais de os últimos estarem construindo novas formas de representação, cuja cabal compreensão não pode simplesmente ser equacionada em termos de democracia direta e cujos traços parecem diferir daqueles próprios às instituições de representação convencionais das democracias liberais. Por certo, isso confirma a importância da distinção entre participação de cidadãos comuns e de organizações civis, bem como a necessidade de se iniciar uma discussão sobre a emergência de formas de representação do cidadão em instituições políticas de participação.” (HOUTZAGER; LAVALLE; ACHARYA, 2004, p. 260-273).

${ }^{186}$ Registre-se, ainda, opinião de Oliveira: "Os conselhos municipais não se consubstanciam em forma de participação política direta, pois os conselhos são instâncias de representação. Todavia, são evidentemente considerados como forma de participação direta." (OLIVEIRA, 2005, p. 100).
} 


\section{Auad acrescenta que:}

A escolha dos Conselheiros que representam a sociedade civil deve ocorrer por meio de um processo democrático realizado periodicamente. Conforme estabelecem o art. 204, II, da Constituição Federal, e o art. 88, II, do Estatuto da Criança e do Adolescente, a participação da sociedade civil se dá por meios de organizações representativas. Assim, não é exigido do Conselheiro civil que seja filiado a um partido político, pois a lógica da escolha é outra; baseia-se na relação do candidato a uma entidade ou movimento relacionados à proteção dos direitos infantojuvenis, aproximando o processo de escolha ao instituto do mandato imperativo. Este requisito tem como objetivo garantir que, na arena da deliberação política, participem, ao lado do governo, pessoas que tenham um certo conhecimento técnico na área, para que a decisão política seja proferida com mais qualidade. (AUAD, 2007, p. 36).

Da mesma forma, deve caminhar de mãos dadas com as técnicas deliberativas ${ }^{187}$ :

[...] Por fim, vale mencionar que a área de intersecção entre as propostas participativa e deliberativa conta com a perspectiva de ampliação horizontal da democracia. A teoria deliberativa, ao reconhecer o espaço informal de opinião pública como essencial para a formação do discurso político, defende a ampliação dos espaços em que a formação da vontade se constitui. O mesmo ocorre com a concepção participativa, que vê na democratização dos locais de trabalho e na intensificação dos movimentos sociais, sobretudo em nível local (associações de moradores, por exemplo) um caminho necessário para a ampliação democrática. $\mathrm{O}$ fortalecimento da participação nessas e em outras esferas contribuiria para a inclusão das redes informais que se formam na opinião pública, por meio do debate de questões coletivas comuns. Enfim, a percepção da democracia pelas duas teorias em questão - a participativa e a deliberativa - apresenta um núcleo comum formado por elementos complementares que, juntos, apontam com mais força para um mesmo sentido. (MENDES, 2004, p. 101).

Detenhamo-nos nesse ponto, a fim de estabelecer claramente o que se entende por democracia deliberativa, para que invocamos a lição de Brugué:

Já nos referimos à democracia deliberativa como um processo decisório baseado no princípio da argumentação. Agora gostaríamos de precisar essa ideia inicial a partir dos 5 pontos que Gutmann e Thompson nos propõem para articular uma definição operante de democracia participativa:

\footnotetext{
${ }^{187}$ Correntemente, na linguagem não técnica, é comum a confusão, o nivelamento e aproximação de ambos os conceitos: “A diferenciação entre 'democracia participativa' e 'democracia deliberativa' é muito difícil de identificar. $\mathrm{Na}$ linguagem corrente, as duas expressões parecem intercambiáveis. É possível, porém, distinguir ambas as noções, a partir da consideração de que a deliberação é um aspecto da participação. (ROBBE, 2007, p. 14, traduzimos).
} 
a) Em primeiro lugar, em uma democracia deliberativa as decisões, para se justificar, hão de ser fundamentadas. A deliberação supõe um intercambio de razões e argumentos. Estes devem se expressar a partir do respeito mútuo e têm como objetivo construir espaços de cooperação.

b) Em segundo lugar, o intercâmbio de razões há de ser compreensível e acessível aos cidadãos. É dizer, a deliberação deve ser pública no duplo sentido de se produzir em um espaço público e de ser compreensível para a cidadania.

c) Em terceiro lugar, as decisões que derivam de um processo deliberativo devem ser vinculantes, ainda que somente durante um certo período de tempo. A deliberação não é um bate-papo informal, mas um processo que deve gerar decisões concretas. Ao mesmo tempo, essas decisões são sempre revisáveis em uma deliberação posterior.

d) O processo deliberativo, em quarto lugar, é sempre dinâmico. Tal como já se afirmava no ponto anterior, o debate deve se fechar para gerar conclusões concretas, ainda que se possa abrir em outro momento para revisão. Essa permanente provisoriedade se justifica tanto pelo fato de as decisões serem sempre imperfeitas como pela necessidade de renovar de forma continuada os acordos políticos.

e) Finalmente, a deliberação se rege pelo princípio da economia moral do desacordo. Trata-se, durante o processo de intercâmbio de razões, de maximizar o respeito mútuo e de minimizar as diferenças. $\mathrm{O}$ desacordo se aceita, ainda que se prioriza a vontade de trabalhar juntos e buscar espaços de acordo e cooperação.

Assim, pois, para esses autores, a democracia deliberativa define uma forma de governar na qual os cidadãos livres e iguais (e seus representantes) se incorporam a um processo de intercâmbio de razões e argumentos, que se realiza de forma pública e compreensível e que serve para justificar decisões concretas, as quais, sem embargo, podem voltar a se revisar no futuro. Tudo a partir do respeito e seguindo o princípio da economia dos desacordos morais. (BRUGUÉ, 2009, p. 131-132, traduzimos).

Nesse diapasão, defendemos uma complementaridade, uma relação de íntima e mútua sustentação entre as noções de participação e deliberação, que passam, assim, a indissociáveis.

Realmente, a partir do momento em que se admite a influência da população nos rumos a serem tomados e nas opções políticas do Estado, a forma a ser adotada, o processo, assumirá, invariavelmente, a forma de discussões em que as diversas opiniões típicas de uma sociedade plural - serão expostas e tomadas em consideração para a adoção do "veredicto" final.

Conforme esclarece Benetulliere, citando Manin:

A democracia participativa inicia [...] verdadeira mudança na concepção da legitimidade que prevalece nas ordens jurídicas. a fonte da legitimidade não é mais a vontade já determinada dos indivíduos, mas são processos de formação, a deliberação [...]. Como a característica da decisão política é se impor à todos, somos levados a pedir a deliberação 
de todos, ou mais exatamente, outorgar a todos o direito de participar da deliberação como a condição de legitimidade essencial. [...] A decisão legítima não é mais a vontade de todos, mas aquela que resulta a deliberação de todos; é o processo de formação das vontades que confere essa legitimidade ao resultado, não as vontades já formadas. [...] a deliberação e o debate político são considerados assim como os motores da mudança [...]. Pelos defensores da democracia participativa, a deliberação não repousa sobre o consenso entre valores preexistentes à deliberação, mas na compatibilização entre eles e as diversas opiniões. O acordo e o consenso não serão mais antecedentes à deliberação, mas sim um seu resultado. Portanto, já não é mais tanto o consenso que representa a noção central da deliberação política, mas sobretudo a possibilidade de que um real dissenso possa efetivamente se exprimir. E, por conseguinte, a criação de um consenso em uma situação ou a expressão de um dissenso podem conferir legitimidade às instituições democráticas em um universo marcado por conflitos sociais e políticos. (BENEULLIERE, 2007, p. 68-69, traduzimos).

Assim, enquanto a faceta participativa da democracia assume um conteúdo eminentemente material, traduzido na efetiva influência popular nos rumos das políticas públicas, o seu aspecto deliberativo exprime um aspecto instrumental, procedimental, correspondente à forma por meio da qual essa participação se dará, com a prolação e tomada em consideração das mais diversas opiniões e posicionamentos expressos na sociedade.

Pontuados esses aspectos, cumpre-nos redirecionar o olhar para o nosso objeto de estudo, qual seja, o Conselho Municipal dos Direitos da Criança e Adolescente de São Paulo, que justamente se desenvolve a partir de uma interessante e interdependente combinação das três modalidades de exercício democrático suprarreferidas. ${ }^{188}$

A participação popular aí se dá por intermédio de representantes eleitos a partir de uma lógica de descentralização e capilarização, cujos mandatos duram dois anos, e que deliberam a respeito dos rumos das políticas públicas da infância e adolescência no município.

Essa representação se estabelece não com pessoas individualmente consideradas, mas com entidades do Terceiro Setor que, por si só, e sob determinado aspecto, já congregam interesses coletivos comuns a determinados grupos e que, portanto,

\footnotetext{
${ }^{188}$ Nas palavras de Cunha e Pinheiro, "os conselhos de política, portanto, foram instituídos a partir dos seguintes princípios : participação — ampliação dos canais de participação política da sociedade —, representação - possibilidade de que diferentes concepções (defendidas por atores sociais e estatais) sobre a amplitude e a direção dos direitos de cidadania se expressem —, deliberação - as decisões sobre a política pública devem ser percebidas por debates inclusivos e públicos — , publicidade - transparência quanto à posição dos atores, aos debates e às decisões que têm efeito vinculante — , autonomia — possibilidade de construírem as regras do seu funcionamento e os seus critérios de decisão." (CUNHA; PINHEIRO, 2009, p. 146).
} 
transcendem o ideal egoístico e individualista tradicionalmente associado ao exercício do poder político nas vias representativas.

\subsection{O destaque das esferas locais de decisão e poder ${ }^{189}$}

O sistema federativo sob o qual está organizado o Estado brasileiro tem como característica fundamental a divisão de competências entre os diversos entes federados.

Daí a União, os Estados, o Distrito Federal e o Município gozarem de atribuições próprias - ainda que por vezes comuns ou concorrentes - e serem regidos pelos princípios existenciais básicos da autonomia, autogoverno e descentralização.

Referidos princípios, por sua vez, se desdobram em outros, de configuração das decisões políticas: federalismo, participação e subsidiariedade. ${ }^{190}$

O desiderato da descentralização, assim como a subsidiariedade, relacionam-se mais diretamente com os municípios, entes mais próximos - e portanto acessíveis — à população.

A Constituição Federal de 1988 dispensou grande destaque a essa esfera até então bastante negligenciada, especificamente quanto à sua autonomia e à extensão de seu âmbito de atuação. ${ }^{191}$

\footnotetext{
${ }^{189}$ Entendido aqui, conforme lição de Gohn, nos seguintes termos: "Nos anos 90 do século XX o poder local passou a ser visto, de um lado, como sede político-administrativa do governo municipal, e mais especificamente, de suas sedes urbanas - as cidades; e de outro, como dinamizador das mudanças sociais por meio das novas formas de participação e organização popular." (GOHN, 2004, p. 63).

${ }^{190}$ Já abordada, com mais detalhes, anteriormente.

${ }^{191}$ Realmente, permanecia até pouco tempo atrás alguma discussão acerca de seu status de ente federativo, conforme retrata Oliveira: "Há, na doutrina, duas posições claras em relação ao município a ser considerado entidade da federação. De um lado, considera-se que o município não pode ser entidade da federação, fundado em argumentos relativos ao princípio federativo, tal como é reconhecido em seus traços históricos principais, como existência de um Senado que representa as entidades que compõem a federação, possibilidade de propor emendas à Constituição da República, possibilidade de submissão ao controle concentrado de constitucionalidade pelo Supremo Tribunal Federal, possibilidade de autonomia plena e existência de Poder Judiciário e Tribunal de Contas próprios. Os autores nessa linha são José Nilo de Castro, Elton Krause e José Afonso da Silva. De outro lado, o município é considerado entidade da federação com fundamento na própria Constituição de 1988, que afirma textualmente tal condição em seu artigo 18, bem como na idéia de que federalismo não é um conceito rígido e que cada ordenamento jurídico lhe dá as características convenientes. Daí, argumenta-se, em contrário, que a existência de Senado, submissão ao controle concentrado do Supremo Tribunal Federal e a possibilidade de propor ementas à Constituição não são necessárias à federação, mas são características que podem ou não ser adotadas em relação aos municípios. Em relação à autonomia municipal, esta foi assegurada, ainda que haja necessidade de legislação estadual para sua criação, pois veja-se que os Estados também não podem ser criados sem interferência de lei federal. E se a existência de tribunal de Contas não é característica histórica inerente ao conceito de federação, veja-se que quanto ao Poder Judiciário, até pouco tempo na União não havia uma justiça federal e que por longo período os municípios tiveram atribuições judiciárias, o que em nada interferiu na caracterização das entidades da federação." (OLIVEIRA, 2005, 48-49).
} 
Atualmente se detecta mesmo uma tendência de "municipalização" da atividade estatal, ou "movimento municipalista", expressamente consagrada no artigo 88 do Estatuto da Criança e do Adolescente e decorrente da própria noção de subsidiariedade. ${ }^{192}$

A subsidiariedade outorga posição de destaque aos entes menores, o que explica, inclusive, a adoção, tanto pela Constituição Federal ${ }^{193}$ quanto pelo Estatuto da Criança e do Adolescente, ${ }^{194}$ de uma estrutura descentralizada e nacionalmente pulverizada.

Voltemos aos princípios existenciais, sob a perspectiva municipal.

No que tange à autonomia: "O teor da autonomia municipal e os traços do federalismo integram o chamado regime jurídico municipal, que deve, no mínimo, tratar de questões como: princípios informadores, estrutura das autoridades municipais com governo próprio, regime de eleições, competências e regime financeiro com fontes próprias." (OLIVEIRA, 2005, p. 46)

Quanto ao autogoverno, corresponde à possibilidade de eleição, à livre estruturação e escolha de seus representantes, sem ingerências externas quaisquer.

A descentralização, finalmente, liga-se ao modo de distribuição de competências, à forma organizacional voltada à obtenção dos melhores resultados.

$\mathrm{Na}$ lição de Oliveira, "o sistema constitucional brasileiro atual adotou a descentralização como a forma de tornar as tarefas estatais melhor realizadas, baseando-se na distribuição de tais tarefas" (OLIVEIRA, 2005, p. 54).

Segundo dispõe o artigo 30, I, II e V, da nossa Carta, aos municípios compete: a) legislar sobre assuntos de interesse local; b) suplementar a legislação federal e a estadual no que couber; c) organizar e prestar, diretamente ou sob regime de concessão ou permissão, os serviços públicos de interesse local, incluído o transporte coletivo, que tem caráter essencial.

A distribuição constitucional de competências vincula portanto a esfera municipal aos interesses locais, ${ }^{195}$ às peculiaridades próprias de sua população e às suas necessidades.

\footnotetext{
192 “A Constituição de 1988 é marcada pelo 'movimento municipalista' que obteve êxito ao incluir vários dispositivos que pudessem referir um regime municipal autônomo e tanto é assim que o município tem seu regime estipulado em capítulo próprio (Cap. IV, Título III), em que se dispõe, por exemplo, sobre as competências municipais, com relevância especial para o interesse local. [...] No regime municipal da Constituição de 1988, a inovação principal é de que há eleições em todos os municípios, sem as restrições constitucionais anteriores, com elaboração de suas próprias leis orgânicas, sendo que as competências foram aumentadas e os controles de gestão ficaram mais rígidos. [...] A municipalização, portanto, tem esse viés de distribuição das tarefas do município, como entidade autônoma, num sentido jurídico constitucional e num sentido político." (OLIVEIRA, 2005, p. 47-53).

${ }^{193}$ Artigo 204, I e II.

194 Artigo 88.
} 
Estabelecidos esses pontos, não cabe a conclusão — um tanto apressada — de que a competência municipal seria residual, traduzida, exclusivamente, nos assuntos dos quais as esferas mais abrangentes não tivessem condições de cuidar.

Tal entendimento não se coaduna com a essência da subsidiariedade, determinante de cenário diametralmente oposto: em toda e qualquer circunstância em que seja viável ao município agir, não haverá que se falar em atuação estatal ou federal. ${ }^{196}$

E a subsidiariedade, da mesma forma que a descentralização, não se direciona exclusivamente às esferas federativas, aos entes federados; vai mais além, assumindo uma faceta política, intimamente ligada à ideia de participação.

[...] na evolução do princípio, tratou-se de aplicá-lo na relação entre comunidades e a organização estatal. O princípio passou a ter uma conotação política. A relação, então entre comunidade maior e menor poderia ser exemplificada por meio das relações entre associações na comunidade e os órgãos estatais.

[...] a subsidiariedade facilita a participação da comunidade nas decisões, pois aquilo que a própria comunidade puder realizar ficará a seu cargo. Portanto, é princípio relacionado diretamente à participação política. Por essa razão é preciso que os municípios, já no exercício prático da

195 Concordamos, no que tange à delimitação sobre o que se entende por interesse local, com a lição de Liberati e Cyrino: “[...] entendemos que a expressão interesse local em nenhum momento quer se referir ao interesse exclusiva do Município, não havendo antinomia entre interesses locais e interesse gerais. Esse também é o pensamento de Cretella Junior, que afirma que 'o traço que torna diferente o interesse local do interesse geral é a predominância, jamais a exclusividade.”” (LIBERATI; CYRINO, 2003, p. 76). Ainda com relação a esse ponto, vale trazer à baila o denominado critério das escalas, também referido pelos autores, e segundo a qual haveria diversas escalas determinantes da atribuição de funções nos diversos níveis federativos, especificamente no que tange à infância e adolescência: (i) escala do poder político, determinante da competência municipal para edição da legislação supletiva à legislação estadual e federal; (ii) escala geográfica, pela qual caberia ao município a manutenção de instituições e programas de âmbito local; (iii) escala financeira, que fixa aos municípios a competência para complementar os recursos federais e estaduais, além de mobilizar outras fontes; (iv) escala técnica, que atribui-lhes o dever de providenciar assistência técnica, dentro de suas possibilidades, a entidades não governamentais; (v) escala econômica, relacionada à viabilidade de alguns serviços de natureza predominantemente econômica. (LIBERATI; CYRINO, p. 79)

196 “O município é o local em que pessoas se inserem na vida do Estado e onde há essa aproximação maior com a organização estatal, percebendo-se maior confiança das pessoas, como demonstrado em pesquisa em que $55 \%$ das pessoas apontaram a prefeitura como instituição de governo de maior importância, sendo a seguir o governo federal com $26 \%$ e o governo estadual com $15 \%$ [...]. [...] o sentido geral do princípio passou a ser formulado como: aquilo que a entidade menor puder fazer bem, ela deve fazer; se não puder fazê-lo, aí a entidade maior fará. [...] Tendo em vista tal formulação, a subsidiariedade exige um juízo em relação a esse 'fazer'. A expressão deve ser relativamente flexível, pois deve-se examinar a questão de fato em cada caso, de acordo com as variáveis históricas relativas à possibilidade de consecução de cada esfera. [...] Em outras palavras, a subsidiariedade significa que deve haver uma limitação relativa ao exercício das macro comunidades, em favor da comunidades intermediárias ou menores, de acordo com a aptidão destas para realizar melhor as tarefas, em virtude da proximidade com as necessidades. A proximidade da necessidade do 'fazer' é que determina que o mais próximo fará o julgamento sobre a possibilidade de 'fazer'. Com a evolução do princípio da subsidiariedade, este relaciona-se com o federalismo, por tratar-se de organização de relações entre várias esferas ou comunidades estatais. Assim, no caso brasileiro, em que há três esferas de federação, considera-se o município como comunidade menor em relação ao Estado-membro e à União, e comunidade menor o Estado-membro em relação à União, que será sempre a comunidade maior." (OLIVEIRA, 2005, p. 44-60). 
subsidiariedade, devem criar, por legislação municipal, mecanismos jurídico-políticos que estimulem a participação da comunidade no debate das questões públicas para determinar o interesse local de acordo com as peculiaridades de cada município.

[...] Em síntese, a subsidiariedade é princípio aplicável à atual realidade municipal brasileira, significando que tudo que comunidade local puder realizar por si, deve lhe caber, exceto se for imprescindível a intervenção do município, cuja ação sempre será preferencial em relação à intervenção do Estado-membro e da União. A adoção desse princípio leva, necessariamente, ao estimulo à participação da comunidade municipal nos assuntos públicos locais e na definição do interesse local. (OLIVEIRA, 2005, p. 59-63).

Isso porque o município já não pode ser visto como a menor esfera por meio da qual é dado ao cidadão participar ativa e politicamente.

Devemos levar em conta outras instâncias, ainda menores e mais fortemente vinculadas à comunidade, ${ }^{197}$ com a qual se relacionam:

[...] na formulação atual do princípio, no que tange ao municipalismo, há duas relações evidentes: a preferência para a ação da comunidade local em relação à do município e preferência da ação do município em relação às ações das demais entidades da federação. A comunidade menor é, no primeiro caso, a própria comunidade local, e, no segundo, o município, que estão mais próximos das necessidades que estão a ensejar alguma ação. [...] A subsidiariedade apresenta limites às ações estatais, de modo que não pode haver ingerência indevida do Estado na vida dos particulares ou das outras entidades da federação, nos municípios. $\mathrm{O}$ papel da comunidade maior - do município em relação à comunidade local ou das demais entidades da federação em relação aos municípios é sempre de promover, coordenar, estimular e auxiliar e não substituir-se nas ações que não lhes são próprias (OLIVEIRA, 2005, p. 60-61).

Registremos, ainda, lição de Moreira Neto, que nesse particular se refere às denominadas "entidades intermédias", 198 ainda "menores" que os municípios, e traduzidas

\footnotetext{
${ }^{197}$ Conforme bem salienta Oliveira, a noção de comunidade ganha, para além do conceito de sociedade, uma outra conotação, na medida em que "a comunidade baseia-se em um sentido de solidariedade, como resultado de relações afetivas ou tradicionais dos participantes, e a sociedade é baseada em uma união no sentido racional entre pessoas, não necessariamente o consentimento formal de participação no grupo sociedade, mas pelo menos a crença no dever de participar. No município, forma-se necessariamente uma sociedade municipal, mas é bem mais comum a formação no sentido de comunidade, em vista da proximidade entre as pessoas." (OLIVEIRA, 2005, p. 41).

198 "[...] E aqui se apresentam as entidades intermédias, antiga figura com roupagens novas. Embora perdendo algumas de suas características históricas herdadas da antiga teoria dos corpos intermédios, tal como a via Montesquieu, hoje elas derivam de uma concepção pluralista da sociedade. Nem por outra razão, foram elas identificadas por Tocqueville nos Estados Unidos da América como fundamentais ao regime liberal. Isso explica porque só recentemente, com a expansão contemporânea dos interesses metaindividuais, elas tornaram a encontrar campo fértil para sua multiplicação. A expressão abrange tanto as entidades intermediárias criadas pela sociedade para cuidar de problemas derivados da existência desses novos interesses coletivos e difusos quanto as criadas pelo Estado para atuar, por delegação, mais proximamente
} 
nos entes estatais e não estatais voltados ao atendimento mais capilarizado, eficiente, responsivo e próximo à população dos interesses coletivos.

No que toca à descentralização, aliás, temos, ainda:

[...] impôs-se a revisão da estrutura do próprio Estado, ou seja, da sua Administração Direta, antes concedida em termos essencialmente unitários e hierarquizados. Foram criados órgãos e agentes autônomos em relação ao chefe do Poder Executivo, ou seja, não integrantes da linha hierárquica tradicional da Administração Pública. A estes fenômenos têm sido ultimamente agregados mecanismos de atuação conjunta da Administração Pública com entidades privadas, mecanismos esses que vão além da tradicional conjugação de esforços para o atendimento de objetivos públicos comuns, alcançando formas jurídicas híbridas, nas quais o Estado não só as apoia como, atraindo-as ao seu âmbito, chega, em certa medida, a participar de sua administração.

Note-se, a esse respeito, que a doutrina vem denominando o atual estágio da organização político-administrativa como o da "devolução de poderes", caracterizada pela retomada de espaços de atuação pública por instituições parciais do Estado e da sociedade. (ARAGÃO, 2003, p. 118).

Nas palavras de Machado:

Salientemos que mais uma vez esta conclusão que se extrai de todo o exposto: a "descentralização" engendra um espaço de participação e de negociação que, dando voz e peso às diversas autonomias sociais, opõem uma barreira ao totalitarismo das maiorias (à "autocracia electiva") e torna a democracia mais rica e mais humana, impedindo a "estatização". Descentralização é, com efeito, o outro nome da liberdade. Representando, nas suas múltiplas manifestações, princípios organizativos da acção diferentes do Estado, em círculos cada vez mais

das comunidades diretamente interessadas." (MOREIRA NETO, 2007, p. 242). E segue o autor: "O mais importante, porém, é que essas entidades intermédias apresentam sensíveis vantagens sobre a tradicional atividade burocraticamente centralizada. O administrativista francês Guy Braibant sintetiza duas: a participação dos interesses e a leveza da gestão. Pode-se lhes acrescentar uma tríade particularmente importante de vantagens: a política, a técnica e a fiscal. A vantagem política reside na abertura da participação do administrado, propiciando um clima de colaboração intenso e benéfico, aumentando, em consequência a legitimidade das decisões da entidade intermédia. A vantagem técnica está na despolitização de inúmeras decisões que, em vez de serem tomadas por indivíduos das áreas política ou burocrática, descomprometidos pessoalmente com os resultados, no sentido do que não são por eles atingidos, passam a ser negociadas pelos grupos sociais mais diretamente interessados, evitando posturas políticas, ideológicas, teorias esdrúxulas, experiências desastrosas e as indefectíveis generalizações fáceis. A vantagem fiscal, por fim, está no fato de que esses entes de cooperação podem vir a ser criados sem gerar novos ônus para o Estado prescindindo de novos tributos para custeá-los, uma vez que os recursos necessários para mantê-los e desenvolver-lhes as atividades, podem vir a ser cobrados a todos os diretamente beneficiados. A utilização da descentralização social por meio de entidades intermédias com personalidade de direito privado, não obstante virem a ter a sua constituição orientada por iniciativa do Poder Público e submetida a modelos estatutários oficialmente preconizados, acrescenta as vantagens peculiares ao aproveitamento mais intenso da sinergia social no trato de problemas complexos. Com efeito, [...] as entidades privadas incumbidas da gestão de interesses públicos se beneficiarão não só da proximidade social com os segmentos da sociedade diretamente interessados numa solução concertada de problemas, como de uma maior riqueza de soluções, que é própria da interação participativa." (MOREIRA NETO, 2007, p. 244-245). 
convizinhos da pessoa do cidadão e indo até o reconhecimento da autonomia pessoal deste, ela garante aquela interação dialéctica capaz de impedir que o mesmo Estado se produza a si próprio, que a massa dos cidadãos funcione, através das eleições políticas, como simples "transductor" de forças que, engendraras pelo enquadramento estatal, a ele regressam sob a aparência de uma legitimação formal mas profundamente autêntica. (MACHADO, 1982, p. 64-65).

Ganham relevo, assim, as organizações locais, que, não obstante não necessariamente integrarem o aparato estatal, representam, mais e mais, verdadeiras instâncias de poder, na medida em que congregam opiniões e posturas determinantes dos rumos a serem adotados pela comunidade correspondente.

Desenvolvem funções de extrema relevância social, já que acabam sendo responsáveis, ou viabilizadoras, dos mais diversos mecanismos de participação popular.

São novas esferas de poder - posto que atuam determinantemente na fixação das prioridades, definição e controle das políticas públicas, por exemplo —, ainda mais restritas, e que se traduzem, dentre outros mecanismos, nos Conselhos.

O exercício da cidadania política, ${ }^{199}$ a efetivação da participação democrática, realmente se opera de maneira muitíssimo mais marcante, direta e efetiva no contexto municipal ou local, comunitário.

A atuação descentralizada — tanto geográfica quanto politicamente — vem transformando a forma de planejamento, gestão e controle de políticas públicas, com o surgimento de uma verdadeira rede participativa.

Nas palavras de Gohn:

O poder local passou a ser visto como espaço de gestão políticoadministrativa e não como simples sede das elites (econômicas, sociais e políticas). Mudanças na conjuntura política e no cenário econômico explicam tais alterações. O poder local foi redefinido como sinônimo de força social organizada, enquanto forma de participação da população, na

\footnotetext{
${ }^{199}$ Confira-se, nesse ponto, a lição de Silva, Jaccoud e Beghin: “A cidadania ampliada, ou a cidadania com iniciativa (Gohn, 1997), pode ser ainda potencialmente produtora de uma nova cultura política; assim, a sociabilidade dela decorrente seria de reciprocidade, isto é, operando num espaço de trocas sancionadas por um novo contrato social no qual a cidadania se constitui na obrigação política vertical entre os cidadãos e o Estado como na obrigação horizontal entre cidadãos. Ou seja, a cidadania é ampliada à medida que acrescenta aos direitos sociais básicos a solidariedade social. Segundo essa perspectiva, ser cidadão significa ser portador de direitos e deveres, mas também poder estar com o outro, num processo de ajuda mútua visando aliviar as carências sociais e ampliar a realização das potencialidades de vida de cada um. Alarga-se, pois, o conceito de esfera pública: numa perspectiva democrática, entende-se que a cidadania não se restringe ao âmbito do Estado, que a 'vida pública' não é feita apenas de atos de governo, mas também de ações de grupos, instituições e indivíduos que têm por fim atender objetivos sociais. Essa nova concepção de cidadania se constitui num controle público não estatal sobre o Estado, o mercado e sobre a própria sociedade." (SILVA; JACCOUD; BERGHIN, 2005, p. 400).
} 
direção do que tem sido denominado empowerment ou "empoderamento" da comunidade, isto é, a capacidade de gerar processos de desenvolvimento auto-sustentável, com a mediação de agentes externos - novos educadores, principalmente das ONGs do Terceiro Setor. O novo processo ocorre, predominantemente, nas novas redes societárias, sem articulações políticas mais amplas com formas tradicionais de organização, tais como partidos políticos ou sindicatos. (GOHN, 2004, p. $63)$.

Esse fenômeno se insere em um contexto maior, de governança local:

Governança local é um conceito híbrido que busca articular elementos do governo local com os de poder local. Ele se refere a um sistema de governo em que a inclusão de novos atores sociais é fundamental, por meio do envolvimento de um conjunto de organizações públicas (estatais e não estatais) e organizações privadas. Ou seja, trata-se de um sistema que poderá envolver, entre outros, as ONGs, os movimentos sociais, o Terceiro Setor de uma forma geral, assim como entidades privadas e órgãos públicos estatais. A governança local diz respeito ao universo das parcerias, a gestão compartilhada entre diferentes agentes e atores, tanto da sociedade civil como da sociedade política, a exemplo do programa de orçamento participativo e os conselhos de representantes municipais de São Paulo. (GOHN, 2004, p. 64).

A esfera pública é ampliada, com a incorporação de atores oriundos da sociedade civil, e que assumem relevante função pública e social. ${ }^{200}$

Nesse contexto se insere, à perfeição, o Conselho Municipal dos Direitos da Criança e do Adolescente: sua composição - não obstante resultante de uma lógica representativa - traduz os anseios, a perspectiva das diversas entidades atuantes na área,

\footnotetext{
200 “O espaço público, quando é utilizado para estabelecer uma arena de interlocução com organizações estatais institucionalizados, sobre problemas públicos, de forma direta ou indireta - através da internet, por exemplo, adentra a esfera pública. Assim, concebemos esfera pública como um lugar de mediação institucional da participação organizada da sociedade civil e de representantes da sociedade política. Trata-se de uma arena para o cidadão expressar, organizar e sistematizar suas demandas, reivindicações, projetos, ações coletivas num processo de relação discursiva entre sociedade civil organizada em função de demandas sociais, Estado e, eventualmente, agentes de corporações do mercado, do poder econômico, onde há uma clara interlocução pública, sobre assuntos públicos. [...] A esfera pública tem um grau de institucionalidade porque há normatizações jurídicas que orientam, formam e informam suas ações. [...] há uma ampliação dos atores presentes na cena das políticas públicas — antes restritos aos agentes administrativos governamentais. Surge assim mais uma explicação para a ampliação da esfera pública, para designar espaços de interação entre a sociedade civil organizada e os gestores públicos instituídos de poder. Portanto, a esfera pública tem como cenário uma relação necessária com os poderes constituídos, com a sociedade política. [...] A esfera pública é um espaço de relações sociopolíticas e culturais, de negociações, de debates, objetivando planejar, equacionar, encaminhar, fazer escolhas, priorizar ações e intervenções a serem feitas pelo poder público, sozinho ou em parceria com entidades da sociedade civil organizada, ou por meio de contratos de concessões de poderes de execução de projetos determinados (no tempo e espaço territorial), com entidades privadas sem fins lucrativos, como ONGs ou outras organizações do Terceiro Setor, em áreas de interesse social, econômico e/ou cultural." (GOHN, 2004, p. 71-73).
} 
com a criação de um diálogo constante e ininterrupto entre os setores mais difusos da população e o governo.

Essa lógica guiou fortemente o sistema concebido pelo Estatuto da Criança e do Adolescente, que depende da manifestação - e atuação expressiva — das populações mais dispersas territorial e socialmente.

Por essa via se busca a almejada responsividade e eficiência das políticas públicas:

\begin{abstract}
Os conselhos gestores (na área da Saúde, do Idoso, da Criança e Adolescente, ou da Assistência Social) atuam e influenciaram a criação de inúmeras outras formas de conselhos institucionalizados, tais como os distritais, regionais temáticos (recursos hídricos, por exemplo: conselhos da bacia de determinado rio), conselhos de representantes de bairros e regiões etc. No plano local os conselhos municipais, distritais ou regionais possuem visibilidade e possibilidades maiores porque estão ao alcance dos cidadãos, dos munícipes que reconhecem de perto a realizada que vivem. Quer seja um conselho gestor, quer seja um conselho de representantes para atuar junto às subprefeituras ou a um programa de orçamento participativo; quer seja um conselho para participar do plano diretor de uma cidade, da discussão dos planos regionais, hidrográficos; quer sejam conselhos comunitários de segurança pública, de defesa dos cidadãos, atuando no plano preventivo no combate à violência e à contravenção, os conselhos de âmbito municipal ou regional tendem a despertar maior interesse na população. Eles têm mais possibilidade de publicizarem suas ações, reunindo condições para serem mais eficientes. (GOHN, 2004, p. 67).
\end{abstract}

Temos, assim, a dimensão do município - e das entidades intermédias enquanto comunidade, como uma rede de relacionamentos em que se desenvolve um sentimento de pertencimento, uma ligação, mais que jurídica e política, social e emocional dos seus cidadãos.

\title{
2.4 Arcabouço normativo aplicável
}

Conforme mencionado em algumas oportunidades ao longo do presente trabalho, a matriz constitucional do Conselho Municipal dos Direitos da Criança e do Adolescente está assente nos artigos 227 e 204 da CF.

A lei nacional disciplinadora desses desideratos é o Estatuto da Criança e do Adolescente — Lei n. 8.069, de 13 de julho de 1990 -, que, em seu artigo 88, II, fixa como norte da política de atendimento, além da municipalização, da descentralização político-administrativa e da mobilização da opinião pública com vista a incrementar a 
participação, a "criação de conselhos municipais, estaduais e nacional dos direitos da criança e do adolescente, órgãos deliberativos e controladores das ações em todos os níveis, assegurada a participação popular paritária por meio de organizações representativas, segundos leis federal, estadual e municipal."

Temos assim que o arcabouço geral e inafastável dos conselhos é fixado pela norma nacional — sua natureza deliberativa, paritária, controladora da ação estatal e participativa -, ficando a sua disciplina e compatibilização com as demandas locais a cargo de cada unidade federativa.

Em nível municipal, a Lei Orgânica do Município de São Paulo estabelece, em seu artigo $7^{\circ}$, parágrafo único, que "a criança e o adolescente são considerados prioridade absoluta do Município".

O artigo 41, consagrador do princípio da participação popular, determina que a "Câmara Municipal, através de suas comissões permanentes, na forma regimental e mediante prévia a ampla publicidade, [...] convocará obrigatoriamente pelo menos duas audiências públicas durante a tramitação de projetos de leis que versem sobre: [...] XII atenção relativa à criança e ao adolescente.”

De seu artigo $200, \S 3^{\circ}$, consta disposição segundo a qual:

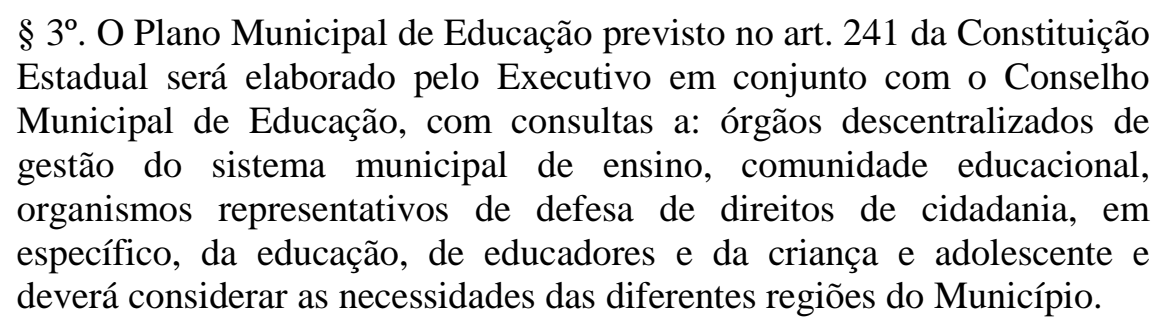

De acordo com o artigo 229: “O Município estimulará, apoiará e, no que couber, fiscalizará as entidades e associações comunitárias que mantenham programas dedicados às crianças, aos adolescentes, aos idosos e aos portadores de deficiência.”

Tem-se, pois, o reconhecimento da posição especial da criança e do adolescente neste Município.

Reconhece-se, também, e ainda que por vezes indiretamente, a importância e magnitude da função desempenhada pelo Conselho Municipal dos Direitos da Criança e Adolescente, cuja atuação é determinante para a satisfatória efetivação das diretrizes constantes do Estatuto e do ordenamento como um todo - incluída aí a Lei Orgânica em questão. 
A lei disciplinadora do Conselho Municipal dos Direitos da Criança e Adolescente é a de número 11.123, de 22 de novembro de 1991, regulamentada pelo Decreto n. 31.319, de 17 de março de 1992. ${ }^{201}$

Referida sistemática foi, nos seus pontos mais relevantes, tratada no item 2.1 supra, ao qual nos remetemos.

À parte esses instrumentais, há também as Resoluções do Conselho, que serão oportunamente objeto de mais detida análise.

Desde já merece destaque, dentre elas, a veiculadora do seu regimento interno e do planejamento estratégico.

Trata-se, a primeira, da Resolução n. 79/2005, que, além de reafirmar diversos mandamentos fixados pela legislação, determina que ao Conselho cabe: a) garantir a efetivação dos direitos da criança e do adolescente referentes à vida, à saúde, à alimentação, à educação, à cultura, ao esporte, ao lazer, à profissionalização, à dignidade, ao respeito, à liberdade e à convivência familiar e comunitária; b) garantir junto às autoridades competentes, o atendimento, conforme estabelecido em lei, nas seguintes hipóteses em que os direitos referidos na alínea "a" forem ameaçados ou violados: (i) por ação ou omissão da sociedade ou do Estado; (ii) por falta, omissão ou abuso dos pais ou responsáveis; (iii) em razão de sua conduta; c) estabelecer políticas públicas municipais que garantam os direitos da criança e do adolescente; d) acompanhar e avaliar as ações governamentais e não governamentais dirigidas ao atendimento dos direitos da criança e do adolescente, no âmbito do Município; e) participar da elaboração da proposta orçamentária destinada à execução das políticas públicas voltadas à criança e ao adolescente, inclusive a que se refere aos Conselhos Tutelares; fiscalizar e controlar o cumprimento das prioridades estabelecidas na formulação das políticas referidas no inciso anterior; gerir o Fundo Municipal para Atendimento dos Direitos da Criança e do Adolescente - Fumcad, ${ }^{202}$ a que se refere o inciso IV do artigo 88 da Lei federal n. 8.069/90 (ECA), definindo o percentual de utilização de seus recursos, alocando-os nas respectivas áreas, de acordo com as prioridades definidas no planejamento anual; f) controlar e fiscalizar o emprego e utilização dos recursos destinados a esse Fundo; g) elaborar seu Regimento Interno; h) solicitar as indicações para o preenchimento de cargo de Conselheiro, nos casos de vacância; i) nomear e dar posse aos membros dos Conselhos Tutelares; j) manifestar-se sobre a conveniência e oportunidade de implementação de

\footnotetext{
${ }^{201}$ Posteriormente alterado pelos Decretos n. 36.385/97, n. 40.996/2001, n. 44.728/2004 e n. 45.744/2005.

202 Doravante desta forma designado.
} 
programas e serviços, bem como sobre a criação de programas governamentais; k) inscrever programas, com especificação dos regimes de atendimento, das entidades governamentais e não governamentais de atendimento, mantendo registro das inscrições e suas alterações, do que fará comunicação aos Conselhos Tutelares, à autoridade judiciária e ao Ministério Público; 1) proceder ao registro das entidades não governamentais de atendimento e autorizar o seu funcionamento, observado o parágrafo único do artigo 91 da Lei federal n. 8.069/90 (ECA), comunicando-os aos Conselhos Tutelares e à autoridade judiciária da respectiva localidade; m) divulgar o ECA (Estatuto da Criança e do Adolescente - Lei federal n. 8.069, de 13 de julho de 1990) no âmbito do Município; n) informar e sensibilizar a comunidade, através dos diferentes órgãos de comunicação e de outros meios, sobre os indicadores sociais da criança e do adolescente na sociedade; o) garantir a reprodução e afixação da relação dos direitos da criança e do adolescente, em local visível, nas instituições públicas e privadas, e proceder ao esclarecimento e orientação sobre esses direitos e a utilização dos serviços prestados; p) receber, analisar e encaminhar denúncias ou propostas para melhor processamento da defesa da criança e do adolescente; q) levar ao conhecimento dos órgãos competentes, mediante representação, os crimes, as contravenções e as infrações que violarem interesses coletivos e/ou individuais da criança e do adolescente; r) promover conferências, estudos, debates e campanhas visando a formação de pessoas, grupos e entidades dedicadas a solução de questões referentes à criança e o adolescente; s) deliberar quanto à fixação da remuneração dos membros dos Conselhos Tutelares, conforme disposto na Lei municipal n. 13.116, de 09 de abril de 2001 e no Decreto municipal n. 40.779 de 26 junho de 2001; t) realizar assembleia anual aberta à população com a finalidade de prestar contas; u) consolidar, atualizar e manter os dados enviados pelos Conselhos Tutelares prioritariamente através do SIPIA ${ }^{203}$ ou outros relatórios mensais.

A segunda, também vinculante da atuação conselheira e administrativa, ${ }^{204}$ veicula o planejamento estratégico, e foi editada originalmente em 2004, sob o número 73.

Tomava por base, então, os problemas à época levantados e constatados, assim como a proposição dos resultados esperados — para cuja consecução fixou ações nominalmente atribuídas aos diversos integrantes do Conselho.

\footnotetext{
${ }^{203}$ Vide nota 177 , supra.

204 Vejam-se, nesse ponto, as ponderações anteriormente traçadas a respeito da força vinculante dos instrumentos de planejamento.
} 
Tratou-se de iniciativa louvável, que possibilitou, a partir do planejamento e organização das ações a serem articuladas, inegável aumento da eficiência e capacidade de atuação - além do fortalecimento institucional do Conselho.

O planejamento assume posição cada vez mais essencial e indispensável à Administração atual, pretensamente garantidora ou promotora das demandas sociais de forma responsiva e responsável.

Lembremos, nesse particular, das palavras de Auad: “[...] para que conquiste um grau de credibilidade satisfatório, o Conselho precisa transmitir confiabilidade à sociedade, e, para isso, torna-se imprescindível que se estruture enquanto órgão, bem como que estabeleça um planejamento estratégico de suas atividades, principalmente para garantir as suas ações" (AUAD, 2007, p. 44-45). ${ }^{205}$

Configura o planejamento imperativo inafastável, que pode ser exigido, inclusive, pelos órgãos de controle, tanto social quanto externo, tal como o Ministério Público.

Atualmente, vige o planejamento estratégico do período 2010-2012, aprovado por meio da Publicação n. 230/2010 do CMDCA-SP, veiculada no Diário Oficial do Município do dia 28 de fevereiro de 2010.

Além do arcabouço normativo específico suprarrelacionado, vale lembrar que irradiam efeitos sobre o CMDCA/SP e suas ações as leis orçamentárias ${ }^{206}$ — plano plurianual, lei de diretrizes orçamentárias e orçamento anual —, além da Lei Complementar n. 101/2000.

\footnotetext{
${ }^{205}$ Vale registrar, ainda: "No início da década de 1960, Miguel Reale já identificava a transformação do eixo primário de atuação do Estado, ao indicar a necessidade de uma ação estatal ativamente voltada à conformação da vida no país. Para ele, 'objetivando a realização de uma comunidade concreta, seria absurdo continuarmos a pregar uma concepção de Estado apático e anêmico, disposto a agir só quando provocado, ao sabor dos intermitentes apelos dos grupos particulares interessados; um Estado sem visão planificadora de conjunto, sem finalidades próprias e sem diretrizes claramente definidas, sem refletir a autoconsciência do destino nacional'. O planejamento, como atividade planificadora de racionalização do emprego dos meios disponíveis para deles retirar os efeitos mais favoráveis e como método de intervenção social e econômica, de um lado, e o plano, de outro, como a 'peça técnica' que adota a forma normativa para torná-la juridicamente vinculante, constituem os exemplos dessa atuação político-jurídica do Estado. Segundo Comparato, em todos os países, a atividade de governar muda de configuração, pois o government by policies veio substituir o government by Law, passando a exigir o exercício combinado de várias tarefas em que o governar não se restringe à administração da conjuntura, mas, sobretudo, ao planejamento do futuro, por meio do estabelecimento de políticas a médio e longo prazo.” (MASSA-ARZABE, 2006, p. 53).

206 "Em uma democracia, pode-se dizer, em síntese, que orçamento público é o instrumento através do qual os cidadãos, por intermédio de lei aprovada por seus representantes no Parlamento, fixam a despesa e preveem a receita para o período de um ano, a partir da determinação dos serviços públicos que serão prestados pelo Estado e dos demais objetivos da política orçamentária, bem como da definição de quais, e de que forma, setores da sociedade financiarão a atividade estatal.” (FURTADO, 2009, p. 42).
} 
Gozam elas de eficácia norteadora da atuação administrativa, na medida em que assumem natureza de lei, tanto em sentido formal quanto material ${ }^{207}$ :

[...] o ordenamento jurídico brasileiro atribui ao Poder Legislativo, nesse aspecto função primordial para o exercício do Estado Democrático de Direito, que é o atuar como freio e contrapeso às pretensões do Executivo. No Brasil, o orçamento é ato final do Poder Legislativo. É lei aprovada, salvo alterações específicas no processo legislativo $(\mathrm{CF}$, art. $166, \S 7^{\circ}$ ), como qualquer outra, começando mediante o projeto formulado pelo Executivo, que será discutido, submetido a emendas e pareceres de comissão, devendo ir à aprovação final, sanção, promulgação e publicação. Esse trâmite possibilita à lei orçamentária ser expressão da vontade popular, aspecto esse que qualifica o orçamento como lei material em sua substância. [...] É importante ressaltar que, desde a edição da Lei 4.320/64, foi adotada no Brasil a ideia do orçamento-programa, cujas características essenciais são as seguintes: a) o orçamento representa o elo entre o planejamento e as ações governamentais; b) a destinação dos recursos está atrelada ao alcance de objetivos e metas; c) as decisões sobre alocações de recursos são realizadas mediante avaliação com base científica das possibilidades existentes; d) as despesas são agrupadas não só pela sua natureza econômica, mas também segundo a classificação funcional-programática, ou seja, os recursos são alocados segundo as funções e programas de governo; e) a organização administrativa do ente e o planejamento são os delineadores da estrutura do orçamento; f) o controle vai além do exame da legalidade, avaliando a eficiência, a eficácia e efetividade das ações governamentais, com base em índices e padrões de mensuração dos resultados dos programas. Tem-se, assim, que o orçamento é de grande importância para o País, e se for mal planejado, ou mal executado, proporcionará graves prejuízos no desempenho da atividade estatal, com vistas ao cumprimento de sua missão. (FURTADO, 2009, p. 46)

O plano plurianual $2010-2013^{208}$ consagra diversas ações — com as respectivas estimativas orçamentárias - a serem patrocinadas e implementadas com a intervenção do Fundo Municipal dos Direitos da Criança e Adolescente, gerenciado pelo CMDCA/SP, dentre as quais merecem destaque:

\footnotetext{
${ }^{207}$ Referido posicionamento, vale registrar, não é pacífico, havendo quem defenda opinião diversa: “[...] o conceito de Kioshi Harada: o 'orçamento é uma lei ânua, de efeito concreto, estimando as receitas e fixando as despesas, necessárias à execução da política governamental'. Ele leva em consideração 'que a própria Constituição Federal confere ao orçamento a natureza de lei (art. 165, III e $\S \S 5^{\circ}, 6^{\circ}$ e $8^{\circ}$ )'. Em sentido diverso é a posição de Luiz Emigdio F. da Rosa Jr., para que 'o orçamento é lei formal, que por ser disciplinada pela Constituição em seção diferente daquela própria das leis, deve também ser considerada lei especial, mas seu conteúdo é de mero ato da administração. Isto porque fixa as despesas públicas e prevê as receitas públicas não podendo versas sobre outra matéria que não seja a orçamentária." (FURTADO, 2009, p. 45).
}

${ }^{208}$ Nos termos da Lei n. 15.090, de 29 de dezembro de 2009. 
1. O fortalecimento da rede de proteção social básica, pelo desenvolvimento de serviços, programas e projetos de acolhimento, convivência e socialização às famílias e indivíduos em situação de vulnerabilidade, com a prevenção de situações de risco.

Dentre as iniciativas aí incluídas estão: a) a administração do Conselho Municipal dos Direitos da Criança e Adolescente; b) prevenção socioeducativa e defesa da criança, do adolescente e do jovem; c) ação socioeducativa e preventiva à criança, ao adolescente e ao jovem; d) infraestrutura da prevenção socioeducativa e defesa da criança, do adolescente e do jovem

2. A defesa dos direitos humanos, a cargo da Secretaria de Governo Municipal, mas com participação, da mesma forma, do Fumcad.

Traduz-se esta última, segundo o plano: a) na proteção especial a crianças e adolescentes ameaçados de morte - PPCAAM, e em b) ações da Comissão Municipal de Enfrentamento à Violência, Abuso e Exploração Sexual contra Crianças e Adolescentes.

Tal norma de planejamento se coloca em termos bastante genéricos, ${ }^{209}$ como um norte a ser observado pelos demais instrumentos orçamentários e orientadora de todas as posturas assumidas pelo Conselho Municipal dos Direitos da Criança e do Adolescente (daí a importância de sua efetiva atuação em todo o processo de propositura e votação da lei).

A Lei de Diretrizes Orçamentárias do ano de $2012,{ }^{210}$ por sua vez, determina, em seu artigo 20, que:

O orçamento de cada um dos órgãos da Administração direta e seus fundos, bem como o das entidades autárquicas, fundacionais e empresas estatais dependentes, discriminará suas despesas, no mínimo com os seguintes níveis de detalhamento:

I - programa de trabalho do órgão;

II - despesa do órgão detalhada por grupo de natureza e modalidade de aplicação;

III - despesa por unidade orçamentária, evidenciando as classificações institucional, funcional e programática, detalhando os programas segundo projetos, atividades e operações especiais, e especificando as dotações

\footnotetext{
${ }^{209}$ Conforme esclarece Furtado, o plano plurianual "é o instrumento de planejamento de médio prazo que deve ser elaborado nas três esferas de governo (federal, estadual e municipal); tem por objetivo estabelecer os programas e as metas governamentais para o período de quatro anos; é formalmente estruturado em programas voltados para a solução de problemas ou atendimento de demandas da sociedade. [...] O plano plurianual, repita-se, não contempla as ações de manutenção administrativa (despesas com pessoal, etc.), o pagamento de benefícios previdenciários e os encargos financeiros. Com efeito, em sede de planejamento para quatro anos, não teria sentido discutir questões relacionadas a aspectos imprescindíveis da manutenção da máquina pública. Nesse espaço, cabe discutir tão-somente aquilo que é passível de escolha.” (FURTADO, 2009, p. 97-98).

${ }^{210}$ Lei n. 15.415 , de 22 de julho de 2011.
} 
por, no mínimo, categoria econômica, grupo de natureza de despesa e de aplicação.

Inescapável a adoção de referidas providências pelo CMDCA/SP.

Sujeitam também diretamente o Conselho os artigos 29 e 30 da LDO:

Art. 29. Na realização das ações de sua competência, o Município poderá transferir recursos a instituições privadas sem fins lucrativos, desde que compatíveis com os programas constantes da lei orçamentária anual, mediante convênio, ajuste ou congênere, pelo qual fiquem claramente definidos os deveres e obrigações de cada parte, a forma e os prazos para prestação de contas.

Art. 30. Fica vedada a realização, pelo Poder Executivo Municipal, de quaisquer despesas decorrentes de convênios, contratos de gestão e termos de parceria celebrados com entidades sem fins lucrativos que deixarem de prestar contas mensalmente à Secretaria Municipal responsável, com informações detalhadas sobre a utilização de recursos públicos municipais para pagamento de funcionários, contratos $\mathrm{e}$ convênios, com os respectivos comprovantes.

$\S 1^{\circ}$. As entidades de que trata este artigo abrangem as organizações sociais - OSs, organizações da sociedade civil de interesse público OSCIPs e demais associações civis e organizações assemelhadas.

$\S 2^{\circ}$. As informações relativas à celebração de convênios, contratos de gestão e termos de parceria serão publicadas no Portal da Prefeitura do Município de São Paulo na internet.

Considerada a Lei Orçamentária do ano de 2012, ${ }^{211}$ por fim, cumpre-nos reafirmar que a receita estimada para o Fundo Municipal dos Direitos da Criança e Adolescente corresponde a R\$ 120.643.543,00 (cento e vinte milhões, seiscentos e quarenta e três mil e quinhentos e quarenta e três reais).

Quanto a essa peça orçamentária, a inter-relação com o Conselho se opera em ambos os sentidos: da mesma forma que ele deve observar as diretrizes fixadas, tem o dever de participar ativamente da sua discussão e elaboração. É o que dispõe o artigo $8^{\circ}$, III e IV, da Lei n. 11.123/91:

Art. $8^{\circ}$. Compete ao Conselho Municipal dos Direitos da Criança e do Adolescente:

[...]

III - Participar da elaboração da proposta orçamentária destinada à execução das políticas públicas voltada à criança e ao adolescente, inclusive a que se refere aos conselhos tutelares;

IV - Fiscalizar a controlar o cumprimento das prioridades estabelecidas na formulação das políticas referidas no inciso anterior;

${ }^{211}$ Lei municipal n. 15.520, de 05 de janeiro de 2012. 
Nas palavras de Barbosa:

\begin{abstract}
A participação no processo orçamentário do município - nos momentos de elaboração do Plano Plurianual, da Lei de Diretrizes Orçamentárias e da Lei Orçamentária Anual - é importante para o exercício das competências de elaboração de um Plano de Políticas Públicas para a Proteção Integral da Criança e do Adolescente e de um Plano de Ação para as verbas do Fundo. Trata-se de um importante desafio na capacitação dos membros dos Conselhos de Direitos. (BARBOSA, 2009, p. 32).
\end{abstract}

Tratemos, por fim, das resoluções do Conselho Nacional dos Direitos da Criança e do Adolescente - Conanda, criado pela Lei federal n. 8.242, de 12 de outubro de 1991 e atualmente regulamentado pelo Decreto n. 5.089, de 20 de maio de 2004.

Referido instrumento legislativo atribui ao Conselho Nacional o dever de elaborar as normas gerais da política nacional de atendimento dos direitos da criança e do adolescente e avaliar a política estadual e municipal e a atuação dos Conselhos Estaduais e Municipais da Criança e do Adolescente.

A primeira atribuição é corporificada por instrumentos como a Resolução n. 42, que justamente fixa "diretrizes nacionais para a política de atenção integral à infância e adolescência nas áreas de saúde, educação, assistência social e trabalho para a garantia de direitos".

A competência atribuída ao Conanda, nesse particular, é adstrita às normas gerais, em razão da própria simetria a ser observada com relação ao texto constitucional, no caso de competência concorrente fixada no artigo $24, \mathrm{XV}$, da $\mathrm{CF}^{212}$

Qualquer dispositivo que desborde desse parâmetro não será consentâneo com o ordenamento jurídico.

\footnotetext{
${ }^{212}$ Conforme assevera Machado Horta "as Constituições federais passaram a explorar, com maior amplitude, a repartição vertical de competência, que realiza a distribuição de idêntica matéria legislativa entre a União Federal e os Estados-membros, estabelecendo verdadeiro condomínio legislativo, consoante regras constitucionais de convivência. A repartição vertical de competências conduziu à técnica da legislação federal fundamental, de normas gerais e de diretrizes essenciais, que recai sobre determinada matéria legislativa de eleição do constituinte federal. A legislação federal é reveladora das linhas essenciais, enquanto a legislação local buscará preencher o claro que lhe ficou, afeiçoando a matéria revelada na legislação de normas gerais às peculiaridades e às exigências estatuais. (MACHADO HORTA, 1995, p. 366). Não fosse isso, os artigos $2^{\circ}$ da Lei n. 8.242/91 e do Dec. n. 5.089/40 são expressos em dizer que ao Conanda cabe "elaborar normas gerais da política nacional de atendimento dos direitos da criança e adolescente", observados sempre os parâmetros fixados pelo Estatuto da Criança e do Adolescente — o qual, por sua vez, e conforme já afirmado, repousa sobre a lógica da descentralização e municipalização.
} 
No que toca à segunda atribuição, eventuais avaliações levadas a efeito pelo órgão federal em hipótese alguma poderão se traduzir em controle efetivo sobre a atuação dos Conselhos das demais esferas, não tendo qualquer caráter mandatório ou vinculante.

Tal assertiva não impede a mobilização, pelo órgão nacional, dos órgãos de controle externo, com vista a garantir uma atuação compatível com as diretrizes nacionalmente traçadas nos diversos níveis.

Referida postura, porém, não tomará por base qualquer hierarquia ou poder de ingerência, sendo usual manifestação de controle externo, ou, por vezes, social.

É o que claramente reconhece, inclusive, e a título ilustrativo, a Resolução n. 44 do Conanda:

Art. $1^{\circ}$ Nos centros urbanos que sejam capitais dos Estados da Federação e no Distrito Federal deverá, no prazo de doze meses, ser providenciada a integração operacional dos órgãos do Poder Judiciário, do Ministério Público, da Defensoria Pública ou serviço congênere, da Segurança Pública e da Assistência Social, preferencialmente no mesmo espaço físico, com vistas à agilização do atendimento inicial ao adolescente a quem se atribua autoria de infração.

Art. $5^{\circ}$ A não obediência ao prazo demarcado no art. $1^{\circ}$ desta Resolução implicará o encaminhamento de representação ao Ministério Público, para os procedimentos legais cabíveis, por descumprimento ao art. 88, inc. V, da Lei 8.069/90.

A Resolução n. 129 explicita a mesma visão:

A Presidente do Conselho Nacional dos Direitos da Criança e do Adolescente - Conanda, no uso das atribuições legais estabelecidos na Lei 8.242, de 12 de outubro de 1991 , art. $5^{\circ}$, parágrafos $1^{\circ}$ ao $6^{\circ}$ do Regimento Interno e a deliberação do Conselho, em sua $158^{\mathrm{a}}$ Assembleia realizada nos dias 12 e 13 de Dezembro 2007 e considerando a aprovação na VII CNDCA, resolve:

Art. $1^{\circ}$ - divulgar e tornar publica as deliberações aprovadas na VII CNDCA, a seguir:

[...] 1 - Regulamentar e implementar os Fundos da Infância e da Adolescência - FIA definindo legalmente um percentual da receita líquida orçamentária nacional, estadual, distrital e municipal para o FIA, respectivamente, e ao mesmo tempo garantir sistematicamente ações de captação de recursos sob a responsabilidade dos conselhos nacional, estadual, distrital e municipal.

[...] 3 - Estabelecer e implementar os parâmetros para operacionalização e fortalecimento do FIA nas três esferas de governo respeitando a autonomia e o caráter deliberativo dos conselhos dos direitos bem como aprovação imediata do PL 1.300/99 que visa a desburocratização dos procedimentos de destinação do imposto de renda. (grifamos) 
Essa lógica se aplica em todos os sentidos e direções: não é só o órgão federal que pode controlar a atuação dos estados e municípios; estes gozam rigorosamente da mesma prerrogativa. ${ }^{213}$

Tal posicionamento toma por base o princípio federativo e a autonomia dos entes federados, consagrados como essenciais pela nossa Carta.

O mesmo raciocínio se aplica quanto ao poder vinculante de todas as outras Resoluções oriundas do Conanda: não se admite a sua ingerência nas demais esferas, sob pena de grave ofensa ao pacto federativo e subversão da premissa de ausência de hierarquia entre os entes, que gozam unicamente de searas de atuação distintas, sem qualquer ordem de prevalência.

Nas palavras de Barbosa:

Cabe notar que o ECA reforça a prioridade assegurada pela Constituição à efetivação dos direitos da criança e ao adolescente com a "destinação privilegiada de recursos públicos nas áreas relacionadas com a proteção à infância e à juventude" (art. $4^{\circ}$ ).

Essa destinação privilegiada dá-se mediante a atribuição de um Fundo Especial a cada Conselho dos Direitos da Criança e do Adolescente, nos diversos níveis da Federação. Os Conselhos (nacional, estaduais e municipais) gerem os respectivos Fundos, denominados Fundos da Infância e da Adolescência - FIA, com autonomia. Não há hierarquia entre eles. (BARBOSA, 2009, p. 38, grifamos).

Vejamos também: "Não há que se falar em hierarquia entre os Conselhos Nacional, Estaduais e Municipais. Cada qual tem seu âmbito de atuação com as respectivas competências que devem desempenhar" (AUAD, 2007, p. 17).

Inexiste hierarquia, subordinação entre os diversos entes políticos, da mesma forma que quanto aos seus respectivos órgãos.

O Estatuto da Criança e Adolescente foi todo erigido sobre as bases da descentralização $^{214}$ e municipalização, noções absolutamente incompatíveis com uma pretensa atuação dominante e norteadora do órgão nacional. ${ }^{215}$

213 “As relações entre a União, os Estados e os municípios, na aplicação do Estatuto implicam, necessariamente, o mútuo controle de desvios eventualmente identificados. A União (vale dizer, o Governo federal) é legitimada para a propositura de ações cíveis por não oferta ou oferta irregular de serviços devidos por parte dos Estados e dos municípios. Cabe ao Conanda (Conselho Nacional dos Direitos da Criança e do Adolescente) papel especial nesse contexto. Sendo ele um controlador das ações em todos os níveis deve atentar para os casos de não oferta ou oferta irregular de serviços pelos Governos federal, estaduais e municipais. Conta o Conanda com o Ministério Público Federal para a adoção de medidas judiciais e extrajudiciais cabíveis". (SEDA, 2008).

${ }^{214}$ Conforme expressamente determina o artigo 204 da CF, aplicável à questão da infância e adolescência em razão do artigo 227, $\S 7^{\circ}$, da mesma Carta: “Art. 204. As ações governamentais na área de assistência social 
O Judiciário já teve oportunidade de manifestar opinião no mesmo sentido:

Ação civil pública. Obrigação de fazer. Sentença que obriga o Município à apresentação de projeto de lei visando a criação de mais um Conselho Tutelar, sob pena de multa diária. Apelação da Municipalidade. Ausência de previsão legal e concreta a respeito. Recomendação do Conanda que não vincula a administração. Ingerência indevida do Poder Judiciário na Administração Municipal e na própria autonomia do Legislativo local. Recurso a que se dá provimento, a fim de julgar improcedente a ação. (TJ/SP, Ap. 990.10.517737-9, Câmara Especial).

O Tribunal de Contas do Estado do Paraná, por unanimidade, entendeu de forma a deixar transparecer a adoção do mesmo posicionamento, ${ }^{216}$ adotando como premissa o fato de que "as medidas propostas na Resolução n. 75/2001 do Conanda são de caráter meramente norteador, e jamais vinculativas". ${ }^{217}$

Outro fundamento possível decorre do fato de às leis de um ente não ser dado interferir na atuação de outro ${ }^{218}$ — o que, com mais razão, se estende às suas resoluções.

serão [...] organizadas com base nas seguintes diretrizes: I - descentralização político-administrativa, cabendo a coordenação e as normas gerais à esfera federal e a coordenação e execução dos respectivos programas às esferas estadual e municipal, bem como a entidades beneficentes e de assistência social; II - participação da população, por meio de entidades representativas, na formulação das políticas públicas e no controle das ações em todos os níveis."

${ }^{215}$ Conforme expõe Seda, de forma contundente: “[...] O primeiro perigo é representado pelo Conanda, Conselho Nacional dos Direitos da Criança, quando desrespeita o princípio da descentralização políticoadministrativa constante do artigo 204 da Constituição Republicana. Essa burocracia federal anda emitindo resoluções inconstitucionais, querendo agir sob o princípio da centralização político-administrativa. Tal centralização vigorava na ditadura, quando esta (através da Lei 4.513, hoje revogada pelo artigo 267 do Estatuto) dava poderes ao obsoleto, extinto, revogado Conselho Nacional do Bem-Estar do Menor (tempo do menorismo oficial) para ditar diretrizes aos municípios. O Conanda não tem competência para traçar diretrizes para municípios. Tem o dever de respeitar as diretrizes constantes do artigo 88 do Estatuto da Criança e do Adolescente. Na ditadura, as diretrizes eram autocraticamente estabelecidas pela burocracia federal (centralização). No regime republicano atual, as diretrizes estão, objetivamente, estabelecidas na lei federal (artigo 88 do Estatuto). E essas diretrizes devem ser cumpridas pela União, pelos Estados e pelos Municípios. O Estado Democrático Brasileiro hoje é uma Democracia Representativa formada pela União, cada Estado e cada Município. Esses três Entes federativos são autônomos e independentes entre si, harmonizados pelos princípios e regras da Constituição Republicana de 1988. O Conanda não pode, portanto, pretender tutelar municípios com regras emitidas por resoluções, porquanto a Constituição Republicana (artigo 24) prevê que, nessa matéria, a União opera exclusivamente com normas gerais. Tais normas gerais são constantes de uma lei, que é o Estatuto da Criança e do Adolescente. Resolução do Conanda não é lei. E as regras para criação, organização e funcionamento do Conselho Tutelar estão sistematicamente previstas no Estatuto Federal, cabendo aos municípios (princípio da municipalização) exercer sua autonomia para a organização de seus serviços essenciais (artigo 30 da mesma Constituição). Não tem cabimento o Conselho Nacional querer tutelar 5.560 municípios, desrespeitando a autonomia constitucional de cada um deles, em atenderem suas peculiaridades locais na organização dos serviços que garantem direitos humanos de crianças e adolescentes." (SEDA, 2008, p. 81-82).

${ }^{216}$ Consulta protocolada sob o n. 296.124/02, do Município de Tijucas do Sul, e que deu origem ao Parecer n. 89/2003, relatado pelo Conselheiro Fernando Augusto Mello Guimarães.

${ }^{217}$ Referida Resolução, vale consignar, encontra-se atualmente substituída pela de n. 139, de 17 de março de 2010 - o que não altera, por óbvio, a validade do conteúdo da decisão colacionada.

218 Excetuadas, aqui, as normas de origem nacional, única transcendente de uma esfera federativa, isoladamente. 
Tal conclusão não leva a que não se deva buscar sempre uma atuação concertada, apta a efetivamente promover de forma eficiente os interesses e direitos da criança e adolescente em todo o território nacional, independentemente das peculiaridades marcantes de cada ente federado. É o que se dessume do princípio constitucional da eficiência, anteriormente abordado com mais detalhes.

\subsection{Composição do Conselho}

O Conselho Municipal dos Direitos da Criança e do Adolescente de São Paulo é composto, conforme asseverado, por representantes do governo e da sociedade civil.

Com relação aos primeiros, a Lei municipal n. 11.123/91, com suas posteriores alterações, elenca os órgãos que deverão indicar representantes com assento no colegiado. $^{219}$

Os representantes governamentais serão conduzidos - considerados os parâmetros normativos respeitantes aos órgãos contemplados com assentos — a partir de decisão discricionária dos respectivos titulares, que se consubstanciará em uma lista tríplice com nomes de agentes ligados à sua estrutura.

A partir desses três indicados — os quais poderão estar inseridos tanto na categoria de efetivos quanto na de comissionados, vez que a legislação não faz qualquer restrição nesse sentido - caberá ao Prefeito escolher dois nomes, um do titular e outro do suplemente a representar a Secretaria no Conselho.

As únicas exigências postas pelo ordenamento local são de que as pessoas indicadas gozem de "poderes de decisão no âmbito de sua Pasta e sejam identificados com a questão".

Conforme asseveram Liberati e Cyrino: "De nada adianta ter assento no Conselho um funcionário que não possa nunca responder pela entidade que representa. Não podemos esquecer que as deliberações do Conselho constituem manifestação do Estado, do Poder Público, com caráter normativo, vinculante, sendo grande a responsabilidade de quem representará a sua entidade.” (LIBERATI; CYRINO, 2003, p. 110).

\footnotetext{
${ }^{219}$ Correspondentes, atualmente, e, conforme Decreto n. 31.319/92, alterado pelo de n. 45.744/05, a: a) Secretaria Municipal de Assistência e Desenvolvimento Social; b) Secretaria Municipal de Saúde; c) Secretaria Municipal de Educação; d) Secretaria Municipal de Finanças; e) Secretaria Municipal de Participação e Parceria; f) Secretaria de Negócios Jurídicos; g) Secretaria Municipal de Esportes, Lazer e Recreação; h) Secretaria Municipal de Cultura.
} 
Aspecto desencadeante de diversas discussões é a possibilidade de a legislação municipal inserir, ${ }^{220}$ entre os membros do Conselho, representantes de instâncias outras, marcadamente do Judiciário e do Ministério Público.

O CMDCA/SP — não obstante sua composição híbrida e sua qualificação como espaço público - está administrativamente vinculado à estrutura do Executivo:

Com a Constituição de 1988, os conselhos de políticas públicas, nos níveis federal, estadual e municipal, se afirmam como parte da estrutura administrativa do Estado, e ao mesmo tempo, canal de expressão e decisão autônomo, composto por representantes do poder público e da sociedade civil. Na década de 1990, esses princípios inspiraram a emergência de um conjunto amplo e diversificado de instâncias colegiadas no âmbito da administração pública, em suas mais diversas áreas. (TATAGIBA, 2004, p. 332)

Adotada essa premissa, posicionam-se Liberati e Cyrino contrariamente à destinação de assentos a representantes de instituições outras:

O juiz da infância e o promotor de justiça da infância podem ter assento no Conselho? Entendemos que não. Aplicando-se analogicamente o disposto no artigo 140, parágrafo único, do ECA, fica vedada a participação de autoridade judiciária e do Ministério Público nos Conselhos dos Direitos da Criança e do Adolescente. Porém, ainda que se possa negar aplicação analógica, recomenda-se a não participação, ou, pelo menos, não assegurar assento em tal Conselho a tais autoridades. No

220 "Vale registrar que a iniciativa de Lei criadora dos Conselhos em âmbito municipal é exclusiva do Prefeito, conforme se depreende, por simetria, do disposto no artigo 61, $\S 1^{\circ}$, II, e, da Constituição Federal: São de iniciativa exclusiva do Presidente da República as leis que: II - disponham sobre: “[...] e. criação e extinção de Ministérios e órgãos da administração pública, observado o disposto no artigo 84, VI; Trata-se de, mais que poder, de dever-poder: É obrigação do prefeito enviar o projeto de lei. Veja-se o raciocínio estabelecido: A) a Constituição Federal de 1988, no art. 204, II, estabelece como exigência a participação da população na formulação de políticas na área da assistência. B) A Lei 8.069/90 (ECA), no art. 87, II, estabelece como diretriz da política de atendimento a criação dos Conselhos, por lei, o respectivo nível de governo. C) Ainda, a Lei 8.069/90 prescreve, no art. 261, parágrafo único, que 'a União fica autorizada a repassar aos Estados e Municípios, e os Estados aos Municípios, os recursos referentes aos programas e atividades previstas nesta lei, tão logo estejam criados os Conselhos dos Direitos da Criança e do Adolescente nos respectivos níveis.' Ora, analisando primeiro a disposição constitucional (CF, art. 204, II), vê-se que o Município precisa assegurar a participação popular na formulação das políticas de atendimento na área de assistência à infância e à juventude. [...] Tais Conselhos deverão ser criados por lei, no caso municipal. Se não fizer a lei, inviabilizará a participação popular; e, assim o fazendo, qualquer política a ser adotada pelo Município será inconstitucional. Por outro lado, extrai-se do parágrafo único do art. 261 do ECA, a contrario sensu, que a União não está autorizada a repassar aos Estados e Municípios, recursos para os programas e atividades previstas na Lei 8.069/90 se não estiverem criados os Conselhos de Direitos. A omissão do prefeito implicará a ausência de recursos financeiros para programas de atendimento de crianças e jovens, negando-lhes o direito à cidadania. Pelo caput do art. 277 da Constituição, e art. $4^{\circ}$ do ECA, fica expresso o dever do Estado (União, Estado-membro, Município e Distrito Federal ) de garantir, com absoluta prioridade, os direitos fundamentais de crianças e jovens. Para garantir a execução da política relativa a cada um dos direitos fundamentais é preciso a existência do Conselho dos Direitos, como órgão formulador de políticas públicas. Assim, resta evidenciado que o prefeito tem o dever de enviar o projeto de lei criando o Conselho dos direitos." (LIBERATI; CYRINO, 2003, p. 102). 
máximo, é aceitável uma atuação de fato, junto ao Conselho, sem direito a voto, evidentemente. [...] É preciso assegurar a independência do órgão ministerial e a imparcialidade do juiz para agirem, até mesmo, e principalmente, se forem obrigados a desconstituir decisões do Conselho, pela via judicial. (LIBERATI; CYRINO, 2003, p. 110).

Da mesma forma, não vislumbramos como aceitável a destinação de cadeiras a membros do Legislativo - ou representantes por ele indicados.

$\mathrm{O}$ desiderato da separação de poderes, com respeito à autonomia de qualquer deles, deve ser respeitado, como forma de garantia, inclusive, do equilíbrio e perfeito funcionamento da engrenagem institucional do Estado.

Não poderia o Parlamento, lançando mão de sua competência legiferante, interferir no âmbito de atuação desse órgão acoplado à estrutura administrativa, com vista a efetivamente causar ingerências em seu funcionamento, com influência sobre os posicionamentos do Conselho e em seu poder de decisão.

Nesse sentido a lição de Moreira, em informativo do Centro de Estudos e Pesquisas de Administração Municipal - $\mathrm{CEPAM}^{221}$ :

[...] ressalte ser bastante comum a indagação sobre a possibilidade de participação de parlamentares nos Conselhos. Adiantamos que não, à luz do princípio da separação e independência dos Poderes $\left(\mathrm{CF}\right.$, art. $\left.2^{\circ}\right)$, pois, sendo os Conselhos órgãos deliberativos ligados ao Executivo, a presença de parlamentares em sua composição viola o princípio da independência dos Poderes, afronta a vedação do exercício de funções simultâneas em mais de um Poder. O mesmo se diga com relação a representantes do Poder Judiciário. (MOREIRA, 2001, p. 25).

O Supremo Tribunal Federal já teve oportunidade de se manifestar na mesma linha:

Constitucional. Ação direta de inconstitucionalidade. Constituição do Ceará, art. 230, $\S 1^{\circ}$. Nomeação de membros para o Conselho de educação. I - As nomeações para os cargos da Administração, ressalvadas as hipóteses inscritas na Constituição, são da competência do Chefe do Poder Executivo (CF, art. 84, XXV), facultadas as delegações indicadas no parágrafo único do mesmo artigo 84, CF. II - Cautelar deferida para suspensão da eficácia, no $\S 1^{\circ}$ do art. 230 da Constituição do Ceará, que cuida da nomeação dos membros do Conselho da Educação, das expressões: "indicados na seguinte proporção: um terço pelo Secretário

${ }^{221}$ Centro de Estudos e Pesquisas de Administração Municipal - CEPAM, fundação ligada à Secretaria Estadual de Planejamento e Desenvolvimento Regional de São Paulo, que, segundo esclarece o seu site: <http://www.cepam.sp.gov.br/index.php?option=com_content\&task=view\&id=1\&Itemid=2>, apoia os municípios no aprimoramento da gestão e no desenvolvimento de políticas públicas. 
de Educação do Ceará e dois terços pelo Legislativo". (MC em ADI 1434/CE, rel. Min. Carlos Veloso)

De igual forma, o Ministério Público do Paraná:

[...] o Conselho de Direitos da Criança e do Adolescente integra o Poder Executivo em virtude de seus fins institucionais que são a elaboração e o controle na execução das políticas públicas para a área infanto-juvenil. Isso demonstra - apesar de haver abalizadas opiniões em contrário que os membros do Poder Público que o integram são apenas os representantes do Poder Executivo, uma vez que nem o Legislativo, nem o Judiciário são possuidores de prerrogativas similares àquelas do Conselho de Direitos, as quais são desempenhadas pelo Executivo. Tratase do respeito ao princípio da separação de poderes (art. $2^{\circ}, \mathrm{CF}$ ). (Disponível http://www2.mp.pr.gov.br/cpca/telas/ca_cd_doutrina_1_7.php. Acesso em: 25 jan. 2012)

Devemos repisar, porém, que o Conselho não integra a esfera estatal, não traduzindo atuar unicamente institucionalizado: trata-se de instância democrática, de espaço público que, justamente por essa condição, deve traduzir os anseios da população junto ao Executivo, sem a interferência de quaisquer instâncias mediadoras.

Sua vinculação à estrutura administrativa tem escopo exclusivamente organizacional, de apoio, cabendo-lhe, mais que se sujeitar ao controle Legislativo, corporificar o controle social da Administração - paralelamente à atuação constitucionalmente reservada ao parlamento.

Trata-se muito mais de verdadeira instância de participação, de fórum de discussão e fixação de diretrizes para a solução dos problemas e demandas sociais, que de tradicional órgão executivo.

Posicionamo-nos, com Oliveira, pela caracterização do Conselho como espaço público, ou esfera pública, afastada a noção tradicional de órgão estatal ${ }^{222}$ :

[...] esfera pública é o espaço dedicado à diversidade de opiniões, onde as pessoas têm oportunidade de igualdade como debatedores, demonstrando a pluralidade de idéias. É a expressão da essência política. A análise da esfera pública tem como pressuposto a necessidade do debate público acerca de questões políticas, tendo como origem o debate político que

\footnotetext{
222 Invocamos, ilustrativamente, Draibe: "Afinal, o que são os conselhos? Constituem estruturas governamentais - nesse caso, submetidos à lógica do Estado e às pressões do sistema de forças hegemônicas? Ou conformam uma esfera pública, ao alargar o espaço democrático e transformarem-se no lócus por excelência da constituição de atores coletivos e de autônomos sujeitos políticos [...]. Os conselhos representam e advogam, ou também fiscalizam e executam? [...] Onde se localizam as fronteiras que separam conselhos e governo, no campo concreto das deliberações políticas?” (DRAIBE, 1998, p. 2).
} 
ocorria na polis grega. [...] A esfera pública e o debate político estão relacionados no sentido de que a esfera pública é o locus onde se dá o debate político no regime democrático, pois permite a participação mais ampla possível de debatedores. É o debate no âmbito da esfera pública que possibilita a identificação de necessidades das pessoas e a implementação de valores comuns. Veja-se que no âmbito da esfera pública trata-se de debate político e identificação de necessidades políticas e não estritamente de bens econômicos. [...] É no âmbito da esfera pública que se devem propiciar fóruns de discussão política com vista à formação de opinião onde atuam, por exemplo, os partidos políticos, os grupos de pressão, as organizações não-governamentais e outras associações. [...] O processo de debate político na esfera pública propicia que os debatedores obtenham mais informações e melhorem ou consolidem a idéia daquilo que realmente são seus objetivos e desejos e possam chegar a uma deliberação sobre a solução razoável e aceitável para todos e não necessariamente de uma verdade absoluta. [...] Em síntese, a participação política em âmbito local deve estar de acordo com a idéia de esfera pública como locus de debate público e de formação da opinião pública. Para isso, devem ser desenvolvidos outros instrumentos de participação política local que não apenas as eleições. (OLIVEIRA, 2005, p. 88-93).

Conforme assevera Dromi, “definitivamente, público e estatal não se identificam. Atualmente existem entidades que não são do Estado, mas que cumprem atividades idênticas às deste e se regulam primordialmente pelo direito público" (DROMI, 1996, p. 131).

Nesse mesmo sentido a lição de Barroso (2009, p. 61-62) e Cassese (2012, p. 34).

Daí que o Conselho não se qualifica como órgão estatal, como integrante do Executivo. Considerado o pluralismo determinante da atuação e participação do maior número de atores possível ${ }^{223}$-, o impeditivo quanto à destinação, ao Legislativo, de assentos no Conselho, poderia, à primeira vista, ceder: desde que o projeto originalmente apresentado pelo Executivo ${ }^{224}$ para aprovação contemplasse essa possibilidade, ela não teria por que ser rechaçada.

Nesses moldes já teve oportunidade de se posicionar o Ministro Sepúlveda Pertence, em voto divergente proferido no julgamento da medida cautelar em ADI n. 143/CE:

\footnotetext{
${ }^{223}$ Nas palavras de Oliveira, "pode-se enumerar alguns requisitos para melhor funcionar a deliberação na esfera pública, tornando efetivo o debate político: a) maior número possível de interessados presentes na deliberação e decisão; b) oportunidades iguais no debate a todos os participantes, para incluir assuntos, argumentar e criticar; c) os argumentos utilizados devem ser racioneis e comprováveis; d) as maiorias não podem estar isolados e a composição de minorias e maiorias devem ser mutáveis de acordo com assuntos em pauta. (OLIVEIRA, 2005, p. 90).

${ }_{224}$ Nos termos exigidos pelo artigo 61, § 1 ${ }^{\circ}$, II, da Constituição Federal.
} 
[...] Não creio que se possa, de logo, irrogar de inconstitucional que a lei, ou no caso a Constituição Estadual, em homenagem ao princípio da "gestão democrática", determine que parte do Conselho, responsável pela administração do "ensino público" no Estado, seja diretamente indicada pelo órgão de representação popular. Não me comove o argumento, que antevejo, de que também o governador do Estado é um mandatário democraticamente escolhido; bastasse isso e o dispositivo do art. 206, VI, seria absolutamente inócuo. Se se considerar que basta que se trate de nomeados pelo governador do Estado para que se tenha 'gestão democrática', então tudo se reduziria à competência do Poder Executivo para prover cargos públicos. (MC em ADI n. 143-4/CE. Relator Min. Carlos Veloso)

Desse olhar compartilha também Perez:

[...] uma das funções genéricas do Legislativo é controlar e fiscalizar a atuação da Administração Pública (art. 49, X, da Constituição Federal). Indicar representantes ou referendar a indicação de representantes que venham a atuar em conselho deliberativo de participação popular na Administração encontra-se dentro do arco de possibilidades oferecidas genericamente ao Legislativo pelo art. 49, X, da Constituição Federal, representando uma forma a mais de controle e fiscalização da Administração (PEREZ, 2009, p. 151).

Não podemos abandonar o foco da natureza da atividade exercida pelo Conselho, de definição e implementação de políticas públicas, portanto análoga àquela desempenhada pelo Executivo.

A designação "separação de poderes" foi há muito substituída pela ideia de separação de funções - as quais não podem reciprocamente se engessar ou impedir seu livre exercício.

Ainda que por vezes os atores institucionais (tradicionais "poderes") e as funções estatais se interpenetrem, em um processo de fixação de diretrizes, previsão em tese, regulamentação e transporte para a realidade, implementação e controle, devem eles estar claramente definidos e incomunicáveis, sob pena de invalidação e neutralização de qualquer possibilidade de controle ou contraposição de visões.

O processo de formulação e execução de políticas públicas segue exatamente essa lógica; não pode estar sujeito à ingerência de atores cuja competência para agir já se exauriu, sob pena de criar uma sucessão de atos circulares, desprovidos de uma lógica verdadeiramente voltada a um resultado prático.

Ao Legislativo cabe fixar as normas gerais e abstratas, enquanto ao Executivo ou à função administrativa, a ser desempenhada inclusive pelo Conselho - , cabe 
transportá-las para o mundo palpável, de forma responsável, responsiva e compatível com os anseios sociais.

Essa racionalidade deve ser rigorosamente respeitada. Uma das funções não pode pretender subverter o aperfeiçoamento das demais. Daí a persistência da vedação de interferência de um Poder — ou melhor, de uma função — sobre outra.

Intacta, ainda sob um ponto de vista democraticamente mais evoluído e aberto, a vedação da participação direta do Legislativo nos Conselhos — por ofensiva à lógica e à dinâmica das funções estatais, e não em razão do desiderato da separação de Poderes, tal como tradicionalmente definido.

Com fundamento na autonomia dos entes federativos, não vislumbramos ser compatível com o ordenamento pátrio, ainda, e da mesma forma, a admissão no Conselho municipal/estadual de representantes estaduais e/ou federais.

Tal postura findaria por comprometer a liberdade e independência de atuação daquelas esferas, as quais, como sói ser, gozam de posicionamento absolutamente equivalente entre si, sem quaisquer traços de subordinação ou hierarquia.

Os representantes da sociedade civil no Conselho serão escolhidos em eleições convocadas pela Administração dentre os indicados por movimentos ou entidades cujos objetivos correspondam a: a) atendimento social à criança e ao adolescente; b) defesa dos direitos da criança e do adolescente; c) defesa da melhoria das condições de vida da população; d) defesa dos trabalhadores vinculados à questão; d) estudos pesquisas e formação com intervenção política na área. Esses aspectos foram mais detidamente objeto de considerações no item 2.1 supra.

Vale ressaltar, porém, que tal participação não se opera individualmente, a partir de cada cidadão isoladamente considerado; contrariamente, se operacionaliza por meio de organizações/entidades.

Nessa categoria estão inseridos tanto entidades do Terceiro Setor quanto os movimentos, ${ }^{225}$ conforme determinado pelos artigos $227, \S 7^{\circ}$, combinado com o 204 da

\footnotetext{
${ }^{225}$ Nas palavras de Houtzager, Lavalle e Acharya, “como conceito, movimento social enfrenta problemas até maiores que 'ONG'. Como ocorreu com as ONGs, um grupo muito diversificado de atores definiram-se como movimento social; pior, um conjunto ainda mais diverso de atores afirma ser membro de movimento social. Esse é o ponto crucial da dificuldade. O conceito é usado nas ciências sociais e no discurso público para referir tanto os atores específicos, que com freqüência usam o termo 'movimento' no nome (o Movimento dos Sem-Teto ou o Movimento de Moradia do Centro de São Paulo), como os agrupamentos de atores coletivos e individuais que partilham uma agenda ou identidade comum (o movimento de saúde, movimento de meio ambiente ou movimento de mulheres). No último caso, organizações civis individuais pertencem a (ou participam de) um movimento social, que aprece ser o uso sociologicamente mais correto e analiticamente mais útil do conceito." (HOUTZAGER; LAVALLE; ACHARYA, 2004, p. 283). Recapitulemos, porém, o disposto no artigo $6^{\circ}, \S 1^{\circ}$ do Decreto n. $31.319 / 92$, com redação outorgada pelo
} 
Constituição Federal; 88, II, do Estatuto da Criança e do Adolescente, e $7^{\circ}$, II, da Lei municipal n. 11.123/91.

Sua escolha se aperfeiçoa por um procedimento democrático, do qual podem participar, na condição de eleitores, quaisquer cidadãos residentes no município de São Paulo, bastando, para tanto, que estejam no gozo de seus direitos políticos e procedam à prévia inscrição. ${ }^{226}$

Consideramos a sistemática estabelecida bastante vantajosa e interessante sob o ponto de vista da participação e da própria democracia: é mais que razoável que a população que será - ainda que por vezes de forma indireta — atingida pelas decisões e políticas públicas estabelecidas pelo Conselho, contribua - ou possa contribuir — para a definição de seus representantes.

O fato de o ordenamento pátrio estabelecer esse liame de representatividade torna incontornável a possibilidade de todo e qualquer cidadão inserido em determinado contexto político-geográfico ter a sua opinião tomada em conta de forma decisiva.

Não obstante a clareza dessa visão, cumpre-nos registrar a existência de pensamento divergente:

[...] verifica-se que a abertura das eleições para todos os residentes da cidade de São Paulo, no exercício pleno de seus direitos políticos, desnatura o mandato dos Conselheiros, o qual se assemelha à natureza do mandato imperativo. Tal abertura foi determinada pelo Decreto 44.728/04 e tem sido alvo de muitas críticas principalmente de militantes e especialistas que atuam em prol dos direitos da criança e do adolescente, os quais alertam para o perigo de eleitores sem qualquer relação com o tema serem cooptados a participar e votarem sem qualquer identificação real com a causa infanto-juvenil, o que põe em risco a própria formação do colegiado conselhista, cujo funcionamento se sustenta a partir da formação de um grupo de conselheiros que tenham um certo conhecimento técnico da área. A redação original do Decreto 31.319/92, apesar de apresentar um processo eleitoral bastante complexo, de certa forma garantia a ligação do eleitor à causa infanto-juvenil, pois limitava o poder de voto apenas aos cidadãos, escolhidos em Assembléias Setoriais, que estivessem ligados aos segmentos que foram descritos no parágrafo anterior. (AUAD, 2007, p. 37)

Não acompanhamos esse ponto de vista da autora, o qual ofende, a nosso ver, e conforme asseverado, a própria lógica participativa e democrática.

Decreto n. 45.744/2005: $\S 1^{\circ}$. "Para efeitos deste decreto, entende-se por Movimento todas as organizações não constituídas juridicamente, que comprovem sua atuação no Município por um período mínimo de 6 (seis) meses de funcionamento."

${ }^{226}$ É o que determinam os artigos $8^{\circ}, \S 2^{\circ}$ e $9^{\circ}$ do Decreto municipal n. 31.319/92. 
$\mathrm{O}$ direito fundamental de participação se insere na categoria dos de quarta geração, sendo dessa forma tanto exercitáveis por quanto oponíveis a toda a sociedade, de maneira marcadamente difusa e não individualizada:

Quanto à quarta camada ou geração de direitos fundamentais [...], é de
assinalar: 1. por vezes são designados também direitos de destinatário
difuso, designação a que não há nada a opor caso com ele não se pretenda
reduzir tais direitos, enquanto subjectivamente radicados, a meros
interesses difusos, assim os dissolvendo; 2 . nessa camada são também
incluídos, por alguma doutrina, os chamados 'direitos de participação
social' que, em rigor, não se reconduziria a qualquer das outras três
gerações e se caracterizariam pelo peso da sua dimensão objectiva, neles
se integrando sejam os direitos de participação social colectiva, como são
entre nós os direitos das comissões de trabalhadores, das associações
sindicais, das associações representativas da família e das associações de
professores, alunos e pais [...], sejam os direitos de participação social
individual como é o direito dos professores e alunos participarem na
gestão democrática das escolas (NABAIS, 2004, p. 53).

Mais um argumento contrário à tese restritiva dos eleitores: na medida em que de direito fundamental se trata, não há razoabilidade na fixação de condições pessoais para o seu exercício - ou, mais que isso, conforme aponta o excerto supratranscrito, na limitação do seu reconhecimento, de sua existência, quanto a apenas um pequeno grupo: aqueles que "guardem alguma relação com o tema".

Entendemos como superficial e descabida a defesa de que a comunidade em geral, toda a organização populacional, não guarda, de alguma forma, e ainda que reflexamente, ligação com a questão da infância e da adolescência.

São elas fatores preponderantemente determinantes do futuro de qualquer organização social, e, portanto, o seu tratamento, a fixação dos rumos a serem adotados para a proteção e a promoção de seus direitos são assuntos insitamente interessantes a todos os integrantes da sociedade - os quais deverão ter garantidos, por todos os meios, e de forma alheia a quaisquer preconceitos ou "etiquetamentos", a tomada em consideração de suas ideias.

\subsection{Titularidade dos mandatos}

A questão da titularidade dos mandatos, se considerada estritamente sob a ótica da legislação constitucional e federal, torna-se de tranquila aferição - a disciplina do assunto é bastante direta e expressa, como adiante será exposto. 
Alguns Conselhos estaduais e municipais, porém - inclusive o do município de São Paulo, foco do nosso estudo - vêm trazendo certa polêmica para esse campo.

As interpretações nebulosas e hesitantes decorrem, no caso do CMDCA/SP, da própria redação dos dispositivos regulamentadores da matéria.

Tomemos, primeiramente, o artigo $9^{\circ}$, caput e $\S 2^{\circ}$, do Decreto municipal $n$. 31.319/92:

Art. $9^{\circ}$. Os representantes da sociedade civil serão eleitos em Assembleia Geral, convocada pelo Executivo para essa finalidade, constituída por munícipes e representantes de entidades e movimentos que tenham entre seus objetivos aqueles referidos nas alíneas "a" e "e" do inciso II do "caput" do artigo $6^{\circ}$, dentre outros.

[...]

$\S 2^{\circ}$. Para fins de participação de seus representantes na Assembleia Geral, na condição de candidatos às vagas de Conselheiros, as entidades e movimentos serão credenciados pelo Conselho Municipal dos Direitos da Criança e do Adolescente, devendo o credenciamento ser referendado pela Comissão Eleitoral.

O texto supratranscrito cria certa confusão, deixando entrever, em algumas passagens, que os candidatos em questão seriam as pessoas físicas, não as entidades e movimentos. Tanto que foi essa a interpretação levada ao Regimento Interno do CMDCA/SP, cujo artigo $4^{\circ}, \S 2^{\circ}$, rege: “Art. $2^{\circ}$. O edital de convocação da eleição dos membros da sociedade civil deverá conter o local, a data, o horário de abertura e encerramento, os segmentos e nomes dos candidatos, seguidos da entidade ou movimento que representam, já credenciados e referendados pela comissão eleitoral.” (grifamos)

Outros dispositivos há, porém, e no mesmo Decreto n. 31.319/92, que conduzem o raciocínio para um desfecho diverso:

Art. 10. Para fins de participação dos seus representantes nas Assembléias Setoriais, as entidades e movimentos serão credenciados pelas Secretarias Municipais ligadas à sua área de atuação, devendo o credenciamento ser referenciado pela Comissão Eleitoral.

$\S 2^{\circ}$. O credenciamento será deferido às entidades e movimentos que atendam as seguintes condições. [...]

Art. $6^{\circ}$. O Conselho é constituído por 16 (dezesseis) membros, na seguinte conformidade:

[...] $\S 3^{\circ}$. Na ausência de candidaturas dos movimentos e entidades referidos no inciso II do caput deste artigo, as vagas serão preenchidas pelos representantes das organizações ou movimentos que obtiverem o maior número de votos e não forem contemplados com as vagas reservadas à categoria à qual pertençam. (destacamos). 
A discussão colocada não se traduz em estéril exercício dialético, vez que a adoção de uma interpretação ou outra trará efeitos absolutamente importantes e distintos.

Tomemos, por exemplo, a hipótese de vacância da função de Conselheiro em razão de morte.

Dispõe o artigo 26 do Decreto municipal n. 31.319/92 que “Art. 26. Na hipótese de substituição e vacância, os suplentes assumirão as vagas dos membros efetivos, ficando como seus respectivos suplentes os candidatos que constarem com número imediatamente inferior de votos, sucessivamente, na lista de eleitos, sempre respeitada a distribuição de vagas prevista no artigo $6^{\circ}$ deste Decreto."

Quem deverá assumir o assento deixado, o suplente, ou um outro representante, vez que a vaga seria da entidade ou movimento, os quais gozam da prerrogativa de nomear um substituto para falar e agir em seu nome?

O fato de os eleitores haverem votado, por ocasião das eleições, em nomes específicos dos candidatos das entidades/movimentos tem o condão de arrastar para o cenário colocado um nível de pessoalidade tal que, uma vez desaparecido o representante eleito, um segundo colocado faria jus à nomeação?

Nesse sentido, inclusive, consulta endereçada pelo CMDCA/SP à Assessoria Jurídica da Secretaria Municipal de Participação e Parceria, em agosto de 2007, por meio do Memorando n. 135/2007/CMDCA.

Desse documento constava questionamento segundo o qual se relatava o afastamento do conselheiro da entidade a que estava vinculado quando da eleição, com a indagação de quem deveria assumir seu lugar.

Defendemos, para a solução do impasse, o raciocínio a seguir desenvolvido.

Consideremos, primeiramente, o artigo $8^{\circ}$ da Resolução n. 115 do Conanda, bastante claro ao articular que:

Art. $8^{\circ}$. A representação da sociedade civil garantirá a participação da população por meio de organizações representativas.

[...]

$\S 4^{\circ}$. O mandato no Conselho dos Direitos da Criança e do Adolescente pertencerá à organização da sociedade civil eleita, que indicará um de seus membros para atuar como seu representante;

Ainda que defendamos - e defendemos — que as resoluções internas de órgãos federais não são dotadas de abstração e generalidade indispensáveis à vinculação de 
quaisquer outras esferas ou entes que lhes sejam alheios, ${ }^{227}$ trata-se, indubitavelmente, de orientação resultante de refletido amadurecimento e consideração do assunto e que, portanto, não deve ser desprezada, como norte, sem qualquer poder de vinculação.

Não fosse o conteúdo dessa norma, há outra, de hierarquia efetivamente superior, veiculada pela própria Constituição Federal, em seu artigo 204, também incidente, como visto, sobre as políticas afetas à infância e juventude.

Tal dispositivo é expresso ao fixar como uma das diretrizes da atuação governamental nessa seara a "participação da população, por meio de organizações respectivas, na formulação das políticas e no controle das ações em todos os níveis".

No mesmo sentido o artigo 88, II, da Lei n. 8.069/90:

Art. 88. São diretrizes da política de atendimento:
II - criação de conselhos municipais, estaduais e nacional dos direitos da
criança e do adolescente, órgãos deliberativos e controladores das ações
em todos os níveis, assegurada a participação popular paritária por meio
de organizações representativas, segundo leis federal, estaduais e
municipais.

Ainda que não fossem tão diretos esses dispositivos, não temos por razoável admitir que a exigência do ordenamento jurídico fosse que o candidato pessoa física lograsse êxito em se aproximar de uma entidade/movimento com a qual não tivesse qualquer ligação, tão somente para conseguir uma indicação condicionante da sua candidatura pessoal.

Circunstâncias como essa esvaziariam a atuação das entidades e movimentos que desempenhariam função unicamente figurativa, adstrita ao aval da candidatura de determinado candidato.

Nesse caso, não haveria porque se exigir referido aval; uma vez não desempenhando as entidades/movimentos qualquer papel relevante, a candidatura deveria ser tida como aberta a todos os cidadãos capazes e no gozo dos seus direitos políticos, e a obrigatoriedade de relação com eles se tornaria completamente ilógica e inexplicável.

Há, ainda, um outro aspecto: retomada a questão anunciada no item 2.1 supra, relativa à vedação de mais de uma recondução dos representantes da sociedade civil estabelecida no artigo $7^{\circ}, \S 4^{\circ}$, da Lei municipal n. 1.123/91.

${ }^{227}$ Conforme anteriormente explanado. 
Defendemos, nesse particular, e observado o até aqui exposto, que referida limitação estaria direcionada às entidades/movimentos, verdadeiros titulares dos assentos no Conselho, detentores dos respectivos mandatos.

Inócua, portanto, qualquer pretensão de substituição apenas dos representantes: uma vez se mantendo a representada, o rodízio determinado pela Lei $^{228}$ não restaria observado com a mera substituição do representante.

No que toca à referida sistemática de "rodízio", posicionamo-nos contrariamente, entendendo que não se coaduna com o princípio constitucional da soberania popular e a com própria noção de participação democrática - a qual se estabelece, a nosso ver, e para além de um princípio ${ }^{229}$ e de um direito fundamental, ${ }^{230}$ na condição de cláusula pétrea do Texto Maior.

Referido princípio, originariamente tido como implícito e decorrente dos desideratos democrático e do Estado de Direito (se bem que já da redação de 1988 constavam diversas indicações específicas expressas quanto à sua incidência ${ }^{231}$ ), foram explícita e genericamente introduzidos por meio da Emenda Constitucional n. 19/1998:

A norma democrática está radicada em todo o texto da Carta de 1988, configurando-se como um princípio geral constitucional concretizado ou explicitado diretamente através do art. $1^{\circ}$ (por meio da definição da República Federativa do Brasil como um Estado Democrático e de Direito) e indiretamente através de outros princípios (como da igualdade, do sufrágio universal, entre outros) ou de regras específicas (como a da periodicidade das eleições para Executivo e o Legislativo, ou a da liberdade da criação de partidos políticos). [...] Tanto o princípio democrático como o princípio do Estado de Direito, uma vez inseridos na Constituição, assumem uma caracterização relativamente complexa, pois passam a nortear a conduta do Estado e da sociedade por parâmetros contemporaneamente aceitos. Melhor dizendo, extrai-se do princípio democrático não somente a obrigação do Estado de respeitar as mais elementares normas da democracia representativa (eleições periódicas, separação de poderes, liberdade partidária), mas também, como salienta

\footnotetext{
${ }^{228}$ Art. $7^{\mathrm{o}}, \S 4^{\mathrm{o}}$, da Lei municipal n. 11.123/91.

229 “[...] da soma de todas as referências expressas que a Constituição Federal brasileira faz à participação popular na Administração e de sua conjugação com os princípios democráticos do Estado de Direito e da eficiência extrai-se que a participação administrativa, em termos constitucionais, representa bem mais que um emaranhado de regras esparsas autorizantes da adoção de institutos participativos em situações específicas. Trata-se, a participação administrativa, de um autêntico princípio constitucional.” (PEREZ, 1999, p. 62).

230 "O direito de constituir organizações da sociedade civil é um dos direitos humanos fundamentais que pertence aos indivíduos e não é concedido pelo governo. Decorre dos direitos basilares da liberdade de expressão e associação, que devem ser consagrados na lei fundamental dos países. Enquanto tal, esse direito não pode ser condicionado à concessão de autoridade pública nem limitado por restrições indevidas, como as relativas ao condicionamento dos pedidos de inserção como membros." (SALAMON, 2005).

${ }^{231}$ Como, exemplificativamente, os artigos 10; 194, VII; 29, X; 187; 198, III; 204, II; 205; 206, VI; 216, § $1^{\text {o; }}$ $225 ; 227, \S 1^{\circ}$.
} 
Canotilho, que ele "implica a estruturação de processos que ofereçam aos cidadãos efetivar possibilidades de aprender a democracia, participar nos processos de decisão, exercer o controle crítico na divergência de opiniões, produzir inputs políticos democráticos", importando, por isso, numa "forma de organização" do Estado e, ao que no interessa, da Administração Pública. Daí concluirmos, desde logo, que tanto o princípio democrático, quanto o do Estado de Direito se expressam no ordenamento jurídico brasileiro como "princípios de organização", ou seja, impõem, para além de uma acepção meramente axiológica, uma forma de organização das funções do Estado que seja voltada a plena realização da democracia participativa e dos direitos fundamentais. [...] Se assim é, ainda que não contasse com nenhuma referência expressa no Texto Constitucional de 1988 (ao avesso do que verdadeiramente ocorre [...], deduziríamos a presença implícita de norma constitucional autorizante da criação de institutos de participação popular na Administração Pública, através dos princípios democrático e do Estado de Direito, princípios básicos de organização do Estado Brasileiro, conforme definido pelo art. $1^{\circ}$ da Constituição Federal. [...] De certa forma, a Emenda Constitucional 19 [...] deu maior ênfase e destaque à participação popular na Administração Pública, afinal, muito embora fossem bastante constantes as referências da Constituição à participação popular, enquanto instrumento de organização de diversos serviços públicos, carecia dessa participação de uma diretiva inserida no âmbito das disposições gerais da Administração pública, no art. 37. (PEREZ, 1999, p. 54-55-59).

Não pode uma lei municipal vir a restringir consideravelmente o alcance de direito fundamental, qualquer que seja ele, de forma, inclusive, a neutralizar a sua previsão, inviabilizando o seu exercício, após a observância de determinadas condições: seria admitir que alguns direitos basilares do nosso ordenamento, uma vez exercidos - ou "utilizados" - expirassem, ficando a sua existência condicionada ao número de vezes que seus titulares deles tivessem lançado mão.

Posicionamo-nos, assim, contrariamente à limitação de vezes de ocupação de assentos no Conselho por parte da sociedade civil, ao menos da forma definitiva e inafastável, como determina a norma vigente.

Vislumbramos a possibilidade de o legislador local vedar a permanência indefinida de determinados conselheiros, em mandatos consecutivos - observada a "quarentena" legalmente fixada, porém, de se admitir a nova candidatura - e eleição de entidades da sociedade civil e movimentos com pretensão de ocupar um lugar junto ao CMDCA.

\subsection{Natureza das decisões}


As decisões do Conselho são veiculadas por meio de resoluções, após considerados os posicionamentos e ponderações de cada um dos integrantes do colegiado, em processo decisório norteado pela técnica da deliberação já explicitada no item 2.2 deste capítulo.

São proferidas a partir de sistemática determinada, ainda que em linhas gerais, pela própria Constituição Federal, que, ao consagrar a participação popular, criou um novo lócus para o desenvolvimento das opções e ações políticas - o qual é investido, portanto, de um grau de legitimidade nunca inferior às demais formas de exercício do poder político, tradicionalmente seguidoras do modelo representativo:

[...] os Conselhos são canais de participação popular, modos de exercício do poder político, oriundos da Constituição Federal como um novo lócus para a escolha das opções políticas de governo. Desta feita partilhadas, suas deliberações já constituem uma escolha com natureza estatal, feita por governantes e pela sociedade civil. (LIBERATI; CYRINO, 2003, p. 89)

[...] a Constituição Federal reservou certas matérias próprias do Executivo para serem formuladas diferentemente do lugar comum: certas manifestações de poder restaram reservadas para um outro lócus de decisão. Assim, as matérias relacionadas aos atendimentos de crianças e jovens, em vez de serem tratadas por seus órgãos da administração direta, com exclusividade, por força de norma de extensão contida no artigo 227, $\S 7^{\circ}$, da Constituição, devem, necessariamente, passar por uma instância diferenciada de poder, a saber, os Conselhos. Não ocorrendo dessa forma, haverá inconstitucionalidade. A clareza do legislador constitucional quanto á intenção de garantir outro local de decisão política, como reserva de manifestação do poder, foi cristalina. [...] além da descentralização política - traduzida pela municipalização, na forma disposta na lei - impôs-se a descentralização administrativa, ou seja, a retirada do poder de formulação, decisão e controle, exclusivamente pela administração direta do poder público. (LIBERATI; CYRINO, 2003, p. 87)

Conforme já asseverado, o Conselho cristaliza as decisões públicas direcionadas — e vinculantes — de toda a sociedade, exatamente da mesma forma que qualquer outro órgão integrante da estrutura institucional estatal tradicional.

Daí suas resoluções assumirem a condição de atos administrativos:

As resoluções são atos administrativos complexos de natureza normativa e, portanto, possuem um comando prescritivo. [...] é um ato administrativo, e, dessa forma, está ligada a uma lei que lhe dê suporte, já que não existe a figura da "resolução anômala" em nosso ordenamento jurídico. Assim, o Direito Infanto-Juvenil está embasado, de forma geral, na seguinte estrutura hierárquico-normativa: comandos constitucionais, 
disposições legais, decretos regulamentares do Poder Executivo e resoluções do Conselho de Direitos. (AUAD, 2007, p. 49).

Nesse particular, acompanhamos a lição de Justen Filho, segundo quem todo e qualquer ente que se encontre no exercício de função pública tem o condão de prolatar/praticar atos administrativos, com todos os atributos ${ }^{232}$ e grau de vinculação que lhe são característicos: "ato administrativo é uma manifestação de vontade funcional apta a gerar efeitos jurídicos, produzida no exercício da função administrativa" (JUSTEN FILHO, 2012, p. 343).

No que toca às resoluções do CMDCA/SP, há quem defenda revestirem-se da condição de atos administrativos complexos, ${ }^{233}$ vez que, para a sua prolação, concorreriam diversos agentes:

[...] ocorre uma transferência do locus onde se dará a escolha ou opção política - a discricionariedade administrativa - que deixa de ser atividade exclusiva do Chefe do Executivo, passando para uma instância colegiada, fazendo com que o ato administrativo se torne um ato complexo, sujeito a múltiplas vontades, as quais serão, depois, sintetizadas em um único ato (resolução) exteriorizado como vontade da Administração ou vontade geral (LIBERATI; CYRINO, 2003, p. 88).

Ressaltamos, porém, que todos os envolvidos na prolação dessas resoluções encontram-se inseridos em um mesmo contexto, em um mesmo órgão - motivo suficiente para atraí-lo para a categoria dos atos simples, que, segundo Bandeira de Mello,:

232 Que, segundo Di Pietro, são: a) presunção de legitimidade ou de veracidade (“A presunção de legitimidade diz respeito à conformidade do ato com a lei; em decorrência desse atributo, presumem-se, até prova em contrário, que os atos administrativos foram emitidos com observância da lei. A presunção de veracidade diz respeito aos fatos; em decorrência desse atributo, presumem-se verdadeiros os fatos alegados pela Administração"); b) imperatividade ("Imperatividade é o atributo pelo qual os atos administrativos se impõem a terceiros, independentemente de sua concordância. Decorre da prerrogativa que tem o Poder Público de, por meio de atos unilaterais, impor obrigações a terceiros”); c) autoexecutoriedade ("Consiste a autoexecutoriedade em atributo pelo qual o ato administrativo pode ser posto em execução pela própria Administração Pública, sem necessidade de intervenção do Poder Judiciário") e d) tipicidade (“Tipicidade é o atributo pelo qual o ato administrativo deve corresponder a figuras definidas previamente pela lei como aptas a produzir determinados resultados. Para cada finalidade que a Administração pretende alcançar existe um ato definido em lei. [...] A tipicidade só existe com relação aos atos unilaterais; não existe nos contratos porque, com relação a eles, não há imposição de vontade da Administração, que depende sempre da aceitação do particular; nada impede que as partes convencionem um contrato inominado, desde que atenda ao melhor interesse público e ao do particular.” (DI PIETRO, 2012, p. 204-208).

${ }^{233} \mathrm{Na}$ lição de Di Pietro, "quanto à formação da vontade, os atos administrativos podem ser simples, complexos e compostos. [...] Atos complexos são os que resultam da manifestação de dois ou mais órgãos, sejam eles singulares ou colegiados, cuja vontade se funde para formar um ato único. As vontades são homogêneas; resultam de vários órgãos de uma mesma entidade ou de entidades públicas distintas, que se unem em uma só vontade para formar o ato. Há identidade e conteúdo e fins.” (DI PIETRO, 2012, p. 229). 
[...] são aqueles produzidos pela declaração jurídica de um único órgão. [...] os atos simples podem ser simples singulares e simples colegiais. No primeiro caso a vontade expressada no ato provém de uma só autoridade, como é corrente. No segundo caso provém do concurso de várias vontades unificadas de um mesmo órgão no exercício de uma mesma função jurídica e cujo resultado final substancia-se na declaração do órgão colegial. É o caso das decisões de Comissões, Conselhos etc. (BANDEIRA DE MELLO, 2012, p. 341).

Referidos atos, em razão da própria competência de que é investido o Conselho — lócus de discussão e elaboração de políticas públicas -, têm um alcance tal que findam por restringir a esfera de discricionariedade do Executivo.

Conforme já explicitado no item 2.1 deste Capítulo, o ordenamento pátrio organizou a distribuição de competências na seara da infância e adolescência de forma que essas arenas de participação ocupassem lugar de destaque. ${ }^{234}$

Voltemos, pois, à discussão quanto ao seu poder vinculante - ou não - dos demais órgãos públicos, privados e cidadãos em geral.

Registremos, de plano, que nem todas as resoluções apresentam idêntica função; existem, na lição de Oliveira, ao menos seis espécies delas:

Em relação aos temas que abordam, podemos classificar, de forma genérica, em seis tipos: resoluções que prevêem políticas públicas para a infância e juventude, aquelas que dispõem sobre ações fiscalizatórias para tais políticas, as que organizam o Conselho Tutelar e o procedimento de suas eleições, as que estabelecem os requisitos para a inscrição dos programas de atendimento das entidades governamentais e nãogovernamentais, bem como o registro de funcionamento destas, as que organizam a realização das Conferências Lúdicas e Municipais dos Direitos da Criança e do Adolescente, além das resoluções que traçam normas para organizar o funcionamento dos Conselhos de Direitos. (OLIVEIRA, 2005, p. 42).

\footnotetext{
234 "Defendemos o ponto de vista de que a extensão dos decretos regulamentares do Poder Executivo na área do Direito Infanto-juvenil é pequena e pode abranger tão somente um detalhamento melhor do conteúdo normativo previsto em lei ordinária, esta emanada do Poder Legislativo e fruto de um processo democrático de deliberação. Todas as diretrizes relacionadas ao desenho de políticas públicas para a criança e o adolescente, conforme determina o art. 204, II, conjugado como art. 227, § $7^{\circ}$, ambos da Constituição Federal, devem ser da competência do Conselho de Direitos. Também defendemos que os detalhes relacionados à estrutura interna dos Conselhos devem ser previstos por meio de um Regimento Interno, a ser publicado no formato de resolução, e não por meio de Decreto do Poder Executivo, a fim de que seja dada aos Conselhos liberdade para, respeitados os parâmetros constitucionais e legais, organizar seu funcionamento com as estruturas administrativas que considerar mais convenientes para enfrentar sua realidade social." (AUAD, 2009, p. 49-50).
} 
No que tange à sua natureza jurídica, porém, todas podem ser incluídas no mesmo contexto, de atos administrativos veiculadores de diretrizes e orientações aos órgãos públicos e à população em geral.

Isso porque o Conselho, conforme afirmado, e inobstante a sua composição híbrida, congregadora de representantes do governo e da sociedade civil, apresenta natureza de órgão público. ${ }^{235}$

Apesar desse seu "acoplamento" à estrutura administrativa, tal fato não implica, conforme exposto, submissão da sua vontade, da decisão alcançada após discussões e deliberações, ao controle hierárquico pelo Executivo.

Não fosse pela dimensão pública, transcendente da estatal, que assume o colegiado, pela sua própria autonomia - incompatível, por si só, com qualquer pretensão de hierarquização ou dominação.

Legalmente, portanto, pode-se afirmar que o Conselho Municipal dos Direitos da Criança e Adolescente de São Paulo assume a condição de órgão público autônomo, livre para decidir sobre as questões que lhe são correlatas. E, como tal, desempenha papel absolutamente fundamental quanto à fixação de diretrizes e definição de políticas públicas.

Daí a sua função de órgão limitante da discricionariedade do Executivo.

\footnotetext{
${ }^{235}$ Registramos aqui nossa preferência pela noção de órgão público em relação a órgão estatal, na medida em que esta última expressão automaticamente arrasta para o contexto em que se insere a compreensão tradicional - e, a nosso ver já ultrapassada - do Estado piramidal, hierarquicamente organizado e marcado pelo controle subordinante em cascatas. Referido modelo foi sucedido, conforme exposto no primeiro capítulo do presente estudo, por uma concepção pulverizada, marcada pela forte aproximação entre as esferas pública e privada, a horizontalização de suas relações. Referimo-nos, assim, à Administração em rede, cujos órgãos não se inserem no padrão subordinante, burocrático e restrito, sendo mais permeáveis e abertos à comunidade. Nas palavras de Junqueira: “A concepção mecânica, com interações rígidas próprias da metáfora piramidal da organização característica do taylorismo, cede lugar a outras formas de conceber a gestão. Valorizam-se as interações entre pessoas, organizações numa perspectiva dinâmica, enfatizando as dimensões horizontal e participativa. Esses atores articulam-se na concepção de objetivos comuns, tendo em vista o bem coletivo, mas preservando sua identidade. Nessa perspectiva é que a noção de rede assume importância, significando a conexão das pessoas e instituições. Ela não é uma realidade em si, mas a possibilidade de estabelecer relações entre diversos atores, preservando as diferenças. Isso remete à idéia de autonomia, de sistema e de complexidade. A rede constitui uma proposta de ação, um modo espontâneo de organização, em oposição a uma dimensão formal e instituída. Ao invés de ser um processo rígido e estereotipado, é criativo e inventivo para buscar saídas novas. A rede surge na percepção conjunta dos problemas comuns e da possibilidade de resolvê-los de maneira integrada. Por isso que a linguagem da rede é uma linguagem de vínculos. Das relações que se estabelecem entre os diversos atores sociais que a constituem, mediados por objetivos construídos coletivamente. Na mesma linha que se pode situar a gestão intersetorial como a integração das diversas políticas setoriais para solucionar os problemas sociais que afetam a população que ocupa o mesmo espaço. Nessa perspectiva que se pode situar também os conselhos. Formas de gestão participativa, que articulam e integram pessoas e instituições na gestão das políticas sociais. Nesse particular, os conselhos assumem um papel relevante. Constituídos por indivíduos que representam diversos segmentos sociais e organizacionais, articulam-se para definir missão, objetivos, avaliar e monitorar desempenho." (JUNQUEIRA, 2001, p. 27).
} 
Uma vez deliberada no Conselho, a medida/política passará a ser de observância obrigatória por todos os demais órgãos/entes públicos municipais, conforme assinala Cunill Grau (2006, p. 182-183).

Os próprios "poderes instituídos" deverão se curvar às decisões tomadas a partir desse importante mecanismo democrático, o qual encontra sua legitimidade diretamente na soberania popular e nos anseios sociais.

Dessa forma, ainda que o Executivo venha a discordar de diretriz fixada pelo Conselho, deverá a ela se curvar; não poderá, em hipótese alguma, e conforme exposto no item 1 supra, revogar ou alterar qualquer ato dessa arena advindo. ${ }^{236}$

Não há como sustentar que o Executivo goza de maior legitimidade que o Conselho, já que foi seu representante escolhido por meio de eleições gerais, em que a todos os cidadãos politicamente ativos foi dada a possibilidade de manifestação e escolha. O colegiado, nesse aspecto, finda por gozar de legitimidade ainda mais evidente, vez que representa mecanismo de participação direta da própria sociedade, por meio de entidades e movimentos, sem a intermediação de um terceiro que delas se descole. ${ }^{237}$

Nesse sentido, posicionamento do STJ:

\footnotetext{
${ }^{236}$ Vale registrar posição divergente de Luciano Ferraz, para quem seria possível o afastamento das orientações do Conselho, desde que motivadamente: "Penso que as decisões do Conselho assumem, de fato, esta característica, o que determina que a autoridade competente se quiser adotar orientação diversa da definida pelo órgão deverá fazê-lo de maneira tecnicamente motivada. Trata-se de noção parelha à de quase vinculação, que desenvolvi a propósito do julgamento das contas dos Chefes do Executivo, que se devem preceder de parecer prévio das Cortes de Contas. Vale dizer que se a decisão da autoridade alinha-se ao que deliberou o Conselho ela - a decisão — nasce automaticamente motivada. Do contrário, se intenta a autoridade afastar-se da deliberação do Conselho deverá demonstrar as razões de ordem técnica, operacional e política que subsidiam a decisão, sob pena de nulidade do ato. (FERRAZ, 2008, p. 7).

237 "É falacioso o argumento de que o Poder Executivo tem legitimidade nas urnas, enquanto que os Conselhos dos Direitos, não, conforme explica Elenaldo Celso Teixeira: 'Quanto ao caráter deliberativo dos Conselhos, devemos considerar dois aspectos. A rigor somente os organismos eleitos por sufrágio universal ou que recebem delegação explícita teriam o poder decisório num regime democrático, em que a regra da maioria é o princípio basilar que se traduz na eleição por voto universal. Devemos considerar, porém, que o nosso regime representativo sofre uma grave crise de legitimidade decorrente do uso de mecanismos ilícitos no processo eleitoral e das distorções do sistema que descaracterizam a vontade do eleitorado. Por outro lado, estamos diante de um processo de mudanças nas relações entre Estado e sociedade em que vários espaços de interlocução e de negociação começam a surgir. Estes passam a ser uma legitimidade que denominamos de substantiva, embora não se pautem pelas regras de uma legitimidade 'procedimental' provinda de eleições ou decisão de maiorias. Embora não sejam eleitos como representantes da maioria da população, a legitimidade dos membros do Conselho decorre da sua estreita vinculação à sociedade através das entidades representadas e do processo de interlocução que estes desenvolvem ou podem desenvolver com a população. Ademais, a simples manifestação periódica da vontade em torno de candidatos construídos pela mídia não torna os cidadãos influentes nas políticas ou nas decisões específicas que não são publicamente explicitadas.' Percebe-se, portanto, que a democracia participativa estrutura um novo modelo institucional em que a legitimidade das urnas não é mais o único instrumento para garantir que os anseios populares ecoem para dentro do aparelho estatal." (AUAD, 2007, p. 62-63).
} 
Administrativo e processo civil - ação civil pública - ato administrativo discricionário: nova visão.

1. Na atualidade, o império da lei e o seu controle, a cargo do Judiciário, autoriza que se examinem, inclusive, as razões de conveniência e oportunidade do administrador.

2. Legitimidade do Ministério Público para exigir do Município a execução de política específica, a qual se tornou obrigatória por meio de resolução do Conselho Municipal dos Direitos da Criança e do Adolescente.

3. Tutela específica para que seja incluída verba no próximo orçamento, a fim de atender a propostas políticas certas e determinadas.

4. Recurso especial provido. (grifamos) (STJ, REsp. 492.811/SP, rel. Min. Eliana Calmon)

Assentado esse ponto, cabe-nos tratar especificamente dos casos de incompatibilidade entre a análise política do Conselho e as ponderações técnicas da Administração, quando o Conselho, por exemplo, aprova o registro de alguma entidade ou projeto, ou opta por determinada política pública em dissonância com o ordenamento jurídico.

Em situações tais, mais além da autonomia do colegiado e do caráter vinculante de suas decisões, verifica-se um vício comprometedor da legalidade em sentido lato.

Conforme anteriormente visto, a noção legalidade — ou de juridicidade — traz em seu bojo a exigência de eficiência, que implica, por sua vez, a aplicação da melhor solução possível para um dado contexto.

Incompatível com os parâmetros técnicos, a decisão conselhista não atenderá a esses desideratos, motivo pelo qual poderá ser tida por nula pelo próprio colegiado ou pelo Judiciário - a ser provocado tanto pelo Executivo, pelo Ministério Público, ou qualquer outro interessado, via controle social.

Justamente pela natureza da função que exercem - eminentemente política — os conselheiros devem se furtar a ingressar na seara técnica, a qual fica reservada aos agentes especializados incumbidos de tal análise.

Conforme salienta Oliveira, "não é possível passar ao povo o direito de tomada de decisões técnicas acerca de obras e serviços, pois para tal é necessário corpo técnico especializado. De fato, torna-se necessário, na atribuição de tarefas no âmbito municipal, distinguir-se entre o âmbito técnico e político.” (OLIVEIRA, 2005, p. 116).

Convém esclarecer que a teoria do município não pretende que o agir político absorva todas as funções comuns, pois uma coisa é o mundo das grandes e importantes decisões - fins -, reservadas ao povo, e outra a execução dos serviços - meios —, que, por seu caráter técnico, devem 
ser executados pela administração especialmente capacitada. É necessário, então, estabelecer uma clara distinção de possibilidades; [...]. Se tivéssemos que sintetizar, diríamos: politizar o cidadão e despolitizar o mundo técnico dos serviços municipais cuja política está a cargo dos primeiros. (GOMEZ, 1991, p. 59, traduzimos).

\subsection{As atividades/projetos passíveis de custeio pelo Fundo Municipal dos Direitos da Criança e do Adolescente - Fumcad: complementaridade}

De acordo com previsão constante do artigo 88, IV, do Estatuto da Criança e do Adolescente, todos os entes federados deverão instituir, em seus respectivos âmbitos, e paralelamente aos Conselhos de Direitos, fundos a eles vinculados.

Referidos fundos - ora denominados Fundo da Infância e Adolescência, ora Fundo da Criança e do Adolescente —, têm justamente a missão de custear e viabilizar as políticas públicas a serem promovidas pelo Conselho correlato.

Na lição de Barbosa, "os fundos da infância e da adolescência são instrumentos de gestão pública que se inserem na lógica da democracia participativa, pois respaldam as deliberações políticas dos Conselhos de Direitos da Criança e do Adolescente" (BARBOSA, 2009, p. 43).

Apresentam natureza de fundo especial, ${ }^{238}$ nos termos do artigo 71 da Lei federal n. 4.320/64, que veicula a seguinte definição: "constitui fundo especial o produto de receitas especificadas que por lei se vinculam à realização de determinados objetivos ou serviços, facultada a adoção de normas peculiares de aplicação". ${ }^{239}$

São vinculados a finalidades específicas e inescapáveis, constituindo unidade orçamentária com destinação própria e configurando exceção à regra da unidade de tesouraria, consagrado no artigo 56 da Lei federal n. 4.320/64 ${ }^{240}$ :

Uma terceira nota distintiva consiste em que o fundo especial não se subordina ao princípio da unidade de tesouraria (art. 56 da Lei 4.320/56), isto é, os seus recursos podem ser mantidos fora da "caixa única" do governo. Os fundos especiais criados por lei, da mesma forma que aqueles previstos na Constituição, ficam sob uma certa suspeita de serem

\footnotetext{
${ }^{238}$ Conforme lição de Liberati e Cyrino, “da especialidade e da especificação resulta a necessidade de vinculação do produto dessas receitas à realização de objetivos predeterminados, sendo esta a verdadeira razão de existência dos fundos.” (LIBERATI; CYRINO, 2003, p. 219).

${ }^{239}$ De se registrar que a disciplina correlata à criação de fundos dependeria da edição de Lei Complementar disciplinadora do disposto no artigo $165, \S 9^{\circ}$, II, da Constituição Federal. Na ausência de referida norma, porém, necessário o recurso à referida Lei n. 4.320/64.

240 "Art. 56. O recolhimento de todas as receitas far-se-á em estreita observância ao princípio da unidade de tesouraria, vedada qualquer fragmentação para criação de caixas especiais."
} 
prejudiciais à administração financeira, pela pulverização dos recursos que provocam e pela manutenção de contas bancárias à margem da caixa única. A sua legitimidade dependerá dos objetivos específicos e relevantes de suas despesas e da possibilidade de angariar receitas extraorçamentárias, como é o caso dos fundos da criança e do adolescente. (TORRES, p. 6).

No âmbito do Município de São Paulo, o Fundo Municipal dos Direitos da Criança e Adolescente foi criado pela Lei municipal n. 11.247 , de $1^{\circ}$ de outubro de $1992 .^{241}$

As suas receitas são oriundas $\mathrm{de}^{242}$ :

1. Dotação consignada no Orçamento Municipal, necessária ao funcionamento dos Conselhos Tutelares e do Conselho Municipal dos Direitos da Criança e do Adolescente;

2. Recursos provenientes dos Fundos Estadual e Nacional dos Direitos da Criança e do Adolescente;

3. Doações, auxílios, contribuições e legados que lhe venham a ser destinados, inclusive as contribuições realizadas pelas instituições financeiras que desejarem gozar do benefício concedido pelo artigo 27 da Lei municipal n. 13.476, de 30 de dezembro de $2002 ;^{243}$

4. Valores repassados pela União e pelo Estado ao Município, provenientes de multas decorrentes de condenações ou ações civis ou de imposições de penalidades administrativas aplicadas no Município de São Paulo, previstas na Lei federal n. 8.069, de 13 de julho de 1990;

\footnotetext{
241 “Art. $1^{\circ}$. Fica criado, na Secretaria Municipal do Bem Estar Social, o Fundo Municipal dos Direitos da Criança e do Adolescente - FUMCAD —, de natureza contábil, com a finalidade de proporcionar os meios financeiros complementares às ações necessárias ao desenvolvimento das políticas públicas destinadas à criança e ao adolescente, bem como ao exercício da competência do Conselho Municipal dos Direitos da Criança e Adolescente e dos Conselhos Tutelares.” A vinculação do Fundo foi alterada algumas vezes, prevalecendo atualmente, conforme Decreto n. 46.716/2005, com relação à Secretaria Municipal de Participação e Parceria.

${ }^{242}$ Artigo $3^{\circ}$ da Lei municipal 11.247/92, com algum detalhamento inserido pelo Decreto n. 43.135/2003.

243 “Art. 27. As instituições financeiras que contribuírem ao Fundo Municipal dos Direitos da Criança e do Adolescente - FUMCAD - poderão descontar do valor mensal devido a título de Imposto sobre Serviços de Qualquer Natureza - ISS, incidente sobre os serviços descritos nos itens 15.03, 15.07, 15.14, 15.16 e 15.17 da lista do caput do art. $1^{\circ}$ da Lei 13.701, de 24 de dezembro de 2003, o valor doado ao referido fundo, até o limite de $1 / 6$ (um sexto) do valor do imposto devido. $\S 1^{\circ}$. Os valores doados no mês poderão ser utilizados para o desconto do Imposto com vencimento no mês subseqüente, respeitado o limite definido no caput deste artigo e vedada a compensação em outros meses. $\S 2^{\circ}$. A comprovação do direito ao desconto previsto no caput deste artigo será feita mediante documento próprio emitido pelo Conselho Municipal dos Direitos da Criança e do Adolescente - CMDCA." (Nova redação, outorgada pela Lei n. 14.865, de 29 de dezembro de 2008).
} 
5. Contribuições dos governos e organismos nacionais, estrangeiros e internacionais;

6. Rendas eventuais, inclusive as resultantes de depósitos e aplicações de capitais;

7. Outros recursos que lhe forem destinados.

Advêm, portanto, de diferentes origens, dentre as quais merecem destaque as relacionadas ao orçamento municipal e às doações e destinações de terceiros.

No que toca àquelas receitas — provenientes do orçamento municipal -, observado o disposto no artigo $3^{\circ}$ do Decreto n. $43.135 / 2003,{ }^{244}$ podem ser destinadas a: a) manutenção do funcionamento do Conselho Municipal dos Direitos da Criança e do Adolescente; b) capacitação dos Conselheiros de Direitos e Tutelares; c) organização da Conferência Municipal dos Direitos da Criança e do Adolescente e de outros eventos de interesse público relacionados aos direitos da criança e do adolescente; d) participação de delegação em encontros estaduais, nacionais e internacionais.

As segundas - resultantes de mobilização de terceiros estranhos à Administração municipal —, por sua vez, são direcionadas ao financiamento de projetos complementares às políticas públicas para a criança e para o adolescente. ${ }^{245}$ Essas as que mais de perto nos interessam, por se ligarem diretamente à atividade de fomento. ${ }^{246}$

Sua destinação não se confunde com a promoção e efetivação de toda e qualquer política pública ligada à infância e adolescência: a sua vocação é o patrocínio de programas especiais e complementares, conforme explicita o $\S 2^{\circ}$ do artigo $3^{\circ}$ do Decreto municipal n. 43.135/2003.

Vale trazer à baila, nesse particular, o disposto no artigo $10, \S 3^{\circ}$, desse mesmo Decreto $^{247}$ : “Os convênios de projetos não poderão duplicar políticas públicas existentes".

São estabelecidas também outras condicionantes dos convênios para custeio de atividades de interesse público de entidades do Terceiro Setor: inovação; fiel respeito à isonomia, com outorga de iguais condições de custeio para todos os projetos/entidades.

Não seria admissível, portanto, e a título de ilustração, o custeio, com receitas conduzidas ao Fumcad por meio de destinação ou doação ${ }^{248}$ de particulares, de programas

\footnotetext{
${ }^{244}$ Com redação alterada pelo Decreto n. 43.935/2003.

${ }^{245}$ Art. $3^{\circ}, \S 2^{\circ}$ do Decreto n. $43.135 / 2003$.

${ }^{246}$ Nesse ponto, cumpre invocar as ponderações traçadas no item 1.4.4, supra, segundo as quais a atividade de fomento somente é passível de operacionalização em situações em que o agente fomentado goze de competência originária para a sua realização. Inviável, portanto, recaia sobre aspectos constitucionalmente atribuídos ao Estado, com exclusividade e que, portanto, deverão ser satisfeitas por mecanismos afetos de prestação de serviços.

${ }^{247}$ Redação outorgada pelos Decretos n. $47.669 / 2007$ e n. 43.9535/2003.
} 
inerentes à área da saúde, assistência social ou educação (manutenção de creches, escolas etc.). ${ }^{249}$

A própria noção de fomento desenvolvida no capítulo primeiro do presente leva a essa mesma conclusão: não se pode admitir a dispensa de incentivo público com vista a incitar a realização de atividades que se encontrem inseridas na esfera de dever da Administração pública:

[...] entendemos que os recursos do Fundo não podem ser destinados às políticas sociais básicas, pois estas são de obrigação originária do Poder Executivo. A inexistência ou a insuficiência dessas políticas, ao mesmo tempo em que ensejam ações judiciais, no máximo podem levar a buscar a compreensão nas políticas de caráter supletivo. Talvez fosse admitido o uso de tais recursos, se no Plano de Aplicação e no Plano de Metas se fizesse constar essas ações e respectivos valores, com o necessário repasse do Poder Executivo, o qual não se desobriga, contudo, a destinar em orçamento os percentuais constitucionais, sendo os recursos do Fundo, no caso, uma atividade complementar. (LIBERATI; CYRINO, 2003, p. 234).

Na lição de Albino:

${ }^{248}$ Registre-se que os dois institutos não se confundem e convivem paralelamente: os particulares podem tanto doar determinado montante ao Fundo, diretamente e independentemente de qualquer contraprestação, quanto optar por lhe destinar uma parcela do valor devido a título de tributos. Neste último caso, não há que se falar em liberalidade, em facultatividade quanto ao desembolso do valor em questão: o contribuinte será compelido a efetivar o pagamento, com a especificidade de poder escolher o seu destinatário. A ele caberá optar, portanto, entre os cofres públicos genericamente considerados, à época própria, e o Fundo, seja no momento estabelecido para o recolhimento do tributo, seja de forma antecipada. Daí não considerarmos tecnicamente exata a utilização da expressão "doação" para as hipóteses de simples realocação de valores em prol da infância e juventude. Em ambas as hipóteses, e como só de ser, tão logo ingressem no Fundo, os valores assumem automaticamente a natureza de receita pública, se desvencilhando totalmente de sua origem e da liberalidade que lhe deu causa. Nesse diapasão, vale trazer à baila decisão do Superior Tribunal de Justiça, ementada nos seguintes termos: "Tributário. Recurso especial. Imposto de renda pessoa física. Dedução de contribuição. Art. 12, I, da Lei 9.250/95. Interpretação restritiva. 1. Nos termos do art. 12, I, da Lei 9.250/95, podem ser deduzidas do imposto de renda 'as contribuições feitas aos fundos controlados pelos Conselhos Municipais, Estaduais e Nacional dos Direitos da Criança e do Adolescente’. Essa norma não comporta interpretação extensiva ou analógica com o efeito ampliativo de admitir a dedução também para contribuições feitas, não a fundo, mas a entidade particular, ainda que inscrita nos referidos Conselhos. 2. Recurso especial a que se nega provimento" (Resp. n. 10.45459/DF, rel. Min. Teori Albino Zavascki).

249 "São unidades orçamentárias vinculadas a uma finalidade própria. As dotações orçamentárias das áreas de saúde ou assistência, em programas destinados a crianças e adolescentes, não são substituídas por recursos dos Fundos da Infância e da Adolescência. Os Fundos viabilizam recursos para a implantação de programas especiais e complementares dirigidos ao segmento infanto-juvenil. Os recursos destinados à criação ou adequação de estruturas, implantação ou ampliação de atendimento a crianças, adolescentes e suas famílias devem constar, prioritariamente, na dotação própria dos órgãos da administração pública encarregados de sua execução. Um programa de tratamento para drogadição, por exemplo, deve ser custeado com recursos próprios do orçamento dos órgãos responsáveis pelo setor de saúde; um programa de apoio e proteção à família deve ser custeado com recursos próprios da área de assistência social e assim por diante devendo, cada órgão da administração, arcar com uma parcela de recursos para implementação e manutenção das políticas correspondentes, servindo os recursos captados pelo Fundo da Infância e Adolescência para ações complementares." (BARBOSA, 2009, p. 30-31). 
[...] é vedado o uso do Fundo da Infância e da Adolescência no financiamento de políticas públicas setoriais, que já dispõem de fundos específicos, como é o caso das políticas na área de educação, saúde ou assistência social. $\mathrm{O}$ atendimento das situações de direitos fundamentais, corriqueiramente assegurados a qualquer segmento da comunidade, deve ser resolvidos pelas políticas setoriais com seus fundos próprios, uma vez que já possuem o mesmo instrumento de facilitação gerencial de recursos públicos.

[...] Nesse diapasão, as despesas objeto de dotação orçamentária específica não poderiam ser destinatárias de recursos do FIA, haja vista que o Poder Executivo já tem obrigação legal de custear essas despesas, sendo certo que a sua omissão não poderia ser suprida pelo FIA, cujo fundamento de criação está ligado à política especial de atendimento da população infanto-juvenil. (ALBINO, 2010, p. 42).

De fato, se determinada ação consta especificamente do planejamento e orçamento públicos, sendo atribuída a órgão ou ente específico, não se poderá falar em fomento e, portanto, em destinação de valores provenientes do Fundo.

Referidos programas não poderão sequer ser inscritos e registrados no Conselho, vez que não integram o rol do artigo 90 do Estatuto da Criança e do Adolescente $^{250}$ :

Art. 90. As entidades de atendimento são responsáveis pela manutenção das próprias unidades, assim como pelo planejamento e execução de programas de proteção e socioeducativos destinados a crianças e adolescentes, em regime de: I - orientação e apoio sociofamiliar; II apoio socioeducativo em meio aberto; III - colocação familiar; IV abrigo; V - liberdade assistida; VI - semi-liberdade; VII - internação.

Parágrafo único. As entidades governamentais e não governamentais deverão proceder à inscrição de seus programas, especificando os regimes de atendimento, na forma definida neste artigo, junto ao Conselho Municipal dos Direitos da Criança e do Adolescente, o qual

\footnotetext{
${ }^{250}$ No que toca especificamente à questão da educação, o Município de São Paulo traz norma expressa, constante dos artigos $4^{\circ}$ da Lei n. 13.326/2002 e do Decreto n. 42.248/2002: "A Prefeitura de São Paulo, através do órgão gestor do Sistema Municipal de Ensino deve adotar providências e condições para normatizar, autorizar o funcionamento, credenciar e supervisionar os estabelecimentos públicos e particulares de educação infantil, isto é, creches e escolas de educação infantil da cidade de São Paulo.” E: “Aos órgãos do Sistema Municipal de Educação, a saber, o Conselho Municipal de Educação, com função normativa, e a Secretaria Municipal de Educação, com funções normativa e executiva, competirá: I - fixar normas para autorizar o funcionamento, credenciar e supervisionar as instituições públicas e privadas de educação infantil do Município de São Paulo." Ainda com relação a esse específico aspecto, vale trazer à baila orientações do Conanda constantes das Resoluções n. 71, art. $3^{\circ}$, e 105, artigo 17, $\S 3^{\circ}$, respectivamente: “Art. $3^{\circ}$. Os Conselhos Municipais dos Direitos da Criança e do Adolescente não concedem registros para funcionamento de entidades educacionais formais, tais como: creche, pré-escola, ensino fundamental e médio.” E, “Art. 17. Quando do registro ou renovação, os Conselhos Municipais e Distrital dos Direitos da Criança e do Adolescente, com o auxílio de outros órgãos e serviços públicos, deverão certificar-se da adequação da entidade e/ou do programa, às normas e princípios estatutários, bem como a outros requisitos específicos que venha a exigir, por meio de resolução própria. [...] $\S 3^{\circ}$. Os Conselhos Municipais e Distrital dos Direitos da Criança e do Adolescente não concederão registros para funcionamento de entidades ou inscrição de programas que desenvolvam apenas atendimento em modalidades educacionais formais de educação infantil, ensino fundamental e médio.’"
} 
manterá registro das inscrições e de suas alterações, do que fará comunicação ao Conselho Tutelar e à autoridade judiciária.

Uma vez vedada a sua inscrição e registro, automaticamente restará inviabilizado o desenvolvimento das atividades pretendidas, da mesma forma que o direcionamento de recursos do Fundo para o custeio, o fomento, de quaisquer programas que sejam.

É o que explicitamente determina o artigo $4^{\circ}$, $\S \S 1^{\circ}$ e $2^{\circ}$ da Resolução $n$. 77/2005/CMDCA/SP:

Artigo $4^{\circ}$. Para o financiamento dos projetos propostos por organizações governamentais e não governamentais, o CMDCA/SP fará publicar no Diário Oficial da Cidade edital de inscrição que conterá:

I - Indicação dos eixos de promoção, controle e defesa;

II - Critérios do processo de seleção e de aprovação dos projetos propostos por eixo de ação;

$\S 1^{\circ}$ - A proposta do projeto de organização governamental será apreciada desde que seus programas, voltados à criança e adolescente, estejam devidamente inscritos no CMDCA/SP.

$\S 2^{\circ}$ - A proposta de projeto de organização não governamental somente será considerada aprovada se a organização proponente estiver devidamente registrada no CMDCA/SP.

Tal visão decorre diretamente do disposto no artigo 91 daquele Estatuto: “As entidades não-governamentais somente poderão funcionar depois de registradas no Conselho Municipal dos Direitos da Criança e do Adolescente, o qual comunicará o registro ao Conselho Tutelar e à autoridade judiciária da respectiva localidade".

Nesse mesmo sentido, as Resoluções n. 37 e n. 94 do Conselho paulistano, respectivamente:

1. As entidades de atendimento que não tiverem seus programas inscritos no CMDCA ficam desautorizadas a cumpri-los;

2. As entidades deverão efetuar inscrição de novo programa e/ou sua alteração junto ao CMDCA;

3. Somente com registro no CMDC, a entidade poderá desenvolver outras atividades.

[...] Considerando que os convênios com o Poder Público só são firmados com as organizações não-governamentais que possuam registro ativo no Conselho Municipal dos Direitos da Criança e do Adolescente, o CMDCA/SP, no uso das atribuições que lhe são conferidas por Lei, resolve:

Art. $1^{\circ}$. As organizações não governamentais poderão solicitar registro no CMDCA/SP, com validade de 6 (seis) meses, desde que apresentados os documentos pertinentes aos projetos e/ou programas de implantação pretendido e laudo de habitabilidade, quando for o caso, conforme 
previsão das Resoluções 47, 59, 66 e 68 do CMDCA/SP, observados os procedimentos para a concessão do registro.

Art. $2^{\circ}$. O registro poderá ser prorrogado por mais 6 (seis) meses, desde que apresentados documentos comprobatórios do processo de implantação do projeto e/ou programa pretendido.

\subsection{O regime financeiro do Fundo Municipal dos Direitos da Criança e do Adolescente: sujeição às regras gerais orçamentárias?}

A questão que inaugura o presente tópico decorre da discussão quanto a estarem as receitas integrantes dos Fundos da Infância e Adolescência oriundas de doações ou destinações de particulares inseridas na categoria de receitas públicas, portanto sujeitas ao regime geral orçamentário aplicável à Administração.

O visão adotada a respeito dessas prejudiciais será determinante de um outro ponto: a admissibilidade — ou não — de vinculação de valor destinado a projeto específico.

Pontuemos, nessa linha, e de plano, que os valores integrantes do Fumcad inserem-se, independentemente da sua origem, na classe das receitas públicas, conforme lição de Meirelles (2008, p. 151-152) — e compõem, portanto, o orçamento municipal. ${ }^{251 \text {, }}$ 252

Essa conclusão decorre direta e inevitavelmente do princípio da universalidade, basilar no Direito Financeiro e, consequentemente, regente de todas as ações correlatas às finanças públicas.

Trata-se de desiderato expressamente consagrado pela Carta Maior, em seu artigo $165, \S 5^{\circ}$, I, II e III, ${ }^{253}$ cujo enunciado foi nos seguintes termos sintetizado: "A universalidade impõe a inclusão no orçamento anual de todas as receitas e despesas da Administração, consoante determina a Constituição da República (art. 165, §5º),

\footnotetext{
251 "Classicamente, o orçamento é uma peça que contém a previsão das receitas e autorização das despesas." (HORVATH; OLIVEIRA, 2002, p. 88).

252 "A lei orçamentária anual (LOA) deve compreender: o orçamento fiscal referente aos Poderes municipais, aos seus Fundos, órgãos e entidades da Administração direta e indireta; o orçamento de investimento das empresas em que o Poder Público Municipal, direta ou indiretamente, detenha maioria do capital social com direito a voto; o orçamento da seguridade social, incluindo todas as entidades e órgãos a ela vinculados (CF, art. 165, § 5 ).” (MEIRELLES, 2008, p. 280).

253 “\$ $5^{\circ}$ A lei orçamentária anual compreenderá: I - o orçamento fiscal referente aos Poderes da União, seus fundos, órgãos e entidades da administração direta e indireta, inclusive fundações instituídas e mantidas pelo Poder Público; II - o orçamento de investimento das empresas em que a União, direta ou indiretamente, detenha a maioria do capital social com direito a voto; III - o orçamento da seguridade social, abrangendo todas as entidades e órgãos a ela vinculados, da administração direta ou indireta, bem como os fundos e fundações instituídos e mantidos pelo Poder Público."
} 
compreendendo o das entidades da Administração direta e indireta, órgãos e fundos." (MEIRELLES, 2008, p. 282).

Conforme asseveram Horvath e Oliveira:

O princípio da universalidade significa que todas as receitas e despesas devem estar previstas na lei orçamentária. Dispõe o $\$ 5^{\circ}$ do art. 165 que: "A lei orçamentária anual compreenderá: I - o orçamento fiscal referente aos Poderes da União, seus fundos, órgãos e entidades da administração direta e indireta, inclusive fundações instituídas e mantidas pelo Poder Público; II - o orçamento de investimento das empresas em que a União, direta ou indiretamente, detenha a maioria do capital social com direito a voto; III - o orçamento da seguridade social, abrangendo todas as entidades e órgãos a ela vinculados, da administração direta ou indireta, bem como os fundos e fundações instituídos e mantidos pelo Poder Público." O princípio ganha novo conteúdo com o advento da nova Constituição Federal. Não há qualquer possibilidade de exclusão. Tudo deve estar previsto no orçamento. (HORVATH; OLIVEIRA, 2002, p. 92)

Uma vez inseridos na classe das receitas públicas, todos os valores integrantes do Fumcad devem, obrigatoriamente, observar as regras relativas ao orçamento e finanças públicas, ${ }^{254}$ havendo, inclusive, orientação expressa do Conanda nesse sentido, conforme se vê dos artigos $7^{\circ}, \S \S 2^{\circ}$ e $3^{\circ}$, e $8^{\circ}, \S 4^{\circ}$, da sua Resolução n. $137 .^{255}$

Não obstante referidas diretrizes do colegiado federal não sejam, conforme salientado, vinculantes dos demais entes, atuam, inquestionavelmente, como importante norte de atuação e organização.

Passemos à possibilidade de vinculação de referidas receitas a projetos ou programas específicos.

Nesse diapasão, cumpre-nos trazer à baila a celeuma que envolve a discussão, que conta com adeptos das duas correntes - contra e a favor da viabilidade da denominada "doação direcionada".

\footnotetext{
${ }^{254}$ Respeitada a possibilidade excepcional, trazida pelo artigo 71 da Lei n. 4.320/64, que faculta "a adoção de normas peculiares de aplicação."

255 "Art. $7^{\circ}$. O Fundo dos Direitos da Criança e do Adolescente não deve possuir personalidade jurídica própria e deve utilizar o mesmo número base de inscrição no Cadastro Nacional da Pessoa Jurídica (CNPJ) do órgão ou da Secretaria à qual for vinculado por lei, conforme dispõe o artigo $2^{\circ}$ da presente Resolução. [...] $\S 2^{\circ}$. O Fundo dos Direitos da Criança e do Adolescente deve constituir unidade orçamentária própria a ser parte integrante do orçamento público. $\S 3^{\circ}$. Devem ser aplicadas à execução orçamentária do Fundo as mesmas normas gerais que regem a execução orçamentária da União, dos Estados, do Distrito Federal e dos Municípios.”
} 
Merecem destaque, de plano, alguns posicionamentos, como o oriundo do Ministério Público: as Promotorias da Infância e Juventude de Mogi das Cruzes, ${ }^{256}$ do Rio de Janeiro, ${ }^{257}$ de Duque de Caxias, ${ }^{258}$ do Distrito Federal ${ }^{259}$ — além do Fórum Nacional de Coordenadores de Centros de Apoio da Infância e da Juventude e da Educação dos Ministérios Públicos dos Estados - e o próprio Ministério Público Federal, em Brasília, ${ }^{260}$ advogam pela inadmissibilidade de tal sistemática. ${ }^{261}$

${ }^{256}$ Conforme ação civil pública proposta pelo Ministério Público, voltada à anulação de convênio formalizado entre a Telesp, a Fundação Telefônica e o Município de Mogi, representado pelo seu Prefeito e pelo Presidente do Conselho da Criança e Adolescente, por meio do qual os dois últimos partícipes se comprometiam a doar ao Fundo Municipal dos Direitos da Criança e Adolescente montantes a serem aplicados exclusivamente no projeto "Rede Mogi da Criança e Adolescente" (e de todos os atos daí decorrentes).

${ }^{257}$ Nos termos da ação civil pública proposta contra o Estado do Rio de Janeiro e autuada sob o número 2009-206.014655-7, em que foi deferida tutela antecipada no sentido de "determinar: 1. a paralisação de todos os procedimentos administrativos para escolha dos projetos que integrarão o banco de projetos do CEDCA; 2; o cancelamento dos convênios eventualmente já celebrados; 3 . vedar a emissão de "certificados de captação' ou quaisquer outros mecanismos que signifiquem doação casada; 4. que toda e qualquer deliberação acerca da distribuição de verba do FIA obedeça aos ditames da legislação federal, com a deliberação específica e circunstanciada dos Conselheiros, e obediência às formalidades administrativas, licitatórias e orçamentárias, devendo, até julgamento da demanda, haver pronta comunicação a este juízo".

${ }^{258}$ Essa a linha adotada nos autos da Ação Civil Pública n. 2009.021.029810-4, proposta pela Organização de Direitos Humanos Projeto Legal em face do Município de Duque de Caxias, com o escopo justamente de garantir a liberação de valores direcionados a projeto titularizado pela autora em razão da sistemática da destinação vinculada. Em primeiro grau, referida ação foi julgada extinta sem julgamento com base no artigo 267, IV do CPC (que articula a ausência de pressupostos de constituição e de desenvolvimento válido e regular do processo traduzidos, no caso, na natureza individual dos resultados pretendidos e a ilegitimidade da autora para pleitear, em nome próprio, direito alheio, consistente nos repasses em benefício também de outras entidades). A pretensão original tomava por base o disposto na Deliberação n. 11/2005/CMDCA-DC, posteriormente revogada, após alerta do Ministério Público pela via administrativa, pela de número 128/2009/CMDCA-DC. Instado a se manifestar em segunda instância, defendeu o Parquet, ainda que incidentalmente, a ilegalidade daquelas que denomina "doações casadas". A decisão de segunda instância, prolatada em 19 jul. 2011, reafirmou o mesmo entendimento do juízo a quo, mantendo a extinção do processo sem julgamento do mérito.

${ }^{259}$ O Fórum em questão chegou, inclusive, a expedir Enunciado nesse sentido: "É ilegal qualquer ato que autorize a prática da denominada 'doação casada' ou qualquer outra forma que induza ou permita o direcionamento pelo doador de verbas ao Fundo, com indicação de entidade, programa ou projeto beneficiário da verba."

${ }^{260}$ Nos termos da ação civil pública proposta contra a União Federal e autuada sob o número 3378788.2010.4.01.3400. Na hipótese, requeria o órgão ministerial não só a declaração de nulidade dos artigos 12 e 13 da Resolução n. 137/2010/CONANDA, mas também de todos os atos que permitiam a captação direta por particulares de recursos do Fundo dos Direitos da Criança e Adolescente ou que permitiam ao destinador o direcionamento daqueles recursos. Após negativa da liminar pleiteada, decidiu o magistrado de primeira instância (sentença n. 37/2011-A, da 21. ${ }^{a}$ Vara Federal do Distrito Federal, prolatada em 09 de setembro de 2011), em julgamento antecipado da lide, pela procedência da ação quanto à nulidade dos referidos artigos, outorgando à decisão, porém, efeitos ex nunc. Referida sentença teve a sua execução suspensa pelo Tribunal Regional Federal da 1. ${ }^{a}$ Região (suspensão de execução de sentença 0006955-62.202.4.01.0000/DF), em 23 de fevereiro de 2012, sob o argumento de que postura nesse sentido "interfere indevidamente nas atribuições e competência do Conanda, com aptidão concreta para acarretar substancial decréscimo nas doações para os Fundos da Criança e do Adolescente."

${ }^{261}$ Vale trazer à baila, ainda, e no mesmo sentido, posicionamento da Comissão Nacional Permanente da Infância, Juventude e Educação - Copeije, consolidado no evento promovido pelo Ministério Público do Rio de Janeiro denominado "A atuação do Ministério Público na fiscalização do fundo da infância e adolescência", e consubstanciado nos enunciados seguintes: Enunciado n. 1: "Ao ingressar nos Fundos de Direitos da Criança e do Adolescente ou Fundo da Infância e Adolescência (FIA) os recursos passam a ter 
Ponderam os que defendem a viabilidade do direcionamento a projeto específico, para além do argumento pragmático - e verdadeiro ${ }^{262}$ - da elevação dos valores arrecadados, a ampliação das possibilidades de participação popular para patamares superiores ao número de assentos da sociedade civil no Conselho, vez que é dado ao próprio contribuinte, sujeito passivo na obrigação tributária, optar onde, como e em que circunstâncias os valores por ele devidos serão empregados.

Compartilham dessa visão o Conanda e o CMDCA/SP, cujas Resoluções n. 137/2010 e n. 77/2005, respectivamente dispõem:

Art. 12. A definição quanto à utilização dos recursos dos Fundos dos Direitos da Criança e do Adolescente, em conformidade com o disposto no artigo $7^{\circ}$, deve competir única e exclusivamente aos Conselhos dos Direitos.

$\S 1^{\circ}$. Dentre as prioridades do plano de ação aprovado pelo Conselho de Direitos, deve ser facultado ao doador/destinador indicar aquela ou aquelas de sua preferência para a aplicação dos recursos doados/destinados.

$\S 2^{\circ}$. As indicações previstas acima poderão ser objeto de termo de compromisso elaborado pelo Conselho dos Direitos para formalização entre o destinador e o Conselho de Direitos.

Art. 13. Deve ser facultado ao Conselho dos Direitos da Criança e do Adolescente chancelar projetos mediante edital específico.

natureza jurídica de verba pública, estando sujeitos aos princípios que regem a Administração Pública." Enunciado n. 2: "O contribuinte ou doador subsidiado, ao efetuar depósito nos Fundos de Direitos da Criança e do Adolescente ou Fundo da Infância e Adolescência (FIA), não pode escolher, por qualquer meio, a destinação dos recursos." Enunciado n. 3: "Os recursos depositados pelo contribuinte ou doador subsidiado no Fundo de Direitos da Criança e do Adolescente ou Fundo da Infância e Adolescência (FIA) não podem ser condicionados à vinculação, através de convênio ou qualquer outro instrumento jurídico, a um projeto ou programa específico." Enunciado n. 4: "Os Conselhos de Direitos da Criança e do Adolescente são órgãos deliberadores de políticas públicas em matéria de infância e adolescência, por força do artigo 204, inciso II da Constituição da República e do artigo 88, inciso II da Lei federal 8.069/90 (ECA), sendo os únicos gestores do Fundo de Direitos da Criança e do Adolescente ou Fundo da Infância e Adolescência (FIA), conforme artigo 214, caput, da Lei federal 8.069/90 (ECA)." Enunciado n. 5: "O Ministério Público, em razão do exercício da fiscalização de que trata o artigo $260, \S 4^{\circ}$ do ECA, não pode ter assento como membro no Conselho de Direitos da Criança e do Adolescente, reputando-se inconstitucionais as normas que prevejam tal atribuição." Enunciado n. 6: "Na destinação de recursos dos Fundos de Direitos da Criança e do Adolescente ou Fundos da Infância e Adolescência (FIA), os Conselhos de Direitos da Criança e do Adolescente devem observar o disposto no artigo 260, § $2^{\circ}$ da Lei 8.069/90 (ECA)."

${ }^{262}$ Conforme se depreende da correlação entre os valores arrecadados pelo Fumcad a título de destinação do imposto de renda ao longo dos anos e o momento a partir do qual se passou a admitir a vinculação em questão: em 2004, foram R\$ 121.720,58 (cento e vinte e um mil, setecentos e vinte reais e vinte e oito centavos); em 2005, R \$ 7.774.222,55 (sete milhões, setecentos e setenta e quatro mil, duzentos e vinte e dois reais e cinqüenta e cinco centavos); em 2006, $\mathrm{R} \$ 17.419 .578,71$ (dezessete milhões, quatrocentos e dezenove mil, quinhentos e setenta e oito reais e setenta e um centavos); em 2007, R\$28.238.900,40 (vinte e oito milhões, duzentos e trinta e oito mil, novecentos reais e quarenta centavos); em 2008, R\$ 35.553.909,83 (trinta e cinco milhões, quinhentos e cinqüienta e três mil, novecentos e nove reais e oitenta e três centavos). Fonte: Sistema de Execução Orçamentária do Município de São Paulo - Novo SEO - órgão 90 - Fundo Municipal dos Direitos da Criança e Adolescente para os dados de 2004 a 2008. Lembre-se que referida possibilidade passou a ser admitida, no município de São Paulo, a partir da edição da Resolução n. 77/2005/CMDCA/SP. 
$\S 1^{\circ}$. Chancela deve ser entendida como a autorização para captação de recursos aos Fundos dos Direitos da Criança e do Adolescente destinados a projetos aprovados pelos Conselhos dos Direitos da Criança e do Adolescente, segundo as condições dispostas no art. $9^{\circ}$ desta Resolução. $\S 2^{\circ}$. A captação de recursos ao Fundo dos Direitos da Criança e do Adolescente, referida no parágrafo anterior, deverá ser realizada pela instituição proponente para o financiamento do respectivo projeto.

$\S 3^{\circ}$. Os Conselhos dos Direitos da Criança e do Adolescente deverão fixar percentual de retenção dos recursos captados, em cada chancela, de no mínimo $20 \%$ ao Fundo dos Direitos da Criança e do Adolescente.

$\S 4^{\circ}$. O tempo de duração entre a aprovação do projeto e a captação dos recursos não deverá ser superior a 2 (dois) anos.

$\S 5^{\circ}$. Decorrido o tempo estabelecido no parágrafo anterior, havendo interesse da instituição proponente, o projeto poderá ser submetido a um novo processo de chancela.

$\S 6^{\circ}$. A chancela do projeto não o deve obrigar seu financiamento pelo Fundo dos Direitos da Criança e do Adolescente, caso não tenha sido captado valor suficiente.

Artigo $5^{\circ}$ A pessoa física ou jurídica, valendo-se de mecanismo legal de incentivo tributário, poderá indicar, através de oficio dirigido ao Presidente do CMDCA/SP e contendo copia do comprovante de deposito no FUMCAD/SP, o projeto ou eixo previamente aprovado, cujo desenvolvimento pretenda auxiliar.

Os argumentos trazidos à baila pelos defensores da primeira corrente são, basicamente, os seguintes:

\section{A competência para a disciplina das renúncias fiscais é exclusiva da União} Federal, ${ }^{263}$ nos termos dos artigos $150, \S 6^{\circ},{ }^{264}$ e 151 , III, ${ }^{265}$ o que impediria a sua regulação por órgão municipal, sob pena de criação de benefício fiscal heterônomo, ${ }^{266}$ vedado pelo ordenamento pátrio.

\footnotetext{
263 “Art. 48. Cabe ao Congresso Nacional, com a sanção do Presidente da República, não exigida esta para o especificado nos arts. 49, 51 e 52, dispor sobre todas as matérias de competência da União, especialmente sobre: I - sistema tributário, arrecadação e distribuição de rendas."

264 “§ $6^{\circ}$ Qualquer subsídio ou isenção, redução de base de cálculo, concessão de crédito presumido, anistia ou remissão, relativos a impostos, taxas ou contribuições, só poderá ser concedido mediante lei específica, federal, estadual ou municipal, que regule exclusivamente as matérias acima enumeradas ou o correspondente tributo ou contribuição, sem prejuízo do disposto no art. $155, \S 2^{\circ}$, XII, g."

265 "Art. 151. É vedado à União: III - instituir isenções de tributos da competência dos Estados, do Distrito Federal ou dos Municípios."

266 "As isenções tributárias também podem ser concedidas por meio de lei complementar, nos termos do art. $155, \S 2^{\circ}$, XII, $e$, e do art. $156, \S 3^{\circ}$, II, ambos da CF. Estes são os únicos casos em que nosso ordenamento jurídico admite isenções heterônomas, isto é, isenções concedidas por pessoa diversa daquela que tem competência constitucional parra instituir o tributo. Relembramos que, de regra, as isenções são autonômicas, conforme se infere da só leitura do art. 151, III da Carta Magna ('é vedado à União instituir isenções e tributos da competência dos Estados, do Distrito Federal ou dos Municípios')." (CARRAZZA, 2012, p. 9991000)
} 
Nesse sentido assevera o Ministério Público do Estado do Rio de Janeiro, em memoriais apresentados nos autos da ação civil pública referida ${ }^{267}$ :

\begin{abstract}
A propósito, frise-se que a competência legislativa para regulamentação da matéria é exclusiva da União Federal, já que se trata de definição de forma de escrituração de crédito tributário para fins de Imposto de Renda, conforme disposição do art. 48, I da CF. Sendo assim, não é possível aos Estados e Municípios a edição de Leis ou atos normativos que disciplinem a matéria de modo diferente, sob pena de caracterizar-se benefício fiscal heterônomo, o que afronta o Sistema Tributário Nacional contrariando expressamente o art. $150 \S 6^{\circ}$ e o preceito contido no art. 151, III, da Carta Magna. (p. 25).
\end{abstract}

Ocorre, porém, que as normas municipais ou estaduais que estabelecem a possiblidade de direcionamento vinculado não criam, em hipótese alguma, qualquer espécie de benefício fiscal. $^{268}$

Contrariamente ao que defendem os seus opositores, referida sistemática simplesmente institui uma outra forma de diálogo entre Conselho e sociedade civil, à qual é dada a oportunidade de indicar, dentre os projetos previamente aprovados e chancelados, qual o merecedor de parcela originariamente devida a título de Imposto de Renda.

O incentivo fiscal já foi oportunamente criado pelo Estatuto da Criança e do Adolescente e regulamentado pela União, dentro de sua esfera de competências, ficando a sua implementação a cargo justamente da esfera destinatária (no caso, o município de São Paulo).

E a disciplina desse assunto — assim como a gestão de referidas receitas — é competência exclusiva do Conselho, ${ }^{269}$ que, portanto, pode criar o procedimento que julgar mais conveniente e consentâneo com o interesse público.

\footnotetext{
${ }^{267}$ Ação Civil Pública proposta contra o estado do Rio de Janeiro e autuada sob o número 2009-206.0146557.

${ }^{268}$ A esta questão retornaremos mais adiante no capítulo 3.

${ }^{269}$ Conforme artigo 260, $\S 2^{\circ}$, do Estatuto da Criança e Adolescente: “Art. 260. Os contribuintes poderão deduzir do imposto devido, na declaração do Imposto sobre a Renda, o total das doações feitas aos Fundos dos Direitos da Criança e do Adolescente - nacional, estaduais ou municipais — devidamente comprovadas, obedecidos os limites estabelecidos em Decreto do Presidente da República. [...] $\S 2^{\circ}$ Os Conselhos Municipais, Estaduais e Nacional dos Direitos da Criança e do Adolescente fixarão critérios de utilização, através de planos de aplicação das doações subsidiadas e demais receitas, aplicando necessariamente percentual para incentivo ao acolhimento, sob a forma de guarda, de criança ou adolescente, órfãos ou abandonado, na forma do disposto no art. 227, § $3^{\circ}$, VI, da Constituição Federal. Nas palavras de Maranhão, Juntamente à criação destes conselhos, foram criados os fundos especiais a eles vinculados. Estes são compostos por recursos vinculados a serviços e objetivos definidos em suas leis de criação e foram determinados pelas leis federais de cada área específica como já mencionado. Em geral, seja na Assistência Social, na Saúde ou na Criança e Adolescente, para mencionar as áreas afins nas quais o funcionamento dos conselhos e dos fundos encerra certa semelhança, devem ser criados fundos nas três esferas da federação vinculados aos respectivos conselhos gestores. Neste sentido, cabe ao conselho paritário definir qual será o
} 
Nesse sentido, decisão do TRF da $1^{\text {a }}$ região prolatada nos autos da ação civil pública anteriormente referida:

Antes da sua edição, a Resolução do FIA foi objeto de consulta pública, com amplo debate pela sociedade, inclusive com a participação do Ministério Público. Com a devida vênia, parece haver certo exagero do MPF em relação à matéria, quando afirma que a indicação de um plano de ação pelo doador implica, ipso facto, ilegalidade ou usurpação de atribuições do poder público. A indicação do doador, que não é vinculativa para o Conanda, ocorre entre os projetos previamente escolhidos, segundo critérios estipulados em edital de chamada pública. Não se trata de um ato puramente subjetivo ou voluntarioso do doador, em atenção a interesses particulares, senão de uma manifestação de vontade submetida a verificação positiva do Conanda, o que equivale a dizer que a administração dos recursos oriundos da renúncia fiscal é da esfera pública. Em nenhum momento o ECA veda a possibilidade de o doador indicar um projeto específico, e, por outro lado, prevê a competência do Conanda para fixar critérios de utilização do Fundo. Se a chancela ou a destinação pode ser elemento motivador de doações, até que se prove o contrário, a resistência do Ministério Público e a interferência do Judiciário podem, de fato, representar grave impacto nas verbas destinadas ao financiamento de programas destinados à proteção $\mathrm{e}$ defesa dos direitos da infância e da adolescência. ${ }^{270}$

Temos que a concepção defendida pelo Tribunal se mostra absolutamente compatível com o princípio da descentralização político-administrativa das ações governamentais, consagrado, além do artigo 88 do Estatuto, ${ }^{271}$ pelo Decreto federal regulamentar do Fundo Nacional dos Direitos da Criança e Adolescente. ${ }^{272}$

plano de aplicação do recurso aportado no fundo. Desta maneira, se institui a possibilidade de um debate público em torno da definição do destino a tais recursos." (MARANHÃO, 2003, p. 6).

270 Tribunal Regional Federal da $1^{\mathrm{a}}$ Região. Suspensão de execução de sentença 000695562.202.4.01.0000/DF.

271 “Art. 88. São diretrizes da política de atendimento: I - municipalização do atendimento; II - criação de conselhos municipais, estaduais e nacional dos direitos da criança e do adolescente, órgãos deliberativos e controladores das ações em todos os níveis, assegurada a participação popular paritária por meio de organizações representativas, segundo leis federal, estaduais e municipais; III - criação e manutenção de programas específicos, observada a descentralização político-administrativa; IV - manutenção de fundos nacional, estaduais e municipais vinculados aos respectivos conselhos dos direitos da criança e do adolescente; V - integração operacional de órgãos do Judiciário, Ministério Público, Defensoria, Segurança Pública e Assistência Social, preferencialmente em um mesmo local, para efeito de agilização do atendimento inicial a adolescente a quem se atribua autoria de ato infracional; VI - integração operacional de órgãos do Judiciário, Ministério Público, Defensoria, Conselho Tutelar e encarregados da execução das políticas sociais básicas e de assistência social, para efeito de agilização do atendimento de crianças e de adolescentes inseridos em programas de acolhimento familiar ou institucional, com vista na sua rápida reintegração à família de origem ou, se tal solução se mostrar comprovadamente inviável, sua colocação em família substituta, em quaisquer das modalidades previstas no art. 28 desta Lei; VII - mobilização da opinião pública para a indispensável participação dos diversos segmentos da sociedade."

${ }^{272}$ Artigo $2^{\circ}$, II, do Decreto n. 1.196/94. 
2. As destinações realizadas nesses moldes configurariam doações em benefício de pessoas privadas travestidas de atos públicos, com o comprometimento, inclusive, da impessoalidade:

[...] ao permitir que terceiros (seja o particular, seja qualquer outro órgão do Poder Público) indiquem para qual projeto ou entidade deverá ser destinado o recurso, imediatamente o Conselho de Direitos deixa de agir de forma impessoal, já que autoriza que o cidadão $X$ ou a pessoa jurídica $\mathrm{Y}$, decida de forma nominal quais serão os beneficiários do aporte, conduta vedada pela Carta Magna na gestão da coisa pública. (Promotoria de Justiça de Mogi das Cruzes, em ação civil pública especificada na nota 177 supra, p. 34).

Nas palavras de Araújo:

Assim ocorre porque ao permitir que o próprio doador indique para onde será destinado o recurso, imediatamente o Conselho de Direitos deixa de agir de forma impessoal e autoriza que o cidadão $X$ ou a pessoa jurídica Y, de forma nominal, aja como se Gestora de Recursos Públicos fora, o que se mostra vedado por lei, máxime em se tratando de trato de dinheiro público. (ARAÚJO, p. 10)

A norma invocada a embasar tal argumento é o artigo $1^{\circ}$, parágrafo único, da Lei n. 8.666/93:

Art. $1^{\circ}$. Esta Lei estabelece normas gerais sobre licitações e contratos
administrativos pertinentes a obras, serviços, inclusive de publicidade,
compras, alienações e locações no âmbito dos Poderes da União, dos
Estados, do Distrito Federal e dos Municípios.
Parágrafo único. Subordinam-se ao regime desta Lei, além dos órgãos da
administração direta, os fundos especiais, as autarquias, as fundações
públicas, as empresas públicas, as sociedades de economia mista e
demais entidades controladas direta ou indiretamente pela União,
Estados, Distrito Federal e Municípios.

Nesse particular, lembramos que a relação que se estabelece a partir das receitas do fundo é, contrariamente do que se dá com os contratos a que se refere a Lei n. 8.666/93, de fomento, baseada em vínculos de natureza absolutamente distinta, conforme veremos no próximo capítulo.

E, no que tange ao princípio da impessoalidade consagrado pelo artigo 37 da Constituição Federal, a sistemática criada pela Lei de Licitações é tão somente uma dentre várias possíveis — forma de atendimento. 
Realmente, esse desiderato pode tranquilamente ser atingido por meios outros que não a realização de procedimento licitatório propriamente dito.

Assim se dá com a seleção e classificação de projetos a serem potencialmente custeados com recursos direcionados do Fundo, que, além de passarem por análise técnica e contábil, se sujeitam também à apreciação da idoneidade e da existência de condições mínimas da entidade proponente.

A todos os interessados em contribuir para o desenvolvimento de políticas públicas definidas pelo Conselho e devidamente consagradas no orçamento anual serão dadas iguais oportunidades, por meio da edição do chamamento público de projetos cuja elaboração, publicação e desenrolar estão constantemente sujeitos ao controle, tanto administrativo quanto social, sendo possível o questionamento de quaisquer atos ou procedimentos potencialmente lesivos da impessoalidade, isonomia ou qualquer fundamento sobre o qual se erige o ordenamento pátrio.

Ressaltamos, nesse ponto, que o mecanismo do direcionamento ao Fundo de parte do valor devido a título de Imposto de Renda não se confunde com o instituto da doação, ${ }^{273}$ o qual pressupõe que o doador tenha a propriedade e a livre disposição do bem/valores objeto dela.

A afirmativa fica ainda mais evidente quanto atentamos para que os referidos procedimentos gozam de regimes jurídicos completamente distintos, como se vê da decisão prolatada pelo Superior Tribunal de Justiça:

Tributário. Recurso Especial. Imposto de Renda Pessoa Física. Dedução de Contribuição. Art. 12, I, da Lei 9.250/95. Interpretação Restritiva. 1. Nos termos do art. 12, I, da Lei 9.250/95, podem ser deduzidas do imposto de renda "as contribuições feitas aos fundos controlados pelos Conselhos Municipais, Estaduais e Nacional dos Direitos da Criança e do Adolescente". Essa norma não comporta interpretação extensiva ou analógica com o efeito ampliativo de admitir a dedução também para contribuições feitas, não a fundo, mas a entidade particular, ainda que inscrita nos referidos Conselhos. 2. Recurso especial a que se nega

273 Em sentido contrário, porém admitindo, da mesma forma, a legitimidade do mecanismo do direcionamento vinculado, veja-se: “[...] o mecanismo do incentivo fiscal considera dois momentos; o da doação do contribuinte ao Fundo da Infância e Adolescência (relação em que as partes são a pessoa física ou jurídica doadora e o respectivo conselho) e o momento posterior em que o contribuinte deseja abater do imposto de renda devido o valor da doação (dentro do limite legal). Esta relação se dá entre o contribuinte e a União e é regida pelo direito tributário. A dedução fiscal é posterior à doação. A primeira relação (doação) dá-se no âmbito do direito civil. Nada obsta conforme art. 53 do Código Civil que o doador condicione a doação. O parágrafo único deste artigo assinala que caso o encargo seja a benefício de interesse geral o Ministério Público poderá exigir sua execução. Portanto, a doação direcionada ao fundo com indicação de aplicação em projeto específico aprovado pelo Conselho (portanto, de interesse geral)." (BARBOSA, 2007, p. 2). 
provimento. (STJ, REsp. 1045459/DF, j. 20.04.2008, rel. Min. Teori Albino Zavascki).

3. Alegada inadmissibilidade de particulares elegerem a política pública a ser apoiada, usurpando a competência do Conselho, com suposta ofensa, inclusive, à lógica da democracia participativa aplicada ao contexto.

No dizer da Promotoria de Justiça de Mogi das Cruzes:

[...] o Ministério Público tem buscado enfrentar a perniciosa, ilegal, imoral e personalizada prática de "doação casada" ou "destinação vinculada" de recursos dos Fundos de Direitos da Criança e Adolescente. E referido mal deve mesmo acabar. Não é possível aceitar, sob o pálio de pseudo filantropia, assistencialismo ou benemerência, que os Conselhos de Direitos abram mão de suas competências fixadas por lei e, portanto não delegáveis, para que terceiros - do setor privado - decidam ao seu alvedrio, sobre a destinação de recursos públicos dos Fundos de Direitos da Criança e do Adolescente. [...] Mais. Aquele que deposita recursos ao Fundo de Direitos não detém competência para orientar a destinação e aplicação dos recursos. Considerando que os recursos do Fundo de Direitos não são "privados" (particulares), mas sim públicos, inadmissível que o CMDCA delegue sua competência a quem quer que seja (particulares ou mesmo outros órgãos do Poder Público), sob pena de violação do princípio constitucional da legalidade. (Ação Civil Pública anteriormente referida, p. 31-34). ${ }^{274}$

Esse mesmo promotor de justiça, signatário da peça em questão, defendeu tese intitulada "Da destinação ilegal de recursos dos fundos dos direitos da criança e do adolescente e a sujeição dos conselheiros de direitos à Lei de Improbidade Administrativa", onde se lê:

Ora, se o Conselho de Direitos da Criança e do Adolescente já tem em sua formação, representantes do Poder Público e da Sociedade Civil artigo 88, II, do Estatuto da Criança e do Adolescente automaticamente a pessoa física ou jurídica doadora de recurso ao Fundo dos Direitos da Criança e do Adolescente já está sendo representada, direta (pelo segmento da sociedade civil que fora eleito e participa do respectivo Conselho) e indiretamente pelo segmento do Poder Público (representantes indicados pelo Chefe do Executivo que fora eleito pelo povo e o representa na chefia da Administração Pública), ou seja, presente a democracia participativa.

A permissão de direcionamento ao doador da destinação dos recursos do Fundo ofende tal princípio democrático que deve ser respeitado. Mais, o doador não detém competência para a orientação sobre a destinação dos recursos, logo ausente um dos requisitos do ato administrativo, pois não

${ }^{274}$ BRASIL. Tribunal Regional Federal da $1^{\text {a }}$ Região. Ação Civil Pública n. 33787-88.2010.4.01.3400. Rel. João Batista Moreira. 
age o Conselho de Direitos na gestão de recursos "privados" (particulares), mas sim públicos, de modo que não tem o Poder de Delegação sobre parcela de sua competência, tornando tal permissão ilegal. (ARAÚJO, p. 10)

Vejamos, também:

Qualquer competência pública, por representar, em sua natureza, verdadeiro poder-dever do administrador, é irrenunciável e, salvo disposição legal expressa, é intransferível. Assim sendo, não estão os Conselhos dos Direitos autorizados - ainda que de forma indireta - a delegar a terceiros a escolha dos programas e projetos que serão financiados pelas verbas dos fundos; fazê-lo implica tornar letra morta o princípio da democracia participativa que inspirou sua criação. (TAVARES, 2007, p. 291)

Os defensores dessa linha não admitem, portanto, o que detectam como transferência da missão de especificação dos projetos a serem implementados aos destinadores.

Ocorre que as receitas destinadas ao Fundo a partir do Imposto de Renda seriam, não fosse o mecanismo criado pelo artigo 260 do Estatuto, exclusivamente federais.

A possibilidade de sua destinação aos Fundos municipais e estaduais é expressão da lógica descentralizadora da política da infância e juventude adotada pelo ordenamento pátrio - que traz em seu bojo, necessariamente, uma maior participação, a aproximação entre Estado e sociedade civil, entre público e privado, justamente na intenção de melhor alcançar a eficiência e o atendimento das demandas sociais.

Defendemos, nesse ponto, o abandono à noção de imperatividade, de verticalidade entre Estado e sociedade; muito pelo contrário, a dinâmica a ser perseguida é a da complementaridade, da atuação conjunta, da união de esforços.

Nesse cenário, vemos como natural que o integrante da sociedade civil que optou por se mobilizar a ponto de ativamente impedir o encaminhamento de parte dos valores por ele devidos para os cofres gerais da União possa participar também do processo de destinação efetiva e definição quanto a quais necessidades serão atendidas, e de que forma.

A subtração dessa possibilidade findaria por comprometer toda a estrutura do incentivo fiscal em prol da infância e juventude, que seria então orientada pela participação tão somente até certo ponto. 
Não temos como razoável pretender que um mecanismo de participação democrática - o Conselho - tenha o condão de inviabilizar quaisquer outros, tão fundamentados nos princípios democrático e da soberania popular quanto aquele.

A restrição defendida pelo Ministério Público não consta do texto constitucional, não integra a dinâmica do incentivo e, portanto, não pode ser aceita como válida.

Uma vez que o órgão colegiado e paritário de participação popular manifesta posição pelo alargamento das possibilidades de diálogo com aqueles que são os titulares e destinatários da função pública, entendemos que tal opção deve ser respeitada e operacionalizada em toda a sua extensão.

Esse desiderato foi adotado pelo ordenamento pátrio, ao disciplinar o Fundo Nacional da Criança e do Adolescente, ${ }^{275}$ com a consagração expressa (decorrente, necessariamente, dos fundamentos constitucionais e nacionais sobre o tema) do princípio da participação das entidades governamentais e não governamentais: “Art. 20. O FNCA tem como princípios: I - a participação das entidades governamentais e nãogovernamentais, desde o planejamento até o controle das políticas e programas voltados para a criança e o adolescente."

Tendo em vista se tratar de receitas públicas, tais assertivas não afastam a necessidade de fiscalização pelo Conselho, da mesma forma que a indispensável compatibilidade entre o projeto a ser desenvolvido com as receitas do Fundo e as diretrizes gerais, o plano de ação e prioridades traçado pelo colegiado.

Posta a problemática sob esse enfoque - que entendemos ser o único juridicamente sustentável, e que é, efetivamente, o adotado pelo CMDCA/SP —, até mesmo o representante da Promotoria da Infância e Juventude do Rio Grande do Sul, manifestamente contrário à destinação direcionada, reconhece a exatidão da argumentação desenvolvida pelos partidários da sua admissão:

Também é certo que estes recursos públicos, uma vez captados pelo FIA, deixam de "pertencer" ao doador e/ou à entidade para qual em princípio estariam destinados, pois se tornam de domínio público, devendo, obrigatoriamente, ser destinados a programas de atendimento à criança, ao adolescente e/ou às suas respectivas famílias, que o Conselho de Direitos entenda prioritário manter ou implementar dentro da política de atendimento por ele traçada. Nesse contexto, evidente que, caso a entidade que "buscou" a doação desenvolva um programa de atendimento que o Conselho de Direitos da Criança e do Adolescente considere prioritário, e que portanto mereça receber recursos do FIA para sua

${ }^{275}$ Decreto federal n. 1.196/94. 
manutenção ou mesmo ampliação, nada impede que a verba captada, no todo ou em parte, seja repassada àquela própria. Tal repasse, no entanto, não pode ocorrer sem maiores formalidades e cautelas, pois devemos lembrar que estamos lidando com um recurso público, que tem sua destinação sempre vinculada e deve ter sua utilização rigorosamente fiscalizada. Assim é que, no momento do repasse, deve o Conselho de Direitos, celebrar convênio específico, em que seja descrito o programa de atendimento onde será a verba aplicada, com a indicação pormenorizada de sua forma de utilização, que deve estar obviamente de acordo com as regras gerais nesse sentido editadas pelo próprio Órgão Gestor e com as normas e princípios traçados pela Lei 8.069/90. (DIGIÁCOMO).

Ressaltemos, por fim, que as "contemplações" levadas a termo pelos contribuintes são meramente indicativas, sendo certo que, no caso de o projeto indicado como destinatário do apoio se mostrar inviável ou por qualquer motivo incompatível com o ordenamento pátrio, estarão referidos valores sujeitos à livre deliberação do colegiado.

4. Alegada ofensa à moralidade administrativa, decorrente da escolha direta e específica do beneficiário dos valores originariamente devidos em função do Imposto de Renda, independentemente de procedimento licitatório:

O princípio da moralidade também é violado porque da forma como se propõe (permissão de qualquer pessoa física ou jurídica direcionar parte da destinação dos recursos do Fundo) a Resolução deixa ao talante dos Conselheiros de Direitos e dos doadores o sabor pela escolha de tal ou qual projeto ou entidade beneficiária, abrindo um abismo para a corrupção, em detrimento do interesse social infanto-juvenil. Permite-se carga absolutamente irrestrita de subjetivismo, afastando por completo a moralidade da motivação do ato administrativo na destinação dos recursos, pois quem o faz, não precisa apresentar critérios. (ARAÚJO, p. 10-11).

E:

Outra normativa que se vê rasgada com as práticas ora questionadas, é a instituída pela Lei 8.666/93, que institui normas para licitações e contratos da Administração Pública. De acordo com o parágrafo único do artigo $1^{\circ}$ desta lei, a ela subordinam-se, além dos órgãos da administração direta, os fundos especiais, as autarquias as fundações públicas, as empresas públicas, as sociedades de economia mista e demais entidades controladas direta ou indiretamente pela União, Estados, Distrito Federal e Municípios. Permitir ao contribuinte - ou 'doador' - um atuar em substituição à lei, na escolha da entidade de atendimento mais apta à execução de determinado projeto, impedindo, no caso concreto, a aplicação das normas referentes às licitações e contratos, viola, flagrantemente, o dispositivo legal supra mencionado. (Promotoria da 
Infância e Juventude de Duque de Caxias, em parecer recursal exarado nos autos da ação civil pública referida ${ }^{276}$ ).

E, ainda:

Com tal sistemática, de legalidade e acima de tudo moralidade no mínimo altamente duvidosa, os Fundos Especiais para a Infância e Adolescência acabam tendo desvirtuada sua própria razão de ser, pois passam a servir unicamente aos interesses privados daqueles que fazem as doações e das entidades que as recebem, pouco importando a orientação da política municipal de atendimento à criança e ao adolescente definida pelo Conselho de Direitos respectivo. (DIGIÁCOMO).

Quanto a esse aspecto, pontuamos que a lógica da atividade pública de fomento não se mostra sequer compatível com a noção de licitação, vez que não se trata de contrato administrativo, marcado pela prestação e contraprestação, e no qual os valores de economicidade e eficiência assumem um tom muito mais econômico (se bem que não exclusivo) que social.

A partir do momento em que o fim maior buscado é o desenvolvimento de políticas públicas, não podemos falar em preço, ou em competitividade, nos estritos termos da Lei n. 8.666/93.

Claramente, não podem ser afastados os princípios consagrados no artigo 37 da Constituição Federal — os quais restarão igualmente observados, de forma muito mais apropriada e eficiente, por mecanismos de seleção outros. ${ }^{277}$

Nesse sentido o artigo $4^{\circ}$ da Resolução n. 77 do CMDCA/SP:

Artigo $4^{\circ}$ - Para o financiamento dos Projetos propostos por organizações governamentais e não governamentais, o CMDCA/SP fará publicar no Diário Oficial da Cidade edital de inscrição que conterá:

I - Indicação dos eixos de promoção, controle e defesa;

II - Critérios do processo de seleção e de aprovação dos projetos propostos por eixo de ação;

$\S 1^{\circ}$ - A proposta do projeto de organização governamental será apreciada desde que seus programas, voltados à criança e adolescente, estejam devidamente inscritos no CMDCA/SP.

$\S 2^{\circ}$ - A proposta de projeto de organização não governamental somente será considerada aprovada se a organização proponente estiver devidamente registrada no CMDCA/SP.

\footnotetext{
${ }^{276}$ Ação Civil Pública proposta contra o estado do Rio de Janeiro e autuada sob o número 2009-206.0146557.

${ }^{277}$ Conforme esclarecido no capítulo 1.
} 
$\S 3^{\circ}$ - Os Projetos governamentais que visem financiamento com recursos provenientes do FUMCAD/SP poderão ser contemplados desde que previamente aprovados pelo CMDCA/SP.

[...]

$\S 5^{\circ}$ - O CMDCA/SP fará publicar no Diário Oficial da Cidade a lista dos Projetos, aprovados, indicando a classificação dos mesmos.

Entendemos que a sistemática desenhada nesses moldes permite que todos os projetos que apresentem condições de aprovação e compatibilidade com o interesse público consolidado no orçamento anual e nos planos de ação e aplicação sejam aprovados e, portanto, gozem da possibilidade de virtual custeio pelo Fundo.

Lembramos, nesse ponto, que há uma ordem de classificação, tradutora de decisão discricionária ${ }^{278}$ do Conselho e determinante de quais serão os projetos prioritariamente custeados com verbas não provenientes dos direcionamentos vinculados.

É bem verdade que as regras gerais dos concursos de projetos e chamamentos públicos deveriam constar de lei formal, o que garantiria uma maior segurança jurídica tanto dos meios quanto dos resultados.

$\mathrm{Na}$ ausência de um diploma com esses contornos, porém, a sistemática adotada finda por garantir o respeito aos princípios administrativos basilares, dentre os quais merece destaque a isonomia.

Ainda no que toca ao argumento ora enfocado, repisamos que a escolha, a indicação pelo contribuinte, não poderá, em hipótese alguma, ser direcionada a qualquer projeto, ou a qualquer instituição; contrariamente, somente poderão ser beneficiados os projetos previamente aprovados pelo Conselho, cujos requisitos legais, de conveniência e oportunidade foram cabalmente analisados pelo órgão legalmente incumbido de tal missão. $^{279}$

\footnotetext{
${ }^{278}$ Nos termos referidos no item 2.1 do presente capítulo.

${ }^{279}$ Como estabelecem os artigos $3^{\circ}$ e $4^{\circ}$ da Resolução n. 77/CMDCA/SP: “Artigo $3^{\circ}$ Os projetos inovadores, de proteção especial, executado por organização governamental ou não governamental, deverão ser aprovados por $2 / 3$ (dois terços) dos membros do CMDCA/SP com direito a voto. $\S 1^{\circ}$. Os Projetos previstos no caput deste artigo e aprovados pelo CMDCA/SP serão vinculados, exclusiva e necessariamente, a um eixo de ação e sua execução dependerá da disponibilidade de recursos no Fumcad/SP. § $2^{\circ}$. Eventuais propostas de alteração nos Projetos aprovados pelo CMDCA/SP deverão ser submetidas à deliberação da plenária do referido. Conselho, observada proporcionalidade prevista no caput deste artigo. Artigo $4^{\circ}$. Para o financiamento dos Projetos propostos por organizações governamentais e não governamentais, o CMDCA/SP fará publicar no Diário Oficial da Cidade edital de inscrição que conterá: I - Indicação dos eixos de promoção, controle e defesa; II - Critérios do processo de seleção e de aprovação dos projetos propostos por eixo de ação; $\S 1^{\circ}$ - A proposta do Projeto de organização governamental será apreciada desde que seus programas, voltados à criança e adolescente, estejam devidamente inscritos no CMDCA/SP. $§ 2^{\circ} \mathrm{A}$ proposta de Projeto de organização não governamental somente será considerada aprovada se a organização proponente estiver devidamente registrada no CMDCA/SP. $\S 3^{\circ}$ Os Projetos governamentais que visem financiamento com recursos provenientes do FUMCAD/SP poderão ser contemplados desde que previamente aprovados pelo CMDCA/SP. $\S 4^{\circ}$ Trimestralmente, a organização governamental responsável pela execução
} 
Nesse sentido:

[...] a Resolução 137/2010 possibilita duas situações de indicação da verba doada/ destinada pelo doador/ destinador: (i) aplicação dos recursos em políticas prioritárias pré-definidas pelo conselho dos direitos e estabelecidas em seu plano de ação. Pode ser que algum doador/ destinador queira ter a sua imagem associada, ou queira promover alguma política pública específica destinada à infância e à adolescência, como o combate à violência sexual de crianças e adolescentes, por exemplo. Isso pode ocorrer desde que a política pública em questão esteja contemplada no plano de ação do conselho dos direitos; (ii) chancela de projetos por parte do conselho dos direitos. A chancela funciona como uma aprovação prévia de projetos e deve ser entendida como a autorização para captação de recursos ao Fundo dos Direitos da Criança e do Adolescente pelas instituições proponentes para o financiamento dos projetos aprovados pelo conselho dos direitos da criança e do adolescente. A chancela não pode trazer prejuízo às atribuições do conselho dos direitos sobre o Fundo dos Direitos. (SADECK FILHO, 2010, p. 118)

Defendemos que a visão norteadora dos combatentes da destinação vinculada significaria, em última análise, desprestígio, o desprezo e negação da competência juridicamente atribuída ao Colegiado, ao qual caberá decidir, sempre, quais são as políticas dignas de apoio, os projetos merecedores de apoio e estímulo.

Ultrapassada essa fase, somente, e estabilizado o quadro dos beneficiários possíveis, é que o contribuinte pode se manifestar - em um cenário já previamente desenhado pelo órgão competente para tanto, que analisou todos os aspectos condicionantes do custeio das ações pretendidas.

Conforme bem explicita Barbosa:

A nosso ver, não há óbice jurídico à admissibilidade de doação direcionada desde que os projetos contemplados pelo contribuinte tenham prévia aprovação do conselho. O art. 260 do Estatuto da Criança e do Adolescente assinala aos conselhos dos direitos da criança e do adolescente o dever de definir os critérios para aplicação dos recursos. Estes só podem se destinar a entidades previamente registradas e a projetos aprovados pelo conselho. Portanto, a escolha do contribuinte não é arbitrária e respeita a competência do conselho. Além disso, o repasse dos recursos exige instrumento de convênio ou termo de parceria no qual se estabelecem critérios de prestação de contas, de resto submetidas ao controle externo. Admitir que o contribuinte direcione a doação é um mecanismo que apenas reforça o controle social e por isto mesmo alavanca recursos aos fundos. A proteção à infância e à juventude é

do Projeto financiado com recursos do FUMCAD/SP encaminhará ao CMDCA/SP relatório de atividades que deverá dispor, sobre o alcance das metas indicadas, a consecução dos objetivos os indicadores qualitativos e a execução financeira. $§ 5^{\circ} \mathrm{O}$ CMDCA/SP fará publicar no Diário Oficial da Cidade a lista dos Projetos, aprovados, indicando a classificação dos mesmos." 
"prioridade absoluta", nos termos do art. 227 da Constituição Federal; a doação direcionada ajuda a concretizá-la. [...] a doação direcionada ao fundo com indicação de aplicação em projeto específico aprovado pelo conselho (portanto, de interesse geral) há de ser prestigiada pelo Ministério Público e não obstacularizada. (BARBOSA, 2007, p. 2).

5. Suposta inviabilidade decorrente do disposto no artigo $2^{\circ}, \S 2^{\circ}, \mathrm{I}$, da Lei federal n. 4.320/64, segundo o qual "acompanharão a Lei de Orçamento: I - quadros demonstrativos da receita e planos de aplicação dos fundos especiais".

Nos dizeres do representante ministerial de Duque de Caxias, em parecer recursal à ação civil pública suprarreferida:

Os Conselhos Municipais dos Direitos da Criança e Adolescente são os órgãos destacados pelo legislador estatutário para exercer a gestão política dos Fundos Municipais dos Direitos da Criança e do Adolescente, função que abarca, dentre outras, a autoridade para indicar os critérios de utilização dos recursos que o compõem.

Esta atividade é exercida por meio de dois instrumentos financeiros, que devem, obrigatoriamente, acompanhar a lei orçamentária municipal. São estes o plano de ação e o plano de aplicação (art. $2^{\circ}, \S^{\circ}$, inciso I da Lei 4.320/64). O primeiro consiste, em síntese, na indicação dos programas de trabalho a serem prioritariamente contemplados com as verbas do fundo; o segundo viabiliza a materialização do que ali é estabelecido por meio da indicação dos projetos referentes a tais programas, com respectivos prazos, metas, possíveis órgãos executores e, ainda, pela qualificação e distribuição dos respectivos aportes financeiros. Não é por outra razão que o $\$ 2^{\circ}$ o artigo 260 da Lei $8.069 / 90$ estabelece que os Conselhos Municipais, Estaduais e Nacional dos Direitos da Criança e Adolescente fixarão, através dos planos de aplicação, os critérios de utilização das doações subsidiadas e demais receitas. (p. 6). ${ }^{280}$

Ponderemos, quanto a esse particular, que os quadros e planos de aplicação exigidos pela Lei devem, realmente, ser elaborados pelos Conselhos de Direitos - e que referidos documentos referenciais orientarão a elaboração do orçamento anual. ${ }^{281}$

\footnotetext{
${ }^{280}$ Ação Civil Pública proposta contra o estado do Rio de Janeiro e autuada sob o número 2009-206.0146557.

281 “A feição antidemocrática do modelo orçamentário resulta da concentração de poderes no Executivo, da subalternidade parlamentar e do total afastamento popular do processo decisório. [...] Isso parece contrariar a equação política ideal do orçamento, que se baseia na divisão de poder, no equilíbrio das funções e na necessidade de controle estatal, como medidas de legitimidade. A "razão de ser" do sistema orçamentário é muito simples, não importa o modelo econômico: é a sociedade quem deve decidir o que fazer com o dinheiro público. Em última análise, os princípios do Estado Democrático de Direito exigem o compartilhamento decisório no sistema orçamentário, em todas as suas etapas. Nos orçamentos materializamse as diretrizes da política econômico-financeira e o compromisso das autoridades em cumprir os objetivos fundamentais do país, expressos na Constituição. Está em jogo a política de desenvolvimento e, portanto, a qualidade de vida de milhões de pessoas: é dever do Estado gastar bem, no momento certo, para garantir um futuro melhor a esta e às próximas gerações. Quando se fala em democracia e recurso público, pois, não basta argumentar com requisitos formais. A pior maneira de enxergar o orçamento é por meio de lentes
} 
Nenhuma restrição pode ser feita, porém, quanto aos fundamentos sobre os quais deverão referidos órgãos erigir esses instrumentos, de modo que lhes é possível, em prestígio inclusive ao princípio democrático, levar em consideração os anseios da comunidade, os quais se traduzem justamente na eleição do projeto a ser suportado desde que atendidos todos os requisitos legais, com a necessária aprovação pelo Conselho (que, dessa forma, chancelará a sua propriedade e compatibilidade com as políticas demandadas).

Esses quadros e planos, portanto, não só podem, como devem tomar por base as sugestões trazidas pela sociedade civil, como meio para a conquista da responsividade, atualmente alçada a integrante indispensável da própria noção de legitimidade dos atos administrativos e políticas públicas.

Assim, da mesma forma que a sociedade civil inspira a elaboração dos planos de ação e aplicação, está a eles adstritos, de forma que o edital de chamamento dos projetos a serem analisados e, se aprovados, admitidos como possíveis destinatários das receitas do Fundo, deverão seguir fielmente suas diretrizes.

Ao edital de chamamento caberá concretizar essa lógica, em uma compatibilização constante e efetiva das demandas sociais com as expectativas e pretensões orçamentárias e financeiras.

6. Haveria o risco de a vontade do destinador substituir a vontade do legislador, na medida em que alguns programas obrigatórios poderiam restar desguarnecidos em detrimento de outros, apresentados pela sociedade civil.

Em outras palavras, a preocupação manifestada pelos defensores da inviabilidade da destinação direcionada seria com o desprezo aos investimentos mínimos nas searas exigidas pelo Legislador federal, como no caso do artigo 227, § $3^{\circ}$, VI, da Constituição Federal:

A distribuição de verbas destinada ao Banco de Projetos ofende a norma impositiva do art. 260 do Estatuto da Criança e do Adolescente que obriga aos Conselhos de Direitos a destinação de percentual do fundo

burocráticas - altamente vocacionadas para reduzir questões de relevo (desigualdades sociais, endividamento, equilíbrio macroeconômico etc.) a exigências de procedimento ou, simplesmente, a indicadores e relatórios estéreis. De outro lado, o consentimento popular não constitui, apenas, fator de segurança para as decisões da autoridade, mas implica responsabilidade coletiva pelos erros e acertos da política orçamentária. Eventuais equívocos na destinação de recurso público e no desenvolvimento nacional ganham nova dimensão, se decorrem da autorização social para o planejamento: não há culpados; somos todos responsáveis." (SABBAD, 2011, p. 458). 
gerido para "incentivo ao acolhimento, sob a forma de guarda, de criança ou adolescente, órfão ou abandonado, na forma do disposto no art. 227 $\S 3^{\circ}$, VI da CF”. No caso, não há tal previsão já que o recurso arrecadado será destinado à entidade eleita pelo patrocinador, o que importa em negativa de vigência ao dispositivo comentado. (BARROS, p. 11).

Registramos, nesse particular, que toda a sistemática a ser desenvolvida pelo Conselho em relação ao Fundo deve se sujeitar às normas que o ordenamento jurídico fixa quanto a esse particular.

Uma vez criada a exigência legal de aplicação em determinadas ações, caberá ao Conselho, quando da elaboração do edital de chamamento de projetos, levar esses parâmetros em conta, sob pena de ilegalidade.

A própria ausência de total liberdade para a indicação de projetos traduz essa ressalva: somente poderão ser contemplados os projetos compatíveis com o ordenamento pátrio, ou seja, a destinação se desenvolverá sempre em um contexto limitado, específico em que a chancela do Conselho já se aperfeiçoou.

De todo o exposto, temos que não merecem guarida os argumentos contrários à destinação em prol de projeto específico, a qual será meramente indicativa e se desenvolverá dentro de todos os parâmetros legais.

\subsection{Conclusão parcial}

Do quanto até o momento exposto, temos que o Conselho Municipal dos Direitos da Criança e do Adolescente de São Paulo é órgão autônomo e deliberativo, vinculado à Secretaria Municipal de Participação e Parceria tão somente para fins procedimentais ou burocráticos.

Trata-se de arena de participação integrada por representantes tanto do governo quanto da sociedade civil - o que o exclui da estrutura estatal tradicionalmente considerada e hierarquicamente arranjada, o conduzindo ao campo dos entes públicos não estatais.

Nessa condição, não estão sujeitos ao controle hierárquico do Executivo, sendo responsáveis, na sua seara de atuação, pelo exercício do poder político e pelo exercício da discricionariedade administrativa. 
Sua atividade é controlada e limitada, assim, e sob esses aspectos, tão somente pelo ordenamento jurídico e pelos atores fiscalizatórios externos encarregados de fazer-lhe valer.

As suas rotinas técnico-formais ficam a cargo da Secretaria Municipal de Participação e Parceria - que responderá por eventuais irregularidades perpetradas no desempenho dessa função.

É incumbido da gestão do Fundo Municipal dos Direitos da Criança e do Adolescente, integrado por receitas tanto originariamente orçamentárias quanto provenientes de destinações de percentuais de valores devidos a título de impostos, a partir da atividade de fomento.

Referido Fundo se sujeita integralmente às regras de Direito Financeiro e Orçamentário comuns a toda a Administração Pública, com os desdobramentos daí resultantes.

Os valores aí alocados serão destinados, entre outros, ao custeio de atividades de fomento em prol das políticas da infância e juventude — sobre a qual nos debruçaremos no capítulo seguinte.

Completo, assim, o cenário que nos cumpria imprimir para o satisfatório desenvolvimento de nossas considerações.

Assentadas as noções e discussões atinentes à atividade administrativa de fomento e ao Conselho Municipal dos Direitos da Criança e do Adolescente, cumpre-nos evoluir nosso raciocínio para o momento em que ambos os arcabouços se encontram e se interpenetram.

Passemos, pois, à análise do desenvolvimento do ciclo do fomento por intermédio do Conselho Municipal dos Direitos da Criança e do Adolescente de São Paulo. 


\section{A ATIVIDADE ${ }^{282}$ DE FOMENTO EXERCIDA POR INTERMÉDIO DO CMDCA}

\subsection{Incentivo fiscal ao setor econômico e subvenções às entidades do Terceiro Setor: delimitação do objeto de investigação}

A fonte de recursos do Fumcad-SP que mais de perto nos interessa é, como se depreende do que foi até o momento exposto, a iniciativa privada - que encontra fundamento para a sua mobilização justamente na concessão estatal de incentivo físcal relativo ao Imposto de Renda - IR. Este o ponto de partida.

Não obstante existam incentivos também relativos ao Imposto Sobre Serviços ${ }^{283} \mathrm{e}$ ao Imposto Predial e Territorial Urbano ${ }^{284}$ (este último qualificado como benefício fiscal propriamente dito, conforme termos a seguir expostos), deles não trataremos no presente trabalho.

Salientamos que a operacionalização dos incentivos ligados ao IR não se dá de forma a desonerar, ainda que parcialmente, o contribuinte: o que se tem é a criação de uma possibilidade de vinculação dos valores devidos a uma finalidade específica, no caso, à “alimentação" do Fumcad.

Assim, os valores destinados ao referido Fundo (seja em época próxima à da apresentação da declaração, seja ao longo do ano), os quais já saíram do "bolso do contribuinte", não terão que ser pagos em duplicidade, observados os limites legais de

\footnotetext{
${ }^{282}$ Conforme pontuamos nas linhas inaugurais do presente estudo, a atividade administrativa é instrumental da respectiva função que, conforme lição de Mello, "pode ser realizada pelo Estado ou por quem aja em seu nome, o que implica a possibilidade de o particular praticar a função administrativa." (MELLO, 2003, p. 27). ${ }^{283}$ Nesse sentido, o disposto no artigo 27 da Lei municipal n. 13.476/02: "Art. 27. As instituições financeiras, que contribuírem ao Fundo Municipal dos Direitos da Criança e do Adolescente - Fumcad, poderão descontar do valor mensal devido a título de Imposto Sobre Serviços de Qualquer Natureza - ISS incidente sobre os serviços descritos no item 95 da Tabela anexa à Lei 10.423, de 29 de dezembro de 1987, o valor doado ao referido Fundo, até o limite de 1/6 (um sexto) do valor do Imposto devido sobre os serviços descritos no aludido item 95." Referida norma encontra-se atualmente inaplicável em decorrência da revogação, pela Lei municipal n. 14.125/2005, da referida Lei n. 10.423/87.

${ }^{284}$ Lei municipal n. 14.501, de 20 de setembro de 2007: "Art. 1'. Fica instituído incentivo fiscal para as agremiações, federações e confederações desportivas sediadas no Município de São Paulo, a ser utilizado no abatimento do Imposto Territorial Urbano incidente sobre imóveis de propriedade das referidas entidades, efetiva e habitualmente utilizados no exercício de suas atividades. Parágrafo único. As federações e confederações desportivas poderão se beneficiar do incentivo fiscal ora instituído, desde que tenham projetos sociais direcionados às crianças e adolescentes em execução e devidamente registrados no Conselho Municipal dos Direitos da Criança e do Adolescente - CMDCA." Referido diploma encontra-se regulamentado pelo Decreto municipal n. 48.918, de 09 de novembro de 2007.
} 
desconto - $1 \%$ (um por cento) para as pessoas jurídicas e $6 \%$ (seis por cento) para as físicas. $^{285}$

Não há em tal sistemática renúncia fiscal, diminuição de receita pública, mas tão somente a realocação de valores originariamente destinados aos cofres da União e, por opção do contribuinte, redirecionados ao Fundo.

A perfeita compreensão do conceito de incentivo fiscal é determinante para o presente estudo.

Trata-se de mecanismo voltado à mobilização da iniciativa privada, da sociedade em geral, por quaisquer meios, em prol de um determinado fim tido pela legislação como digno de proteção e promoção governamental.

Entendemos não se identificar com os benefícios fiscais, que implicam necessária desoneração do particular, com decréscimo de receita nos cofres públicos. ${ }^{286}$

Os benefícios fiscais produzem efeitos financeiros similares aos das despesas públicas, mais especificamente as subvenções, na medida em que ambos são instrumentos utilizados para transferir ao particular beneficiado recursos financeiros que a priori pertenceriam ao Estado. [...] "benefício" auferido pelos contribuintes abrangidos por um benefício fiscal é exatamente a diminuição, parcial ou total, do valor de tributos a ser pago. Essa redução, em caráter excepcional, da tributação sobre determinado fato tem como resultado a manutenção da propriedade de

285 Conforme disposto no artigo $1^{\circ}$ do Decreto federal n. 794, de 05 de abril de 1993, que trata especificamente das pessoas jurídicas, "o limite máximo de dedução do Imposto de Renda devido na apuração mensal das pessoas jurídicas, correspondente ao total das doações efetuadas no mês, é fixado em um por cento." No que tange às pessoas físicas, tem-se, segundo o artigo 22 da Lei federal n. 9.532, de 10 de dezembro de 1997, que "a soma das deduções a que se referem os incisos I a III do art. 12 da Lei 9.250, de 1995, fica limitada a seis por cento do valor do imposto devido, não sendo aplicáveis limites específicos a quaisquer dessas deduções." Considere-se, por fim, em nível legislativo municipal, o artigo $1^{\circ}$, VII, “ $f$ ", da Lei n. 15.276, de 02 de setembro de 2010: “Art. $1^{\circ}$ O Poder Público Municipal, quando da formulação e realização da Política Municipal de Prevenção e Combate do Trabalho Infantil em suas Piores Formas, se pautará pelas seguintes diretrizes, como objetivos ou ações, entre outras possíveis e necessárias à prevenção do trabalho infantil e para a proteção de crianças e adolescentes inseridos em situação de trabalho infantil, especialmente nas formas consideradas como penosas, insalubres e perigosas: VII - divulgação dos danos causados pela violação dos direitos da criança e do adolescente, seguindo-se, sempre que possível, os seguintes parâmetros: f) esclarecimento do público em geral, pessoas físicas e jurídicas, sobre as formas de apoio aos programas e projetos definidos pelos planos de aplicação do Conselho Municipal dos Direitos da Criança e do Adolescente por meio de doações ao Fundo Municipal dos Direitos da Criança e do Adolescente, informando, principalmente, sobre a permissão de dedução do Imposto de Renda devido, ou seja, de $1 \%$ (um por cento) para pessoa física e de $6 \%$ (seis por cento) para pessoa jurídica."

${ }^{286}$ Ressalvados os benefícios não onerosos, representados pela noção de "benefícios a custo zero". Nas palavras de Henriques, "esse é o caso dos benefícios fiscais que não acarretam efetiva redução da arrecadação, uma vez que são instituídos para atender a pessoas físicas e jurídicas que ainda não são contribuintes dos tributos beneficiados. O exemplo clássico desse benefício é a isenção do Imposto sobre a Propriedade Territorial Urbana (IPTU) e do ISS concedida por um município para determinada pessoa jurídica com o objetivo de que ela se estabeleça em seu território. Como essa pessoa jurídica, na ocasião da promulgação de tais benefícios, ainda não está estabelecida no território do município, não gera arrecadação tributária, motivo pelo qual as referidas isenções não criam efetivamente nenhuma redução na arrecadação tributária municipal.”(HENRIQUES, 2009, p. 101-102). 
determinados valores pelo particular, os quais, sem tal norma, a princípio seriam pagos ao erário (HENRIQUES, 2009, p. 4-12).

Ainda que a doutrina ${ }^{287,288}$ e a jurisprudência ${ }^{289}$ por vezes admitam o uso de uma expressão pela outra, a sinonímia entre benefício e incentivo fiscal, é importante fazer essa diferenciação: o incentivo fiscal não acarreta necessário ganho direto ao particular; o que se busca, mais que uma vantagem individualizada, é o estímulo à assunção de determinada postura.

Não se confundem, portanto, as figuras, conforme se depreende do disposto no artigo 195, § $3^{\circ}$, da CF:

Art. 195. A seguridade social será financiada por toda a sociedade, de forma direta e indireta, nos termos da lei, mediante recursos provenientes dos orçamentos da União, dos Estados, do Distrito Federal e dos Municípios, e das seguintes contribuições sociais: [...]

$\S 3^{\circ}$ - A pessoa jurídica em débito com o sistema da seguridade social, como estabelecido em lei, não poderá contratar com o Poder Público nem dele receber benefícios ou incentivos fiscais ou creditícios. (grifamos)

A mesma conclusão exsurge dos artigos $155, \S 2^{\circ}$, XII, “ $g$ ”, e 156, § $3^{\circ}$, III:

Art. 155. Compete aos Estados e ao Distrito Federal instituir impostos sobre:

[...] II - relativamente a bens móveis, títulos e créditos, compete ao Estado onde se processar o inventário ou arrolamento, ou tiver domicílio o doador, ou ao Distrito Federal; [...]

$\S 2^{\circ} \mathrm{O}$ imposto previsto no inciso II atenderá ao seguinte: [...]

XII - cabe à lei complementar: [...]

g) regular a forma como, mediante deliberação dos Estados e do Distrito Federal, isenções, incentivos e benefícios fiscais serão concedidos e revogados. (grifamos)

Art. 156. Compete aos Municípios instituir impostos sobre:

[...]

287 “[...] O estudo jurídico desse instituto, entretanto, é ainda incipiente. O próprio conceito não possui uma definição rigorosa, sendo expresso pela doutrina e legislação por diversos vocábulos, tais como 'benefícios fiscais', 'incentivos fiscais', 'desoneração tributária, 'isenções', 'privilégios fiscais', 'alívio fiscal', entre outros.” (HENRIQUES, 2009, p. 12).

${ }^{288}$ Para Geraldo Ataliba, os incentivos fiscais seriam gênero no qual estariam inseridas as isenções, as alíquotas reduzidas, a suspensão de impostos, a manutenção de créditos, bonificações, créditos especiais etc., sempre com a intenção de "impulsionar ou atrair os particulares para práticas das atividades que o Estado elege como prioritárias, tornando, por assim dizer, os particulares, em participantes e colaboradores da concretização das metas postas como desejáveis ao desenvolvimento econômico e social por meio da adoção do comportamento ao qual são condicionados." (ATALIBA, 1991, p. 167).

${ }^{289}$ Conforme Resp. n. 509.802/AM (1. ${ }^{a}$ T., rel. Min. José Delgado) e n. 297.641/CE (2. ${ }^{a}$ T., rel. Min. José Duarte Noronha). 
$\S 3^{\circ}$ Em relação ao imposto previsto no inciso III do caput deste artigo, cabe à lei complementar:

III - regular a forma e as condições como isenções, incentivos $e$ benefícios fiscais serão concedidos e revogados. (grifamos)

De fato, se ambos os institutos fossem sinônimos, coincidentes, não haveria justificativa plausível para o desdobramento realizado pelo Legislador Constituinte; bastaria a referência a "benefícios fiscais", e todas as possibilidades intentadas estariam devidamente abarcadas.

Entendemos, portanto, que a sistemática de mobilização da sociedade civil com vista à destinação de recursos do Fumcad/SP traduz-se como medida não inserta no conceito técnico de benefício, mas de incentivo fiscal.

A sua previsão legal originária consta do artigo 260 da Lei federal n. 8.069/90:

Art. 260. Os contribuintes poderão deduzir do imposto devido, na declaração do Imposto sobre a Renda, o total das doações feitas aos Fundos dos Direitos da Criança e do Adolescente - nacional, estaduais ou municipais - devidamente comprovadas, obedecidos os limites estabelecidos em Decreto do Presidente da República. (Redação dada pela Lei 8.242, de 12.10.1991)

I - limite de $10 \%$ (dez por cento) da renda bruta para pessoa física;

II - limite de 5\% (cinco por cento) da renda bruta para pessoa jurídica.

O Decreto federal n. 3.000, de 26 de março de 1999, procedeu ao seu regulamento, no que tange às pessoas jurídicas:

Art. 591. A pessoa jurídica poderá deduzir do imposto devido, em cada período de apuração, o total das doações efetuadas aos fundos dos Direitos da Criança e do Adolescente - nacional, estaduais ou municipais - devidamente comprovadas, obedecidos os limites estabelecidos pelo Poder Executivo, vedada a dedução como despesa operacional.

Quanto às pessoas físicas, incide o disposto no artigo 12 da Lei federal n. 9.250, de 26 de dezembro de 1995, segundo o qual "do imposto apurado na forma do artigo anterior, poderão ser deduzidos: I - as contribuições feitas aos Fundos controlados pelos Conselhos Municipais, Estaduais e Nacional dos Direitos da Criança e do Adolescente e pelos Conselhos Municipais, Estaduais e Nacional do Idoso" (Redação dada pela Lei n. 12.213, de 2010). 
Observemos, ainda, o disposto na INRF n. 1.131, de 21 de fevereiro de $2011 .^{290}$

Esse o primeiro momento da verticalização do incentivo, em que se dá a indispensável mobilização tanto do Legislativo como do Executivo do ente cujos cofres serão atingidos com a sua criação — no caso, federal.

Proposta, aprovada e publicada a sua disciplina geral concretizadora do autorizativo veiculado pelo ECA, imprescindível a atuação de seus entes destinatários responsáveis por sua implementação, cujos orçamentos serão prestigiados - no caso, os Municípios.

Essa iniciativa regulamentar não ficará, nesse contexto, a cargo do Executivo: conforme salientado no capítulo anterior, a definição, gestão e efetivação das políticas públicas na área da infância e juventude são atribuídas ao Conselho da Criança e Adolescente, o qual congrega representantes e, portanto, opiniões do governo e da sociedade civil.

Trata-se de forma peculiar do exercício da discricionariedade administrativa que, nessas circunstâncias, não é apenas limitada, mas exercida diretamente por essa arena de participação:

\footnotetext{
${ }^{290}$ Que traz, em linhas gerais, a seguinte disciplina para a matéria: “Art. $1^{\circ}$ Os procedimentos a serem adotados para fruição dos benefícios fiscais relativos ao Imposto sobre a Renda das Pessoas Físicas nas doações aos Fundos dos Direitos da Criança e do Adolescente, nas doações aos Fundos do Idoso, nos investimentos e patrocínios em obras audiovisuais, nas doações e patrocínios de projetos culturais, nas doações e patrocínios em projetos desportivos e paradesportivos e na contribuição patronal paga à Previdência Social incidente sobre a remuneração do empregado doméstico são efetuados de acordo com as disposições desta Instrução Normativa. Art. $2^{\circ}$ A pessoa física pode deduzir do imposto apurado na Declaração de Ajuste Anual, a que se refere o art. 54, as doações feitas no ano-calendário anterior aos Fundos Nacional, Estaduais e Municipais dos Direitos da Criança e do Adolescente. $\S 1^{\circ}$ As importâncias deduzidas a título de doações sujeitam-se à comprovação, por meio de documentos emitidos pelos conselhos gestores dos respectivos fundos. $\S 2^{\circ}$ As doações efetuadas em moeda devem ser depositadas em conta específica, aberta em instituição financeira pública, vinculada ao respectivo fundo. Art. $3^{\circ} \mathrm{A}$ dedução de que trata $\mathrm{o}$ art. $2^{\circ}$ deve atender ao limite global estabelecido no art. 55 desta Instrução Normativa. Art. $4^{\circ}$ Os Conselhos Municipais, Estaduais ou Nacional dos Direitos da Criança e do Adolescente, controladores dos fundos beneficiados pelas doações, devem emitir comprovante em favor do incentivador. $\S 1^{\circ} \mathrm{O}$ comprovante deve: I - ter número de ordem, o nome e o endereço do emitente; II - ter o nome, o número de inscrição no Cadastro Nacional das Pessoas Jurídicas (CNPJ) do respectivo fundo que o Conselho administra; III - ter o nome e o número de inscrição no Cadastro de Pessoas Físicas (CPF) do contribuinte, a data e o valor efetivamente recebido em dinheiro; e IV - ser firmado por pessoa competente para dar a quitação da operação. $\S 2^{\circ}$ No caso de doação em bens, o comprovante deve conter a identificação e o valor pelo qual esses bens foram doados, mediante sua descrição em campo próprio ou em relação anexa, informando também, se houve avaliação, os números de inscrição no CPF ou no CNPJ dos responsáveis pela avaliação. [...] Art. $6^{\circ} \mathrm{A}$ Secretaria da Receita Federal do Brasil (RFB) fiscalizará, no âmbito de suas atribuições, a captação dos recursos efetuada na forma do art. $2^{\circ}$. Parágrafo único. Para efeito do caput, os órgãos responsáveis pela administração das contas dos Fundos dos Direitos da Criança e do Adolescente deverão informar à RFB, dados relativos ao valor das doações recebidas, nos termos do art. 57 desta Instrução Normativa. Art. $7^{\circ}$ Para fins de comprovação, cada Fundo deverá registrar em sua escrituração os valores recebidos e manter em boa guarda a documentação correspondente pelo prazo decadencial. Art. $8^{\circ} \mathrm{O}$ descumprimento das determinações dos arts. $4^{\circ}$ e $6^{\circ}$ sujeita o infrator à multa de $R \$ 80,79$ (oitenta reais e setenta e nove centavos) a $R \$ 242,51$ (duzentos e quarenta e dois reais e cinquenta e um centavos), por comprovante ou relação não entregues."
} 
Um novo "locus" de discricionariedade nasce, então, a partir de criação de Conselhos como forma de participação na gestão do poder político. Tradicionalmente a escolha das opções políticas criativas, feitas através de um juízo de oportunidade e conveniência, coube ao Executivo, nas diferentes esferas do poder público. [...] Contudo, a partir do momento em que se reconhece o instituto da participação do povo na gestão do poder político, como legítimo modo de exercício do poder, impõe reconhecer-se que, em certas matérias, a escolha das opções políticas criativas ganharão outro foro de decisão, quebrando a tradição de escolha única pelo Poder Executivo, na forma clássica. (LIBERATI; CYRINO, 2003, p. 86)

Nesse sentido, o CMDCA/SP editou a Resolução n. 70/2003, para os fins ora analisados substituída pela $\mathrm{n} .77 .^{291}$

Constatamos da referida Resolução que: a) as destinações realizadas ao Fumcad/SP a partir do incentivo fiscal são controladas inicialmente pela Secretaria à qual o Fundo se encontra vinculado (atualmente, a Secretaria Municipal de Participação e Parceria), e, em um segundo momento, pelo Conselho; b) no caso das destinações vinculadas a projeto específico, dez por cento do valor ficará necessariamente à disposição do Conselho, a quem caberá fixar sua destinação; ${ }^{292}$ c) na hipótese de os contribuintes indicadores de projetos beneficiários desejarem "capitalizar" essa sua iniciativa, adquirindo assim um "selo de responsabilidade social", deverão necessariamente apontar a vinculação desses valores ao Fundo.

Aí surge uma das "pontas", um dos extremos da dinâmica que nos propusemos a analisar: a atividade administrativa de estímulo tem início junto à iniciativa privada pessoas físicas ou jurídicas —, que lança mão de um arcabouço legislativo específico,

\footnotetext{
${ }^{291}$ Cujos artigos $2^{\circ}, \S 2^{\circ}$ e $5^{\circ}$ assim dispõem: “§ $2^{\circ}$. A Secretaria municipal responsável pela gestão administrativa do Fumcad/SP deverá encaminhar trimestralmente ofício ao CMDCA/SP indicando a relação nominal de doadores e os valores individuais correspondentes que, por meio de incentivo tributário, foram destinados ao Fumcad/SP no mês anterior, devendo os referidos documentos ser apreciados pelo COT Conselho de Orientação Técnica. Art. $5^{\circ}$. A pessoa física ou jurídica, valendo-se de mecanismo legal de incentivo tributário, poderá indicar, através de ofício dirigido ao Presidente do CMDCA/SP e contendo cópia do comprovante de depósito no Fumcad/SP o projeto ou eixo previamente aprovado, cujo desenvolvimento pretenda auxiliar. $\S 1^{\circ}$. Do valor destinado ao Fumcad/SP, de que trata o caput deste artigo, $10 \%$ (dez por cento) serão reservados para financiamento de outros projetos aprovados pelo CMDCA/SP, conforme Decreto 43.135/03. $\S 2^{\circ}$. As pessoas físicas e jurídicas que utilizarem o mecanismo indicado no caput deste artigo e desejarem dar publicidade ou divulgar este ato, por qualquer meio, deverão dispor expressamente e de forma legível que 'os valores aplicados no projeto foram destinados ao Fundo Municipal dos Direitos da Criança e Adolescente - FUMCAD/SP e abatidos do imposto' especificando se é imposto de renda ou imposto sobre serviços." Das questões afetas a este último dispositivo já tratamos anteriormente.

${ }^{292}$ Registre-se que a reserva em questão vem a ratificar o entendimento de que não se pode falar, conforme pretendem os opositores da sistemática da destinação a projeto específico, em "doação à iniciativa privada travestida de ato público".
} 
autorizativo e estimulante da destinação de percentual devido a título de Imposto de Renda ao Fumcad/SP.

Essa postura indutiva, traduzida em estímulos à promoção e garantia dos direitos da criança e do adolescente, arrasta a atividade administrativa em questão para a seara do fomento, conforme explicitado no capítulo 1.

E os elementos do fomento são, como da mesma forma asseverado, necessária e inevitavelmente: a) sujeitos — agente fomentador e destinatário(s), mediato e imediato —; b) objeto; c) meios.

$\mathrm{O}$ agente fomentador é, em um primeiro momento, o próprio Estado (criador e regulador, em termos gerais, do incentivo), porém não isolada e tradicionalmente considerado - a concretização do estímulo, como dito, fica a cargo do Conselho, esfera de atuação pública não estatal.

Seus destinatários diretos são a iniciativa privada contribuinte do Imposto de Renda, e seus beneficiários, as entidades do Terceiro Setor devidamente registradas no CMDCA/SP, cujos projetos tenham sido aprovados e tidos como compatíveis com o interesse público e que venham, em um desdobramento coerente de ações, a parceirizar com a Administração.

Referidas entidades passarão, em um segundo momento, a destinatárias diretas de uma segunda relação de fomento, estabelecida com a Administração/Conselho, e operacionalizada por meio de convênios veiculadores de transferências de receitas públicas.

É com elas, pois, que se estabelecem os laços voltados especificamente ao atendimento do interesse público — ou dos interesses públicos — traduzidos em demandas sociais tidas como dignas de acolhimento e promoção pelo Conselho.

Referidos laços são marcados pelas seguintes características fundamentais: a) inserem-se no âmbito da contratualização, da Administração contratual, concretizando-se por meio de convênios - espécie de contrato lato sensu, como mais adiante veremos; b) estão vinculados à promoção e realização de fins de interesse público inicialmente fixados; c) implicam a transferência direta de valores aos entes fomentados — os quais ficam afetados àqueles fins; d) as ações fomentadas devem guardar uma relação de responsividade com as demandas públicas, gerar um impacto social desejado; e) não tem o seu regime limitado ou restrito pelas normas constantes da Lei federal n. 4.320/64. 
Daí assumirem a natureza jurídica de subvenções ${ }^{293}$ (nos moldes explicitados no capítulo 1), a serem instrumentalizadas via convênios.

À parte das entidades sem finalidades lucrativas de natureza privada, podem figurar como destinatários dessas receitas órgãos/entes públicos que se insiram, de alguma forma, na lógica do fomento, nos termos anteriormente construídos.

A esses destinatários caberá aplicar as receitas em prol do bem comum, com o desenvolvimento direto de ações em benefício da infância e juventude, independentemente de qualquer contraprestação financeira (que não se confunde com a contrapartida, de que adiante se tratará).

Não há remuneração, pagamento, nem sinalagma; o que se vê é o repasse de valores com fins de atendimento a objetivos específicos de apelo coletivo.

Não se trata de relação contratual stricto sensu, nos moldes preconizados pela Lei n. 8.666/93 ${ }^{294}$ : inexistem interesses no mesmo sentido e direções opostas, prestação e contraprestação; não há uma compra de bens ou contratação de serviços:

O próprio espírito colaborativo do convênio, de parceria entre o poder público e o privado para se atingir objetivos comuns, conduz a esta conclusão. Se o objetivo for a contratação de serviços ou aquisição de bens, a figura jurídica adequada será o contrato administrativo. Como o fomento público objetiva incentivar ações e atividades privadas afetadas ao interesse público e coletivo, pode-se afirmar que os convênios administrativos colaborativos, celebrados entre o poder público e entidades privadas estão atrelados às funções fomentadoras do Estado. (LIMA, 2010, p. 33).

A lógica adotada é absolutamente distinta: o que temos é uma mobilização conjunta, uma união de esforços em prol do bem comum e cujo móvel fundamental é a

\footnotetext{
293 "Embora seja possível encontrar um conceito de subvenção, uma considerável quantidade de estudiosos do conceito tende a concordar com o fato de que, sendo as subvenções espécie do gênero de despesa pública, consistem em transferências diretas de recursos financeiros do Estado para entidades privadas. Tais transferências, no entanto, têm como característica definidora o fato de não possuírem uma contraprestação (Gegenleistung). Conforme visto, toda despesa pública tem como característica própria o dispêndio de recursos financeiros. Entretanto, em quase todos os casos o Estado recebe uma contraprestação pelo valor despendido, a qual não existe no caso das subvenções. Daí a conclusão de Michael Rodi de que as subvenções são prestações do Estado para específicos entes privados sem uma correspondente contraprestação econômica. A par desses critérios, todavia, é comum também se encontrar na doutrina e legislação a vinculação do conceito de subvenção a um critério finalístico, segundo o qual tais transferências de recursos públicos teriam como objetivo gerar um efeito econômico de interesse público, como o estímulo à geração de empregos e ao crescimento de empregos e ao crescimento econômico.” (HENRIQUES, 2009, p. $15)$.

294 “Art. $2^{\circ}$. [...] Parágrafo único. Para os fins desta Lei, considera-se contrato todo e qualquer ajuste entre órgãos e entidades da Administração Pública e particulares, em que haja um acordo de vontades para formação de vínculo e a estipulação de obrigações recíprocas, seja qual for a denominação utilizada."
} 
solidariedade, princípio angular da sociedade contemporânea, e cuja inteligência deve seguir o preconizado no capítulo 1.

Em suma, o presente objeto de estudo se manifesta em dois momentos muito bem delineados: a) a relação de fomento entre poder público e inciativa privada contribuinte do IR, sendo aquele o ente fomentador, esta a sua destinatária direta, e, as entidades do Terceiro Setor "agraciadas" com os valores para seus projetos, suas destinatárias indiretas; b) a relação de fomento entre a Administração e as entidades do Terceiro Setor, sendo aquela o agente fomentador, estas seu destinatário direto e, as crianças e adolescentes, os beneficiários ou destinatário indireto. Tudo isso permeado pela lógica do consensualismo, da Administração mediadora, mobilizadora, não autoritária e não imperativa.

Em torno dessas relações que se desenvolverão nossas ponderações a seguir.

\subsection{A nova contratualização administrativa: administração por contratos}

Os novos paradigmas contextuais e do próprio Direito a que vimos nos referindo ao longo do presente geram uma série de consequências diretas quanto à atuação da Administração Pública.

Dentre elas, cumpre-nos repousar o olhar, neste momento, sobre a sua forma de relacionamento com a sociedade em geral e os entes e órgãos públicos.

Nesse cenário, ganha importância fundamental o consensualismo, técnica de estabelecimento de vínculos baseada na acomodação e compatibilização de interesses, no diálogo, que vem, com relação a muitos aspectos, substituir o império e atuação autoritária, impositiva e unilateral tradicionalmente associados à Administração:

A análise do fenômeno do consensualismo [...] ultrapassa o emprego do contrato para a obtenção de resultados meramente econômicos ou patrimoniais. O ponto em destaque diz respeito à extensão e à intensidade com que técnicas consensuais vêm sendo empregadas, como soluções preferenciais - e não unicamente alternativas - à utilização de métodos estatais que veiculem unilateral e impositivamente comandos para os cidadãos, empresas e organizações da sociedade civil. [...] no âmbito estatal, em campos habitualmente ocupados pela imperatividade há a abertura de consideráveis espaços para a consensualidade. Aplicada ao terreno da Administração pública, essa orientação gerou expressões como Administrar por contrato, Administrar por acordo, Administração paritária, Administração dialógica, e mais recentemente, Administração consensual. [...] O sentido das expressões elencadas sinalizam um novo caminho, no qual a Administração pública passa a valorizar (e por vezes privilegiar) uma forma de gestão cujas referências são o acordo, a negociação, a coordenação, a cooperação, a colaboração, a conciliação, a 
transação. Isso em setores e atividades preferencial ou exclusivamente reservados ao tradicional modo de administrar: a administração por via impositiva ou autoritária. (OLIVEIRA; SCHWANKA, 2008, p. 132-133).

Pondera Moreira Neto que, mesmo no campo político, o Estado deverá priorizar cada vez mais os mecanismos baseados na cooperação e colaboração, preferindo a consensualidade, como a "ampliação do campo de debate aberto e de negociação de interesses metaindividuais", com a consequente mobilização do interesse público — que “deixa de ser, cada vez mais claramente, aquele confundido com o seu próprio para ser não mais que a incumbência que o Direito põe a seu cargo". (MOREIRA NETO, 2008, p. 16).

Desponta assim uma Administração, mais que prestadora e promotora direta das necessidades e demandas sociais, garantidora, mobilizadora e mediadora entre os diversos interesses que aí figuram.

Nas palavras de Justino de Oliveira:

\begin{abstract}
A função estatal de mediação emana da propagação do ideal democrático para além do quadrante da política, resultado do alargamento das bases de legitimação do exercício do poder estatal, por meio da democratização da democracia. Incumbências do Estado mediador passam a ser, não somente as de estabelecer e de conferir eficácia aos canais de participação e de interlocução com os indivíduos e grupos sociais, mas a de com eles constantemente interagir, instituindo e mantendo vínculos robustos e duradouros. Tais vínculos são tidos hodiernamente como indispensáveis para a atribuição de eficácia e de efetividade às ações estatais, as quais vêm sendo amplamente desenvolvidas em espaços de forte interseção entre Estado e sociedade civil, esferas em processo contínuo de recíproca interpenetração. Ademais disso, cabe notar que a principal tarefa da Administração mediadora passa a ser a de compor conflitos envolvendo interesses estatais e interesses privados, definitivamente incluindo os cidadãos no processo de determinação e densificação do interesse público, o qual deixa de ser visto como um monopólio estatal, com participação exclusiva de autoridades, órgãos e entidades públicos. Eis os aspectos em que reside a relevância do consensualismo na Administração Pública, inserido em um contexto de Estado em rede e de Governança Pública, manifestado em fenômenos como a concertação administrativa e a contratualização das ações administrativistas, e exercido por meio e instrumentos como os acordos administrativos, a conciliação e a transação administrativa. (OLIVEIRA; SCHWANKA, 2008, p. 128).
\end{abstract}

Surge um novo modus operandi, uma nova postura marcante da atuação administrativa e da sua interação, das suas diversas interfaces com a sociedade.

Os atos administrativos, historicamente marcados por atributos como imperatividade, autoexecutoriedade, tipicidade e presunção de legitimidade ou veracidade 
(DI PIETRO, 2012, p. 204-209), passam a ser moldados — também —, como atos, ou antes processos, negociais e negociados, como acordos de que participam diversos atores titulares, representantes e/ou responsáveis por direitos fundamentais coletivos e que estabelecem entre si uma sincronia voltada ao agir conjuntamente, à união de esforços em prol do bem comum.

A crise da noção autoritária de ato administrativo, portanto, na moderna sociedade pluralista, vem apontando para uma tendência de opção por formas de atuação administrativa negociadas, concertadas, nas quais o papel dos administrados não se restringe a destinatários dos atos, mas a co-participantes da atuação administrativa, bem como autônomos sujeitos de um verdadeiro relacionamento jurídico com a Administração. (BATISTA JUNIOR, 2007, p. 251).

A Administração pública passa a agir apoiada em processos dialógicos, em uma cultura da interação em que deve se orientar pelas emanações da diversidade social (OLIVEIRA; SCHWANKA, 2008, p. 131).

Esse processo desemboca, dentre outras, na noção de contratualismo, fundada no diálogo constante, no consenso e nos processos deliberativos.

Lembramos que o conceito de contrato nesse cenário adotado não coincide com o tradicional, não corresponde à espécie disciplinada pela Lei de Licitações, a qual retrata uma noção restrita desse instrumento.

Hodiernamente, imperiosa se faz a consideração dos contratos administrativos como gênero, dentro do qual se inserem as mais variadas espécies, com os mais diversos escopos (inclusive os contratos stricto sensu).

Nas palavras de Justino de Oliveira:

[...] o reconhecimento cumulativo dos critérios assinalados em técnicas, medidas ou experiências negociais permite demonstrar que estar-se-ia perante modelos correspondentes à nova contratualização administrativa, ou seja, de espécies do gênero módulo convencional da Administração pública. Eis a acepção do termo contrato quando o mesmo é empregado para retratar a base consensual dessas novas relações, as quais desenvolvem-se no cenário ora apresentado. [...] Como instrumentos de ação da Administração Consensual pode-se referir aos institutos e mecanismos utilizados pelos órgãos e entidades administrativas para o desenvolvimento de suas atividades a partir de uma perspectiva que privilegia o emprego de técnicas e métodos negociais. (OLIVEIRA; SCHWANKA, 2008, p. 139). 
Justen Filho, a seu turno, refere-se a contratos comutativos e colaborativos. ${ }^{295}$

Ainda quanto ao fenômeno da contratualização, importante trazer à baila lição de Gaudin, cuja obra traz uma estruturação teórica do que batizou de "administração por contratos".

Para o autor, esse novo enfoque do agir público, via contratos, instrumentaliza a atuação estatal subsidiária, descentralizada, tanto sob o aspecto político-geográfico quanto social-organizacional: "A difusão das abordagens contratuais se operam na França, portanto, sob a perspectiva de uma dupla renovação relativa às formas de participação/consulta política, e aos modos de coordenação entre instituições e atores sociais que participam da ação pública" (GAUDIN, 1999, p. 29, traduzimos).

Sua doutrina faz remissão aos contratos que denomina "de ação pública", marcados por três características fundamentais: a) um acordo entre os participantes com vista à consecução de objetivos comuns; b) a vinculação sob um cronograma detalhado e compatível com o orçamento anual e as diretrizes de planejamento traçadas; c) a disponibilização, por todos os envolvidos, de contribuições, quer de natureza financeira, quer técnica ou de recursos humanos, voltadas à consecução do objetivo conjunto final (GAUDIN, 1999, p. 28).

Tal lição sustenta nossa visão, segundo a qual os convênios se inserem na categoria dos contratos lato sensu, ou, nas palavras do autor, de ação pública.

Segundo o mesmo Gaudin, essa contratualização seria resultado de uma série de elementos:

Em todos os lugares, décadas após décadas, o panorama dos métodos das políticas públicas foram se modificando na França: mobilização dos serviços púbicos em torno de projetos de serviços; descentralização de competências e abundância de políticas contratuais; relaxamento da dicotomia público/privado, notadamente através de autoridades independentes. Em todos os cantos, as diversas mudanças parecem ir em uma mesma direção: a negociação mais explícita da ação pública e a

\footnotetext{
295 “A teoria geral do direito já pôs em destaque que o conceito tradicional de contrato está referido, fundamentalmente a uma função 'distributiva' ou 'comutativa', em que o contrato é instrumento de repartição de riqueza. Mas existem avenças de natureza 'cooperativa' (ou organizacional), que são meio de aproveitamento conjunto e simultâneo dos bens e recursos humanos. Em um contrato 'comutativo', os interesses das partes são contrapostos: a vantagem de uma parte corresponde à desvantagem de outra. Já nos contratos 'cooperativos', não se configura essa contraposição de interesses, pois todos os partícipes do negócio estão voltados à consecução de um objetivo comum. Desse tipo, por exemplo, são os contratos societários. [...] Já no chamado 'convênio administrativo', a avença é instrumento de realização de um determinado e específico objetivo, em que os interesses não se contrapõem — ainda que prestações específicas e individualizadas, a cargo de cada partícipe. No convênio, a assunção de deveres destina-se a regular a atividade harmônica de sujeitos integrantes da Administração Pública, que buscam a realização imediata de um mesmo e idêntico interesse publico.” (JUSTEN FILHO, 2012, p. 1086-1087).
} 
multiplicação de contratos relativos às políticas públicas. (GAUDIN, 1999, p. 10)

Elenca, como elementos imprescindíveis à implementação e desenvolvimento da democracia participativa: a) a abertura do debate público, por meio fóruns e discussões mediados por "negociadores de opinião", ou "empreiteiros da mediação"; b) as relações policêntricas, que põem em cheque a histórica (marcadamente na França, tipicamente centralizadora) hierarquia centro-periferia. (GAUDIN, 1999).

Estabelecidos os parâmetros fundamentais da atuação administrativa contratualizada, registramos que a sua construção se dá por meio de um processo de discussão conjunta, de troca de ideias e de coautoria quanto ao instrumento final.

Não há que se falar em modelos e minutas previamente aprovadas e impostas, unilateralmente, pelo parceiro público, transpondo-se a noção de consenso, de diálogo, ao momento final, ao contrato lato sensu formalmente considerado e propriamente dito.

A troca, a mobilização concertada se inicia em momento a ele anterior, quando da discussão e fixação das bases em que se desenvolverá.

Conforme esclarece Justino de Oliveira:

Importa destacar que na concertação não há uma relação de subordinação entre a Administração e as entidades parceiras, pois subjacente a ela reside um processo de negociação para a composição de eventuais dissensos entre as partes, aspecto que pressupõe o reconhecimento da autonomia dos parceiros envolvidos. Daí empregar-se comumente a locução Administração paritária para caracterizar esta forma de administrar, fundada em módulos negociais. A contratualização administrativa retrata a substituição das relações administrativas baseadas na unilateralidade, na imposição e na subordinação por relações fundadas no diálogo, na negociação e na troca. [...] A utilização de meios consensuais pela Administração ganha relevância na medida em que estes se transformam em instrumentos da participação dos particulares diretamente envolvidos ou simplesmente interessados - no processo de tomada das decisões administrativas, possibilitando mais aceitação do que imposição, especialmente no âmbito das relações contratuais administrativas. [...] Trata-se da Administração Consensual, a qual marca a evolução de um modelo centrado no ato administrativo (unilateralidade) para um modelo que passa a contemplar os acordos administrativos (bilateralidade e multilateralidade). Sua disseminação tem por fim nortear a transição de um modelo de gestão pública fechado e autoritário para um modelo aberto e democrático, habilitando o Estado contemporâneo a bem desempenhar suas tarefas e atingir os seus objetivos, preferencialmente, de modo compartilhado com os cidadãos. (OLIVEIRA; SCHWANKA, 2008, p. 137-142). 
Inseridos na noção dessa nova contratualização, de acordos fundados na Administração consensual, estão os mais diversos instrumentos jurídicos de mobilização conjunta, quais sejam, os convênios, termos de cooperação, termos de parceria, contratos de gestão etc.

Especificamente dos primeiros trataremos no item seguinte.

\subsection{Instrumental utilizado: convênios}

Conforme pontuado, diversos são os instrumentos viabilizadores da Administração consensual, muitas são as roupagens jurídicas aptas a veicular esses acordos.

No contexto em análise, restrito à atividade de fomento exercida por meio do CMDCA/SP, elegeu-se uma forma específica de fazê-lo.

Estabelece o artigo 10 do Decreto municipal n. 43.135/03: “Art. 10. O financiamento de projetos das associações civis sem fins econômicos pelo FUMCAD será realizado sob a forma de convênio, pelo prazo máximo de 1 (um) ano, a ser celebrado com a Secretaria Especial para Participação e Parceria." (Redação outorgada pelo Decreto n. 47.669/07).

Os convênios foram a alternativa escolhida para a consecução das atividades em questão, para a mobilização conjunta da Administração — patrocinadora das ações, via Fumcad, e responsável pela cogestão e controle do objeto acordado —, e das entidades eleitas, a quem será atribuída a execução direta das ações fomentadas. ${ }^{296,297}$

\footnotetext{
${ }^{296}$ Registre-se que o escopo dos convênios não se esgota em situações que tais. Contrariamente, trata-se de instrumentais marcados pela multifuncionalidade, podendo se prestar aos mais diversos fins: "Os convênios muitas vezes formalizam tão-somente a transferência de recursos financeiros de uma entidade federativa para outra entidade federativa ou administrativa (transferências voluntárias). Por outro lado, conforme foi ressaltado, como acordo administrativo colaborativo, o convênio é utilizado largamente para a formação de vínculos de colaboração com quaisquer tipos de entidades privadas, com ou sem fins lucrativos, independentemente de serem detentoras de uma qualificação especial prévia." (OLIVEIRA, 2007, p. 246).

297 Saliente-se, ainda, que os convênios podem vincular tanto entes públicos como públicos e privados. A primeira hipótese já se encontra melhor assentada e assimilada, tanto pela Administração quanto pela legislação brasileiras, vez que conta com previsão constitucional desde a Carta de 1967. De fato, referido diploma trazia, em seu artigo $8^{\circ}, \S 1^{\circ}$, norma no seguinte sentido: “a União poderá celebrar convênios com os Estados para a execução, por funcionários estaduais, de suas leis, serviços ou decisões." Dignos de nota, ainda, seus artigos 13, §3 $3^{\circ}$ : “a União, os Estados e os Municípios poderão celebrar convênios para execução de leis, serviços ou decisões, por intermédio de funcionários federais, estaduais ou municipais;" 16, § 4". "Os Municípios poderão celebrar convênios para a realização de obras ou exploração de serviços públicos de interesse comum, cuja execução ficará dependendo de aprovação das respectivas Câmaras Municipais;" 19, § $7^{\circ}$ "Mediante convênio, a União, os Estados, o Distrito Federal e os Municípios poderão, delegar, uns aos outros, atribuições de administração tributária, e coordenar ou unificar serviços de fiscalização e arrecadação de tributos;" 27: "Sem prejuízo do disposto no art. 25, os Estados e Municípios, que celebrarem com a União convênios destinados a assegurar a coordenação dos respectivos programas de investimento e administração
} 
Em princípio, as destinatárias das ações de fomento em foco são as entidades integrantes do Terceiro Setor, quais sejam, aquelas marcadas pelas características fundamentais de: a) ausência de finalidade lucrativa; b) voluntariedade; c) finalidade de interesse público, geral e não segmentado; d) autonomia com relação ao Estado; e) personalidade jurídica de Direito Privado e desvinculada do Estado. (OLIVEIRA, 2007, p. 217).

Somente em caráter excepcional é que se poderão admitir, na condição de beneficiárias, as entidades sem finalidade lucrativa não integrantes do Terceiro Setor, ou seja, aquelas que não preenchem qualquer dos requisitos referidos no parágrafo anterior.

Dentre essas, citamos, por exemplo, as entidades de auxílio mútuo, as entidades religiosas, as integrantes do "sistema $\mathrm{S}$ " — que somente na hipótese de efetiva e comprovadamente prestarem-se a desenvolver atividade inquestionavelmente direcionada à população (crianças e/ou adolescentes) em geral, sem distinções subjetivas e marcadas pela universalidade, e uma vez outorgado o crivo do CMDCA, é que estarão aptas a integrar a relação de fomento:

Embora não enquadráveis no conceito de Terceiro Setor adotado, trata-se de entidades privadas sem fins lucrativos e, portanto, autorizadas a receber recursos públicos diretamente repassados pela Administração federal. Apesar de essas entidades almejarem objetivos de seus sócios e membros, a exemplo dos sindicatos, organizações de funcionários de grandes empresas, tais entidades também podem desempenhar atividades

tributária, poderão participar de até dez por cento na arrecadação efetuada, nos respectivos territórios, proveniente dos impostos referidos no art. 22, IV e V, excluído o incidente sobre fumo e bebidas." A atual Constituição de 1988 não reproduz tais dizeres mas estabelece, em seu artigo 23, que "lei complementar fixará normas para a cooperação entre a União e os Estados, o Distrito Federal e os Municípios, tendo em visa o equilíbrio do desenvolvimento e do bem-estar em âmbito nacional." De se comentar, ainda, o artigo 241, que faz expressa referência a "convênios de cooperação entre os entes federados." Em nível infraconstitucional, tem-se o Decreto-Lei n. 200, de 25 de fevereiro de 1967, disciplinador da primeira Reforma Administrativa Federal, cujo artigo 10, $\S 1^{\circ}$, "b", trouxe os convênios como forma de descentralização "da administração federal para as unidades federadas, quando estejam devidamente aparelhadas." O Código Tributário Nacional, em seu artigo 83, também faz referência aos convênios entre Estados e Municípios com a União, como instrumentos "destinados a assegurar a ampla e eficiente coordenação dos respectivos programas de investimentos e serviços públicos [...]." O artigo 48 do Decreto federal n. 93.872, de 23 de dezembro de 1986 (atualmente revogado pelo Decreto n. 6.170, de 25 de julho de 2007), estabelecia que "os serviços de interesse recíproco dos órgãos e entidades da administração federal e de outras entidades públicas ou organizações particulares, poderão ser executados sob regime de mútua cooperação, mediante convênio, acordo ou ajuste." O artigo 53 desse mesmo diploma estabelecia, ainda, que "os órgãos da administração direta poderão fixar entendimentos sobre matéria de comum interesse, mediante convênio, com o objetivo de somar esforços e obter melhor rendimento no emprego de seus recursos." Desse rápido panorama histórico-legislativo, depreende-se, com total segurança, que os convênios foram, durante um longo período, considerados como típico instrumento de relacionamento entre entes públicos. Essa talvez seja uma das explicações para a resistência — e dificuldade de aceitação — de parte da doutrina e jurisprudência, que insistem em sujeitar tal mecanismo a normas típicas da Administração pública, sem quaisquer modulações ou adaptações. Essa temática será com mais vagar desenvolvida adiante. 
de interesse público e coletivo, visando a atingir grupos sociais alheios aos seus próprios membros. (LIMA, 2010, p. 26).

\section{Com relação às entidades com finalidade lucrativa, temos como igualmente} viável, em termos gerais, a formalização de convênio ${ }^{298,299}$ — desde que as finalidades em prol das quais se dê a mobilização conjunta sejam tradução do interesse público:

No tocante às entidades privadas com fins lucrativos, integrantes do mercado e do setor produtivo da economia, os convênios administrativos colaborativos permitem a estas entidades receberem: incentivos fiscais, bens públicos em doação, autorização utilização de bens públicos, knowhow, entre outros benefícios para realizarem suas atividades. Em contrapartida, as atividades por elas desempenhadas devem proporcionar efeitos de interesse coletivo, a exemplo da geração de empregos, aumento da arrecadação de tributos, desenvolvimento de novas tecnológicas, entre outros. Essas entidades privadas também podem celebrar convênios administrativos colaborativos para realizar atividades de natureza social, no âmbito de sua responsabilidade social corporativa, valorizada após a promulgação da CF/88. (LIMA, 2010, p. 33).

Esse autorizativo, porém, não se aplica às relações de convênio construídas com a intervenção do CMDCA/SP, a partir das receitas do Fumcad, vez que o já referido artigo

\footnotetext{
${ }^{298}$ Registre-se, porém, e em sentido contrário, o disposto no artigo $1^{\circ}$ do Decreto federal n. 6.170 , de 25 de julho de 2007: "Art. $1^{\circ}$ Este Decreto regulamenta os convênios, contratos de repasse e termos de cooperação celebrados pelos órgãos e entidades da administração pública federal com órgãos ou entidades públicas ou privadas sem fins lucrativos, para a execução de programas, projetos e atividades de interesse recíproco que envolvam a transferência de recursos oriundos do Orçamento Fiscal e da Seguridade Social da União." (redação dada pelo Decreto n. 6.428 de 2008). O diploma municipal paulistano disciplinador do assunto, em linhas gerais, não trouxe qualquer reserva a esse respeito, conforme se depreende do seu artigo $1^{\circ}$ : "Este Decreto regulamenta a celebração, liberação de recursos, a execução e seu acompanhamento, a fiscalização e a prestação de contas de convênios celebrados pelos órgãos e entidades da administração pública municipal direta e indireta com órgãos ou entidades públicas ou privadas, para a execução de programas, projetos, atividades e eventos de interesse recíproco, que envolvam a transferência de recursos oriundos do orçamento municipal." Da mesma forma, seu artigo $2^{\circ}$, III, define concedente como "órgão da administração pública direta ou indireta de qualquer esfera de governo, bem como entidade privada, com o qual a administração municipal pactua a execução de programa, projeto, atividade e evento, mediante a celebração de convênio". O orçamento anual de 2012, porém, estabelece, em seu artigo 29, que "na realização das ações de sua competência, o Município poderá transferir recursos a instituições privadas sem fins lucrativos, desde que compatíveis com os programas constantes da lei orçamentária anual, mediante convênio, ajuste ou congênere, pelo qual fiquem claramente definidos os deveres e obrigações de cada parte, a forma e os prazos para prestação de contas." Digno de registro, ainda, seu artigo 30: "Fica vedada a realização, pelo Poder Executivo Municipal, de quaisquer despesas decorrentes de convênios, contratos de gestão e termos de parceria celebrados com entidades sem fins lucrativos que deixarem de prestar contas mensalmente à secretaria municipal responsável, com informações detalhadas sobre a utilização de recursos públicos municipais para pagamento de funcionários, contratos e convênios, com os respectivos comprovantes." A redação deste último artigo leva à conclusão, igualmente, de que somente seriam possíveis os convênios com entidades sem fins lucrativos. Quanto a essa discussão, já teve oportunidade de se manifestar a Procuradoria Geral do Município de São Paulo. (Parecer exarado nos autos do processo n. 2005.0.016.723-7, e atualmente superado pelos dispositivos legais expressos colacionados).
}

${ }^{299}$ Nesse sentido, DIAS, 2008b, p. 284. 
10 do Decreto municipal n. 43.135/03 é específico ao se referir a "entidades sem fins lucrativos".

Enfocado o conceito, temos, nas palavras de Sílvio Luiz Ferreira da Rocha, que:

Os convênios, como regra, são definidos como acordos firmados por entidades públicas de qualquer espécie, ou entre estas e organizações privadas, para a realização de objetivos de interesse comum dos parceiros. [...] Os convênios seriam o instrumento jurídico adequado para a execução, em regime de mútua cooperação, de serviços de interesse recíproco dos órgãos e entidades da administração pública ou organizações particulares. Dois aspectos são relevantes na definição dos convênios: o regime de cooperação mútua e o interesse recíproco. (ROCHA, 2006, p. 61).

Para Di Pietro, "o convênio é um dos instrumentos de que o Poder Público se utiliza para associar-se quer com outras entidades públicas quer com entidades privadas" (DI PIETRO, 2011, p. 231).

Hely Lopes Meirelles, não obstante o contexto jurídico-normativo da época, sempre admitiu formalização de convênios entre entes públicos e privados, ${ }^{300}$ na medida em que os tinha como "acordos firmados por entidades públicas de qualquer espécie, ou entre estas e organizações particulares, para realização de objetivos de interesse comum dos partícipes" (MEIRELLES, 2012, p. 458).

Quanto às características fundamentais dessa espécie de acordo que, no ambiente tomado, viabiliza o exercício da atividade de fomento da iniciativa privada de interesse público, elenca Di Pietro ${ }^{301}$ : a) objetivos institucionais comuns entre convenente e concedente; b) competências institucionais também comuns; c) busca de um mesmo objetivo, a ser usufruído por todos os partícipes; ${ }^{302}$ d) mútua colaboração, a qual pode se manifestar de várias formas: repasse de verbas, uso de equipamentos, recursos humanos e/ou materiais, compartilhamento e know-how etc. — daí não se poder falar em

\footnotetext{
300 Postura essa expressamente acolhida pela $\mathrm{CF} / 88$, em seu artigo 199, § $1^{\text {o: }}$ "As instituições privadas poderão participar de forma complementar do sistema único de saúde, segundo diretrizes deste, mediante contrato de direito público ou convênio, tendo preferência as entidades filantrópicas e as sem fins lucrativos."

${ }^{301}$ Registre-se, por pertinente, que a autora faz referência, ainda, a que, diferentemente do que se dá com os contratos, em que incide a figura dos contratantes, no terreno dos convênios somente poderia se falar em partícipes. A nosso ver, referida característica não pode ser elencada entre as fundamentais, da essência dessa última espécie de atos. Não obstante seja denominação bastante usual, temos que se trata de questão meramente incidental, linguística, e inserta na esfera de autonomia de cada ente federativo, aos quais será dada sua disciplina da forma que melhor lhes aprouver.

${ }^{302}$ Nesse ponto, defendemos a ressalva de que somente sob o aspecto indireto esse requisito tem procedência. Até porque, em muitas hipóteses - como usualmente se dá no caso das ações custeadas com recursos do Fumcad/SP —, o beneficiário, aquele que efetivamente usufruirá dos resultados da união de esforços lastreada no fomento, será um terceiro alheio à relação estabelecia e a ambos os partícipes.
} 
remuneração, em pagamento, em contraprestação -; e) vontades dos agentes envolvidos paralelas, em um mesmo sentido; f) inadmissibilidade de cláusula de permanência obrigatória, fundada na própria natureza do ato: a partir do momento em que se trata de uma união de esforços, de mobilização espontânea e não coativa, não há que se falar em dever de permanência, em cláusula proibitiva de denúncia. (DI PIETRO, 2011, p. 232233).

Dos elementos asseverados — cuja essência para o ato convenial reputamos de fato inafastável —, resta claro que a atividade de fomento corporificada por instrumentais jurídicos tais não implica delegação, quer de serviço, quer de função pública:

Quanto ao convênio entre entidades públicas e entidades privadas, ele não
é possível como forma de delegação de serviços públicos, mas como
modalidade de fomento. Caracteriza-se este por ser uma forma de
incentivas a iniciativa privada de interesse público. Difere do serviço
público, porque, neste, o Estado assume como sua uma atividade de
atendimento a necessidades coletivas, para exercê-la sob regras total ou
parcialmente públicas; no fomento, o Estado deixa a atividade na
iniciativa privada e apenas incentiva o particular que queira desempenhá-
la, por se tratar de atividade que traz algum benefício para a coletividade.
[...] O convênio não se presta à delegação de serviço público ao
particular, porque essa delegação é incompatível com a própria natureza
do convênio; na delegação ocorre a transferência de atividade de uma
pessoa para outra que não a possui; no convênio, pressupõe-se que as
duas pessoas têm competências institucionais comuns e vão prestar mútua
colaboração para atingir seus objetivos. (DI PIETRO, 2011, p. 234).

Esse aspecto foi oportunamente aventado no capítulo 1.

A esses traços básicos, somamos o fato de as receitas transferidas não passarem a integrar o patrimônio do convenente; contrariamente, mantêm referidos valores intocada a sua natureza de receitas públicas, sujeitos, portanto, a regime peculiar e mecanismos de controle mais rígidos.

Nas palavras de Di Pietro, o valor repassado em razão do convênio "não muda sua natureza por força do convênio; ele é transferido e utilizado pelo executor do convênio, mantida sua natureza de dinheiro público (no sentido de que está destinado a fim público)" (DI PIETRO, 2011, p. 236).

Nesse mesmo sentido, lição de Salinas, segundo quem "nos convênios, diferentemente dos contratos, interessa à Administração controlar a destinação dos recursos repassados, porque a satisfação do interesse público e social dependerá do seu correto, regular e eficiente emprego" (SALINAS, 2008, p. 82). 
Cumpre-nos, ainda, tecer algumas considerações quanto à impossibilidade de inclusão de cláusula proibitiva de denúncia, a qual já foi expressamente reconhecida pelo STF: "[...] pela sua precariedade, os beneficiários do convênio administrativo não têm direito à sua manutenção, nem muito menos direito adquirido a ela" (STF RE n. 119.2569, rel. Min. Moreira Alves).

Não obstante essa vedação, no caso de denúncia ou retirada de qualquer dos partícipes em momento anterior ao originalmente acordado, deverá o retirante arcar com todos os prejuízos decorrentes dessa sua postura.

Tal responsabilidade não se fundamenta nas disposições contratuais — ou conveniais - , mas no princípio da boa-fé objetiva, ou da confiança legítima, que, por sua vez, “[...] se refere à realização de promessas ou compromissos da Administração que geraram, no cidadão, esperanças fundadas [...]”. (MEDAUAR, 2003, p. 247)

Na lição de Moreira Neto:

[...] nos contratos de longa duração que seguem esse modelo, não existe um compartilhamento estanque de riscos. Ao assumi-los, com vistas a alcançar um objetivo comum, as partes estabelecem uma situação estável de parceria caracterizada pelo esforço comum em lograr a realização plena do próprio objeto contratual, que passam ambas a perseguir. Ora, é de sabença tradicional que nos contratos, cada parte tem interesse próprio, a motivar a sua presença em um dos pólos da relação: por isso, a cada um corresponde um objeto (um bem, um serviço, certo lucro etc.). Essa é a visão clássica do instituto, mas no Direito contemporâneo, naqueles contratos com as características mencionadas acima, além desses interesses próprios de cada um dos contratantes, paira um interesse comum a reger-lhes as relações contratuais de um modo mais amplo. Este interesse comum que se formaliza como um objetivo contratual e que nele fica expresso ou implicitamente compartilhado, deriva da finalidade, que é também comum, traduzida no interesse solidário dos contratantes em levarem a cabo a execução do objeto contratual, até como forma de assegurar a viabilização dos seus interesses próprios. É essa solidariedade de interesses entre as partes que, assim gerada, as compele racional e razoavelmente a buscar agir cooperativa e não antagonicamente para superar os eventuais obstáculos que possam ocorrer no curso da execução contratual. Reside, portanto, na ideia-força da boa-fé objetiva a obrigação de ambas partes de empreenderem seus melhores esforços para que solidariamente consigam cumprir o acordado, de modo a concluí-lo a bom termo. (MOREIRA NETO, 2007, p. 458-459).

Segue o autor:

Ora, sem sombra de dúvida, essa ideia central de confiança mais ainda se reforça quando em jogo uma entidade da Administração Pública, eis que o contratante privado se torna um parceiro na concepção solidária deste 
Direito Administrativo pós-moderno, impregnado por princípios democráticos (legitimidade) e morais (licitude) e, nestas condições, passa a ter um direito subjetivo público substantivo de esperar que os órgãos e entidades da Administração Pública sejam co-responsáveis [...]. (MOREIRA NETO, 2007, p. 464).

Esse ponto foi objeto de considerações, também, no capítulo 1 da presente dissertação.

No que toca ao regime jurídico dos convênios em geral, cumpre-nos tomar em conta, primeiramente, o caput do artigo 116 da Lei n. 8.666/93: "Aplicam-se as disposições desta Lei, no que couber, aos convênios, acordos, ajustes e outros instrumentos congêneres celebrados por órgãos e entidades da Administração."

Atentemos para a ressalva aí inserida, traduzida pela expressão "no que couber", e em torno da qual gravitam as discussões quanto às hipóteses em que essa aplicação se faz de fato cabível.

Ingressamos, nessa questão, em terreno instável, nebuloso e, nas palavras de Vanice Regina Lírio do Valle, marcado pela subjetividade: "tal disposição gera um razoável número de perplexidades, na medida em que remete a um juízo subjetivo de cabimento e aplicação dos dispositivos da Lei de Licitações”. (BITTENCOURT, 2005, p. 42).

Como observa Lima:

[...] apesar de a legislação brasileira ter avançado na criação de outros instrumentos consensuais, o artigo 116 da Lei de Licitações confere aos acordos, convênios e ajustes congêneres tratamento que não auxilia na construção jurídica da consensualidade. $O$ dispositivo não define a natureza jurídica dos instrumentos nele listados, além de não estabelecer hipóteses de celebração. Tampouco define os dispositivos da Lei de Licitações aplicáveis aos acordos, convênios e pactos. (LIMA, 2010, p. 29).

Além dessa condicionante — "no que couber" —, há ainda uma outra, decorrente do artigo 22, XXVII, segundo o qual somente podem vincular as demais esferas federativas as normas gerais em matéria de contratos (aqui considerados em sentido lato, correspondente aos acordos em geral, dentre os quais os convênios, conforme assentado).

É nessa categoria que se pretende inserido o referido artigo 116, o qual seria, então, vinculante das três esferas federativas.

Tal conclusão resulta da utilização da expressão "Administração Pública", sem quaisquer especificações, e da referência à Assembleia Legislativa e Câmara Municipal, 
no $\S 2^{\circ}$ do dito artigo: "Assinado o convênio, a entidade ou órgão repassador dará ciência do mesmo à Assembleia Legislativa ou à Câmara Municipal respectiva”.

Ainda que se intente inserir essa competência no âmbito de abrangência do referido inciso do artigo 22, algumas ressalvas devem ser feitas.

A primeira delas se traduz no fato de que as normas gerais - vinculantes das três esferas federativas —, pela sua própria definição, não podem descer a minúcias e detalhes cuja disciplina é atribuída tão somente aos entes respectivos:

Em suma, a norma geral não pode invadir a esfera de autonomia mínima, que dá identidade a uma federação. É vedado a norma geral disciplinar o modo de administração dos bens municipais ou estabelecer regras sobre a organização do ente federativo. Ou seja, limites da norma geral são estabelecidos pelo conceito de federação. (JUSTEN FILHO, 2012, p. 179).

Imprescindível o respeito à autonomia dos entes federados:

Essa tentativa, contudo, parece infrutífera, porquanto, por se constituir numa ferramenta de cooperação entre entes públicos ou entre esses e organizações privadas, tudo leva a crer que deve ser vista apenas sob a ótima busca do atendimento à autonomia administrativa e financeira dos convenentes. Damos, conseqüentemente, inteira razão a Jessé Torres quando, apreciando o assunto, considera que essa índole de norma geral só se admite na observação das exigências mínimas a serem observadas, não sendo possível abstrair a competência de Estados, Municípios e Distrito Federal para também legislarem sobre o tema. (BITTENCOURT, 2005, p. 33-34).

Diante desse cenário, devemos perquirir quais as normas da Lei de Licitações passíveis de inclusão na categoria de "normas gerais".

Para tanto, imprescindível o perfeito delineamento de quais as normas passíveis de inserção nessa classe, das suas características fundamentais - conclusão essa condicionante da sua aplicação aos convênios.

Em outras palavras, as regras constantes da Lei n. 8.666/93 somente vincularão os demais entes federativos na medida em que puderem ser compreendidas como normas gerais — o que não se dá com todos os seus dispositivos.

Conclusão distinta implicaria supressão da possibilidade de atuação legislativa municipal ou estadual determinante de ofensa à sistemática de distribuição de 
competências, e, portanto, ao já referido artigo 22 da CF. ${ }^{303}$

O diagnóstico quanto à inclusão — ou não — de dispositivos na categoria de normas gerais - considerado o silêncio do legislador — deve partir de critérios de razoabilidade, de forma que não se poderá pretender a incidência, sobre os convênios, de regras que venham a deturpar sua natureza, finalidades e funcionalidade: "É evidente, por outro lado, que regras voltadas tão-somente para contratos não se aplicam aos convênios, porquanto estariam comprometendo a eficácia da modalidade convenial no sentido de conjugação de esforços com objetivo comum.” (BITTENCOURT, 2005, p. 43).

À parte desse juízo negativo, necessária a construção de uma premissa mais segura e objetiva para as nossas ponderações - para o que nos socorrermos da doutrina e da jurisprudência —, nos termos a seguir desenvolvidos.

A lição de Diogo Moreira Neto, invocado por Borges, esclarece que somente podem ser inseridas na categoria de "normas gerais" aquelas veiculadoras de valores, de uma moldura legislativa de natureza notadamente principiológica:

\begin{abstract}
Assim é que à União não compete mais que estabelecer uma moldura subprincipiológica (Rahmenvorschrift), dentro da qual cabe amplamente aos estados e aos municípios estabelecerem suas peculiaridades e respectivas legislações administrativas sobre as licitações. A solução simplista, de dizer-se que é norma geral aquela que a União diga que o é, embora cômoda, atenta contra o princípio da autonomia federativa (Constituição, art., 18, caput) e, por isso, deve ser afastada; essa solução, potestativa, tolheria o aperfeiçoamento doutrinário e jurisprudencial do conceito e reduziria os estados a legisladores suplementares em vez de complementares e, eventualmente, até os excluiria. Em outros termos: a União legisla especificamente, esgotando as hipóteses, quando regula as licitações no âmbito federal e legisla genericamente, sem descer a regras específicas, para os estados, Distrito Federal e Municípios, de modo a não invadir-lhes a reserva de competência constitucional para regular suas próprias licitações. (MOREIRA NETO, 1989, p. 139). ${ }^{304}$
\end{abstract}

\footnotetext{
303 “A União, ao editar a Lei federal 8.666/93, de 21 de junho de 1993, que regulamenta o inciso XXI do art. 37 da Constituição Federal, foi muito além, desconhecendo, como se verifica do seu art. $1^{\circ}$, a atribuição dos demais entes federados para estatuir legislativamente, nessas áreas, as competentes normas particulares. Acabou, assim, por editar referida lei com a pretensão de submeter todas as unidades da Federação ao mesmo regime licitatório. Esse o comportamento da União só pode ser havido como inconstitucional, desprovido, portanto, da eficácia que seus mentores desejaram, conforme é reconhecido pela doutrina e pela jurisprudência. Desse modo, é evidente que Estados-membros, Distrito Federal e Município não perderam, nessas áreas, a competência legislativa que a Lei Maior lhes assegura, podendo editar suas leis de licitações e contratos observadas as normas gerais ou valer-se das leis já produzidas, aplicando-as às suas licitações e contratos em tudo que não violar as normas gerais da Lei federal das Licitações e Contratos da Administração Pública.” (GASPARINI, 2012, p. 561).

${ }^{304}$ MOREIRA NETO, Diogo. Curso de Direito Administrativo. Rio de Janeiro: Forense, 1989, p. 139, apud BORGES, 1991, p. 21.
} 


\section{Na lição de Borges:}

Se as normas gerais são direito sobre direito; se constituem comandos genéricos expedidos para as diversas ordens federativas, se representam, portanto, na melhor doutrina, diretrizes para legislar; se, por seu turno, a Constituição assegura aos estados e municípios o poder de regerem-se por suas próprias leis, dentro de uma compatibilidade com o Texto Maior, é de repelir-se uma interpretação de tal modo linear e literal do art. 22 e de seu parágrafo, que conduza ao total manietamento da competência das ordens federativas em matéria administrativa, pena de tornar-se letra morta a autonomia administrativa e legiferante dos estados e municípios, indissociável do princípio máximo e intocável da federação. (BORGES, 1991, p. 23).

Segue a autora, ainda invocando lição de Moreira Neto, para quem quatro são os aspectos fundamentais das normas gerais:

1. São principiológicas, pelo que têm por função estabelecer diretrizes para obrigar o grau de decisão subseqüente, impondo sua observância, não só pelo legislador, na edição da norma legal derivada, como pelo aplicador, na ação do Estado ou dos indivíduos, mas não têm aplicação direta e imediata, nas relações jurídicas concretas.

2. São nacionais, tendo por fim "a uniformização do essencial sem cercear o acidental, peculiar das unidades federadas". Sua atividade homogeneizadora se justifica, quando a excessiva diversificação normativa possa prejudicar o conjunto do País. Preserva-se aquilo que a Constituição quer que seja nacional, mas sem sacrifício do espaço necessário para que tal diversidade enriqueça culturalmente toda a nação. 3. São limitativas, na medida em que, como princípios, limitam a União, o estado, e, eventualmente, o município e o particular; e em que, como norma de aplicação, limitam os seus aplicadores, sejam quais forem.

4. Não devem detalhar relações jurídicas substanciais, descendo a pormenores e detalhes. (MOREIRA NETO, 1988). ${ }^{305}$

E conclui:

Então, as normas gerais há de ser as que instrumentalizam princípios constitucionais, quanto a aspectos cuja regulamentação seja essencial à atuação integral do preceito que as fundamenta; deverão ser regra que assegurem sua aplicação uniforme na disciplina de situações homogêneas, apenas no quantum satis necessário à plena realização da norma fundamental. (BORGES, 1991, p. 42-43).

\footnotetext{
${ }^{305}$ MOREIRA NETO, Diogo. Competência concorrente limitada: o problema da conceituação das normas gerais. Revista de informação legislativa, v. 25, n, 100, p. 127-162, out./dez. 1988. Disponível em <http://www2.senado.gov.br/bdsf/item/id/181992>, apud BORGES, 1991, p. 39-40.
} 
No que toca à jurisprudência, o STF já teve oportunidade de se manifestar nesse mesmo sentido, em voto de lavra do Ministro Carlos Veloso: 'Penso que 'norma geral', tal como posta na Constituição, tem o sentido de diretriz, de princípio geral. A norma geral federal, melhor será dizer, nacional, seria a moldura do quadro a ser pintado pelos Estados e Municípios dentro do âmbito de suas competências" (STF, ADI-MC 972-3/RS, rel. Min. Carlos Veloso).

Vejamos, também:

[...] a União Federal, ultrapassando o domínio normativo das regras gerais, não pode, sob pena de transgredir domínio constitucionalmente reservado ao Estado-membro, editar legislação que desça a pormenores, que minudencie condições específicas ou que se ocupe de detalhamento que descaracterizem o coeficiente de maior generalidade e abstração que se requer das normas gerais referidas no texto da Constituição, pois estas, mais do que fórmulas simplesmente genéricas contidas nas leis em sentido material, não de veicular princípios, diretrizes e bases essenciais à regulação de determinada matéria [...]. (STJ, ADI 2.903-7/PB, rel. Min. Celso de Mello).

E ainda:

[...] Pois o certo é que norma geral, em matéria de licitação, é a lei ordinária que desdobra, debulha, desata, faz render, enfim, um comando nuclearmente constitucional, de sorte a conformar novas relações jurídicas sobre o mesmo assunto. É por esse necessário vínculo funcional com a norma de lastro constitucional - seja ela um princípio, seja uma simples regra - , que a norma geral de que falo é de aplicabilidade federativamente uniforme. (STF, ADI-MC 3059/RS, rel. Min. Ayres Brito).

Com relação a esta última manifestação, temos que a norma constitucional em questão é a constante do artigo 37, caput e inciso XXI. ${ }^{306}$

Imprescindível, portanto, guardarem as normas gerais, em sua essência, relação com os princípios constitucionais regentes da Administração Pública em geral e, em especial, aqueles regentes dos contratos por ela firmados. Nada além disso.

\footnotetext{
306 “Art. 37. A administração pública direta e indireta de qualquer dos Poderes da União, dos Estados, do Distrito Federal e dos Municípios obedecerá aos princípios de legalidade, impessoalidade, moralidade, publicidade e eficiência e, também, ao seguinte: [...] XXI - ressalvados os casos especificados na legislação, as obras, serviços, compras e alienações serão contratados mediante processo de licitação pública que assegure igualdade de condições a todos os concorrentes, com cláusulas que estabeleçam obrigações de pagamento, mantidas as condições efetivas da proposta, nos termos da lei, o qual somente permitirá as exigências de qualificação técnica e econômica indispensáveis à garantia do cumprimento das obrigações."
} 
Concluímos, nesses termos, que somente podem ser tidas como "normas gerais" referidas no artigo 22 da $\mathrm{CF}$, no que tange aos convênios, aquelas: a) veiculadoras de normas principiológicas, de valores, as denominadas normas-quadro; e b) que não venham a subverter a lógica dessa espécie de acordo.

Considerada a realidade dos convênios, entendemos somente poderem ser inseridos nessa categoria, exemplificativamente, os princípios relativos à escolha das pessoas que se relacionarão com a Administração Pública, ficando as regras veiculadoras das diversas modalidades licitatórias definitivamente excluídas dessa classe.

Como explicitado por Bandeira de Mello:

\begin{abstract}
Normas que estabelecem particularizadas definições, que minudenciam condições específicas para licitar ou para contratar, que definem valores, prazos e requisitos de publicidade, que arrolam exaustivamente modalidades licitatórias e casos de dispensa, que regulam registros cadastrais, que assinalam minúcias o iter e o regime procedimental, os recursos cabíveis, os prazos de interposição, que arrolam documentos exigíveis de licitantes, que preestabelecem cláusulas obrigatórias de contratos, que dispõem até sobre encargos da administração contratante no acompanhamento da execução da avença, que regulam penalidades administrativas, inclusive quanto aos tipos e casos em que cabem, evidentissimamente sobre não serem normas de Direito Financeiro, menos ainda serão normas gerais, salvo no sentido de que toda norma por sê-lo — é geral. (BANDEIRA DE MELLO, 1987, p. 16). ${ }^{307}$
\end{abstract}

Estabelecidas essas premissas teóricas, e transcendendo esse campo, restam algumas questões pontuais, que suscitam — ou suscitaram, em um passado muito próximo —, embates doutrinários e jurisprudenciais.

Nesse espectro insere-se a suposta exigibilidade de realização de prévio procedimento licitatório para o conveniamento, que será tratada no próximo item.

Consideremos, neste momento, os parágrafos do artigo 116 da Lei de Licitações, ${ }^{308}$ os quais entendemos, juntamente com Salinas (2008, p. 86), dignos de

${ }^{307}$ BANDEIRA DE MELLO, Celso Antônio. Licitações. RDP, n. 83, p. 16-29, 1987, apud BORGES, 1991, p. 46.

308 "§ $1^{\circ}$ A celebração de convênio, acordo ou ajuste pelos órgãos ou entidades da Administração Pública depende de prévia aprovação de competente plano de trabalho proposto pela organização interessada, o qual deverá conter, no mínimo, as seguintes informações: I - identificação do objeto a ser executado; II - metas a serem atingidas; III - etapas ou fases de execução; IV - plano de aplicação dos recursos financeiros; V cronograma de desembolso; VI - previsão de início e fim da execução do objeto, bem assim da conclusão das etapas ou fases programadas; VII - se o ajuste compreender obra ou serviço de engenharia, comprovação de que os recursos próprios para complementar a execução do objeto estão devidamente assegurados, salvo se o custo total do empreendimento recair sobre a entidade ou órgão descentralizador. $\S 2^{\circ}$ Assinado o convênio, a entidade ou órgão repassador dará ciência do mesmo à Assembléia Legislativa ou à Câmara Municipal respectiva. $\S 3^{\circ}$ As parcelas do convênio serão liberadas em estrita conformidade com o plano de aplicação 
crítica, na medida em que não diferenciam, não trazem qualquer especificidade no tratamento dos convênios firmados com entidades públicas e privadas, como se ambas as hipóteses se desenvolvessem em idênticos contextos, com as mesmíssimas finalidades.

Outro ponto em que podemos detectar criticável técnica legislativa: a redação desses dispositivos, a estrutura que traduzem pode levar o leitor mais desavisado a concluir que somente seriam admissíveis os convênios que tivessem por objeto a consecução de projeto específico.

Diversamente dessa apressada conclusão, temos por plenamente admissível a formalização de acordos dessa natureza com o escopo de desenvolver serviços contínuos, nenhum óbice havendo quanto à atividade de interesse público a ser desenvolvida:

aprovado, exceto nos casos a seguir, em que as mesmas ficarão retidas até o saneamento das impropriedades ocorrentes: I - quando não tiver havido comprovação da boa e regular aplicação da parcela anteriormente recebida, na forma da legislação aplicável, inclusive mediante procedimentos de fiscalização local, realizados periodicamente pela entidade ou órgão descentralizador dos recursos ou pelo órgão competente do sistema de controle interno da Administração Pública; II - quando verificado desvio de finalidade na aplicação dos recursos, atrasos não justificados no cumprimento das etapas ou fases programadas, práticas atentatórias aos princípios fundamentais de Administração Pública nas contratações e demais atos praticados na execução do convênio, ou o inadimplemento do executor com relação a outras cláusulas conveniais básicas; III - quando o executor deixar de adotar as medidas saneadoras apontadas pelo partícipe repassador dos recursos ou por integrantes do respectivo sistema de controle interno. $\S 4^{\circ}$ Os saldos de convênio, enquanto não utilizados, serão obrigatoriamente aplicados em cadernetas de poupança de instituição financeira oficial se a previsão de seu uso for igual ou superior a um mês, ou em fundo de aplicação financeira de curto prazo ou operação de mercado aberto lastreada em títulos da dívida pública, quando a utilização dos mesmos verificar-se em prazos menores que um mês. $\S 5^{\circ}$ As receitas financeiras auferidas na forma do parágrafo anterior serão obrigatoriamente computadas a crédito do convênio e aplicadas, exclusivamente, no objeto de sua finalidade, devendo constar de demonstrativo específico que integrará as prestações de contas do ajuste. § $6^{\circ}$ Quando da conclusão, denúncia, rescisão ou extinção do convênio, acordo ou ajuste, os saldos financeiros remanescentes, inclusive os provenientes das receitas obtidas das aplicações financeiras realizadas, serão devolvidos à entidade ou órgão repassador dos recursos, no prazo improrrogável de 30 (trinta) dias do evento, sob pena da imediata instauração de tomada de contas especial do responsável, providenciada pela autoridade competente do órgão ou entidade titular dos recursos." No que tange ao parágrafo segundo, inadmissível a imposição, pelos Legisladores estaduais ou municipais, da obrigatoriedade de prévia e especifica autorização legislativa para a formalização do convênio. Nesse sentido, inclusive, acórdãos do STF, prolatados nos autos das ADIs n. 1.666-9/DF e 342/PR, e ementados nos seguintes termos: "Ação direta de inconstitucionalidade. Art. 60, XXVI, da Lei Orgânica do Distrito Federal. Alegada incompatibilidade com os arts. 18 e 25 a 28, todos da Carta da República. Dispositivo que, ao submeter à Câmara Legislativa distrital a autorização ou aprovação de convênios, acordos ou contratos de que resultem encargos não previstos na lei orçamentária, contraria a separação de poderes, inscrita no art. $2^{\circ}$ da Constituição Federal. Precedentes. Ação julgada procedente." E: "Direito constitucional. Convênios: autorização ou ratificação por assembléia legislativa. Usurpação de competência do Poder Executivo. Princípio da separação de poderes. Ação direta de inconstitucionalidade do inciso XXI do art. 54 da Constituição do Estado do Paraná que diz: 'compete, privativamente, à Assembleia legislativa: XXI - autorizar convênios a serem celebrados pelo Governo do Estado, com entidades de direito público ou privado e ratificar os que, por motivo de urgência e de relevante interesse público, forem efetivados sem essa autorização, desde que encaminhados à Assembléia Legislativa, nos noventa dias subseqüentes à sua celebração'. 1. A jurisprudência do Supremo Tribunal Federal é firme no sentido de que a regra que subordina a celebração de acordos ou convênios firmados por órgãos do Poder Executivo à autorização prévia ou ratificação da Assembléia Legislativa, fere o princípio da independência e harmonia dos poderes (art. $2^{\circ}$, da CF). Precedentes. 2. Ação Direta julgada procedente para a declaração de inconstitucionalidade do inciso XXI do art. 54 da Constituição do Estado do Paraná." 
[...] em determinadas hipóteses, o objetivo do convênio é o de estabelecer a mútua colaboração para a prestação de serviços contínuos a terceiros, em áreas como educação, ensino, cultura, por exemplo; [...] Na realidade, o art. 116 não faz referência específica a "projeto", mas deixa mais ou menos implícita essa idéia, com a referência a "plano de trabalho", "etapas e fases de execução", "previsão de início e fim da execução do objeto, bem assim da conclusão das etapas ou fase programadas" ( $\left(1^{\circ}\right.$, incisos III e VIII). [...] É evidente, contudo, que os convênios podem ter por objeto a prestação de serviços contínuos, desde que estejam presentes as características apontadas com relação aos ajustes dessa natureza (DI PIETRO, 2012, p. 350).

No que tange especificamente aos convênios viabilizadores da atividade de fomento custeada com os recursos do Fumcad/SP, notamos alguma confusão, resultante, uma vez mais, da má técnica legislativa. Isso porque as normas específicas que tratam do assunto trazem, expressa e objetivamente - em um primeiro momento — essa limitação a projetos específicos.

Nesse sentido o artigo $3^{\circ}$, $\S \S 2^{\circ}$ e $3^{\circ}$, e o artigo 10 do Decreto n. 43.135/2003, bem como o artigo $4^{\circ}$ da Resolução n. 77 CMDCA/SP:

$\S 2^{\circ}$. O financiamento de projetos complementares às políticas públicas para a criança e o adolescente dependerá de captação externa ou de transferências fundo a fundo.

$\S 3^{\circ}$. No caso de doação condicionada à utilização em projeto específico, proposto por órgão governamental ou pela sociedade civil e aprovado pelo CMDCA, permanecerão no Fumcad $10 \%$ (dez por cento) do valor doado para subsidiar outras propostas.

Art. 10. O financiamento de projetos das associações civis sem fins econômicos pelo FUMCAD será realizado sob a forma de convênio, pelo prazo máximo de 1 (um) ano, a ser celebrado com a Secretaria Especial para Participação e Parceria. (Redação determinada pelo Decreto 47.669/07).

Artigo $4^{\circ}$. Para o financiamento dos Projetos propostos por organizações governamentais e não governamentais, o CMDCA/SP fará publicar no Diário Oficial da Cidade edital de inscrição que conterá:

I - Indicação dos eixos de promoção, controle e defesa;

II - Critérios do processo de seleção e de aprovação dos projetos propostos por eixo de ação; (grifos nossos).

Segundo, porque tais convênios não podem ter prazo de duração superior a um ano, ${ }^{309}$ nem duplicar políticas existentes,${ }^{310}$ e devem apoiar ações complementares às

\footnotetext{
${ }^{309}$ Artigo 11, III do Decreto municipal n. 43.135/2003.

${ }^{310}$ Artigo 10, § $3^{\circ}$, do Decreto municipal n. 43.153/2003.
} 
políticas públicas $^{311}$ - fatores esses que poderiam ser tidos como limitantes de atividades de longo prazo, que se estendessem no tempo.

Não compactuamos com essa conclusão apressada, que não resiste a uma consideração mais apurada dessa mesma legislação municipal, em especial os $\S \S 1^{\circ}$ e $2^{\circ}$ do referido artigo 10 do Decreto n. 43.135/03:

$\S 1^{\circ}$. Para os fins deste decreto, entende-se como projeto o conjunto de ações que abranjam programas de prevenção, de proteção e de defesa de direitos, bem como programas para cumprimento de medidas socioeducativas, a serem desenvolvidas em determinado período de tempo, exclusivamente com recursos captados pelo Fumcad, tendo como beneficiários segmentos de crianças e adolescentes, segundo as linhas de ação previstas na Lei 8.069, de 13 de julho de $1990^{-}$Estatuto da Criança e do Adolescente, em caráter inovador e complementar às políticas públicas, que poderão, ao final de sua execução, serem incorporadas à rede pública de serviços regulares, conforme avaliação de seus resultados, nos termos do disposto no $\S 2^{\circ}$ do artigo $9^{\circ}$ deste decreto. (Redação outorgada pelo Decreto 43.935/03).

$\S 2^{\circ}$. Em razão do prazo determinado e da necessidade de concorrência em igualdade de condições com as demais propostas de projetos inscritos no CMDCA, os convênios não serão renovados ou aditados, salvo nos casos em que ficar demonstrado não se tratar de serviços de continuidade e estarem mantidos os requisitos de inovação $e$ complementaridade às políticas públicas, condicionados à disponibilidade orçamentário-financeira, hipótese em que serão exarados novos pareceres pelo COT e pela Secretaria afim (grifos nossos).

Detectamos, assim, e logo na sequência daqueles primeiros dispositivos, regras que afastam a limitação supostamente colocada pelos referidos artigos $3^{\circ}$ e 10 , caput - o que determina, em uma análise sistemática, a admissibilidade de custeio de ações não restritas a um projeto específico, mas que, por outro lado, sejam compatíveis com a isonomia, com o não monopólio dos valores integrantes do Fundo por um, ou alguns beneficiários.

Quanto às limitantes relativas à vedação de duplicação de políticas públicas, à duração superior a um ano e à exigência de complementaridade às políticas públicas, temos que da mesma forma não afastam o incentivo a ações traduzidas em serviços de prestação contínua.

Caso assim se entendesse, teria o suprarreferido $\S 2^{\circ}$ comprometido sua razão de ser e sua coerência, tanto legislativa quanto lógica.

${ }^{311}$ Artigo 10, § $1^{\circ}$, do Decreto municipal n. 43.135/2003. 
Nesse particular, portanto, o limitador quanto ao objeto dos convênios guarda muito mais relação com a imperiosa rotatividade, com o potencial benefício do maior número de entidades sem fins lucrativos - e respectivas atividades — possível com as receitas do Fundo.

Lançadas essas bases, e conforme asseverado, enveredamos por caminhos ainda mais delicados, traduzidos, especificamente, na obrigatoriedade de realização de procedimento licitatório para a escolha do parceiro convenente.

Este o foco de nossas ponderações no item seguinte.

\subsection{A escolha das entidade/projetos a serem fomentados e os limites e grau de vinculação do edital}

Ao ingressar em tão espinhosa seara, devemos esclarecer que a temática envolvendo licitação e convênios desencadeia discussões diversas, que devem ser de plano extremadas, com vista a evitar confusões comprometedoras das nossas análises.

Temos, assim, aquelas relacionadas ao processo de escolha da entidade convenente - de que ora trataremos —, e as decorrentes do relacionamento dessas com terceiros encarregados de viabilizar a consecução e efetivação das ações correlatas ao objeto do convênio - as quais serão objeto de análise a seguir.

A doutrina se manifesta de forma dissonante quanto à necessidade de escolha da entidade convenente a partir de procedimento licitatório.

Tomemos, primeiramente, o posicionamento segundo o qual seria ele absolutamente imprescindível - salvo as exceções constantes expressamente da própria Lei n. 8.666/93, de dispensa ou inexigibilidade.

A ideia macro a fundamentar tal tese é que seria o convênio uma forma de "deslocamento", de alteração da titularidade da gestão de recursos públicos — os quais mantêm essa natureza e não se definem como contraprestação ou remuneração do convenente.

Estaríamos perante situação juridicamente inserida em patamar análogo àquelas decorrentes dos contratos administrativos em sentido estrito, porém com o "agravante" da manutenção da natureza pública dos valores repassados. 
Defendem essa posição Szklarowsky, ${ }^{312}$ Odete Medauar ${ }^{313}$ e Marçal Justen Filho,
invocado em parecer exarado pela Procuradoria Geral do Município de São Paulo. ${ }^{314}$
No outro extremo estão aqueles que excluem a exigência de licitação ou outras

formalidades procedimentais para a escolha da destinatária do fomento viabilizado por meio do convênio.

Invocam o fato de a relação de parceria não seguir a lógica do menor preço, não ser compatível com uma situação de competitividade objetivamente estabelecida, decorrendo o diagnóstico quanto ao melhor parceiro da sua expertise, da sua experiência e vivência na área que se pretende fomentar — sendo esse diagnóstico possível somente quando do surgimento das demandas sociais desencadeantes da necessidade de conveniar.

Nessa linha, lição de Carlos Ari Sundfeld, ao tratar da incidência das regras da Lei de Licitações sobre os termos de parceria:

Todas essas normas [da Lei n. 8.666/93] são anteriores ao ciclo das parcerias - e, portanto, foram feitas tendo como preocupação central os contratos então importantes: as empreitadas de obra pública (o chamado "contrato de obras"). O resultado foi uma disciplina normativa exigindo rigidez no procedimento, objetividade absoluta no julgamento (em regra, feito pelo menor preço) e a definição prévia, pela Administração, de todos os detalhes das prestações do contratado; ademais, proibiu-se a

312 “Questão importante é a relativa à necessidade ou não de licitação para a realização de convênios. Ela poderá ser dispensada ou declarada inexigível nas mesmas hipóteses previstas para os contratos ou outros ajustes. Mas — ensinam alguns doutrinadores - supondo a realização de convênios entre um órgão ou uma entidade estatal e um ente privado, se várias forem as entidades que se prestem para a consecução dessas atividades, inquestionavelmente deverá realizar-se licitação.” (SZKLAROWSKY, 1998).

313 "No tocante aos convênios entre órgãos e entes estatais e entidades particulares, o que, sobretudo, fundamenta a desobrigação de licitação é a especificidade do objeto e da finalidade. No entanto, se a Administração pretender realizar convênio para resultado e finalidade que poderão ser alcançados por muitos, deverá ser realizada licitação ou se abrir a possibilidade de conveniar sem limitação, atendidas as condições fixadas genericamente." (MEDAUAR, 2012, p. 258).

314 "[...] caso a Secretaria Especial para Participação e Parceria opte por firmar convênio ou parcerias com ONG's ou OSCIP's deverá, obrigatoriamente, adotar procedimento licitatório para a sua escolha porque, nas palavras de Marçal Justen Filho, 'não é facultado à Administração escolher, sem prévio procedimento licitatório, uma determinada organização da sociedade civil para realizar um 'termo de parceria' e, a partir daí, atribuir-lhe recursos para contratações as mais diversas', salvo na hipótese de ser identificada uma única ONG ou OSCIP que possa ser parceira da PMSP para os fins de implementação da ação, situação em que a Secretaria consulente poderá proceder à contratação direta, sem necessidade de procedimento licitatório, com base no artigo 25 da Lei 8.666/93 por inviabilidade de competição, o que deverá ser plenamente demonstrado e justificado." (Parecer da Procuradoria Geral do Município de São Paulo exarado nos autos do Processo n. 2005-0.016.723-7). Referida manifestação, vale registrar, já não pode ser tida como válida, tendo em vista a publicação dos Decretos municipais n. 49.539/2008 e n. 46.979/2006, cujos artigos $8^{\circ}$ e $2^{\circ}$ dispõem: “Art. $8^{\circ}$ A celebração de convênio com entidades privadas poderá ser precedida, a critério do concedente, de chamamento público, visando a seleção de projetos ou entidades que tornem mais eficaz o objeto do ajuste" e “Art. $2^{\circ}$. Para fins deste Decreto, a escolha da OSCIP dar-se-á mediante concurso de projetos, a ser realizado pelo órgão interessado da Administração direta, observadas as normas gerais da Lei Federal 8.666, de 21 de junho de 1993 e respectivas alterações. Parágrafo único. O concurso de projetos somente poderá ser dispensado se a entidade enquadrar-se nas hipóteses previstas nos artigos 24 e 25 da Lei Federal 8.666, de 1993, obedecidos os requisitos e formalidades neles estabelecidos." 
inclusão de financiamento entre os encargos do contratado. Mas se esse modelo pode ser bom para as contratações de empreitadas, não se ajusta tão bem aos contratos de parceria. Primeiro porque em muitas delas o objetivo não é obter a proposta mais barata, mas sim elegera entidade que melhor encarne o perfil público; daí as leis das OS e OSCIPs afastarem a licitação para a celebração de contratos de gestão e dos termos de parceria. (SUNDFELD, 2005, p. 19-20). ${ }^{315}$

\title{
Na lição de Di Pietro,
}

Quanto à exigência de licitação para a celebração de convênios, ela não se aplica, pois neles não há viabilidade de competição; esta não pode existir quando se trata de mútua colaboração, sob variadas formas, como repasse de verbas, uso de equipamentos, recursos humanos, imóveis. Não se cogita de preço ou de remuneração que admita competição. (DI PIETRO, 2012, p. 350-351).

Da mesma forma, Bittencourt: "caracterizando-se o convênio, como já fartamente explicitado, por uma união de esforços, com livre adesão dos partícipes em face de objetivos comuns, é evidente que não há possibilidade de coexistência com procedimentos competitivos. A situação singulariza o objeto, afastando a licitação" (BITTENCOURT, 2005).

Outro fundamento invocado para justificar a não obrigatoriedade de licitação é a ausência de previsão legal, o próprio princípio da legalidade:

\begin{abstract}
Aliás, o convênio não é abrangido pelas normas do art. $2^{\circ}$ da Lei 8666; no caput é exigida licitação para obras, serviços, compras, alienações, concessões, permissões e locações, quando contratadas com terceiros; e no parágrafo único define-se o contrato por forma que não alcança os convênios e outros ajustes similares, já que nestes não existe a "estipulação de obrigações recíprocas" a que se refere o dispositivo. (DI PIETRO, 2011, p. 237).
\end{abstract}

Consideradas as duas correntes doutrinárias invocadas, cumpre-nos consignar que não se nos afigura razoável a exigência de procedimento licitatório para a formalização de convênios.

Tal assertiva não exclui, porém, a imprescindível observância dos princípios constitucionais - e legais — orientadores da ação administrativa.

Dessa forma, ainda que não se promova a licitação, quer nas formas disciplinadas pela Lei n. 8.666/93, quer na modalidade pregão, indispensável a realização de

315 SUNDFELD, Carlos Ari. Guia jurídico das parcerias público-privadas. In: SUNDFELD, Carlos Ari. Parcerias público-privadas. São Paulo: Malheiros, 2005, p. 19-20, apud ZEN, 2008, p. 87-88. 
procedimento apto a garantir a fiel observância, em especial, aos princípios da isonomia e impessoalidade.

Posicionamo-nos, assim, pela obrigatoriedade de o concedente proceder de forma pública e geral no sentido de dar a conhecer a todos os potenciais interessados a pretensão de formalizar convênio, seus objetivos e condições.

Do instrumento concretizador dessas exigências deverão constar os critérios objetivos e impessoais — de seleção do(s) parceiro(s)/projeto(s)/ação(ões) mais adequado(s) ao eficiente e responsivo atendimento ao interesse público.

Temos, pois, que, independentemente da existência de qualquer dispositivo legal expresso, a sistemática constitucional condiciona a formalização de convênios a mecanismos como a publicação de edital de chamamento público, cujos moldes serão fixados por cada uma das esferas federativas.

Nas palavras de Sílvio Luis Ferreira da Rocha:

Quanto for impossível atender a todos os possíveis beneficiários, por escassez de recursos, melhor estabelecer entre eles um procedimento licitatório que privilegie uma solução definidora extremamente objetiva — como o sorteio —, se restar demonstrado que os participantes estão em situações idênticas. A atividade de fomento será submetida, outrossim, aos princípios da razoabilidade e da proporcionalidade, que impõe limites à configuração normativa da sua atividade, exigindo que ela se revele adequada, necessária e ponderada aos valores constitucionais. Desta forma, por força dessa adequação, ela deve constituir meio jurídico idôneo para atingir os interesses públicos específicos que presidem sua razão de ser, sendo que, na verificação da idoneidade, as finalidades devem ser acolhidas, expressa ou implicitamente, pelos princípios constitucionais - especialmente pelo princípio da isonomia - , de modo que o fomento será legítimo se o fim desejado por causa jurídica prestante a justificar o tratamento infraconstitucional diferenciado nele previsto (ROCHA, 2006, p. 32-33).

No mesmo sentido, ainda que a partir de premissas outras, Souza e Violin:

[...] quer nos parecer que a própria Lei n. 8.666/93 não tem a intenção de aplicar as exigências do procedimento licitatório aos convênios. A análise vem da leitura conjugada do artigo $2^{\circ}$, que em seu parágrafo único define a figura dos contratos sujeitos à licitação, com a análise do artigo 116, que ressalva a aplicação da lei no que couber aos convênios. Sendo mais específico, o artigo $2^{\circ}$ é expresso em dizer que os contratos da Administração Pública com terceiros serão precedidos de licitação, seja qual for a denominação utilizada, o que significa dizer que todo o acordo de vontades da Administração Pública que tenha conteúdo contratual está sujeito a licitação. Também implica dizer que todo acordo de vontade da Administração Pública que não tenha conteúdo contratual não está sujeito 
a licitação. Desta forma, não precisaria outro dispositivo para dizer que os convênios e outros instrumentos de natureza não contratual não estariam sujeitos à licitação. [...] No entanto, oportuno salientar que o afastamento da exigência de submissão ao procedimento licitatório não significa a desnecessidade de a Administração Pública pautar a escolha do parceiro privado com base nos princípios da impessoalidade, da moralidade, isonomia, publicidade, a que está sujeita. E assim expomos para defender a necessidade de a Administração Pública levar a cabo, quando o objeto do convênio permitir que mais de um interessado se habilite, processo de seleção que identifique o projeto mais adequado aos interesses comuns buscados. Embora em relação aos convênios seja usual defender a inviabilidade de competição decorrente da reciprocidade de interesses afasta o regime licitatório, temos para nós que a pluralidade de entidades capacitadas a realizar o interesse público objeto do convênio leva à pluralidade de projetos para alcançar o fim almejado, exigindo que a Administração Pública realize procedimento de seleção do projeto mais adequado (SOUZA, 2010, p. 172-173).

[...] nos posicionamos no sentido de que para se firmar convênios [...] não é obrigatória a realização de licitação prévia. Entretanto, existindo mais de um interessado em situação de igualdade, com interesse em firmar convênio com a Administração Púbica, não poderá o administrador, sem qualquer justificativa, escolher sua entidade "preferida". Nessa situação, para o melhor atendimento do interesse público e princípios como o da moralidade, isonomia e publicidade, a Administração está vinculada a realizar processo de escolha, com divulgação da intenção de firmar o convênio, e seleção por meio de critérios predefinidos, cabendo até o sorteio se a situação de igualdade se mantiver. (VIOLIN, 2010, p. 332).

E, ainda, Souza: “de fato, acredito que o melhor, por mostrar-se mais consentâneo com a forma republicana de Estado, seria que fixassem a regra geral da obrigatoriedade da realização dos processos administrativos assecuratórios da isonomia [...]" (SOUZA, 2011, p. 118).

Limitada, nesses moldes, a discricionariedade do administrador - no caso em estudo, do próprio Conselho - , que não desborda para a liberdade absoluta nem chega a configurar formalismo excessivo ${ }^{316}$ :

\footnotetext{
${ }^{316}$ Até porque, em se tratando de Administração pública, e liberdade absoluta efetivamente não se pode falar. Nesse sentido: "[...] Em outras hipóteses, o regramento não atinge todos os aspectos da atuação administrativa; a lei deixa certa margem de liberdade de decisão diante do caso concreto, de tal modo que a autoridade poderá optar por uma dentre várias soluções possíveis, toda válidas perante o direito. Nesses casos, o poder da Administração é discricionário, porque a adoção de uma ou outra solução é baseada em critérios de mérito - oportunidade, conveniência, justiça, igualdade, a serem perquiridos pela autoridade, porque não definidos pelo legislador. Foi este que, ao regrar a matéria, deixou intencionalmente a decisão para a Administração, segundo critérios que só podem ser levados em consideração adequadamente, diante do caso concreto. Mesmo aí, entretanto, o poder de ação administrativa, embora discricionária, não é totalmente livre, porque, sob alguns aspectos, em especial a competência, a forma e a finalidade, a lei impõe limitações. Daí por que a discricionariedade implica liberdade de atuação nos limites traçados pela lei; se a Administração ultrapassar esses limites, sua decisão passa a ser arbitrária. A arbitrariedade coloca-se do outro lado da linha que demarca o limite da discricionariedade. Aquela é a liberdade de ação que ultrapassa os limites da lei; esta é a liberdade de ação exercida nos limites da lei.” (DI PIETRO, 2012, p. 61-62).
} 
A seleção das entidades privadas sem fins lucrativos no âmbito dos programas de fomento constitui importante requisito para celebração dos convênios administrativos colaborativos. [...] Muito embora se reconheça a desnecessidade de licitação, nos moldes do procedimento aplicável às contratações de obras e serviços pela Administração pública, não é razoável conceber a escolha das entidades privadas convenentes como ato discricionário da entidade pública, despido de parâmetros técnicos e objetivos de seleção. Afinal, constitui dever da Administração pública, inclusive na implementação de programas de fomento, motivar suas decisões, por força do princípio da motivação dos atos administrativos, bem como observar o princípio da isonomia. Os recursos públicos disponíveis no âmbito dos programas de fomento são finitos. Dispensar procedimento público para seleção de convenentes somente seria possível se houvesse montante de recursos suficientes para permitir a adesão de qualquer entidade habilitada e qualificada nos programas de fomento. Havendo limitação de recursos, a oportunidade de adesão aos referidos programas e, consequentemente, a celebração do convênio administrativo colaborativo, deverá ser franqueada a todos os interessados, em igualdade de condições [...]. (LIMA, 2010, p. 110-111).

Restarão atendidos, assim, os princípios constitucionais de Direito Público, já que, no que tange aos convênios, é corriqueira a possibilidade de haver mais de uma entidade apta a atender determinada demanda da infância ou juventude.

No âmbito do Fumcad, essa visão é acolhida nos artigos $4^{\circ}$ e $5^{\circ}$ da Resolução n. $70^{317}$ e $6^{\circ}$ da Resolução n. $77^{318}$ do CMDCA/SP, que guardam consonância com o disposto na Resolução n. 137/10 do Conanda, que, não obstante não vincular os Conselhos estaduais e municipais, traz a mesma diretriz, em seu artigo $9^{\circ}, \mathrm{V},{ }^{319}$ e são atualmente veiculadas pelo Edital Fumcad 2012, voltado a:

\footnotetext{
317 “Artigo $4^{\circ}$ Para o financiamento dos Projetos propostos por organizações governamentais, o CMDCA/SP fará publicar em Diário Oficial edital de inscrição que conterá ao menos: Indicação dos eixos de ação a serem financiadas; Critérios de classificação dos Projetos propostos por eixo de ação; Composição da Comissão de análise das propostas, determinando o número de integrantes dos órgãos e Secretarias municipais bem como os conselheiros municipais de direito, equipe técnica e demais participantes. Artigo $5^{\circ}$ Para o financiamento dos projetos propostos por organizações não governamentais, o CMDCA/SP fará publicar em Diário Oficial edital de convocação que conterá ao menos: Indicação dos eixos de ações a serem financiadas; Critérios do processo de seleção e de aprovação dos projetos propostos por eixo de ação; Composição da Comissão de análise das propostas, determinando o número de integrantes dos órgãos e Secretarias municipais bem como os conselheiros municipais de direito, equipe técnica e demais participantes."

318 "Artigo $6^{\circ}$. O CMDCA/SP definirá em edital as linhas de ação prioritárias dentro dos respectivos eixos de promoção controle e defesa. I - Os Editais FUMCAD deverão abrir seleção quadrimestral de apresentação de projetos a serem financiados pelo mesmo."

319 "Art. $9^{\circ}$ Cabe ao Conselho dos Direitos da Criança e do Adolescente, em relação aos Fundos dos Direitos da Criança e do Adolescente, sem prejuízo das demais atribuições: V - elaborar editais fixando os procedimentos e critérios para a aprovação de projetos a serem financiados com recursos do Fundo dos Direitos da Criança e do Adolescente, em consonância com o estabelecido no plano de aplicação e obediência aos princípios de legalidade, impessoalidade, moralidade e publicidade."
} 
Estabelecer procedimento e tornar público o Edital de Seleção Pública para realizar processo de análise e seleção de projetos que poderão ser financiados com recursos subsidiados do Fundo Municipal dos Direitos da Criança e do Adolescente - Fumcad/CMDCA-SP que estejam em consonância com as políticas públicas da Criança e do Adolescente da Cidade de São Paulo e que sejam inovadores e/ou complementares a essas políticas, conforme deliberação em Reunião Extraordinária deste CMDCA - SP, realizada aos 05 de março de 2012, que aprovou o texto final deste Edital. (SÃO PAULO, 2012).

A partir de editais como esse, publicados anualmente, é constituído um banco de projetos e ações aprovados e classificados, os quais estarão aptos a captar recursos pela sistemática do incentivo fiscal objeto deste estudo, nos termos referidos anteriormente (captação direcionada a projeto específico).

Superada a questão da promoção de procedimento público e objetivo, resta-nos tratar da definição dos parâmetros a fundamentarem as escolhas dos parceiros.

Considerada a inviabilidade de competição propriamente dita, ${ }^{320}$ tem-se optado por indicativos relacionados à experiência das entidades e à correlação de seus projetos com as demandas diagnosticadas e tidas como prioritárias pelo Conselho.

O objetivo buscado é, portanto, a coerência da ação proposta com os instrumentos de planejamento, tanto municipais como estaduais e federais — os quais ganham marcante destaque, conforme podemos observar no referido edital Fumcad/2012. ${ }^{321}$

\footnotetext{
320 "As exigências de impessoalidade e moralidade reclamam um procedimento objetivo de escolha do parceiro do Estado, para verificar-se se existem interessados em concorrer. Afinal, a perspectiva para o Terceiro Setor é abrir espaço e estimular a maior participação possível de sujeitos organizados da sociedade em atividades de interesse público. Essa almejada concorrência é reconhecida por Luiz Carlos Bresser Pereira e Nuria Cunill Grau — citados por Fernando Borges Mânica — quanto afirmam que a reforma do Estado deve induzir 'as entidades públicas não estatais a competir entre si para prestar serviços à comunidade com financiamento parcial do Estado.' Não é lícito ao Poder Público escolher arbitrariamente uma dentre as Organizações da Sociedade Civil de Interesse Público porventura interessadas, por exemplo." (ROTHENBURG, 2007, p. 102).

321 “Artigo 4". Para avaliação dos projetos apresentados pelas Organizações Governamentais e Entidades de natureza privada sem fins lucrativos a comissão de análise/classificação observará os seguintes critérios: a) A consonância da proposta com o Plano Nacional de Promoção, Proteção e Defesa do Direito de Crianças e Adolescentes à Convivência Familiar e Comunitária; b) A consonância da proposta com as Resoluções do CMDCA; c) A consonância com a legislação e normativas vigentes relacionadas à criança e ao adolescente, em especial ao Estatuto da Criança e do Adolescente e aos Planos Nacional e Municipal dos Direitos da Criança e do Adolescente; d) O mapeamento da distribuição dos serviços implantados na cidade de São Paulo (divisão administrativa da cidade) registrados e/ou inscritos no CMDCA (Anexo VI); e) Capacidade técnica e administrativa da Organização Governamental e das Entidades de natureza privada sem fins lucrativos para executar o projeto; f) Quadro de recursos humanos compatíveis com a proposta, observando-se a função do mesmo no projeto; g) Compatibilidade entre a proposta apresentada, a natureza e os padrões específicos que compõem o tipo do projeto a ser conveniado. Artigo 16 Os projetos serão aprovados e classificados pela Comissão de Análise/Classificação de acordo com o diagnóstico da criança e do adolescente da cidade de São Paulo, observando-se na sequência o disposto no Capítulo I, os critérios abaixo descritos e os critérios apontados no capitulo III deste edital. I. Eixos prioritários; II. Projetos destinados ao atendimento direto da criança e do adolescente; III. Melhor custo / benefício (per capta); IV. Índice de Vulnerabilidade da região, de acordo com a classificação oficial de SMADS; V. De maior impacto social.” Digno de registro, ainda, o
} 
As entidades que atenderem plenamente às condicionantes do edital serão então aprovadas e devidamente classificadas — o que implica autorização para que possam

disposto no seu artigo 13: "Será constituída uma Comissão de Análise/Classificação de projetos, composta da seguinte forma: 12 Conselheiros de Direito, sendo 06 representantes da sociedade civil e 06 representantes do Governo, que se constituirão em equipe técnica, para o trabalho de análise técnica dos projetos no período de 18/04/2012 a 13/07/2012; Parágrafo Primeiro: Se houver projetos envolvendo outras Secretarias afins à temática do projeto que não conte com representante no Conselho de Direito, o mesmo será analisado pelo Conselheiro de Direito de uma das secretarias com assento no CMDCA indicado pela Comissão de Análise/Classificação no prazo máximo de 5 (cinco) dias contados do recebimento da solicitação. Parágrafo Segundo: Os Conselheiros de Direito, representantes das Secretarias com o respectivo eixo temático, deverão emitir pareceres pela Secretaria fim, conforme Decreto 47.669/06 considerando ao menos: I) A experiência da Entidade proponente na área do projeto; II) Viabilidade do projeto quanto ao objeto, à metodologia proposta e ao cronograma; III) Interesse público. Parágrafo Terceiro: A composição da Comissão de Análise e Classificação deverá ser publicada no Diário Oficial da Cidade até dia 17 de abril de 2012. Parágrafo Quarto: Mediante solicitação da Comissão de Análise/Classificação, o CMDCA poderá reunir-se extraordinariamente, para deliberar sobre os projetos. Parágrafo Quinto: A Comissão de Análise/Classificação apresentará seus pareceres para deliberação CMDCA /SP até 25 de julho de 2012. Parágrafo Sexto: A Comissão de Análise/Classificação apresentará os projetos classificados em reunião ordinária do CMDCA/SP até dia 30 de julho de 2012." Em sentido bastante próximo, os artigos $4^{\circ}$, respectivamente dos editais Fumcad 2009 e 2010 (com idêntica redação) e 2011: “Art. 4. Para avaliação dos projetos apresentados pelas organizações governamentais e não governamentais, a comissão de análise observará os seguintes critérios: a) Consonância do projeto com a legislação e normativas vigentes relacionadas à criança e ao adolescente, em especial ao Estatuto da Criança e do Adolescente, às Resoluções do CMDCA/SP e aos Planos Nacionais e Municipais dos Direitos da Criança e do Adolescente; b) O diagnóstico da criança e do adolescente da cidade de São Paulo; c) O mapeamento feito da distribuição dos serviços implantados na cidade de São Paulo (divisão administrativa da cidade) registrados e/ou inscritos no CMDCA (Anexo VIII); d) Capacidade técnica e administrativa da Organização Social para executar o projeto, devendo o proponente apresentar a relação dos recursos humanos da Organização Social que atuarão diretamente no desenvolvimento do projeto em questão; e) Quadro de recursos humanos compatíveis com a proposta, observando-se a função do mesmo no projeto. f) Justificativa dos itens previstos na planilha de aplicação de recursos." E: “Artigo 4. Para avaliação dos projetos apresentados pelas Organizações Governamentais e Organizações Sociais a comissão de análise/classificação observará os seguintes critérios: a) A consonância da proposta com o Plano Nacional de Promoção, Proteção e Defesa do Direito de Crianças e Adolescentes á Convivência Familiar e Comunitária; b) A consonância da proposta com as Resoluções do CMDCA; c) A consonância com a legislação e normativas vigentes relacionadas à criança e ao adolescente, em especial ao Estatuto da Criança e do Adolescente e aos Planos Nacionais e Municipais dos Direitos da Criança e do Adolescente; d) O mapeamento feito da distribuição dos serviços implantados na cidade de São Paulo (divisão administrativa da cidade) registrados e/ou inscritos no CMDCA (Anexo VI); e) Capacidade técnica e administrativa da Organização Social para executar o projeto; f) Quadro de recursos humano compatíveis com a proposta, observando-se a função do mesmo no projeto; g) Compatibilidade entre a proposta apresentada, a natureza e os padrões específicos que compõe o tipo do projeto a ser conveniado." Vale notar a inexatidão técnica traduzida na referência restritiva a Organizações Sociais, que gozam de regime próprio e têm como "acordo paradigma" os contratos de gestão. De se desconsiderar, assim, a aparente restrição, de forma a compatibilizar o dispositivo com o restante do ordenamento jurídico. Também com relação a esse instrumental, registrem-se os artigos 16 dos editais 2009 e 2010, e 15 do edital 2011, segundo os quais: "Artigo $16^{\circ}$. Os projetos aprovados serão classificados prioritariamente de acordo com o diagnóstico da criança e do adolescente da cidade de São Paulo, observando-se na sequência o disposto no Capítulo I e demais critérios estabelecidos neste edital. Parágrafo Único. Em caso de projetos que tenham a mesma proposta e que estejam na mesma Região, será utilizada, de forma subsequiente, os seguintes critérios de desempate: I. Projetos prioritários; II. Projetos destinados ao atendimento direto da criança e do adolescente; III. Melhor custo / benefício; IV. Índice de Vulnerabilidade da região, de acordo com classificação oficial da SMADS - Secretaria Municipal de Assistência e Desenvolvimento Social (Anexo VI)." E: "Artigo 15 Os projetos serão aprovados e classificados pela Comissão de análise/classificação de acordo com o diagnóstico da criança e do adolescente da cidade de São Paulo, observando-se na sequiência o disposto no Capítulo I, os critérios abaixo descritos e os critérios apontados no capitulo III deste edital. I. Eixos prioritários; II. Projetos destinados ao atendimento direto da criança e do adolescente; III. Melhor custo/benefício; IV. Índice de Vulnerabilidade da região; V. De maior impacto social.” 
mobilizar a iniciativa privada de modo a buscar a destinação de percentuais de Imposto de Renda ao seu projeto específico.

Ainda que não logre sucesso nessa empreitada, haverá sempre a possibilidade de custeio do projeto/ações aprovados com receitas destinadas ao Fundo por meio da sistemática referida no artigo $3^{\circ}$, $\S 3^{\circ}$, do Decreto municipal n. 43.135/03. ${ }^{322}$

Além dos critérios e requisitos postos nos editais do CMDCA/SP, imprescindível a observância, pelas entidades que se pretendam beneficiárias da atividade de fomento, do fiel atendimento ao disposto no Decreto municipal n. 52.830, de 01 de dezembro de 2011, que regulamenta a criação do Cadastro Único de Entidades Parceiras do Terceiro Setor, dispondo, em seu artigo $2^{\circ}$, que: “Todas as entidades sem fins lucrativos que tenham celebrado ou pretendam celebrar convênios, termos de parceria, contratos de gestão e instrumentos congêneres com órgãos da Administração Municipal Direta, Autárquica e Fundacional deverão estar inscritas no CENTS.”

E o $§ 2^{\circ}$ desse mesmo artigo determina que: "Para inscrição no Cents, exigir-se-á das entidades referidas neste artigo a comprovação de sua habilitação jurídica e de regularidade fiscal e contábil, na forma e condições a serem estabelecidas em portaria da Secretaria Municipal de Planejamento, Orçamento e Gestão.”

Inviável, portanto, o conveniamento com entidades que se encontrem em situação de irregularidade, quer contábil, quer fiscal ou jurídica, ${ }^{323}$ conforme explicita o artigo $4^{\circ}$ :

\begin{abstract}
Art. $4^{\circ}$. É vedado aos órgãos da Administração Municipal Direta, Autárquica e Fundacional celebrar convênios, termos de parceria, contratos de gestão ou instrumentos congêneres, bem como prorrogar os respectivos prazos de validade desses ajustes, com entidades que não estiverem cadastradas no CENTS, observado o disposto no artigo 16 deste decreto.
\end{abstract}

\footnotetext{
322 "§ $3^{\circ}$. No caso de doação condicionada à utilização em projeto específico, proposto por órgão governamental ou pela sociedade civil e aprovado pelo CMDCA, permanecerão no FUMCAD 10\% (dez por cento) do valor doado para subsidiar outras propostas."

${ }^{323}$ Referidas normas têm por escopo garantir que o destinatário final dos recursos públicos, que a eles fará jus a título de contraprestação de um serviço prestado ou um bem fornecido, possa ser qualificado como cioso e cumpridor de suas obrigações para com o Estado. Muito se questiona quanto a essa função fiscalizatória emprestada pela lei ao procedimento licitatório, mais especificamente com relação à exigência de demonstração da regularidade fiscal do contratado - e, no cenário ora considerado, dos convenentes. Isso porque tal expediente findaria por promover não o controle das relações contratuais da Administração, mas a regularidade fiscal dos particulares - o que configuraria, segundo parte da doutrina, desvio de finalidade da Lei, com a utilização de meio transverso de arrecadação aos cofres públicos. Nesse sentido a lição de Justen Filho. (JUSTEN FILHO, 2012, p. 475).
} 
A forma de aferição do atendimento a esses imperativos se dará a partir de critérios fixados por órgão municipal — afastada a incidência do regime trazido pelos artigos 28 e $29^{324}$ da Lei n. 8.666/93.

Desse diploma resta a aplicação das normas originalmente relacionadas aos contratos administrativos stricto sensu constantes do seu artigo 87 , III e IV, ${ }^{325}$ conforme determina o artigo 11 do Decreto municipal:

Art. 11. Poderão ser aplicadas às entidades inscritas as seguintes penalidades:

I - advertência: quando deixar de promover as atualizações cadastrais na forma do artigo $9^{\circ}$ deste decreto;

II - cancelamento da inscrição:

a) automático, quando forem aplicadas à entidade as penalidades de suspensão temporária de participação em licitação e impedimento de contratar com a Administração e de declaração de inidoneidade para licitar ou contratar com a Administração, na forma da legislação pertinente, por decisão que encerra a instância administrativa;

b) por solicitação da unidade interessada, quando a entidade deixar de prestar contas sem justificativa ou por justificativa não acatada pela Administração.

Cumpre-nos perquirir, neste ponto, se referidos incisos do artigo 87, veiculadores

de limites à liberdade de iniciativa, integram a noção de "normas gerais", sendo, portanto, extensíveis aos convênios, em todos os níveis da federação.

\footnotetext{
324 “Art. 28. A documentação relativa à habilitação jurídica, conforme o caso, consistirá em: I - cédula de identidade; II - registro comercial, no caso de empresa individual; III - ato constitutivo, estatuto ou contrato social em vigor, devidamente registrado, em se tratando de sociedades comerciais, e, no caso de sociedades por ações, acompanhado de documentos de eleição de seus administradores; IV - inscrição do ato constitutivo, no caso de sociedades civis, acompanhada de prova de diretoria em exercício; V - decreto de autorização, em se tratando de empresa ou sociedade estrangeira em funcionamento no País, e ato de registro ou autorização para funcionamento expedido pelo órgão competente, quando a atividade assim o exigir. Art. 29. A documentação relativa à regularidade fiscal e trabalhista, conforme o caso, consistirá em: I - prova de inscrição no Cadastro de Pessoas Físicas (CPF) ou no Cadastro Geral de Contribuintes (CGC); II - prova de inscrição no cadastro de contribuintes estadual ou municipal, se houver, relativo ao domicílio ou sede do licitante, pertinente ao seu ramo de atividade e compatível com o objeto contratual; III - prova de regularidade para com a Fazenda Federal, Estadual e Municipal do domicílio ou sede do licitante, ou outra equivalente, na forma da lei; IV - prova de regularidade relativa à Seguridade Social e ao Fundo de Garantia por Tempo de Serviço (FGTS), demonstrando situação regular no cumprimento dos encargos sociais instituídos por lei. V - prova de inexistência de débitos inadimplidos perante a Justiça do Trabalho, mediante a apresentação de certidão negativa, nos termos do Título VII-A da Consolidação das Leis do Trabalho, aprovada pelo Decreto-Lei 5.452, de $1^{\circ}$ de maio de 1943. “

325 "Art. 87. Pela inexecução total ou parcial do contrato a Administração poderá, garantida a prévia defesa, aplicar ao contratado as seguintes sanções: [...] III - suspensão temporária de participação em licitação e impedimento de contratar com a Administração, por prazo não superior a 2 (dois) anos; IV - declaração de inidoneidade para licitar ou contratar com a Administração Pública enquanto perdurarem os motivos determinantes da punição ou até que seja promovida a reabilitação perante a própria autoridade que aplicou a penalidade, que será concedida sempre que o contratado ressarcir a Administração pelos prejuízos resultantes e após decorrido o prazo da sanção aplicada com base no inciso anterior."
} 
Tal ponto é de fulcral importância, na medida em que, justamente pela natureza restritiva de direitos dos particulares, referidas regras devem necessariamente ser veiculadas por lei em sentido formal.

Em se concluindo pela natureza geral daquelas regras da Lei de Licitações, plenamente válida a ressalva veiculada — ou repetida — pelo Decreto municipal.

Por outro lado, caso não se admita essa sua natureza, incompatíveis com o ordenamento jurídico as regras em comento, por ofensivas ao princípio da legalidade.

Temos, primeiramente, que se trata de dispositivos tradutores, em nível infraconstitucional, dos valores basilares da moralidade, da eficiência e da isonomia, uma vez que as empresas ou entidades privadas em falta com as suas obrigações contratualmente assumidas, ao mesmo tempo em que ocasionam prejuízo à Administração, se locupletam imotivadamente com os valores recebidos a título de remuneração por serviços não prestados, prestados com defeito, ou por bens não disponibilizados conforme o acordado.

Tal situação poderia vir a comprometer a isonomia destes entes com relação a todos os outros particulares ciosos de suas obrigações e zelosos do cumprimento de seus compromissos.

A parte disso, temos que a replicação da constituição de vínculos com entidades reconhecidamente não sérias, descumpridoras de suas obrigações, faria emergir questionamentos quanto à eficiência e moralidade da atuação administrativa.

Concluímos se tratar, portanto, de normas concretizadoras de princípios constitucionais basilares da atuação administrativa - em total consonância com a conceituação de "normas gerais" anteriormente desenvolvida, de forma que consideramos as restrições em foco perfeitamente compatíveis com o ordenamento pátrio.

Ultrapassados a escolha da entidade parceira e os requisitos para tanto, foquemos no segundo ponto enunciado no título do presente subitem: a vinculação dos convênios ao respectivo edital de chamamento, assim como a extensão e limites dessa peça, da qual decorre uma série de situações de fundamental importância quanto à viabilidade, o regime jurídico e a própria juridicidade dos instrumentos firmados.

Quanto a esse aspecto, a premissa básica e inafastável é a imperiosa compatibilidade do disposto no instrumento convocatório com o ordenamento jurídico, tanto nacional quanto municipal.

Imprescindível guarde ele consonância com o disposto na $\mathrm{CF}$, no Estatuto da Criança e do Adolescente, no plano plurianual, na Lei de Diretrizes Orçamentárias, no 
orçamento anual, na Lei municipal n. 11.123/91, na Lei municipal n. 11.247/92 — e respectivos decretos regulamentares —, além de nas resoluções do CMDCA/SP e demais legislação pertinente.

No caso de contradição entre o estabelecido no edital e qualquer norma hierarquicamente superior aplicável, necessário o seu afastamento, a desconsideração das regras porventura dissonantes - que deve ser levada a termo pelo próprio Conselho, no exercício das prerrogativas inerentes à autotutela, ou pelos órgãos de controle externo, conforme exposto no anteriormente.

Tais situações de contradição, cujas soluções se apresentam com clareza aparentemente cristalina, dão azo a impasses que merecem ser levados em conta e que por vezes decorrem da omissão, do silêncio das normas, tanto editalícias como legais e/ou regulamentares.

Hipóteses há, da mesma forma, em que a manifestação do Conselho - quer via resolução, quer no próprio edital — findam por gerar tais dilemas.

Tomemos por paradigma, para ilustrar nossas ponderações, os editais Fumcad/SP 2009, 2010, 2011 e 2012.

Mais especificamente, a hipótese de captação pela entidade (após a aprovação do projeto, sua classificação e expedição de autorizativo para tanto) de apenas parcela do valor necessário à consecução das ações propostas.

Surge, nesse cenário, dúvida quanto à possibilidade de liberação desses valores — insuficientes ao custeio do objeto a ser conveniado em sua completude —, de forma a impedir fiquem eles indefinidamente paralisados no Fundo, em situação de potencial frustração daqueles que contribuíram ativamente para a relação de fomento.

Situações como essas foram determinantes da publicação pelo CMDCA/SP, no ano de 2006, da Resolução n. 86, cujo artigo $1^{\circ}$ assim dispõe:

Artigo $1^{\circ}$ - Os projetos aprovados no Edital FUMCAD/2005 chamado pelo CMDCA/SP, e que receberem recursos direcionados parcialmente poderão ser conveniados, [condicionados] ao recebimento do pedido da entidade em realizar parcialmente $\mathrm{o}$ projeto, sem prejudicar a metodologia e os objetivos do mesmo, depois de aprovados pelo Colegiado do CMDCA/SP.

I - Para realizar parcialmente o projeto o mesmo deverá ter no mínimo $10 \%$ (dez) do valor captado.

II - Excepcionalmente o CMDCA/SP poderá deliberar pela aprovação automática de valores inferiores ao disposto no inciso I. 
A Resolução em causa — não obstante a sua péssima redação — vem sendo reiterada e integralmente reafirmada por todos os editais subsequentes do Fumcad, de forma que a sua sistemática se aplica a todos os projetos aprovados desde então. ${ }^{326}$

Nessa esteira, o edital de 2009 foi explícito ao autorizar que "o financiamento de projetos, aprovados pelo CMDCA, que tenham ou não recursos direcionados pelo FUMCAD será permitido para: I - Financiamento total ou parcial de projetos". 327

Da mesma forma, os editais de 2010 (cujo artigo 19 tem redação idêntica à transcrita), 2011, em seu artigo 18:

Art. 18. O financiamento de projetos, aprovados e classificados pelo CMDCA, que tenham ou não recursos direcionados pelo FUMCAD será permitido para: I - Financiamento total ou parcial de projetos, e 2012: O financiamento de projetos, aprovados e classificados pelo CMDCA, que tenham ou não recursos direcionados pelo FUMCAD será permitido para: I - Financiamento total ou parcial de projetos, desde que haja disponibilidade financeira.

Referidos dispositivos não fazem menção expressa à readequação dos projetos que lograram captação apenas parcial - assunto este tratado, porém, na já referida Resolução n. 86/CMDCA, incorporada, na condição de anexo, aos editais, e consonante com o entendimento da Procuradoria Geral do Município:

[...] em princípio, não é possível destinar recursos públicos do Fumcad em favor de projeto que, sabe-se de antemão, não será executado na extensão ou no modo que antes o recomendava. Mais ainda, a execução parcial de um projeto não equivalerá necessariamente à implementação de uma versão reduzida do projeto original. [...] A superação do problema, salvo melhor juízo, está a exigir que a entidade beneficiária adapte o projeto original ao lastro financeiro verificado no FUMCAD, submetendo a alteração a novo crivo do CMDCA [...]. Desse modo, em resumo, a liberação de doações correspondentes a uma parcela do projeto específico a que se destinavam seria possível mediante a prévia adaptação deste projeto aos recursos financeiros existentes no FUMCAD, adaptação essa que deverá ser apreciada pelo CMDCA para aferição da

\footnotetext{
${ }^{326}$ Ressalvadas os seus dispositivos incompatíveis com o ordenamento jurídico (cuja análise e interpretação fica a cargo da Procuradoria Geral do Município e da Secretaria de Negócios Jurídicos). Esse o caso, por exemplo, do seu artigo $4^{\circ}$, cuja redação, a ser desprezada, é a seguinte: "Artigo $4^{\text {o }}$ - Para realização de projetos que contenham construção de imóvel e o valor captado seja só referente à construção do mesmo, a proponente deverá assinar um termo de compromisso para que a utilização do mesmo seja destinado para os fins descritos no projeto em questão. I - A Entidade assinara um termo de compromisso no qual se compromete a atender a no mínimo $30 \%$ da demanda proposta do projeto, caso a mesma não complete sua captação. II - Caso a entidade proponente encerre suas atividades, ou mude seus objetivos, o imóvel construído através de recursos repassados pelo Fumcad, deverá ser revertido para Associações com Registro no CMDCA/SP, com projetos aprovados pelo mesmo."

327 Artigo 19.
} 
permanência do interesse público que o recomendara. (Parecer da Procuradoria Geral do Município ementado sob o número 10.974).

Passemos à discussão quanto à possibilidade de utilização dos valores captados, ainda que parcialmente, para a realização de construções ou obras em imóveis privados.

Constatamos, uma vez mais, ao longo dos últimos quatro anos, diversos autorizativos — ainda que condicionados —, de lavra do Conselho.

Realmente, o edital de 2009 veiculava o seguinte:

Artigo 12. Não serão cobertas despesas com:

[...]

h) Realização de despesas exclusivamente com obras e benfeitorias, observada sempre a necessária prestação, desde o primeiro momento, de atendimento efetivo à criança e ao adolescente; (grifamos)

Artigo 13. As despesas com a realização de obras somente serão admitidas, em princípio, em terrenos públicos municipais, e mediante prévia autorização da Prefeitura. Excepcionalmente, poderá se admitir a execução de obras e benfeitorias em terreno particular, desde que a Organização social comprove o exercício pleno dos poderes inerentes à propriedade do imóvel, mediante certidão atualizada do cartório de registro de imóveis competente, admitindo-se, condicionadas à garantia subjacente de uso pelo período mínimo de vinte anos, as seguintes hipóteses alternativas:

a) posse do imóvel: em área desapropriada ou em desapropriação pela União, Estado ou Município, ou, ainda, em área devoluta;

b) imóvel recebido em doação: da União, Estado ou Município, já aprovada em lei, conforme o caso e se necessária, inclusive quando o processo de registro de titularidade ainda se encontre em trâmite, ou, ainda, de pessoa física ou jurídica, inclusive quando o processo de registro de titularidade ainda se encontre em trâmite, neste caso, com promessa de doação irretratável e irrevogável;

c) imóvel cuja utilização esteja consentida pelo seu proprietário, por instrumento contratual hábil, com autorização expressa irretratável.

Parágrafo Primeiro. Nas hipóteses previstas nas alíneas "b" e "c", é imperativa a anuência formal do titular da propriedade, como interveniente garantidor do uso do imóvel cedido ou doado, comprometendo a si e aos respectivos herdeiros e sucessores a cumprir a cláusula de cessão gratuita de uso ou doação do imóvel. (grifamos)

Artigo 19. O financiamento de projetos, aprovados pelo CMDCA, que tenham ou não recursos direcionados pelo FUMCAD será permitido para: III - Construção, reforma, ampliação ou locação de imóveis necessários à implantação e/ou implementação do atendimento à criança e ao adolescente, conforme disposições deste edital; 
No caso de 2010, não obstante a idêntica repetição do permissivo, o artigo 13 sofreu significativas alterações: “As despesas com a realização de obras somente serão admitidas, em terrenos públicos municipais, e mediante prévia autorização da Prefeitura".

Da mesma forma, o artigo 19, III:

Artigo 19. O financiamento de projetos, aprovados pelo CMDCA, que tenham ou não recursos direcionados pelo FUMCAD será permitido para: [...]

III - Construção, reforma, ampliação, somente em terreno público municipal necessários à implantação e/ou implementação do atendimento à criança e ao adolescente, conforme disposições deste edital;

Notamos de plano, no contexto até este ponto retratado, uma sensível mudança de regime, que passa a ainda mais restritivo que o preconizado pela $\mathrm{PGM}^{328}$ uma vez limitadas as hipóteses de custeio de obras com valores públicos a imóveis também marcados por essa natureza, enquanto o órgão jurídico municipal maior defende a possibilidade de realização de pequenas obras, ainda que em propriedade particular, e desde que a partir da aplicação de receitas provenientes de destinações direcionadas via IR.

Tais restrições perduraram, nos mesmos moldes, nos editais de $2011^{329}$ e $2012 .^{330}$

\footnotetext{
328 "Os recursos do Fumcad devem, em princípio, destinar-se a atividades de atendimento direto à criança e ao adolescente que a entidade proponente já esteja estruturada a desenvolver. Não se nos afigura possível, pois, a celebração de convênio cujo escopo seja a estruturação física da entidade. O dinheiro público não pode, em princípio, ser usado para financiá-la. Até 2001, aliás, exigia-se na seleção dos projetos financiados pelo Fumcad que os recursos públicos pretendidos não fossem versados na 'construção, ampliação, reforma de espaço físico e aquisição de bens permanentes'. Com a efetivação da possibilidade de as doações serem dirigidas a projetos específicos, os critérios parecem ser sido amainados. [...]. A teórica razão para isso talvez seja a compreensão de que, por sua origem privada, as doações dirigidas não se submeteriam ao rigor com que se costuma analisar o emprego de recursos hauridos diretamente do erário. [...] Mas é também certo que não se pode frustrar desarrazoadamente a expectativa do cidadão que, acorrendo ao convite da Administração, realizou doações na perspectiva e que um determinado projeto aprovado pelo CMDCA fosse executado, ainda que, circunstancialmente, nele esteja embutida a reforma de espaço físico e a aquisição de bens permanentes de pequena monta como providências instrumentais necessárias à consecução do convênio publicamente anunciado. Consideradas essas premissas, creio ser possível conjugar essas duas órbitas de valor do seguinte modo: (a) os recursos do Fumcad procedentes do orçamento municipal não podem ser usados na 'construção, ampliação, reforma de espaço físico e aquisição de bens permanentes'; (b) os recursos do Fumcad originados de doação direta podem ser usados em projetos já previamente avaliados pelo CMDCA que envolvam, circunstancialmente, a adaptação de imóvel (e não de construção) [...] desde que compatível com o prazo do convênio [...]." (grifamos) (Parecer da Procuradoria Geral do Município ementado sob o n. 10.974)

329 "Artigo 12. As despesas com a realização de obras somente serão admitidas em terrenos públicos municipais, e mediante apresentação do termo de concessão de uso expedido pela Prefeitura." (grifamos)

330 "Artigo 12. As despesas com a realização de obras somente serão admitidas em terrenos públicos municipais, e mediante apresentação do termo de permissão de uso expedido pela Prefeitura com respectivo Projeto de Obra aprovado pela Prefeitura Municipal de São Paulo, quando for o caso.” (grifamos)
} 
O instrumento de chamamento 2009 conjugava a visão mais restritiva com o posicionamento da Procuradoria Geral. ${ }^{331}$

Cumpre-nos registrar nossa discordância quanto ao fator diferencial adotado pela PGM, traduzido na origem dos valores direcionados ao Fundo, vez que não nos parece razoável a incidência de regime jurídico diferenciado em razão desse critério, tendo em vista que as normas de Direito Financeiro e Orçamentário não traçam essa distinção em momento algum.

A referência que se faz é, genericamente, a receitas públicas, integrantes dos cofres públicos e sujeitos, portanto, a idênticas regras de cunho orçamentário-financeiro. ${ }^{332}$

Uma vez ingressados no Fundo, os valores passam a se submeter, automática e imediatamente, ao regime público, com todas as especificidades daí decorrentes.

Na esteira do que foi por diversas vezes salientado, não obstante a sua autonomia, o CMDCA deve observância ao ordenamento jurídico, motivo pelo qual não lhe é dado aprovar projetos cuja execução poderá afrontar, em qualquer medida, os preceitos postos.

De se considerar, tanto no momento da elaboração de seus editais e resoluções, como no da aprovação dos projetos (e de sua eventual readaptação), a sua conformidade jurídica - o que reforça a imprescindibilidade da análise, pela Assessoria Jurídica da Pasta a que administrativa/burocraticamente relacionado o Conselho, de referidos instrumentais, de modo a conciliar, a harmonizar os aspectos político e técnico.

Retomemos as considerações de mérito quanto à viabilidade de conveniamento a partir de valores apenas parcialmente captados, e à possibilidade de utilização de tais receitas para a realização de obras/construções.

No que toca à primeira, de se lembrar que a execução parcial do projeto aprovado não necessariamente corresponde ao seu regular desenvolvimento, apenas em escala reduzida.

Em tal contexto, é possível que a parcela arrecadada seja suficiente tão somente ao custeio das medidas preparatórias do desenvolvimento das atividades em prol da infância e juventude propriamente ditas.

\footnotetext{
331 “Artigo 19. O financiamento de projetos, aprovados e classificados pelo CMDCA, que tenham ou não recursos direcionados pelo Fumcad será permitido para: [...] III - Construção, reforma, ampliação, somente em terreno público municipal, necessários a implantação e/ou implementação do atendimento à criança e ao adolescente, desde que tenham recursos direcionados. (grifamos)

${ }^{332}$ Registre-se, quanto a esse aspecto, que o permissivo constante do artigo 74 da Lei federal n. 4.320/64, ao admitir a criação de regimes especiais ("A lei que instituir fundo especial poderá determinar normas peculiares de controle, prestação e tomada de contas, sem de qualquer modo, elidir a competência específica do Tribunal de Contas ou órgão equivalente"), não autoriza, em momento algum, a criação de diversos regimes especiais, a incidirem sobre um mesmo fundo.
} 
Em situações tais, a autorização do levantamento dos valores parciais poderia vir a resultar em aparelhamento e estruturação da entidade (e/ou das atividades) — sem que nenhum resultado efetivo se desenvolvesse quanto aos seus potenciais beneficiários.

Bastaria que as captações cessassem, que a entidade não mais conseguisse mobilizar contribuintes em prol da sua causa - e não lhe fosse possível aproveitar nenhuma parcela dos valores integrantes o Fumcad nos temos do artigo $3^{\circ}$, $\S 3^{\circ}$, do Decreto municipal n. 43.135/03.

Os projetos, que possuem prazo de validade, ${ }^{333}$ estariam fadados à inconclusão, não obstante a destinação de receita pública que lhes houvesse aproveitado.

Defendemos, nesse particular, obrigatória readaptação do projeto original, de forma a compatibilizá-lo com os valores disponíveis.

Imprescindível, aí, uma nova manifestação do Conselho, dentro do mesmo processo de chamamento público, nos termos expressamente autorizados pela Resolução n. $86^{334}$ e pelo $\S 2^{\circ}$ do artigo $3^{\circ}$ da Resolução n. 77 do CMDCA. ${ }^{335}$

No que tange à utilização das receitas para a realização de obras e/ou benfeitorias, posicionamo-nos pela sua viabilidade jurídica no que toca aos bens públicos.

Da mesma forma se forem os bens particulares; mas, aí, desde que: a) sejam as obras de pequena monta, limitadas a um determinado percentual (a ser fixado pelo Conselho) com relação ao projeto integral; b) não sejam capazes de exaurir os valores captados, de forma a colocar em risco o posterior efetivo atendimento aos interesses da infância e juventude.

Ultrapassadas as limitantes relativas à captação parcial e à utilização de receitas do Fumcad para obras, cumpre-nos analisar uma outra, inserida no mesmo contexto, e de certa forma relacionada àquelas.

A questão que se coloca é a eventual necessidade de aditamento do convênio em montante superior a $25 \%$ do valor original, como consequência justamente da admissão de levantamento dos valores parcialmente captados.

Voltamos, uma vez mais, às normas gerais: estaria o artigo $65, \S \S 1^{\mathrm{o}}$ e $2^{\mathrm{o}},{ }^{336} \mathrm{da}$ Lei n. 8.666/93, inserido nessa categoria? Em outras palavras, estariam os convênios

\footnotetext{
${ }^{333}$ Nos termos dos artigos 10, caput, e $\S 2^{\circ}$ do Decreto municipal n. 43.135/2003.

${ }_{334}^{334}$ Que disciplina, justamente, da liberação de valores parcialmente captados.

335 “ $\$ 2^{\circ}$. Eventuais propostas e alteração nos projetos aprovados pelo CMDCA/SP deverão ser submetidas à deliberação da plenária do referido Conselho, observada a proporcionalidade prevista no caput deste artigo."

336 " $§ 1^{\circ} \mathrm{O}$ contratado fica obrigado a aceitar, nas mesmas condições contratuais, os acréscimos ou supressões que se fizerem nas obras, serviços ou compras, até $25 \%$ (vinte e cinco por cento) do valor inicial atualizado do contrato, e, no caso particular de reforma de edifício ou de equipamento, até o limite de $50 \%$ (cinqüenta
} 
municipais — inclusive aqueles custeados com valores do Fundo — sujeitos a essa limitação?

De se lembrar que o projeto aprovado pelo Conselho é o parâmetro a ser utilizado - ainda que o convênio seja efetivado, em um primeiro momento, com valores menores, por déficit na arrecadação.

Isso porque a manifestação da vontade pública, o assentimento no que toca à extensão, à amplitude das ações a serem desenvolvidas, já se deu regularmente quando da sua análise de mérito.

O conveniamento em valores e ações a menor decorre de contingências de ordem prática, vinculadas à não mobilização de contribuintes em grau suficiente para a cobertura de todas as despesas originalmente previstas.

E a delimitação do objeto a ser fomentado se aperfeiçoa, efetivamente, quando da aprovação do projeto pelo Conselho, e não durante o desenrolar dos atos subsequentes, de formalização do quanto aprovado e autorizado.

Daí que as alterações dentro dos limites do projeto original aprovado estariam implicitamente autorizadas pela própria sistemática do levantamento - e parceirização parciais.

Necessária a perquirição, porém, quanto às situações em que os limites inicialmente apresentados - e os montantes captados — sejam superados.

Vale registrar, nesse ponto, que o artigo 65 da Lei de Licitações trata de duas espécies distintas de aditamentos: os quantitativos e os qualitativos, com regimes jurídicos absolutamente diferenciados, conforme se depreende da doutrina abaixo invocada.

No que toca aos primeiros, não há grandes discussões quanto à sua sujeição aos referidos limites de 25 ou $50 \%$.

A mesma tranquilidade não impera quanto às alterações qualitativas, com relação às quais muitos defendem a não incidência dos limites:

[...] Alguns doutrinadores, em vista das mudanças aludidas, cifraram-se a dar como certo, sem maiores considerações, que não mais se admite qualquer ultrapassagem dos percentuais referidos ('exempli gratia' Jessé Torres Pereira Junior - Comentários à Lei de Licitações e Contratos da Administração Pública, Ed. Renovar, $3^{\text {a }}$ ed., 1995, pág. 417 e Diógenes Gasparini - Direito Administrativo, Ed. Saraiva, 4 a ed. 1995, págs. 400/401). Todavia, os que se debruçaram sobre o tema com alguma

por cento) para os seus acréscimos. $\S 2^{\circ}$ Nenhum acréscimo ou supressão poderá exceder os limites estabelecidos no parágrafo anterior, salvo: II - as supressões resultantes de acordo celebrado entre os contratantes." 
detença assumiram outra posição. Vejamos, em resenha, que disseram estes últimos. Entre eles cumpre salientar, inicialmente, as lições de Caio Tácito, por se tratar, para além de qualquer dúvida ou entre dúvida, em um dos mais notáveis administrativistas brasileiros de todos os tempos, de Antonio Carlos Cintra do Amaral e de Marçal Justen Filho, por serem eles, com justa razão, reputadíssimos monografistas sobre licitação e contratos. Caio Tácito (parecer, RDA/198, págs. 363 e sgs.) sustenta que os limites a que se reporta a lei, inclusive, pois, em seu $\$ 2^{\circ}$, I, atinam à hipótese de modificações meramente quantitativas mencionadas na letra "b", do art. 65, I, não, porém, em relação às qualitativas, é dizer, às contempladas na letra "a" do art. 65, I (modificação do projeto ou das especificações, para melhor adequação técnica aos seus objetivos), as quais, em sendo necessárias para a "plena consecução da finalidade do contrato", são admissíveis. Disse o referido mestre: "As alterações quantitativas do contrato, objeto do capítulo anterior, são manifestações unilaterais da Administração, por motivo de conveniência do serviço, que podem processar, dentro dos limites permitidos, sem que se modifiquem as especificações do contrato e os critérios definidos nas planilhas que o integram. A ordem a ser emitida, de obrigatório acatamento pelo contratado, pressupõe nos explícitos termos da lei, o atendimentos das "mesmas condições contratuais"” (pág. 365/366). E pouco além: "As alterações qualitativas, precisamente porque são, de regra, imprevisíveis, senão mesmo inevitáveis, não têm limite pré-estabelecido, sujeitando-se a critérios de razoabilidade, de modo a não se desvirtuar a integridade do objeto do contrato." (pág. 366). Antonio Carlos Cintra do Amaral (Ato Administrativo, Licitação e Contrato Administrativo, Malheiros Eds., 1995, págs. 122 a 135), em seu aprofundado exame, também entende que a alteração do projeto - a qual em certos casos pode e em outros deve ser efetuada - não fica sujeita sempre aos aludidos limites percentuais. $\mathrm{O}$ autor, ao que parece, não estabelece cerceamentos quanto à extensão ou profundidade das alterações, entendendo que, respeitado o objeto do contrato - o qual não inclui em sua delimitação o que Carlos Ari denominou de "dimensão" do objeto - e desde que suscitadas por circunstâncias supervenientes, imprevisíveis e excepcionais haverão de ser aceitas todas as que sejam impostas pelo interesse público primário ainda que nada se tolere além delas “... já que o limite real é ditado pelo satisfatório atendimento do "interesse coletivo primário"” (pág. 131). Além disto, ao contrario de Caio Tácito, é explicito em dizer que para exceder os limites legais é necessária a concordância do contratado (pág. 133, letra "h"). [...] Assim, pois, uma primeira conclusão, que de logo sufragamos, pode ser firmada: a Lei 8.666/93 adite, nas hipóteses da letra "a", superação dos limites que menciona, pois estes só dizem respeito à letra "b". (BANDEIRA DE MELLO, 2001, p. 8-10).

Ainda mais restrito, portanto, o campo de discussão ora desenvolvida, vez que dele estão excluídos: a) as alterações, quantitativas ou qualitativas, já previstas e/ou englobadas no projeto originalmente aprovado pelo Conselho; b) os acréscimos de ordem qualitativa que vão além daquela primeira versão, desde que haja receita a lhes fazer frente. 
Quanto a essas últimas, de se verificar, de plano, se implicariam alteração do objeto convenial, hipótese expressamente vedada pelos últimos quatro editais de chamamento do Fumcad, ${ }^{337}$ visto ser potencialmente maculadora de todas as atividades pretendidas, em razão, inclusive, de afronta à isonomia.

Afastada essa possibilidade, entendemos que a limitação estaria, da mesma forma, superada, em decorrência da própria natureza, da própria lógica dos convênios.

Referidos instrumentos se prestam a concretizar situações em que os envolvidos compartilham interesses comuns, de sorte que não se pode falar em risco de prejuízo, quer ao erário, quer ao interesse público, em razão de sua ampliação.

Além disso, os valores necessários ao custeio de tais medidas são captados especificamente para essa finalidade, de forma que ficam "carimbados", estando, em princípio, vinculados ao objeto proposto - seja na sua versão original, seja na restrita, em razão da insuficiência dos valores inicialmente destinados ou, ainda, na ampliada.

O próprio princípio da confiança legítima impediria que fosse diferente, que a Administração traísse a confiança daqueles que cederam aos seus apelos lançados a partir do exercício da função de fomento.

A única hipótese de os valores destinados serem desvinculados do projeto avalizado pelo Conselho corresponde à sua aprovação em contrariedade à lei, ou à perda das condições objetivas que a entidade deve manter para o conveniamento. Verificada a ocorrência dessas hipóteses, deverá ser aberta a possibilidade para o destinador redirecionar os valores originalmente vinculados ao projeto que não se poderá desenvolver. Não exercitado esse direito no prazo fixado para tanto, a receita em questão deve ter a sua aplicação determinada pelo próprio Conselho, nos mesmíssimos moldes do que se dá com os dez por cento referidos no $\S 3^{\circ}$ do art. $3^{\circ}$ do Decreto n. 43.135/03.

Excepcionados esses impeditivos, haverá, naquelas condições, a) interesse público já formalmente reconhecido pelo Conselho e b) valores disponíveis para o custeio das ações pretendidas e vinculadas ao projeto específico em questão - ambos determinantes do pronto afastamento do limite de vinte e cinco por cento, observada a fidelidade necessária para com o objeto original. ${ }^{338}$

\footnotetext{
${ }^{337}$ Editais 2011 e 2012, em seus artigos 11; editais 2009 e 2010, artigo 12, sempre com idênticas redações: "Não serão cobertas despesas com: [...] Aditamento com alteração do objeto."

${ }^{338}$ Em sentido contrário, parecer da PGM exarado nos autos do Parecer da Procuradoria Geral do Município ementado sob o número 11.188, e enunciado nos seguintes termos: "Administrativo. Convênio. Possibilidade de se proceder à alteração do convênio, nos termos do disposto no artigo $65, \S 1^{\circ}$, da Lei 8.666/93, alteração essa balizada, necessariamente, pelos limites fixados neste dispositivo legal para os acréscimos ou supressões em $25 \%$ (vinte e cinco por cento) ou 50\% (cinqüenta por cento), a depender do caso."
} 
Ainda que não se entenda dessa forma, em razão dos argumentos aventados, de se ver que as regras constantes do artigo $65, \S \S 1^{\circ}$ e $2^{\circ}$, da Lei de Licitações não se inserem na categoria das normas gerais, vez que não veiculam nem concretizam diretrizes gerais, noções basilares ou universais.

Sua observância por todas as esferas federativas, em idênticos termos, não se faz imprescindível ao atendimento da lógica constitucional e da própria Administração do século XXI.

Traduzem, contrariamente, aspectos práticos, procedimentais, específicos e, portanto, inseridas no âmbito de autonomia própria dos entes federados — donde, sob outro fundamento, sua não incidência sobre os convênios e as demais esferas políticas.

A derradeira limitação aos editais e resoluções do CMDCA que nos cumpre elencar está prevista no artigo $7^{\circ}$ do Decreto municipal n. 53.177, de 04 de junho de 2012:

\begin{abstract}
Art. $7^{\circ}$. Todas as entidades sem fins lucrativos que mantiverem convênios, termos de parceria, contratos de gestão e instrumentos congêneres ou que, por qualquer outra forma, recebam verbas de órgãos da Administração Municipal Direta, Autárquica e Fundacional, deverão comprovar que seus diretores não incidem nas vedações constantes do artigo $1^{\circ}$ deste decreto. ${ }^{339}$
\end{abstract}

\footnotetext{
339 “Art. 1. A vedação estabelecida na Emenda 35 à Lei Orgânica do Município de São Paulo de nomeação, contratação, admissão, designação ou posse para cargos, empregos e funções públicas da Administração Direta e Indireta do Município de São Paulo de pessoas que incidam nas hipóteses de inelegibilidade previstas na Lei Complementar 64, de 18 de maio de 1990, alterada pela Lei Complementar 135, de 4 de junho de 2010, compreende: I - os que tenham perdido o mandato no Congresso Nacional, Assembleias Legislativas, Câmara Legislativa do Distrito Federal e Câmaras Municipais por infringência ao disposto nos incisos I e II do artigo 55 da Constituição Federal, dos dispositivos equivalentes sobre perda de mandato das Constituições Estaduais e Leis Orgânicas dos Municípios e do Distrito Federal, durante o período remanescente do mandato para o qual foram eleitos e nos 8 (oito) anos subseqüentes ao término da legislatura; II - os que tenham perdido o cargo de Governador e Vice-Governador de Estado e do Distrito Federal e de Prefeito e Vice-Prefeito por infringência a dispositivo da Constituição Estadual, da Lei Orgânica do Distrito Federal ou da Lei Orgânica do Município, durante o período remanescente do mandato perdido e pelo prazo de 8 (oito) anos subseqüentes ao término do mandato para o qual tenham sido eleitos; III - os que tenham contra sua pessoa representação julgada procedente pela Justiça Eleitoral, em decisão transitada em julgado ou proferida por órgão colegiado, em processo de apuração de abuso do poder econômico ou político, durante o período do mandato da eleição na qual concorrem ou tenham sido diplomados, bem como nos 8 (oito) anos seguintes; IV - os que tenham sido condenados, em decisão transitada em julgado ou proferida por órgão judicial colegiado, desde a condenação até o transcurso do prazo de 8 (oito) anos após o cumprimento da pena, pelos crimes: a) contra a economia popular, a fé pública, a administração pública e o patrimônio público; b) contra o patrimônio privado, o sistema financeiro, o mercado de capitais e os previstos na lei que regula a falência; c) contra o meio ambiente e a saúde pública; d) eleitorais, para os quais a lei comine pena privativa de liberdade; e) de abuso de autoridade, nos casos em que houver condenação à perda do cargo ou à inabilitação para o exercício de função pública; f) de lavagem ou ocultação de bens, direitos e valores; g) de tráfico de entorpecentes e drogas afins, racismo, tortura, terrorismo e hediondos; $h$ ) de redução à condição análoga à de escravo; i) contra a vida e a dignidade sexual; e j) praticados por organização criminosa, quadrilha ou bando; V - os que tenham sido declarados indignos do oficialato ou com ele incompatíveis, pelo prazo de 8 (oito) anos; VI - os que tiverem suas contas relativas ao exercício de cargos ou funções públicas rejeitadas por irregularidade insanável que configure ato doloso de improbidade administrativa, por decisão irrecorrível do órgão competente, salvo se esta houver sido suspensa ou anulada pelo Poder Judiciário, nos 8
} 
Trata-se de medida moralizadora, voltada à satisfatória e efetiva observância dos princípios constitucionais regentes da atividade administrativa lato sensu, e a ser observada, portanto, por todos aqueles que de alguma forma interajam com o interesse e as receitas públicas.

\subsection{Gestão privada de recursos públicos}

O repasse de valores integrantes do Fumcad às entidades sem fins lucrativos por meio dos convênios configura, conforme já sinalizado, gestão privada de recursos públicos - a qual se desenvolve em um contexto maior, de cogestão da atividade fomentada, cuja execução direta fica a cargo da entidade.

(oito) anos seguintes ao da rejeição, contados a partir da data da decisão, aplicando-se o disposto no inciso II do artigo 71 da Constituição Federal a todos os ordenadores de despesa, sem exclusão de mandatários que houverem agido nessa condição; VII - os detentores de cargo na administração pública direta, indireta ou fundacional, que beneficiarem a si ou a terceiros, pelo abuso do poder econômico ou político, que tenham sido condenados em decisão transitada em julgado ou proferida por órgão judicial colegiado, nos 8 (oito) anos seguintes ao da condenação; VIII - os que hajam exercido cargo ou função de direção, administração ou representação, em estabelecimentos de crédito, financiamento ou seguro, que tenham sido ou estejam sendo objeto de processo de liquidação judicial ou extrajudicial, nos 12 (doze) meses anteriores à respectiva decretação, enquanto não forem exonerados de qualquer responsabilidade; IX - os que tenham sido condenados, em decisão transitada em julgado ou proferida por órgão colegiado da Justiça Eleitoral, por corrupção eleitoral, por captação ilícita de sufrágio, por doação, captação ou gastos ilícitos de recursos de campanha ou por conduta vedada aos agentes públicos em campanhas eleitorais que impliquem cassação do registro ou do diploma, pelo prazo de 8 (oito) anos a contar da condenação; X - os que tenham renunciado aos mandatos de Presidente da República, Governador de Estado e do Distrito Federal, Prefeito, Senador, Deputado Federal, Estadual e Distrital e Vereador, nas hipóteses em que haja sido oferecida representação ou petição capaz de autorizar a abertura de processo por infringência a dispositivo da Constituição Federal, da Constituição Estadual, da Lei Orgânica do Distrito Federal ou da Lei Orgânica do Município, durante o período remanescente ao do mandato ao qual hajam renunciado e nos 8 (oito) anos subsequentes ao término da legislatura; XI - os que tenham sido condenados à suspensão dos direitos políticos, em decisão transitada em julgado ou proferida por órgão judicial colegiado, por ato doloso de improbidade administrativa que importe lesão ao patrimônio público e enriquecimento ilícito, desde a condenação ou o trânsito em julgado até o transcurso do prazo de 8 (oito) anos após o cumprimento da pena; XII - os que tenham sido excluídos do exercício da profissão, por decisão sancionatória do órgão profissional competente, em decorrência de infração ético-profissional, pelo prazo de 8 (oito) anos, salvo se o ato houver sido anulado ou suspenso pelo Poder Judiciário; XIII - os que tenham sido condenados, em decisão transitada em julgado ou proferida por órgão judicial colegiado, em razão de terem desfeito ou simulado desfazer vínculo conjugal ou de união estável para evitar caracterização de inelegibilidade, pelo prazo de 8 (oito) anos após a decisão que reconhecer a fraude; XIV - os que tenham sido demitidos do serviço público em decorrência de processo administrativo ou judicial, pelo prazo de 8 (oito) anos, contado da decisão, salvo se o ato houver sido suspenso ou anulado pelo Poder Judiciário; XV - a pessoa física e os dirigentes de pessoas jurídicas responsáveis por doações eleitorais tidas por ilegais por decisão transitada em julgado ou proferida por órgão colegiado da Justiça Eleitoral, pelo prazo de 8 (oito) anos após a decisão; e XVI - os magistrados e os membros do Ministério Público que forem aposentados compulsoriamente por decisão sancionatória, que tenham perdido o cargo por sentença ou que tenham pedido exoneração ou aposentadoria voluntária na pendência de processo administrativo disciplinar, pelo prazo de 8 (oito) anos. Parágrafo único. A vedação de que trata o inciso IV deste artigo não se aplica aos crimes culposos e àqueles definidos em lei como de menor potencial ofensivo, nem aos crimes de ação penal privada." 
Sua execução direta fica a cargo da entidade, sendo sua fiscalização, controle e acompanhamento atribuições do parceiro público - no caso, o próprio Conselho, que para tanto se servirá, inclusive, do aparato técnico e administrativo da Pasta à qual relacionado (no caso, a Secretaria Municipal de Participação e Parceria).

$\mathrm{O}$ perfeito delineamento das ações a serem desenvolvidas, dos expedientes empregados e o respectivo cronograma, tanto físico quanto financeiro, por sua vez, são incumbências conjuntas, desenvolvidas a partir do diálogo e construção de ambos os parceiros.

O que no momento mais de perto nos interessa são as questões atinentes - e decorrentes - do repasse de valores e sua destinação, pelo parceiro destinatário direto do convênio - o qual pode ser, conforme já asseverado, tanto de origem pública como privada.

Tal análise deve partir do regime jurídico a que se sujeitam as parcerias e as entidades beneficiárias, enquanto tais - sobre os quais lançaremos nosso olhar no item que segue.

\subsubsection{Regime jurídico ${ }^{340}$}

A discussão ora colocada apresenta, conforme anunciado, dois enfoques básicos: a) o relativo às entidades parceiras de Direito Privado; ${ }^{341}$ b) o relacionado às parcerias propriamente ditas.

Quanto ao primeiro, dois aspectos convivem em cenários aparentemente paradoxais e determinantes de regimes antagônicos: enquanto a natureza privada desses partícipes seria em princípio anunciante da incidência também do regime de Direito Privado (marcado pela liberdade mais ampla, restrita tão somente por dispositivos expressos e específicos), a natureza da receita que lhes dá sustentação seria indiciária do regime de Direito Público, com todas as suas restrições, formalidades e rigor inerentes.

A discussão gravita, pois, em torno de como conciliar — e dosar — esses dois aspectos, de forma que as condições não sejam tão liberais a ponto de permitir a

\footnotetext{
340 "O direito administrativo rege direitos e interesses sociais. O civil ou privado, direitos e interesses privados. $\mathrm{O}$ direito administrativo versa em geral sobre interesses de ordem pública. $\mathrm{O}$ civil ou privado sobre títulos, convenções e provas autênticas. O primeiro presta-se a considerações de equidade e utilidade pública; o segundo atende somente às regras positivas de justiça e ao rigor do direito.” (URUGUAI, 2002, p. 104).

${ }^{341}$ Com relação às parceiras de natureza pública, muito mais singela a solução: uma vez que ambos os envolvidos, tanto convenente quanto concedente, são sujeitos ao mesmo regime jurídico obrigatório e geral de Direito Público, este é que deverá prevalecer, sem quaisquer atenuações ou modulações.
} 
apropriação de receitas públicas, o descompromisso com a seriedade e a rigidez que a aplicação desses valores exige, nem tão estritas que descambem para a formalidade, o controle e a burocracia tais que comprometam a eficiência ou, pior, inviabilizem a parceria como um todo e, assim, o atendimento ao interesse público.

Trata-se de terreno espinhoso, em que vários posicionamentos convivem.

Há os que defendem a incidência predominante das regras públicas, dentre as quais se insere, inclusive, a exigência de licitação, da qual se tratará especificamente mais adiante.

Outros se manifestam pela relativização das normas publicísticas, de modo que a liberdade, a elasticidade e a agilidade sejam preservadas e enfatizadas, com vista a possibilitar o atendimento mais satisfatório possível da eficiência.

Poderia se vislumbrar, a partir de um olhar mais desavisado, um suposto embate entre a legalidade e a eficiência - embate este que não resiste a uma análise mais profunda e abalizada, conforme explicitado no capítulo 1.

Defende aquela primeira postura, mais estrita, Paulo Modesto:

Hoje o direito administrativo brasileiro permanece fortemente referido ao exercício da função administrativa, nos aspectos objetivo, subjetivo e instrumental, mas também é aplicado a entidades privadas que não realizam função administrativa, não são delegadas do Estado, nem manifestam poderes públicos, mas que firmam voluntariamente com o Poder Público vínculos de parceria e fomento essenciais ao desenvolvimento da própria coletividade e à realização da justiça social, pois viabilizam a concretização de direitos fundamentais. [...] Aplica-se a entidades privadas que não exercitam prerrogativas públicas, nem integram o aparato do Estado, mas que estão sujeitas a deveres públicos, por manejarem recursos de fomento do Estado vinculados a atividades socialmente relevantes. Para essas entidades o direito administrativo pode e deve ser invocado parcialmente pela expressiva presença do interesse público, seja pelo fato de atividade referida encerrar a aplicação vinculada de recursos públicos, seja pela notória relevância pública da atividade desenvolvida ou ainda por manter a atividade estreitos vínculos com a proteção de direitos fundamentais do cidadão e com deveres de garantia do próprio Estado. (MODESTO, 2011, p. 26-27).

\footnotetext{
Nesse mesmo sentido o Acórdão n. 1.070/2003, prolatado pelo Plenário do TCU, ${ }^{342}$
}

342 “Levantamento de Auditoria. Convênio. Irregularidades. Licitação em desacordo com a Lei 8.666/93. Audiência. Acolhimento das razões de justificativa em razão da existência de norma específica que ampara o procedimento adotado. Licitação realizada por particular para a aplicação de recursos oriundos de convênio. Aplicação de procedimento análogo ao do Estatuto. Considerações. Impossibilidade. Art. 37, inciso XXI, exige lei específica na sua regulamentação. Licitação nos termos da Lei 8.666/93. Obrigatoriedade, ainda que 
No outro extremo, defende Oliveira a manutenção preponderante das marcas de liberdade típicas da esfera privada - salvo previsão expressa em lei formal (OLIVEIRA, 2007, p. 229-247).

As duas correntes têm em comum o fato de reconhecerem que, em alguma medida, o regime predominante deve conviver com o outro, que se manifestaria, então, de maneira recessiva.

Tal constatação - a qual implica em alto grau de fluidez e inexatidão decorrentes da não determinação de um regime jurídico em sua inteireza, mas apenas indicativo de uma sistemática predominante — justifica a abordagem nominal de aspectos tradutores de maiores polêmicas.

A solução dependerá da matização a ser realizada quanto às normas de Direito Público - cuja incidência, e em que dimensão, será discutida nos tópicos a seguir.

Antes, porém, vale tecer a ressalva de que, no que toca ao regime jurídico, e tendo em vista a natureza privada das entidades, as ponderações estarão adstritas à sua atuação enquanto parceiras da Administração, enquanto mobilizadas em razão de um objeto específico na condição de convenentes.

No mais, o Direito Privado é soberano: trata-se de seu regime original, básico, que somente pode ser derrogado em condições especiais, assumidas justamente pelo ingresso na relação de parceria.

Nada impede que uma entidade parceira dispense uma espécie relacionamento com a sociedade, no exercício rotineiro de suas atividades, marcada por valores típicos da esfera privada.

Tal regime somente não poderá ser tolerado quanto às atividades desempenhadas no âmbito do convênio, custeadas com as receitas do Fumcad.

\subsubsection{Obrigatoriedade de licitação?}

Tomemos a necessidade — ou não — de observância, pelo parceiro privado, das

convenente particular. [...] 4. No entanto, o particular, ao firmar convênio com a administração pública, assume todos os deveres e obrigações de qualquer gestor público, estando, como este, sujeito aos princípios da legalidade, da impessoalidade, da moralidade e dos demais princípios informadores da gestão da coisa pública, dentre os quais destacamos o da licitação e o do dever de prestar contas, insculpidos no art. 37 , inciso XXI, e art. 70, parágrafo único, da Constituição Federal, respectivamente.” 
regras veiculadas pela Lei federal n. 8.666/93 e pela legislação pertinente ao pregão. ${ }^{343}$

A hipótese aqui tratada não se confunde com aquela analisada anteriormente, de escolha da entidade parceira; o que ora se analisa é o regime de execução do convênio, a forma de relacionamento da entidade convenente com terceiros cuja mobilização seja imprescindível à efetivação do objeto acordado.

Quanto a este aspecto, esclarecemos que a noção empregada ao termo "licitação" é, para a finalidade ora tomada, correspondente ao procedimento ditado pela Lei federal $\mathrm{n}$. 8.666/93, em todas as modalidades ali referidas, à qual se soma o pregão. ${ }^{344}$

Trata-se de procedimento específico, marcado por regras próprias e por formalidades procedimentais ínsitas e legalmente fixadas.

Ubiratan Aguiar, Ana Cláudia Martins, Paulo Roberto Martins e Pedro Tadeu Silva (AGUIAR et. al, 2005, p. 31) defendem sua obrigatória observância pelos parceiros $\operatorname{privados}^{345}$ : "Recebidos os recursos, o gestor do convênio deve proceder ao exame do procedimento licitatório a ser adotado, devendo, no caso, observar a Lei n. 8.666/93 ou a Lei n. 10.520/02".

Não tecem os partidários desse posicionamento qualquer ressalva quanto às regras de caráter geral e especial — o que pode potencialmente resultar em situação de subversão da lógica do sistema, decorrente do fato de nos contratos administrativos stricto

${ }^{343}$ Lei federal n. 10.520/2002, regulamentada pelos Decretos n. 5.450/2005 e n. 3.555/2000. Na esfera municipal, Lei n. 13.278/2002 e Decretos n. 43.406/2003, n. 44.279/2003, n. 46.662/2003, com posteriores alterações.

${ }^{344}$ Conforme lição de Violin, "A licitação é o gênero que se subdivide em várias modalidades, entre elas a concorrência, a tomada de preços, o convite, o concurso e o leilão, conforme a Lei 8.666/93, assim como a nova modalidade pregão, nos termos da Lei 10.520/2002." (VIOLIN, 2010, p. 225).

${ }^{345}$ Vale referir o Decreto federal n. 5.504/2005, que "estabelece a exigência de utilização do pregão, preferencialmente na forma eletrônica, para entes públicos ou privados, nas contratações de bens e serviços comuns, realizadas em decorrência de transferências voluntárias de recursos públicos da União, decorrentes de convênios ou instrumentos congêneres, ou consórcios públicos." Referido diploma foi duramente criticado pela doutrina, que o inquinou, inclusive, de inconstitucional: "Embora seja louvável a iniciativa do governo federal, entendemos que o decreto ora enfocado é ilegal, por diversos aspectos, e jamais poderia instituir validamente a obrigatoriedade de licitar [...], em relação às contratações de bens e serviços com recursos financeiros federais derivados dos termos de parceria eventualmente firmados com o Poder Público. O Dec. 5.504/05 afronta o inc. XXVII do art. 22 e o inc. XXI do art. 37, ambos da Constituição da República. Os dois preceitos constitucionais são de clareza solar quando estipulam como destinatários da obrigatoriedade de licitar os órgãos e entidades da Administração Pública direta e indireta." (OLIVEIRA, 2007, p. 37). Entendemos que esse diploma foi revogado pelo Decreto federal n. 6.170/07, cujo artigo 11 tem a seguinte redação: "Art. 11. Para efeito do disposto no art. 116 da Lei 8.666, de 21 de junho de 1993, a aquisição de produtos e a contratação de serviços com recursos da União transferidos a entidades privadas sem fins lucrativos deverão observar os princípios da impessoalidade, moralidade e economicidade, sendo necessária, no mínimo, a realização de cotação prévia de preços no mercado antes da celebração do contrato." Não foi esse, porém, o entendimento do TCU, em decisão prolatada em 08 maio 2012, Acórdão n. 3153/2012, 2. ${ }^{a}$ Câm., TC 020.217/007-3, rel. Min. José Jorge: “A aquisição de bens ou de serviços comuns por Organização Social, efetuada com recursos federais transferidos por meio de contrato de gestão, demanda a utilização de pregão, preferencialmente na sua forma eletrônica, conforme estipula o art. $1^{\circ}$, caput e $\S \S 1^{\circ}$ e $5^{\circ}$, do Decreto 5.504/05." 
sensu a competição ser real, os princípios da isonomia e impessoalidade incidirem mais gravemente, vez que o seu comprometimento pode acarretar - mais que a mobilização de uma entidade ao invés de outra, mas sempre em prol do interesse público - o lucro de um, a satisfação de um interesse particular em detrimento de outro - e do próprio interesse público.

Em outras palavras, o nível de formalidade precedente aos contratos administrativos é expressivamente maior que aquele preparatório dos convênios.

É real o risco de um contrato assinado com o particular em detrimento de outro gerar dano ao erário e ao interesse público - enquanto que a preterição, no âmbito dos convênios, se estabelecerá sempre entre maneiras alternativas de atendimento aos interesses públicos.

Além disso, em se falando em contrato administrativo, os contratantes são necessariamente entes públicos, seja da Administração direta, seja indireta.

Nas situações ora abordadas, os contratantes são entes privados, tipicamente sujeitos, portanto, e em princípio, ao regime de Direito Privado.

No cenário com maior risco latente (contratos stricto sensu), desenvolvem-se grandes discussões quanto às normas vinculantes somente da esfera federal e aquelas incidentes sobre todas as outras.

No que toca aos convênios, e às contratações dele decorrentes, os defensores da necessidade de licitação — seja nas modalidades tradicionais, seja no pregão — não cogitam de uma modulação em razão dos entes destinatários e a natureza das normas.

Levam, dessa forma, a que a Lei federal de licitações incidiria em sua inteireza, inclusive com relação às regras excluídas da noção de "normas gerais" e, portanto, afastadas salvo reprodução fiel pelas demais esferas administrativas, nos contratos administrativos formalizados com entes estaduais e municipais.

Tal situação poderia levar a que, na prática, e caso acolhida a tese da obrigatoriedade de licitação, as entidades convenentes de Direito Privado se sujeitassem a regime formalmente mais rígido que os próprios entes públicos contratantes, bastando para tanto que as suas respectivas legislações de licitações (dos estados e municípios) fossem mais brandas que as regras especiais da Lei n. 8.666/93.

Os defensores da inviabilidade da imposição licitação aos entes do Terceiro Setor, por outro lado, repousam suas opiniões, em linhas gerais, em dois argumentos: a) 
inexistência de norma legal específica, com alegada ofensa ao princípio da legalidade; ${ }^{346}$ b) inviabilidade material de as entidades privadas cumprirem esse requisito, sob pena de comprometimento do convênio e, assim, dos próprios resultados esperados:

Examinando-se o direito vigente é inevitável concluir que as entidades privadas sem fins lucrativos, realizadoras de atividades de relevância pública, não estão submetias ao dever de licitar para o dispêndio de recursos recebidos em transferência, mas apenas a outros constrangimentos jurídicos. Não há lei que imponha este dever a particulares [...]. (SOUZA, 2011, p. 135).

Conforme restou evidenciado neste trabalho, entidades privadas não lucrativas, ainda que parceiras do Poder Público em decorrência de acordos administrativos com ele firmados, não passam a integrar a organização administrativa. Com o Poder Público tais entidades detêm um vínculo consensual, e não um vínculo orgânico, como, por exemplo, ocorre com as entidades descentralizadas que compõem a Administração indireta. Mais do que isso, para ser destinatária da obrigação constitucional de licitar, a premissa técnico-jurídica é que a entidade detenha com a Administração um vínculo de natureza orgânica, o que, com efeito, não ocorre com as entidades privadas sem fins lucrativos componentes do Terceiro Setor. (OLIVEIRA, 2007, p. 37).

Quanto à inviabilidade técnica, tem-se que a complexidade das normas de licitação vigentes muitas vezes inviabiliza seu satisfatório atendimento até mesmo pelas entidades públicas, em tese adequadas e equipadas para tanto. ${ }^{347}$

Nesse cenário, em que as próprias destinatárias primeiras dessas regras encontram essa dificuldade, realmente questionável se exigir que as entidades do Terceiro Setor, usualmente marcadas pela carência de estrutura burocrático-organizacional, ${ }^{348}$ sejam a ela também submetidas.

Concordamos com o posicionamento dos que defendem, como alternativa compatível com a sistemática constitucional disciplinadora da atuação administrativa - e, por extensão, da aplicação de recursos públicos — o desenvolvimento de procedimentos

\footnotetext{
${ }^{346}$ Nas palavras de Souza, “[...] nenhuma das citadas leis manda licitar (ao menos explicitamente nenhuma o faz), mas há regulamentos que prevêem a faculdade de instauração de algum processo de seleção apelidado ora de 'concurso de projetos', ora de 'chamamento público', cada qual com suas peculiaridades." (SOUZA, 2011, p. 113).

${ }^{347}$ Como pontua Di Pietro, “A Constituição de 1988 exagerou nos formalismos impostos à Administração Pública, em especial à Administração Indireta, que recebeu tratamento praticamente igual ao da Administração Direta.” (DI PIETRO, 2011 p. 300).

${ }^{348}$ Conforme lembra Modesto, "no famoso estudo A administração ao ritmo da economia da sociedade, Martín Bullinger defendeu que a administração pública não segue em geral o princípio da celeridade, mas o princípio do detalhismo. A lei exige do administrador público que examine com cautela e minúcia a situação fática e legal, os interesses envolvidos e ouça, antes de decidir, sempre que possível, os interessados e os que possam ser afetados por sua atuação. Por isso, segundo o autor, há uma defasagem estrutural entre o ritmo da sociedade e o ritmo da Administração Pública.” (MODESTO, 2010, p. 21).
} 
próprios, simplificados (com relação à Lei federal n. 8.666/93), ${ }^{349}$ por meio dos quais se assegure a isonomia, a impessoalidade, a economia, a moralidade e a eficiência das contratações. $^{350,351}$

Temos que, demonstrados o atendimento à isonomia, a razoabilidade dos preços contratados, a economicidade no dispêndio do dinheiro público, a escolha dos fornecedores a partir de critérios técnicos objetivos, transparentes e norteados pela eficiência, nenhum vício poderá ser imputado às convenentes.

Passemos a um outro aspecto, também fonte de celeumas: a contratação de pessoal, pelas entidades convenentes, com vista ao desempenho das atividades objeto do convênio.

\subsubsection{Contratação de pessoal}

Neste particular, assim como no tópico anterior, a discussão com relação a convênios público-públicos não tem pertinência, haja vista a identidade de regimes jurídicos entre ambos os parceiros. Centremo-nos, pois, nas entidades privadas sem fins lucrativos.

Enquanto os entes públicos se sujeitam a um regime específico de contratação e relacionamento com os seus agentes, determinante de regras com fortes repercussões financeiras e orçamentárias, a iniciativa privada tem como premissa básica a liberdade para contratar e desligar, observada a legislação de cunho trabalhista pertinente.

Os embaraços surgem quando as receitas públicas, sujeitas ao referido regime específico, são direcionados, por entidades privadas, à contratação de pessoal apto a desempenhar as atividades de interesse público objeto do convênio.

\footnotetext{
${ }^{349}$ Conforme lição de Violin, "o chamamento público não seria uma licitação, com todos os procedimentos, regras, prazos fixados em lei, mas uma forma de garantir os atendimentos aos princípios constitucionais [...]." (VIOLIN, 2010, p. 342).

350 "As normas para seleção prévia aos contratos a serem firmados pelo Terceiro Setor com o uso de recursos públicos devem ser estabelecidas em regulamentos próprios. Estes regulamentos podem prever mecanismos simplificados e céleres de seleção, contanto que tenham conteúdo compatível com os princípios aplicáveis a estas entidades responsáveis pelo uso do dinheiro público. Não se exige, portanto, que os regulamentos próprios das entidades repitam as normas da lei de licitações. Dentro da moldura constitucional há espaço para inovações, sem que haja vinculação expressa a procedimentos formais da Lei 8.666/93." (SANTOS, 2007, p. 303).

351 "Em primeiro plano, é preciso consignar que para a escolha da entidade parceira, [...] é necessária a realização de procedimento público de escolha. Tal necessidade decorre dos princípios gerais da igualdade e da impessoalidade, os quais detêm, na hipótese, densidade normativa ampliada pelo princípio setorial da licitação. É importante ressaltar, contudo, que o processo de escolha da entidade não deve, obrigatoriamente, seguir o procedimento previsto pela Lei Geral de Licitações e Contratos, a Lei n. 8.666/93." (MÂNICA, 2010, p. 166-167).
} 
Os desdobramentos dessa situação repercutem de forma bastante séria no que pertine ao momento de encerramento ao convênio, quando a entidade pode se ver com um quadro inflado, incompatível com as suas demandas usuais, e desprovida dos repasses até então efetuados para custeá-lo.

Inviável, nesse ponto, o custeio, com valores repassados pelo concedente, do pagamento de salário dos empregados usuais da entidade, que compõem a sua estrutura o que não impede, como veremos adiante, a sua consideração a título de contrapartida:

[...] os órgãos aplicadores da referida legislação, dos quais se pode destacar os órgãos gestores de programas, bem como o TCU, não permitem que se remunere, por meio de convênios, empregados da própria entidade convenente, que mantêm com esta vínculo permanente, em conformidade com a Consolidação das Leis Trabalhistas (CLT). Embora não haja previsão legal que institua o referido impedimento, temse admitido, tão-somente, a contratação temporária de serviços de terceiros que não possuam vínculo trabalhista com a entidade. (SALINAS, 2010, p. 120-121).

Considerado esse cenário, de se perquirir quanto à possibilidade de as entidades convenentes efetivamente contratarem pessoal com vista unicamente ao regular desempenho das atividades conveniadas.

Em se admitindo essa possibilidade, claro restará que não estava ela, no momento da formalização do convênio, aparelhada para o desenvolvimento das ações implicadas na parceria.

Diante desse cenário, muitos defendem a inviabilidade de aperfeiçoamento do próprio convênio, vez que somente seria dado à Administração parceirizar com aqueles que tivessem plenas condições de desempenho do acordado: "Ora, o pressuposto é de que os quadros de pessoal da entidade serão utilizados na consecução do objeto, sem a necessidade de remuneração extra com os recursos do convênio. As despesas realizadas com esses colaboradores não podem sequer ser utilizadas como contrapartida." (AGUIAR et al., 2005, p. 46).

Defendemos que tal postura deve ser vista com reserva: não se nos afigura razoável exigir que as entidades disponham, no momento do conveniamento, de pessoal ocioso, pronto e aguardando a virtual formalização da parceria.

Uma vez que o convênio implica o aumento nas demandas e na capacidade de atuação da entidade, entendemos possível a contratação de pessoal para fazer frente a tais exigências. 
No que tange especificamente aos convênios custeados a partir do Fumcad, há ainda um outro elemento favorável a esse posicionamento que não deve ser olvidado: a exigência de prévio registro da entidade junto ao Conselho é requisito essencial para sua participação no processo de seleção de projetos - e faz pressupor, desde logo, uma seriedade quanto a sua existência e efetivo funcionamento.

Na lição de Liberati e Cyrino:

As entidades de atendimento irão compor a rede de serviços do Município. O Conselho, por sua vez, é um órgão do Poder Público, com funções constitucionais e legais de, também, controlar as ações em todos os níveis. Ora, antes de controlar as ações é necessário que se controlem as entidades que irão promover as ações. Significa controlar sua existência legal. Por imposição estatutária, as entidades nãogovernamentais somente poderão funcionar depois de registradas no Conselho Municipal. A Lei 8.069/90 estabeleceu as condições mínimas para a autorização e funcionamento dessas entidades. Sendo exigências mínimas, pode o Conselho deliberar outras, de sua conveniência. (LIBERATI; CYRINO, 2003, p. 118).

Condicionam a concessão do registro, conforme parágrafo único do artigo 91 da Lei federal n. 8.069/90: a) a existência de instalações físicas em condições adequadas de habitabilidade, higiene, salubridade e segurança; b) a apresentação de plano de trabalho compatível com os princípios do ECA; c) a constituição regular da entidade pleiteante; d) que tenha a entidade quadro de pessoas composto por pessoas idôneas.

Necessária também a observância das posturas elencadas nos artigos $1^{\text {o }}, 352$ e $2^{\text {o353 }}$ da Resolução n. 47 CMDCA/SP e no artigo $1^{\circ}$ da Resolução n. 67 CMDCA/SP, ${ }^{354}$ além do

352 "I - executar o plano de trabalho compatível com os princípios da Lei $8.069 / 90$, fazendo constar de cada
um dos programas a porcentagem de gratuidade; II - prestar atendimento sistemático e contínuo; III - estar
regularmente constituída; IV - oferecer instalações físicas compatíveis com o regime de atendimento
proposto, em condições de habitabilidade, higiene, salubridade e segurança; V - realizar atendimento de
acordo com os programas e regimes preceituados pelo artigo 90 do ECA; VI - ter em seu quadro pessoas
idôneas; VII - apresentar a documentação exigida pelo CMDCA - São Paulo; VIII - constar das finalidades
estatuárias da entidade, o atendimento à crianças e/ou adolescentes."
353 Redaçãa dada pela Resolução 59: "I - requerimento dirigido ao Presidente do CMDCA/SP, em papel
timbrado da entidade, solicitando registro para o funcionamento e inscrição do programa ou atualização de
dados ou, ainda, segunda via do registro; II - plano de trabalho por programa, compatível com cada projeto,
em total consonância com a Lei $8.069 / 90$ - ECA; III - demonstrativo de instalação - planta física ou croqui
do local; IV - prova de constituição legal: a) certidão atualizada do registro civil de pessoa jurídica do
cartório competente; b) ata da eleição da atual diretoria; c) Cadastro Nacional de Pessoa Jurídica - CNPJ
atualizado, bem como de cada unidade a ser inscrita; d) Cadastro de Contribuinte Mobiliário - CCM, emitido
pela Secretaria Municipal de Finanças; e) Certidão Negativa de Débito junto ao INSS - CND, com validade
atualizada; f) certificado de regularidade referente ao Fundo de Garantia por Tempo de Serviço junto ao
Ministério do Trabalho; g) balanço patrimonial e financeiro dos últimos 2 anos assinado pelo contador, pelo
representante da entidade e pelo tesoureiro. V carimbo da entidade com o número do CNPJ, endereço, etc.;
VI - declaração que consigne a não remuneração da Diretoria devidamente assinada pelo Presidente da
entidade; VII - relação numérica das crianças e adolescentes atendidos por faixa etária e sexo; VIII - licença 
disposto na Resolução n. 40 CMDCA/SP, veiculadora dos "indicadores de monitoramento e fiscalização de casa de passagem/abrigo e entidades governamentais e não governamentais que prestam atendimento à criança e ao adolescente”.

Essas condicionantes denotam ao menos uma presunção da seriedade, da efetiva atuação e mesmo da existência das entidades sem fins lucrativos, o que tornaria a transferência de valores qualificada por maior segurança e poderia sustentar, como um argumento a mais, a admissão de contratação de pessoal especificamente para o desempenho do objeto do convênio: a Administração terá de antemão acessado e fiscalizado a atuação da entidade, havendo lhe outorgado registro e, assim, ainda que de maneira relativa, a avalizado.

Sustentamos, pois, que, tendo em vista tratar de entidade privada, sujeita originariamente ao Direito Privado, e somente atraída parcialmente para o campo das normas publicísticas em razão do convênio, a lógica a ser observada é a aplicação das regras privatistas ${ }^{355}$ orientadas pelos princípios da Administração.

de funcionamento e verificação da regularidade da entidade, em face da legislação pertinente à edificação e, em especial, às normas de parcelamento, de uso e ocupação do solo, de segurança, de higiene e de sossego público, expedida órgão competente do Município em certidão própria; IX - alvará do Corpo de Bombeiros; X - atestado da Secretaria da Saúde do Estado - Centro de Vigilância Sanitária, se for o caso; XI - atestado de antecedentes dos membros da diretoria; XII - comparecimento do Presidente ou seu representante legal, munido da competente procuração, para entregar a documentação e assinará declaração do CMDCA/SP. No que toca aos programas de abrigos, há ainda outros requisitos, veiculados pela Resolução 53."

354 “Artigo $1^{\circ}$ Os projetos aprovados pelo CMDCA para financiamento com recursos do Fumcad deverão ter pareceres favoráveis das Comissões Permanentes de Finanças, Políticas Públicas, Relações Institucionais, do COT e das Secretarias afins; bem como deverão ser baseados no Plano de Proteção Integral, aprovados e deliberados em reunião ordinária do CMDCA e publicados no DOM para conhecimento e providências das Secretarias afins e entidades sociais envolvidas."

${ }^{355}$ As quais já contam com os limites veiculados pelo artigo $7^{\circ}$ da CF: "São direitos dos trabalhadores urbanos e rurais, além de outros que visem à melhoria de sua condição social: I - relação de emprego protegida contra despedida arbitrária ou sem justa causa, nos termos de lei complementar, que preverá indenização compensatória, dentre outros direitos; II - seguro-desemprego, em caso de desemprego involuntário; III - fundo de garantia do tempo de serviço; IV - salário mínimo, fixado em lei, nacionalmente unificado, capaz de atender a suas necessidades vitais básicas e às de sua família com moradia, alimentação, educação, saúde, lazer, vestuário, higiene, transporte e previdência social, com reajustes periódicos que lhe preservem o poder aquisitivo, sendo vedada sua vinculação para qualquer fim; $\mathrm{V}$ - piso salarial proporcional à extensão e à complexidade do trabalho; VI - irredutibilidade do salário, salvo o disposto em convenção ou acordo coletivo; VII - garantia de salário, nunca inferior ao mínimo, para os que percebem remuneração variável; VIII - décimo terceiro salário com base na remuneração integral ou no valor da aposentadoria; IX remuneração do trabalho noturno superior à do diurno; $\mathrm{X}$ - proteção do salário na forma da lei, constituindo crime sua retenção dolosa; XI - participação nos lucros, ou resultados, desvinculada da remuneração, e, excepcionalmente, participação na gestão da empresa, conforme definido em lei; XII - salário-família pago em razão do dependente do trabalhador de baixa renda nos termos da lei; XIII - duração do trabalho normal não superior a oito horas diárias e quarenta e quatro semanais, facultada a compensação de horários e a redução da jornada, mediante acordo ou convenção coletiva de trabalho; XIV - jornada de seis horas para o trabalho realizado em turnos ininterruptos de revezamento, salvo negociação coletiva; XV - repouso semanal remunerado, preferencialmente aos domingos; XVI - remuneração do serviço extraordinário superior, no mínimo, em cinqüenta por cento à do normal; XVII - gozo de férias anuais remuneradas com, pelo menos, um terço a mais do que o salário normal; XVIII - licença à gestante, sem prejuízo do emprego e do salário, com a duração de cento e vinte dias; XIX - licença-paternidade, nos termos fixados em lei; XX - proteção do 


\section{Compartilha dessa opinião Janaína Schoenmaker:}

Não caberia exigir das entidades do terceiro setor a realização de concurso ou seleção pública para admissão de pessoal, por ser incompatível a aplicação do regime público sob esse aspecto, a despeito de obrigada a obedecer a certos princípios (publicidade, igualdade, moralidade etc.). [...] Atuar em sentido contrário seria violar a liberdade própria das entidades privadas, a ser respeitada por serem parceiras do Estado e não integrantes de sua estrutura. (SCHOENMAKER, 2011, p. 119).

Assentada essa premissa, cabe pontuar a natureza do vínculo a se estabelecer, o qual poderá ter desdobramentos inclusive quando da sua dissolução, com a virtual incidência de encargos pelos quais poderá o parceiro público vir a responder.

Nesse aspecto, imprescindível a disciplina e acompanhamento e fiscalização pelo concedente, conforme assevera Mânica:

[...] na hipótese de fomento estatal a uma atividade privada de saúde, é possível ao agente estatal incentivador estabelecer uma série de requisitos a serem preenchidos para que a atividade privada incentivada seja apta a receber o apoio estatal. Isso porque no fomento a atividade continua a ser privada (de utilidade pública) e o incentivo depende do preenchimento de requisitos pela entidade para que ela faça jus ao benefício oferecido pelo Estado. [...] Nesse contexto, é lícito à entidade administrativa fomentadora exigir determinadas condutas privadas, relacionadas, inclusive, à observância dos requisitos para a contratação de pessoal. (MÂNICA, 2010, p. 169-170).

mercado de trabalho da mulher, mediante incentivos específicos, nos termos da lei; XXI - aviso prévio proporcional ao tempo de serviço, sendo no mínimo de trinta dias, nos termos da lei; XXII - redução dos riscos inerentes ao trabalho, por meio de normas de saúde, higiene e segurança; XXIII - adicional de remuneração para as atividades penosas, insalubres ou perigosas, na forma da lei; XXIV - aposentadoria; XXV - assistência gratuita aos filhos e dependentes desde o nascimento até 5 (cinco) anos de idade em creches e pré-escolas; XXVI - reconhecimento das convenções e acordos coletivos de trabalho; XXVII proteção em face da automação, na forma da lei; XXVIII - seguro contra acidentes de trabalho, a cargo do empregador, sem excluir a indenização a que este está obrigado, quando incorrer em dolo ou culpa; XIX ação, quanto aos créditos resultantes das relações de trabalho, com prazo prescricional de cinco anos para os trabalhadores urbanos e rurais, até o limite de dois anos após a extinção do contrato de trabalho. XXX proibição de diferença de salários, de exercício de funções e de critério de admissão por motivo de sexo, idade, cor ou estado civil; XXXI - proibição de qualquer discriminação no tocante a salário e critérios de admissão do trabalhador portador de deficiência; XXXII - proibição de distinção entre trabalho manual, técnico e intelectual ou entre os profissionais respectivos; XXXIII - proibição de trabalho noturno, perigoso ou insalubre a menores de dezoito e de qualquer trabalho a menores de dezesseis anos, salvo na condição de aprendiz, a partir de quatorze anos; XXXIV - igualdade de direitos entre o trabalhador com vínculo empregatício permanente e o trabalhador avulso. Parágrafo único. São assegurados à categoria dos trabalhadores domésticos os direitos previstos nos incisos IV, VI, VIII, XV, XVII, XVIII, XIX, XXI e XXIV, bem como a sua integração à previdência social.” 
Quanto aos convênios suportados pelo Fumcad, especificamente, essa questão se torna em tese mais tranquila, em regra. Isso porque o prazo máximo de vigência de tais instrumentos é, conforme visto, de um ano, prorrogável por apenas mais um. ${ }^{356}$

Nesse cenário, a alternativa mais indicada seria a observância da sistemática estabelecida pela Lei federal n. 9.601/98, que dispõe sobre o contrato de trabalho por prazo determinado dando assim efetividade ao estabelecido no artigo $443^{357}$ da CLT.

Referido diploma foi regulamentado pelo Decreto federal n. 2.490/98, que estabelece para essas contratações o prazo máximo de dois anos - limite temporal coincidente justo com o prazo máximo de vigência dos convênios Fumcad.

Basta a entidade seguir esse regime de contratação que não terá quaisquer problemas com a eventual dispensa sem justa causa de agentes contratados por prazo indeterminado.

Excepcionalmente, porém, poderão esses convênios ultrapassar os dois anos, nos termos da autorização constante do artigo $10, \S 2^{\circ}$, do Decreto municipal n. 43.135/03 — o que traria de volta à cena a discussão quanto ao regime a ser adotado.

Nessas hipóteses, o processo de contratação e fixação de seu regime no instrumento convenial deverá ser cercado de maiores cautelas, vez que o "garante" das relações a partir daí firmadas poderá vir a ser a Administração e, portanto, o erário público. $^{358}$

\footnotetext{
${ }^{356}$ Artigos 10, § 2 $2^{\circ}$, e 11, III do Decreto municipal n. 43.135/2003.

357 "Art. 443. O contrato individual de trabalho poderá ser acordado tácita ou expressamente, verbalmente ou por escrito e por prazo determinado ou indeterminado. $\S 1^{\circ}$ Considera-se como de prazo determinado o contrato de trabalho cuja vigência dependa de termo prefixado ou da execução de serviços especificados ou ainda da realização de certo acontecimento suscetível de previsão aproximada. $\S 2^{\circ} \mathrm{O}$ contrato por prazo determinado só será válido em se tratando: a) de serviço cuja natureza ou transitoriedade justifique a predeterminação do prazo; b) de atividades empresariais de caráter transitório; c) de contrato de experiência." A obrigatória observância desse parágrafo segundo, porém, foi afastada pelo artigo $1^{\circ}$ da Lei federal $\mathrm{n}$. 9.601/98: "Art. $1^{\circ}$ As convenções e os acordos coletivos de trabalho poderão instituir contrato de trabalho por prazo determinado, de que trata o art. 443 da Consolidação das Leis do Trabalho - CLT, independentemente das condições estabelecidas em seu $\S 2^{\circ}$, em qualquer atividade desenvolvida pela empresa ou estabelecimento, para admissões que representem acréscimo no número de empregados."

${ }^{358}$ Nesse sentido decidiu, em julgamento antecipado da lide, a 10. ${ }^{\text {a }}$ Vara da Fazenda Pública do Estado de São Paulo, em sentença de que se reproduz o seguinte excerto, tanto pela novidade da discussão tema em nosso ordenamento, quanto pelo seu interesse no que pertine à questão colocada: "[...] No convênio administrativo, busca-se a realização de interesses comuns, seja entre entidades e órgãos estatais, ainda que de espécies diferentes, seja entre órgãos públicos e entidades privadas, como ocorreu no caso em questão, em que o interesse comum entre as partes radicava na realização de um programa de desenvolvimento agrário, com a aquisição do respectivo know-how. Em face desse interesse comum, cabia à autora, dentre outras obrigações, a de manter um pessoal especializado à execução dos serviços inerentes ao programa, mão de obra, contudo, que seria, toda, indicada por um órgão governamental; no caso, pelo Itesp, então integrante da estrutura administrativa da Secretaria da Justiça. A remuneração desse pessoal deveria ser e foi custeada pelos recursos do convênio. Donde se conclui que o vínculo jurídico entre as partes de um convênio continua a existir mesmo depois da extinção do convênio: as obrigações, com efeito, continuam a existir, e por seu cumprimento respondem as partes que integram o respectivo convênio, depois que esgotado a reserva do
} 
Nesse contexto, em regra, e em princípio, as relações entre a entidade convenente e as pessoas físicas contratadas para a implementação do objeto convenial revestem-se das características da pessoalidade, não eventualidade, subordinação e remuneração.

Esses quatro elementos combinados, conforme bem observa Martins (2002, p. 138), levam à configuração do vínculo empregatício.

Constatada essa situação, inviável o afastamento do regime celetista, em razão do princípio da primazia da realidade, segundo o qual, no Direito do Trabalho, "são privilegiados, portanto, os fatos, a realidade, sobre a forma ou a estrutura empregada" (MARTINS, 2002, p. 79).

A Administração deverá então estar bastante atenta, de modo a impedir eventuais burlas do regime mais garantista da CLT, com a contratação de profissionais autônomos para fazer as vezes de empregados.

Aperfeiçoada a contratação por prazo indeterminado, deverá a entidade se planejar adequadamente, de modo a provisionar os valores necessários ao custeio de futuras verbas rescisórias.

Ainda quanto à contratação de pessoal pela entidade, vale esclarecer que as despesas respectivas não se inserem dentre as computadas para fins de atendimento ao

fundo criado para o custeio do objeto do convênio. [...]. No caso em questão, comprovou a autora ter sido, depois que extinto o convênio, acionada pela Justiça do Trabalho por seus ex-empregados, contratados em função do convênio celebrado com os requeridos, e o de ter sido condenada em várias dessas ações trabalhistas, sendo certo que por força dessas condenações, está a autora a responder com seu patrimônio. Sua condição jurídico-material-processual de empregadora a obriga a assumir a condição de parte nesses processos, e de a seus efeitos submeter-se. Mas se lhe reconhece o direito de ser reembolsada do montante que em razão dessas ações trabalhistas tiver despendido, porque os efeitos patrimoniais gerados por essas condenações judiciais dizem respeito a serviços que formavam o núcleo do objeto do convênio firmado entre as partes, a como se fez referência. Assim, como validamente argumenta a autora, não importa que os efeitos patrimoniais decorrentes das condenações judiciais tenham surgido depois da extinção do convênio, porque o que é de se considerar é que se trata de despesas relacionadas com o objeto do convênio. Não é, com efeito, o momento em que surgem tais despesas, o critério a ser utilizado, mas sim o da natureza jurídica das despesas, para definir-se se elas devem ser assumidas pelas partes integrantes do convênio, ou não. A contratação de mão de obra pela autora deu-se exclusivamente em função do convênio e para atender seu objetivo. A autora não a teria contratado, se não fosse pela existência do convênio, como se pode presumir das circunstâncias retratadas na lide. É o que importa considerar, para definir que seu custeio, agora sob a forma de reembolso, é obrigação vinculada ao convênio celebrado pela autora com os requeridos, os quais, portanto, devem reembolsá-la integralmente dos gastos que ela tiver suportado em razão dessas condenações [...] As circunstâncias que dizem respeito diretamente às lides trabalhistas (por exemplo, se houve ou não houve hora extra, se houve algum conluio ou fraude processual), essas circunstâncias são estranhas à análise do vínculo jurídico entre a autora e os requeridos, considerado o convênio administrativo em que figuraram como partes. Basta, para essa análise, que se trate de uma despesa relativa ao objeto do convênio, para que, objetivamente, seja fixada a vinculação entre receita e despesa, sem qualquer outra ordem de consideração, cabendo ao fundo de receita suportar seu pagamento. [...] Reconhece-se a condição de devedores solidários dos requeridos, em razão da natureza da relação jurídico-material e do regime jurídico que se aplica ao convênio.” (Processo n. 0102129-46.2008.8.26.0053). 
artigo 19 da Lei de Responsabilidade Fiscal ${ }^{359}$ :

[...] Os gastos com pessoal das entidades privadas parceiras fomentadas ou delegatárias - não devem ser incluídos no cálculo para definição do limite com gastos com pessoal. [...] nos casos de fomento estatal a atividades privadas de saúde - o que ocorre nos casos de termos de parcerias e convênios - não restam dúvidas de que os gastos com pessoal contratado, desde que não configure mera interposição de mão de obra, não sofrem incidência da limitação prevista pelo art. 19 da Lei de Responsabilidade Fiscal. Afinal, trata-se de atividade privada incentivada, o que não se subsume à hipótese do artigo em referência. (MÂNICA, 2010, p. 171-172).

Tal conclusão decorre do fato de que o pessoal nesses moldes contratados não podem ser tomados por agentes públicos, não desenvolvendo, portanto, vínculo com a Administração concedente.

Não se qualificam, dessa forma, como despesa com pessoal, em sua acepção técnica.

Por derradeiro, existe uma outra alternativa a ser considerada, que ganha cada vez mais espaço em nossa sociedade: a mobilização de trabalhadores voluntários, que, nos termos do parágrafo único do artigo $1^{\circ}$ da Lei federal n. 9.608/98, "não gera vínculo empregatício nem obrigação de natureza trabalhista, pecuniária ou afim”.

As pessoas físicas sujeitas a essa espécie de relação podem, com base no mesmo diploma, prestar serviços junto a entidades públicas de qualquer natureza ou privadas, desde que sem fins lucrativos, sendo certo que o trabalho voluntário é compatível com todo e qualquer tipo de atividade, seja subalterna, seja de direção.

Tal vínculo é expresso por meio de um termo de adesão, do qual deverão constar o objeto e as condições do trabalho voluntário que se pretende desenvolver (artigo $2^{\circ}$ da Lei).

359 “Art. 19. Para os fins do disposto no caput do art. 169 da Constituição, a despesa total com pessoal, em cada período de apuração e em cada ente da Federação, não poderá exceder os percentuais da receita corrente líquida, a seguir discriminados: I - União: 50\% (cinquenta por cento); II - Estados: 60\% (sessenta por cento); III - Municípios: $60 \%$ (sessenta por cento). $\S 1^{\circ} \mathrm{Na}$ verificação do atendimento dos limites definidos neste artigo, não serão computadas as despesas: I - de indenização por demissão de servidores ou empregados; II relativas a incentivos à demissão voluntária; III - derivadas da aplicação do disposto no inciso II do $\S 6^{\circ}$ do art. 57 da Constituição; IV - decorrentes de decisão judicial e da competência de período anterior ao da apuração a que se refere o $\S 2^{\circ}$ do art. 18; V - com pessoal, do Distrito Federal e dos Estados do Amapá e Roraima, custeadas com recursos transferidos pela União na forma dos incisos XIII e XIV do art. 21 da Constituição e do art. 31 da Emenda Constitucional 19; VI - com inativos, ainda que por intermédio de fundo específico, custeadas por recursos provenientes: a) da arrecadação de contribuições dos segurados; b) da compensação financeira de que trata o $\S 9^{\circ}$ do art. 201 da Constituição; c) das demais receitas diretamente arrecadadas por fundo vinculado a tal finalidade, inclusive o produto da alienação de bens, direitos e ativos, bem como seu superávit financeiro. $\S 2^{\circ}$ Observado o disposto no inciso IV do $\S 1^{\circ}$, as despesas com pessoal decorrentes de sentenças judiciais serão incluídas no limite do respectivo Poder ou órgão referido no art. 20.” 
São duas as principais "vantagens" do estabelecimento desse tipo de relação: a) a possibilidade de reembolso das despesas efetuadas para o desenvolvimento da atividade voluntária; b) a prevenção quanto a futuras eventuais ações trabalhistas.

Nesse campo, ganham relevância as ações de voluntariado empresarial, nos termos expostos por Barbosa:

[...] o programa de voluntariado empresarial propriamente dito consiste no apoio formal e organizado de uma empresa a empregados que desejam servir uma comunidade, voluntariamente, com o seu tempo e habilidades - podendo incluir familiares dos funcionários e aposentados. [...] o investimento em programas de voluntariado tem, segundo estudos no exterior, um excedente retorno, pois estes melhoram a imagem da empresa, favorecem o ambiente interno, motivas os empregados e ajudam em seu desenvolvimento pessoal e profissional. (BARBOSA, 2007, p. $155)$.

\subsubsection{A contrapartida}

Conforme desenvolvido no item 1.6, supra, a concessão de subvenções por meio de convênios, no exercício da atividade administrativa do fomento, não é incompatível com a oferta, pelo concedente, de contribuição concreta, voltada à consecução do objetivo final da parceria.

A oferta de bens, valores ou recursos (humanos ou materiais) constitui, em verdade, requisito fundamental dos convênios: por meio dela se concretiza a união de esforços, a mobilização conjunta entre ambos os partícipes:

No âmbito dos programas de fomento, contudo, parece razoável entendêla como elemento obrigatório dos convênios administrativos colaborativos. $\mathrm{O}$ fomento público volta-se a estimular o desenvolvimento de atividades de interesse público e não ao custeio das atividades beneficiárias dos programas. Por essa razão, deve-se não só aferir a capacidade financeira das entidades convenentes, [...] mas também exigir correspondente contrapartida, proporcional à capacidade financeira da convenente. (LIMA, 2001, p. 122).

Essa assertiva consta expressamente da Lei de Responsabilidade Fiscal, que determina, em seu artigo 25, parágrafo $1^{\circ}$, IV, “d”:

Art. 25. Para efeito desta Lei Complementar, entende-se por transferência voluntária a entrega de recursos correntes ou de capital a outro ente da Federação, a título de cooperação, auxílio ou assistência financeira, que 
não decorra de determinação constitucional, legal ou os destinados ao Sistema Único de Saúde.

$\S 1^{\circ}$ São exigências para a realização de transferência voluntária, além das estabelecidas na lei de diretrizes orçamentárias:

[...]

IV - comprovação, por parte do beneficiário, de: [...]

d) previsão orçamentária de contrapartida

A contrapartida "consiste na parcela de gastos a ser arcada pela convenente, estabelecida de acordo com sua capacidade financeira, por meio de recursos financeiros ou bens e serviços economicamente mensuráveis." (ALMEIDA, 2008, p. 105). ${ }^{360}$

Com relação a quais são as atividades, valores, bens e serviços admitidos como tais, alguns autores defendem a inviabilidade de admissão das despesas de manutenção da entidade, vez que tais despesas necessariamente incorreriam, independentemente da formalização do convênio com ente público, dele não decorrendo ou apresentando qualquer liame.

Seguem essa tendência, ainda que com algumas concessões, Aguiar, Martins, Martins e Silva:

\begin{abstract}
$\mathrm{Na}$ primeira edição deste livro afirmamos que não são aceitas, como contrapartidas, valores concernentes às despesas de custeio regularmente realizadas pela entidade convenente. Essa afirmativa deriva de interpretação da finalidade da norma reguladora da matéria que, ao exigir a contrapartida, busca a cooperação também do convenente, de acordo com sua capacidade. Caso contrário, o ato consistiria em um simples repasse de recursos federais ao partícipe, quando o objetivo da norma é contar com uma contribuição efetiva das partes envolvidas na consecução do objeto. Desse modo, raras exceções, devidamente justificadas ou respaldadas na lei, despesas ordinárias de custeio do partícipe não podem ser consideradas como contrapartida. Explicando melhor: se o que se busca com a norma é um esforço extra de ambas as partes para o alcance do objeto, não pode o Governo Federal cumprir sua obrigação no acordo, repassando o recurso, e o beneficiário incorporar tal quantia como reforço para o custeio de gastos ordinários. (AGUIAR; et al., 2005, p. 29-30).
\end{abstract}

O fomento se traduz, conforme visto no capítulo 1, em estímulo às mobilizações de interesse coletivo - o qual se direciona às atividades, e não diretamente ao seu executor, no caso, convenente.

\footnotetext{
${ }^{360}$ ALMEIDA, Guilherme Henrique de la Rocque. Controle das transferências financeiras da União. Belo Horizonte: Fórum, 2008, p. 105, apud LIMA, 2010, p. 122.
} 
Essa premissa não exclui, porém, que, uma vez desaparecida a entidade fomentada, restarão comprometidas, também, as suas atividades - ficando o fomento sem destinatário.

Ainda que restem outras entidades capazes de executar as ações privadas de interesse público, essa é uma tendência que pode vir a comprometer, a longo prazo, a lógica do Estado fomentador — e a própria sustentabilidade social: se todas essas atividades tivessem que ser absorvidas pelo aparato estatal, o sistema de amparo e proteção à criança e adolescente entraria em colapso, pois a parcela oferecida a título de contrapartida teria então que ser disponibilizada também pelo Estado.

A postura fomentadora pressupõe um tratamento diferenciado, um auxílio, enfim, um estímulo concreto para os que voluntariamente optam por mobilizar seus esforços em prol do coletivo prosperem - pois com eles prosperará, também, o atendimento aos interesses tidos como dignos de apoio pelo Conselho (ou da Administração em geral, em hipóteses outras).

Compartilha dessa visão Salinas, que nenhuma restrição faz à possibilidade de oferta, a título de contrapartida, das despesas de custeio da entidade ${ }^{361}$ :

[...] despesas operacionais da entidade, como telefone, luz, internet e outros acabam, ainda que sem previsão legal, sendo abrangidos no conceito de taxa de administração pelos gestores dos recursos públicos, de modo que aquelas não podem igualmente ser custeadas com os recursos públicos transferidos com o convênio. Tais despesas, no entanto, poderão configurar a própria contrapartida da convenente para a realização do objeto ajustado. (SALINAS, 2008, p. 120).

Repisemos que contrapartida deverá obrigatoriamente existir, como forma de tradução do próprio partilhar de ônus e responsabilidades.

O edital Fumcad/2012 foi explícito ao impor essa exigência em seu artigo $10 .{ }^{362}$

\footnotetext{
${ }^{361}$ A autora vai além, e defende o custeio de referidas despesas diretamente com os valores repassados por ocasião do convênio: "Duas problemáticas, no entanto, decorrem dessa proibição: (i) uma fração considerável das despesas operacionais da entidade — como telefone, luz, custos com internet, cópias reprográficas, bem como despesas com pessoal, embora não tenham caráter temporário, são aplicadas na execução do objeto do ajuste, durante o período de sua vigência; (ii) parte considerável das entidades sem fins lucrativos, sem vocação para a captação de auxílio financeiro privado, muitas vezes revelam-se impossibilitadas de arcar, por meio de recursos próprios, com despesas operacionais e custos administrativos que estariam obrigada a fornecer como contrapartida. Novamente, observa-se que a proibição ora tratada revela-se mais ajustável às parcerias público-privadas (entre União e Estados ou entre União e Municípios), em que ambos os partícipes, via de regra, possuem meios para arcar com seus custos administrativos. No tocante às parcerias entre União e entidades do terceiro setor, o referido dispositivo normativo revela-se rígido e desajustado à realidade de grande maioria das organizações não governamentais, incapazes de angariar recursos privados para sua manutenção." (SALINAS, 2008, p. 121).
} 
Entendemos, porém, que essa é exigência que, por guardar referência com a própria essência do convênio, deveria constar de normas outras, de superior hierarquia e duração mais perene e estável.

Realmente, situações comprometedoras da estabilidade jurídica poderiam advir da sua previsão meramente editalícia, como, por exemplo, a alteração dos requisitos relativos à contrapartida no ínterim entre a aprovação do projeto e a captação à iniciativa privada dos valores mínimos necessários a autorizar o conveniamento.

Entendemos essa carência de previsão normativa mais robusta, pois, ofensiva aos princípios constitucionais da eficiência e economicidade.

\subsubsection{Controle}

O controle sobre as atividades da entidade convenente - e sobre a própria relação de convênio - é fundamental não só para a legalidade, mas também para a legitimidade da atuação pública.

Não pressupõe uma postura de desconfiança quanto à parceria estabelecida, servindo a uma necessidade decorrente do próprio processo democrático, cuja regularidade implica a transparência, na responsividade, na eficiência e eficácia das ações fomentadas. $^{363}$

Apresenta como paradigmas, atualmente: a) mais que a legalidade, a juridicidade da atuação da Administração e seus parceiros; b) o destaque aos processos e procedimentos, e não mais aos atos administrativos, exclusiva e isoladamente

\footnotetext{
362 "Art. 10. Constitui ainda condição para análise do projeto, bem como celebração do convênio, a oferta, pela organização governamental ou entidade proponente, de contrapartida, a qual não se confunde com o percentual referido no parágrafo $2^{\circ}$ do artigo $3^{\circ}$ do Decreto $43.135 / 03$, e que poderá assumir a forma de transferência de recursos financeiros ou de bens ou serviços, desde que economicamente mensuráveis e claramente detalhados no plano de trabalho. $\S 1^{\circ}$. Quando financeira, a contrapartida será depositada na conta bancária específica do convênio, observada sempre a evolução afinada e valores repassados pela municipalidade e ofertados pela organização social [sic], de forma que o cronograma de gastos preveja um proporcional desembolso, ao longo da execução do convênio, por ambos os partícipes. § $2^{\circ}$. Quando atendida por meio de bens e serviços, a razoabilidade do valor correspondente à contrapartida deverá ser aferida por meio de pesquisa de preços de mercado, a qual necessariamente instruirá os autos do conveniamento. $\S 3^{\circ}$. A contrapartida deverá ser de no mínimo 5\% do valor total do projeto, regularmente demonstrada no momento do conveniamento, por meio, inclusive, da apresentação de recibos, notas fiscais, entre outros."

${ }^{363}$ Nas palavras de Dias, "o controle das ações da administração pública não diz respeito a pré-conceitos relacionados à desconfiança ou à certeza da ineficiência — seja da própria administração pública, seja das entidades privada sem fins lucrativos que recebem recursos financeiros do Estado -, mas integra o próprio processo democrático de legitimação e regulação das atividades estatais [...]." (DIAS, 2008b, p. 353).
} 
considerados; ${ }^{364} \mathrm{c}$ ) o enfoque sobre a gestão, sobre os resultados, e não somente sobre as formalidades e aspectos burocráticos (DIAS, 2008b, p. 353).

No cenário do século XXI o controle ganha uma nova dimensão, traduzida na noção de accountability, que, conforme afirma Vales Bento, traz "uma dimensão ativa de participação e de responsabilização" (BENTO, 2003, p. 92).

Na lição de Almeida:

O princípio da responsabilidade fiscal equivaleria ao conceito e accountability, termo de difícil precisão semântica ao ser traduzido à língua vernácula. Pode-se, contudo, enaltecer sua dimensão ética ao permitir que se conheça da gestão dos recursos não apensas por parte dos órgãos de controle, mas pela sociedade. Não se trata apenas de realizar a obra ou implantar o projeto, mas fazê-lo da melhor forma, identificando e assumindo possíveis equívocos para futura melhoria (ALMEIDA, 2011, p. 581).

A lógica da accountability requer, nas palavras de Dias, “a) especificação antecipada dos níveis de desempenho; b) autoridade para determinar como os recursos serão empregados para produzir os resultados desejados; c) um processo de avaliação para saber se os resultados foram obtidos" (DIAS, 2008b, p. 257).

Invocamos a definição de controle de Dromi, que a tem como um instrumento voltado a:

[...] analisar a legitimidade (fundamento jurídico) e a oportunidade (fundamento político) da forma (procedimento), bem como a finalidade (causa final) da atuação da autoridade, como meio de constatar a compatibilidade entre antecedente e conseqüente, entre a forma prevista e o fim proposto pelo legislador com a forma executada e a finalidade atingida pelo administrador. (DROMI, 2004, p. 36, traduzimos).

Ceneviva e Farah relatam a classificação da accountability em vertical - ligada ao controle exercido pela sociedade civil sobre os governantes e burocratas - e horizontal

\footnotetext{
364 “Ao não se ter mais como possível uma atuação unilateral e autoritária, por conta da inexistência de um interesse público previamente definido a ser tutelado, será necessário à Administração Pública identificar quais os interesses coletivos legítimos subjacentes para, então, ponderá-los no caso concreto, sendo o processo administrativo o meio adequado para que se possa proceder à identificação dos interesses públicos legítimos existentes e à ponderação desses a fim de escolher um ou alguns para atendimento no caso concreto. [...] Somente por meio de uma atuação concertada entre Administração Pública e particulares, na qual a Administração tenha, com a participação dos envolvidos, a oportunidade de identificar os interesses em jogo, ponderá-los e definir qual o prevalecente, é que se poderá desenvolver a atividade administrativa. $\mathrm{O}$ processo administrativo tem a função, então, de permitir o desenvolvimento da atividade administrativa no atual contexto do direito administrativo. É o meio pelo qual se realiza a função de arbitramento, característica da atual Administração Pública." (SCHIRATO, 2010, p. 17).
} 
— via mecanismos institucionalizados de fiscalização mútua, na forma de freios e contrapesos (CENEVIVA; FARAH, 2007, p. 136-137).

Discordam dessa classificação, sob o argumento de que o controle levado a termo por instâncias formais oficiais também se desenvolve, por vezes, em uma relação vertical, referindo-se às hipóteses de controle hierárquico.

O controle pode ser classificado com base em diversos critérios.

Quanto ao momento em que exercido, pode ser prévio, concomitante ou $a$ posteriori.

No que tange aos entes controladores, interno ou externo - incluídas aí a atuação tanto do Ministério Público, do Judiciário, dos Tribunais de Contas.

Pode se desenvolver, ainda, a partir da própria sociedade, no chamado controle social - que não se insere, conforme mais adiante veremos, na categoria do controle externo sctricto sensu.

Há também uma subdivisão baseada nos limites da atuação controladora, se de mérito ou meramente formal, burocrática.

Ainda no que se refere à natureza, pode ser a fiscalização contábil, operacional, patrimonial, financeira e orçamentária. ${ }^{365}$

Dispõe o artigo 47 da Lei Orgânica do Município de São Paulo:

Art. 47 - A fiscalização contábil, financeira, orçamentária, operacional e patrimonial do Município e das entidades da administração direta e indireta, quanto à legalidade, legitimidade, economicidade, aplicação das subvenções e renúncia de receitas, será exercida pela Câmara Municipal, mediante controle externo e pelo sistema de controle interno dos Poderes Executivo e Legislativo.

$\S 1^{\circ}$ - Prestará contas qualquer pessoa física ou jurídica, de direito público ou de direito privado, que utilize, arrecade, guarde, gerencie ou administre dinheiro, bens e valores públicos ou pelas quais o Município responda, ou que, em nome deste, assuma obrigações de natureza pecuniária.

As entidades do Terceiro Setor convenentes também estão sujeitas, portanto, ao controle, tanto interno quanto externo e social, sendo certo, porém, que a sua relação fiscalizatória se estabelecerá, direta e imediatamente, com o órgão concedente.

Somente em situações excepcionais é que se reportarão elas aos órgãos de controle externo como, por exemplo, o Tribunal de Contas.

Passemos à consideração de cada uma dessas espécies.

${ }^{365}$ Cf. SCHOENMAKER, 2011, p. 82-86. 


\subsubsection{O momento de incidência}

Iniciemos nossas ponderações sobre o controle exercido em momento anterior ao aperfeiçoamento do ato convenial propriamente dito, relacionado ao exame e aprovação dos projetos, assim como a instrução de todo o procedimento voltado à parceirização.

Nas palavras de Schoenmaker (2011, p. 137), "O controle poderá se dar antes da realização de ato ou no curso do procedimento administrativo para sua prática, por exemplo, durante certificação, qualificação, realização do certame, concurso público, chamamento público ou seleção de projetos e a própria celebração do instrumento".

Entende a autora que esse controle teria início com a apresentação do projeto ou plano de trabalho, ${ }^{366}$ visão que não se compatibiliza com o cenário ora considerado: no que tange aos convênios Fumcad, abrange ele todos os atos preparatórios à publicação do edital de chamamento público até a efetiva assinatura do convênio. ${ }^{367}$

Vale lembrar, ainda, dos atos de controle levados a termo pelo Conselho quando do registro das entidades, nos termos das diversas resoluções anteriormente referidas.

Ultrapassada essa fase, e uma vez formalizada a parceria, caberá aos órgãos responsáveis o controle concomitante, consistente, em linhas gerais, no acompanhamento e fiscalização das atividades executadas em decorrência do convênio.

Incide sobre os gastos da receita transferida e as ações disponibilizadas à sociedade - no caso, crianças e adolescentes. ${ }^{368}$

É condicionante do próprio controle a posteriori que, se exercitado de forma inaugural e isolada, poderá ter toda a sua efetividade comprometida. ${ }^{369,370}$

\footnotetext{
366 “O controle prévio incidirá quando a entidade do terceiro setor submeter seu plano de trabalho a apreciação pelo órgão gestor de recursos de determinado programa." (SCHOENMAKER, 2011, p. 139).

367 Conforme explicita LIMA, "a seleção as entidades proponentes, como base na capacidade técnicooperacional, constitui o principal mecanismo de controle prévio.” (LIMA, 2010, p. 141).

368 "O controle concomitante envolve acompanhamento e fiscalização da execução do convênio administrativo colaborativo. Entre os instrumentos, citem-se: instituição de procedimentos prévios à realização de despesas com recursos públicos repassados por meio do convênio; constante acompanhamento da execução do convênio pelos agentes da concedente; e as prestações de contas parciais, quando aplicáveis." (LIMA, 2010, p. 141-142).

369 "O controle concomitante é realizado durante a execução do instrumento de parceria, a partir do ato de sua celebração. Face às inúmeras malversações, o TCU tem proposto a ampliação do controle concomitante das parcerias sob pena de ineficácia do controle realizado a posteriori." (SCHOENMAKER, 2011, p. 154).

${ }^{370} \mathrm{Na}$ lição de Salinas, "[...] é reservado à gestão propriamente dita dos recursos públicos, quando a entidade contemplada se dedica a executar, com o uso da verba transferida, o plano de trabalho previamente aprovado pela unidade governamental responsável pelo referido repasse. Embora a entidade privada sem fins lucrativos se obrigue a agir em estrita consonância com os termos do convênio aprovado, uma série de obrigações adicionais decorrentes de instrumentos normativos [...] incidem sobre a maneira como os recursos deverão ser geridos." (SALINAS, 2008, p. 109).
} 
Um de seus mecanismos de execução básicos é a prestação de $\operatorname{contas}^{371}$ parcial, apresentada periodicamente, ao longo da relação convenial, em momentos previstos no plano de trabalho, e que se volta à análise da legalidade, da regularidade das despesas efetuadas a partir das receitas públicas, sem quaisquer ponderações ou análises quanto aos seus resultados ou efetividade (LIMA, 2010, p. 137).

A regularidade das prestações de contas parciais condiciona tanto os futuros repasses quanto a própria manutenção do convênio.

Defendemos a intensificação desse controle concomitante, de forma a não deixar que eventuais irregularidades, quanto constatadas em momento posterior, já estejam cristalizadas - e o prejuízo ao interesse público, assim, irremediavelmente instalado.

Sob essa mesma inspiração foi incluída no anteprojeto de Lei Orgânica da Administração Pública Federal a figura do termo de ajustamento de gestão, disciplinado no seu artigo 57: “Art. 57. Os órgãos de controle público podem propor a assinatura de termos de ajustamento de gestão para o efeito de afastar a aplicação de penalidades ou sanções e adequar os atos e procedimentos do órgão ou entidade controlada aos padrões de regularidade."

Mais que um enfoque repressivo, o contexto atual e o ideal de governança impõem um controle muito mais voltado ao planejamento, acompanhamento e direcionamento, com o escopo central de cuidado constante para a garantia e efetivo atendimento ao interesse coletivo de forma didática e orientadora - e não somente a aplicação de sanções. ${ }^{372}$

O controle posterior, iniciado após o encerramento do convênio, é definido por Schoenmaker nos seguintes termos:

O controle a posteriori dos convênios e contratos de repasse refere-se ao momento da demonstração, por meio da prestação de contas e apresentação de vários documentos [...] atestando: (i) a utilização dos recursos públicos e (ii) a não geração de dano ou prejuízo ao erário por

\footnotetext{
${ }^{371}$ Nas palavras de Lima, “a prestação de contas constitui-se de procedimento formal a ser realizado pela convenente, com o objetivo de demonstrar à concedente regularidade da aplicação dos recursos públicos, repassados por meio de convênios, com a legislação aplicável e o cronograma de desembolso previsto no plano de trabalho. Via de regra, as prestações de contas são instruídas com os seguintes documentos; relatório de cumprimento o objeto; declaração de realização dos objetivos do convênio; relação de bens adquiridos, quanto houver; relação de treinados ou capacitados, quando aplicável; relação dos serviços prestados, quando aplicável; e comprovante de recolhimento do saldo de recursos.” (LIMA, 2010, p. 136-137).

372 "Quanto às expectativas em relação aos papéis das cortes de contas, destacam-se, em vez de seu caráter meramente punitivo ou sancionatório, funções de: orientação, educação e prevenção; avaliação dos resultados e da efetividade das políticas governamentais; atuação pari passu, concomitante, in loco (agilidade); busca de maior eficácia no cumprimento de suas atribuições; mais transparência e maior contato com a sociedade civil." (DIAS, 2008a, p. 3.459).
} 
parte das entidades do terceiro setor. A obrigação é personalíssima, devendo o gestor responder por ela, inclusive com patrimônio pessoal. (SCHOENMAKER, 2011, p. 167)

Sua ferramenta por excelência é a prestação de contas final - ou única, caso inexistente a previsão de outra, ou outras, parciais.

No mais das vezes, incide, da mesma forma que nas prestações parciais, sobre aspectos de legalidade, não adentrando àqueles relacionados ao mérito ou aos resultados alcançados $^{373}$ — daí o usual divórcio constatado entre a realidade documental apresentada e o que de fato sucedeu.

Tal fato decorre de que, em se tratando de análise focada unicamente na apresentação de documentos comprobatórios de despesa, nasce possibilidade de utilização e emprego de elementos que não necessariamente guardam relação com o acordo:

Como o controle da execução física e financeira dos projetos é, pelas razões já expostas, muito deficitário, a análise da prestação de contas final revela-se ainda mais inefetiva. É comum, nesta seara, que os convenentes apresentem notas referentes a compras e serviços que não realizaram, mas que o órgão repassador jamais terá como ser certificar, já que falhou no acompanhamento da execução do projeto. (SALINAS, 2008, p. 140).

Alternativa possível para se evitar cenário como esse seria, além da via original, a exigência de que todo e qualquer documento integrante da prestação de contas trouxesse em seu corpo especificação quanto a se referir ao convênio numericamente especificado.

Além disso, o concedente deveria vir também indicado de forma expressa, com vista a evitar a utilização do mesmo documento em mais de uma prestação de contas.

Defendemos a importância, também, de aposição de carimbo do concedente nos documentos apresentados, de forma a denotar-lhes a conferência, aceitação e computação para fins prestação de contas.

A ausência da apresentação da prestação de contas acarretará a instauração de procedimento de tomada de contas especial, consistente em "um processo de rito próprio, de competência do TCU, que objetiva apurar a responsabilidade daquele que der causa a perda, extravio ou outra irregularidade de que resulte dano ao erário" (SALINAS, 2008, p. 141).

373 "Os instrumentos normativos vigentes não oferecem parâmetros de execução física dos projetos vinculados a programas orçamentários, sendo este um tema visivelmente negligenciado." (SALINAS, 2008, p. 139). 
Vejamos, então as demais classificações do controle.

\subsubsection{Os entes controladores}

Conforme já acenamos, estão incluídas sob essa divisão o controle interno, externo e social.

Enquanto o primeiro é exercido pela própria estrutura administrativa — tanto pelo prolator do ato/postura a ser controlada quanto pelos seus superiores hierárquicos —, o segundo pressupõe uma interface com órgãos ou pessoas alheias a ela - sejam eles o Ministério Público, o Tribunal de Contas, o Judiciário.

O terceiro parte da própria sociedade civil, organizada ou não. ${ }^{374}$

O controle interno se manifesta, segundo lição de Dias (2008b, p. 362), a) no controle hierárquico, vinculante da Administração direta; b) na tutela administrativa e c) no controle finalístico, direcionado à Administração indireta.

Constitui um poder-dever da Administração, que não pode validamente se furtar ao seu exercício, havendo sido consagrado em duas súmulas do STF: n. $346^{375}$ e n. $473 .{ }^{376}$

Conforme já afirmado no presente estudo, o Conselho Municipal dos Direitos da Criança e do Adolescente constitui órgão público ligado à estrutura estatal unicamente por vínculos administrativos-organizacionais-burocráticos e não está, portanto, sujeito ao controle hierárquico de quaisquer órgãos integrantes da estrutura municipal ou mesmo do Prefeito.

Sua discricionariedade, na área da infância e juventude, é plena, observados apenas os limites e parâmetros legais.

O controle interno abrange tanto o controle de legalidade quanto o de mérito e de resultados, ${ }^{377}$ e encontra escopo constitucional no artigo 74 de nossa Carta:

Art. 74. Os Poderes Legislativo, Executivo e Judiciário manterão, de forma integrada, sistema de controle interno com a finalidade de:

\footnotetext{
${ }^{374}$ Sobre esse regime de controle se falará, em especial, mais adiante.

375 "A administração pública pode declarar a nulidade de seus próprios atos."

376 “A administração pode anular seus próprios atos, quando eivados de vícios que os tornam ilegais, porque deles não se originam direitos; ou revogá-los, por motivo de conveniência ou oportunidade, respeitados os direitos adquiridos, e ressalvada, em todos os casos, a apreciação judicial."

377 "Os órgãos internos de controle devem atuar visando à verificação da legalidade, avaliação dos resultados quanto á eficácia e à eficiência, gestão financeira e aplicação de recursos repassados às entidades privadas sem fins lucrativos por meio de convênios administrativos colaborativos, informando ao TCU ilegalidades e irregularidades verificadas, tendo em vista o disposto no artigo 74, II e $\S 1^{\circ}$, da Constituição Federal." (LIMA, 2008, p. 143).
} 
I - avaliar o cumprimento das metas previstas no plano plurianual, a execução dos programas de governo e dos orçamentos da União;

II - comprovar a legalidade e avaliar os resultados, quanto à eficácia e eficiência, da gestão orçamentária, financeira e patrimonial nos órgãos e entidades da administração federal, bem como da aplicação de recursos públicos por entidades de direito privado;

III - exercer o controle das operações de crédito, avais e garantias, bem como dos direitos e haveres da União;

IV - apoiar o controle externo no exercício de sua missão institucional.

$\S 1^{\circ}$ - Os responsáveis pelo controle interno, ao tomarem conhecimento de qualquer irregularidade ou ilegalidade, dela darão ciência ao Tribunal de Contas da União, sob pena de responsabilidade solidária.

$\S 2^{\circ}$ - Qualquer cidadão, partido político, associação ou sindicato é parte legítima para, na forma da lei, denunciar irregularidades ou ilegalidades perante o Tribunal de Contas da União.

Com redação muito próxima, a Lei Orgânica do Município de São Paulo:

Art. 53 - Os Poderes Executivo e Legislativo manterão, de forma integrada, sistema de controle interno, com a finalidade de:

I - avaliar o adequado cumprimento das metas previstas no plano plurianual, a execução dos programas de governo e dos orçamentos do Município;

II - comprovar a legalidade e avaliar os resultados quanto à eficácia e à eficiência da gestão orçamentária, financeira e patrimonial dos órgãos da administração direta e indireta, bem como de aplicação de recursos públicos por entidades de direito privado;

III - exercer o controle das operações de crédito, avais e garantias, bem como dos direitos e haveres do Município;

IV - apoiar o controle externo, no exercício de sua missão institucional, o qual terá acesso a toda e qualquer informação, documentos ou registro que repute necessários para o cumprimento de sua função;

V - organizar e executar, por iniciativa própria ou por solicitação do Tribunal de Contas do Município, programação trimestral de auditorias contábil, financeira, orçamentária, operacional e patrimonial nas unidades administrativas sob seu controle.

$\S 1^{\circ}$ - Para fins do disposto neste artigo, a Câmara Municipal e o Tribunal de Contas do Município terão acesso direto, através de sistema integrado de processamento de dados, às informações processadas em todos os órgãos da administração direta e indireta do Município.

$\S 2^{\circ}$ - Os responsáveis pelo controle interno, ao tomarem conhecimento de qualquer irregularidade, ilegalidade ou ofensa ao art. 37 da Constituição da República, deverão representar à autoridade competente, dando ciência à Câmara Municipal, sob pena de responsabilidade solidária.

Sujeita-se aos parâmetros, ainda, do artigo 25 do Decreto-Lei n. 200/67, ${ }^{378}$ da Lei federal n. 4320/64, ${ }^{379}$ e da Lei Complementar n. 101/2000. ${ }^{380}$

378 “Art. 25. A supervisão ministerial tem por principal objetivo, na área de competência do Ministro de Estado: I - Assegurar a observância da legislação federal. II - Promover a execução dos programas do 
No que toca especificamente ao controle interno dos convênios no âmbito do município de São Paulo, vale registrar a incidência universal do Decreto n. 51.501/10, que determina que a "celebração, a alteração e a prorrogação de convênios de qualquer natureza, que envolvam a transferência ou o recebimento de recursos financeiros, serão previamente analisadas pela Secretaria Municipal de Planejamento, quanto aos aspectos orçamentários e à adequação às diretrizes do planejamento municipal”.

Digna de críticas essa norma, uma vez que ofensiva da lógica de descentralização e desburocratização incorporadas como norte da atuação administrativa brasileira desde a Reforma do Estado da década de 1990.

Incide o controle interno também sobre as entidades privadas sem finalidade lucrativa que recebam receitas públicas - hipótese que Dias (2008, p. 367) defende se restringir ao controle de resultados.

Discordamos, nesse ponto, da autora, na medida em que, por mais que os novos paradigmas do Direito Administrativo e da gestão pública apontem para uma ênfase na fiscalização finalística, tal circunstância não afasta o controle de legalidade - como a apreciação, exemplificativamente, da regularidade da forma adotada para escolha de fornecedores, sobre um suposto regulamento de compras.

Não tem como traço fundamental a espontaneidade, de modo que pode ser exercido tanto de ofício como a partir de provocação externa - hipótese em que estará inserido em um contexto maior de controle social (caso o desencadeante integre a sociedade civil, não tenha nenhum nível de institucionalização) ou controle externo (hipótese em que provocado por quaisquer outros atores).

Pode incidir em qualquer dos três momentos retratados no subitem anterior.

Governo. III - Fazer observar os princípios fundamentais enunciados no Título II. IV - Coordenar as atividades dos órgãos supervisionados e harmonizar sua atuação com a dos demais Ministérios. V - Avaliar o comportamento administrativo dos órgãos supervisionados e diligenciar no sentido de que estejam confiados a dirigentes capacitados. VI - Proteger a administração dos órgãos supervisionados contra interferências e pressões ilegítimas. VII - Fortalecer o sistema do mérito. VIII - Fiscalizar a aplicação e utilização de dinheiros, valores e bens públicos. IX - Acompanhar os custos globais dos programas setoriais do Governo, a fim de alcançar uma prestação econômica de serviços. X - Fornecer ao órgão próprio do Ministério da Fazenda os elementos necessários à prestação de contas do exercício financeiro. XI - Transmitir ao Tribunal de Contas, sem prejuízo da fiscalização deste, informes relativos à administração financeira e patrimonial dos órgãos do Ministério."

379 "Estatui Normas Gerais de Direito Financeiro para elaboração e controle dos orçamentos e balanços da União, dos Estados, dos Municípios e do Distrito Federal.”

${ }^{380}$ Estabelece normas de finanças públicas voltadas para a responsabilidade na gestão físcal e dá outras providências. 
Defendemos a importância fundamental dessa espécie de controle nos dias atuais, em que, mais que repressão ou punição, a Administração pública deve buscar uma atuação eficaz e efetiva, consentânea com o papel didático e de orientação do controle.

A prevenção de vícios, a possibilidade de evitar a sua ocorrência deve ser muito mais prestigiada que a repreensão por comportamentos distorcidos já aperfeiçoados, com a consequente consolidação da ineficiência, da atuação torta e disforme ao ordenamento jurídico.

O exercício do controle interno de forma preventiva, pronta, ágil e eficaz tem o condão, em última análise, de evitar que muitos dos vícios e dos prejuízos — tanto materiais quanto sociais - venham a se materializar. ${ }^{381}$

Daí a posição de absoluto destaque ocupado pelas assessorias jurídicas e órgãos de gestão integrantes da estrutura Administrativa - que, além de (e inclusive por) estarem inseridos no contexto da atuação pública, têm muito mais intimidade com a sua fisiologia, as suas reentrâncias.

Pode - e deve - ser exercido pelos órgãos técnicos em geral e pelos próprios órgãos políticos, devendo sempre guardar consonância com os parâmetros inicialmente estabelecidos para as ações sub análise.

No município de São Paulo ganham destaque a Corregedoria Geral do Município e a Procuradoria Geral do Município, disciplinados, respectivamente, pela Lei municipal n. 14.349/2007 e pelo Decreto municipal n. 27.231/88.

Exercem esses órgãos controle não baseado na hierarquia, mas fundamentado na legalidade e no próprio mérito da atuação administrativa e do dispêndio de receitas públicas - podendo apreciar, inclusive, a regularidade dessa atuação quanto aos resultados alcançados.

Complementar ao interno, há também o controle externo, exercido por órgãos estranhos à estrutura administrativa, sejam integrantes do Judiciário, do Legislativo — que atuam, ou devem atuar, conjuntamente com os Tribunais de Contas —, ou o Ministério Público.

\footnotetext{
381 "Ao subordinar a função de controle ao trabalho de correição, verifica-se que o Brasil se distanciou da experiência internacional. Ao proceder dessa forma, a contribuição do órgão de controle interno para o aprimoramento da administração pública pode estar sendo debilitada em decorrência da subordinação da atividade consultiva, essencial para o aprimoramento das práticas gerenciais, às atividades puramente coercitivas - não tão abrangentes e menos tempestivas em razão da busca da segurança jurídica." (ROCHA, 2002, p. 3-4).
} 
Sob essa designação não incluímos o controle social, que, não obstante desenvolvido em seara alheia à Administração, não pressupõe dos seus atores uma competência institucional, essencial e específica.

Realmente, as instituições responsáveis pelo controle externo stricto sensu têm em seu íntimo, de forma indissociável, essa atribuição, sendo essa uma missão, dentre outras, inerente.

Exercem o controle social, por outro lado, entes ou pessoas não institucionalizados ou não investidos de função fiscalizatória essencial ou primária.

A sua investidura na condição de controladores se dá apenas incidentalmente, sendo essa uma atribuição latente e atípica - razão pela qual o excluímos do âmbito do controle externo. ${ }^{382}$

A fiscalização pelo Judiciário se opera, em regra, a posteriori (salvo as hipóteses acautelatórias e assecuratórias - DIAS, 2008b, p. 373), podendo vir a ser utilizada como instrumento do controle social, como no caso das ações populares.

Em tempos passados se limitava à análise de legalidade formal dos atos administrativos, havendo, a partir do século XIX, evoluído para considerações também quanto ao mérito, ao menos quanto aos atos de gestão (os atos de governo permaneciam inicialmente indevassáveis), chegando, atualmente, a alcançar todas as situações potencialmente comprometedoras de direitos juridicamente protegidos, individuais ou coletivos. (DIAS, 2008b, p. 374-375).

O controle judicial é atualmente bastante amplo, havendo alcançado o patamar da juridicidade - a qual traz em seu bojo os diversos princípios e valores consagrados, expressa ou implicitamente, no ordenamento jurídico.

Não se pode imiscuir, porém, em questões afetas à reserva de atuação constitucionalmente traçada em favor da Administração, referentes às suas opções políticas (ou de quem lhes faça as vezes, como no caso dos Conselhos).

Furtar-nos-emos a tecer considerações mais detidas quanto a esse aspecto, posto não se inserir no escopo do presente trabalho.

No que toca aos convênios com entidades do Terceiro Setor, o controle judicial se direciona às posturas assumidas tanto pela concedente - anteriormente, durante ou após a sua formalização - , quanto pela convenente - aí, somente direcionado às condutas

\footnotetext{
${ }^{382}$ Nesse sentido, DIAS, 2008b e VALLE, 2002, p. 84. Essa foi também a postura adotada pelo Anteprojeto de Lei Orgânica da Administração Pública Federal, em seu artigo 55. Em sentido contrário, incluindo a sociedade civil como titular do controle externo, LIMA, 2008, p. 143.
} 
concomitantes ou posteriores ao estabelecimento da parceria (salvo as hipóteses acautelatórias já mencionadas).

O controle externo é exercido, ainda, e de forma imbricada, por duas instâncias: o Legislativo $^{383}$ e o Tribunal de Contas, auxiliar daquele, para os fins ora considerados.

No que toca aos Tribunais de Contas, cumpre registrar a nova redação do parágrafo único do artigo $70 \mathrm{da} \mathrm{CF}$, segundo a qual se passou a exigir, também, a prestação de contas "de qualquer pessoa física ou jurídica, pública ou privada, que utilize, arrecade, guarde, gerencie ou administre dinheiros, bens e valores públicos ou pelos quais a União responda, ou que, em nome desta, assuma obrigações de natureza pecuniária”.

Essa redação, introduzida pela EC n. 19/98, responsável pela Reforma do Estado, estendeu a submissão à atividade de controle dos Tribunais de Contas às entidades do Terceiro Setor que recebam receitas públicas - não obstante a sua natureza privada:

Em regra, não cabe ao particular prestar contas aos Tribunais de Contas ou submeter-se ao seu controle. Mesmo quando celebre contrato administrativo com o Poder Público, não deverá fazê-lo, pois os recursos públicos, nestes casos, são-lhe atribuídos como ressarcimento ou remuneração pelos serviços prestados, e não como fomento para o desenvolvimento de atividades de interesse social sem finalidade lucrativa, quando não perdem a sua natureza de bens públicos. (SCHOENMAKER, 2011, p. 75).

Elenca a autora, como fundamentos para a sujeição dessas entidades ao dever de prestar contas: a) destinação pública a título da qual os recursos são cedidos; b) natureza pública das atividades face ao interesse visado; c) existência de vínculos formais com a Administração (no caso, os convênios).

Ainda nesse contexto, merece registro a incidência do artigo 113 da Lei federal n. $8.666 / 93 .^{384}$

\footnotetext{
${ }^{383} \mathrm{O}$ controle legislativo se manifesta, nos termos dispostos pela $\mathrm{CF}$, pelos seguintes instrumentais: controle externo, com auxílio dos Tribunais de Contas, em matéria notadamente financeira e orçamentária (artigos 31; 33, § 2 $;$; 49, IX; 70 a 73); sustação de atos do Executivo (artigo 49, V); fiscalização da Administração direta e indireta (art. 49, X); aprovações e autorizações de decisões do Executivo para produzir efeitos ou tornaremse válidos (artigos 49, II e III; 52, III e XI, e 101, parágrafo único); convocação para comparecimento (artigo 50); tomada de contas do chefe do Executivo, quando não apresentadas ao Legislativo no prazo de sessenta dias, contados da abertura da sessão legislativa (artigo 51, II); impeachment por crime de responsabilidade contra agentes públicos (artigo 52, caput, I e II e 86); Recebimento de petições, reclamações, representações e queixas contra atos ou omissões de autoridades (artigo $58, \S 2^{\circ}$, IV e V). Ainda que não haja especificação quanto à observância dessa lógica em níveis estadual e federal, a sua obrigatória replicação decorre do próprio princípio federativo. Registre-se ainda, o disposto no artigo 75 da Carta Maior: "Art. 75. As normas estabelecidas nesta seção aplicam-se, no que couber, à organização, composição e fiscalização dos Tribunais de Contas dos Estados e do Distrito Federal, bem como dos Tribunais e Conselhos de Contas dos Municípios."
} 
O controle pelo Tribunal de Contas sobre as convenentes assumirá forma indireta, devendo suas prestações de contas ser entregues ao concedente - ao qual caberá implementar todas as medidas fiscalizatórias e de interlocução com aquele Tribunal. ${ }^{385}$

Outro ator responsável pelo poder-dever de fiscalização externa é o Ministério Público.

Tal competência encontra fundamento na atribuição genérica de zelar pelos interesses sociais ou individuais indisponíveis outorgada a essa instituição (DIAS, 2008b, p. 398), assim como nos artigos 129 , III, ${ }^{386}$ da $\mathrm{CF}$ e 66 do $\mathrm{CC}^{387}$ (no que tange especificamente às fundações).

Referido órgão vem acompanhando a atuação dos Conselhos de forma bastante próxima e constante - de modo que, constatada qualquer suspeita de irregularidade, lança mão de mecanismos como os inquéritos civis e ações civis públicas.

Foi o que se deu com o Inquérito Civil n. 29/10, instaurado pela $9^{\text {a }}$ Promotoria de Justiça de São Bernardo, e que deu origem à ação civil pública processada sob o número de ordem 11.110/10, em que se discute justamente a validade de outorga de registro, pelo Conselho, a entidade que não disponha de local de atendimento no município respectivo, havendo inclusive suspeita de inidoneidade dos integrantes de seu quadro de agentes, em potencial ofensa ao disposto na alínea " $d$ " do parágrafo único do artigo 91 do ECA. ${ }^{388}$

Afora todas as espécies de controle retratadas, vale registrar, ainda, a lição de Schoenmaker, para quem referida atividade pode se desenvolver a partir dos seguintes parâmetros: a) legalidade; b) legitimidade; c) economicidade; d) exame da aplicação das subvenções e renúncia de receitas (SCHOENMAKER, 2011, p. 81).

Feitas essas ponderações, concentremos nossas atenções sobre uma espécie de controle que vem traduzindo de forma até simbólica o novo contexto jurídico, administrativo e social do século XIX.

Trata-se do controle social, cujo estudo e implementação se encontra em franca evolução, e a respeito do qual traçaremos considerações específicas no próximo subitem.

\footnotetext{
384 “Art. 113. O controle das despesas decorrentes dos contratos e demais instrumentos regidos por esta Lei será feito pelo Tribunal de Contas competente, na forma da legislação pertinente, ficando os órgãos interessados da Administração responsáveis pela demonstração da legalidade e regularidade da despesa e execução, nos termos da Constituição e sem prejuízo do sistema de controle interno nela previsto."

385 "Em regra, não cabe ao particular prestar contas aos Tribunais de Contas ou submeter-se ao seu controle." (SCHOENMAKER, 2011, p. 75).

386 “Art. 129. São funções institucionais do Ministério Público: [...] III - promover o inquérito civil e a ação civil pública, para a proteção do patrimônio público e social, do meio ambiente e de outros interesses difusos e coletivos."

387 "Art. 66. Velará pelas fundações o Ministério Público do Estado onde situadas."

${ }^{388}$ Referida ação corre em segredo de justiça e pende de decisão definitiva.
} 


\subsection{Controle social}

O controle social desempenha nos dias que correm um "papel preponderante e de centralidade em relação aos mecanismos institucionais de controle, por ser difuso e por provocar os demais instrumentos de controle”. (DIAS, 2002, p. 405).

Realmente, constitui um dos principais pilares da legitimidade, da eficiência e da responsividade da atuação administrativa.

Muito se discute quanto ao fato de o controle social integrar - ou não - a noção de accountability exposta anteriormente.

Ceneviva e Farah lembram posicionamentos de autores que restringem essa noção aos agentes institucionalizados ${ }^{389}$ ou àqueles que gozem da capacidade de efetivamente impor uma sanção, responsabilizando o destinatário da atividade de controle. $^{390}$

Rechaçando essas limitações, defendem, a nosso ver acertadamente, que:

[...] não só os agentes institucionais possam ou devam desempenhar função de fiscalização e controle do Poder Público, mas, vale repetir, advoga-se aqui que também associações de cidadãos ou usuários de serviços públicos, organizações da sociedade civil e a mídia também podem incumbir-se da tarefa de zelar pela administração pública. (CENEVIVA; FARAH, 2007, p. 136)

Daí o conceito desenvolvido, segundo o qual:

O controle social é uma forma de accountability vertical que não se esgota em um processo eleitoral. Pelo contrário, dá-se de maneira ininterrupta, sem, no entanto, se contrapor às formas clássicas de controle. Efetivamente, [...] está sujeito às mesmas condições que garantem a qualidade dos demais mecanismos de representação democrática, como o processo eleitoral: informação e debate entre cidadãos, instituições que viabilizem a fiscalização e regras legais, e normas sociais que incentivem o pluralismo e reprimam o privilégio de

\footnotetext{
${ }^{389}$ Referindo-se aos posicionamentos de autores como Fernando Abrucio e Maria Fernanda Loureiro: “[...] apenas os mecanismos de controle formais e institucionais devem ser compreendidos pela noção de accountability. Tais autores adotam uma noção de responsabilização que não compreende em seus limites as relações informais de fiscalização e controle, não considerando assim, como agentes de accountability, a imprensa e as organizações da sociedade civil que comumente se incumbem de monitorar e denunciar abusos e condutas impróprias de agentes públicos no exercício do poder. Nesse sentido, esses autores defendem uma noção menos abrangente de accountability." (CENEVIVA; FARAH, 2007, p. 130).

${ }^{390}$ Esclarece o autor, invocando o posicionamento de Delmer Dunn, Robert Keohane e Ronald Oakerson, que as sanções aí referidas incluem não apenas a de ordem legal, as também as de conotação simbólica.
} 
grupos mobilizados em detrimento da maioria desorganizada, bem como o respeito ao império da lei e aos direitos dos cidadãos. Entre os atributos que distinguem o controle social das demais formas de responsabilização durante o mandato, destaca-se a possibilidade de ampliação do espaço público, ponto fundamental para que os governantes sejam controlados mais atentamente e respondam de maneira efetiva às demandas e aspirações dos cidadãos nos períodos entre as eleições. (CENEVIVA; FARAH, 2007, p. 145).

Conforme lição de Almeida, os mecanismos internacionais frisam a importância de promoção da coesão social, de forma que os particulares participem das políticas públicas, em uma mobilização voltada à boa governança. Assinala, ainda, que a accontability foi introduzida em nosso ordenamento pela Lei de Responsabilidade Fiscal, podendo ser considerada como um rumo certeiro para as boas práticas administrativas as quais devem ser fiscalizadas não só pelos órgãos técnicos, mas por toda a sociedade, “fonte, inclusive, das receitas públicas" (ALMEIDA, 2011, p. 593).

A matriz constitucional do controle social repousa no artigo $1^{\circ}$, caput, e inc. II, e no artigo 37, ambos da CF.

Ayres Britto ${ }^{391}$ vislumbra essa importante ferramenta da democracia como um direito público subjetivo, um instrumento de embate entre os particulares e o Estado, que estaria, assim, sujeito às exigências daqueles voltadas à defesa e promoção dos direitos individuais e coletivos:

Com efeito, seja qual for a maneira pela qual o controle se manifeste (denúncia, representação, reclamação...), o objetivo do particular é simplesmente desfrutar de uma situação jurídica ativa contra o Poder Público. Ele não quer formar propriamente a vontade do Estado, mas impor ao Estado a vontade dele, particular que é a de penetrar na

\footnotetext{
${ }^{391}$ Referido autor busca, nessa obra, apartar as noções de participação e controle social: "O agente privado a que assiste qualquer das vias do controle do Poder Público não se assume enquanto autoridade normante. Não produz uma regra nova de Direito, mas, simplesmente, aplica norma constitucional preexistente. Numa palavra, não participa do processo de elaboração jurídica, e, portanto, de participação popular não se cuida. Se, por acaso, da sua iniciativa controladora, vier a ser gestada uma regra de direito (até para desfazer uma outra insanavelmente viciada), a autoria do espécime jurídico novo será exclusivamente do Estado." (BRITTO, 1992). Pela identidade de conteúdo, "o controle social da administração pública, também comumente nomeado participação popular, em que pesem suas contribuições mais recentes, ainda carece de melhores contornos no direito público brasileiro." (DIAS, 2008b, p. 402). Atente-se, ainda, para a lição de Valle: "[...] o controle social e a participação social, embora se tenham aproximado, não se confundem. Os fenômenos guardam, em verdade, uma relação estreita, podendo mesmo se afirmar que a última constitui gênero, do qual o controle é espécie. Essa proximidade conceitual, todavia, implica necessariamente que uma sensibilidade cidadão para o fato que o aumento da participação popular resultará necessariamente em desenvolvimento, igualdade, da atividade de controle social. E na verdade, o processo é de retroalimentação: quando os administrados no exercício do poder popular coadjuvam o processo decisório de formação de normas abstratas de condutas e de designação dos representantes da coletividade; justamente por essas atividades terem feito parte, estarão especialmente habilitados a intensificar o potencial de sindicabilidade da opção empreendida pela Administração." (VALLE, 2002, p. 86).
} 
intimidade das repartições públicas para reconstruir fatos ou apurar responsabilidades. Do ângulo do Estado, então, os efeitos do controle social implicam uma posição de subalternidade ou capitis deminutio. Qualquer que seja a forma de uso do direito ao controle, o Estado é obrigado a "baixar a crista", passando a figurar numa relação jurídica concreta em que o direito subjetivo (alheio) passa a falar mais alto do que o poder político (próprio). (BRITTO, 1992, p. 191-192).

Não compartilhamos dessa visão, na medida em que a relação entre Estado e sociedade civil já não pode ser vista como de oposição, de embate; deve, conforme se depreende de todo o exposto, ser tida como uma relação de complementaridade, de harmonia, de orquestramento e mobilização conjunta.

Ainda que, em situações específicas, a assunção de uma postura mais autoritária e baseada no "poder" se faça necessária, a ênfase típica do Estado Pós-Social em que vivemos determina o desenvolvimento de um vínculo de muito mais horizontalidade, consensualidade, aproximação e responsabilidade solidária pela consecução do bem comum. $^{392}$

E o controle social implica, diferentemente do que defende o autor, a participação da coletividade no processo de definição do interesse público — ou melhor, dos interesses públicos - e das políticas públicas vocacionadas ao seu atendimento. ${ }^{393}$

Em outras palavras, incide também por meio do controle prévio suprarreferido, em momento anterior à cristalização das posturas administrativas, por meio dos mais diversos processos - audiências públicas, participação em conselhos de políticas públicas, consultas (SALINAS, 2008, p. 160) ${ }^{394}$ etc. $^{395}$

Essa postura vem sendo oficialmente prestigiada desde a edição do Plano de Reforma do Aparelho do Estado, do Ministério da Administração Federal e Reforma do Estado de 1995, que consagrou, entre seus objetivos, “[...] fortalecer práticas de adoção de mecanismos que privilegiem a participação da sociedade tanto na formulação quanto na

\footnotetext{
392 "É nesse momento de transformação social que participação social e controle social como instrumentos trazidos a um plano de relevância que antes não se lhes conferia. E isso não é difícil de compreender, já que, se o movimento de renovação do regime jurídico da Administração Pública bem se inspirando em um resgate da importância da pessoa do administrado, é fundamental que ele tenha uma possibilidade real - e não meramente formal — de interseção, de desempenho de seu próprio papel." (VALLE, 2002, p. 77).

393 "Os recursos públicos sempre são escassos em relação às necessidades da população, daí a importância do processo de decisão sobre como e onde aplicar os recursos disponíveis. Nesse processo, o povo, destinatário da atuação estatal, que é diretamente afetado pelos erros e acertos na gestão dos recursos públicos, deve ser consultado." (DALLARI, 2011, p. 320).

${ }^{394}$ Em manifestação tendente à minimização da relevância e papel de destaque atualmente ocupado pelo controle social, vale a consulta ao acórdão prolatado pela 3. ${ }^{\mathrm{a}}$ Turma do Tribunal Regional Federal da $4^{\mathrm{a}}$ Região no Agravo de Instrumento n. 2005.04.01.020976-0/PR, Relator José Paulo Baltazar Junior. Disponível no site http://www.trf4.jus.br/trf4/revistatrf4/arquivos/Rev60.pdf.

${ }^{395}$ Veja-se, também, DIAS, 2002, p. 406.
} 
avaliação de desempenho da organização social, visando o controle social". (BRASIL. Ministério da Administração Federal e Reforma do Estado. 1995, p. 46-47).

A Lei de Licitações prevê expressamente, no $\S 1^{\circ}$ do seu artigo 113: "§ $1^{\circ}$ Qualquer licitante, contratado ou pessoa física ou jurídica poderá representar ao Tribunal de Contas ou aos órgãos integrantes do sistema de controle interno contra irregularidades na aplicação desta Lei, para os fins do disposto neste artigo".

Digno de registro, ainda, o disposto nos artigos 39 , caput, ${ }^{396}$ e $41, \S 1^{\text {o }},{ }^{397}$ dessa mesma Lei.

Em nível municipal, a Lei Orgânica de São Paulo dispõe, em seu artigo $2^{\circ}$ :

Art. $2^{\circ}$ - A organização do Município observará os seguintes princípios e diretrizes:

I - a prática democrática;

II - a soberania e a participação popular;

III - a transparência e o controle popular na ação do governo; (grifamos)

Conforme se infere da redação deste último dispositivo, a transparência, o livre acesso a informações e dados é condicionante fundamental dessa espécie de controle: não há hipótese de se fiscalizar o que se desconhece.

Nas palavras de Valle (2002, p. 79), "A verdade é que — sabe-se — controle social e transparência da Administração Pública guardam relação visceral: não há como se avaliar a conformidade da atuação do Estado com o Direito e com as aspirações da sociedade que o justifica, sem conhecer não só o que se decidiu, mas como e porque".

A própria CF, no artigo $5^{\circ}, \mathrm{XVIII}^{398}{ }^{\mathrm{XXXIII}}{ }^{399}$ e XXXIV, “ $b ",{ }^{400}$ garante o imprescindível acesso do cidadão a informações cujo conhecimento possa condicionar o

\footnotetext{
396 “Art. 39. Sempre que o valor estimado para uma licitação ou para um conjunto de licitações simultâneas ou sucessivas for superior a 100 (cem) vezes o limite previsto no art. 23, inciso I, alínea c desta Lei, o processo licitatório será iniciado, obrigatoriamente, com uma audiência pública concedida pela autoridade responsável com antecedência mínima de 15 (quinze) dias úteis da data prevista para a publicação do edital, e divulgada, com a antecedência mínima de 10 (dez) dias úteis de sua realização, pelos mesmos meios previstos para a publicidade da licitação, à qual terão acesso e direito a todas as informações pertinentes e a se manifestar todos os interessados."

397 " $\$ 1^{\circ}$. Qualquer cidadão é parte legítima para impugnar edital de licitação por irregularidade na aplicação desta Lei, devendo protocolar o pedido até 5 (cinco) dias úteis antes da data fixada para a abertura dos envelopes de habilitação, devendo a Administração julgar e responder à impugnação em até 3 (três) dias úteis, sem prejuízo da faculdade prevista no $\S 1^{\circ}$ do art. 113 ."

398 "XVIII - a criação de associações e, na forma da lei, a de cooperativas independem de autorização, sendo vedada a interferência estatal em seu funcionamento;"

399 "XXXIII - todos têm direito a receber dos órgãos públicos informações de seu interesse particular, ou de interesse coletivo ou geral, que serão prestadas no prazo da lei, sob pena de responsabilidade, ressalvadas aquelas cujo sigilo seja imprescindível à segurança da sociedade e do Estado."

400 "XXXIV - são a todos assegurados, independentemente do pagamento de taxas: b) a obtenção de certidões em repartições públicas, para defesa de direitos e esclarecimento de situações de interesse pessoal.”
} 
exercício de um seu direito ou possam de alguma forma repercutir nos interesses da coletividade, e traz mecanismos direcionados ao controle social.

\author{
Da mesma forma os artigos $10 ;^{401} 31, \S 3^{\mathrm{o}} ;{ }^{402} 37, \S 3^{\mathrm{o}} ;^{403} 150, \S 5^{\mathrm{o}} ;^{404} 165, \S 3^{\mathrm{o} 405}$ \\ e $216, \S 1^{\text {o }}{ }^{406}$
}

Sem transparência, fidedignidade e clareza das informações, não há como os cidadãos se apropriarem dos dados das avaliações para cobrar os agentes públicos. Além disso, a atuação dos atores interessados é, em grande parte, mas não exclusivamente, condicionada pela incorporação de regras e procedimentos de fiscalização via participação social, que assegurem o direito e os meios das organizações da sociedade civil, dos usuários dos serviços públicos e, mais amplamente, dos cidadãos de participarem de modo ativo da definição e do processo de cobrança e fiscalização dos governantes e burocratas. (CENEVIVA; FARAH, 2007, p. 151).

Desempenham papel também fundamental as diretrizes do devido processo legal,

do acesso à justiça, da publicidade dos atos processuais e da gratuidade dos atos inerentes à cidadania.

No âmbito do município de São Paulo, digno de menção o Decreto municipal 52.710, de 07 de outubro de 2011, ${ }^{407}$ com redação outorgada pelo Decreto n. 52.939, de 23

401 “Art. 10. É assegurada a participação dos trabalhadores e empregadores nos colegiados dos órgãos públicos em que seus interesses profissionais ou previdenciários sejam objeto de discussão e deliberação."

402 " $\S 3^{\circ}$ As contas dos Municípios ficarão, durante sessenta dias, anualmente, à disposição de qualquer contribuinte, para exame e apreciação, o qual poderá questionar-lhes a legitimidade, nos termos da lei.”

403 "§ $3^{\circ}$ A lei disciplinará as formas de participação do usuário na administração pública direta e indireta, regulando especialmente: I - as reclamações relativas à prestação dos serviços públicos em geral, asseguradas a manutenção de serviços de atendimento ao usuário e a avaliação periódica, externa e interna, da qualidade dos serviços; II - o acesso dos usuários a registros administrativos e a informações sobre atos de governo, observado o disposto no art. $5^{\circ}$, X e XXXIII; III - a disciplina da representação contra o exercício negligente ou abusivo de cargo, emprego ou função na administração pública."

404 “ $\S 5^{\circ}$ - A lei determinará medidas para que os consumidores sejam esclarecidos acerca dos impostos que incidam sobre mercadorias e serviços."

${ }^{405} \S 3^{\circ}$ - O Poder Executivo publicará, até trinta dias após o encerramento de cada bimestre, relatório resumido da execução orçamentária.

${ }^{406} \S 1^{\circ}$ - O Poder Público, com a colaboração da comunidade, promoverá e protegerá o patrimônio cultural brasileiro, por meio de inventários, registros, vigilância, tombamento e desapropriação, e de outras formas de acautelamento e preservação.

407 "Art. $1^{\circ}$. Fica convocada a $1^{\text {a }}$ Conferência Municipal sobre Transparência e Controle Social, a realizar-se no dia 27 de fevereiro de 2012, na Cidade de São Paulo, com o tema: "A sociedade no acompanhamento e controle da gestão pública", como etapa preparatória da $1^{\text {a }}$ Conferência Nacional sobre Transparência e Controle Social - $1 .{ }^{\text {a }}$ Consocial. Parágrafo único. A Conferência terá como objetivos: I - debater e propor ações de promoção da participação da sociedade civil no acompanhamento e controle da gestão pública, bem como de fortalecimento da interação entre sociedade e governo; II - promover, incentivar e divulgar o debate e o desenvolvimento de novas idéias e conceitos sobre a participação social no acompanhamento e controle da gestão pública; III - estimular os órgãos e entidades públicas a implementar mecanismos de transparência e acesso a informações e dados públicos, assim como fomentar o uso dessas informações e dados pela sociedade; IV - debater e propor mecanismos de sensibilização e mobilização da sociedade em prol da participação no acompanhamento e controle da gestão pública; V - discutir e propor ações de capacitação e 
de janeiro de 2012, que convocou a $1^{\text {a }}$ Conferência Municipal sobre Transparência e Controle Social, realizada no dia 27 de fevereiro de 2012, com a temática "A sociedade no acompanhamento e controle na gestão pública”.

Referido evento dialógico e participativo foi preparatório das conferências estatual $^{408}$ e nacional ${ }^{409}$ que se seguiram, e que constituíram verdadeiro marco na história do controle social.

No que tange especificamente aos atos praticados com a intervenção do CMDCA/SP, digno de menção o artigo $5^{\circ}$, parágrafo único, I, do Decreto n. 43.135/03, que impõe à Secretaria Municipal de Finanças o dever de "fazer publicar mensalmente no Diário Oficial do Município o volume de recursos recebidos pelo FUMCAD provindos de transferências e doações". 410

Quanto ao acesso aos processos administrativos em geral, dispõe o artigo $14 \mathrm{da}$ Lei municipal n. 14.141, de 27 de março de 2006:

Art. 14. São legitimados como interessados no processo administrativo: I - pessoas físicas ou jurídicas que o iniciem ou nele figurem; II - aqueles que, sem terem iniciado o processo, têm direitos ou interesses que possam ser afetados pela decisão a ser proferida; III - as pessoas, organizações e associações regularmente constituídas, no tocante a direitos e interesses coletivos ou difusos.

Tal dispositivo deve ser interpretado em consonância com o disposto na Lei de Acesso à Informação (Lei federal n. 12.527/2011), a qual veio trazer um aperfeiçoamento dos mecanismos de conhecimento geral dos meandros da atuação administrativa ${ }^{411}$ - e,

qualificação da sociedade para o acompanhamento e controle da gestão pública que utilizem, inclusive, ferramentas e tecnologias de informação; VI - desenvolver e fortalecer redes de interação dos diversos atores da sociedade para o acompanhamento da gestão pública; VII - debater e propor medidas de prevenção e combate à corrupção que envolvam ações governamentais, de empresas e da sociedade civil."

$4081^{\text {a }}$ Conferência Estadual sobre Transparência e Controle Social, realizada na cidade de São Paulo entre os dias 30 de abril e $1^{\circ}$ de março de 2012.

${ }^{409}$ Levada a termo entre os dias 18 e 20 de março, em Brasília. Para maiores detalhes, remetemo-nos aos relatórios relativos às Conferências, disponíveis nos sites <http://www.consocial.prefeitura.sp.gov.br> e <http://www.consocial.sp.gov.br>.

410 Não obstante a afirmação veiculada pelo parágrafo único do referido artigo, de que a publicação em questão estaria vocacionada a possibilitar o desenvolvimento das atribuições do Conselho de Orientações Técnicas do CMDCA/SP, se presta ela, inquestionavelmente, a viabilizar o controle social de que ora se trata. 411 “Art. $3^{\circ}$. Os procedimentos previstos nesta Lei destinam-se a assegurar o direito fundamental de acesso à informação e devem ser executados em conformidade com os princípios básicos da administração pública e com as seguintes diretrizes: I - observância da publicidade como preceito geral e do sigilo como exceção; II divulgação de informações de interesse público, independentemente de solicitações; III - utilização de meios de comunicação viabilizados pela tecnologia da informação; IV - fomento ao desenvolvimento da cultura de transparência na administração pública; V - desenvolvimento do controle social da administração pública." (grifamos). 
portanto, do próprio controle social, inclusive com relação, diretamente, às entidades do

Terceiro Setor e aos valores a elas repassados nas relações de parceirização:

Art. $2^{\circ}$. Aplicam-se as disposições desta Lei, no que couber, às entidades privadas sem fins lucrativos que recebam, para realização de ações de interesse público, recursos públicos diretamente do orçamento ou mediante subvenções sociais, contrato de gestão, termo de parceria, convênios, acordo, ajustes ou outros instrumentos congêneres.

Parágrafo único. A publicidade a que estão submetidas as entidades citadas no caput refere-se à parcela dos recursos públicos recebidos e à sua destinação, sem prejuízo das prestações de contas a que estejam legalmente obrigadas.

As entidades do Terceiro Setor poderão figurar tanto no polo ativo quanto passivo do controle social: quando parceira do Estado e gestora de valores públicos, estarão a ele sujeitas; caso contrário, poderão sempre lançar mão dos mecanismos disponíveis, quer de participação popular quer de garantia de acesso aos órgãos de controle externo institucionalizados, para defender os interesses públicos. ${ }^{412}$

Lembramos a lição de Longo, para quem "a informação produzida pela Administração é de domínio público, e não pode, por isso, ser patrimonializada pelas classes políticas ou pela burocracia" (LONGO, 2008, p. 315).

Dignas de registro as recomendações da OCDE para a transparência orçamentária:

a) o orçamento e os documentos a ele relacionados devem ser detalhados relativamente a cada programa de receita e despesa discriminada pra cada unidade administrativa; b) o orçamento deve incluir uma perspectiva de médio prazo. Informações comparativas sobre receitas e despesas no último ano e previsão atualizada para o ano corrente devem ser fornecidas para cada programa, bem como as despesas classificadas por unidade administrativa. c) são vários os relatórios orçamentários previstos: além dos orçamentos prévios, mensais, anuais e de longo prazo, sugerem-se também os relatórios pré-eleitorais, ou seja, que informam o estado geral das finanças governamentais no período imediatamente anterior a sua eleição; d) devem ser divulgadas igualmente as hipóteses econômicas subjacentes ao orçamento, bem como ativos e passivos financeiros e não financeiros do governo, as obrigações derivadas do pagamento de inativos e responsabilidades contingentes que dependem de eventos futuros, que poderão ou não ocorrer; e) um resumo das políticas de prestação de contas relevantes deve acompanhar todos os relatórios, incluindo o método contábil utilizado e informar quaisquer desvios a parti

\footnotetext{
${ }^{412}$ Furtaremo-nos a tecer maiores considerações a respeito da legitimidade dessas entidades do Terceiro Setor para defesa de interesses com os quais seus membros não guardem relação direta, por alheio ao escopo do presente. Para maiores detalhes sobre o assunto, porém, remetemo-nos a VALLE, 2002, item 4.3.
} 
das práticas contábeis; f) um sistema dinâmico de controles financeiros internos, incluindo auditorias para assegurar a integridade das informações contidas nos relatórios orçamentários e a declaração de responsabilidade do ministro das Finanças e de funcionários graduados responsáveis; g) além da auditoria de órgãos superior especializado, deve-se dar ao Pode Legislativo a oportunidade e os recursos para examinar efetivamente qualquer relatório fiscal; g) o Ministério das Finanças de promover ativamente a compreensão do processo orçamentário pelos cidadãos e organizações da sociedade civil. (OCDE, 2002, p. 272). ${ }^{413}$

Consigne-se, ainda, que "[...] há que se distanciar a nova concepção de transparência, daquele vezo antigo, em que se supunha que, em relação ao Estado, seria de prevalecer uma espécie de princípio de autoridade, que o desonere de explicitar com maiores detalhes o conjunto de elementos de determina seu processo decisório". (VALLE, 2002, p. 79).

A transparência, enquanto nova dimensão da publicidade, transcende a mera disponibilização de dados: implica na viabilização da efetiva inteligência, pelo cidadão comum, das informações franqueadas.

Outra marcante interface do controle social se desenvolve com a eficiência, vez que se traduz, em última análise, em mecanismos de cobrança e exigência de uma boa atuação administrativa, responsiva, efetiva e eficiente.

Nas palavras de Modesto (2001, p. 6), “[...] pode-se definir o princípio da eficiência como a exigência jurídica, imposta aos exercentes de função administrativa, ou simplesmente aos que manipulam recursos públicos vinculados de subvenção ou fomento, de atuação idônea, econômica e satisfatória na realização de finalidades públicas assinaladas por lei, ato ou contrato de direito público."

O controle social não está adstrito a questões meramente formais, procedimentais; "ultrapassados ficam os limites de mera fiscalização quanto à legalidade formal" (VALLE, 2002, p. 85), nos termos a serem descortinados no próximo subitem.

Nas palavras de Batista Junior, “o tecnicismo da atuação administrativa [...] estreita a faixa do mérito, uma vez que possibilita a sindicância jurisdicional perante atos de manifesta ineficiência ou desarrazoabilidade, apurados pela má utilização de meios e conhecimentos técnicos”. (BATISTA JUNIOR, 2007, p. 249).

\footnotetext{
${ }^{413}$ ORGANIZAÇÃO PARA A COOPERAÇÃO E DESENVOLVIMENTO ECONÔMICO - OCDE. Best Practices for Budget Transparency. OECD Journal on Budgeting. 2002. Disponível em: 〈http://www.oecd.org/governance/budgetingandpublicexpenditures/1905258.pdf>, p. 272, apud ABRUCIO; LOUREIRO, 2004, p. 91.
} 
Conforme salientam Abrucio e Loureiro, "a perspectiva da accountability democrática supõe a conciliação, tanto do ponto de vista analítico quanto ao ponto de vista normativo, entre as exigências da eficiência e os imperativos da democracia”. (ABRUCIO; LOUREIRO, 2004, p. 79).

Nesse diapasão, temos que o controle sobre o atuar administrativo discricionário $^{414}$ já não pode ser tido como totalmente descabido — dependendo a solução do fato de referida liberdade se inserir no campo técnico ou político.

Na hipótese de discricionariedade técnica, ${ }^{415,416}$ será sempre dado à população e aos órgãos de controle em geral - a sindicabilidade da atuação administrativa, que se concentrará nas razões da escolha do administrador, se efetivamente denotadora da melhor alternativa, sob o aspecto técnico, para determinada situação fática ${ }^{417}$ :

A aferição, portanto, dos parâmetros técnicos que tenham determinado uma decisão sujeita igualmente à hoje denominada discricionariedade

\footnotetext{
${ }^{414}$ Registre-se, nesse ponto, lição de Cassagne, para quem “enquanto o poder discricionário aparece com uma margem de arbítrio do órgão administrativo que se opõe ao caráter regrado ou vinculado da respectiva faculdade (que surge, desse modo, predeterminada pelo ordenamento), o juízo de conveniência ou mérito se vincula ao poder de apreciar, livremente ou com sujeição a certas pautas do ordenamento positivo, a oportunidade de ditar um ato administrativo por razões de interesse público (p. ex. revogação de permissão), independentemente de razões inerentes a seus vícios ou defeitos de legitimidade". (CASSAGNE, 2003, p. 96, traduzimos).

415 “[...] se a lei utiliza critérios técnicos, não há discricionariedade propriamente dita [...]. Há opções a serem feitas por critérios de oportunidade e conveniência. Não há decisão política a ser tomada conforme avaliação do interesse público. Existe uma solução única a ser adotada com base em critérios técnicos fornecidos pela ciência." (DI PIETRO, 2012, p. 122).

${ }^{416}$ Cassagne rejeita essa figura, posicionando-se pela adoção da noção de conceitos jurídicos indeterminados, nos seguintes termos referidos: "A técnica dos conceitos jurídicos indeterminados, que se afirma na Alemanha do pós guerra, vem a limitar a doutrina da discricionariedade, como âmbito isento do controlador judicial, ao permitir o julgamento pleno de certas decisões administrativas que consistiam em aplicar conceitos definidos genericamente pelo ordenamento positivo, tais como 'oferta mais conveniente', 'enfermidade contagiosa', etecétera. À diferença da discricionariedade, esta técnica não implica em uma livre eleição entre duas ou várias possibilidades, senão m um problema de aplicação do Direito que se traduz, essencialmente, em reduzir o marco de decisão a uma única solução justa [...] A aparição dessa categoria dos conceitos jurídicos indeterminados responde pelo fortalecimento da concepção que postula que no Estado de Direito a Administração deve se encontrar sempre vinculada à lei e controlada pelos juízes com as menores lacunas possíveis." (CASSAGNE, 2003, p. 99).

${ }^{417}$ Exemplo trazido pela autora: "Suponhamos que determinada entidade administrativa que ainda se valha exclusivamente de registros e documentos físicos; e que essa mesma unidade opte por dar início a seu processo de entrada na era da informática, cogitando, por uma sugestão infeliz, de desenvolver seus sistemas corporativos (de administração de pessoal, controle contábil, e outros) em uma linguagem de programação totalmente ultrapassada - Cobol, por exemplo. Ora, essa é uma opção que há de se dar, se pautar por critérios eminentemente técnicos, que repudiam, decerto, o início de um processo de informatização a partir de uma linguagem e desenvolvimento de sistemas que já não se usa. Os critérios orientadores da decisão disponibilizadores de profissionais desenvolvedores do mercado, compatibilidade da linguagem para agregar funcionalidades disponíveis via Web, intercomunicabilidade com outros sistemas etc., etc. — são todos de ordem eminentemente técnica, sem qualquer colorido político oponível em favor da solução, que pudesse fazer pender a balança do interesse público pela opção COBOL. A decisão administrativa, nessa hipótese, fia subordinada por uma espécie de zona de certeza negativa, ditada por critério técnico — outras soluções técnicas seriam até possíveis — mas esta, não" (VALLE, 2002, p. 104).
} 
técnica, é passível de inclusão no âmbito das atividades da Administração Pública objeto de possível controle social, até porque essa compreende opções relacionadas, muitas vezes, àquilo que Moreira Neto denomina interesse social que ultrapassa os limites do público estatal. (VALLE, 2002, p. 105).

A discricionariedade política não enseja a mesma solução, apresentando-se excluída da esfera de controle - quer social, quer externo stricto sensu ou mesmo interno - posto que relacionada intimamente com a competência para a prática do ato e as decisões a ele correlatas. ${ }^{418}$

Temos, do exposto, que o controle social configura importantíssimo meio de legitimação da ação administrativa e das próprias políticas públicas - pelo que integra mais uma ferramenta de aferição da juridicidade dessa atuação. ${ }^{419}$

Importantes órgãos de interlocução e viabilização do controle social são as ouvidorias; a do município de São Paulo foi instituída pelo Decreto municipal n. 40.248, de 12 de janeiro de $2001,{ }^{420}$ com as seguintes atribuições:

I - Receber e apurar denúncias, reclamações e representações sobre atos considerados ilegais, arbitrários, desonestos, ou que contrariem o interesse público, praticados por servidores públicos do Município de São Paulo, empregados da Administração Indireta, agentes políticos, ou por pessoas, físicas ou jurídicas, que exerçam funções paraestatais, mantidas com recursos públicos;

II - Propor aos órgãos da Administração, resguardadas as respectivas competências, a instauração de sindicâncias, inquéritos e outras medidas destinadas à apuração das responsabilidades administrativas, civis e criminais, fazendo ao Ministério Público a devida comunicação, quando houver indício ou suspeita de crime;

III - Realizar diligências nas unidades da Administração, sempre que necessário para o desenvolvimento de seus trabalhos;

IV - Proceder correições preliminares nos órgãos da Administração, por iniciativa própria ou mediante solicitação da Prefeita ou dos Secretários Municipais, sem prejuízo da competência legal atribuída ao Conselho da Procuradoria Geral do Município;

$\mathrm{V}$ - Requisitar, diretamente e sem qualquer ônus, de qualquer órgão municipal, informações, certidões, cópias de documentos ou volumes de autos relacionados com investigações em curso;

\footnotetext{
${ }^{418}$ Cf. VALLE, 2002.

419 "[...] por força da intensificação das comunicações, o grande elemento de diferenciação entre as pessoas, um referencial de valorização individual no grupo passa a ser, sem dúvida, o conhecimento - que favorece a mobilidade e a resiliência que uma sociedade em constante mutação exige. E, ao final, quem conhece, porque conhece, necessariamente deseja participar, seja para partilhar seu conhecimento, seja para multiplicá-lo, seja para subordinar a atuação da Administração a esse mesmo saber.” (VALLE, 2002, p. 77).

${ }^{420}$ Curioso o disposto no artigo $5^{\circ}$ do Decreto: “A Ouvidoria Geral do Município terá caráter provisório, funcionando até a aprovação, pela Câmara Municipal, de Projeto de Lei criando a Ouvidoria Geral do Município de São Paulo.” Referida lei não foi, até o momento, editada.
} 
VI - Manter sigilo sobre denúncias e reclamações, bem como sobre sua fonte, providenciando proteção aos denunciantes;

VII - Manter serviço telefônico gratuito, destinado a receber denúncias ou reclamações;

VIII - Recomendar a adoção de providências que entender pertinentes, necessárias ao aperfeiçoamento dos serviços prestados à população pela Administração Pública do Município de São Paulo;

IX - Realizar as investigações de todo e qualquer ato lesivo ao patrimônio público, mantendo atualizado arquivo de documentação relativa às reclamações, denúncias e representações recebidas;

$\mathrm{X}$ - Recomendar aos órgãos da Administração a adoção de mecanismos que dificultem e impeçam a violação do patrimônio público e outras irregularidades comprovadas;

XI - Encaminhar ao Tribunal de Contas do Município notícias de fatos apurados e sua respectiva documentação, nas matérias de sua competência;

XII - Promover estudos, propostas e gestões, em colaboração com os demais órgãos da Administração Municipal, objetivando minimizar a burocracia prejudicial ao bom andamento da máquina administrativa;

XIII - Elaborar e publicar, trimestral e anualmente, relatório de suas atividades;

XIV - Realizar seminários, pesquisas e cursos versando assuntos de interesse da Administração Municipal, no que tange ao controle da coisa pública;

XV - Elaborar seu Regimento Interno, a ser aprovado pela Prefeita, do qual deverão constar as rotinas de procedimentos e fluxo dos expedientes, de forma a acelerar a sua tramitação;

Referidos órgãos extraem sua lógica de atuação do binômio reclamação-dever de qualidade (VALLE, 2002, p. 116), que orienta a atividade administrativa em geral, seja ela estatal ou não.

O controle social ganha, neste despontar do século XXI, um novo aliado na composição do arsenal voltado ao incremento da qualidade da atuação administrativa e, portanto, da promoção e satisfação dos interesses públicos.

Trata-se do controle de resultados, do qual nos ocuparemos no subitem seguinte.

\subsubsection{O controle da eficiência/resultados versus controle burocrático}

O controle da atividade administrativa foi historicamente baseado em critérios formais, procedimentais e dissociados de qualquer espécie de sopesamento entre os resultados pretendidos e os efetivamente alcançados.

A atividade fiscalizatória se desenvolvia, então, a partir de premissas que retratavam o agir administrativo como um fim em si mesmo, de forma divorciada de suas 
repercussões no mundo dos fatos, e sem qualquer preocupação com a responsividade, com o real atendimento ao interesse público.

Tendo em vista a ineficácia e a característica iníqua dessa forma de controle, a sua performance já não pode ser tida como satisfatória. ${ }^{421}$

Realmente, o controle unicamente burocrático já não condiz com as necessidades e expectativas contemporâneas, devendo ser complementado, pois, por indicativos outros, mais profundos e assecuratórios — ou persecutórios — da promoção e incremento da qualidade do agir público.

Os novos paradigmas orientadores da atuação administrativa e social - e da interação entre esses dois campos - exigem meios voltados à real avaliação da qualidade da ação administrativa e do gasto público, sob uma perspectiva marcadamente do destinatário final dessa atuação e do atendimento às demandas coletivas tidas como dignas de promoção e atendimento pela esfera pública.

Segundo Moreira Neto (2008, p. 127), “Contém-se, portanto, na abordagem filosófica, o sentido substantivo de democracia, significando - mais do que um simples método de decisão coletiva e, em particular, de escolha dos governantes e da lei que deve nos reger - uma exigência de resultados coerentes com os valores que a informam.”

Nas palavras de Ceneviva e Farah:

\begin{abstract}
A introdução de mecanismos de controle social e de responsabilização da administração pública pelo desempenho de políticas e programas governamentais aparece [...] como uma promessa de substituição de um modelo no qual impera o controle burocrático baseado na observância a normas e procedimentos, sem a participação dos cidadãos, para outro no qual se estabelece o controle a posteriori dos resultados da ação governamental, e no qual a sociedade participa da definição de metas e dos índices de desempenho, assim como da avaliação direta de bens e serviços públicos. (CENEVIVA; FARAH, 2007, p. 147).
\end{abstract}

Essa tendência restou bem retratada no anteprojeto da Lei Orgânica da Administração Pública, formulado por comissão de juristas de escol, ${ }^{422}$ em sua exposição de motivos:

\footnotetext{
${ }^{421}$ Nesse sentido a exposição de motivos do anteprojeto de Lei Orgânica a Administração Pública. Ministério do Planejamento, Orçamento e Gestão. 2007, p. 14.

${ }^{422}$ Participaram da comissão os professores Almiro do Couto e Silva, Carlos Ari Sundfeld, Floriano de Azevedo Marques Neto, Paulo Eduardo Garrido Modesto, Maria Coeli Simões Pires, Sergio de Andréa e Maria Sylvia Di Pietro.
} 
Tendo isso em vista e levando em conta o forte processo de mudança que o controle tem sofrido no direito comparado (em especial na União Europeia), as diretrizes gerais do controle, adotadas no anteprojeto, foram ditadas pela supressão de controles meramente formais ou cujo custo seja evidentemente superior ao risco (diretriz já constante do Decreto-lei 200/67), pelo fortalecimento do controle a posteriori (ao invés da vertente ex ante que predomina atualmente); pelo predomínio da verificação de resultados (ao invés do controle formal hoje prevalecente); pela simplificação dos procedimentos, erradicação de sobreposição de competências e instrumentos de controle (a fim de que a multiplicidade de mecanismos de controle não acarrete a sobreposição e, com ela, a ineficiência); pela obrigatoriedade dos órgãos ou entes de controle verificarem a existência de alternativas compatíveis com as finalidades de interesse público dos atos ou procedimentos que sejam por eles impugnados; e pela responsabilização pessoal do agente que atuar com incúria, negligência ou improbidade (a responsabilização do próprio gestor).

Mais que ir além do controle burocrático, referido projeto o afastou em definitivo, concentrando toda sua carga no controle de resultados - em opção que pode vir a trazer, da mesma forma, e a nosso ver, grandes embaraços.

Primeiramente, porque a mudança radical e repentina de um extremo a outro tende a gerar perplexidades e dificuldades de compreensão e, portanto, aplicação aos seus destinatários - agentes públicos, fundamentalmente - cuja cultura e postura há tempos sedimentada tende a resistir e encontrar dificuldades de adaptação.

Segundo, porque, ainda que, em exagero, finde por gerar dificuldades e prejuízo para o desenvolvimento dos atos e, assim, contingências ao atendimento dos interesses públicos, o respeito a formas preestabelecidas e voltadas à aferição do destino outorgado às receitas públicas repassadas, se inserido em um contexto maior, de ênfase - mas não dominação exclusiva - da perquirição de resultados, pode se apresentar de grande utilidade.

Defendemos um sistema de controle, composto por essas duas modalidades formal e gerencial, de resultados - como meio de melhor satisfação possível aos objetivos finais da ação fiscalizada ${ }^{423}$ :

A responsabilidade por resultados. A boa Administração segue exigindo a adequação da conduta dos servidores públicos a elevados standards de probidade e jogo limpo, mas sua exigências vão mais além da mera observância dos procedimentos. Os gestores públicos também devem tomar responsabilidade pelos resultados de sua atuação, o que obriga à

\footnotetext{
${ }^{423}$ Nesse sentido, manifestação do TCU no Acórdão n. 2.640/2008, $1^{\text {a }}$ Câm. rel. Min. Marcos Bemquerer,
} item 2.1.19. 
colocação em andamento de mecanismos efetivos de exigência e rendição de contas, mas implica, sobretudo, interiorizar a responsabilização pelos resultados como um valor inerente á gestão pública. [...] A orientação a resultados não pode incorporar-se às custas de vulnerar uma série de exigências procedimentais básicas. (LONGO, 2008, p. 297-309, traduzimos).

Aspecto preliminar dessa espécie de controle é a prévia fixação de metas e resultados pretendidos - sem a qual ficará aquele absolutamente comprometido.

Referida definição não se dá a partir de ferramentas exclusivamente técnicas; contrariamente, segue critérios em grande medida políticos (CENEVIVA; FARAH, 2007, p. 149), posto que umbilicalmente ligados ao processo de planejamento e definição de políticas públicas (os quais poderão, ou deverão, ser também acompanhados e coprotagonizados por atores da sociedade civil).

No que tange aos objetivos do controle de resultados, tem-se, com Ceneviva e Farah: a) a modificação do comportamento excessivamente autorreferenciado da burocracia, a qual passa a contar - e a dever observar - metas e resultados claros, que não serão fixados unilateralmente por atores internos à Administração, mas também por integrantes da sociedade civil; b) o desenvolvimento de uma modalidade de accountability baseada no desempenho de políticas e programas governamentais, na qualidade da gestão pública, a qual tenderá a ser, nesses moldes, mais legítima e responsiva. (CENEVIVA; FARAH, 2007, p. 152).

Não obstante a relevância das ponderações apresentadas, e a importância da adoção do controle de resultados para o bom desempenho das funções públicas e, portanto, para a satisfação dos interesses coletivos, essa não tem sido, via de regra, a tônica, no que tange aos convênios.

Realmente, em se tratando dessa espécie de parceirização, o que normalmente se constata é concentração das ações fiscalizatórias sobre os aspectos formais, burocráticos e procedimentais do gasto das receitas públicas e atuação das entidades parceiras. ${ }^{424}$

Essa característica não se restringe ao controle efetivado pela Administração, estendendo-se também aos diversos atores institucionais de controle externo.

Apesar dessa tendência observada, a concepção da fiscalização dos convênios e das relações dele decorrentes não têm que, necessariamente, seguir esses moldes.

\footnotetext{
${ }^{424}$ Nesse sentido, o Decreto federal n. 6.170/98, a IN n. 01/97, o Decreto municipal n. 49.539/2008 e o próprio artigo 116 da Lei de Licitações.
} 
Aliás, não é mesmo recomendável que assim o seja, vez que assente, conforme exposto, a insuficiência desses mecanismos.

Tal visão foi incorporada à legislação municipal de São Paulo relativa aos convênios formalizados na área da assistência social, para os quais se criou uma série de indicativos de resultados, de eficácia e qualidade. ${ }^{425}$

${ }^{425}$ Conforme artigo $8^{\circ}$, II, da Lei municipal 13.153/01: “Art. $8^{\circ}$. A análise do órgão competente sobre as propostas de convênio apresentadas deverá ser submetida a audiência pública convocada através do Diário Oficial do Município: II - o órgão competente deverá publicar no Diário Oficial do Município a homologação do convênio, especificando seu valor, sua quantificação, prazo e padrões de qualidade a serem assegurados." Atente-se, ainda, para o disposto nos artigos 23, 24, 25 e 26 da Portaria n. 28/08/SMADS: "Art. 23. As organizações sem fins lucrativos conveniadas deverão apresentar anualmente, até o dia 15 de janeiro, a Grade de Ofertas de Atividades Socioassistenciais - Groas, por meio da qual dimensionarão a operação do serviço conveniado durante o respectivo ano, observando-se os parâmetros definidos pela Secretaria Municipal de Assistência e Desenvolvimento Social. § $1^{\circ}$. A Grade de Ofertas de Atividades Socioassistenciais - Groas deverá conter o detalhamento necessário para orientar o conteúdo do processo mensal de supervisão técnica que verificará se o desempenho do serviço corresponde, em quantidade e qualidade, ao programado e conveniado para efeito de convalidar, em seu parecer técnico, o valor do pagamento mensal; § $2^{\circ}$. A Secretaria Municipal de Assistência e Desenvolvimento Social estabelecerá planilhas específicas, a serem entregues mensalmente pelas organizações conveniadas, para demonstração da qualidade e a quantidade dos serviços realizados, a serem avaliados de acordo com o previsto na Groas e no índice de satisfação dos usuários. Art. 24. Para registro e demonstração da execução dos serviços, do acompanhamento técnico, da supervisão técnica e da prestação de contas da aplicação dos recursos financeiros e demais procedimentos complementares dos serviços socioassistenciais conveniados, são instituídos os instrumentos que seguem, que poderão ser disponibilizados pela Secretaria Municipal de Assistência e Desenvolvimento Social, preferencialmente, com extensão 'xxls': I - Demes - Declaração Mensal da Execução do Serviço Socioassistencial, que deve ser preenchida e assinada pelo responsável designado pela organização e entregue mensalmente à Supervisão de Assistência Social ou à Secretaria Municipal de Assistência e Desenvolvimento Social, dependendo da responsabilidade pelo acompanhamento da execução do serviço conveniado, da qual conste: a) a grade de atividades desenvolvidas no mês, o número de usuários atendidos, a confirmação da aplicação de normas técnicas que orientam a metodologia socioeducativa; b) o desenvolvimento do serviço sob gestão conveniada com observância dos direitos dos usuários; c) a confirmação de envio das informações mensais para o(s) sistema(s) de monitoramento e avaliação da Secretaria Municipal de Assistência e Desenvolvimento Social; d) a confirmação do registro dos usuários e da atualização de seus dados no respectivo cadastro de usuários; e) a vinculação do funcionamento do serviço ao Sistema Único de Assistência Social - Suas, demonstrado pelos vínculos de acesso por meio do Centro de Referência da Assistência Social, a ação em rede e, o controle de qualidade das aquisições dos usuários através do(s) sistema(s) de monitoramento e avaliação. II - Resup - Relatório Mensal de Supervisão Técnica, do qual conste: a) parecer da supervisão técnica; b) ações desenvolvidas no mês para qualificação da gestão do respectivo serviço, como reuniões, treinamentos, entre outras informações sobre a qualidade e quantidade da prestação de serviço pela conveniada e a necessidade de aplicação de alguma nova ação pela conveniada para a readequação da prestação do serviço ou para qualificação dos trabalhadores sociais; c) manifestação de concordância e a cada final do trimestre, quando for o caso, com a alteração do valor de aplicação do recurso financeiro entre os elementos de despesa previstos; d) manifestação sobre a regularidade da conveniada quanto à entrega da Demes e da Degref. [...] VII - Groas - Grade de Ofertas de Atividades Socioassistenciais, planejadas para desenvolvimento no decorrer do ano, de acordo com o padrão técnico e metodológico estabelecido para o serviço e as características do grupo de usuário para melhor alcance da qualidade de resultados e previsão de horas técnicas no desenvolvimento das atividades, devendo ser apresentada até o $15^{\circ}$ dia de janeiro de cada ano para apreciação, analise e manifestação do técnico supervisor; VIII - Sistema(s) de monitoramento e avaliação destinados(s) ao registro e acompanhamento mensal dos resultados dos serviços conveniados, de projetos e de atividades como parte do Sistema Único de Assistência Social. Art. 25 - A aferição mensal da qualidade e quantidade do serviço socioassistencial conveniado será realizada através dos seguintes meios e procedimentos: I - responsabilidade nominal de um servidor, como técnico supervisor do serviço socioassistencial, designado através de ato publicado em Diário Oficial da Cidade pelo Supervisor de Assistência Social da Coordenadoria de Assistência Social e Desenvolvimento da Subprefeitura quando se tratar de serviço descentralizado ou, no caso de serviço cuja supervisão seja realizada diretamente pela 
Imprescindível, portanto, um aggiornamento do tratamento legislativo, técnicoadministrativo e jurisprudencial dispensado ao controle, no que respeita aos convênios, tanto público-públicos quanto público-privados — sob pena de ficar esse instrumental defasado e descompassado com o atual cenário técnico-dogmático e, mais que isso, com as próprias demandas da sociedade do século XXI.

Nas palavras de Moreira Neto:

[...] essa expressão do controle, assim ampliado par se tornar também prospectivo, tanto em sede política, quanto em sede jurídica, registra notável empenho no aprofundamento cada vez mais intenso dos judiciários no controle de políticas públicas, nele compreendida a da eficiência e a da economicidade de sua formulação, de sua execução e, sobretudo da legitimidade de seus resultados, abrangendo, assim, todo seu espectro temporal e todos os seus desdobramentos prováveis, o que se vai tornando cada vez mais importante para evolver aos cidadãos a segurança quanto a seu próprio futuro e a de seus respectivos países, ao abrir-lhes a possibilidade de participarem mais intensamente e com grande proveito geral, no governo e na administração do que á seu - na gestão da res publica. (MOREIRA NETO, 2008, p. 142).

Firmado esse cenário, cumpre-nos passar à análise da incidência dos vários momentos do ciclo do fomento àquele implementado por meio do CMDCA/SP, inclusive no que tange ao próprio controle. É o que faremos no item seguinte.

Secretaria Municipal de Assistência e Desenvolvimento Social, pela Chefia de Gabinete desta; II responsabilidade nominal de um técnico como gerente do serviço conveniado, designado pela organização parceira por meio de declaração formal protocolada junto à Supervisão de Assistência Social da Subprefeitura ou da unidade responsável da Secretaria Municipal de Assistência e Desenvolvimento Social, conforme o caso; III - manutenção, pela Coordenadoria de Gestão de Pessoas da Secretaria Municipal de Assistência e Desenvolvimento Social, de Banco de Dados dos Técnicos Supervisores e dos Gerentes de Serviços indicados pelas organizações conveniadas, especificando o número de serviços supervisionados/gerenciados e formação profissional; IV - entrega mensal da Demes, assinada pelo gerente designado pela organização conveniada, até o $3^{\circ}$ dia útil, de cada mês, para a Supervisão de Assistência Social ou para a Secretaria Municipal de Assistência e Desenvolvimento Social, conforme o caso; V elaboração mensal do Resup pelo técnico supervisor do respectivo serviço até o $5^{\circ}$ dia útil do mês subseqüente à prestação do serviço. Caso constatada quaisquer das irregularidades ou impropriedades previstas no $\S 3^{\circ}$, incisos I e II, do artigo 116 , da Lei federal n. 8.666/93, o técnico supervisor responsável deverá indicá-la no Relatório Mensal de Supervisão - Resup, bem como as providências que determinou serem tomadas pela organização parceira para saná-las e, ainda, a medida de retenção de parcelas do convênio até o saneamento das impropriedades verificadas. Neste caso deverá informar a medida também na Planilha Mensal de Liquidação. Art. 26 - A Secretaria Municipal de Assistência e Desenvolvimento Social designará equipes para realizar verificações programadas no local onde se realiza o serviço sob gestão conveniada, para o monitoramento e avaliação dos resultados da ação e da correta aplicação dos recursos financeiros, requisitando os documentos comprobatórios das despesas realizadas e os registros técnicos necessários." 


\subsection{Os quatro momentos do ciclo do fomento na esfera do Conselho Municipal dos Direitos da Criança e do Adolescente de São Paulo}

Conforme assente no capítulo 1, a atividade administrativa de fomento observa, em seu exercício, um ciclo, que tem início no diagnóstico das demandas sociais, com o planejamento dessa atuação, passando pela sua efetivação propriamente dita, seu controle e a responsabilização dos envolvidos por eventuais deslizes.

Referida dinâmica se reproduz, à perfeição, no CMDCA/SP.

\subsubsection{Planejamento}

O planejamento do fomento, no âmbito da criança e adolescente na cidade de São Paulo, se inicia com ações de diagnóstico que, conforme exige o ordenamento jurídico, deverão ser levadas a termo com vista a orientar os passos seguintes desse ciclo.

Temos, nesse sentido, o diagnóstico da situação da infância e juventude como um dos pilares das políticas públicas a serem desenvolvidas.

Trata-se de medida louvável, uma vez que possibilita a efetiva coerência entre as ações a serem desenvolvidas - e, portanto, a mobilização e investimentos públicos - e as demandas reais.

Encontra previsão, em nível federal, na Resolução n. 137 do Conanda, cujos artigos $9^{\circ}$, II e III, e 15, III, assim dispõem:

Art. $9^{\circ}$. Cabe ao Conselho dos Direitos da Criança e do Adolescente, em relação aos Fundos dos Direitos da Criança e do Adolescente, sem prejuízo das demais atribuições:

[...]

II - promover a realização periódica de diagnósticos relativos à situação da infância e da adolescência bem como do Sistema de Garantia dos Direitos da Criança e do Adolescente no âmbito de sua competência; III - elaborar planos de ação anuais ou plurianuais, contendo os programas a serem implementados no âmbito da política de promoção, proteção, defesa e atendimento dos direitos da criança e do adolescente, e as respectivas metas, considerando os resultados dos diagnósticos realizados e observando os prazos legais do ciclo orçamentário;

Art. 15 A aplicação dos recursos do Fundo dos Direitos da Criança e do Adolescente, deliberada pelo Conselho de Direitos, deverá ser destinada para o financiamento de ações governamentais e não-governamentais relativas a:

III - programas e projetos de pesquisa, de estudos, elaboração de diagnósticos, sistemas de informações, monitoramento e avaliação das 
políticas públicas de promoção, proteção, defesa e atendimento dos direitos da criança e do adolescente;

Referido diagnóstico é previsto, desde o ano de 2004, pela Resolução n. 73 do CMDCA/SP, e foi finalizado no ano de 2007, a partir de parceria levada a termo pela Secretaria Municipal de Participação e Parceria ${ }^{426}$ (à época, Secretaria Especial).

$\mathrm{O}$ artigo $3^{\circ}$ do Decreto municipal n. 43.135/03 estabelece que "o Fumcad contará com verba procedente do orçamento municipal para: III - organização da Conferência Municipal dos Direitos da Criança e do Adolescente e de outros eventos de interesse público relacionados aos direitos das crianças e adolescentes”.

Vale lembrar, ainda, a Lei municipal n. 15.114, de 14 de janeiro de 2010, que, além de tratar da "criação de Observatório de proteção integral à infância e adolescência", estabelece também o Sistema de Diagnóstico da Situação da Criança e do Adolescente, constituído por indicadores sociais relativos a essa temática.

Referida Lei foi regulamentada pelo Decreto municipal n. 51.885, de 27 de outubro de $2010 .^{427}$

Os indicativos decorrentes desses diagnósticos e da atuação do observatório orientam os editais Fumcad, ${ }^{428}$ fazendo-se necessária, portanto, a sua constante atualização, na medida em que o contexto social e populacional são dinâmicos, sendo a

426 Os resultados do diagnóstico efetivado podem ser conferidos no site: <http:// www.conferenciapermanente.com/diagnostico2007/consultas.php>. Digna de menção, ainda, a pesquisa "Conhecendo a realidade", promovida conjuntamente pela Secretaria Especial dos Direitos Humanos da Presidência da República e pelo Conanda, no ano de 2007. Os resultados encontram-se disponíveis no site: <http://www.promenino.org.br/Portals/0/docs/ficheros/200707170012_15_0.pdf>.

${ }^{427}$ Cujos artigos $2^{\circ}$ e $3^{\circ}$ têm a seguinte redação: "Art. $2^{\circ}$. O Observatório deverá reunir informações com vistas ao diagnóstico da situação da criança e do adolescente na Cidade de São Paulo, utilizando-se de indicadores sociais, compostos por indicadores socioeconômicos, indicadores específicos para crianças e adolescentes e indicadores de controle. $\S 1^{\circ}$. Os indicadores sociais sobre crianças e adolescentes são medidas relevantes que possibilitam avaliar detalhadamente as principais características do segmento e referem-se a: I - saúde; II - educação; III - assistência social; IV - proteção e defesa; V - protagonismo; VI - controle. $\S 2^{\circ}$. Os indicadores socioeconômicos são informações que caracterizam condições de vida e situação econômica da população e do segmento de interesse, contendo: I - contingente populacional; II - composição etária; III densidade demográfica; IV - tipo de domicílio, abrangendo: a) renda por domicílio; b) condição de ocupação do domicílio; c) densidade domiciliar; d) domicílios em setores subnormais; e) cobertura de saneamento básico (água e esgoto); f) cobertura de coleta de lixo; g) jovens responsáveis por domicílio. $\S 3^{\circ}$. Os indicadores de controle são instrumentos de informações gerenciais que auxiliam no planejamento estratégico, seus desdobramentos e no desenvolvimento das atividades do Conselho Municipal dos Direitos da Criança e do Adolescente - CMDCA e demais órgãos de controle e de fiscalização. $\S 4^{\circ}$. Os indicadores referidos neste decreto, para os efeitos e observadas as definições constantes da Lei 15.114, de 2010, serão objeto de especificação e seleção por grupo de trabalho constituído para essa finalidade. Art. $3^{\circ}$. Compete ao Conselho Municipal dos Direitos da Criança e do Adolescente - CMDCA, por força das atribuições que lhe são conferidas em leis próprias, adotar as medidas necessárias à implementação e operacionalização da Lei 15.114, de 2010."

${ }^{428}$ Os editais Fumcad 2009 a 2012 trazem, na qualidade de anexos, o diagnóstico de vulnerabilidade social das crianças e adolescentes no município, assim como o mapeamento dos serviços e atendimentos oferecidos, por região - os quais orientarão a análise e classificação dos projetos apresentados. 
paralização no levantamento de informações extremamente prejudicial das políticas públicas a serem desenvolvidas.

Outra importante ferramenta de orientação ao planejamento, na seara da infância e juventude, são as Conferências, tradicionais e lúdicas, ${ }^{429}$ que ocorrem em nível municipal, estadual e federal, de forma a criar um verdadeiro sistema de proteção à criança e adolescente, com o desenvolvimento de políticas e posturas coerentes, harmônicas e complementares.

Nas palavras de Ferrarizi e Oliveira:

Hoje, as Conferências lideradas pelos governos são consideradas espaços institucionalizados de participação social, nos quais sociedade civil e Estado mobilizam-se, dialogam e avaliam a política e as ações desenvolvidas, produzindo propostas e diretrizes a serem incorporadas nas agendas governamentais. Conferências são um meio para lidar com questões complexas de políticas públicas. Permitem aos governos adquirirem conhecimento, anteciparem padrões e demandas emergentes, e experimentarem diálogo e colaboração com participantes, com potencial de gerar resiliência (NS6, 2009) - capacidade de se adaptar a adversidades e se antecipar a mudanças. São espaços para aprendizagem. A sociedade aprende sobre o modo de funcionamento do Estado e sobre a própria participação, assumindo parte da responsabilidade pelo interesse coletivo. O governo, por sua vez, aprende a dialogar, reconhecer demandas e adaptar mecanismos burocráticos para interlocução. Em conjunto, contribuem para obter melhores resultados de políticas públicas e também para obter resultados cívicos (reconhecimento e legitimidade de atores, das demandas e decisões geradas, com compromissos recíprocos na esfera pública). A capacidade de os movimentos sociais e associações civis serem resilientes na democratização, de se adaptar e inovar, gerou novos papéis para a sociedade (coprodução de políticas, colaboração, compromissos recíprocos) e para o governo, que ao se abrir à interlocução, gerou um campo novo de atuação que tem que integrar informações e conhecimentos que vem da base social. (FERRAREZI; OLIVEIRA, 2010, p. 1-2).

Constituem importante canal de comunicação entre Estado e sociedade, por meio do qual se fará possível a conquista de uma atuação da Administração marcada pela legitimidade, responsividade e eficiência, com o consequente incremento das condições

\footnotetext{
429 “Conferências 'Lúdicas' são espaços de participação democrática, formados por crianças e adolescentes representantes de suas associações (escolas, entidades, outros) como o objetivo de avaliar e conferir como as políticas públicas para o segmento infanto-juvenil estão sendo executadas. A dinâmica de uma Conferência Lúdica respeita a diversidade étnica, social, de origem, gênero e a fase peculiar de desenvolvimento, portanto, a linguagem e a forma de discutir a política estão diretamente relacionadas aos protagonistas do evento, ou seja, fazer a Conferência com as crianças e adolescentes. [...] O marco legal é o próprio Estatuto da Criança e do Adolescente. Não há essa nomenclatura "conferências lúdicas" no ECA, mas há a compreensão ampla do direito à participação na vida política e da Educação para o exercício da cidadania, conforme artigos 15; 16; 58 e 59." (LONGO, 2011).
} 
sociais, econômicas, culturais e democráticas da comunidade. Vem sendo adotada em diversos países, como Espanha, Suíça e Itália, sempre com resultados bastante satisfatórios. (OCDE, 2008, p. 47).

Não obstante as suas conclusões não gozarem de efeitos vinculantes para os governantes, ${ }^{430}$ entendemos que o seu afastamento deve ser amplamente justificado - sob pena de déficit de legitimidade (a qual, conforme anteriormente visto, integra o conceito moderno de legalidade ${ }^{431} \mathrm{e}$, portanto, de juridicidade dos atos).

Nesse cenário, a discricionariedade do administrador será relativizada, vez que compartilhada: as demandas sociais consubstanciadas a partir das Conferências se situarão em posição superior - em uma escala de compatibilidade com o interesse público e capacidade de satisfação das demandas sociais — que as demais, igualmente viáveis, porém não qualificadas por esse plus legitimante e democrático. ${ }^{432}$

Ultrapassada a etapa do diagnóstico, necessário o planejamento das ações propriamente dito - o que se fará a partir de um imbricado sistema de normas, lastreadas desde a Constituição Federal até as Resoluções do CMDCA/SP.

Todo esse processo deverá ser permeado, conforme se depreende do até o momento exposto, por constante diálogo e participação social.

Nesse sentido, o artigo 41, XI, da Lei Orgânica do Município de São Paulo:

Art. 41 - A Câmara Municipal, através de suas Comissões Permanentes, na forma regimental e mediante prévia e ampla publicidade, convocará obrigatoriamente pelo menos 2 (duas) audiências públicas durante a tramitação de projetos de leis que versem sobre:

$[\ldots]$

XI - atenção relativa à Criança e ao Adolescente.

\footnotetext{
${ }^{430}$ Veja-se, nesse sentido: "Não é suficiente nem conveniente que o resultado das consultas populares seja vinculante para o Executivo, pois este deve ter uma visão mais ampla do todo o conjunto de projetos e programas, tendo, pois, condições para promover a possível conciliação entre todos os interesses, no momento de formalização da proposta a ser encaminhada ao Legislativo. Porém as manifestações dos diversos segmentos da sociedade não podem ser inócuas. A participação popular exercitada no âmbito do Executivo precisa ser continuada no decurso do processo legislativo da lei orçamentária. Os interesses dos segmentos populares devem, sim, ser devidamente sopesados pelos representantes do povo das casas legislativas, diante dos interesses globais da coletividade, ali representada." (DALLARI, 2011, p. 322).

431 Especificamente no que tange à relação entre as diretrizes traçadas nas Conferências e a atividade legislativa, recomenda-se a consulta ao número 27/2010 da série Pensando o Direito (BRASIL. Ministério da Justiça, 2010).

${ }^{432}$ Registre-se, porém, análise externada no Plano Estratégico do CMDCA/SP 2010-2012, em que se aponta a não observância, pelo Executivo municipal, das conclusões alcançadas pelas Conferências em questão, em vista do que propõe a entrega das propostas e respectivos planos de execução ao Executivo, Legislativo e Judiciário, com vista a "sensibilizar quanto à importância da inclusão das propostas no PPA e construir o plano de execução das propostas das conferências."
} 
A elaboração das leis orçamentárias e do plano diretor também contará com a marcante participação da população, em um processo transestatal e transinstitucional de produção legislativa e planejamento de ações retratado nos incisos I, II, III e IV desse $\operatorname{artigo} 41$.

Aperfeiçoadas as discussões e assentadas as opções correspondentes nos instrumentos legislativos decorrentes, caberá primordialmente ao CMDCA/SP lhes outorgar efetividade, a partir da elaboração dos planos de metas e aplicação. ${ }^{433}$

A esses se seguirão as resoluções correspondentes e, por fim, os editais Fumcad, encarregados especificamente de estabelecer as regras a serem seguidas nas relações de fomento. $^{434}$

Nesse diapasão, assinalamos a fixação, pelo órgão de participação popular, dos eixos temáticos prioritários que orientarão toda a atividade de incentivo na área da infância e juventude no âmbito do município.

Referidos eixos constam do plano estratégico de atividades do Conselho, veiculado pela Publicação n. 230/2010 do CMDCA, $^{435}$ e são: a) funcionamento institucional e estrutura administrativa; b) interlocução com outros atores e relações institucionais; c) Fumcad e COT; ${ }^{436}$ d) conferência dos direitos da criança e do adolescente; e) comunicação; f) conselhos tutelares.

Além desses, há também os eixos temáticos, veiculados pelos editais Fumcad. ${ }^{437}$

\footnotetext{
${ }^{433} \mathrm{Na}$ lição de Moreira Neto, “[...] o primeiro nível do complexo de processamentos é predominantemente político, consistindo na decisão de objetivos e na elaboração do planejamento - de como o Governo pretende dar cumprimento à sua missão constitucional, ou seja, através de planos, gerais e setoriais, sendo exemplo dos primeiros, o plano plurianual (art. 84, XXIII, CF) e, dos segundos, o plano de governo (84, XI, $\mathrm{CF}$ ), além da previsão de vários planos setoriais (art. 21, IX, 39;165, § $4^{\circ}$ e 182, § $1^{\circ} ; 20, \mathrm{CF}$ ). O segundo nível entrelaça a formulação política e a administração, consistindo na etapa financeiro-orçamentária, na qual os planos recebem a sua expressão orçamentária em forma de dotações de recursos constantes do plano plurianual (165, I), das diretrizes orçamentárias (art. 165, II), e dos orçamentos anuais (art. 165, III, CF). O terceiro nível do complexo processual, por fim, é o predominantemente administrativo, consistindo no processo em que se desenvolve a programação executiva dos planos aprovados e orçamentados (art. 84, II, CF) para sua efetivação. Como se observa, apenas neste terceiro nível processual, de caráter executivo, que sobrevém ao planejamento e à orçamentação, é que os interesses gerais realmente atingem sua expressão juridicamente precisa, ou seja, identificados com interesses específicos, de modo que quaisquer políticas públicas devem observar esse iter constitucionalmente disposto para formulá-las, orçá-las e executá-las." (MOREIRA NETO, 2008, p. 125)

${ }^{434}$ As quais contam com previsão expressa, inclusive, no artigo 229 da Lei Orgânica do Município: “Art. 229. O Município estimulará, apoiará, e, no que couber, fiscalizará as entidades e associações comunitárias que mantenham programas dedicados às crianças, aos adolescentes, aos idosos e aos portadores de deficiência."

${ }^{435}$ Publicada no Diário Oficial da Cidade do dia 28 de dezembro de 2010.

${ }^{436}$ Conselho de Orientação Técnica.

437 No caso do Edital/Fumcad/2012: I - Assistência Social A - Sistema Nacional de Atendimento Socioeducativo ao Adolescente em Cumprimento de Medidas Socioeducativas e suas ações: a) Atendimento a adolescentes egressos das medidas de internação e semiliberdade e que cumpram medidas socioeducativas em meio aberto, excepcionalmente até 21 anos; b) Formação de Operadores do Sistema de Atendimento
} 
Socioeducativo ao Adolescente em cumprimento de medidas socioeducativas; c) Apoio a Serviços de Defesa Técnica dos Adolescentes em cumprimento de Medidas Socioeducativas; d) Apoio a projetos que visem à disseminação de práticas restaurativas; e) Projetos que tenham como objetivo: auxílio, apoio e orientação à família, a criança e ao adolescente (atendimento psicossocial e/ou jurídico) e ações que estimulem e provoquem o desacolhimento e propiciem os encaminhamentos necessários para garantir o direito à convivência familiar natural, ampliada ou substituta e comunitária conforme $\S 2^{\circ}$ do art. 260 do ECA. B Sistema de Garantia dos Direitos da Criança e do Adolescente e suas ações: a) Fortalecimento dos Fóruns de defesa da criança e do adolescente; b) Incentivo à participação ativa da criança e adolescente na elaboração de ações visando seu desenvolvimento; c) Apoio a Estudos e Pesquisas sobre Infância e Adolescência; d) Capacitação de Profissionais para Promoção e Defesa dos Direitos da Criança e do Adolescente; e) Capacitação de Profissionais envolvidos na educação formal e integral da criança e do adolescente (gestores, educadores e/ou professores); f) Capacitação dos atores e profissionais com atuação no acolhimento institucional e familiar; g) Fortalecimento da gestão organizacional; h) Capacitação dos atores do sistema de garantia de direito; i) Apoio a Promoção de Boas Práticas de Fortalecimento do Sistema de Garantia de Direitos. C - Enfrentamento ao trabalho infantil: a) Projetos voltados a intensificar a conscientização, a divulgação, aprofundamento nas discussões sobre o tema; b) Projetos que possibilitem o fortalecimento da articulação local bem como de esclarecimento e informação aos alunos e comunidade escolar; c) Projetos que desenvolvam atividades de fortalecimento do vínculo entre responsáveis e crianças/adolescentes retirados do trabalho infantil; d) Projetos que intensifiquem a inclusão das crianças e adolescentes retiradas do trabalho infantil, em atividades comunitárias (culturais esportivas e/ou lúdicas); e) Projetos voltados ao diagnostico de crianças e adolescentes em situação de trabalho infantil; f) Projetos voltados ao apoio, orientação e acompanhamento sócio familiar das crianças e adolescentes em situação de trabalho infantil; g) Prevenção e erradicação do trabalho infantil; h) Crianças e Adolescentes na rua, bem como Crianças e Adolescentes em situação de Moradia de Rua; h-1) Projetos voltados ao diagnostico de crianças e adolescentes em situação de moradia de rua e na rua; h-2) Projetos voltados ao apoio, orientação e acompanhamento sócio familiar das crianças e adolescentes em situação de moradia de rua e na rua; h-3) Projetos voltados ao atendimento de crianças e adolescentes em situação de moradia de rua e na rua. II - Saúde: a) Projetos voltados à promoção, prevenção, atendimento e acompanhamento de crianças e adolescentes em sofrimento mental; b) Projetos voltados à promoção, prevenção, atendimento, acompanhamento e/ou tratamento ao abuso de álcool, tabaco e outras drogas; c) Projetos voltados à promoção, prevenção, acompanhamento e/ou tratamento da DST/AIDS e sexualidade na adolescência; d) Projetos voltados á disseminação da Cultura de Paz: d-1) Níveis de prevenção e atendimento as vitimas de violência sexual, bem como combate ao abuso e exploração sexual; d2) Violência doméstica: projetos que tenham como objetivo a prevenção, acompanhamento e atendimento às violências domésticas. e) Acidentes Domésticos: e-1) projetos que tenham como objetivos campanha para informação, orientação e prevenção dos acidentes domésticos; e-2) projetos que tenham como objetivo o acompanhamento e/ ou atendimento as vitimas de acidentes domésticos; f) Projetos para crianças e adolescentes com deficiências voltadas ao diagnóstico, acompanhamento e/ou tratamento e inclusão social; g) Projetos voltados à promoção, prevenção e acompanhamento de distúrbios alimentares em crianças e adolescentes; h) Projetos voltados à promoção, prevenção, acompanhamento e/ou tratamento em saúde bucal; i) Projetos voltados à promoção, prevenção, acompanhamento e/ou tratamento em saúde ocular. III Educação: a) Projetos de educação ambiental e/ou formação de jovens agentes ambientais; b) Projetos de formação em valores para a convivência na escola; c) Projetos que visem à disseminação de práticas restaurativas e de mediação para resolução de conflitos no âmbito da escola; d) Projetos de formação de leitor; e) Projetos que propiciem o ensino de línguas estrangeiras; f) Projetos voltados aos alunos provenientes de famílias de imigrantes, com atenção especial às latino-americanas, tendo como objetivo a sua integração e convivência na escola; g) Projetos de orientação para pais sobre o ciclo de vida, fases e educação dos seus filhos; h) Projetos complementares à ação da escola no âmbito da inclusão das crianças e adolescentes deficientes; i) Projetos que desenvolvam as diferentes linguagens no campo das artes sejam: música, dança, teatro, literatura e artes visuais; j) Projetos voltados à complementação cultural, esportiva e educacional para os CEUs (incluindo cursos para docentes: treinamento/rendimento; iniciação esportiva; atividade física e saúde; curso para alunos: formação profissionalizante em arbitragem esportiva); k) Projetos voltados à inclusão digital, incluindo cursos, capacitação e formação profissional em informática. IV Esporte, Cultura e Lazer: a) Projetos que possibilitem a realização de ações ligadas à promoção do esporte, cultura e lazer que tenham como foco a inclusão social e ações preventivas. V - Trabalho: a) Iniciativas voltadas à formação e/ou qualificação profissional do adolescente — apoio à entrada no mercado de trabalho e geração de renda. b) Projetos que propiciem a aprendizagem com base na Lei do Aprendiz 10.097/00, que permitam a formação técnica profissional e metódica de jovens entre 14 e 18 anos, dentro dos princípios da proteção integral do adolescente garantido pela legislação brasileira, bem como apoio à entrada no mercado 
Enquanto os primeiros vinculam a atividade conselheira em sua plenitude, os segundos se adstringem à atividade de fomento iniciada com a publicação do edital, com o posterior conveniamento e demais repercussões decorrentes.

Repisamos, por fim, que essa atividade do Conselho é marcada pela liberdade regrada correspondente à discricionariedade: nesse ponto, o papel protagonista dos governantes é transferido a essa arena de participação, a qual estará submetida, nas suas decisões, única e exclusivamente ao ordenamento jurídico.

Estabelecidos os parâmetros a serem observados nas futuras atividades de fomento e, portanto, nas parceirizações levadas a efeito pelo Conselho com as receitas do Fundo, chegamos ao momento de sua formalização propriamente dita, tema do próximo subitem.

\subsubsection{Incidência propriamente dita: a efetivação da relação de fomento com o destinatário imediato}

A efetivação da relação de fomento, no âmbito da infância e juventude e do Fumcad/SP se dá, conforme assentado, por meio do instrumental do convênio - o qual será necessariamente precedido da publicação de edital de chamamento público voltado a dar a conhecer, a todos os potenciais interessados, da viabilidade parceirização, seus requisitos e condições.

O processo de mobilização da sociedade civil, porém, tem início em momento anterior: na medida em que somente poderão receber recursos do Fumcad - e conveniar - as entidades e projetos devidamente registrados e inscritos no CMDCA/SP, indispensável esse ato preparatório.

Na fase de registro são analisados e avaliados a idoneidade da entidade pleiteante, suas condições materiais de atuação, condicionantes da viabilidade técnica do projeto que se pretende fomentado, e a sua compatibilidade - e de seus programas - com as prioridades e políticas públicas na área da infância e juventude previamente fixadas por ocasião dos atos referidos no subitem anterior.

O registro e análise prévia são também imprescindíveis para as entidades governamentais que pretendam receber auxílio do Fumcad. ${ }^{438}$

de trabalho e geração de renda. Parágrafo único: As Entidades de natureza privada sem fins lucrativos devem ficar atentas a não abrirem serviços (tratamentos) que ultrapassem o tempo de convênio (doze meses).

${ }^{438}$ Artigo $8^{\circ}$, XI, da Lei municipal n. 11.123/91. 
Efetuados os registros, o processo de conveniamento avança com a publicação dos editais do Fumcad.

A partir daí, terão lugar a análise e classificação dos projetos, com a expedição do certificado de autorização para captação $-\mathrm{CAC}^{439}$ — para aqueles que se mostrem conformes as políticas públicas e linha de ação traçadas.

De posse desse documento, as entidades estarão aparelhadas para dar início ao processo de captação de destinações junto à iniciativa privada contribuinte, no caso em foco, do Imposto de Renda.

Remanescerá sempre a possibilidade, para aqueles que não lograrem êxito nessa tarefa, de ter seus projetos custeados pela receita orçamentária originária do Fundo (à qual se acrescerão os dez por cento retidos em todas as destinações vinculadas a projetos específicos, conforme artigo $3^{\circ}$, $\S 3^{\circ}$, do Decreto n. 43.135/03). ${ }^{440}$

Chegamos ao momento da formalização, da assinatura do convênio - a qual deve ser efetivada, conforme disposição expressa do inciso V do artigo 11 do Decreto municipal n. 43.135/2003, pelo Secretário Municipal de Participação e Parceria: "V - os termos de convênio serão assinados pelo titular da Secretaria Especial para Participação e Parceria e pelo representante legal da entidade conveniada".

Não obstante a clareza do dispositivo, valem algumas ponderações.

Temos, primeiramente, que, apesar da competência para ordenar as despesas decorrentes do convênio ser exclusiva do Secretário, não sendo o Conselho reconhecido como unidade orçamentária autônoma e, portanto, não gozando de capacidade de manipular o ordenamento municipal, não se pode olvidar da sua atuação prévia absolutamente decisiva para a concretização do acordo.

Realmente, todas as decisões que sustentam a relação de fomento foram tomadas diretamente pelo Conselho, tanto durante a fase de planejamento (ocasião em que eventualmente participaram outros atores, externos) quanto nos atos preparatórios do convênio, com o registro das entidades, análise e classificação dos projetos e posicionamento quanto à conveniência e oportunidade de outorga do auxílio.

É como se, chegado o momento tão esperado do conveniamento, o Conselho fosse alijado de qualquer contato ou relação com o ato em si, o qual seria entregue, em sua completude, à autoridade que, considerada a lógica do sistema, estaria encarregada unicamente de garantir a disponibilização, pelo órgão que titulariza, de apoio técnico.

\footnotetext{
${ }^{439}$ Conforme Resolução n. 80 CMDCA/SP.

${ }^{440}$ Referidas receitas são usualmente referidas, no âmbito do Conselho, como "fundão".
} 
E a problemática não se encerra aí: a partir do momento em que se transferem todos os atos e providências referentes à relação de fomento à Secretaria, essa ficaria automaticamente responsável, da mesma forma, pelos atos fiscalizatórios e de prestação de contas.

Nesse sentido, o disposto no caput, incisos VI, VII, XII e XII, e parágrafo único, do artigo 11 do Decreto n. 43.135/2003, com redação outorgada pelo Decreto n. $47.669 / 2006 .{ }^{441}$

Ocorre que referido órgão não goza de conhecimento técnico ou condições de proceder à fiscalização de mérito de forma satisfatória - até porque essa forma satisfatória exige, nos termos expostos anteriormente, minuciosa análise de resultados, com o sopesamento quanto ao efetivo atendimento ao interesse público pretendido.

$\mathrm{O}$ controle estaria fadado, portanto, à superficialidade, à limitação aos aspectos técnicos, se desenvolvendo de forma absolutamente divorciada do que razoavelmente dele se espera. $^{442}$

O fato de o Conselho ser carente de personalidade jurídica, assumindo a condição de ente despersonalizado, não é impeditivo - conforme já exposto com mais minúcias anteriormente - do estabelecimento de relações desse com outras esferas.

A negativa de tal possibilidade, além de não se coadunar com a lógica da estrutura e da atuação administrativas contemporâneas, configuraria ofensa ao princípio da eficiência, determinante, entre outros aspectos, da atuação concertada, harmônica e coerente dos diversos polos de atribuição pública.

\footnotetext{
441 "VI - os pagamentos das parcelas do convênio serão realizados pela Secretaria Especial para Participação e Parceria; VII - as associações conveniadas, sem fins econômicos, apresentarão, periodicamente, de acordo com o cronograma de pagamento previsto nos respectivos convênios, o requerimento de pagamento, por meio de relatório de atividades devidamente aprovado pela Secretaria Especial para Participação e Parceria, que consultará, se entender necessário, os técnicos da Secretaria Municipal afim à área de ação do projeto, quanto ao adequado cumprimento das obrigações conveniadas; [...] XII - o não cumprimento das cláusulas do convênio, bem como a inexecução total ou parcial do plano de trabalho aprovado configuram irregularidades passíveis das seguintes penalidades, aplicadas cumulativamente e/ou progressivamente, além de outras previstas pela Secretaria Especial para Participação e Parceria; XIII - constatada a ocorrência de irregularidades, a associação civil conveniada deverá ser cientificada, mediante notificação exarada pelo órgão competente da Secretaria Especial para Participação e Parceria, no prazo máximo de 5 (cinco) dias úteis; Parágrafo único. A Secretaria Especial para Participação e Parceria deverá notificar o CMDCA a respeito de situações que indiquem suspensão, interrupção ou rescisão dos convênios de projetos em execução."

${ }^{442}$ Nesse ponto, vale registrar o disposto no $9^{\circ}$ do Decreto municipal n. 43.135/2003, ao determinar que "os critérios de avaliação dos projetos serão estabelecidos pelo CMDCA, quer para sua aprovação, quer para avaliação de seus resultados." Digno de menção, também, o disposto no seu parágrafo $2^{\circ}$ : “A avaliação dos resultados do projeto poderá indicar alterações e inovações a serem feitas nas políticas públicas, ou mesmo a adoção da proposta inicial como política pública a ser incluída no orçamento do ano posterior."
} 
A "dependência" administrativa não poderia ser determinante de o Conselho órgão autônomo, lembre-se — ver a concretização dos convênios que já julgou viáveis, compatíveis com o interesse público, convenientes e oportunos, ao alvedrio unicamente da autoridade em integrante do Executivo, inclusive no que tange à aferição de resultados e efetividade das medidas.

$\mathrm{O}$ fato de os atos de controle interno prévios à assinatura ficarem a cargo do aparato técnico do Executivo (encarregado da análise e aprovação da minuta de convênio e demais aspectos técnicos — ressalvada a atuação do Conselho de Orientação Técnica COT, cujas competências constam do artigo $5^{\circ}$ do Decreto municipal n. 43.135/03 ${ }^{443}$ ), atrai para esse órgão a responsabilidade por eventuais incongruências nesse âmbito perpetradas.

No que tange aos atos aperfeiçoados em momento anterior, porém, não vemos como imputar qualquer espécie de responsabilidade ao Executivo, que não tem sobre eles ingerência (invocamos, a título de exemplo, a hipótese de falha na classificação dos projetos capaz de viciar a ordem de liberação dos valores integrantes do orçamento do Fundo originário dos cofres municipais, e, portanto, o convênio respectivo, ou a valoração autorizativa de adaptação de projeto originalmente apresentado).

A responsabilidade ficaria, então, e a se defender a desvinculação do Conselho nesse aspecto, acéfala, posto que inexistente o nexo de causalidade entre a mobilização estatal, por seus órgãos executivos, e o desvio porventura perpetrado. ${ }^{444}$

Nessas condições, não se nos afigura razoável defender a responsabilidade estatal, $^{445}$ posto que o Conselho age "em seu próprio nome", não representando, no exercício da discricionariedade política, o Estado.

443 “Art. $5^{\circ}$. O Conselho de Orientação Técnica terá as seguintes atribuições: I - assessorar a Comissão
Permanente de Orçamento e Finanças do CMDCA na elaboração dos planos anuais de captação e na fixação
do percentual anual de utilização dos recursos captados; II - avaliar e dar parecer financeiro sobre projetos de
aplicação dos recursos captados; III - analisar e dar parecer sobre as prestações de contas, balancetes e
demais demonstrativos econômico-financeiros referentes à movimentação dos recursos do Fumcad; IV -
assessorar o CMDCA na tarefa de preparar as propostas para o Orçamento Participativo do Município, no
que diz respeito à execução das políticas voltadas à criança e ao adolescente. Parágrafo único Com vistas ao
desenvolvimento das atribuições do COT, a Secretaria de Finanças e Desenvolvimento Econômico deverá: I -
fazer publicar mensalmente no Diário Oficial do Município o volume de recursos recebidos pelo Fumcad
provindos de transferências e doações; II - informar ao COT, no mínimo mensalmente, os valores repassados
pela União e pelo Estado, em conformidade com a Lei federal 8.069, de 13 de julho de $1990 . ”$
444 Resgatamos nesse ponto nosso posicionamento anteriormente exposto, segundo o qual o CMDCA não
integra a estrutura estatal stricto sensu.
445 Em sentido contrário, Liberati e Cyrino: "Com os Conselhos dos Direitos da Criança e Adolescente tal
fato não ocorre. A responsabilidade objetiva será do Estado, com ação regressiva em relação a quem houver
agido com dolo ou culpa.” (LIBERATI; CYRINO, 2003, p. 118). Tal posicionamento não se sustenta, na
medida em que essa lógica de responsabilidade vige, lembre-se, quanto às hipóteses em que o órgão ou ente
despersonalizado age e se manifesta em nome, representando - ou presentando - do Estado. No caso em 
Personifica o interesse público, definido a partir da conjugação e combinação das manifestações daquele e da sociedade civil — tanto que, em havendo discussões ou questionamentos quanto às suas decisões, o Conselho é chamado a integrar a respectiva ação judicial ou inquérito civil junto ao Ministério Público. ${ }^{446}$ Somente ele poderá prestar os esclarecimentos relacionados ao mérito da relação de fomento que se mostrarem eventualmente necessários.

Considerados todos os virtuais desdobramentos referidos, defendemos que ambos os entes - Executivo e Conselho - devem formalmente integrar o ato: aquele representante do colegiado responsável pelas análises de ordem política, discricionária da relação de fomento, e o titular da estrutura administrativa encarregada da avaliação de sua viabilidade e implementação técnica.

No que pertine ao instrumento de convênio propriamente dito, necessária a inclusão de alguns dispositivos específicos — sendo outros defesos, principalmente com relação às despesas passíveis de custeio.

Nesse contexto, consideramos a cláusula de vigência não superior a um ano, com prorrogação excepcionalmente autorizada nos termos dos artigos $10, \S 2^{\circ}$, 447 e 11 , III, do Decreto municipal n. 43.135/03. ${ }^{448}$

Imprescindível também a apresentação do correspondente e minucioso plano de trabalho, que, nos termos fixados no artigo 11, II, desse mesmo Decreto, “deverá conter cronograma físico-financeiro, nos termos da legislação de licitação e contratos, será apresentado com a carta de anuência do CMDCA, bem como com as cópias da resolução do Conselho, dos pareceres do COT e da Secretaria afim". ${ }^{449}$

questão, o liame de representatividade que se estabelece é porém outro: personifica o Conselho, para além do Estado, o interesse público, definido a partir da conjugação e combinação das manifestações daquele e da sociedade civil.

446 Nesse particular, lição de Liberati e Cyrino: "Embora não tenham personalidade jurídica, têm os Conselhos capacidade de ser parte. A capacidade processual dos Conselhos existe para a defesa de suas prerrogativas, de seus direitos subjetivos, suscetíveis de proteção judicial quando ameaçados ou violados. Os conselhos não têm personalidade jurídica, mas têm personalidade judiciária, que é, exatamente, a capacidade processual de ser parte." (LIBERATI; CYRINO, 2003, p. 117).

447 "§ $2^{\circ}$ Em razão do prazo determinado e da necessidade de concorrência em igualdade de condições com as demais propostas de projetos inscritos no CMDCA, os convênios não serão renovados ou aditados, salvo nos casos em que ficar demonstrado não se tratar de serviços de continuidade e estarem mantidos os requisitos de inovação e complementariedade às políticas públicas, condicionados à disponibilidade orçamentáriofinanceira, hipótese em que serão exarados novos pareceres pelo COT e pela Secretaria afim.”

448 "III - os termos de convênio terão prazo de vigência de no máximo 1 (um) ano, renovável somente na hipótese do $\S 2^{\circ}$ do artigo 10 deste decreto."

449 Digno de críticas referido dispositivo: não vislumbramos razoabilidade em se exigir que o parceiro privado apresente, uma vez mais, cópias de referidos documentos, de lavra de divisões da própria administração. Trata-se de inadmissível resquício da burocracia desmesurada, abusiva e sem qualquer sentido. 
O mesmo artigo 11, inciso XI, disciplina as hipóteses de rescisão do convênio. ${ }^{450}$

Existe também a possibilidade de aplicação das penalidades de advertência formal, suspensão dos repasses (o Decreto refere-se, equivocadamente, a "pagamentos") e rescisão (artigo 11, XII).

Admitimos também, a fixação no instrumento convenial de penalidades outras, além dessas normativamente expostas (VILLAR EZCURRA, 1999, p. 128-129). ${ }^{451}$

Aperfeiçoada a relação de fomento, e estabelecidos os seus parâmetros de desenvolvimento, partilha de responsabilidades e regime, terá início a sua execução — a qual ensejará, por sua vez, a incidência dos mecanismos de controle voltados justamente a aferir e garantir a efetiva promoção e atendimento ao interesse público.

\subsubsection{Controle}

Formalizado o convênio, ganha dimensão a exigência de seu regular desenvolvimento, do satisfatório atendimento às cláusulas e condições estabelecidas e a fiel observância do plano de trabalho proposto e aprovado - o que não implica que referida atividade somente tenha início nesse momento, a partir da concreta assinatura do instrumento convenial.

Contrariamente, incide sobre todas as etapas anteriores e posteriores, podendo (ou devendo) advir dos mais diversos atores - inclusive, e cada vez com mais destaque, da própria sociedade.

Dentre os atos de controle prévio, ganham relevância aqueles perpetrados pela própria Administração, e que usualmente contribuem de forma decisiva para o regular desenvolvimento da relação de fomento de forma harmônica, funcional e eficiente.

Nessa seara se insere a apreciação, pela assessoria jurídica do órgão a que administrativamente ligado o Conselho (no caso, a SMPP), das minutas do edital e do termo de convênio, conforme previsão do parágrafo único do artigo 38 da Lei federal n. $8.666 / 933^{452,453}$

\footnotetext{
450 "XI - o convênio do projeto poderá ser rescindido nos seguintes casos: a) descumprimento de qualquer disposição prevista em suas cláusulas, mediante denúncia da parte prejudicada, independentemente de interpelação judicial ou extrajudicial. b) a qualquer tempo, por mútuo acordo, mediante lavratura do Termo de Rescisão; c) unilateralmente, de pleno direito, à critério da Administração, por irregularidades constatadas, referentes à administração dos valores recebidos, à execução do plano de trabalho aprovado ou ao cumprimento dos critérios estabelecidos pelo CMDCA, que será cientificado a respeito.

${ }^{451}$ Em sentido contrário, DI PIETRO, 2012, p. 232-233.

452 "Parágrafo único. As minutas de editais de licitação, bem como as dos contratos, acordos, convênios ou ajustes devem ser previamente examinadas e aprovadas por assessoria jurídica da Administração."
} 
Ainda que se defenda não se incluir referida regra dentre as "normas gerais" da Lei de Licitações, portanto não vinculante dos municípios, nem na expressão "no que couber" constante do artigo 116 daquele diploma, tal exigência decorre do próprio princípio da legalidade, segundo o qual a atividade administrativa deve primar pelo respeito à Lei e ao ordenamento jurídico como um todo.

Na hipótese de ser apontada alguma ilegalidade ou inconformidade jurídica, deverá o Conselho de plano acolhê-la, posto a competência para questões de ordem técnica, de cunho jurídico, ser específica daquela assessoria, conforme expressamente dispõe o artigo 12, I, do Decreto municipal n. 27.231/88. ${ }^{454,455}$

Ainda no âmbito do controle interno prévio, cumpre aos órgãos técnicos analisarem a compatibilidade da parceria pretendida com o arcabouço normativo respeitante aos convênios - que, com relação especificamente ao Conselho e ao Fumcad é, em linhas gerais, lacônico ou omisso.

Considerada essa carência de normas potencialmente comprometedora da segurança jurídica, e não obstante haja dispositivo expresso excluindo essas parcerias das regras municipais gerais sobre convênios, ${ }^{456}$ defendemos a aplicação analógica de suas diretrizes genéricas fundamentais.

Tal posicionamento se fundamenta em que não se pode pretender que, na ausência de regras expressas, efetivas e satisfatoriamente detalhadas, fiquem as relações conveniais - e a própria segurança da relação de fomento e o interesse público por meio dela buscado, bem como a aferição dos resultados alcançados —, comprometidos.

A incorporação daquelas diretrizes deverá, pois, ser trazidas para o âmbito da relação convenial pelo instrumento de convênio, de modo a garantir estândares

\footnotetext{
453 "Para serem formalizadas, as minutas de convênios a serem submetidas à apreciação técnica e jurídica do órgão concedente devem prever cláusulas obrigatórias, muitas das quais reproduzindo informações do plano de trabalho aprovado, como objeto do projeto, obrigações de cada um dos partícipes, inclusive a contrapartida, período de vigência, liberação dos recursos condicionada ao cronograma de desembolso etc. Há outras cláusulas, além daquelas, que estabelecem prerrogativas e obrigações aos partícipes condizentes com o regime de direito público incidente sobre os convênios." (SALINAS, 2008, p. 131).

454 “Art. 12. São atribuições da assessoria jurídico-consultiva do Gabinete da Procuradoria Geral do Município: I - emitir pareceres por determinação do Secretário de Negócios Jurídicos ou do Procurador Geral do Município."

${ }^{455}$ A alternativa de que gozará o Conselho será, no caso de "discordância" com a manifestação jurídica exarada, provocar a assessoria jurídico-consultiva superior - no caso, a Procuradoria Geral do Município, cujo posicionamento, uma vez acolhido pelo Secretário de Negócios Jurídicos, vinculará toda a atividade administrativa em âmbito municipal (ainda que seja ela, como é o caso, exercida pelo Conselho). O acolhimento de referida postura técnica não se insere, por evidente, no âmbito de discricionariedade dos conselheiros, de modo que deve ser compulsoriamente acolhida — sob pena de ilegalidade do ato, a qual poderá ser reconhecida tanto por atuação dos órgãos de controle externo quanto por iniciativa de qualquer cidadão.

${ }^{456}$ Decreto municipal n. 49.539/2008.
} 
satisfatórios de fiscalização e promover uma padronização dos diversos convênios firmados em nível municipal - o que em muito facilitaria seu próprio acompanhamento pelas respectivas divisões administrativas.

Dessa interpretação resulta a necessidade de movimentação dos recursos transferidos e das eventuais contrapartidas financeiras em conta específica, e a obrigatória realização de pagamento a fornecedores e prestadores de serviços mediante crédito nas respectivas contas bancárias, nos termos postos nos artigos $6^{\circ}, \S 1^{\circ},{ }^{457} 12$, I e II, ${ }^{458}$ daquele Decreto municipal.

Imprescindível, ainda, a aplicação dos recursos transferidos e da contrapartida, enquanto não utilizados, no mercado financeiro. ${ }^{459}$

O detalhamento das regras relativas aos repasses, prestações de contas, aplicação dos valores e efetivação de despesas fica a cargo da Portaria Intersecretarial n. 06/2008/SF/Sempla — que nenhuma restrição faz à sua incidência sobre os convênios relacionados ao CMDCA/SP e ao Fumcad, salvo no que tange à obrigatória e prévia autorização do Prefeito (artigo $4^{\circ}, \S 3^{\circ}$ ).

$\mathrm{O}$ artigo $5^{\circ}$ desse diploma elenca os elementos essenciais do plano de trabalho ${ }^{460}$ e seu artigo 11 veicula vedações quanto à destinação dos valores repassados. ${ }^{461}$

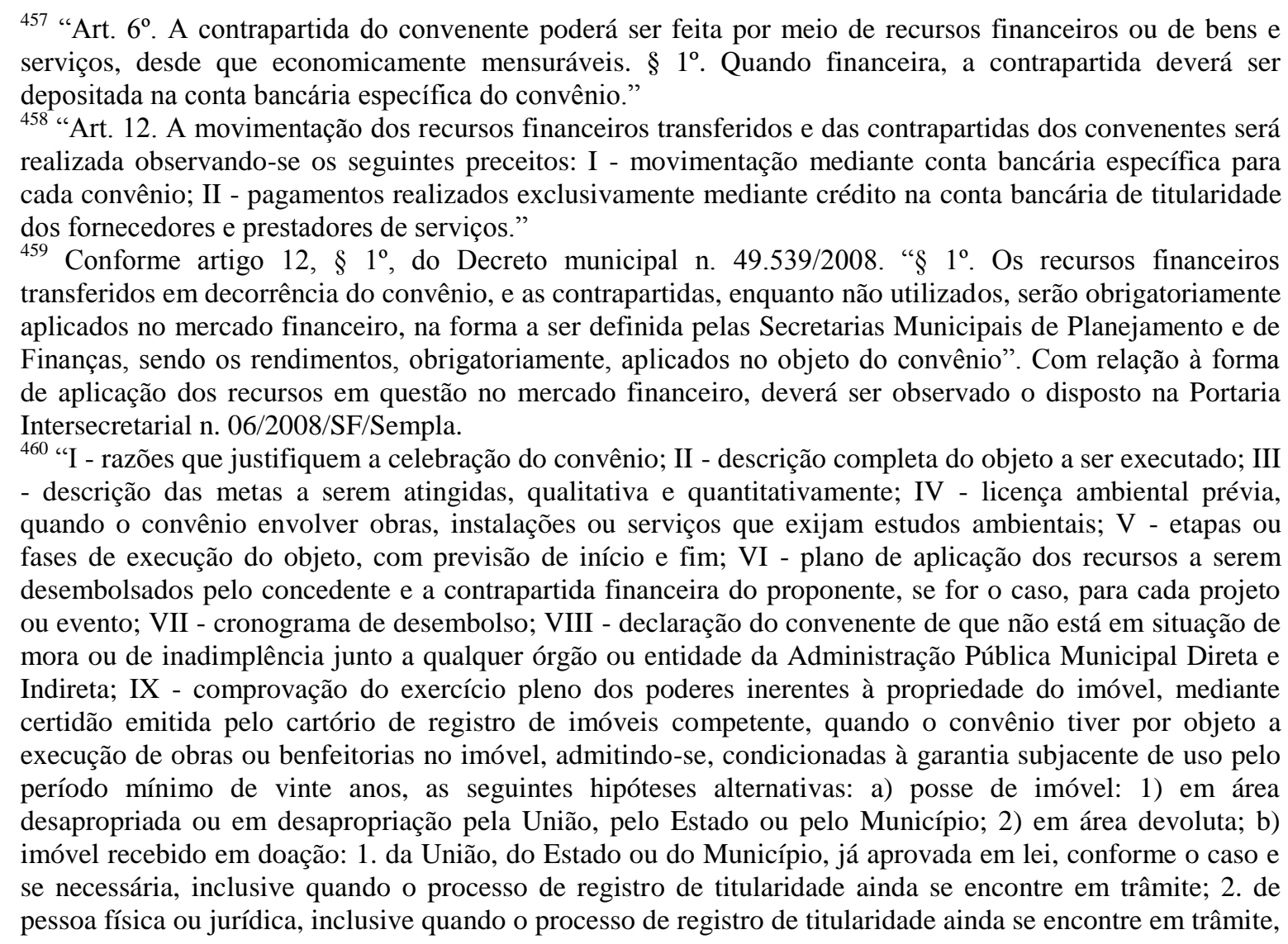


Desatendidos os parâmetros necessários, o controle prévio — tanto interno quanto interno ou social — pode gerar a exigência de adequações do pretendido às exigências legais e, em situações mais extremas, até mesmo inviabilizar a formação da parceria, nos termos especificamente pretendidos.

Acentuam Liberati e Cyrino, especificamente quanto ao controle social, que deve ser efetivado pari passu com o agir público.

Defendemos a ideia de uma "prestação de contas política", ou seja, o conselheiro teria, em princípio, o dever ético-político de prestar contas, às suas bases, de toda sua atuação. Poder-se-ia até, quem sabe, no que tange às entidades não governamentais, estabelecer um mecanismo legal no sentido do comparecimento do conselheiro eleito no Fórum-DCA, para esclarecimentos, quando solicitado, sob pena de exclusão, no próximo mandato, da entidade que representa. (LIBERATI; CYRINO, 2003, p. 113).

Implementadas as análises prévias e concretizado o convênio, passa a ter lugar o controle concomitante - que, conforme asseverado, não deve ficar a cargo, unicamente, do Executivo: não obstante seja este incumbido de acompanhar e zelar pelos aspectos técnicos e burocráticos - mormente no que tange às prestações de contas, parciais e final —, a análise de mérito, a mensuração dos resultados e seu cotejamento com as demandas sociais e prioridades cristalizadas no planejamento deverão ser levados a termo pelo Conselho.

O Conselho ficará em posição de dupla repercussão: por um lado, atuará como ente controlador das atividades do Terceiro Setor; ${ }^{462}$ por outro, estará submetido à fiscalização dos mais diversos atores, inclusive a própria sociedade civil.

neste caso, com promessa formal de doação irretratável e irrevogável; c) imóvel cuja utilização esteja consentida pelo seu proprietário, por instrumento contratual hábil, com autorização expressa irretratável."

461 "I - realização de despesas a título de taxa de administração, de gerência ou similar; II - pagamento, a qualquer título, a servidor ou empregado público municipal, integrante de quadro de pessoal de órgão ou entidade pública da administração direta ou indireta, inclusive por serviços de consultoria ou assistência técnica; III - aditamento com alteração do objeto; IV - utilização, mesmo em caráter emergencial, dos recursos em finalidade diversa da estabelecida no convênio; V - realização de despesas com taxas bancárias, multas, juros ou correção monetária, inclusive referentes a pagamentos ou recolhimentos fora dos prazos; VI - realização de despesas com publicidade, salvo as de caráter educativo, informativo ou de orientação social, das quais não constem nomes, símbolos ou imagens que caracterizem promoção pessoal de autoridades ou servidores públicos."

462 "Entre os diversos mecanismos de concreção da participação administrativa, citem-se: as audiências públicas, o orçamento participativo, os conselhos gestores de políticas públicas e as ouvidorias do povo. Sem descurar da importância de cada um desses mecanismos para o controle social da administração pública, os conselhos gestores de políticas públicas mostram-se os mais importantes para o controle das atividades desenvolvidas pelo terceiro setor, haja vista previsão expressa na legislação infraconstitucional acerca desse mecanismo de controle [...].” (DIAS, 2008b, p. 408.). 
O controle a posteriori é igualmente facultado aos diversos atores do controle interno, externo e social — do que se extrai a obrigatoriedade de que todos os atos relacionados ao processo de conveniamento e sua execução estejam sujeitos aos critérios de publicidade e transparência —, inclusive os documentos de posse ou mesmo de uso interno das entidades convenentes (conforme estabelecido na já mencionada Lei de Acesso à Informação).

\subsubsection{Responsabilização}

A responsabilidade por irregularidades perpetradas no âmbito da relação de fomento se dá de maneira caleidoscópica, a partir de um feixe de possibilidades e efeitos. Já foi objeto de ponderações, quanto aos seus aspectos gerais, no capítulo 1.

No cenário específico decorrente da interação, no processo, do CMDCA/SP, podemos vislumbrar as seguintes perspectivas: a) a responsabilidade por inconsistências prévias ao conveniamento, em razão da inobservância, em linhas gerais, do planejamento; b) aquela incidente durante a relação convenial, decorrente de prejuízos perpetrados a terceiros, e desencadeada por atos do concedente ou do convenente (hipótese de omissão do dever de fiscalização); c) a estabelecida, quer concomitantemente quer após o término do convênio, em razão de condutas irregulares de um partícipe frente ao outro.

Iniciemos pela responsabilidade decorrente de condutas repreensíveis anteriores ao aperfeiçoamento do convênio, resultante de desvios durante o estabelecimento e desenvolvimento da relação, quando as opções de planejamento são tomadas.

A atividade administrativa de fomento está submetida a uma lógica sistemática que a antecede e com a qual deve guardar consonância: as posturas e políticas públicas eleitas pelas Leis Orçamentárias ${ }^{463}$ e pelo CMDCA como dignas de apoio devem ser

\footnotetext{
463 “'.... N Não faz sentido algum o delineamento de todo um sistema orçamentário calcado no planejamento e a afirmação do direito à transparência da gestão fiscal, se as dotações orçamentárias não tiverem caráter impositivo. De nada vale assegurar a participação popular no momento de elaboração do orçamento se, no decorrer do exercício financeiro, o Poder Executivo não tiver o dever de executar o que foi planejado, mediante um processo de consulta pública seguido de um cuidadoso exame pelos representantes do povo nas casas legislativas. Pode-se afirmar, com segurança, que o antigo debate sobre o caráter autorizativo ou impositivo do orçamento não tem mais sentido, diante da pletora de normas que não deixam sombra de duvida quanto ao fato de que o sistema de orçamentos é, na verdade, um subsistema do conjunto articulado de projetos e programas que devem orientar o planejamento governamental, o que, nos termos do artigo 174 da CF, é determinante para o setor público.” (DALLARI, 2011, p. 327). Essas limitações, relativas ao Executivo, a ele não se restringem: alcançam todos aqueles responsáveis pela atividade da ação administrativa, inclusive os Conselhos.
} 
plenamente observadas e compatíveis com os valores expressos no ordenamento jurídico que lhes dá sustentação.

São opções tipicamente políticas, que devem trazer a marca da coerência.

Aperfeiçoados os instrumentos de planejamento, esse passa a ser vinculante das ações que se seguirão:

Em termos de Administração concertada, como dizem, Gordillo, Laubadère, Vidal Perdomo tal seja a participação do administrado nos planos, é totalmente inviável excluir a responsabilidade do Estado por atos decorrentes de modificação do planejamento, sejam estes responsáveis (portanto lícitos), sejam irresponsáveis como acontece, muitas vezes, em países em que o grau de responsabilidade dos supremos governantes ainda deixa muito a desejar. (FIGUEIREDO, 2002, p. 13).

Possíveis desvios e afrontas darão azo à responsabilização do agente político no caso, o Conselho - , que responderá pela inobservância dos valores e critérios fixados.

Por outro lado, caso as falhas perpetradas sejam de ordem formal, burocrática, e se insiram no espectro de competência e análise do Executivo, o seu titular é quem será chamado a responder.

Atentemos para o artigo 10 da Lei federal n. 8.429/92:

Art. 10. Constitui ato de improbidade administrativa que causa lesão ao erário qualquer ação ou omissão, dolosa ou culposa, que enseje perda patrimonial, desvio, apropriação, malbaratamento ou dilapidação dos bens ou haveres das entidades referidas no art. $1^{\circ}$ desta lei, e notadamente:

$[\ldots]$

IX - ordenar ou permitir a realização de despesas não autorizadas em lei ou regulamento;

No que toca à relação convenial inserida no ciclo do fomento na área da infância e juventude da cidade de São Paulo, vale tecer algumas ponderações.

Será ela precedida, como visto, de todas as fases de planejamento, consideração das condições da entidade e do projeto proposto (análise de mérito), ultrapassadas as quais o protagonismo passará ao aparato burocrático do Executivo, incumbido dos trâmites de conveniamento. $^{464}$

464 "O Conselho é um órgão da Administração Pública, descentralizado, como técnica, mas sem personalidade jurídica. Portanto, não pode fazer contratações. Deve utilizar a máquina do Executivo, quanto necessitar de algum parecer técnico." (LIBERATI; CYRINO, 2003, p. 116). 
Esse último não tecerá quaisquer considerações acerca da política pública escolhida, da pertinência do projeto aprovado ou da capacidade da entidade selecionada; essas questões já terão sido sopesadas de forma conclusiva pelo Conselho. ${ }^{465}$

Caso seja questionado o convênio com base em qualquer desses indicativos, não caberá ao Executivo responder: não obstante seja ele o ordenador de despesa quanto aos repasses envolvidos, não goza de competência para a análise do mérito da relação construída, a qual se limita ao campo de conhecimento do CMDCA/SP.

Resumindo, considerado o teor do artigo 10, IX, da Lei de Improbidade, podemos vislumbrar duas possibilidades: a) ou o vício que torna a despesa incompatível com a legislação tem origem na análise de mérito atribuída ao Conselho - hipótese em que sobre seus conselheiros recairá o manto da improbidade; ${ }^{466}$ b) ou os vícios são de ordem formal, inserindo-se nas competências do Executivo - que por elas responderá.

Passemos à segunda possibilidade, de a atividade de fomento resultar em dano a terceiros, beneficiários ou não do convênio, com relação à qual se discute se deveria arcar com os prejuízos o ente fomentado ou o fomentador.

Nessas circunstâncias, o agente direto, executor da atuação ensejadora da ofensa é a entidade - que se relaciona diretamente com os beneficiários, nenhum vínculo se estabelecendo entre estes últimos e a Administração Pública. ${ }^{467}$

Têm elas (as entidades) personalidade jurídica de Direito Privado, nos termos do artigo 44 do $\mathrm{CC}$, e se movimentam em seara eminentemente privada, em esfera de competências própria, não havendo que se falar em qualquer espécie de delegação, representação ou serviço público, conforme já assentado.

Nesses termos, e uma vez decorrendo o dano de relação estabelecida unicamente entre agente fomentado e seus beneficiários, sem qualquer concorrência da Administração

\footnotetext{
465 “[...] O poder administrativo é [...] secundário e subordinado ao poder político. Organiza o pensamento deste e o põe em obra. [...] A administração é, portanto, a ação vital do poder político e seu indispensável complemento. O poder político é a cabeça, a administração o braço. O poder político serve-se da administração para fazer prevalecer o seu sistema [...].” (URUGUAI, 2002, p. 91).

${ }^{466}$ Tendo em vista a origem colegiada das decisões do Conselho, todos os seus integrantes serão alcançados, em princípio, pelos efeitos dessas irregularidades — salvo consignação de posição discordante na ata da reunião em que o ponto houver sido discutido e decidido.

467 "O ato ilícito é, pois, o fato gerador de responsabilidade. Desse modo, a responsabilidade pressupõe um comportamento positivo (ação) ou negativo (omissão), que, desrespeitando o contrato ou a ordem jurídica, cause prejuízo a outrem, por ofensa a bem ou a direito seu. Esse comportamento (comissivo ou omissivo) deve ser imputável à consciência do agente, por dolo ou culpa.” (MELLO, 2003, p. 134).
} 
- ainda que patrocinada pelos cofres públicos —, não haverá que se falar, em princípio, em responsabilidade do Estado (HIGA, 2010, p. 247). ${ }^{468}$

Em princípio - pois situações há em que essa regra pode vir a ser excepcionada.

Falamos das hipóteses em que o dano decorra, ainda que indiretamente, da infração, pela Administração, do dever de fiscalização inerente a qualquer contrato lato sensu que venha a formalizar.

Negligenciado esse dever, defende parte da doutrina a incidência da responsabilidade por omissão, baseada na culpa:

A omissão do Estado no tocante ao dever de fiscalização dos agentes fomentados, por si só, não é suficiente para desencadear o dever da Administração Pública de reparar o dano causado por referidas entidades aqui estudadas, embora não se afaste a possibilidade de este vir a responder, em casos excepcionais, desde que presentes os pressupostos relativos à responsabilidade subjetiva. Nessa hipótese, aplicar-se-á a teoria da culpa do serviço - o dever de fiscalização não foi exercido, foi exercido com atraso ou com falha -, e o dever do Estado de reparar o dano será subsidiário, adotando-se, para tanto, a regra geral prevista no artigo 265 do Código Civil. (HIGA, 2010, p. 250).

Dessa opinião não compartilhamos; defendemos, com Marçal Justen Fillho, que a responsabilidade administrativa, em hipóteses tais, independerá de culpa (JUSTEN FILHO, 2012, p. 1228).

Afora esses casos excepcionais, em havendo prejuízo a terceiros a responsabilidade será do agente fomentado - com relação ao qual prevalece o regime jurídico de Direito Privado em alguns pontos derrogado em razão da parceria estabelecida.

O regime básico, em se tratando de responsabilidade civil, é o subjetivo, conforme estabelecem os artigos $927,{ }^{469} 186^{470}$ e $389^{471}$ do CC — os quais defendemos

\footnotetext{
${ }^{468}$ Vale a consulta, quanto à responsabilidade civil do Estado, ao acórdão proferido pelo STF no RE n. 262.651-1/SP, rel. Min. Carlos Veloso: "Constitucional. Administrativo. Civil. Responsabilidade civil do Estado: responsabilidade objetiva. Pessoas jurídicas de direito privado prestadoras de serviço público. Concessionário ou permissionário de transporte de serviço de transporte coletivo. $\mathrm{CF}$, art. $37, \S 6^{\circ}$, I - A responsabilidade civil das pessoas jurídicas de direito privado prestadoras de serviço público é objetiva relativamente aos usuários do serviço, não se estendendo a pessoas outras que não ostentem a condição de usuário. Exegese do art. 37, § 6 $6^{\circ}$ da CF, II - RE conhecido e provido.”

469 "Art. 927. Aquele que, por ato ilícito (arts. 186 e 187), causar dano a outrem, fica obrigado a repará-lo."

470 "Art. 186. Aquele que, por ação ou omissão voluntária, negligência ou imprudência, violar direito e causar dano a outrem, ainda que exclusivamente moral, comete ato ilícito."

471 "Art. 389. Não cumprida a obrigação, responde o devedor por perdas e danos, mais juros e atualização monetária segundo índices oficiais regularmente estabelecidos, e honorários de advogado."
} 
não estarem sujeitos a qualquer derrogação por parte do artigo $37, \S 6^{\circ}$, da $\mathrm{CF},{ }^{472}$ veiculador da regra da responsabilidade objetiva.

Essa conclusão decorre do fato de que a redação desse dispositivo constitucional não se coaduna com o contexto em que se insere a atividade privada de interesse público fomentada: a responsabilidade objetiva submete tão somente: a) a Administração Pública direta e indireta e b) os particulares prestadores de serviços públicos.

Não havendo previsão expressa determinante da sujeição das entidades fomentadas à modalidade objetiva, carece de fundamento a pretensão de a elas estender seus efeitos, seja em hipóteses de responsabilidade extracontratual, seja contratual (hipótese em que se presumirá a culpa pelo mero desatendimento às cláusulas fixadas). ${ }^{473,}$ 474

Assentada a regra, vale considerar a exceção retratada no parágrafo único do mesmo artigo $927,{ }^{475}$ que disciplina a incidência da responsabilidade objetiva nos casos em que legislação especial expressamente a adotar.

É o que se dá, exempli gratia, com o Código de Defesa do Consumidor, criador de hipóteses que tais: em se qualificando a entidade convenente como fornecedor, responderá ela objetivamente por eventuais prejuízos.

Outra possibilidade de responsabilização objetiva se manifesta no caso de o prejuízo experimentado por terceiros decorrer diretamente de ação da Administração com a automática e própria incidência do artigo $37, \S 6^{\circ}$, qual seja, a responsabilidade objetiva.

A derradeira hipótese de responsabilização é a desencadeada em razão de ofensa por qualquer dos partícipes às condições acordadas de forma a potencialmente comprometer a eficácia dos resultados.

\footnotetext{
472 “ $\S 6^{\circ}$. As pessoas jurídicas de direito público e as de direito privado prestadoras de serviços públicos responderão pelos danos que seus agentes, nessa qualidade, causarem a terceiros, assegurado o direito de regresso contra o responsável nos casos de dolo ou culpa."

473 "Conclui-se, pois, neste tópico, que a atuação complementar dos agentes fomentados sofre o influxo de regras publicísticas, como já dito, em razão das finalidades públicas e da gestão de recursos públicos, o que não afasta a sua natureza de pessoa jurídica de direito privado e a natureza jurídica de seus atos como atividade econômica lato sensu. Em face disso, via de regra, aplica-se a responsabilidade civil subjetiva prevista no art. 927, caput, c/c. art. 186 do Código Civil, na hipótese de responsabilidade extracontratual ou no art. 389 do Código Civil, no caso de responsabilidade contratual, seja em relação ao Estado, seja em relação ao terceiro que se utiliza do serviço por ela prestado". (HIGA, 2010, p. 242).

${ }_{474}^{47}$ Nesse sentido, MELLO, 2003, p. 183-184 e HIGA, 2010, p. 234-235.

475 "Parágrafo único. Haverá obrigação de reparar o dano, independentemente de culpa, nos casos especificados em lei, ou quando a atividade normalmente desenvolvida pelo autor do dano implicar, por sua natureza, risco para os direitos de outrem."
} 
Incidirá, nesse contexto, de forma automática e inafastável, em um primeiro momento, a paralisação dos repasses até que a regularidade da atuação seja reestabelecida.

Caso a postura assumida seja irreversível, ou a entidade parceira se quede inerte no prazo fixado pela concedente - ou no prazo razoável, à ausência de fixação expressa —, o caminho a ser adotado será a rescisão do convênio, com a consequente e obrigatória devolução de todos os valores recebidos a título de repasses, devidamente corrigidos e atualizados, sem prejuízo das penalidades eventualmente aplicáveis. ${ }^{476}$

Incide o artigo 19 da Portaria Intersecretarial n. 06/2008/SF/SEMPLA:

Art. 19. O convenente deverá restituir ao concedente o valor transferido e a contrapartida pactuada, atualizados monetariamente desde a data do recebimento, acrescidos de juros legais, na forma do art. $1^{\circ}$ da Lei 10.734 , de 30 de junho de 1989, com a redação conferida pela Lei 13.181, de 4 de outubro de 2001, nos seguintes casos:

I - quando não for executado o objeto da avença;

II - quando não for apresentada, no prazo exigido, a prestação de contas parcial ou final;

III - quando os recursos forem utilizados em finalidade diversa da estabelecida no convênio;

IV - quando não houver aplicação integral dos recursos na consecução do objeto do convênio.

Parágrafo único. A restituição compreende os rendimentos de aplicação no mercado financeiro, ainda que o convenente não a tenha feito. ${ }^{477}$

Caso o partícipe em falta seja o concedente, como, por exemplo, quando injustificadamente faz cessar os repasses, a opção quanto à postura a ser adotada ficará a critério da entidade parceira, que poderá manter as atividades às suas custas, na esperança de que a situação se regularize o quanto antes, ou simplesmente se retirar da relação, denunciando ao convênio.

Outra discussão a ser registrada guarda relação com a possibilidade de fixação de multas e penalidades no convênio.

\footnotetext{
${ }^{476}$ Conforme artigo $18, \S 2^{\circ}$ da Portaria Intersecretarial n. 06/2008/SF/Sempla.

${ }^{477}$ Chama a atenção, em tal dispositivo, a determinação de que a entidade restitua integralmente os valores públicos repassados, por ocasião do convênio, e também aquelas disponibilizadas a título de contrapartida. Nesse particular, temos que a contrapartida, não obstante depositada na conta específica do convênio, tem origem privada, vez que disponibilizada pela entidade parceira. A perda desse montante, diferentemente do retorno dos valores públicos aos cofres estatais, configuraria a imposição de uma penalidade ao particular sem qualquer possibilidade de discussão ou negativa de assunção do ato voluntário de arcar com esses valores, em clara manifestação do 'império' estatal, disponibilizando valores inicialmente oferecidos para a consecução de medidas que, a essa altura, já não mais se concretizarão. Restrição na esfera de direitos nesses moldes, de forma enérgica e violenta, não poderia, constar de Portaria, norma cujos efeitos típicos somente repercutem no âmbito interno da Administração. Defendemos, assim, o afastamento do dispositivo em questão, por inadmissível afronta à lei e à própria Constituição Federal.
} 
Muito embora haja quem contra ela se posicione (DI PIETRO, 2012, p. 232-233), cremos configurar importante ferramenta de defesa e promoção do interesse público seja sob o aspecto didático, seja sob o enfoque repressivo.

Filiamo-nos, nesse particular, ao pensamento de Villar Ezcurra (1999, p. 128129). 


\section{CONCLUSÕES}

Conforme assentado no presente trabalho, a atividade administrativa de fomento ganha destaque em um cenário de desenvolvimento e sedimentação das noções de governança, contratualismo, consensualismo, democratização, responsividade, accountability, eficiência e participação popular.

Ao ser aliada a arenas de participação, como é o caso do Conselho Municipal dos Direitos da Criança e do Adolescente, torna-se mesmo paradigmática da nova Administração Pública democrática, com a face voltada para a sociedade e por ela interpenetrada.

O cenário traçado nos remete à importância que assumem esses novos valores, os quais passam a condicionar o efetivo e eficiente atendimento aos diversos interesses públicos socialmente detectáveis - e, portanto, a própria manutenção e existência do Estado enquanto organização social.

Ganha força a subsidiariedade como princípio da atuação estatal, em decorrência do qual se torna viável uma ação estatal mais racional, organizada e limitada às situações em que absolutamente indispensável.

O fomento - que se desenvolve paralelamente ao serviço público e à política ganha ainda mais legitimidade — e eficiência, e qualidade —, quando desenvolvido a partir dos pilares da democratização e da participação popular.

Assume posição protagônica no contexto de solidariedade e corresponsabilidade entre Estado e sociedade inerente ao século XXI.

As medidas incentivadoras têm o seu potencial em muito aumentado em situações como a considerada no presente estudo, quando exercidas por intermédio da arena de participação traduzida no Conselho Municipal dos Direitos da Criança e Adolescente de São Paulo.

Trata-se de órgão responsável pelo exercício da discricionariedade administrativa no que tange às políticas locais de infância e juventude, que goza de legitimidade democrática - vez que seus membros representantes da sociedade civil são diretamente eleitos pelos cidadãos locais —, e não está inserido na estrutura administrativa estatal — pelo que não se sujeita ao controle hierárquico por qualquer órgão administrativo.

Encontra-se na linha de frente no relacionamento dos agentes fomentados, considerados os dois momentos em que essa atividade se desenvolve, no contexto 
estudado: mobilização dos contribuintes de Imposto de Renda para a "alimentação" do Fundo Municipal dos Direitos da Criança e do Adolescente, e parceirização com o Terceiro Setor voltada à implementação propriamente dita das ações voltadas às crianças e adolescentes.

Sua atuação é sempre permeada por análises e decisões acerca das políticas públicas e prioridades a serem contempladas no âmbito municipal.

Age nos dois polos — tanto ativo quanto passivo — do controle social, sendo sujeito aos órgãos de controle interno (no que toca aos aspectos técnicos de sua atuação) e externo (nas mesmas condições e extensão dos demais administradores públicos), tanto sob o aspecto burocrático tradicional quanto dos resultados (demanda decorrente do próprio Estado pós-social).

No que tange às entidades do Terceiro Setor fomentadas, a sua vinculação ao Conselho as atrai para um âmbito de incidência parcial do regime de Direito Público.

Isso se dá a partir do instrumental dos convênios, ficando elas, assim, e exclusivamente no que toca aos desdobramentos dessa relação, sujeitas a um regime híbrido.

O custeio dos convênios pelo Fundo Municipal dos Direitos da Criança e do Adolescente segue a sistemática orçamentária e financeira típica das receitas públicas, independentemente da sua origem, se orçamentária, municipal ou decorrente do fomento (do Imposto de Renda originariamente devido).

A responsabilização por eventuais deslizes no desenvolvimento do ciclo do fomento, em qualquer dos seus momentos, incorre a partir de um imbricado feixe de responsabilidades, e gera a sujeição daquele que lhe deu causa, conforme a seguinte lógica, aqui colocada em linhas gerais: a) pelas incongruências de ordem política, traduzidas, exemplificativamente, na desobediência de parâmetros de planejamento previamente fixados, responderá o agente político incumbido das decisões dessa natureza - no caso em estudo, o Conselho - ; b) as irregularidades ocorridas durante o convênio serão suportadas pelo partícipe que lhe tenha dado causa (responsabilidade contratual culpa presumida); c) na hipótese de os prejuízos alcançarem terceiros, a responsabilidade ficará, em regra, a cargo da entidade (subjetiva); caso, porém, o Conselho ou o órgão incumbido do suporte técnico-burocrático pequem contra o dever de fiscalizar, serão também trazidos à baila (responsabilidade subjetiva, no primeiro caso, e independente de culpa, no segundo). 
Chegamos, portanto, a que a atividade administrativa de fomento viabilizada por meio do CMDCA traduz, portanto, importante tecnologia jurídica promotora e garantidora dos interesses coletivos, que incita a sociedade civil a assumir a sua parcela de responsabilidade no que toca ao incremento das condições sociais e de vida como um todo.

Trata-se, pois, de importante caminho para se chegar a uma atividade administrativa efetivamente focada no bem comum, nos valores sociais e, em última análise, na própria sociedade - objeto e destinatária primeira do atuar administrativo. 


\section{REFERÊNCIAS}

ABRUCIO, Fernando Luiz; LOUREIRO, Maria Rita. Finanças públicas, democracia e accontability. In: ARVATE, Paulo Roberto; BIDERMAN, Ciro (Orgs.). Economia do setor público no Brasil. Rio de Janeiro: Elsevier, 2004.

AGUIAR, Ubiratan et. al. Convênios e tomadas de contas especial. 2. ed. Belo Horizonte: Fórum, 2005.

ALBINO, Priscilla Linhares (Coord.). Manual do Promotor de Justiça da Infância e Juventude: conselhos e fundos dos direitos da criança e do adolescente: sistema de garantia de direitos da criança e adolescente. Florianópolis: MPSC, 2010.

ALMEIDA, Carlos Otávio Ferreira de. O planejamento financeiro responsável: boa governança e desenvolvimento no Estado contemporâneo. In: CONTI, José Maurício; SCAFF, Fernando Farcury. Orçamentos públicos e Direito Financeiro. São Paulo: RT, 2011.

ALMEIDA, Guilherme Henrique de la Rocque. Controle das transferências financeiras da União. Belo Horizonte: Fórum, 2008, p. 105, apud LIMA, 2010, p. 122.

ARAGÃO, Alexandre Santos. Descentralização administrativa: sua evolução face às reformas à Constituição de 1988. A \& C - Revista de Direito Administrativo e Constitucional. Belo Horizonte, v. 3, n. 11, jan. 2003. Disponível em: <http:// bdjur.stj.jus.br/ dspace/handle/2011/30366>. Acesso em 8 nov. 2011.

ARAÚJO, Fernando Henrique de Moraes. Da destinação ilegal de recursos dos fundos dos direitos da criança e do adolescente e a sujeição dos conselheiros de direitos à lei de improbidade administrativa. Tese apresentada e aprovada no 21. Congresso da Associação Brasileira de Magistrados e Promotores da Infância e da Juventude - ABMP. Disponível em <http://www.mp.sp.gov.br/portal/page/portal/cao_infancia_juventude/ doutrina/doutrinas_artigos/1DA\%20DESTINA\%C3\%87\%C3\%830\%20ILEGAL.doc> Acesso em: 27 mar. 2012.

ARIÑO ORTIZ, Gaspar. Principios de Derecho Público Económico: modelos de Estado, gestión pública, regulación económica. Granada: Comares; Fundación Estudios de Regulación, 2004.

ATALIBA, Geraldo; GONÇALVES, José Artur Lima. Crédito-prêmio de IPI: direito adquirido: recebimento em dinheiro. Revista de Direito Tributário. São Paulo: RT, n. 55, 1991. 
AUAD, Denise. Conselhos e fundos dos direitos da criança e do adolescente: uma opção pela democracia participativa. Tese (Doutoramento em Direito) - Faculdade de Direito, Universidade de São Paulo, São Paulo, 2007.

BAENA DEL ALCÁZAR, Mariano. Sobre el concepto de fomento. Revista de Administración Pública - RAP, n. 54, p. 43-85, set./dez. 1967.

BANDEIRA DE MELLO, Celso Antônio. Curso de Direito administrativo. 29. ed. São Paulo: Malheiros, 2012.

BANDEIRA DE MELLO, Celso Antônio. Extensão das alterações dos contratos administrativos: a questão dos $25 \%$. Revista Diálogo Jurídico. Salvador, n. 6, v. 1, set. 2001. Disponível em: <http://www.direitodoestado.com/revista/REDAE-4-NOVEMBRO2005-CELSO\%20ANTONIO.pdf>. Acesso em: 06 maio 2012.

BARBOSA, Maria Nazaré Lins. Fomento empresarial aos Conselhos dos Direitos da Criança e Adolescente: uma parceria possível. Revista de Direito do Terceiro Setor. Belo Horizonte: Fórum, ano 1, n. 2, jul./dez. 2007.

BARBOSA, Maria Nazaré Lins. Fomento empresarial aos Conselhos Municipais dos Direitos da Criança e Adolescente. Tese (Doutorado em Administração Pública e Governo) - Escola de Administração de Empresas de São Paulo, Fundação Getúlio Vargas. São Paulo, 2009.

BARBOSA, Maria Nazaré Lins. Voluntariado empresarial: aspectos jurídicos. In: OLIVEIRA, Gustavo Justino (Coord.). Terceiro Setor, empresas e Estado: novas fronteiras entre o público e o privado. Belo Horizonte: Fórum, 2007.

BARROS, Danielle Cavalcanti. Da impossibilidade de delegação do poder de gestão dos Fundos Especiais pelos Conselhos de Direitos. Disponível em: <http:// www.mp.ro.gov.br/c/document_library/get_file?p_1_id=1108298\&folderId=1108484\&na me=DLFE-51940.pdf $>$. Acesso em: 30 mar. 2012.

BARROSO, Luis Roberto. Curso de Direito Constitucional contemporâneo. 2. ed. São Paulo: Saraiva, 2010.

BATISTA JUNIOR, Onofre Alves. Transações administrativas: um contributo ao estudo do contrato administrativo como mecanismo de prevenção e terminação de litígios e como alternativa à atuação administrativa autoritária, no contexto de uma Administração Pública mais democrática. São Paulo: Quartier Latin, 2007.

BENETULLIERE, Sébastien. Démocratie participative et citoyenneté. In: ROBBE, François. La démocratie participative. Paris: L’Hamarttan, 2007. 
BENTO, Leonardo Valles. Governança e governabilidade na reforma do Estado: entre eficiência e democratização. Barueri: Manole, 2003.

BINEMBOJM, Gustavo. O princípio da publicidade administrativa e a eficácia da divulgação dos atos do Poder Público pela internet. Revista Eletrônica de Direito do Estado - REDE. Salvador: Instituto Brasileiro de Direito Público, n. 19, jul./set. 2009. Disponível em: <www.direitodoestado.com.br.> Acesso em: 05 dez. 2011.

BITTENCOURT, Sidney, Manual de convênios administrativos. Rio de Janeiro: Temas e Ideias, 2005.

BORGES, Alice Gonzalez. Democracia participativa. Reflexões sobre a natureza e a atuação dos conselhos representativos da sociedade civil. Revista Eletrônica sobre a Reforma do Estado, n. 14, jun./ago. 2008. Disponível em: <http:// www.direitodoestado.com.br>. Acesso em: 13 nov. 2011.

BORGES, Alice Gonzalez. Normas gerais no estatuto de licitações e contratos administrativos. São Paulo: RT, 1991.

BRASIL. Ministério da Administração Federal e Reforma do Estado. Plano de Reforma do Aparelho do Estado. 1995. Disponível em <http://www.bresserpereira.org.br/ Documents/MARE/PlanoDiretor/planodiretor.pdf>. Acesso em 15 jun. 2012.

BRASIL. Ministério da Justiça. Secretaria de Assuntos Legislativos. Pensando o Direito: conferências nacionais, participação social e processo legislativo, n. 27, 2010. Disponível em: <http://portal.mj.gov.br/main.asp?View $=\{329 D 6 E B 2-8 A B 0-4606-B 054-4 C A D 3 C 53$ EE73 \}>. Acesso em: 20 jun. 2012.

BRASIL. Ministério do Planejamento, Orçamento e Gestão. Anteprojeto de Lei Orgânica da Administração Pública Federal. Disponível em: <http://www.planejamento.gov.br/secretarias/upload/Arquivos/seges/comissao_jur/arquiv os/090729_seges_Arq_leiOrganica.pdf>. Acesso em: 10 dez. 2011.

BRASIL. Secretaria Especial dos Direitos Humanos da Presidência da República; Conselho Nacional dos Direitos da Criança e do Adolescente. Pesquisa "conhecendo a realidade". 2007. Disponível em: <http://www.promenino.org.br/Portals/0/docs/ficheros/ 200707170012_15_0.pdf>.

BRASIL. Superior Tribunal de Justiça. Agravo n. 1.192.340/MG. Rel. Min. Luiz Fux, DJE 27 out. 2009.

BRASIL. Superior Tribunal de Justiça. Agravo Regimental no Agravo de Instrumento n. 973.577/SP. Rel. Min. Paulo Campbell Marques, 2. ${ }^{\text {a }}$ T., DJE 19 dez. 2008. 
BRASIL. Superior Tribunal de Justiça. Recurso em Mandado de Segurança n. 30.634/SP. Rel. Min. Carlos Meira, DJE 28 jun. 2010.

BRASIL. Superior Tribunal de Justiça. Recurso em Mandado de Segurança n. 5.590/DF. Rel. Min. Luiz Cernicchiaro, 6 ${ }^{\mathbf{a}}$ T., DJ 10 jun. 1996.

BRASIL. Superior Tribunal de Justiça. Recurso Especial n. 1.045.459/DF. Rel. Min. Teori Albino Zavascki, DJE 25 jun. 2008.

BRASIL. Superior Tribunal de Justiça. Recurso Especial n. 1.133.257/RJ. Rel. Min. Luiz Fux, 1. T., DJE 02 fev. 2010.

BRASIL. Superior Tribunal de Justiça. Recurso Especial n. 297.641/CE. Rel. Min. João Duarte de Noronha, 2. ${ }^{\text {T }}$., p. 01 fev. 2006.

BRASIL. Superior Tribunal de Justiça. Recurso Especial n. 493.811/SP. Rel. Min. Eliana Calmon, p. 15 mar. 2004.

BRASIL. Superior Tribunal de Justiça. Recurso Especial n. 509.802/AM. Rel. Min. José Delgado, 1. ${ }^{\mathrm{a}}$ T., p. 28 nov. 2005.

BRASIL. Supremo Tribunal Federal. Ação Direta de Inconstitucionalidade n. 2.9037/PB. Rel. Min. Celso de Mello, p. 19 set. 2008.

BRASIL. Supremo Tribunal Federal. Medida Cautelar em Ação Direta de Inconstitucionalidade n. 143-4/CE. Rel. Min. Carlos Veloso, j. 06 maio 1993.

BRASIL. Supremo Tribunal Federal. Medida Cautelar em Ação Direta de Inconstitucionalidade n. 927-3/RS. Rel. Min. Carlos Veloso, j. 03 nov. 1993.

BRASIL. Supremo Tribunal Federal. Medida Cautelar em Ação Direta de Inconstitucionalidade n. 3.059-1/RS. Rel. Min. Ayres Brito, j. 15 abr. 2004.

BRASIL. Supremo Tribunal Federal. Medida Cautelar na Ação Direta de Inconstitucionalidade n. 4.259/PB. Rel. Min. Ricardo Lewandoswki, j. 23 jun. 2010, DJe 20 ago. 2010.

BRASIL. Supremo Tribunal Federal. Recurso Extraordinário n. 119.256-9/SP. Rel. Min. Moreira Alves, DJU 29 maio 1992. 
BRASIL. Supremo Tribunal Federal. Recurso Extraordinário n. 262.651-1/SP. Rel. Min. Carlos Veloso, DJU 06 maio 2005.

BRASIL. Tribunal de Contas da União. Acórdão n. 1.070/2003. Rel. Min. Ubiratan Aguiar, Plenário, j. 06 ago. 2003.

BRASIL. Tribunal de Contas da União. Acórdão n. 2.640/2008. Rel. Min. Marcos Bemquerer, $1^{\text {a }}$ Câm., j. 20 ago. 2008.

BRASIL. Tribunal de Contas da União. Acórdão n. 3.153/2012. TC n. 020.217/007-3. Rel. Min. José Jorge, $2^{\text {a }}$ Câm., j. 08 maio 2012,

BRASIL. Tribunal Regional Federal da $1^{\text {a }}$ Região. Ação Civil Pública n. 3378788.2010.4.01.3400. Rel. João Batista Moreira.

BRASIL. Tribunal Regional Federal da 4. ${ }^{a}$ Região. Agravo de Instrumento $n$. 2005.04.01.020976-0/PR. Rel. José Paulo Baltazar Junior, $3^{\text {a }}$ T. Disponível em: <http://www.trf4.jus.br/trf4/revistatrf4/arquivos/Rev60.pdf>. Acesso em: 15 abr. 2012.

BRITO, Carlos Ayres. Distinção entre controle social do Poder e participação popular. Revista de Direito Administrativo, n. 189, p. 114-122, 1992.

BRUGUÉ, Quim. Calidad democrática: de la debilidad liberal a la fuerza deliberativa. In: PARÉS, Marc. (Coord.). Participación y calidad democrática: evaluando las nuevas formas de democracia participativa. Barcelona: Ariel Ciencia Política, 2009.

CAMPILONGO, Celso Fernandes. O Judiciário e a democracia no Brasil. Revista da Universidade de São Paulo. São Paulo: Coordenadoria de Comunicação Social, n. 21, 1994.

CAMPILONGO, Celso Fernandes. Os desafios do Judiciário: um enquadramento teórico. In: FARIA, José Eduardo (Org.). Direitos humanos, direitos sociais e justiça. São Paulo: Malheiros, 2005.

CARRAZZA, Roque Antonio. Curso de Direito Constitucional Tributário. 28. ed. São Paulo: Malheiros, 2012.

CASSAGNE, Juan Carlos. Fragmentos de Derecho Administrativo: entre la justicia, la economía y la política. Buenos Aires: Hammurabi, 2003. 
CASSAGNE, Juan Carlos. Reflexiones sobre las ayudas públicas. Derecho administrativo - Revista de doctrina, jurisprudencia, legislación y práctica. Buenos Aires: De Palma Lexis Nexis, n. 45, p. 601-609, 2003.

CASSESE, Sabino. A crise do Estado. Campinas: Saberes Editora, 2010.

CASTRO, Rodrigo Pironti Aguirre de. O sistema de controle interno e as entidades do Terceiro Setor: perspectiva gerencial e o princípio da eficiência. In: OLIVEIRA, Gustavo Justino (Coord.). Direito do Terceiro Setor. Belo Horizonte: Fórum, 2008.

CAVALCANTI, Themístocles Brandão. Instituições de Direito Administrativo brasileiro. Rio de Janeiro: Freitas Bastos, 1936.

CAVAlieri FILHO, Sergio. Programa de Direito do Consumidor. São Paulo: Atlas, 2011.

CENEVIVA, Ricardo; FARAH, Marta. O papel da avaliação de políticas públicas como mecanismo de controle democrático da Administração Pública. In: GUEDES, Alvaro e FONSECA, Francisco (Orgs.). Controle Social da Administração Pública: cenário, avanços e dilemas no Brasil. São Paulo: Cultura Acadêmica; Oficina Municipal; Rio de Janeiro: FGV, 2007.

COMPARATO, Fábio Konder. Debate "Como pensar". Lua Nova - Revista de Cultura e Política. São Paulo, n. 54, 2001. Disponível em: <http://www.scielo.br/ scielo.php?pid=S0102-64452001000300005\&script=sci_arttext $>$. Acesso em: 20 mar. 2012.

CUNHA, Eleonora Schettini. M.; PINHEIRO, Marcia Maria Biondi. Conselhos nacionais: condicionantes políticos e efetividade social. In: AVRITZER, Leonardo (Org.). Experiências nacionais de participação social. São Paulo: Cortez, 2009.

CUNILL GRAU, Nuria. Espacios públicos no estatales para mejorar la calidad de las políticas: una visión sobre América Latina. In: ISUNZA VERA, Ernesto; J. OLIVEIRA, Alberto (Coords.). Democratización, rendición de cuentas sociedad civil: participación ciudadana y controle social. México: Miguel Ángel Porrúa, 2006.

DALLARI, Adilson de Abreu. Orçamento impositivo. In: CONTI, José Maurício, SCAFF, Fernando Facury (Coords.). Orçamentos públicos e Direito Financeiro. São Paulo: RT, 2011.

DE LA RIVA, Ignacio. Ayudas públicas. Incidencia de la intervención estatal en el funcionamiento del marcado. Buenos Aires: Hammurabi, 2004. 
DI PIETRO, Maria Sylvia Zanella. 500 anos de direito administrativo brasileiro. Revista Diálogo Jurídico. Salvador, n. 10, jan. 2002. Disponível em: <http:// www.direitodoestado.com.br.> Acesso em: 13 nov. 2011.

DI PIETRO, Maria Sylvia Zanella. Direito Administrativo. 25. ed. São Paulo: Atlas, 2012.

DI PIETRO, Maria Sylvia Zanella. Discricionariedade administrativa na Constituição de 1988. 3. ed. São Paulo: Atlas, 2012.

DI PIETRO, Maria Sylvia Zanella. Discricionariedade técnica e discricionariedade administrativa. REDAE - Revista Eletrônica de Direito Administrativo Econômico. Salvador, n. 9, fev./mar./abr. 2007. Disponível em: <www.direitodoestado.com.br>. Disponível em: 13 nov. 2011.

DI PIETRO, Maria Sylvia Zanella. Parcerias na Administração pública: concessão, permissão, franquia, terceirização, parceria público-privada e outras formas. 8. ed. São Paulo: Atlas, 2011.

DIAS, Maria Tereza Fonseca. O exercício do papel regulador do Tribunal de Contas da União sobre as parcerias da Administração pública com as entidades do Terceiro Setor na execução de políticas públicas. In: 27. CONGRESSO NACIONAL DO CONSELHO NACIONAL DE PESQUISA E PÓS-GRADUAÇÃO EM DIREITO - CONPEDI. Anais eletrônicos. Brasília, 2008a. Brasília, p. 3.456-3.486. Disponível em: <http://www.conpedi.org.br/ manaus/arquivos/anais/brasilia/10_598.pdf> Acesso em: 15 maio 2012.

DIAS, Maria Tereza Fonseca. Terceiro setor e Estado: legitimidade e regulação. Por um novo marco jurídico. Belo Horizonte: Fórum, 2008 b.

DIGIÁCOMO, Murillo José. O fundo especial dos direitos da criança e do adolescente e as "doações casadas". Ministério Público do Rio Grande do Sul. Disponível em: <http://ww.mp.rs.gov.br/infancia/doutrina/id522.htm> Acesso em: 30 mar. 2012.

DRAIBE, Sonia Miriam. A nova institucionalidade do sistema brasileiro de políticas sociais: os conselhos nacionais de políticas setoriais. Cadernos de Pesquisa. Campinas: Núcleo de Estudos de Políticas Públicas - NEPP, n. 35, 1998.

DROMI, José Roberto. Derecho Administrativo. 5. ed. Buenos Aires: Ciudad Argentina, 1996.

DROMI, José Roberto. Modernización del controle público. Madri; México: Hispania Libros, 2004. 
ENTRENA CUESTA, Rafael. Apuntes de Derecho Administrativo. 1958.

ESPANHA. Tribunal Constitucional de España. STC n. 207/1996. Pte. Vicente Gimeno Sendra, FJ 4, BOE 22 jan. 1997.

ESPANHA. Tribunal Constitucional de España. STC n. 55/1996. Pte. Carles Viver PiSunyer, FJ 6, BOE 27 abr. 1996.

ESPANHA. Tribunal Constitucional de España. STC n. 66/1995. Pte. Carlos Viver PiSunyer, FJ 5, j. 08.05.1995, BOE 13 jun. 1995.

FEDOZZI, Luciano. Participação nos governos locais do Brasil contemporâneo. Gestão pública e participação. Salvador: Fundação Luís Eduardo Magalhães - FLEM, n. 8, p. 135-168, 2005.

FERRAREZI, Elisabete; OLIVEIRA, Mariana S. de Carvalho. Conferências nacionais de saúde e processos participativos na Administração Pública federal brasileira. Brasília: Casoteca de Gestão Pública. Escola Nacional de Administração Pública - ENAP, 2010. Disponível em: <http://casoteca.enap.gov.br/index.php?option=com_multicategories $\&$ view=article \&id=14:conferencias-nacionais-de-saude-e-processos-participativos-naadministracao-publica-federal-brasileira\&catid=7:estado-e-sociedade\&Itemid=12> . Acesso em: 12 mar. 2012.

FERRAZ, Luciano. Novas formas de participação social na administração pública: conselhos gestores de políticas públicas. Revista Eletrônica sobre a Reforma do Estado, n. 15, set./nov. 2008. Disponível em: <http://www.direitodoestado.com.br>. Acesso em: $21 \mathrm{dez} .2011$.

FIGUEIREDO, Lúcia Valle. O devido processo legal e a responsabilidade do Estado por dano decorrente do planejamento. Revista Diálogo Jurídico, n. 13, abr./maio 2002. Disponível em: <www.direitopublico.com.br>. Acesso em: 15 jan. 2012.

FREITAS, Juarez de. Discricionariedade administrativa e o direito fundamental à boa Administração Pública. São Paulo: Malheiros, 2007.

FURTADO, J. R. Caldas. Elementos de Direito Financeiro. Belo Horizonte: Fórum, 2009.

GABARDO, Emerson. Interesse público e discricionariedade: o Estado e a sociedade civil para além do bem e do mal. Belo Horizonte: Fórum, 2009. 
GARCÍA DE ENTERRÍA, Eduardo; FERNÁNDEZ, Tomás-Ramón. Curso de Derecho Administrativo. 10. ed. Madri: Civitas, 2000.

GARRIDO FALlA, Fernando. Tratado de Derecho Administrativo. 10. ed., Madri: Tecnos, 1992.

GASPARINI, Diógenes. Direito Administrativo. 17. ed. São Paulo: Saraiva, 2012.

GIACOMUZZI, José Guilherme. A moralidade administrativa e a boa-fé na Administração Pública: o conteúdo dogmático da moralidade administrativa. São Paulo: Malheiros, 2001.

GIMENO FELIU, José María. Legalidad, transparencia, control y discrecionalidad en las medidas de fomento del desarrollo económico: ayudas e subvenciones. Revista de Administración Pública, n. 137, maio-ago. 1995.

GOHN, Maria da Glória. Os conselhos municipais e a gestão urbana. In: SANTOS JUNIOR, Orlando Alves; RIBEIRO, Luiz Cesar de Queiroz; AZEVEDO, Sergio (Orgs.). Governança democrática e poder local. Rio de Janeiro: Revan, 2004.

GOMES, Orlando. Contratos. 18. ed. Rio de Janeiro: Forense, 1998.

GOMEZ, Alejandro. Municipalismo y proyectos políticos del gobierno militar. In: MÁRQUEZ, Daniel Alberto; PICONE, Francisco Humberto (Coords.). Temas de Derecho Municipal. Buenos Aires: Pensamiento Jurídico, 1991.

GONÇALVES, Carlos Roberto. Responsabilidade civil. 14. ed. São Paulo: Saraiva, 2012.

GONZALEZ, Checa. Los impuestos con fines no fiscales: notas sobre las causas que los justifican y sobre su admisibilidad constitucional. Revista Civitas. Madri, n. 40, p. 505$516,1983$.

GUÉTARA, Juan Miguel de la. La actividad de la Administración. Madri: Tecnos, 1983.

HENRIQUES, Élcio Fiori. O regime jurídico do gasto tributário no Direito brasileiro. Dissertação (Mestrado em Direito) - Faculdade de Direito, Universidade de São Paulo, São Paulo, 2009. 
HIGA, Alberto Shinji Higa. Terceiro setor: da responsabilidade civil do Estado e do agente fomentado. Belo Horizonte: Fórum, 2010.

HORVATH, Estevão; OLIVEIRA, Régis Fernandes. Manual de Direito Financeiro. 5. ed. São Paulo: RT, 2002.

HOUTZAGER, Peter P.; LAVAllE, Adrian Gurza; ACHARYA, Arnab. Atores da sociedade civil e atores políticos: participação nas novas políticas democráticas em São Paulo. In: AVRITZER, Leonardo (Org.). A participação em São Paulo. São Paulo: Unesp, 2004.

JORDANA DE POZAS, Luis. Ensayo de una teoría del fomento en el Derecho Administrativo. Revista de Estudios Políticos, n. 48, p. 41-54, 1949. Disponível em: $<$ http://dialnet.unirioja.es/servlet/articulo?codigo=2127752>. Acesso em: 02 maio 2011.

JUNQUEIRA, Luciano A. Prates. Conselhos municipais e a gestão em rede das políticas sociais. In: Informativo CEPAM: conselhos municipais nas áreas sociais. São Paulo: Fundação Prefeito Faria Lima - Centro de Estudos e Pesquisas de Administração Municipal - CEPAM. Unidade de Políticas Públicas 2. ed., v. 1, n. 3, 2001.

JUSTEN FILHO, Marçal. Comentários à lei de licitações e contratos administrativos. 15. ed. São Paulo: Dialética, 2012.

JUSTEN FILHO, Marçal. Curso de Direito Administrativo. 8. ed. Belo Horizonte: Fórum, 2012.

KLIKSBERG, Bernardo. Como por em prática a participação? Algumas questões estratégicas. Gestão pública e participação. Salvador: Fundação Luís Eduardo Magalhães - FLEM, n. 8, p. 63-97, 2005.

LAGUNA DE PAZ, José C. El principio de subsidiariedad, pieza clave en la construcción europea. In: AAVV. Comunidades autónomas y Comunidad Europea: relaciones jurídico-institucionales. Valladolid: Cortes de Castilla y León, 1991.

LAVILLE, Jean-Louis. La dimension politique des associations. In: LAFORE, Robert (Coord.). Faire société: les associations de solidarité par temps de crise. Paris: Dunod, 2010.

LIBERATI, Wilson Donizeti; CYRINO, Públio Caio Bessa. Conselhos e fundos no Estatuto da Criança e Adolescente. 2. ed. São Paulo: Malheiros, 2003. 
LIMA, Carolina Caiado. O convênio administrativo colaborativo para transferência de recursos públicos a entidades privadas sem fins lucrativos como instrumento dos mecanismos diretos de fomento públicos. Dissertação (Mestrado em Direito) Faculdade de Direito, Universidade de São Paulo, São Paulo, 2010.

LONGO, Francisco. Há resistência do mundo adulto em compartilhar o exercício de poder. 2001. Disponível em: <http://www.acaoeducativa.org.br/portal/index.php? option=com_content\&task=view\&id=2665\&Itemid=2>. Acesso em: 02 jun. 2012.

LONGO, Francisco. La gestión publica como discurso de valores. In: LONGO, Francisco; YSA, Tamyko (Eds.). Los escenarios de la gestión publica del siglo XXI. Barcelona: Bellaterra, 2008.

LÓPEZ-MUÑIZ, Jose Luis Martínez. La actividad administrativa dispensadora de ayudas y recompensas: una alternativa conceptual al fomento en la teoría de los modos de acción de la Administración pública. In: MORANT, Rafael Gómez-Ferrer (Coord.). Libro homenaje al profesor José Luis Villar Palasí. Madri: Civitas, 1989.

MACHADO HORTA, Raul. Estudos de Direito Constitucional. Belo Horizonte: Del Rey, 1995.

MACHADO, João Baptista. Participação e descentralização. Democratização e neutralidade na Constituição de 76. Coimbra: Almedina, 1982.

MÂNICA, Fernando Borges. Panorama histórico-legislativo do Terceiro Setor no Brasil: do conceito de Terceiro Setor à lei das OSCIP. In: OLIVEIRA, Gustavo Justino de (Coord.). Terceiro Setor, empresas e Estado: novas fronteiras entre o público e o privado. Belo Horizonte: Fórum, 2007.

MÂNICA, Fernando Borges. Seleção de pessoal e regime de gestão das entidades privadas em parcerias com o setor público na área da saúde. In: MODESTO, Paulo; CUNHA JUNIOR, Luiz Arnaldo Pereira. Terceiro Setor e parcerias na área da saúde. Belo Horizonte: Fórum, 2010.

MARANHÃO, Tatiana de Amorim. O enigma da esfinge: identificação entre público e o privado: a relação dos conselheiros municipais de direitos (2000/2002) com o Fundo Municipal dos Direitos da Criança e Adolescente de São Paulo. Tese apresentada no 11. Congresso de Sociologia. Campinas: Unicamp, set. 2003.

MARTINS, Paulo Haus. Convênios com entidades da sociedade civil: entre a lei e os atos administrativos (decretos, INs e portarias). Revista do TCMRJ, ano 25, n. 39, set. 2008. Disponível em: <http://www.tcm.rj.gov.br/Noticias/3294/REV39.pdf>. Acesso em: 26 nov. 2011. 
MARTINS, Sérgio Pinto. Direito do Trabalho. 16. ed. São Paulo: Atlas, 2002.

MASSA-ARZABE, Patrícia Helena. Dimensão jurídica das políticas públicas. In: BUCCI, Maria Paula Dallari (Org.). Políticas públicas. Reflexões sobre o conceito jurídico. São Paulo: Saraiva, 2006.

MATIAS-PEREIRA, José. Finanças públicas: a política orçamentária no Brasil. 4. ed. São Paulo: Atlas, 2009.

MEDAUAR, Odete. A processualidade no Direito Administrativo. 2. ed. São Paulo: RT, 2008.

MEDAUAR, Odete. Direito Administrativo moderno. 16. ed. São Paulo: RT, 2012.

MEDAUAR, Odete. O direito Administrativo em evolução. 2. ed. São Paulo: RT, 2003.

MEIRELLES, Hely Lopes. Direito Administrativo brasileiro. 38. ed. São Paulo: Malheiros, 2012.

MEIRELLES, Hely Lopes. Direito Municipal brasileiro. 16. ed. São Paulo: Malheiros, 2008.

MELlO, Célia Cunha. O fomento da Administração Pública. Belo Horizonte: Del Rey, 2003.

MENDES, Denise Cristina Vitale Ramos. Democracia semidireta no Brasil pós-1988: a experiência do orçamento participativo. Tese (Doutorado em Direito) -Faculdade de Direito, Universidade de São Paulo, São Paulo, 2004.

MENDOZA, Xavier; VERNIS, Alfred. El Estado relacional y la transformación de las administraciones públicas. In: LONGO, Francisco; YSA, Tamyko (Eds.). Los escenarios de la gestión pública del siglo XXI. Barcelona: Bellaterra, 2008.

MINAS GERAIS. Tribunal de Justiça. Apelação n. 1.0183.04.066951-1/001. 2. ' Câm. Cível, j. 04 dez. 2007.

MODESTO, Paulo. Notas para um debate sobre o princípio constitucional da eficiência. Revista Diálogo Jurídico. Salvador: Centro de Atualização Jurídica - CAJ, v. 1, n. 2, maio 2001. Disponível em: <www.direitopublico.com.br>. Acesso em: 15 mar. 2012. 
MODESTO, Paulo. O Direito Administrativo do Terceiro Setor: a aplicação do Direito Público às entidades privadas sem fins lucrativos. In: MODESTO, Paulo; CUNHA JÚNIOR, Luiz Arnaldo (Coords.). Terceiro Setor e parcerias na saúde. Belo Horizonte: Fórum, 2011.

MOREIRA NETO, Diogo Figueiredo. Legitimidade e discricionariedade: novas reflexões sobre os limites e controle da discricionariedade de acordo com a Constituição de 1988. 2. ed. Rio de Janeiro: Forense, 1991.

MOREIRA NETO, Diogo Figueiredo. Mutações do Direito Administrativo. 3. ed. Rio de Janeiro: Renovar. 2007.

MOREIRA NETO, Diogo Figueiredo. Novas tendências da democracia: consenso e direito público na virada do século: o caso brasileiro. Revista Eletrônica sobre a Reforma do Estado, n. 13, mar./maio 2008. Disponível em: <http:// www.direitodoestado.com.br>. Acesso em: 21 dez. 2011.

MOREIRA NETO, Diogo Figueiredo. Quatro paradigmas do Direito Administrativo pós-moderno: legitimidade, finalidade, eficiência e resultados. Belo Horizonte: Fórum, 2008.

MOREIRA, Maria Tarquinia Vieira. Instância deliberativa das políticas públicas de cunho social: contorno jurídico dos conselhos. In: Informativo CEPAM: conselhos municipais nas áreas sociais. São Paulo: Fundação Prefeito Faria Lima - Centro de Estudos e Pesquisas de Administração Municipal - CEPAM. Unidade de Políticas Públicas 2. ed., v. 1, n. 3, 2001.

NABAIS, José Casalta. Algumas considerações sobre a solidariedade e a cidadania. Boletim da Faculdade de Direito. Coimbra: Universidade de Coimbra, v. 75, 1999.

NABAIS, José Casalta. O dever fundamental de pagar impostos: contributo para compreensão constitucional do estado fiscal contemporâneo. Tese (Doutorado em Ciências Jurídico-Políticas) - Faculdade de Direito, Universidade de Coimbra. Coimbra: Almedina, 2004.

NIEBUHR, Joel de Menezes. Dispensa e inexigibilidade de licitação pública. São Paulo: Dialética, 2003.

NOGUEIRA, Rui Barbosa. Curso de Direito Tributário. 4. ed. São Paulo: Instituto Brasileiro de Direito Tributário, 1976.

NOGUER, M.; VALLESPÍN, I. La Diputación de Barcelona otorga sin concurso el $82 \%$ de las subvenciones. El País, Madri, 8 ago. 2012. Cataluña, p. 1 e 2. 
OLIVEIRA, Cristiane Catarina Fagundes de. O município brasileiro: participação política e conselhos municipais. Tese (Doutorado em Direito) - Faculdade de Direito, Universidade de São Paulo, São Paulo, 2005.

OLIVEIRA, Fernando Andrade de. Conceituação do Direito Administrativo. RDA. Rio de Janeiro: Fundação Getúlio Vargas, n. 120, p. 14-48, abr./jun. 1975.

OLIVEIRA, Gustavo Justino. Direito Administrativo democrático. Belo Horizonte: Fórum, 2010.

OLIVEIRA, Gustavo Justino. Estado contratual, direito ao desenvolvimento e parceria público-privada. 2005. Mimeografado.

OLIVEIRA, Gustavo Justino. Gestão privada de recursos públicos para fins públicos: o modelo da OSCIP. In: OLIVEIRA, Gustavo Justino (Coord.). Terceiro Setor: empresas e Estado: novas fronteiras entre o público e o privado. Belo Horizonte: Fórum, 2007.

OLIVEIRA, Gustavo Justino. Participação administrativa. Revista Eletrônica sobre a Reforma do Estado. Salvador: Instituto de Direito Público da Bahia, n. 3, set./nov. 2005. Disponível em: <www.direitodoestado.com.br>. Acesso em: 11 dez. 2011.

OLIVEIRA, Gustavo Justino; SCHWANKA, Cristiane. A administração consensual como a nova face da Administração Pública no século XXI: fundamentos dogmáticos, formas de expressão e instrumentos de ação. In: Anais do 27. Encontro Preparatório para o Congresso Nacional do CONPEDI - Salvador. Florianópolis: Fundação Boiteux, 2008.

ORGANIZAÇÃO PARA A COOPERAÇÃO E DESENVOLVIMENTO ECONÔMICO OCDE. Fortalecendo a governança para o crescimento. 2008. Disponível em: <http://www.seae.fazenda.gov.br/destaque/bb-ocde-relatorio-sobre-a-reformaregulatoria>. Acesso em: 25 ago. 2012.

PAES, José Eduardo Sabo. Fundações, associações e entidades de interesse social: aspectos jurídicos, administrativos, contábeis, trabalhistas e tributários. 6. ed. Brasília: Brasília Jurídica, 2006.

PARANÁ. Ministério Público do Estado do Paraná. Conselho de Direitos da Criança e do Adolescente: o processo de composição. 2008. Disponível em: <http:// www2.mp.pr.gov.br/ cpca/telas/ca_cd_doutrina_1_7.php>. Acesso em: 15 fev. 2012.

PARANÁ. Tribunal de Contas do Estado do Paraná. Consulta n. 296.124/02. Parecer n. 89/2003. Município de Tijucas do Sul. Rel. Fernando Augusto Mello Guimarães. 
PARÉS, Marc. Participación y evaluación de la participación. In: PARÉS, Marc (coord.). Participación y calidad democrática: evaluando las nuevas formas de democracia participativa. Barcelona: Ariel Ciencia Política, 2009.

PEREZ, Marcos Augusto. A Administração Pública democrática. Belo Horizonte: Fórum, 2009.

PEREZ, Marcos Augusto. A participação da sociedade na formulação, decisão e execução das políticas públicas. In: BUCCI, Maria Paula Dallari (Org.). Políticas públicas: reflexões sobre o conceito jurídico. São Paulo: Saraiva, 2006.

PEREZ, Marcos Augusto. Institutos de participação popular na Administração Pública. Dissertação (Mestrado em Direito) - Faculdade de Direito, Universidade de São Paulo, São Paulo, 1999.

REGO BLANCO, Maria Dolores. La discrecionalidad administrativa y su control en materia de subvenciones: un estudio jurisprudencial. Revista Andaluza de Relaciones Laborales, n. 2, p. 171-188, dez. 1996.

RIO DE JANEIRO (Estado). Ministério Público do Estado do Rio de Janeiro. Memoriais na Ação Civil Pública n. 2009.021.029810-4. Disponível em: <http://www.mp.ro.gov.br/c/document_library/get_file?p_l_id=1108298\&folderId=11084 86\&name=DLFE-51954.pdf $>$ Acesso em: 20 fev. 2012.

ROBBE, François. Démocratie représentative et participation. In: ROBBE, François (Org.). Le democrátie participative. Paris: L’Hamartan. 2007.

ROCHA, C. Alexandre Amorim. O modelo de controle externo exercido pelos tribunais de contas e as proposições legislativas sobre o tema. Consultoria Legislativa do Senado Federal, 04 nov. 2002. Disponível em: <http://www.senado.gov.br/ senado/conleg/artigos/direito/Omodelodecontroleexterno.pdf >. Acesso em 30 de março de 2012.

ROCHA, Silvio Luis Ferreira. Terceiro Setor. 2. ed. São Paulo: Malheiros. 2006.

ROTHENBURG, Walter Claudius. Algumas considerações sobre a incidência de direitos fundamentais nas relações do Estado com empresas e Organizações Sociais. In: OLIVEIRA, Gustavo Justino (Coord.). Terceiro Setor: empresas e Estado: novas fronteiras entre o público e o privado. Belo Horizonte: Fórum, 2007. 
SABBAG, César de Moraes. Breves considerações sobre deficiências estruturais do sistema orçamentário brasileiro: propostas para incrementar a legitimidade e a eficiência do modelo. In: CONTI, José Maurício; SCAFF, Fernando Facury (Coords.). Orçamentos públicos e o Direito financeiro. São Paulo: RT, 2011.

SADECK FILHO, Francisco José. O orçamento público federal e a garantia da prioridade absoluta de crianças e adolescentes nas políticas públicas. Dissertação (Mestrado em Direito) - Universidade do Estado do Rio de Janeiro, Rio de Janeiro, 2010.

SALAMON, Lester M. Toward an Enabling Legal Environment for Civil Society. Statement of the Sixteenth Annual Johns Hopkins International Fellows in Philanthropy Conference Nairobi, Kenya. The International Journal of Not-for-Profit Law, v. 8, issue 1, nov. 2005. Disponível em: <http://www.icnl.org/research/journal/vol8iss1/ special_1.htm>. Acesso em 10 fev. 2012.

SALAMON, Lester M.; SOKOLOWSKI, S. Wojciech; HADDOCK, Megan. Measuring the Economic Value of Volunteer Work Globally: Concepts, Estimates and a Roadmap to the Future. Annals of Public and Cooperative Economics, v. 82, n. 3, p. 218-254, set. 2011.

SALINAS, Natasha Schmitt Caccia. Avaliação legislativa no Brasil: um estudo de caso sobre as normas de controle das transferências voluntárias de recursos públicos para entidades do Terceiro Setor. Dissertação (Mestrado em Direito) - Faculdade de Direito, Universidade de São Paulo, São Paulo, 2008.

SANTAMARIA PASTOR, Juan A. Fundamentos de Derecho Administrativo. Madri: Centro de Estudios Ramón Areces, 1988.

SANTAMARIA PASTOR, Juan A. Principios de Derecho Administrativo. 3. ed. Madri: Centro de Estudios Ramón Areces. 2000.

SANTOS JUNIOR, Orlando Alves; AZEVEDO, Sergio; RIBEIRO, Luiz Cesar de Queiroz. Democracia e gestão local: a experiência dos conselhos municipais no Brasil. In: SANTOS JUNIOR, Orlando Alves; AZEVEDO, Sergio; RIBEIRO, Luiz Cesar de Queiroz. (Orgs.). Governança democrática e poder local: a experiência dos conselhos municipais no Brasil. Rio de Janeiro: Revam, 2004.

SANTOS, José Anacleto Abduch. Licitação e Terceiro Setor. In: OLIVEIRA, Gustavo Justino (Coord.). Terceiro setor: empresas e Estado: novas fronteiras entre o público e o privado. Belo Horizonte: Fórum, 2007.

SÃO PAUlO (Estado). Tribunal de Justiça. Processo 0102129-46.2008.8.26.0053. 10. ${ }^{\text {a }}$ Vara da Fazenda Pública do Estado de São Paulo. 
SÃo PAUlO (Estado). Tribunal de Justiça. Processo n. 2005-0.016.723-7. Parecer da Procuradoria Geral do Município de São Paulo.

SÃO PAULO (Município). Conselho Municipal dos Direitos da Criança e do Adolescente de São Paulo. Edital FUMCAD 2012. Disponível em: <http://www.prefeitura.sp.gov.br/ cidade/secretarias/participacao_parceria/conselhos/fumcad/edital/index.php?p=1525>.

Acesso em 25 ago. 2012.

SÃO PAUlO (Município). Parecer da Procuradoria Geral do Município ementado sob o número 10.974.

SÃo PAUlO (Município). Parecer da Procuradoria Geral do Município ementado sob o número 11.188.

SÃO PAUlO (Município). Plano Estratégico CMDCA 2010-2012. Publicação n. 230/2010. DOM 28 dez. 2010.

SÃO PAULO (Município). Secretaria Municipal de Participação e Parceria. Sistema de diagnóstico da situação da criança e do adolescente na cidade de São Paulo. Disponível em: <http://www.conferenciapermanente.com/diagnostico2007/consultas.php>. Acesso em 25 ago. 2012.

SCHIMIDT-ASSMANN, John Eberhard. La teoría general del derecho administrativo como sistema. Tradução Javier Bernés Vázquez et al. Madri: Marcial Pons Ediciones Jurídicas y Sociales, 2003.

SCHIRATO, Vitor Rhein. O processo administrativo como instrumento do Estado de Direito e da Democracia. In: MEDAUAR, Odete; SCHIRATO, Vitor Rhein (Orgs.). Atuais rumos do processo administrativo. São Paulo: RT, 2010.

SCHOENMAKER, Janaína. Controle das parcerias entre o Estado e o Terceiro Setor pelos Tribunais de Contas. Belo Horizonte: Fórum, 2011.

SEDA, Edson. A criança: manual do conselho tutelar: como transformar maus hábitos, usos e costumes em bons hábitos, usos e costumes, contra a agressividade, violência, o crime e o terror. Rio de Janeiro: Adês, 2008.

SEDA, Edson. Construir o passado. Disponível em: <http://www.abmp.org.br/ textos/3.htm>. Acesso em: 12 fev. 2012. 
SILVA, Frederico Barbosa; JACCOUD, Luciana; BEGHIN, Nathalie. Políticas sociais no Brasil: participação social, conselhos e parcerias. In: JACCOUD, Luciana (Org.). Questão social e políticas sociais no Brasil contemporâneo. Brasília: IPEA, 2005.

SODERMAN, Jacob. El derecho fundamental a la buena administración. Discurso pronunciado el Defensor del Pueblo Europeo. In: Ciclo de Conferencias "El papel de los Defensores del Pueblo en un mundo en transición". Mallorca, 28 maio 2001. Disponível em: <http://www.ombudsman.europa.eu/speeches/es/2001-05-28.htm>. Acesso em: 25 ago. 2012.

SOUTO, Marcos Juruena Villela. Direito administrativo da economia: planejamento econômico, fomento, empresas estatais e privatização, defesa da concorrência, do consumidor e do usuário de serviços públicos, responsabilidade fiscal. Rio de Janeiro: Lumen Juris. 2003.

SOUTO, Marcos Juruena Villela. Estímulos positivos. In: OLIVEIRA, Gustavo Justino (Coord.). Terceiro Setor: empresas e Estado: novas fronteiras entre o público e o privado. Belo Horizonte: Fórum, 2007.

SOUZA, Leandro Marins de. Parcerias entre a Administração pública e o Terceiro Setor: sistematização e regulação. Tese (Doutorado em Direito) - Faculdade de Direito, Universidade de São Paulo, São Paulo, 2010.

SOUZA, Leandro Marins. Necessidade ou desnecessidade de licitação para as parcerias do Estado na área da saúde. In: MODESTO, Paulo; CUNHA JUNIOR, Luiz Arnaldo. Terceiro setor e parcerias na área da saúde. Belo Horizonte: Fórum, 2011.

STANCINI, S. A. A gestão pública democrática: perspectivas apontadas pelos conselhos dos direitos da criança e adolescente. Dissertação (Mestrado em Direito) - Faculdade de Direito, Pontifícia Universidade Católica de São Paulo, São Paulo, 1997.

SZKLAROWSKY, Leon Fredja. Convênios, consórcios administrativos, ajustes e outros instrumentos congêneres. Revista dos Tribunais. São Paulo: RT, n. 751, p. 167-171, maio 1998.

TATAGIBA, Luciana. A institucionalização da participação: os conselhos municipais de políticas públicas na cidade de São Paulo. In: AVRITZER, Leonardo (Org.). A participação em São Paulo. São Paulo: Editora Unesp, 2004.

TATAGIBA, Luciana. Os conselhos gestores e a democratização das políticas públicas no Brasil. In: DAGNINO, Evelina (Org.). Sociedade civil e espaços públicos no Brasil. São Paulo: Paz e Terra, 2002. 
TAVARES, Patrícia Silveira. Os conselhos dos direitos da criança e do adolescente. In: MACIEL, Kátia (Coord.). Curso de direito da criança e do adolescente: aspectos teóricos e práticos. 2. ed. Rio de Janeiro: Lúmen Júris, 2007.

TORRES, Ricardo Lobo. Os fundos especiais. Disponível em: <http://www.abmp.org.br/ textos/228.htm> Acesso em: 12 mar. 2012.

URUGAI, Visconde do. Visconde do Uruguai. In: CARVALHO, José Murilo (Org.). São Paulo: Editora 34, 2002.

VALLE, Vanice Regina Lírio. Perspectivas para o controle social e a transparência da Administração pública. Brasília, 2002.

VIEJO, Raimundo et al. La participación ciudadana en la esfera pública: enfoques teóricos-normativos y modelos de democracia. In: PARÉS, Marc (Coord.). Participación y calidad democrática: evaluando las nuevas formas de democracia participativa. Barcelona: Ariel Ciencia Política, 2009.

VILAR EZCURRA, José Luis. Derecho Administrativo especial: actividad pública e actividad de los particulares. Madri: Civitas, 1999.

VILLAR PALASÍ, José Luis. La actividad industrial del Estado en el derecho administrativo. Revista de Administración Pública - RAP, n. 3, p. 53-129, 1950.

VILLAR PALASÍ, José Luis. Las técnicas administrativas de fomento y apoyo al precio político. Revista de Administración Pública - RAP, n. 14, p. 11-121, 1954.

VILLAR PALASÍ, José Luis. Poder de policía y justo precio: el problema de la tasa de mercado. Revista de Administración Pública - RAP, n. 16, p. 11-84, 1955.

VIOLIN, Tarso Cabral. Terceiro Setor e as parcerias com a Administração pública: uma análise crítica. 2. ed. Belo Horizonte: Fórum, 2010.

ZEN, Marcela Roza Leonardo. Licitação e Terceiro Setor: reflexões sobre o concurso de projetos da Lei de OSCIPs. In: OLIVEIRA, Gustavo Justino (Coord.). Direito do Terceiro Setor. Belo Horizonte: Fórum, 2008.

ZENI, Bruna Shlindwein; GONÇALVES, Diogo Marques. Poder local e participação popular na Administração Pública: reflexões acerca dos conselhos municipais no Direito brasileiro. Trabalho publicado nos Anais do 19. Encontro Nacional do CONPEDI. Fortaleza, 09-12 jul. 2010. 